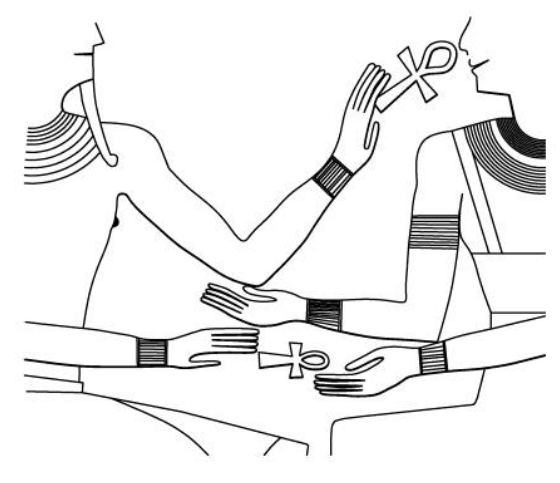

\title{
MEMORIA Y RECUERDO EN EL REINO MEDIO EGIPCIO
}

Acerca de un mito de origen en el papiro Westcar

Leila Salem 
Universidad Nacional de La Plata

Facultad de Humanidades y Ciencias de la Educación

Tesis de Doctorado en Historia

Título: Memoria y recuerdo en el Reino Medio egipcio. Acerca de un mito de origen en el papiro Westcar

Autora: Salem, Leila

Directora: Zingarelli, Andrea

Fecha: Noviembre de 2012 
Para mi papá,

Julio César Salem

y para Lara 
“... Justificase, como fruto de esas actividades, que la Reina diese a luz varios vástagos. Periódicamente, ante la inminencia del suceso, me mandó a abrochar a su muñeca, pues insistía en que yo era su talismán.

$Y$ en los natalicios principescos, oí a las parteras susurrar las fórmulas mágicas que auxiliarían al recién nacido venido, si abría los ojos en el mes de Paophi o en el mes de Athyr, y comprobé la entrada, invisible para los demás, de las diosas especiales que vigilan los nacimientos: las siete mimosas de Hathors de cuerpo femenino, orejas de ternera y cuernos pintados,

la diosa de la Lactancia, la de la Cuna y Heket, la de la cabeza de rana, símbolo de la vida y del renacer..."

MANUEL MUJICA LAINEZ, El escarabajo 
Índice 


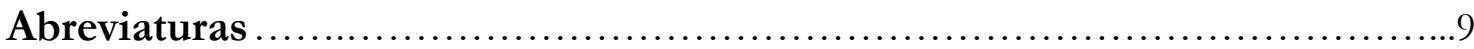

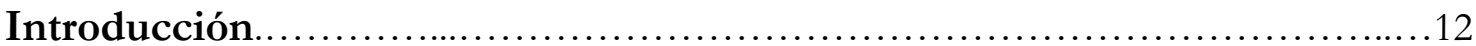

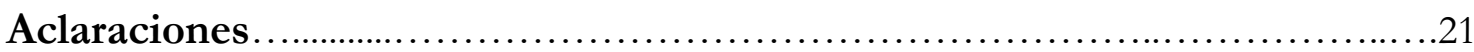

\section{PARTE I}

\section{TRANSLITERACIÓN Y TRADUCCIÓN DE LOS DOS ÚLTIMOS RELATOS DEL PAPIRO WESTCAR}

1. Referencias de la transliteración y traducción de los dos últimos relatos del papiro Westcar..........................................................26

2. Transliteración y traducción del cuarto relato del papiro Westcar..............26

3. Transliteración y traducción del anexo al cuarto relato del papiro Westcar.....36

\section{Capítulo I. ACERCA DEL NACIMIENTO DIVINO DEL REY EN LOS DOS ÚLTIMOS RELATOS DEL PAPIRO WESTCAR}

Mito y literatura en el antiguo Egipto................................... 44

1. La divinidad del rey .................................................. 45

2. Mito del nacimiento divino del rey.......................................49

Diferencias en los espacios de representación

3. Mito de origen de la dinastía V

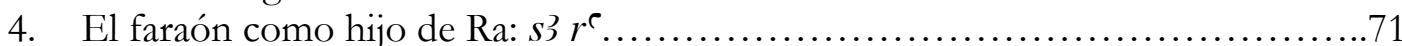

5. Padres divinos: Ra y Amón................................................... 84

6. Ra, señor de Sakhebu.................................................. 92

7. Madres humanas...................................................... 93

\section{Capítulo II. NACIMIENTO DIVINO DEL REY}

Análisis comparativo....

1. Representaciones del nacimiento divino del rey....

2. Similitudes y diferencias entre los relatos del papiro Westcar y los ciclos míticos del Reino Nuevo.

Escenas I y II en el templo de Deir el-Bahari: Amón-Ra y el consejo de dioses. Amón induce a la reina a su encuentro

Escenas I y II en el templo de Luxor: Hathor se encuentra con la reina madre Matemwia ante Amón$\mathrm{R} a$. Amón-Ra se encuentra con Tutmosis IV

Escena III: Amón-Ra se encuentra con Toth

Escena IV en el templo Deir el-Bahariy Luxor: la concepción divina del futuro faraón

Escena V: Amón-Ra se encuentra con Khnum

Escena VT: moldeado del recién nacido y su ka

Escena VII: Toth y la reina

Escena VIII: los dioses conducen a la reina madre a la sala de nacimiento

Escena IX: nacimiento divino.

Escena X: presentación del niño a su padre el dios Amón-Ra por Hathor

Escena XI: segunda presentación del recién nacido ante Amón-Ra

Escena XII: amamantamiento y crianza del futuro rey

Escena XIII: el dios y su ka son llevados ante la divinidad

Escena XIV:Toth/Horus y Amón-Ra sosteniendo al fututo rey y su ka 
Capítulo III. SÍMBOLOS MÍTICOS EN LOS DOS ÚLTIMOS RELATOS DEL PAPIRO WESTCAR.........................................................

1. Simbología mítica................................................... 148

2. Día de nacimiento de los trillizos........................................149

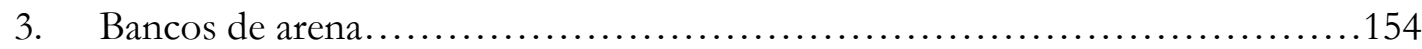

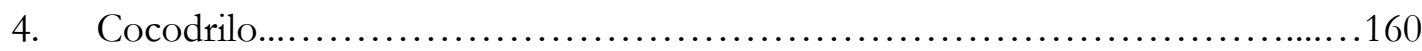

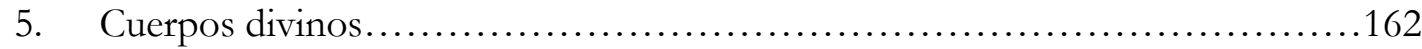

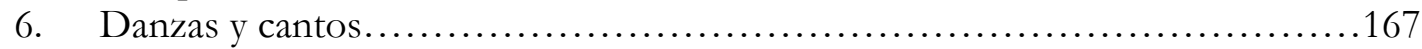

7. Meshkeneh y los ladrillos de nacimiento................................168

8. A modo de cierre ..................................................... 171

\section{PARTE II}

\section{Capítulo IV. LITERATURA Y POLÍTICA}

Invención, política y ficcionalización en el Reino Medio egipcio........................... 174

1. Antecedentes de los textos literarios durante el Primer Periodo Intermedio......175

2. Reino Medio: política y literatura. El surgimiento de los textos literarios..........183

3. Verdad histórica o ficcionalización en los textos literarios del Reino Medio......197

4. Reino Medio: literatura y recuerdo .................................... 201

\section{Capítulo V. MEMORIA Y LITERATURA EN EL REINO MEDIO EGIPCIO}

Memoria futura y recuerdo en los dos últimos relatos del papiro Westcar..................... 204

1. Memoria colectiva, marcos sociales y usos de la memoria.....................205

2. Memoria cultural................................................. 211

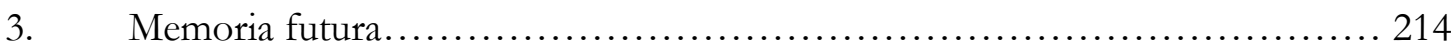

4. La narración literaria y la selección de los hechos del pasado..................219

5. El recuerdo del origen. Acuerdos y discrepancias entre Listas Reales y los relatos del papiro Westcar.................................................221

6. Representaciones del pasado en los relatos literarios del Reino Medio.........225

7. A modo de cierre.....................................................227

\section{PARTE III}

\section{Capítulo VI. LITERATURA EN EL ANTIGUO EGIPTO}

Teoría y aspectos literarios.

1. ¿Qué es la literatura egipcia? Controversias sobre el concepto de literatura egipcia.

\section{Capítulo VII. ACERCA DEL PAPIRO WESTCAR}

Historia, características formales, estudios especificos, datación y argumento...255

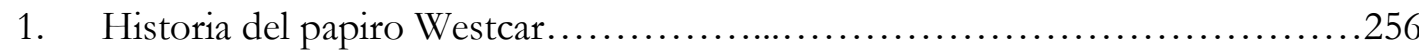

2. Características y conservación del papiro Westcar...........................259

3. Discusiones sobre la datación del papiro Westcar..........................262 
4. Títulos y categorización de los relatos del papiro Westcar....................271

5. Trabajos específicos sobre el papiro Westcar: traducciones, transliteraciones y

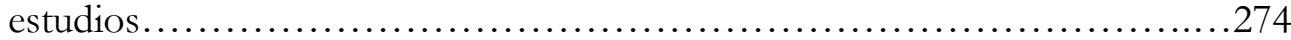

6. Argumento de los relatos del papiro Westcar.............................284

\section{Capítulo VIII. RELATOS DEL PAPIRO WESTCAR}

Unidad de sentidos: estructura, género y estilo..........................293

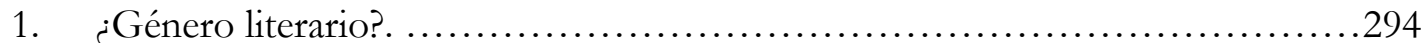

2. Estructura tripartita en los relatos del papiro Westcar.........................301

3. Contenido mágico de los relatos del papiro Westcar.........................312

4. Cultura popular, tradición oral, representación y autoría......................316

5. A modo de cierre......................................................... 331

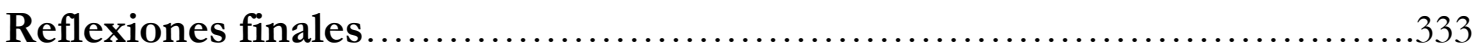

\section{PARTE IV}

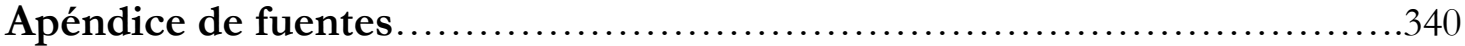

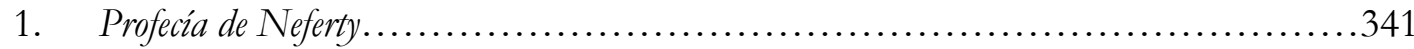

Comentario y argumento

Publicaciones

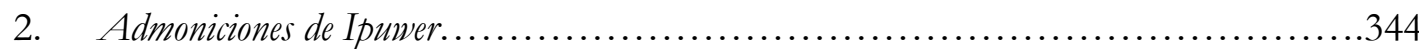

Comentario y argumento

Publicaciones

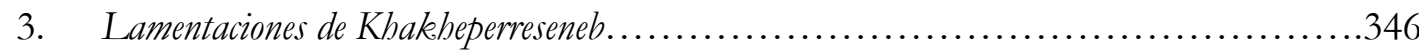

Comentario y argumento

Publicaciones

Cronología 
Abreviaturas 
AEL Loprieno, A. (Ed.). 1996. Ancient Egyptian literature. History and Forms. E.J. Brill, Leiden.

ANET Pritchard, J.B. (Ed.). 1950. Ancient Near Eastern Texts relating to the Old Testament. Princeton University Press, Princeton. Traducciones de textos egipcios a cargo de Wilson, J.A.

$\boldsymbol{A S A E} \quad$ Annales du Service des Antiquités de l'Egypte, El Cairo.

$\ddot{A A T} \quad$ Agypten und Altes Testament, Wiesbaden.

BIAE Bibliotheca Aegyptiaca, Édition de la Fondation égyptologique Reine Élisabeth Bruselas.

$\boldsymbol{B I F A O} \quad$ Bulletin de l'Institut Français d'Archéologie Orientale du Caire, El Cairo.

BMFA Bulletin of the Museum of Fine Arts, Boston.

BSEG Bulletin de la Société d'Egyptologie, Ginebra.

BSFE Bulletin de la Société Française d'Egyptologie, París.

$\boldsymbol{C d E} \quad$ Chronique d'Égypte. Bulletin périodique de la Fondation égyptologique Reine Élisabeth, Bruselas.

GM Göttinger Miszellen, Gotinga.

IFAO Institut français d'archéologie orientale, El Cairo.

JEA Journal of Egyptian Archeology, Londres.

JNES Journal of Near Eastern Studies, Chicago.

JAOS Journal of the American Oriental Society, Massachusetts.

$\mathbf{L} \ddot{A} \quad$ Lexikon der $\ddot{A} g y$ ptologie, Wiesbaden

LAE Simpson, W.K. (Ed.). 1973. The Literature of Ancient Egypt. An Anthology of Stories, Instructions, and Poetry. Vol. 1.Yale University Press, New Haven y Londres. Con traducciones de textos egipcios a cargo de Faulkner, R.O; Wente, E.F. y Simpson, W.K.

$\boldsymbol{M A ̈ S} \quad$ Münchner Ägyptologische Studien, Munich.

MDAIK Mitteilungen des Deutschen Instituts für Ägyptische Altertumskunde in Kairo, Berlín. 
OLA Orientalia Lovaniensia Analecta, Leuven.

$\boldsymbol{R} \boldsymbol{d} \boldsymbol{E}^{2} \quad$ Revue d'Égyptologie, París.

RIHAO Revista del Instituto de Historia Antigua Oriental, Facultad de Filosofía y Letras Universidad de Buenos Aires, Buenos Aires.

RITANC Kitchen, K.A. 2001. Ramesside inscriptions. Translated and annotated. Notes and comments. Blackwell, Oxford.

$\boldsymbol{S A K} \quad$ Studien zur altägyptischen Kultur, Hamburgo.

$\boldsymbol{V A} \quad$ Varia Aegyptica, San Antonio, Texas.

Wb Erman A. y Grapow, H. 1926-1961. Wörterbuch der ägyptischen Sprache, Berlín.

Z̈̈S Zeitschrift für ägyptische Sprache und Altertumskunde, Berlín. 
Introducción 
Hemos basado la hipótesis central de nuestro trabajo en el mito de origen del faraón. La dimensión que elegimos es uno de los aspectos menos estudiados del mito: su narración mítico-literaria. Tomamos como objeto de estudio a los dos últimos relatos escritos en uno de los manuscritos más conocidos, y no por ello más estudiado, el papiro Westcar.

Si tenemos en cuenta la tendencia a basar trabajos de investigación en una multiplicidad de fuentes, alguien podría suponer que es una equivocación pensar que un solo texto puede sostener una tesis. Sin embargo, uno de los objetivos generales de nuestro trabajo es revalorizar, dentro del campo egiptológico, a la fuente literaria, así como dar cuenta explícitamente del diálogo que un texto, como los relatos del papiro Westcar, puede establecer con otras fuentes.

En primer lugar, los relatos del papiro Westcar entablan una relación intertextual con otros relatos literarios contemporáneos. Observaremos que existe un mundo de ideas compartidas entre una multiplicidad de relatos, como Admoniciones de Ipuwer, Profecia de Neferty o Lamentaciones de Khakheperresenebu. Entre ellos hay en común la narración del recuerdo del pasado, un pasado que es codificado como caótico. Además, si bien también hay diferencias el papiro Westcar comparte con Profecía de Neferty una característica que es esencial: se narran profecías. Las especificidades de esa narración profética, sus formas narrativas con relación a la constitución del recuerdo y sus implicancias políticas con respecto a la legitimación del presente en la dinastía XII, serán parte de nuestro análisis. Por el lugar destacado que estos textos ocupan, es que al final de la tesis se propone un breve apéndice en el cual haremos una referencia a las investigaciones más relevantes realizadas en torno a ellos.

Dialogamos también con textos que han sido más bien analizados desde su aspecto político-administrativo, como Listas Reales, las cuales nos permiten interpretar los diferentes modos en que los egipcios se acercaron y construyeron su propio pasado. De este modo, estudiaremos cuáles son las particularidades de la creación del relato literario, desde su definición como texto de ficción y en relación a la figuración de un pasado. 
Consideramos que en los relatos literarios pueden divisarse distintos aspectos del pensamiento egipcio, y que no existen categorías válidas, indistintamente, para cualquiera de ellos. Todos responden a un mundo y a una creencia compartida, que como historiadores intentamos analizar. Los textos no están aislados, no son un eslabón perdido en el pasado, sino que son fruto de su propio tiempo y de un lenguaje compartido. Son un producto de lo histórico que les dio un contexto propicio para su creación, divulgación y discusión.

En segundo término, nos permitimos un diálogo continuo con otras disciplinas, como la teoría literaria o análisis más cercanos a la teoría cultural, que nos facilitan conceptos como recuerdo y memoria cultural. En este sentido, queremos destacar, que sólo recientemente la egiptología se ha abierto a teorías que van por fuera de las propiamente históricas, de aquellas que formaron desde sus inicios su campo historiográfico.

También observamos cómo la disciplina histórica abordó los textos literarios. Muchas veces los debates han discurrido en relación al texto en sí mismo, discutiendo el grado de verdad que un texto literario tuvo en relación al acontecimiento que narra. Pero no se ha avanzado en el análisis de los contextos de producción, motivación, finalidad o difusión del texto. Es decir, a las disputas de poder y a la reconstrucción ideológica-política que se realiza sobre ese pasado narrado en el texto.

En el presente trabajo recurrimos a conceptos y tradiciones analíticas como la memoria y el recuerdo. Los relatos del papiro Westcar, habilitan a reflexionar sobre el pasado egipcio, pero no al pasado en sí mismo, sino a cómo ha sido pensado ese pasado. Es decir, poder pensar las concepciones, ideas y valores que se pusieron en juego al momento de producirlo, que también significa rescatar que ha sido desechado e ignorado al momento de su elaboración.

Consideramos que la fuente literaria es parte constitutiva del pensamiento de una época, y a través de ella se expresan las potencialidades y limitaciones propias de la sociedad que las crea y aprehende. Estos textos generan sentidos de lo que es el orden, advierten cuáles son los peligros, infunden miedos, aleccionan sobre lo que tiene que ser y lo que es prohibido. En ningún momento hemos tratado de forzar 
correlaciones entre hechos históricos y textos literarios. Nuestra intención siempre ha sido comprender lo pensado, lo creado, hacer hincapié en cómo se forman y se modifican las ideas, cómo y por qué son utilizadas o descartadas.

Subyacen a la investigación otros dos objetivos generales. Por un lado, comprender a los textos literarios dentro de las múltiples formas de expresión cultural, política y social que se enuncian en ellos. Particularmente, en las ideas sobre la realeza egipcia durante el Reino Antiguo y el Reino Medio. En segundo lugar, abordar el texto literario en relación al discurso mítico-político que da sentido y legitima a la monarquía egipcia. Entendemos que un texto literario en el antiguo Egipto no es únicamente una narración de ficción, sino que convergen en él una multiplicidad de discursos y expresiones, ya sean políticas, míticas o religiosas. Por lo tanto, el uso que le damos a las fuentes literarias apunta a revalorizar el contexto en que fueron pensados los textos, sin perder de vista la propia cosmología de la sociedad que los (re)crea.

Recurrimos a la teoría de la memoria para comprender y examinar el discurso de los textos literarios. Por medio del concepto de memoria cultural de Assmann entendemos cómo las ideas fueron creándose, pues en los textos se refleja aquello que la sociedad quiere resguardar para su propio presente y su futuro. El recuerdo es un proceso de selección y figuración simbólica del pasado. Los textos literarios son una muestra de ello, pues en cada narración hay un modo de contar, de simbolizar y de estabilizar el recuerdo hacia el futuro. Detectar cuáles han sido estas elecciones y cuáles han sido los símbolos creados es nuestro trabajo.

En los dos últimos relatos del papiro Westcar el recuerdo no es sólo un aspecto central de su argumento. También sostenemos que, a través de él, pueden observarse los conceptos, imágenes y símbolos que en cierto tiempo delinearon uno de los aspectos centrales de la legitimación de la realeza egipcia, esto es, el mito de origen del rey.

El faraón, como centro de la monarquía, fue el protagonista de muchos de los relatos elaborados en el antiguo Egipto. Uno de ellos es el mito de origen del rey, en el cual se lo representó como hijo del dios. Esta descendencia divina le permitió al monarca legitimar su posición en el poder. Los relatos más completos de este 
mito nos han llegado del Reino Nuevo, el primero es el del nacimiento de la reina Hatshepsut y el segundo, el del faraón Amenofis III.

Este mito fue una de las tantas herramientas que se crearon para justificar la posición que el monarca ocupó dentro del sistema de gobierno egipcio. En este trabajo sostenemos cómo hipótesis que los dos últimos relatos del papiro Westcar son el relato de origen de un rey que específicamente, es la narración mítico-literaria del origen de la dinastía $\mathrm{V}$.

Nos centramos en tres puntos que nos permiten afirmarlo. En primer lugar, hay un tema central compartido entre los mitos de origen del rey del Reino Nuevo y los dos últimos relatos del papiro Westcar. En segundo lugar, las estructuras narrativas y argumentos se asemejan. Por último, en los dos últimos relatos del papiro Westcar se hacen presentes signos y símbolos míticos que los convierte también en relatos míticos.

Reconocemos que esta idea ha sido mencionada superficialmente por algunos investigadores, pero hasta el momento no existe ninguna investigación sistemática que compruebe esta afirmación. Es en este sentido nuestro trabajo novedoso y aporta un nuevo marco interpretativo para los textos literarios en general, al entrecruzarlos con el mito.

Asimismo, nuestra exégesis delimita cuáles son los símbolos que se han producido alrededor de la creación del mito de origen de la dinastía V. Afirmamos que en el relato lo histórico no está reflejado en su forma pura (si la hubiese), sino que lo que existe es su interpretación. El pasado es recordado literariamente, de tal modo que lo que construye es una forma de cómo ese pasado quiere ser recordado. A lo largo de nuestro trabajo quedará explícito cómo este recuerdo es construido literariamente en los dos últimos relatos del papiro Westcar.

En la investigación disentimos en algunos aspectos con quienes han analizado anteriormente la misma fuente. Hemos corroborado que no existe una gran cantidad de trabajos específicos que hayan examinado a los relatos del papiro Westcar desde una perspectiva amplia e integradora de lo social, lo cultural, lo mítico, lo religioso y lo político. Si bien los relatos están presentes en la mayoría de 
las antologías literarias, los investigadores se limitan a interpretarlas como un texto meramente ficcional.

Este tipo de abordaje ha llevado a considerar cada relato aisladamente y se ha desestimado una visión de unidad. Proponemos como hipótesis que puede establecerse una unidad entre ellos, que existe una unidad narrativa mínima común. Y agregamos una segunda hipótesis que establece que el quinto relato sólo guarda relación con el papiro, en tanto se vincula, a modo de anexo, al cuarto relato. Veremos que el relato anexo sólo mantiene relación de unidad con el cuarto relato, y en conjunto, estos dos últimos relatos del papiro Westcar forman una composición literaria única, justamente aquella que recuerda el origen de la dinastía $\mathrm{V}$ y que narra su mito de origen.

La tendencia entre los investigadores ha sido "leer" los textos literarios egipcios en clave de las formas modernas de la literatura. Esto ha conducido a categorizarlos dentro de géneros literarios, principalmente como cuentos fantásticos. Una parte de nuestro trabajo la hemos dedicado a establecer nuestra posición al respecto. Exponemos diferentes argumentos por los cuales nos permitimos discrepar con el uso de categorías fijas al momento de analizar textos literarios egipcios. Posición que se observa a lo largo de toda nuestra investigación, en la cual no nos referimos a los textos del papiro Westcar como cuentos, sino como relatos. Consideramos que este concepto es más amplio y nos permite contemplar la diversidad de discursos que se entrecruzan en él, y no hacer referencia únicamente a lo que los vincula con lo ficcional.

Examinaremos también los modos de producción y difusión de los textos egipcios dentro de su propio contexto. Si bien se presentan dificultades al respecto, nos parece fundamental reflexionar sobre ello. Indagamos sobre el posible origen de los relatos del papiro Westcar lejos del centro del poder monárquico, que luego los reproduce en forma escrita; y si se puede, además, hablar de un “autor”. En este sentido nos preguntamos acerca de la posibilidad de circulación y representación de los relatos.

Debemos hacer una mención sobre la metodología de trabajo que ha guiado nuestra investigación. En primer lugar, la exégesis siempre ha partido de lo 
que el texto por sí mismo nos dice o nos silencia. Es decir, primero hemos dejado hablar a la fuente, y luego surgieron las interpretaciones teóricas que nos permitieron encontrarle una explicación a lo que pensábamos que ella nos decía. Por ejemplo, nuestras primeras lecturas de los relatos del papiro Westcar nos sugerían que era una narración que iba más allá de la ficcionalización de un evento. Advertíamos que el recuerdo de sucesos era un argumento fuerte en ellos. De este modo, y a la luz de la teoría, nos permitimos considerarlos como la narración de un origen, lo que a su vez nos posibilitó avanzar sobre la suposición de que en ellos se narraba un mito.

La tesis se estructura en cuatro partes. Cada una de ellas responde a un núcleo temático: el mito como narración literaria, la memoria y el recuerdo en la literatura del Reino Medio egipcio; la literatura del Reino Medio y las discusiones específicas sobre el papiro Westcar; por último, un apéndice bibliográfico.

Esta división prioriza nuestra preocupación central: los dos últimos relatos del papiro Westcar y el mito de origen del rey. Es por ello que no seguiremos la tradicional partición por capítulos que generalmente se encuentran en las antologías y los estudios que analizan relatos literarios egipcios: ello es, una presentación de la fuente continuada por una discusión general sobre la literatura egipcia. Por el contrario, esta problemática será abordada al final de nuestro trabajo, cuando la comprobación de nuestra hipótesis sobre el papiro Westcar nos permita contraponerla con las que se han planteado anteriormente. Esta división permitirá al lector acercarse a ellas por separado sin perder el centro de lo que se quiere discutir.

En la primera parte el eje que guía el estudio es el mito como narración expresada literariamente. Nuestro objetivo es analizar los argumentos que vinculan a los dos últimos relatos del papiro Westcar con los mitos de origen del rey. En primer lugar proponemos la transliteración y traducción de los dos últimos relatos del papiro Westcar. Como consideramos que toda traducción implica una interpretación nos hemos detenido en hacer las referencias gramaticales y de significado que creíamos necesarias. A su vez, hemos comparado con otras 
traducciones y revisado las diferentes de pasajes más controversiales al momento de su traducción.

En el capítulo I, analizaremos cuáles son los temas recurrentes en los mitos de las dinastías XVIII y XIX, también presentes en los dos últimos relatos del papiro Westcar. Daremos cuenta de la importancia que tuvo en la realeza el aspecto divino del rey, para lo cual nos aproximaremos a un aspecto central de su naturaleza divina: el faraón como hijo de un dios, hijo de Ra.

En el capítulo II avanzaremos en la comprobación de la hipótesis, al examinar comparativamente el relato del papiro Westcar con las teogamias del Reino Nuevo. Pondremos en evidencia las similitudes y las diferencias entre ellos.

En el capítulo III nos detendremos a indagar sobre los diferentes símbolos míticos en los dos último de relatos del papiro Westcar. Analizaremos diferentes aspectos que se narran, lo que nos permitirá concluir una relación con lo mítico que va más allá de su estructura narrativa. Por ejemplo, indagaremos en los símbolos míticos alrededor de la fecha de nacimiento de los trillizos, la descripción de sus cuerpos y el rol de los dioses en el relato.

Hasta aquí la primera parte de nuestro trabajo de tesis. Luego, en la segunda parte, nos proponemos analizar los dos últimos relatos del papiro Westcar como relatos mítico literarios que se integran a las representaciones y discursos de la monarquía egipcia. Para ello, en el capítulo IV, indagaremos acerca de los orígenes de la literatura como medio de expresión en el Reino Medio, y delinearemos su relación con la política sostenida por la monarquía egipcia durante ese periodo. En el capítulo $\mathrm{V}$, relacionaremos los textos literarios egipcios con los aspectos propios de la memoria egipcia.

Posteriormente, en una tercera parte, en el capítulo VI realizaremos un recorrido sobre las diferentes ideas en relación a la literatura egipcia, especialmente cómo han sido analizados los relatos del papiro Westcar. En el capítulo VII daremos a conocer la historia del papiro, sus características formales y las discusiones específicas alrededor del manuscrito, cómo su datación. En el capítulo VIII indagaremos en la composición literaria como una unidad narrativa, sobre las 
diferentes unidades de sentido que encontramos en ella, ya sea argumental y estructural.

Por último, en una cuarta parte, realizamos un apéndice de las fuentes literarias con la cuáles más hemos dialogado: Profecía de Neferty, Admoniciones de Ipuwer y Lamentaciones de Khakheperresenebu. Indicamos allí su argumento y algunas de las discusiones establecidas entre los especialistas. Además, mencionamos cuales son las principales publicaciones de las transliteraciones y estudios de los textos.

En esta sección hemos incluido una cronología de la historia del antiguo Egipto. Ésta únicamente pretende ser un marco de referencia para fechas probables de los sucesos que aquí tratamos. No aspiramos realizar una discusión sobre las posibles cronologías, y dejamos abierta toda posibilidad de cambios que sobre ella discutan los especialistas en el tema. 
Aclaraciones 
En primer lugar, con relación a los nombres de los faraones, de los dioses y de las ciudades del antiguo Egipto se ha privilegiado la traducción más difundida dentro de la tradición egiptológica hispana. Así, por ejemplo, al rey Khufu se lo reconocerá como Keops y a la ciudad de Iunu como Heliópolis. Con relación a los nombres de los personajes de los relatos literarios se ha tomado el mismo criterio, y en algunos casos como el de la diosa Meshkeneh se ha optado por ser lo más fiel a la transliteración de su nombre ${ }^{1}$. Asimismo, se ha respetado en las citas textuales la traducción del nombre como la realiza el autor correspondiente, por lo que se observarán algunas discordancias en los nombres. Si fuese necesario, se aclarará con notas a qué personaje se está haciendo referencia.

Las traducciones de los relatos del papiro Westcar son íntegramente nuestras. Hemos realizado la traducción y transliteración completa de los dos últimos relatos del papiro ${ }^{2}$, y parcialmente de los otros del manuscrito que han sido de utilidad en el análisis. En ellas se indica la fuente de dónde se obtuvo y las líneas en el caso que corresponda. Así, el papiro Westcar se señala con las siglas $p W$. y a continuación el número de línea, por ejemplo $p W$. 9.10. Este tipo de traducciones se indican entre comillas y con letra cursiva. La letra cursiva también se emplea para conceptos egipcios para los cuales no contamos con traducción y significado en nuestro idioma, por ejemplo en el caso de ka o maat. Al igual que se emplea la letra cursiva cuando quiere destacarse un concepto importante.

Para algunas inscripciones y principalmente para las referencias bibliográficas, se indica en todos los casos el autor, el año de edición y la página. Éstas se señalan entre comillas y con tipografía normal. En el caso que el idioma original no sea el castellano, las traducciones a dicha lengua son nuestras. Se respetan de todos modos los títulos de las obras en su idioma original, y se traduce entre corchetes al castellano los nombres.

Con respecto a los nombres modernos que se han dado a los relatos, como Admoniciones de Ipuwer o Profecía de Neferty, éstos se indican con cursiva. Cuando se hace referencia al soporte, como por ejemplo el papiro Westcar o el papiro San

\footnotetext{
${ }^{1}$ Por lo general aparece como Meshkenet.

${ }^{2}$ Véase el apartado sobre traducción y transliteración de los dos últimos relatos del papiro Westcar.
} 
Petersburgo 1116B, mantendremos la tipografía habitual (letra normal). Mientras que son analizados brevemente sus argumentos, los textos literarios que son de principal interés en el presente estudio. En el apéndice de fuentes se consignan las principales discusiones que se han dado en torno a ellas. En el caso de otro tipo de fuentes, en la primera mención que se realiza, se indica en nota a pie de página, las principales publicaciones, traducciones, transliteraciones y toda la información pertinente sobre ellas.

Indicaremos con cursiva las referencias a otras fuentes no literarias como por ejemplo: los Textos de las Pirámides; Listas Reales; Libro del Amduat, Piedra de Palermo, Canon de Turín. De este modo se utiliza la referencia más usual empleada en el campo egiptológico para ellas.

Con respecto a algunos términos, hemos decidido por ejemplo que Hijo de Ra solamante se indicará con mayúscula en el caso que haga una referencia directa al quinto título real de los faraones egipcios. Será indicado en minúscula cuando refiera a una expresión, o simplemente esté señalada la filiación de los monarcas como hijos del dios Sol.

Asimismo se han incorporado mapas, imágenes y cuadros que facilitan al lector la compresión de los temas tratados. Agradezco a Ivana Siri quien contribuyó con sus conocimientos a la elaboración de algunas de las imágenes y mapas que aquí se exponen.

Por último, mi agradecimiento a Ada Salem quien leyó detenidamente el texto y realizó correcciones de redacción y estilo. 
PARTE

I 
Transliteración y traducción de los dos últimos relatos del papiro Westcar 


\section{Referencias de la transliteración y traducción de los dos últimos relatos del papiro Westcar}

(6.22): indica el número de la línea

[...]: indica que dicha parte del texto está borrada

$\{\quad\}:$ indica que dicho texto está restituido

\section{Transliteración y traducción del cuarto relato del papiro Westcar}

(6.22) ${ }^{\complement} h^{\ulcorner}\{p w\}$ ir $n$ s3-nswt ḥr-dd-f $f^{3}(6.23) r m d t^{4} \underline{d} d . f[\ldots]\{n\} s\{p\}^{5}[\ldots] m$ rht $n$ $n t y w^{6} s w 3^{7}$

(6.22) Después de esto el hijo del rey Hordedef (6.23) se puso de pie para hablar y dijo: "[...] en el conocimiento de aquellos que pasaron

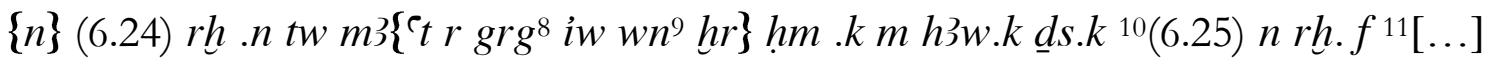
dd in ḥm.f

no (6.24) se sabe distinguir la verdad de la mentira. Hay bajo tu majestad en tu propio tiempo y es desconocido [...]. Entonces su majestad dijo:

\footnotetext{
${ }^{3}$ Traducimos "bijo del rey" por estar escrito el signo determinativo de hijo $s 3$, pero otra posibilidad es “el príncipe Hordedef” ya que su nombre finaliza con el determinativo [1982], p. 100) opta por traducir "Entonces se levantó para hablar el principe...".

${ }^{4}$ Verbo en infinitivo marcado por la $t$.

${ }^{5}$ Los únicos signos que pueden leerse son los siguientes ${ }^{2}$ mmn $\square$. El determinativo del hombre con la mano en la boca puede pertenecer a alguna palabra relacionada con los verbos "bablar" o "narrar". Los signos pueden tener relación con la palabra sp "suceder". Lefebvre (2003 [1982], p. 100) reconstruye "Tú has escuchado hasta abora", mientras que Lichtheim (1973, p. 217) "Hasta abora ha escuchado ejemplos" similar a Simpson (LAE, p. 22) que propone "Has escuchado ejemplos de". Aquí optamos por no traducirlo.

${ }^{6}$ Gardiner (2007 [1927], \$199 y p. 166) lit. "aquellos que".

${ }^{7}$ Gardiner (2007 [1927], p. 127).

${ }^{8}$ Gardiner (2007 [1927], \39) forma sdim.n.tw.f. Lit. "no se sabe la verdad más que la mentira". La fórmula $s \underline{d m} . n . f$ indica una forma pasiva del verbo, y aparecerá reiteradamente en la traducción, pues su uso se destaca en los textos de carácter literario, por lo general se opta su traducción por el tiempo verbal en pasado.

9 Gardiner (2007 [1927], \ 492 y p. 141) “no bay/no bubo".

${ }^{10}$ Gardiner (2007 [1927], § 35).

${ }^{11}$ Lo que sigue en el manuscrito está muy dañado. Decidimos traducir igual que la nota 4 . La opción de Lefevbre (2003 [1982], p. 100) fue incorporar a la traducción: "Pero hay, bajo tu Majestad, en tu propio tiempo, alguien, que no es conocido por ti, y que es un gran mago".
} 


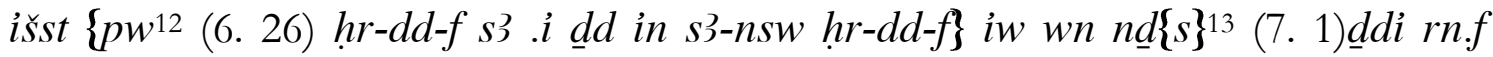
hms.f mdd snfrw me-hrw

“QQuién es? Hordedef, mi hijo”. Entonces el hijo del rey Hordedef dijo: "Hay un $n \underline{d} s$, (7.1) su nombre es Djedi, el vive en (la ciudad) de DjedSnefru ${ }^{14}$, justificado.

iw.f $m$ (7.2) nd $n$ rnpt 110 iw.f hr wnm t $500 \mathrm{rmn}^{15} \mathrm{n} \mathrm{k} 3 \mathrm{~m}$ (7.3) iwf ḥn swri ${ }^{16}$ hnktw ds $100 \mathrm{mn} \mathrm{m} \mathrm{hrw} \mathrm{(7.4)} \mathrm{pn}$

El es un (7.2) $n \underline{d} s$ con 110 años, él es quien come 500 panes y media medida de carne (7.3) de buey que bebe 100 jarras de cerveza hasta el día de hoy ${ }^{17}$.

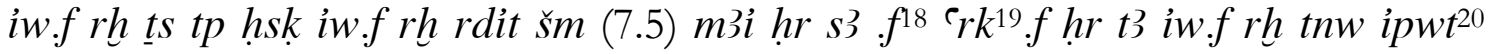
(7.6) $n t$ wnt nt $\underline{\text { dhwty }}$

(7.4) El sabe unir la cabeza cortada y sabe hacer caminar un (7.5) león detrás de él (que está) atado en la tierra. El sabe los números de la cámara secreta (7.6) del santuario del dios Toth.

${ }^{12} \mathrm{El}$ interrogativo ¿que? išst seguido de $p w$ en algunos casos puede significar “¿quién?”. Ver Gardiner (2007 [1927], \500.1), comprendemos que para que adquiera este significado suele estar acompañado por $n t y$, no sería el caso para el papiro Westcar. De todos modos, aquí por el sentido de la oración optamos por "¿Quiés es?".

${ }^{13}$ Optamos por no traducir la palabra $n \underline{d} s$. Su significado no se traduce a ninguna en español. Gardiner (2007 [1927], p. 167) nd s significa "(ser) pequeño, pobre, débil..." y con determinativo de $n \underline{d} s w$ significa "hombre pobre, corriente". Lefebvre (2003 [1982], p. 100) opta por utilizar "burgués", Quirke (2004, p. 83) “compañero", Lichtheim (1973, p. 217) “bombre". Lepper (2008, p. 41) "persona": "menschen".

${ }^{14}$ La ciudad ubicada cerca de la pirámide del rey Snefru en Meidum. El nombre de la ciudad se compone con el del faraón Snefru que está escrito dentro del cartucho y seguido por $m 3^{\circledR}-h r w$. El nombre de la ciudad significa "Snefru es perdurable".

${ }^{15}$ La medida es media arura (Gardiner 2007 [1927], p. 577).

${ }^{16}$ Gardiner (2007 [1927], p. 581) preposición hn` más infinitivo.

${ }^{17}$ Lit. " "basta este día"

${ }^{18}$ Lit. "El léon camina su cara sobre el dorso (del mago)". La idea es que el mago puede hacer caminar un león detrás de su espalda sin que sufra un ataque.

${ }^{19}$ El signo $\uparrow$ c $r k$ debería también entenderse como "cuerda", pero el uso que tiene en aquí como aclara Eyre (1992, p. 281) es incierto.

${ }^{20}$ Gardiner (1925) ha dedicado un artículo en relación a este término. El autor propone leer ipwt como "cámara secreta". Al respecto véase Berggren (2006). 


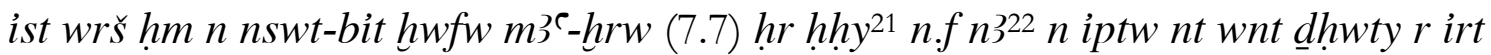
n.f mitt

Entonces, la majestad el rey del Alto y Bajo Egipto Keops, justificado, pasaba todo el día (7.7.) buscando para él las cámaras secretas de Toth para hacer para él lo mismo

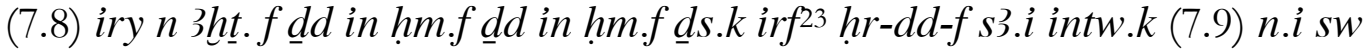

(7.8) para su horizonte. Entonces su majestad dijo: “Tu mismo Hordedef, hijo mío, deberías traerlo (7.9) para mí”.

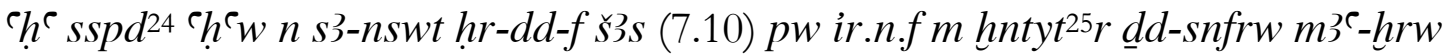

Entonces los barcos fueron preparados para el hijo del rey, Hordedef. (7.10) Este viaje que él realizó navegando hacia el sur hacia (la ciudad de) DjedSnefru, justificado.

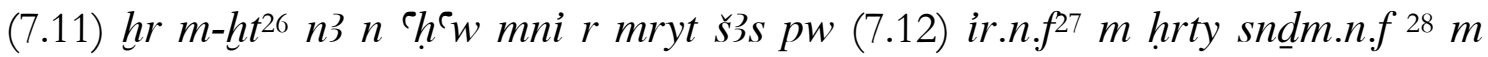
$\{k n\}$ iw n hbny

Después de esto los barcos fueron amarrados en la orilla del río. (7.12). Él hizo que éstos viajaran por la tierra. Él se acomodó en una silla portátil de ébano

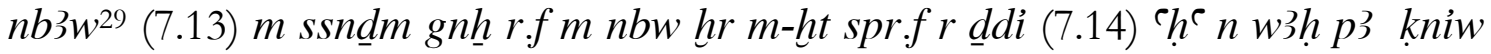
‘he pw ir.n.f

con varas de buena madera (7.13) engastadas en oro. Después él se acercó a Djedi (7.14) y entonces esta silla portátil fue colocada (sobre el suelo). Éste se puso de pie ${ }^{30}$

\footnotetext{
${ }^{21} h r$ más infinitivo expresando causa concomitante.

${ }^{22}$ Demostrativo plural neutro.

${ }^{23}$ Gardiner (2007 [1927], \$252.c).

${ }^{24}$ La formación verbal es $s \underline{d m} . f$ más pasiva dada por el determinativo $s$.

${ }^{25}$ La traducción de hntyt en Faulkner (1991, p. 168) "viaje hacia el sur". Traducimos navegando hacia el sur para darle más sentido a la oración, teniendo en cuenta que está el determinativo de la barca.

${ }^{26}$ Es una construcción: "en el momento de, después de, como resultado de, luego de, a continuación de...".

${ }^{27} \mathrm{Si}$ bien es la misma construcción que en 7.10 la traducción varía para darle un mejor sentido a las frases.

28 Verbo causativo, Gardiner (2007 [1927], \ 275). Si bien no tiene el determinativo traducirlo como "sentarse" por ajustarse mejor al sentido de la oración.

${ }^{29}$ Es una vara y también una medida de longitud. Gardiner (2007 [1927], \266.2).

${ }^{30}$ Lit. "el hizo"
} 


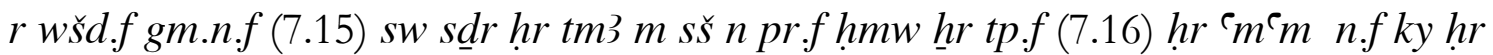
$\sin r d w y . f y$

para saludarlo. Él lo encontró (7.15) acostado sobre una estera en el umbral de su casa. Un esclavo sosteniendo su cabeza (7.16) le untaba su cara, y otro le frotaba sus dos pies.

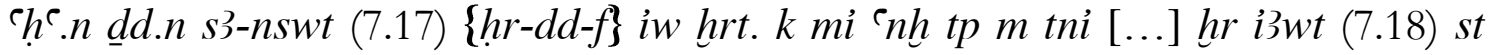
mni krs st sm3 t3 $3^{31}$ sdr $r(7.19)^{32} \check{s} s p^{33}$

Entonces se levantó el hijo del rey (7.17) Hordedef y dijo: "Tu condición es como la vida antes del envejecimiento, ya que la vejez (7.18) es el lugar de la muerte, es el lugar del entierro, es el lugar para unirse a la tierra y pasar unida (a ella) toda la noche hasta el amanecer,

šw $m$ ḩ̧yt nn khkht nt sryt nd (7.20) hr\{t\} im3hy pw ${ }^{34}$ ỉ.n.i 9 r nis r.k $m$ wpwt (7.21) nt it.i hwfw m3e-hrw

(7.19) libre de enfermedad, sin ataques de tos". (Así se) saluda a este (hombre) venerable. He venido (hasta) aquí para llamarte con el mensaje (7.20) de mi padre Keops, justificado.

wnm.k špssw $n d d^{35} n s w t \underline{d} f 3 w$ (7.22) $n$ imyw šmsw.f sb.f tw $m$ `ḥw nfr $n$ itw.k (7.23) imyw hrt-ntr

Tú comerás cosas exquisitas que él da, y las provisiones (7.22) de los que están en su séquito, y él te unirá luego de una vida feliz con tus antepasados (7.23) que están en la necrópolis.

\footnotetext{
${ }^{31}$ Se utiliza la misma construcción anteponiéndose st para indicar "el espacio, el momento o el lugar de..." y luego el sustantivo.

32 Hay varias interpretaciones alrededor de $p W .7 .17-19$. Por un lado, Erman (1889, p. 46) sugiere que $h r$ es una preposición. Gilula (1978, p. 46) afirma que $h r$ debe aceptarse como una partícula no enclítica que introduce una nueva oración, siguiendo lo que Faulkner interpreta de igual modo para Pyr. 604c.

33 Tanto Quirke (2004, p. 84) como Sánchez Rodríguez optan por la transliteración šsp según lo que propone Gardiner según la fonética del signo ${ }^{\$ 999}$. En cambio acordamos en el uso de la transliteración $s \breve{p}$ que también es utilizada por Lepper (2008, p. 43), que es válida para Gardiner para el grupo de signos $\odot$ “luz del día" que aquí optamos interpretar como "amanecer".

34 También puede traducirse como "Este saludo a un venerable", optamos por la otra traducción para darle mayor énfasis literario al texto. Además estamos de acuerdo lo que plantea Lefebvre (2003, p. 101 nota 53) que aquí un narrador interrumpe las palabras del hijo del rey para mostrarle a la audiencia cómo se debe hablarle a un hombre respetable como Djedi.

${ }^{35}$ Forma geminada del verbo $r d i$ antecedida por un predicado nominal $n$ (Gardiner 2007 [1927], \& 134).
} 


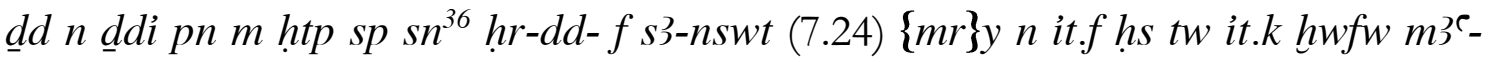
hrw šhnt.f $f^{37}(7.25)\{s\}$ t.k $m$ ỉww

Entonces este Djedi dijo: “¡Estés en paz, en paz Hordedef, hijo del rey, (7.24) amado de su padre! Que tu padre Keops, justificado, te favorezca. Y él promoverá (7.25) tu rango entre los ancianos.

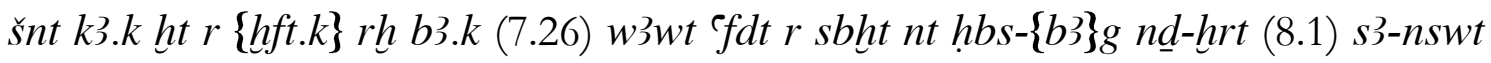
$p w$

¡Que tu ka conjure acciones contra tus enemigos! ¡Que tu ba conozca los caminos que conducen hacia la puerta de Hebesbag38!”. (Es así cómo) se saluda al hijo del rey.

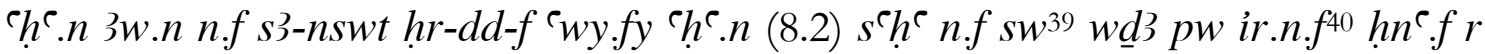
mryt ḥr rdt $n . f^{\complement} f$

Entonces el hijo del rey Hordedef le extendió sus (dos) brazos y (8.2) 10 levantó y entonces lo condujo junto a él hasta la orilla dándole su mano.

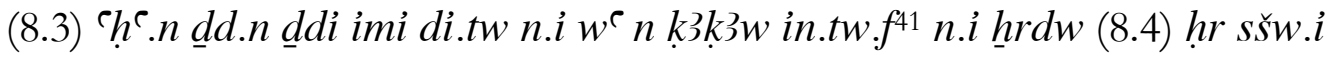

(8.3) Entonces Djedi dijo: "Haz que se me otorgue una barca que me traiga a mis hijos (8.4) y mis libros".

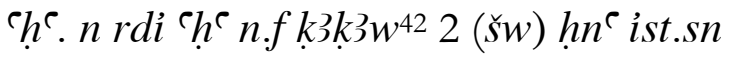

Entonces se hizo que se dispusiera para él dos barcas junto con sus tripulaciones.

\footnotetext{
${ }^{36} \mathrm{La}$ fórmula $s p s n$ indica que la última palabra o parte de ella debe repetirse dos veces.

${ }^{37}$ El significado de shnt en Faulkner (1991, p. 242).

${ }^{38}$ Hebesbag es el nombre propio del "demonio" que cuida de las puertas de acceso al Más Allá, aquí su significado "Aquél que esconde/oculta (hbs) al muerto (b3g)". Para Serrano Delgado (Lefebvre 2003 [1982], p. 102 nota 56) también puede significar el nombre propio de algunas de las puertas o espacios del Más Allá. Algunos autores consideraron que refiere al nombre antiguo de la necrópolis de la ciudad de Heracleópolis.

39 Lit. "Entonces él lo levanto"

${ }^{40}$ Esta es la construcción $s d \underline{d}$ pw ir.n.f su uso se destaca en los textos de carácter literario del Reino Medio, en esta forma se indica la acción como un sustantivo verbal (Gardiner 2007 [1927], \ 392).

${ }^{41}$ Lit: "que ella me traiga", in.tw.f

42 Aquí no aparece la palabra completa, sólo el signo o ideograma de la barca
} 
iwt pw iry. $n^{43}(8.5) \underline{d}$ di $m$ hd $m$ wsh nty s3-nswt hrr-dd-f im.f $f^{44}$

Entonces (8.5) Djedi navegó hacia el Norte en una barcaza en la que estaba el hijo del rey, Hordedef.

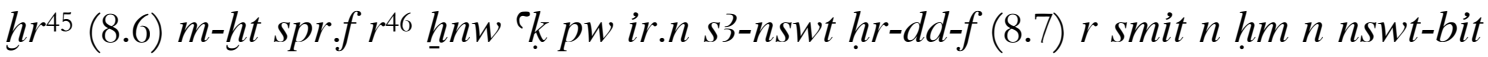
$h w f w m^{3}-h r w$

Después (8.6) él llegó a la Residencia, entonces este el hijo del rey Hordedef entró (8.7) para informarle a la majestad del rey del Alto y Bajo Egipto Keops, justificado.

dd in s3-nswt (8.8) hr-dd-f ity 'nh wd snb nb.i iw ini.n.i ddi dd.in (8.9) hm.f is in n.i $s w$

El hijo del rey, (8.8) Hordedef dijo: "Soberano, v.p.s., mi señor he traído a Djedi". Y su majestad dijo (8.9): "Ve y tráemelo".

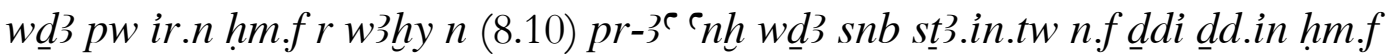

Entonces su majestad fue hacia la sala de recepciones de la (8.10) Gran Casa, v.p.s. y Djedi fue llevado frente a él. Entonces su majestad dijo:

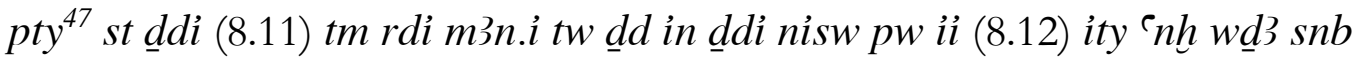

“QQué es esto, Djedi (8.11) por qué tú no me has permitido verte antes?”. Entonces Djedi dijo: "El que es llamado es quien viene, (8.12) soberano v.p.s.".

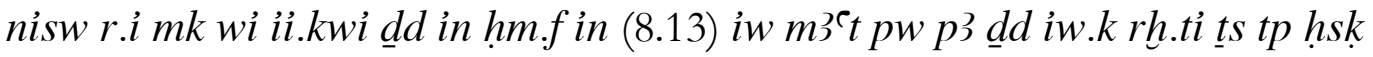

Me ha llamado y mira, ¡he venido! Entonces su majestad dijo: “ $¿ E s$ (8.13) verdad qué tu sabes (como) unir una cabeza cortada?”.

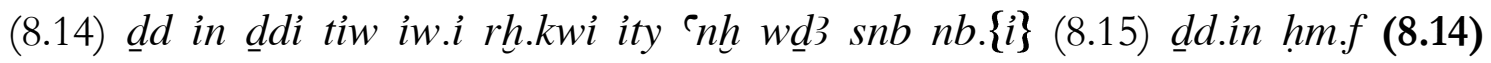
Entonces Djedi dijo: “Si, yo sé soberano v.p.s., mi señor”. (8.15) Entonces su majestad dijo:

\footnotetext{
43 Aquí aparece nuevamente la forma pasiva de la fórmula de la nota 37 s $d m$ pw iry. Lit. "fue un venir lo que bizo".

${ }^{44}$ Lit. "que el hijo del rey Hordedef estaba en ella".

45 Aquí una variación de la proposición $h r \stackrel{\ominus}{\ominus}$ por $\varrho^{\ominus}$.

46 Similar $m$-ȟ spr.f $r$ en línea 7.13.

${ }^{47}$ En Gardiner (2007 [1927], \ 497.3) la partícula interrogativa pty con pronombre dependiente como sujeto real o sustantivo.
} 


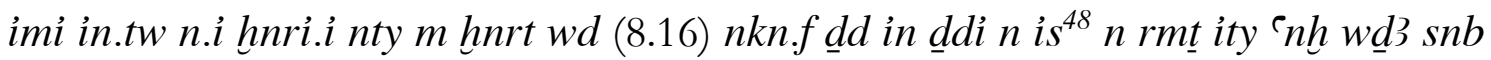
$n b .\{i\}$

“Que se me traiga (uno) de mis prisioneros que está en la prisión para que se ejecute (8.16) su sentencia". Entonces Djedi dijo: "No con humanos soberano v.p.s., mi señor.

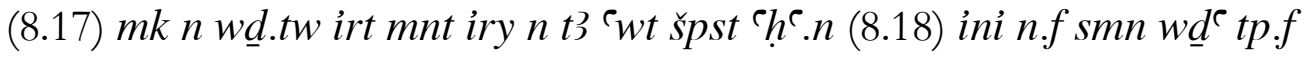

(8.17) ¡Mira, no se puede ordenar hacer algo así con el noble rebaño!”. Entonces (8.18) le fue traído un ganso con su cabeza cortada.

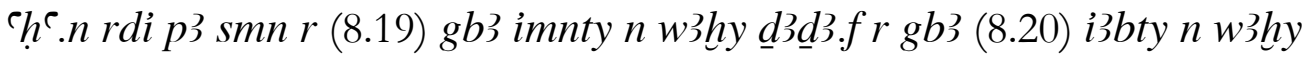

Entonces este ganso fue colocado en el (8.19) lado occidental de la sala de recepciones y su cabeza en el lado (8.20) oriental de la sala de recepciones.

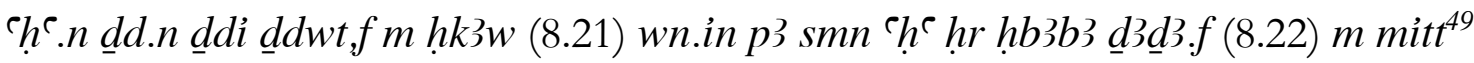

Entonces Djedi recitó sus palabras mágicas (8.21) y el ganso se levantó sobre sus patas (8.22) del mismo modo que su cabeza,

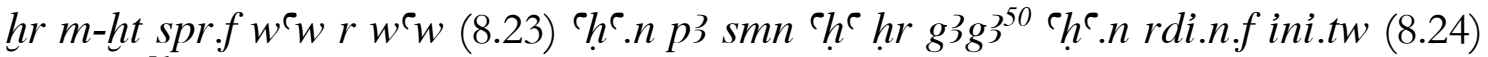
n.f ht- ${ }^{351}$ ir.n.tw r.f m-mitt

y a continuación se acercaron la una con la otra (8.23) y el ganso se levantó cacareando. Entonces él hizo que se le trajera (8.24) un ganso khetaa y lo mismo se hizo para él.

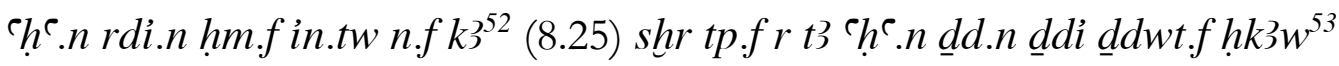

Entonces su majestad hizo que se le trajera un toro (8.25) cuya cabeza fue derribada sobre el suelo.

\footnotetext{
48 Gardiner (2007 [1927], \120) $n$ is oración con predicado adverbial.

${ }^{49}$ Faulkner (1991, p. 104).

${ }^{50}$ Faulkner (1991, p. 288).

51 Significa "gran leño". Es un ave de corral, aparece mencionada en el papiro Harris.

52 Esta oración 8.24 ha sido analizada por Derchain (1986, pp. 15-17), quien acuerda con Vernus que este pasaje le da "gusto" a la escena, generándose un gran dramatismo.

53 Idéntica a 8.20 .
} 


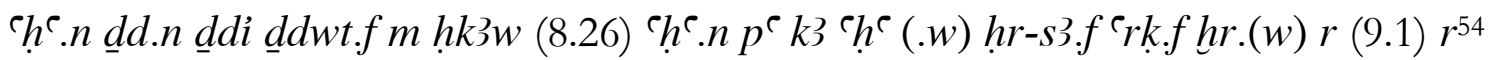
$t 355$

Entonces Djedi recitó sus palabras mágicas (8.26) y éste se levantó sobre su espalda con su cinta caída (9.1) sobre el suelo.

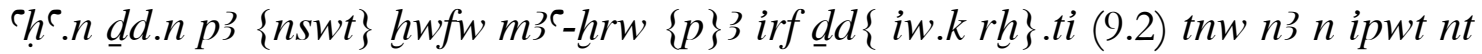
$\{w n t\} n t\{\underline{d} h w t y\}^{56}$

Entonces el rey Keops, justificado, dijo: "Se dice que tu sabes (9.2) los números de la cámara secreta del dios Toth".

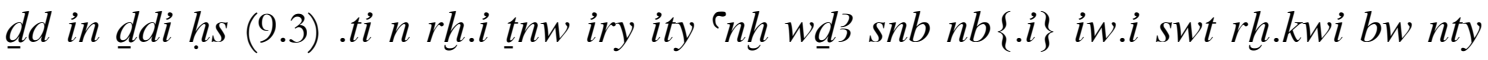
(9.4) st im

Entonces Djedi dijo: "Estés favorable (9.3), yo no conozco su número, soberano, v.p.s., mi señor. (Pero) yo (si) he conocido el lugar dónde está".

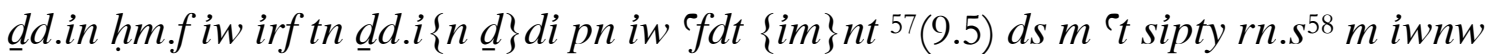
$m k$ st $m$ t 3 'fdt

(9.4) Su majestad dijo: “¿Dónde está?”. Entonces éste Djedi dijo: “Hay un cofre secreto (9.5) de sílex en la habitación llamada del Inventario en Heliópolis. ¡Mira! está en ese cofre”.

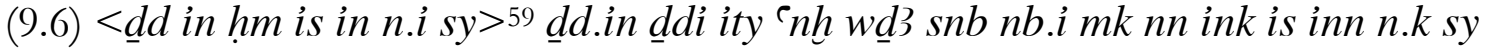
Su majestad dijo: "Ve y tráemelo". Entonces Djedi dijo: "Soberano, v.p.s., mi señor. ¡Mira! No seré yo quien te lo traerá”.

\footnotetext{
${ }^{54}$ Aquí el signo $r$ está duplicado por error del escriba.

55 Esta frase es controversial. Por un lado, porque el signo $\uparrow$ puede ser interpretado de dos modos. Uno como sšd "cinta" por ejemplo así lo considera Lepper (2008, p. 42). Un segundo significado como 'rk "atar/atadura", así lo traduce Sánchez Rodríguez (2003, p. 63). Por otro lado están quienes consideran que esta frase no corresponde a la acción realizada por el toro, sino que el escriba se confunde y olvida escribir el acto mágico realizado con un león que Hordedef había prometido a su padre que Djedi sabía realizar (Lefebvre 2003 [1982], p. 103).

56 Véase nota 17.

${ }^{57}$ No tiene el determinativo

58 Véase Faulkner (1991, p. 212).

${ }^{59}$ Esta oración está completa en Blackman $(8,19-9,9)$ pero no es tomada por todas las traducciones. López (2005, p. 59) interpreta que aquí el escriba se olvida de copiar una frase. Quienes sí la traducen: Lefebvre (2003 [1948], p.103) "SSu majestad dijo: 'Ve y trámelo'?”; Lichtheim (1973, p. 219) "Said his majesty: ["Go, bring it to me]"; Simpson (LAE, p. 25) "His Majesty said: Hasten, Bring it to me]"; López (2005, p. 95) "Su Majestad dijo: Ve y tráemelo". Mientras que otras traducciones (Sánchez Rodriguez 2003, p. 66; Lepper 2008, p. 46) directamente remiten a las palabras de Djedi toman el dd.in $\underline{d} d i$ "Entonces Djedi dijo...".
} 
dd.in hmm.f in $m$ rf (9.7) in.f n.i sy dd.in ddi in smsw ${ }^{60} n$ p3 hrdw 3nty $m$ ht $n$ (9.8) $r(w) d-\underline{d} d t$ in.f $n . k s y$

Entonces su majestad dijo: “¿Quién (9.7) me lo traerá?”. Entonces Djedi dijo: "El mayor de los tres niños (quien) está en el vientre de (9.8) Reddjedet te lo traerá".

dd.in hm.f mrr.i is st $n 3 \underline{d} d y . k$ pty (9.9) sy t3 r(w)d-d dt

Entonces su majestad dijo: "Yo deseo lo que tú dices. Pero, ¿quién es (9.9) esta Reddjedet?”.

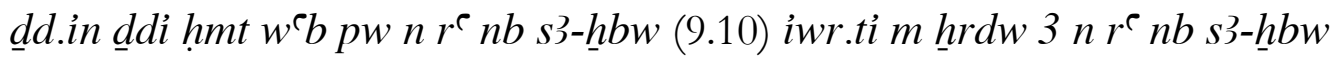

Entonces Djedi dijo: "Es la esposa de un sacerdote wab de Ra, señor de Sakhebu (9.10) embarazada de tres hijos de Ra, señor de Sakhebu".

iw $\underline{d}$ d.n.f r.s iw (9.11) .sn r irt i3t twy mnhwt m t3 pn $r \underline{d}$ r.

Ra ha dicho de ellos que (9.11) realizarán esta función excelente sobre todo el país entero,

iw smsw n.sn (9.12) imy r irt wr m3w $w^{61}$ m iwnw

y el mayor de ellos (9.12) será Grande de los Videntes en Heliópolis.

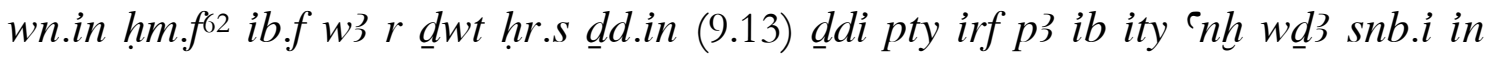
ir.tw hr p3 (9.14) $\underline{h} r d w 3 \underline{d} d . n . i$

Por lo tanto, el corazón de su majestad se entristeció por ello. Entonces Djedi dijo (9.13): “¿Qué es esta tristeza soberano v.p.s., mi señor? ¿Es por motivo de los (9.14) tres niños que he dicho?”.

$k 3^{63}$ s3.k k3 s3.f k3 ww im.s ${ }^{64} \underline{d} d$ in $h m .\{f\}(9.15)$ ms.s irf sy $n w r(w) d-\underline{d} d t$

Piensa, tu hijo, luego su hijo, luego uno de ellos. Entonces su majestad dijo: (9.15) “¿Cuándo dará a luz Reddjedet?”.

\footnotetext{
${ }^{60}$ Claramente lo que aquí el texto pretende señalar es que será el mayor de los niños quién le dará esa información a Keops. De todos modos, podemos sugerir dos transliteraciones para "mayor". Una como wr (Gardiner) aceptada por Sánchez Rodríguez (2003, p. 66), que también significa "principe", por lo que podemos suponer un juego de palabras empleado por el escriba. La segunda como smsw "el mayor, mayor" aceptada por Quirke (2004, p. 85) y Lepper (2008, p. 46).

${ }^{61}$ Respecto a este título sacerdotal véase capítulo I.

${ }^{62}$ Construcción wn.in.f Gardiner (2007 [1927], \ 470).

${ }_{63}$ Optamos aquí traducir $k 3 i$, es decir como verbo "pensar sobre" (Faulkner 1991, p. 283) y no como partícula enclítica $k 3$, como sí lo tomamos luego.

${ }^{64}$ Lit. "uno de ella", pero traduciomos "uno de ellos" por el sentido de la oración.
} 
dd.in $\underline{d}$ di ms.s $m$ 3bd 1 prt sw $15 \underline{d}$ d.in (9.16) hm.fi iw.s ti tsw nw rmwy ${ }^{65}$ hsk

Entonces Djedi dijo: "Ella dará a luz el día 15 del primer mes de la estación prt”. Entonces su majestad dijo (9.16): “ ¿Es cuando los bancos de arena del canal de los Dos Peces quedan al descubierto?”.

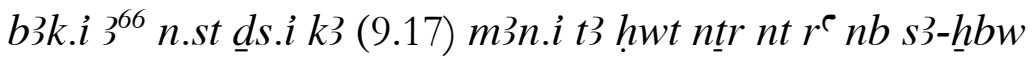

Mi señor, yo los abriré por mi mismo así (9.17) se verá el templo de Ra, señor de Sakhebu.

dd.in didi k3 rdi.i (9.18) hpr mw nw mh 4 hr tsw nw rmwy

Entonces Djedi dijo: “Así, yo haré (9.18) que haya 4 codos de agua sobre el canal de los Dos Peces".

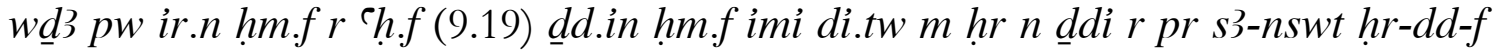
$h m s . f(9.20) h h^{\top} . f$

Su majestad se dirigió hacia su palacio (9.19) y entonces su majestad dijo: "Que se envíe a Djedi a la casa del hijo del rey Hordedef y que viva (9.20) junto a él.

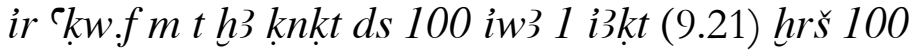

Que le sean dados mil panes, cien jarras de cerveza, un buey y cien paquetes de (9.21) puerros".

ir.in.tw mi wdwt nbt hmm.f

Todo fue hecho como lo ordenó su majestad.

${ }^{65}$ Aquí no hay coincidencias en la transliteración. Para Quirke (2004, p. 86) "Canal de los Dos Peces" se translitera como lo entendemos aquí: rmwy que es el plural del término rm "pez" (Faulkner 1991, p. 149). Mientras que Sánchez Rodríguez (2003, p. 70) opta por ha $3 r-\underline{h} 3 r$. Por otro lado Lepper (2008, p. 47) '3wi.

${ }^{66}$ Véase Faulkner (1991, p. 1). 


\section{Transliteración y traducción del anexo al cuarto relato del papiro Westcar}

w`w m nn hrw wn.in (9.22) r(w)d-d्dt ḥr šnt.s ksn mss.s

Uno de aquello días aconteció que (9.22) Reddjedet estaba sufriendo y su parto era difícil.

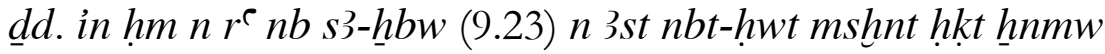

Entonces su majestad Ra, señor de Sakhebu, dijo a (9.23) Isis, Neftis, Meshkeneh, Hequet y Khnum:

hwy 3 33s.tn (9.24) smsy67.tn $r(w) d-d d t m p 3 \underline{h} r d w 3$ nty $m \underline{h}$ t..$^{68}$

"Quisiera que ustedes vayan (9.24) a asistir el parto de los tres niños que están en el vientre de Reddjedet,

nty r irt i3tw (9.25) twy mnhwt m t3 pn $r \underline{d} r . f^{69}$

quienes cumplirán (9.25) esta función excelente sobre este país entero.

kd.sn rw-prw.tn (9.26) sdf3y.sn ḩ3wwt.tn sw3 $\underline{d} . s n$ wdhw.tn s $3 y$ (9.27).sn htpw$n \underline{t}$.tn

Ellos construirán vuestros templos (9.26), abastecerán vuestros altares, enriquecerán vuestras mesas de ofrendas y ellos harán grande (9.27) vuestras ofrendas divinas".

wdי 3 pw ir.n nn ntrw ir.n.sn hprw (10.1).sn $m$ hnwt/hnyt70 $\underline{h}\{n\} m w$ hn'.sn hr kni

Estos dioses se marcharon y ellas (las diosas) (10.1) tomaron la forma de cantantes/bailarinas, junto a ellas Khnum estaba llevando una valija.

spr pw ir.n (10.2).sn $r$ pr $\{w s r\}-r^{\complement}$ gm.n.sn $\{s w\} h^{\complement} \underline{d}$ diw shd

Luego éstos se acercaron (10.2) a la casa de Rauser ${ }^{71}$ y lo encontraron de pie con sus ropas dadas vuelta.

\footnotetext{
${ }^{67}$ En Faulkner (1991, p. 229).

${ }^{68}$ Aquí hemos optado por invertir el orden de la oración y dejar el nombre de Reddjedet al final y obviar el pronombre personal s.

${ }^{69} r \underline{d} r . f$ como "entero" en Gardiner (2007 [1927], p. 194).

${ }^{70}$ En realidad el término designa al músico de género femenino (Faulkner 1991, p. 192).

${ }^{71}$ Aquí la primera mención del esposo de Reddjedet, un sacerdote de Ra cuyo nombre significa " $\mathrm{R} a$ es poderoso".
} 
$\{w n\} . i n .\{s n\}$ hr ms n.f mniwt.sn shmw ${ }^{72}{ }^{\top} h^{\top} . n \underline{d} d . n . f n . s n(10.4) h n w t . i\{m t n\} s t$ pw ntt hr mn.s ksn ms.s

(10.3) Entonces ellos le presentaron a él sus collares menat y sistros. Entonces él les dijo: (10.4) “Mis señoras, miren esta mujer está sufriendo y su parto es doloroso".

‘ hִ .n $\underline{d}$ d.n (10.5).sn di.k m3.n $\{$ sy\} mk $n$ rh.wyn smsy

Entonces ellas dijeron: "Permite que podamos verla. Mira, nosotras sabemos sobre el parto".

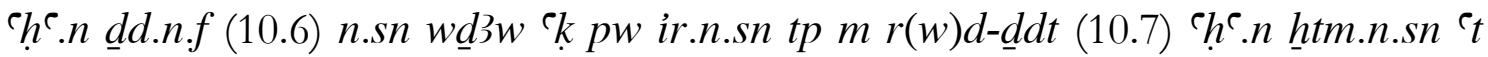
hr.s hhe.s

Entonces él les dijo (10.6): “Proceded”. Éstas entraron ante Reddjedet (10.7) y se encerraron en la habitación junto con ella.

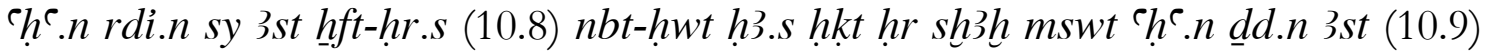
im.k wsr $m$ ht.s $m$ rn.k pwy $n$ wsr-rf

Entonces Isis se colocó enfrente de ella (10.8) y Neftis detrás de ella, (mientras que) Hequet aceleraba el parto. Entonces Isis dijo: (10.9) "No seas poderoso en su útero, éste es tu nombre Useref ${ }^{73 "}$.

$w^{\top} r$ (10.10).in hrd pn tp `wy.sy $m$ hrrd $n$ mh rwd ${ }^{\top 4}$ ksw.f nhbt (10.11) `wt.f $m$ nbw 'fnt.f $m$ hsbd $m)^{\text {? }}$

Este niño se escurrió (10.10) sobre sus manos como un niño de un codo (de largo). Sus huesos eran fuertes y la cobertura de sus (10.11) miembros era de oro y su tocado de verdadero lapislázuli.

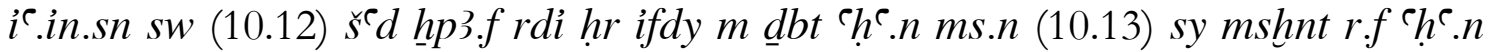
dd.n.s

Entonces ellas lo lavaron (10.12) y cortaron su cordón umbilical y lo colocaron sobre un asiento de ladrillos. Entonces (10.13) Meshkeneh se le presentó ante él y dijo:

\footnotetext{
72 Aquí optamos la traducción de sḥm por "sistro" y no "cetro" siguiendo el contexto de la oración, al considerarse que las diosas se habían convertido en músicas (véase Faulkner 1991, p. 241).

${ }^{73}$ Con este nombre se identifica al primer faraón de la dinastía V, Userkaf. Useref significa "más poderoso que ép'.

${ }^{74}$ Véase Faulkner (1991, p. 148).
} 
nswt ir.ty.fy $y^{75}$ nsyt $m$ t3 $p n$ (10.14) $r \underline{d} r f^{76} \underline{h} n m w$ hr swd $\underline{1} h^{\top} w . f$

“Será un rey que ejercerá la realeza (10.14) sobre esta país entero", (mientras) que Khnum hizo saludables sus miembros.

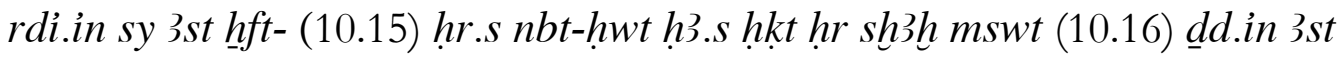

Isis se colocó (10.15) enfrente de ella y Neftis detrás de ella, (mientras que) Hequet aceleraba el parto. (10.16) Isis dijo:

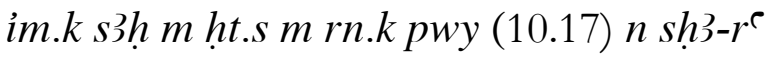

"No te retrases en su útero, éste es tu nombre (10.17) Sahra ${ }^{77 "}$

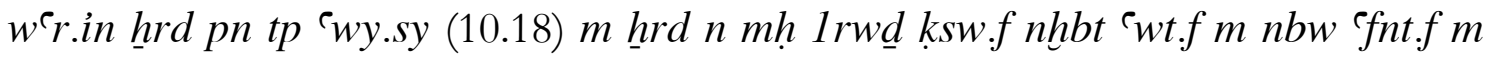
hsbd (10.19) $m 3^{\mathrm{C}}$

Este niño se escurrió sobre sus manos (10.18) como un niño de un codo (de largo). Sus huesos eran fuertes y la cobertura de sus miembros era de oro y su tocado de (10.19) verdadero lapislázuli.

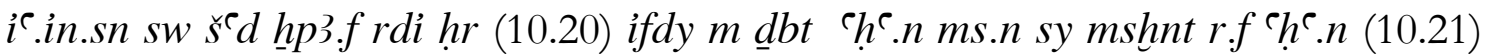
dd.n.s

Entonces ellas lo lavaron y cortaron su cordón umbilical y lo colocaron sobre (10.20) un asiento de ladrillos. Entonces Meshkeneh se le presentó ante él y (10.21) dijo:

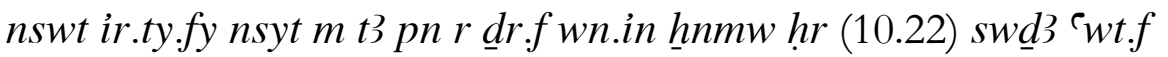

"Será un rey que ejercerá la realeza sobre este país entero", (mientras) que Khnum (10.22) hizo saludables sus miembros.

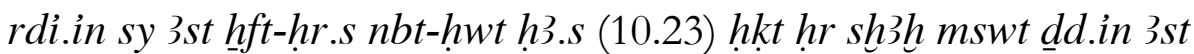

Isis se colocó enfrente de ella y Neftis detrás de ella, (mientras que) (10.23) Hequet aceleraba el parto. Isis dijo:

im.k kkw (10.24) $m$ h ht.s $m$ rn.k pwy $n k k w$

"No seas oscuro en su útero, este es tu nombre $\mathrm{Keku}^{78}$ ".

\footnotetext{
${ }^{75} \mathrm{La}$ fórmula $s \underline{d m . t y} . f y$ como construcción a futuro en Gardiner $₫ 364$.

${ }^{76}$ Igual en $p W .9 .25$.

77 Con este nombre se identifica al segundo faraón de la dinastía V, Sahura. Sahra significa "Ra me ha gratificado".
} 
w'r.in hrd pn tp (10.25) 'wy.sy $m$ hrrd $n$ mh rwd ksw.f nhbt 'wt.f $m$ nbw (10.26) 'fnt.f $m$ hsbd $m)^{\text {? }}$

Este niño se escurrió sobre (10.25) sus manos como un niño de un codo (de largo). Sus huesos eran fuertes y la cobertura de sus miembros era de oro (10.26) y su tocado de verdadero lapislázuli.

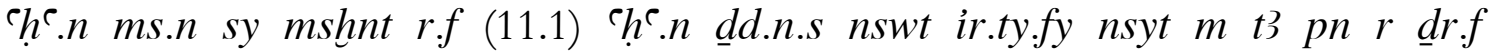
wn.in(11.2) hnmmw hr swd 3 ’ 'wt.f

Entonces Meshkeneh se le presentó ante él (11.1) y dijo: “Será un rey que ejercerá la realeza sobre este país entero", (mientras) que (11.2) Khnum hizo saludables sus miembros.

i`.in.sn sw $\check{s}^{\complement} d(11.3) \underline{h} p 3$.f rdi hr ifdy $m \underline{d} b t$

Entonces ellas lo lavaron y cortaron (11.3) su cordón umbilical y lo colocaron sobre un asiento de ladrillos.

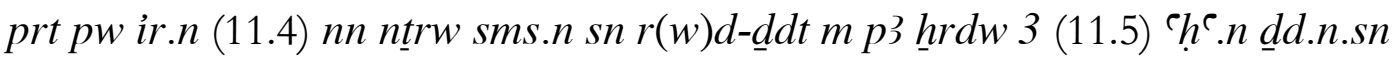

Las diosas salieron (11.4) luego de ayudar a Reddjedet en el parto de los tres niños (11.5) y ellas dijeron:

$n \underline{d} m-i b . k w s r-r^{\ulcorner} m k m s$ n.k (11.6) $\underline{h} r d w 3{ }^{\Upsilon} h{ }^{\ulcorner} . n \underline{d} d . n . f n . s n$

“TTen alegría (en tu corazón) Rauser, te han nacido (11.6) tres niños! Entonces les dijo a ellas:

hnwwwt.i pty irt.i n. (11.7) th ḩ3 di.tn p3 it $n$ p3y.tn hr kni (11.8) it.tn n.tn sw rswnt ${ }^{79}$ tnmw iwh (11.9).in sw hnmw $m$ p 3 it

“Mis señoras, ¿qué puedo hacer yo por (11.7) ustedes? Deseo entregarles esta cebada a quien lleva el maletín ${ }^{80}$ (11.8) y tómenla como recompensa para cerveza”. Entonces Khnum cargó esta cebada.

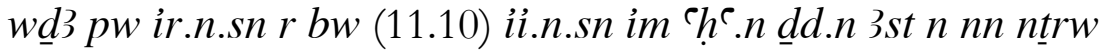

Éstos procedieron a marcharse al lugar (11.10) de dónde habían venido, e Isis les dijo a los dioses:

\footnotetext{
${ }^{78}$ Con este nombre se identifica al tercer faraón de la dinastía V, Neferikara Kakai. Su significado es desconocido.

79 Véase Gardiner (2007 [1927], \178).

${ }^{80}$ Lit. "bajo este portador". Aquí se está haciendo referencia a Khnum quien acompaña a las diosas como maletero.
} 
pty $n 3$ (11.11) ntt $n$ ii.wyn r.s nn irt bỉyt $n$ n3 $n$ (11.12) hrrdw smi.n $n$ p3y.sn it rd iwt.n

“QQué es ésto que hemos venido para no hacer ninguna maravilla para aquellos (11.12) niños según podamos informarle a su padre quién nos ha enviado?".

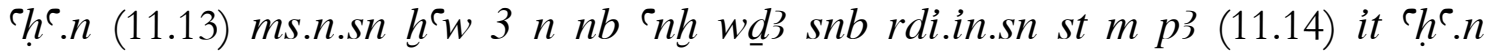
rdi.n.sn iwt pt $m \underline{d}^{e}$ hr hyt

Entonces ellos (11.13) crearon tres coronas de señor, v.p.s. y las colocaron en la (11.14) cebada. Entonces ellas hicieron venir sobre el cielo tormenta y lluvia.

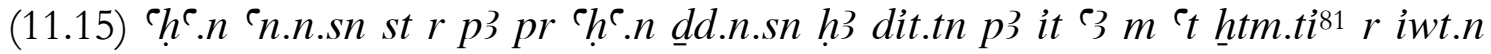
(11.17) hr hntwt mhty

(11.15) Entonces ellas retornaron a su casa y dijeron: "Por favor, coloquen esta cebada aquí, en una habitación cerrada hasta que volvamos (11.17) de un festival de música en el norte".

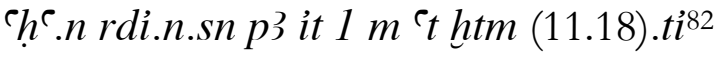

Entonces ellos colocaron la cebada aquí, en una habitación cerrada (11.18).

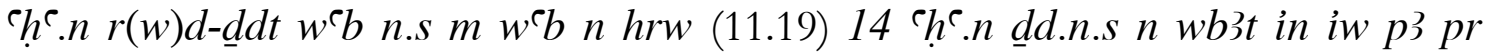
(11.20) sspd

Entonces Reddjedet se purificó luego de los (11.19) 14 días de purificación. Luego ella le dijo a su servidora: “¿Está la casa (11.20) abastecida?”

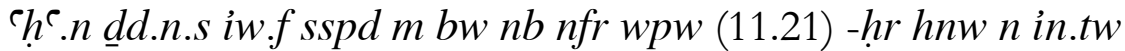

Ella (la servidora) le respondió: "Ella (la casa) está abastecida con toda cosa buena excepto (11.21) por las jarras que no han sido traídas ${ }^{83 " .}$

dd.n. $r(w) d-\underline{d} d t$ tm (11.22).tw $m\{s\}$ in hnw hr-m ${ }^{84}{ }^{\top} h^{\top} . n \underline{d} d . n$ t3 wb3t (11.23) nfr pw

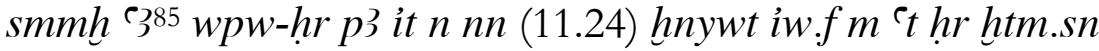

\footnotetext{
81 .ti es una referencia de viejo perfectivo, debería leerse: "que haya sido cerrada".

82 Véase nota anterior.

${ }^{83}$ Hace referencia a jarras de cerveza.

84 Oración con énfasis negativo. Sobre $h r-m$ véase Gardiner (2007 [1927], \496).

${ }^{85}$ El significado de esta oración en Faulkner (1991, p. 228).
} 
Entonces Reddjedet dijo: “¿Por qué (11.22) no han sido traídas las jarras? Entonces la servidora dijo: (11.23) “Aquí no hay nada bueno excepto la cebada de las músicas (1.24) que está en la habitación cerrada".

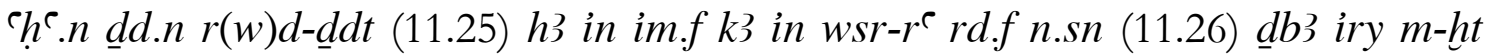
$i w . f$

Entonces Reddjedet dijo (11.25): “Baja y tráela, luego Rauser hará que le sea (la cebada) (11.26) repuesta cuando él regrese".

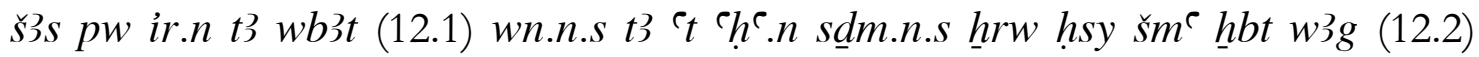
irrwt nbt nswt $m$ t ${ }^{\circ}{ }^{\circ} t$

Luego de esto, la servidora fue (12.1) y abrió la puerta de esta habitación y escuchó en ella sonidos de cantos, bailes, gritos y (12.2) y todo aquello que se hace para el rey en esta habitación.

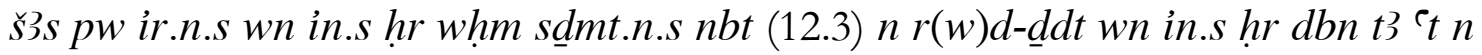
gm.n.s bw irw st im

Luego de ésto se fue y le repitió todo lo que ella escuchó (12.3) a Reddjedet. Entonces ella dio vueltas sobre esta habitación y ella no encontró el lugar dónde se producía.

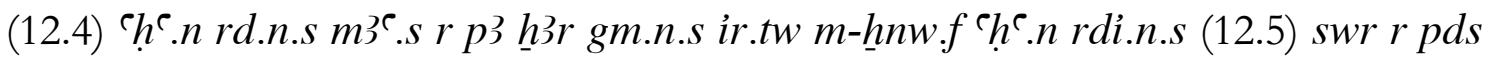
rdi m-hnww ky htm istn $m$ dhrw

Entonces ella colocó su sien en el saco y encontró que éste se producía en su interior. Entonces ella (12.5) (1o) puso en una caja que colocó dentro de otro sello y lo ató con una cinta de cuero,

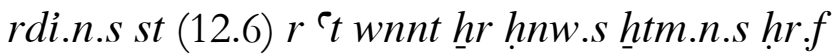

y la colocó (12.6) en la habitación donde estaban sus bienes y luego ella la selló.

iwt pw ir.n wsr-r๔ (12.7) $m$ ii $m \breve{s}^{\complement}$ wn.in $r(w) d-\underline{d} d t$ ḥr whm n.f mdt tn wn.in (12.8) ib.f $n f r$ r $h t n b t$

Luego de ésto llegó Rauser (12.7) que venía del campo. Entonces Reddjedet le repitió estas palabras ${ }^{86}$ y ciertamente (12.8) su corazón se alegró sobre todas las cosas.

\footnotetext{
86 También puede interpretarse como historia o relato.
} 


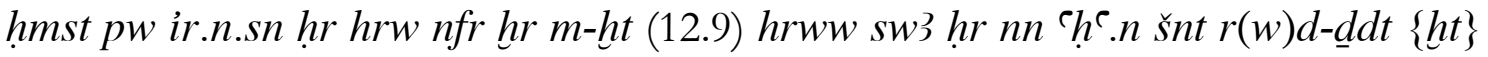
$n$ t3 (12.10) wb3yt rdi.n.s hsf.tw n.s $\{m h\}$ wt

Luego ellos se sentaron y pasaron un día feliz. Después que (12.9) pasaron algunos días de esto, Reddjedet le preguntó (12.10) a su servidora sobre ésto, y ella hizo que se la castigara con un golpe.

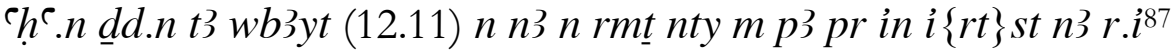

Entonces esta servidora dijo a la gente que estaba en la casa: “¿Ésto se hace contra mí?”.

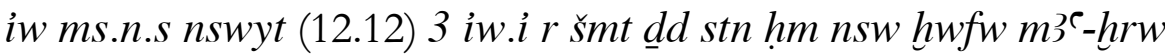

Ella ha dado a luz a tres reyes (12.12), yo voy a ir y yo se lo diré a la Majestad del Alto y Bajo Egipto Keops, justificado.

š3s (12.13) pw ir.n.s gm.n.s sn.s n mwt smsw hr mr mhy nwt hr h̆tyw 88

Luego (12.13) de ésto ella se fue, y se encontró con su hermano mayor de madre, quien estaba atando el lino con hilo para la trilla.

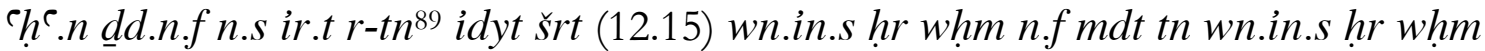
n.f $m d t$ tn

Entonces él le dijo a ella: “¿A dónde vas joven niña?” (12.15) Entonces ella le repitió a él esta historia

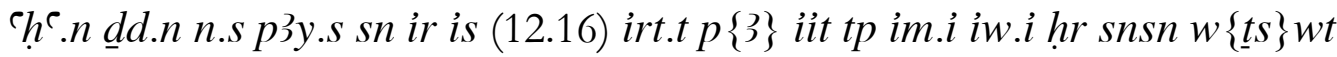

y su hermano le dijo: “¿Es qué (12.16) tu vienes hacia mí para denunciar lo sucedido?".

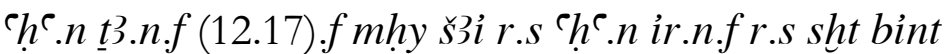

Entonces (12.17) él tomó una vara de lino y le dio un mal golpe.

\footnotetext{
${ }^{87}$ Véase la interpretación que al respecto han hecho Lefebvre (2003 [1982], p. 197, nota 96) y López (2005, p. 104, nota 91), como ejemplo de lenguaje vulgar.

${ }^{88}$ Aquí se han dado diferentes interpretaciones. Por ejemplo, Lichtheim (1973, p. 222) y Sánchez Rodríguez (2003, p. 94) “atando fardos de lino en la era". Mientras que Quirke (2004, p. 89) opta por "atando manojos de lino en la terraza".

${ }^{89}$ Esta interrogación está marcada por $r$-tn que analiza Gardiner (2007 [1927], \$503). Según el autor una traducción literal de ir.t $r$-tn " ¿ $A$ dónde estás haciendo?”. Aquí traducimos según el sentido “ ¿A dónde vas...?
} 
(12.18) $\{\check{s}\}$ 3s pwir.n t3 wb3 $\{y\}$ trint n.s ikn $n\{m w\}$ Cḥ.n ịt (12.19) n sy msh

(12.18) Luego la servidora se fue para traerse una jarra de agua entonces la agarró (12.19) un cocodrilo.

گ3s pw \{iry $r\} \underline{d} d r(w) d-\underline{d} d t i\{n\}$ (18.20) p3y.s sn gm.n.f $r(w) d-\underline{d} d t$ hmsi.ti

Luego de esto, su hermano se fue a decírselo a Reddjedet (18.20) y él encontró que Reddjedet estaba sentada

tp.s hr m3st (18.21).s ib.s $\underline{d w} r$ h ht nbt

con su cabeza sobre sus rodillas (18.21) y su corazón estaba triste por todas las cosas.

‘ḥ.n $\underline{d} d . n . f n . s$ hnnwt.i irrt p3 (18.22) ib hrr-m

Entonces él le dijo a ella: "Mi señora, ¿qué le sucede (18.22) a su corazón?”.

‘h`.n $d$ d.n.s $t 3 p w k t t h\{p r t\} m p 3 p r$

Entonces ella le respondió: "Es por esta joven que creció en esta casa".

$m k m s$ (12.23) sy šm.ti $r \underline{d} d \dot{i} w . i r$ šmt $w\{\underline{t} s\} . i$

Mira, ciertamente ella se ha marchado diciendo: "Yo iré a denunciar".

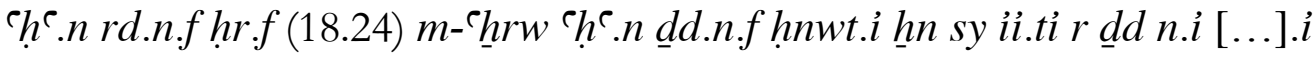

Entonces él agachó su cabeza (18.24) y dijo: "Mi señora, es cierto, que ella ha venido a decirme..."

(18.25) iry.s 3 r.gs.i ‘ ḩ .n ir.n.i n.s sht bint

(18.25) y se detuvo ante mí, entonces yo le di un mal golpe.

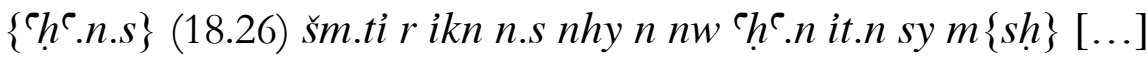

Luego ella (18.26) se fue para traerse un poco de agua, entonces un cocodrilo la agarró.... 


\section{Capítulo I}

\section{ACERCA DEL NACIMIENTO DIVINO DEL REY EN LOS DOS ÚLTIMOS RELATOS DEL PAPIRO WESTCAR}

Mito y literatura en el antiguo Egipto 


\section{La divinidad del rey}

En el antiguo Egipto la realeza fue la principal institución de gobierno. Las formas y conceptos que la legitimaban como pilar de la sociedad fueron creados antes o contemporáneamente al IV milenio (Baines 1995, p. 6). Dentro de este sistema, el faraón cumplía una diversidad de funciones tanto políticas como simbólicas. El rey poseía una relación ambivalente con todos los elementos del cosmos, y ante cada necesidad y cada contexto se lo ve actuando de una u otra manera, lo cual no implicaba una contradicción entre las distintas dimensiones que adquirió el faraón. Es decir, los egipcios concibieron al rey como una figura humana y divina, sin que esta dicotomía les generase ningún tipo de contradicción (Silverman 1991, p. 64; Baines 1995, pp. 9 y ss.).

Si bien sufrió profundos procesos de crisis, la monarquía como forma de gobierno no fue cuestionada, al igual que la idea de realeza y la figura del rey (Hornung 1999a, pp. 311-312)90. Si en algún momento -como los Periodos Intermedios- la centralidad del Estado se vio desequilibrada por fuerzas externas o funcionarios provinciales, no parece haber estado en la intención de los nomarcas imponer otros medios de gobierno por fuera de la realeza. En todo caso, quienes disputaron el poder buscaron siempre adaptarse a las reglas y estereotipos que la monarquía predeterminaba ${ }^{91}$.

De todos modos, la monarquía en sí misma no garantizaba el respeto a la figura del faraón y éste debía buscarse sus propios medios de legitimación que hicieran cumplir efectivamente su poder y parte de ese respeto dependía de las circunstancias de nacimiento del rey (Kemp 2004, p. 241). En este sentido, los ciclos del nacimiento divino del rey pueden ser considerados como una expresión particular de legitimación por parte de los faraones. El mito del origen divino del rey solamente ha sido preservado para muy pocos faraones, lo que seguramente es una

\footnotetext{
${ }^{90}$ Lo que no implica que no haya sido discutido el poder del faraón y sus métodos de actuación. De hecho, algunos textos literarios del Reino Medio parecen ser una proclamación contra ciertas formas de gobierno que posibilitaron el colapso el Estado y dejaron desprotegidas a las clases más altas.

${ }^{91}$ En este sentido, uno de los ejemplos más claros fue el de los reyes hicsos que usurparon el poder de la monarquía egipcia durante el Segundo Periodo Intermedio. Éstos buscaron adecuar su gobierno a las formas tradicionales, por ello llevaron los mismos títulos reales que los faraones egipcios.
} 
cuestión del azar (Baines 1995, p. 18). De todos modos, se sugiere que lo más probable es que dicha concepción fuera dedicada para más monarcas egipcios.

A partir de este fenómeno pueden comprenderse las múltiples políticas de los faraones egipcios de otorgar a sus reinados condiciones legítimas de gobernabilidad, algunas de las cuales se retrotraían a sus propios orígenes. Es decir, a su concepción y nacimiento, identificándose a través de ello que los faraones pertenecían a un linaje divino y real, destacándose principalmente que eran hijos del dios. Por lo tanto, el rey como hijo de la divinidad adquiría por derecho propio el espacio que ocupaba como gobernante, la misma esencia que decíamos que lo posicionaba en un espacio intermedio entre humanidad y divinidad.

Las diferentes interpretaciones de la naturaleza del rey como hombre, como encarnación del dios o como hijo del dios, estaban en consonancia con la poliocularidad, con la multiplicidad de aproximaciones del pensamiento egipcio (Salem 2010a, pp. 274-275). Con estos términos se pretende dar cuenta del modo en que la sociedad antiguo egipcia comprendió y aprehendió su realidad, esto es a través de una diversidad de explicaciones míticas y simbólicas que se rigen mediante el mito como elemento que define el transcurrir, y que se manifiestan en el ritual (Eliade 1992 [1963], pp. 13-14 y pp. 20 y ss. $)^{92}$. Todas ellas no creaban una única visión sobre el medio social, religioso, político y natural que rodeaba al hombre, sino que eran múltiples sus posibles interpretaciones, lo que no significaba que fueran contradictorias, sino que se complementaban las unas con las otras (Frankfort 1998b [1948], pp. 9-12). Según Erik Hornung (1999a), estas características únicas y al mismo tiempo múltiples fueron constitutivas del modo de accionar de los dioses, las que se hicieron extensibles a la figura del faraón ${ }^{93}$. Por lo tanto, la percepción que los egipcios tuvieron del faraón implicaba una multiplicidad de referencias textuales y diversos artefactos no estáticos, produciéndose cambios a lo largo de sus tres mil años de historia (Silverman 1991, p. 58).

\footnotetext{
${ }^{92}$ Hacemos referencia a la primera edición en inglés publicada en el año 1963.

93 Asimismo, por su parte Cervelló Autuori (1996a, pp. 15-18) retoma todas estas postulaciones y reformula la terminología proponiendo la sustitución del concepto de sociedades de discurso mítico por el de sociedades integradas, siendo tres características las que configuran a estas sociedades: repetición; integración; poliocularidad.
} 
El rey podía ocupar una posición intermedia (Baines 1995, pp. 10-11), pues se constituía como el único mediador entre las distintas esferas del mundo, la de los dioses y la de los hombres. Su capacidad de gobierno radicaba en su esencia divina. Algunas veces el dios se encarnaba en el rey para establecerlo como líder de los hombres en la tierra. De este modo, el término ntr desde tiempos tempranos era empleado para referirse de manera directa al faraón como un dios (Silverman 1991, p. 59).

El faraón era un dios, su naturaleza era divina y, por lo tanto, su humanidad era sólo en apariencia (Frankfort 1998b [1948], pp. 60 y ss.). El faraón-dios se constituía así en el centro de la vida social y política, determinando su comportamiento. El faraón era el propio dios Horus, y estaba en consonancia con la teoría de la realeza elaborada por la teología menfita (Frankfort 1998b [1948], pp. 60-63). Pero el faraón también podía ser la imagen viva de otros dioses, por ejemplo de Ra. Esto se ilustra en la autobiografía del visir Rekhmira ${ }^{94}$. En ella se hace referencia a Tutmosis III como: "R $\mathrm{R}$, Señor del cielo, el rey de las Dos Tierras, cuando se levanta el disco del sol se muestra..." (Posener 1940, p. 9) ${ }^{95}$.

El rey únicamente se consideraba un dios en la medida que no existía ningún otro ser capaz de actuar como mediador entre los dioses y la humanidad. Pero con una posición ambigua, ya que nunca el faraón llegó a ser plenamente una divinidad (Moreno García 2004, p. 164). Es interesante notar que esta doble perspectiva divina y humana sobre el faraón no es tan evidente en las imágenes creadas alrededor de las deidades (Silverman 1991, p. 62). Según Lorton (1979, p. 461) si bien no se puede negar que el faraón en algunos momentos adquirió una forma divina, el monarca estaba más cercano a una esencia humana que a ser un dios. Incluso, asegura, ésto se aplica a los mitos del nacimiento divino del rey. Pues, si

\footnotetext{
${ }^{94} \mathrm{La}$ tumba del visir Rekhmira se encuentra en Abd-el Qurna. Fue publicada por Davies (1943, plts. 17-22) y en Porter y Moss (2004, TT100). Una traducción parcial en español en Galán (2002, pp. 142-144).

95 Posener (1940) fue crítico a esta interpretación, por considerarla una concepción rígida, sesgada por fuentes puramente religiosas. Es por ello que el análisis de nuevas fuentes le permite al autor posicionar al faraón como una figura multifacética y ambivalente, multiplicidad que el rey mantuvo en diferentes momentos y espacios (Posener 1940, pp. XIV-XV). Para una interpretación sobre cómo se definía la idea de divinidad por parte de los egipcios véase Silverman (1991, pp. 9-87). Con relación a las diferentes posturas que se han generado en relación a la figura del rey véase Baines (1994, pp. 3-9).
} 
bien la figura paterna es divina, la madre es humana y por lo tanto no puede crearse una figura completamente divina. En cambio, afirma Lorton, para Barta ${ }^{96}$ la participación del rey en el ritual, como su nacimiento y coronación, explicitaban su naturaleza divina ${ }^{97}$. De todos modos, pareciera que la figura materna no condiciona la naturaleza divina del rey, pues lo que adquiere más peso en el relato es que el monarca es hijo de un dios. Por este motivo es que el dios lo llama "su hijo", y la figura materna pareciera ser más un medio para lograr la concepción. Además, en los relatos del Reino Nuevo la madre también es parte de la realeza, por ende comparte la esencia divina que la monarquía tiene como tal.

El monarca adquiría su esencia divina por nacimiento, relación explicitada en el mito del nacimiento divino del rey, en el cual el monarca nacía de la relación divina entre su madre y un dios. Por ejemplo, una de las demostraciones de la naturaleza divina del faraón se expresó en los relatos del papiro Westcar, al anunciarse en el cuarto relato que nacerán tres niños hijos del dios Ra (Goedicke 1985, p. 19), y que serán reyes en Egipto. Este texto literario será el centro de nuestro análisis, el cual consideramos que es la primera expresión escrita del mito de origen del rey.

Que los dos últimos relatos del papiro Westcar exalten la característica divina del monarca, parece estar en consonancia con gran parte de los textos escritos durante la dinastía XII, en los cuales la figura monárquica es parte de ellos ${ }^{98}$. Según Posener (1940, p. 5) durante la dinastía XII se trata de magnificar la realeza por la condición divina del faraón, un énfasis hasta el momento desconocido, debido a que hay un esfuerzo consciente de recuperar el ideal monárquico que se había perdido tras los sucesos del Primer Periodo Intermedio. Según el autor pertenecen a este tipo de relatos Profecía de Neferty, el himno de Sesostris III que se encuentra en el

\footnotetext{
96 Lorton (1979) desarrolla esta idea a partir de su crítica al libro de Barta Untersuchungen zur Goettlichkeit des regierenden Koenigs.

${ }^{97}$ Hay que poner en consideración que la tendencia fue humanizar la figura y la actividad del rey, en cuanto que para los dioses fueron mucho más comunes las representaciones antropomorfas concretándose una metamorfosis entre la figura humana y la esencia divina (Silverman 1991, p. 62). ${ }^{98}$ Los textos literarios del Reino Medio reflejan fisuras con relación a la monarquía, estando vulnerable a equivocaciones, o no pudiendo controlar el derrumbe de la sociedad egipcia. Una interpretación en este sentido en Rosell (2010).
} 
papiro de Lahun y Cuento de Sinhuée9. Si en Profecía de Neferty se narra la llegada de un rey salvador, en los dos últimos relatos del papiro Westcar se relata cómo la divinidad está concedida debido a que los futuros reyes son hijos del dios Ra. Señala Silverman (1991, p. 60) que este tipo de literatura, que considera propagandística, exalta la figura divina del rey. Lo que para Silverman no significa que la población también contemplara y creyera que el rey tenía aspectos propiamente humanos.

\section{Mito del nacimiento divino del rey}

El mito del nacimiento divino del rey puede considerarse como uno de los relatos centrales de las narraciones míticas del antiguo Egipto, en tanto una de las cualidades más destacadas de la realeza divina se relaciona directamente con la idea de que el faraón es un niño divino, es decir que es hijo de un dios (Redford 1986, p. 157). En el mito del nacimiento divino, tanto el futuro rey como su padre el dios son el centro de la narración, en la cual se describe la concepción y el nacimiento del futuro faraón. La relevancia de este tipo de relato mítico dentro de la cosmogonía egipcia se establece a partir del lugar de privilegio que se le otorga al monarca. La figura paterna que los egipcios reconocieron actuando en la configuración de una familia real y divina fue modificándose de acuerdo a la ideología de la monarquía en cada época ${ }^{100}$. De este relato deriva la posición central dentro del sistema de organización social, espacial, política e ideológica que el monarca ocupaba en la sociedad egipcia. En este sentido, el faraón era la única fuente de autoridad

\footnotetext{
99 Se conoce como papiro de Lahun a una colección de textos escritos en hierático encontrados por el egiptólogo Flinders Petrie en el año 1889 y que se conservan actualmente en el University College de Londres. El manuscrito se data en la dinastía XII, específicamente en el reinado de Amenemhat III destacándose en él temas médicos. Fue restaurado y publicado por Griffith (1898a y 1898b). Con respecto al Cuento de Sinubé, las versiones más largas del texto se encuentran en los papiros Berlín 3022 y Berlín 104099, ambos hallados en dos tumbas en Tebas, de las dinastías XII y XIII respectivamente (Galán 1998, p. 63), y actualmente custodiados por el Neues Museum de Berlín. También fragmentos del texto se conservan en ostraca que provienen de Deir el-Medina, entre los que se destacan: el ostracón del Ashmolean Museum de Oxford y el ostracón del British Museum 5629. Diversas transliteraciones y traducciones se han propuesto para Cuento de Sinubé. La transcripción jeroglífica más importante es la realizada por Blackman (1932b). Para traducciones véase: Erman (1927, pp. 14-29); Lichtheim (1973, pp. 222-235); Simpson (LAE, pp. 57-74); Lefebvre (2003 [1982], pp. 33-52); Parkinson (1998, pp. 21-53) y con comentarios Galán (1998, pp. 61-127).

${ }^{100}$ Estas modificaciones en la figura paterna en el mito del nacimiento divino del faraón serán tratadas en un próximo apartado.
} 
(Frankfort 1998b [1948], p. 76) y sus funciones estuvieron siempre ligadas a los ideales cósmicos egipcios, dado que la política y la burocracia respondían a las bases míticas que regían la realidad egipcia (Salem 2010a, p. 274).

La condición del faraón como hijo del dios estuvo presente en el antiguo Egipto desde los primeros tiempos de la monarquía ${ }^{101}$. Las primeras referencias de la paternidad divina del rey dan cuenta de una paternidad asumida por el dios solar Ra. Como examinaremos, las primeras referencias del faraón como hijo de Ra datan del Reino Antiguo y se modificarán hacia el Reino Nuevo cuando la paternidad divina sea encabezada por el dios Amón, o un sincretismo entre el dios Amón y Ra: el dios Amón-Ra ${ }^{102}$.

La relación divina de paternidad adjudicada por el dios fue representada y expresada a través del mito, aquel que los investigadores han dado el nombre de nacimiento divino del rey o teogamia ${ }^{103}$. En los templos de Deir el-Bahari y Luxor se conservan las representaciones más completas del nacimiento divino del rey ${ }^{104}$. En ellos las escenas fueron dedicadas a dos faraones de la dinastía XVIII, a la reina Hatshepsut y al rey Amenofis III respectivamente. El ciclo también fue representado en el Ramesseum, para describir el nacimiento divino del tercer faraón de la dinastía XIX, Ramsés II. Lamentablemente, este último se encuentra muy mal

101 Contrariamente la noción de un rey "divino" por herencia paterna según lo afirma Goedicke (1992, pp. 98-99) es una invención de la reina Hatshepsut. La creación de esta concepción estuvo incentivada por las circunstancias políticas que rodearon su acceso al trono. Con relación a Amenofis III, según el autor nada parece indicar que este faraón necesitara recurrir al designio divino para fortalecer su posición en el reinado, ya que estaba garantizado por la política militar exterior que el rey encabezaba. Amenofis III accedió a representarse como hijo del dios como muestra de agradecimiento hacia el dios Amón, por haberle otorgado un reinado de esplendor, en paz y duradero, y no como una necesidad política de legitimación (Goedicke 1992, pp. 100 y ss.).

${ }_{102}$ Las relaciones específicas que dan cuenta de estas modificaciones, como lo es la aparición del último título que se le adosó a la titulatura del faraón, el de $s 3 r^{\complement}$ Hijo de Ra; el incremento de la solarización de la realeza durante las dinastías IV y V; y una posterior representación de algunos faraones de las dinastías XVIII y XIX como hijos de Amón, serán temas que nos ocuparán en un próximo capítulo.

${ }^{103} \mathrm{El}$ concepto de teogamia refiere a la unión sexual entre la divinidad encarnada en el faraón con la esposa real, y el término se utiliza principalmente para el caso de Hatshepsut.

${ }^{104}$ Este ejemplo no fue considerado por Baines (1996), para quien son pocas las narrativas míticas que se encuentran en inscripciones de templos. Tiene en cuenta los casos del mito de Horus inscripto en el templo ptolemaico de Edfu. 
conservado, al igual que una cuarta representación esculpida en el templo de Karnak, datada en el mismo periodo ${ }^{105}$.

Entre ellos puede establecerse, como ha sugerido Brunner (1964), una unidad temática-narrativa de los ciclos míticos en los templos del Reino Nuevo. Pues, si se analiza cada uno de los ciclos míticos del Reino Nuevo, puede detectarse en ellos una historia que es común. Estas teogamias describen la intención de Amón-Ra de darle a Egipto un nuevo gobernante y la ayuda de la Enéada divina para que encuentre a su consorte. De este modo, es elegida una reina quien será visitada por Amón-Ra, que tomando la forma del rey, mantendrá relaciones con ella. Luego, la reina llamará al dios Khnum para que moldee a su hijo y su ka; que en el caso de Hatshepsut será una niña. Una vez nacidos se hará una presentación formal ante su padre Amón-Ra, quien encargará la educación de sus hijos a los dioses. Cuando éstos crezcan serán coronados como faraón de las Dos Tierras (Salem 2009, pp. 1 2).

Si bien tradicionalmente éstas han sido consideradas las principales expresiones del mito del nacimiento divino, en los dos últimos relatos del papiro Westcar puede retrotraerse la génesis de este mito a tiempos más antiguos, pues los argumentos entre unos y otros son casi exactos. En los dos últimos relatos del papiro Westcar la historia central es el anuncio del nacimiento de tres niños, hijos del dios Ra con Reddjedet, la esposa de un sacerdote de Ra en el templo de Heliópolis. Los trillizos nacerán con la ayuda de las diosas Isis, Neftis, Meshkeneh y Hequet, y del dios Khnum, quienes dejarán un legado divino para los trillizos. Será su condición de hijos del dios Sol lo que les permitirá acceder al trono egipcio, y el mayor de los hermanos también será nombrado como sacerdote en el templo de Ra en Heliópolis.

Ante estas similitudes argumentales entre las teogamias y los dos últimos relatos del papiro Westcar, se añaden otras que refieren a los personajes que actúan

\footnotetext{
105 En este capítulo solamente presentaremos los argumentos centrales de cada ciclo mítico. En un próximo capítulo se analizarán los espacios en que cada uno de ellos fue representado en los templos, pudiendo reconstruir detalladamente el mito del origen divino del rey para cada caso, lo que nos permitirá comparar cada una de las historias con lo que se narra en los dos últimos relatos del papiro Westcar.
} 
en ellos. Los protagonistas son en esencia los mismos en uno u otro relato, como es el caso del dios Khnum o Meshkeneh, para citar algunos ejemplos. Asimismo, para algunos personajes no coinciden los nombres que se les otorga narrativamente, aunque el rol que cumplen es semejante. Por ejemplo, se modifica el nombre de la madre del futuro rey, pero su función es equivalente dentro de los relatos ${ }^{106}$.

En los dos últimos relatos del papiro Westcar hay una figura paterna que es divina, el dios Ra, mientras que el dios Amón (Amón-Ra) lo es para los mitos del Reino Nuevo. Las madres, en los casos de Hatshepsut, Amenofis III y Ramsés II son reinas: Ahmose, Matemwia y Tuya respectivamente. La madre de los trillizos en el papiro Westcar es llamada Reddjedet para quien no se menciona si tiene sangre real. Con respecto a los padres terrenales, en las teogamias son mencionados, e incluso representados como tales, los esposos de las reinas: Tutmosis I, Tutmosis IV y Seti I. En los relatos del papiro Westcar, si bien se destaca la figura del esposo de Reddjedet, apodado Rauser, la narración no explicita que éste sea el padre terrenal de los trillizos ${ }^{107}$.

En relación a los otros dioses que aparecen actuando en ambos relatos, las diosas Isis, Neftis, Hequet y Meshkeneh son las que asisten al parto de Reddjedet por pedido del dios Ra, y son las que están presentes en el momento del nacimiento, llevando adelante un rol de parteras. Quien las acompaña es el dios Khnum, quien también recibe a los recién nacidos y les da su bendición como futuros gobernantes. Si se comparan los que participan en los relatos del papiro Westcar y en las teogamias narradas en los templos de las dinastías XVIII y XIX, en éstos son representados muchos más personajes divinos. Desde los dioses de la Enéada, como por ejemplo, el dios Toth o el enano Bes, o la diosas Hathor, Neith y Selket, y otras divinidades que hacen de parteras y nodrizas. De todos modos, los dioses que actúan en los núcleos narrativos centrales de cada uno de los mitos son los mismos. Tanto Isis, Neftis, Hequet como Meshkeneh participan en el momento del

\footnotetext{
106 La modificación de los nombres de los personajes que aparecen en cada uno de los mitos se ajusta al contexto familiar de cada rey que representó su nacimiento divino.

${ }^{107}$ La posible interpretación es que la paternidad terrenal sería asumida por el esposo de Reddjedet, el sacerdote de Ra llamado Rauser (Goedicke 1982, p. 20).
} 
nacimiento, mientras que el dios Khnum es el encargado de recibir y bendecir, o de moldear el cuerpo y el ka de de cada niño.

Si bien hay diferencias entre las teogamias del Reino Nuevo y los dos últimos relatos del papiro Westcar ${ }^{108}$, sostenemos que entre los mitos expresados en las paredes de los templos del Reino Nuevo y los dos últimos relatos del papiro Westcar se desprende una narración mítica que les es común: el nacimiento de niños, que son hijos del dios y que reinarán en Egipto. Además, entre ambos cuerpos narrativos los personajes y las acciones que éstos ejecutan son las mismas, aunque haya modificaciones en los nombres de algunos de ellos.

En conclusión, estas similitudes nos permiten afirmar que los dos últimos relatos del papiro Westcar son, al igual que las narraciones del Reino Nuevo, mitos del nacimiento divino del rey. Si en el templo de Deir el-Bahari se relata el nacimiento divino de Hatshepsut, en el de Luxor el nacimiento divino de Amenofis III y en el Ramesseum se representa el nacimiento divino de Ramsés II, en los dos últimos relatos del papiro Westcar se narra el origen divino de la dinastía V, el nacimiento de Userkaf, Sahura y Neferikara Kakai ${ }^{109}$. Es decir, los dos últimos relatos del papiro Westcar son la narración literaria del mito de nacimiento divino del faraón. Como afirma Galán (1998, p. 31) el autor de la narración literaria en el papiro Westcar convierte la supuesta profecía del mago Djedi en un relato mítico, el del nacimiento divino del rey ${ }^{110}$.

Naville (1896, p. 12), en su publicación de la representación del nacimiento divino de la reina Hatshepsut en Deir el-Bahari, es uno de los primeros investigadores en indicar que en el papiro Westcar se relata una historia similar a las representaciones del nacimiento de la reina. Según el autor, los relatos del papiro Westcar, al narrar el origen divino de la dinastía $\mathrm{V}$, serían una versión más antigua

\footnotetext{
108 Éstas se analizarán detalladamente en el capítulo II.

109 Más adelante se examinarán los argumentos por los cuales se acepta que los nombres de los trillizos que nacen en los relatos del papiro Westcar son los mismos que llevaron los tres primeros faraones de la dinastía V.

${ }^{110}$ Una posición contraria en Derchain (1986, p. 20). Según el egiptólogo el autor del papiro Westcar no tuvo la intención de demostrar el origen divino de los reyes, sino narrar detalladamente cómo se produce un nacimiento. La intención del relato no puede conocerse, ya que se ignoran las circunstancias en que fue compuesta la obra. Lo único que puede saberse es cómo fue hecha la historia de Reddjedet: fue construida sobre el esquema de la mujer adúltera del relato de Ubaoné, pero de modo inverso.
} 
del mito del nacimiento divino. Por ende para el autor, este tipo de mito, con todos sus detalles, se encontraría desde los primeros tiempos de la historia del antiguo Egipto, pero no puede rastrearse con facilidad (Salem 2009, p. 8; 2010a, p. 288).

Un hipotético origen del ciclo narrativo del nacimiento divino del rey en tiempos tan tempranos como lo es el Reino Antiguo, también fue sugerido por Colin Campbell (1912, p. 12), quien ha realizado uno de los análisis más pormenorizados del ciclo mítico del rey Amenofis III. Según este autor, si bien los relatos del papiro Westcar pueden datarse originalmente en la dinastía XII, no puede determinarse con exactitud cuándo se escribieron por primera vez los relatos acerca del nacimiento divino. Éste era ya un mito conocido entre la realeza egipcia, y es el que fue utilizado como modelo durante el Reino Nuevo en los casos de las dinastía XVIII y XIX, en los cuales se contempla el sincretismo del dios Ra con el dios Amón (Amón-Ra) como la figura de padre divino.

Más recientemente, Gaballa (1976, pp. 53-54), en un extenso estudio comparativo entre las escenas del nacimiento divino del rey de los ciclos míticos de Hatshepsut y Amenofisis III, afirma que los relatos de papiro Westcar son la primera fuente literaria que hasta el momento se conoce del origen divino, en este caso de tres reyes hijos del dios Ra. El interesante análisis de Gaballa se focaliza en la descripción y comparación de las teogamias del Reino Nuevo. El autor reconoce que el mito de origen del rey tiene un antecedente en los relatos del papiro Westcar, pero no los tiene en cuenta en su estudio comparativo. Así también Tyldesley (2011, p. 224) en uno de los últimos libros publicados acerca de textos míticos y literarios del antiguo Egipto, ha aceptado que los relatos del papiro Westcar contienen el mito más antiguo que se conoce del nacimiento divino del rey. De modo similar, Goedicke (1985, p. 19) reconoce que las historias del papiro Westcar podrían ser un prototipo de la pretensión de la reina Hatshepsut de asumir una descendencia divina al proclamarse como hija del dios Amón- $\mathrm{Ra}^{111}$.

111 Más adelante nos detendremos en estas ideas con relación a la paternidad de Ra. 


\begin{tabular}{|c|c|c|c|c|}
\hline & $\begin{array}{l}\text { Papiro } \\
\text { Westcar }\end{array}$ & $\begin{array}{l}\text { Nacimiento } \\
\text { divino de } \\
\text { Hatshepsut }\end{array}$ & $\begin{array}{l}\text { Nacimiento } \\
\text { divino de } \\
\text { Amenofis III }\end{array}$ & $\begin{array}{c}\text { Nacimiento } \\
\text { divino de } \\
\text { Ramsés II }\end{array}$ \\
\hline Padre divino & dios $\mathrm{Ra}$ & $\begin{array}{l}\text { dios Amón } \\
\text { (Amón- Ra) }\end{array}$ & $\begin{array}{l}\text { dios Amón } \\
\text { (Amón- Ra) }\end{array}$ & $\begin{array}{l}\text { dios Amón } \\
\text { (Amón- Ra) }\end{array}$ \\
\hline Padre terrenal & $\begin{array}{l}\text { no es } \\
\text { mencionado }\end{array}$ & faraón Tutmosis I & $\begin{array}{l}\text { faraón Tutmosis } \\
\text { IV }\end{array}$ & faraón Seti I \\
\hline Madre & Reddjedet & $\begin{array}{l}\text { reina Ahmose } \\
i \subsetneq h-m s-s\end{array}$ & $\begin{array}{l}\text { reina Matemwia } \\
m w t-t-w i 3\end{array}$ & reina Tuya \\
\hline $\begin{array}{l}\text { Diosas } \\
\text { principales }\end{array}$ & $\begin{array}{l}\text { Isis } \\
\text { Neftis } \\
\text { Hequet } \\
\text { Meshkeneh }\end{array}$ & $\begin{array}{l}\text { Isis } \\
\text { Neftis } \\
\text { Hequet } \\
\text { Meshkeneh } \\
\text { Neith } \\
\text { Selket }\end{array}$ & $\begin{array}{l}\text { Isis } \\
\text { Neftis } \\
\text { Hequet } \\
\text { Meshkeneh } \\
\text { Neith } \\
\text { Selket }\end{array}$ & ¿? \\
\hline
\end{tabular}

CUADRO I. Comparación entre los principales personajes en el argumento de los dos últimos relatos del papiro Westcar y los ciclos míticos del Reino Nuevo

112 Véase nota anterior. 
Partiendo de estas consideraciones sugerimos que los dos últimos relatos del papiro Westcar serían la primera expresión escrita del mito del origen divino del faraón, como hijo del dios. Aceptamos que el mito de origen del rey debió de tener algún tipo de relevancia política dentro de la ideología de la monarquía durante el Reino Antiguo y el Reino Medio. Como ha sugerido Daumas (1958b, pp. 48-49) el ciclo mítico que incluye las fases de la teogamia, nacimiento y entronización ya era un eslabón más dentro de los mitos egipcios desde el segundo milenio ${ }^{113}$. El mito, según Daumas, se desarrolló ampliamente en Heliópolis, por lo que estas ideas míticas fueron parte de las principales concepciones sobre la realeza del faraón desde los primeros tiempos.

Proponemos que el mito del nacimiento del faraón posee al menos un origen cercano a los dos últimos relatos de papiro Westcar. Según Baines (1995, pp. 17-18) los relatos del papiro Westcar y las teogamias del Reino Nuevo presentan una misma concepción: ambos muestran que el faraón es engendrado por un dios principal (Ra y Amón o Amón-Ra), quien toma la forma del rey (Brunner 1964). A su vez para Baines (1996, pp. 365-367), los relatos del papiro Westcar contienen fórmulas narrativas convencionales, que podrían aludir a una constitución paralela a relatos de tipo oral. Así, el autor encuentra vínculos entre los personajes del papiro Westcar y las acciones ya conocidas para los dioses. Este paralelismo le permite a Baines afirmar que los relatos míticos pudieron ya haber existido tempranamente desarrollados de forma literaria, y que algunas partes del relato eran un mito. De este modo, se crean paralelos con el mito, por ejemplo con la incorporación personajes divinos en el relato.

\footnotetext{
113 Además del posicionamiento y reconocimiento del faraón como hijo de un dios en los mitos del Reino Nuevo, uno de los significados del ciclo mítico del nacimiento divino del rey es el de la adopción de un niño por parte de Amón, como el primer paso a la ceremonia de coronación, siendo así el modo en que junto con la realeza el rey entra en una nueva filiación que es divina, por ende adquiere una nueva biografía: la de ser ahora un hijo del dios (Assmann 1999, p. 31). De hecho, las representaciones que le siguen a las del nacimiento divino son las de coronación; lo que ha sugerido Assmann (1999, p. 31) es que nacimiento y coronación son ciclos que deben estar juntos, pues se complementan. Son los dos últimos relatos del papiro Westcar los que coinciden con las teogamias del Reino Nuevo, es por ello que nuestro análisis se centra en estos relatos del manuscrito. Un indicio en los relatos del papiro Westcar sobre la coronación es narrado en el relato anexo. En éste las diosas fabrican tres diademas como presagio de un buen reinado para los futuros reyes.
} 
Sin embargo, algunos investigadores se han posicionado en contra de esta interpretación. Por un lado Lorton (1979, pp. 460-461 y 463) asegura que los relatos del papiro Westcar, como así también el título de Hijo de Ra, no pueden ser considerados como evidencia de que la historia del nacimiento divino del faraón como hijo del dios estaba vinculado a la realeza y su legitimación con anterioridad al reinado de Hatshepsut ${ }^{114}$. Según Lorton ésta es una perspectiva sesgada por una visión puramente religiosa, sin tener en cuenta otro tipo de enfoque, como él propone que involucre lo político, legal y social.

Kemp (2004, p. 242) se suma a esta discusión. Según afirma el autor, durante el Reino Antiguo surge fuertemente la idea de que el faraón era hijo de Ra, incorporándose esta idea dentro de los cartuchos con el nombre del monarca, además que la devoción al dios Sol también se proclamó en la construcción de las pirámides, y en la dinastía V con los templos solares. Sin embargo, Kemp sostiene que existió una "interpretación más literal” de la expresión "bijo de Ra" en los relatos del papiro Westcar. Concluye que "la narración no es una pieza solemne de teología y tal vez no formaba parte de la teología oficial y seria; pero en el Imperio Nuevo sí que lo hacía” (Kemp 2004, p. 242).

Por lo tanto, para Kemp los relatos del papiro Westcar tendrían que ser descartados como evidencia si queremos interpretar cómo durante el Reino Antiguo se fue formando la legitimidad del rey a partir del reconocimiento de ser hijo de un dios. Para el autor, entonces, los textos literarios son desestimados como fuentes para comprender la conformación de las bases que compusieron el Estado egipcio, ya que diferencia aquellas fuentes "de Estado" con respecto a las literarias. Más adelante discreparemos con esta posición, e interpretaremos a los relatos del papiro Westcar como una narración mítica, en la cual se refleja la constitución de la instauración de la legitimidad del rey como hijo del dios.

En definitiva, lo que se está poniendo aquí en el centro de la discusión es el alcance que pudo tener este mito en las producciones ideológicas de la monarquía en el Reino Antiguo. Analizaremos el mito de la dinastía V desde su contenido, que

\footnotetext{
${ }^{114}$ Lorton desarrolla esta idea a partir de su crítica al libro de Barta Untersuchungen zur Goettlichkeit des regierenden Koenigs.
} 
los trillizos son hijos de $\mathrm{Ra}$, lo que ha sido una de las discusiones más típicas (Hays 2002, p. 21) que se han dado alrededor de los relatos del papiro Westcar. Dichas cuestiones han discurrido en determinar cuál ha sido durante el Reino Antiguo la dinastía más solar. Para algunos el ascenso del culto solar se inicia con la dinastía IV, mientras para otros este culto recién adquiere sus formas con el comienzo de la dinastía $V^{115}$. Esta discusión nos parece sin sentido, pues la línea predominante en estas interpretaciones toma los hechos aisladamente y no los analiza en clave de procesos históricos. Pensamos que es necesario poner en discusión los diferentes aspectos de la ideología de la realeza egipcia durante este periodo, que sostuvieron la monarquía divina. Dentro de ellos se encuentran aquellos que alimentaron el mito divino del faraón, y en el caso específico del relato literario, éste se refiere al origen divino de la dinastía $\mathrm{V}$, de ahí las discusiones en torno a la transición entre la dinastía IV y la dinastía V116.

A través del análisis de la titulatura real, de los nombres de los faraones y de las construcciones que los reyes le dedicaron al dios Sol, podremos visualizar que la ideología del culto a Ra ya estaba presente dentro de la ideología de Estado en las dinastías IV y V. En este sentido, dejaremos en claro que la solarización de la realeza estaba en proceso de construcción hacia la dinastía IV, para consolidarse con los faraones de la dinastía V. Desde esta perspectiva, los dos últimos relatos del papiro Westcar adquieren una importancia única y trascendental, en tanto que éstos constituyen la primera narración mítica y literaria que relata el origen divino del rey, específicamente los inicios de la dinastía V. Fuentes externas demuestran el desarrollo del culto solar para el Reino Antiguo, mientras que los relatos del papiro Westcar ubican los orígenes de este culto con el inicio del reinado de Userkaf.

Estas interpretaciones están circunscriptas a otra discusión que se ha generado alrededor de los relatos del papiro Westcar, nos referimos a la posible fecha de datación del manuscrito. Si bien en otro capítulo desarrollaremos las diferentes posturas que se han esgrimido al respecto, puede sintetizarse que la

\footnotetext{
115 Otra posición la veremos con Kahl (2007).

116 La transición de una dinastía a otra es un problema complejo. Principalmente porque los egipcios no explicitaron cuáles eran los parámetros para conformar una dinastía (Assmann 1995b, pp. 15-17). Además que los egipcios raramente hicieron explícitos los motivos que impulsaron el cambio de gobernante o dinastía (Baines 1995, p. 17).
} 
mayoría de ellas coincide en un contexto original de escritura para mediados-finales de la dinastía XII. Asimismo, también se han sugerido las potenciales relaciones que los relatos pudieron haber tenido con historias orales, posibilidad que está avalada por el tipo de estructura tripartita y repeticiones de párrafos que son propias de una etapa transitoria de la oralidad a la escritura. Para no cerrar definitivamente una fecha de escritura para los relatos del papiro Westcar, consideramos que lo más aceptable es una escritura anterior con relación a los mitos narrados en los templos del Reino Nuevo ${ }^{117}$. Este argumento será un elemento más que tendremos en cuenta para afirmar que el mito del nacimiento divino del rey era una idea que estaba presente en la ideología de Estado y era conocido por los escribas antes de la dinastía XVIII.

Debemos tener en cuenta dos cuestiones que se relacionan con estas discusiones. En primer lugar, se hace presente la problemática acerca del cambio de la figura paterna divina de Ra por la de Amón (Amón-Ra), temática introducida por Colin Campbell (1912). En segundo lugar, esclarecer los motivos que explican la distancia de más de un siglo entre la primera escritura de los relatos del papiro Westcar durante la dinastía XII y su representación en los templos del Reino Nuevo. Esta problemática pone de relieve el hecho de que ni para el Reino Antiguo ni para el Reino Medio se conocen imágenes pictóricas que describan el mito del nacimiento divino del rey (Gaballa 1976, p. 54). Según Gaballa, las posibles causas de esta ausencia podrían estar relacionadas por una situación fortuita, es decir que simplemente no se han preservado, o lo que pareciera más probable, que hasta el Reino Nuevo el mito del nacimiento divino del rey solamente haya sido transmitido en forma literaria. Esto supone un soporte en papiro y una circulación restringida a la elite cultural, la cual tradicionalmente fue considerada como aquella que accedía a este tipo de relatos. De todos modos, puede asumirse que es el ciclo de Hatshepsut y luego el de Amenofis II y Ramsés II- la primera versión conocida del mito de origen adaptada para el uso dentro del templo (Troy 2009, p. 130). La puesta en escena del mito en los templos es parte de los proyectos políticos de cada faraón.

\footnotetext{
${ }^{117}$ En el capítulo VII se tratarán las diferentes propuestas acerca de la datación del papiro Westcar.
} 
Cómo el mito de origen del faraón se adapta a la política real Kemp lo encuentra en el caso de la teogamia de la reina Hatshepsut. En la escena VI118 del relato de su nacimiento aparece uno de los rasgos más señalados con respecto a la figura de Hatshepsut. Si bien las menciones en el texto son femeninas y su nombre es femenino, la figura humana y el ka que moldea el dios Khnum son claramente masculinas; al estar desnuda se observa su falo. Por ello es que Kemp (2004, pp. 243-245) interpreta que la versión del nacimiento divino de la reina Hatshepsut es uno de los mejores ejemplos en el cual puede observarse cómo la autoridad y el poder de un relato mítico bien construido puede reemplazar la realidad. La realeza egipcia era unívoca en una cosa: sus faraones eran hombres.

Las excepciones -como la de Hatshepsut- no fueron tratadas como tales. La figura femenina se acomodó a la masculina sin aceptar diferencias. Si bien históricamente Hatshepsut era una mujer, hija de Tutmosis I y la esposa de Tutmosis II, los acontecimientos terrenales -e históricos- se readaptaron a la visión del mito de origen del rey. El templo era el lugar otorgado para la expresión de lo eterno y validaban un único tipo de monarquía. "Se dejó constancia del reinado de Hatshepsut para que tuviera una coherencia con un modelo formulado de antiguo, y eso era lo único que importaba" (Kemp 2004, p. 245). Una apreciación -en un sentido similar- ya la había realizado tempranamente Breasted (1906, p. 81) para quien existía una clara discordancia entre lo que los relieves indicaban como una tradición que venía ya construida desde tiempos más antiguos de cómo representar la escena, de que la figura por nacer era un hombre y no una mujer. Llama la atención la discordancia entre representación masculina e inscripción en género femenino, pues una femenina no tendría lugar en representaciones antiguas. De todos modos no debe ser interpretada como contradicción o error.

Colin Campbell (1912, p. 29) se pregunta acerca de dónde se encuentran esas antiguas y tradicionales escenas del nacimiento divino, pero no piensa que la parte de la respuesta puede estar en los relatos del papiro Westcar. Es, precisamente, la fuerza del mito lo que explica la discordancia entre el texto y la imagen. Los dos cuerpos -el del futuro rey y el ka- son masculinos mientras que la inscripción que los

118 La analizaremos particularmente en el capítulo II. 
acompaña menciona a "ella" (Naville 1896, p. 15). En este punto el artista en el templo de Luxor no tuvo que afrontar el problema de acomodar la realidad al mito.

En el caso de Hatshepsut, la adaptación no solamente fue considerada para el mito de su nacimiento divino. La mayoría de las veces es llamada rey y es representada como un hombre; para Redford (1967, p. 55) la designación como reina no tenía lugar en la mentalidad egipcia. En muchas oportunidades Hatshepsut optó por resaltar sus rasgos femeninos en detrimento de los masculinos ${ }^{119}$.

Los dos últimos relatos del papiro Westcar son un ejemplo de la inclusión de estructuras narrativas míticas dentro de relatos propiamente literarios (Baines 1996, pp. 365-367). Según Baines, las narraciones literarias hacen accesible el mito, pero no se equiparan a él, y pierden el sentido "utilitario" que el mito posee dentro del ritual. Estas diferencias, que aluden al uso cultual que el mito pudo haber tenido dentro de un espacio como es el del templo, se evidencia entre los dos tipos de soportes y contextos en los cuales fueron expresados el mito del nacimiento divino en los relatos del papiro Westcar y en los templos del Reino Nuevo.

\section{Diferencias en los espacios de representación}

Los primeros escritos sobre papiro y en grafía hierática sugieren una circulación que no necesariamente se restringió a las paredes del templo. El hierático, principalmente escrito sobre papiro, posee signos más simples en comparación a los jeroglíficos exclusivos del arte monumental, lo que posibilitó ligar un signo junto al otro permitiendo una escritura más ágil120. A su vez hay rasgos en

119 En las representaciones que Hatshepsut hizo destacar su femineidad, resaltando su cuerpo y vestimenta de mujer, con todos los adornos dignos de una reina y esposa del dios, fue en aquellas que quería resaltar su condición de gran esposa, dando cuenta del importante vínculo que poseía con el templo de Karnak y los recursos económicos asociados a él. Pero las incongruencias mujerfaraón que generaba en la mentalidad egipcia llevó a que se modificaran a cuerpo de hombre muchas de las figuras femeninas de Hatshepsut. El paso de mujer-reina a hombre-rey fue un proceso de indagación y reflexión de la forma más apropiada de representación (Galán 2009, p. $321)$.

${ }^{120}$ La escritura hierática siempre fue grabada de derecha a izquierda, y en contraposición a la escritura jeroglífica monumental en columnas. Con la dinastía XII se inicia la costumbre de escribir en líneas horizontales, forma que predomina en los textos de carácter literario. Durante el Reino Nuevo se diferenciarán dos estilos en la escritura hierática, uno asociado a un registro rápido para las transacciones comerciales, la administración y el intercambio epistolar; y el otro, signos cuidadosamente grabados para la creación de textos religiosos y literarios (Araújo 2000, p. 27). El 
los textos del papiro que son compartidos con otras narraciones literarias y no meramente míticas, como es el uso de la primera persona que según Parkinson (1991, p. 26) es una de las características casi exclusiva de los relatos literarios.

Lo interesante de los relatos del papiro Westcar es la multiplicidad de discursos involucrados en ellos, entre los que identificaremos un conjunto narrativo ficcional, las inferencias de un texto político, hasta la introducción de narrativas y simbología propias del mito, que también hacen de ellos un texto de carácter religioso. Esta multiplicidad de expresiones no es ajena a los discursos del antiguo Egipto, y si bien los diferentes episodios se combinan entre sí para formar secuencias narrativas, se infiere que en esta diversidad la fuente solamente sea literaria, religiosa, cultual o política. Contradecimos a Quirke (2004, pp. 24 y ss.), quien asume que los relatos son una fuente más literaria que religiosa. Porque en ellos se detectan secuencias narrativas, que los vincula con una función social más reflexiva, la de ser leídos, y no como parte de la función litúrgica o cultual.

Por otro lado, los mitos del nacimiento divino del faraón que fueron representados en imágenes y acompañados por textos expresados en las paredes de los templos funerarios de Hatshepsut, Amenofis III y Ramsés II, simbolizan otro tipo de discurso, que se relaciona con el mundo cultual y ritual en el cual fueron inscriptos.

Los templos en el Reino Nuevo ofrecían al pueblo dos caras opuestas. Una, la de los días festivos y de liberación, durante los cuales se alcanzaba un contacto más personal con la divinidad. La otra, la de un poder temporal del rey representado en las grandes murallas construidas como fortaleza. Únicamente los funcionarios de más alto rango, especialmente los sacerdotes, podían acceder más allá de la gran muralla (Kemp 2004, pp. 227-232). Al contrario de los textos escritos sobre papiro,

hierático también se modificó a partir del Tercer Periodo Intermedio (al respecto de su desarrollo véase Araújo 2000, p. 27). La escritura hierática admitió signos diacríticos y conservó la secuencia de los jeroglíficos y se diferenció de ellos por el uso de la pluma en vez de un elemento punzante (Goody 1990 [1986], p. 49). 
las inscripciones en los templos se realizaban en jeroglífico, predominando también en estelas y grandes monumentos ${ }^{121}$.

El hecho de que los mitos del nacimiento divino del rey en el Reino Nuevo estén narrados en un contexto de eternidad cultual, permite pensar que su lectura estaba circunscrita a un número limitado de visitantes. Su representación en este tipo de espacio posibilita una interpretación absolutamente distinta a los relatos del papiro Westcar, dado que la inscripción monumental es un polo de manifestación cultural egipcia diferenciada de los manuscritos. Según Loprieno (2009, p. 14) lo monumental sirvió para la representación del $\operatorname{poder}^{122}$, y se distinguió claramente de las formas literarias (Parkinson 2002, p. 58). En la sociedad egipcia la permanencia y trascendencia del ser hacia la eternidad era el centro de su sistema cosmogónico. Gran parte de los recursos que la monarquía poseía los destinaba a estrategias que permitieran llegar a lo eterno (Quirke 2003, p. 27). El arte era una de ellas. Los grandes santuarios y sus inscripciones fueron ideados para no perecer y representar el mundo que se deseaba para el Más Allá. Para lograrlo, el artista se comprometía con su trabajo y durante años aprendía las reglas de la representación. Debía instruirse acerca de cómo unir el sistema artístico con la escritura jeroglífica, y así crear a un mundo para la eternidad (Quirke 2003, p. 27).

Las representaciones en los templos implican una discursividad en la cual se relacionan y complementan el texto y la imagen: lo que el texto no dice u oculta puede estar o no presente en la imagen. Los escribas y artistas egipcios por medio de esta expresividad podían "hacer evidente" al ojo del observador el sincretismo o ambigüedad de los personajes y las palabras. Si para Goedicke (1993, p. 24) un lector del papiro Westcar debía conocer la historia egipcia para reconocer un personaje como el de Nebka, un lector de las representaciones de los textos al menos tenía que

\footnotetext{
${ }^{121}$ Parkinson (1991, p. 13) interpreta que el uso de jeroglíficos en monumentos se debía a una función estética y podía tener más de un sentido. La colocación de sus signos y su disposición eran pensados como decoración de las paredes de los templos y tumbas, utilizándose diversas técnicas de relieve y pintura.

122 Se puede analizar también la lengua antigua egipcia a través de las transformaciones que sufrió a partir de su uso, sus funciones en relación al contexto político en que se desarrolló. Algunos periodos se caracterizaron por un tipo de diglosia, de doble textualidad. Al respecto un análisis completo y detallado en Loprieno (2009, pp. 14-22).
} 
estar familiarizado con las imágenes de sus dioses y el texto jeroglífico. Y esto último no era una condición necesaria, dado que la imagen era la mayor de las veces más fuerte que el texto, al mismo tiempo que al ser la escritura jeroglífica de carácter simbólico (Gardiner 2007 [1927], pp. 6 y ss.), el signo refuerza el sentido de lo que quiere ser expresado.

A la vez, el mito en texto e imagen otorga otros modos de expresividad, que se pierden en el literario, en el cual por ejemplo se hace necesario muchas veces hacer más explícito el sincretismo de un personaje. En los relatos del papiro Westcar la figura paterna es $\mathrm{Ra}$ y claramente $\mathrm{Ra}$, y en los templos de Deir el-Bahari y Luxor el dios puede ser tanto Amón o Amón Ra, sin que este sincretismo se interprete como una contradicción. A su vez, en los relatos del papiro Westcar, la escritura hierática pierde uno de los rasgos más sobresalientes de la escritura jeroglífica, su relación del signo con su significado. Quizá esto no era lo importante en este tipo de textos, ya que el mensaje podía ser tanto leído como escuchado.

Por otro lado, el tipo de discurso que representa un texto literario es totalmente distinto al que se encuentra en un templo. En primer lugar, porque el texto en sí mismo se reconoce como un texto de ficción y sus personajes y situaciones no pretenden ser reales. Mientas que un relato como el mito del nacimiento divino -en tanto discurso- sí pretende serlo.

Hasta lo que hemos analizado y retomando aquellas ideas que previamente fueron expuestas por los investigadores en el tema, concluimos que los dos últimos relatos del papiro Westcar son un relato mítico literario en tanto mantiene fuertes paralelismos argumentales con los ciclos míticos que han quedado registrados en los templos del Reino Nuevo. Es decir, que los dos últimos relatos del papiro Westcar también son un relato del nacimiento divino del faraón. Como veremos, los nombres que cada uno de los trillizos adquiere al nacer se asemejan a los que portaron los tres primeros faraones de la dinastía $\mathrm{V}$.

La estructura argumental compartida no es la única relación que podemos esgrimir. En este sentido, quedará explicitado que los roles que los diferentes actores cumplen en cada ciclo mítico son también análogos, por ejemplo el de las diosas que ofician de parteras en el nacimiento de los niños. Por otro lado, los dos últimos 
relatos del papiro Westcar se asemejan a otros mitos conocidos, desde la función que algunos personajes cumplen dentro del relato como lo hacen en otras narraciones míticas, hasta los símbolos propios del mito que aparecen en ellos.

\section{Mito de origen de la dinastía V}

En el anexo al cuarto relato en el papiro Westcar, al narrarse el nacimiento de los trillizos se da a conocer el nombre que cada niño llevará. Para el primero de ellos se lee en la línea 10,9: wsr-r.f que puede traducirse como "más poderoso que ép". El término $w s r$ pretende ser un juego de palabras entre el poder que causa dentro del vientre de Reddjedet, y parte del nombre del recién nacido ${ }^{123}$. La propuesta de Sethe (1927), que ha sido aceptada unánimemente, corrige el nombre por wsr-k.f "su ka es poderoso", que es el nombre con el cual se identifica al primer faraón de la dinastía V, Userkaf.

La mayoría de los investigadores buscan establecer conexiones con los nombres de los reyes de la dinastía $\mathrm{V}$ que están inscriptos en monumentos y Listas Reales para determinar una cronología de los reinados. Como punto de partida se han tomado los que menciona Manetón (Drioton y Vandier 1964 [1938], p. 174)124. Una de las dificultades que ha planteado este tipo de trabajo es la discordancia entre los nombres dados por Manetón y aquellos de los personajes históricos que se

\footnotetext{
123 Como ya lo había notado Lefebvre (2003 [1982], p. 105) este tipo de juego con los términos y significados de los nombres del recién nacido son análogos a los casos que se mencionan en el Antiguo Testamento. En Génesis 35: 16-18, cuando Raquel muere dando a luz a su hijo, y "aconteció que al salirsele el alma (pues murió), llamó su nombre Benoni, más su padre lo llamó Benjamín". Interpreta Lefebvre que el término Benoni significa "bijo de mi dolor", en consonancia al doloroso parto que atraviesa la mujer. En cambio, Jacob que presenciaba la situación corrigió su nombre por uno de buen augurio: Benjamín, "bijo de derecho".

124 Redford (1986) estudia y publica una gran cantidad de Listas Reales. Según Redford (1986, pp. 1 2) una verdadera Lista Real es cuando aparecen escritos tres o más nombres de monarcas, debiendo indicarse: 1- los nombres de los gobernantes en secuencia histórica; 2- la duración de los reinados; 3- los ítems uno y dos juntos. En todos los casos su suporte debería ser el papiro, las otras enumeraciones serían Grupos de Reyes. Siguiendo la definición de Redford únicamente Canon de Turín cumpliría estas características. Según Sist $(2008$, p. 26) Listas Reales son una síntesis de un registro cronológico de reyes, cuya sucesión sigue diferentes criterios. Principalmente los reinados no están contabilizados con el criterio de la secuencia de eventos epónimos (por ejemplo la Piedra de Palermo), pero sí con una estructura de enumeración progresiva, siendo que la dinastía XI da inicio a este sistema ya que cada soberano indica cual es el año de inicio de su reinado. Consideramos por Listas Reales al conjunto de fuentes reales y no reales (aquellas inscriptas en las tumbas de funcionarios) en las cuales se menciona la sucesión de reinados de faraones egipcios.
} 
identifican en otras fuentes. A su vez, estas discrepancias también están presentes entre los nombres que las fuentes egipcias inscriben para los de sus reyes. Con respecto al nombre del primer faraón de la dinastía $\mathrm{V}$, según su nombre de $n s w$-bity que aparece en la Lista Real de Abidos ${ }^{125}$ (número 26) y en la Lista Real de Saqqara'126 (número 25), es justamente el de wsr-k3-f: Userkaf. Se acepta que es el mismo nombre que lleva el personaje en el anexo al cuarto relato en el papiro Westcar.

En el segundo nacimiento, Isis ( $\not W .10 .16-17)$ realiza un juego de palabras con el verbo $s 3 h$ "retrasarse" ( $W b$ 4. 21 referencia 5) que también puede significar "gratificar" (Wb 4. 21 referencia 19) ${ }^{127}$. Término del cual deriva el nombre del niño $s 3 h$-r $r^{e}$ "Ra retrasado/gratificado". De todos modos, como bien lo señala Lefebvre (2003 [1982], p. 105) el nombre que debe leerse aquí no es el de Sahra, sino el Sahura s3h-w-re "Ra me ha gratificado", con el cual se nombra al segundo faraón de la dinastía V. Su nombre de nswt-bit es el de Sahura, así queda atestiguado en la Lista Real de Abidos (número 27) y en la Lista Real de Saqqara (número 26).

El último de los nacimientos ( $\not W .10 .23-25)$ es el de Keku. El juego de palabras se realiza con la palabra $k k w$ "tenebroso/oscuro", del cual derivará el nombre del recién nacido $k k w$, el cual se identifica con el nombre de $s 3 r^{\complement}$ del tercer faraón de la dinastía, Kakai. Ha sido Bochardt (1827) quien ha demostrado que Neferikara (el nombre de nacimiento) y Kakai designan al mismo faraón ${ }^{128}$.

Los tres nombres de los trillizos que son mencionados en el anexo al cuarto relato en el papiro Westcar, son los mismos que son reconocidos para

\footnotetext{
${ }^{125}$ Lista Real de Abidos se encuentra en la Sala de los Ancestros en el Templo funerario de Seti I en Abidos. La Lista está precedida por Seti I y su hijo Ramsés realizando ofrendas a la enumeración de los nombres de los reyes ya fallecidos. Seguramente fue bajo el reinado de Ramsés II que fue compuesta. En ella aparecen un total de setenta y seis reyes que reinaron en Egipto desde Menes de la dinastía I hasta Seti I de la dinastía XIX. Son excluidos nueve faraones de las dinastías XI y XIII, y nueve faraones correspondientes a la dinastía XVIII. Los dibujos fueron publicados por von Beckerath (1997, p. 215) y en Kemp (2004, p. 29). Los textos en jeroglífico en KRI 178-179. Una traducción en inglés en RITA I, 153-156.

126 Lista Real de Saqqara fue encontrada en el año 1861en la ciudad de Saqqara en la tumba de Tenry (CG 34156), un importante funcionario de Ramsés II. En la actualidad se encuentra preservada en el Museo de Egipcio de El Cairo. Los dibujos fueron publicados por Mariette (1864, pp. 169-186) y von Beckerath (1997, p. 216). El texto completo se encuentra en KRI III, 481-482.

127 El significado que Faulkner (1991, p. 210) le da al término es en primer lugar "bick", que hace referencia a una persona ignorante. Una segunda definición más cercana al relato del papiro Westcar es "reach"-" arrive at", entendidas como "alcan ₹ar" y "llegar a" respectivamente.

128 A partir de esta temprana identificación ha sido adoptada por la mayoría de los investigadores.
} 
los tres primeros faraones de la dinastía V. De esta relación es que se han derivado las ideas de que los relatos del papiro Westcar son una narración del origen de esta dinastía. De todos modos, no se ha producido una visión unitaria, ya que están quienes han querido ver en la narración la reproducción de una situación histórica real. Desde esta perspectiva fiel a la realidad histórica, una temprana interpretación fue propuesta por Meyer (1909, p. 205), quien entiende que es una narración que da cuenta de los procesos que llevaron al cambio de dinastía.

Más de medio siglo después Jenni (1998) retoma esta problemática, y realiza un trabajo específico a través del cual contextualiza a los relatos del papiro Westcar como la narración de las circunstancias históricas de la dinastía XII, la corregencia entre el faraón Amenemhat I y Sesostris I. Para Jenni (1998, pp. 113-141) el acto mágico de Djedi de reinsertar la cabeza de los animales recién cortadas y volverlas a la vida, es una metáfora de la reconciliación de Sesostris I con un ambiente hostil, de la que deriva una lectura del relato en clave de propagada real por parte de este rey. Entendemos que una interpretación como la propuesta por Jenni es problemática ya que no encontramos argumentos para vincular la situación política de la transición de la dinastía XII con dichas metáforas literarias.

A diferencia de aquellas interpretaciones que destacan que los textos literarios son meramente ficcionales, Goedicke (1993, p. 32) afirma que es difícil asumir en ellos un contenido histórico. Las desviaciones en los nombres de los personajes con relación a los nombres de los reyes históricos es para Hays (2002, p. 25) uno de los ejemplos más esclarecedores de cómo el relato literario no se ajusta a una realidad histórica. Para el autor puede asumirse como válida una "licencia artística" que el escriba adopta, y que al dejar de lado todo tipo de precisión histórica sobre los nombres de los faraones, el tiempo de la narración se coloca por fuera del tiempo histórico, para ubicarse en el tiempo fuera del tiempo ${ }^{129}$.

\footnotetext{
${ }^{129}$ No es ésta la única falsedad histórica que está presente, según Hays (2002, pp. 24-25), en los dos últimos relatos del papiro Westcar. Otra incongruencia es la que se da entre la cantidad de reyes que reinaron según la profecía de Djedi después de Keops y el gobierno de Sahura, con respecto a los datos proporcionados por Listas Reales y Manetón. La posibilidad de hallar para Reddjedet una relación fehaciente con un personaje histórico nos parece inviable, si bien se la ha querido asimilar con la reina Khentkaues I, como lo veremos más adelante.
} 
Hays nos ubica en la narración de los dos últimos relatos del papiro Westcar en el plano de lo mítico, siendo que en esencia -al igual que los relatos míticos del origen del faraón- los dos son la narración de un origen, el de la dinastía V. Los dos últimos relatos del papiro Westcar narran un origen mítico para la dinastía $\mathrm{V}$, un origen divino para sus tres primeros reyes, que la Historia comprueba como los primeros faraones de la dinastía V. En la sociedad egipcia el origen nos remite indefectiblemente a las ideas constitutivas que rigen su sentido de ser, cómo se aprehende y comprende la realidad (Salem 2009, p. 106).

El origen es lo que determinó en las sociedades antiguas el sentido de su existencia, y fue relatado en el mito (Eliade 1992 [1963], p. 17). Para los egipcios solamente hubo un origen por excelencia que es la creación por el gran dios acontecida en un tiempo inmemorable, la fundación del universo. Este mundo creado es ordenado y se contrapone a lo caótico, desconocido y no creado. Dentro de la cosmogonía se originan todos los elementos que son constitutivos de la naturaleza y de la sociedad de la cual el hombre forma parte.

A los relatos que recrean estos tiempos Eliade (1992 [1963], pp. 28-45) los ha denominado mitos de origen. Concretado el origen del universo se despliegan una multiplicidad de orígenes que dan existencia a todas las cosas, desde la monarquía como forma de gobierno, una piedra, el cielo, las tumbas.

El mito, al narrar un acto realizado por los dioses, se convierte en un hecho sagrado. El mito es una historia sagrada y como tal es significativa, pues rige como modelo ejemplar de las actividades que la sociedad realiza (Eliade 1992 [1963], p. 13). Es decir, que aquel acto primordial que el mito narra es la esencia de la realidad vivida, pues ésta se constituye en su eterna repetición. Para una sociedad como la egipcia el trascurrir de los hechos no era más que un retorno sin fin a los orígenes. Este transcurrir, en términos de Cervelló Autuori (1996a, p. 14) veda toda posibilidad de innovación, de transgredir el modelo mítico originario, pues la repetición de los modelos es lo constitutivo de la sociedad.

La repetición del modelo mítico es lo que ocurre con el relato mítico del origen divino del rey, el cual se expresó primero en forma literaria en los relatos del papiro Westcar, y luego en las paredes de los templos del Reino Nuevo, 
sucediéndose modificaciones según el interés a quien se le adjudicaba el relato. Algunas modificaciones e innovaciones que se producen en cada relato, principalmente están sujetas al contexto para el cual los mismos fueron creados.

Podemos aproximarnos a una definición de mito en las palabras de Cervelló Autuori (1996a, p. 23) “mito e imagen, pues no 'relatan' hechos históricos, contingentes, que pueden ser reducidos de ellos de forma 'directa' o 'integral', sino que evocan hechos paradigmáticos, modélicos, trascendentes, de la esfera de lo cósmico, es decir, los hechos por antonomasia ...”. En palabras de Assmann (1997, p. 48) el pasado se construye como un mito fundacional histórico -sin que esta historia sea un relato de realidad y objetivo desprovisto de ficción- que se consolida y se internaliza en la sociedad, a través de su recuerdo y la construcción de una memoria cultural ${ }^{30}$. Así, quedan desarticulados los análisis que separan a un relato como falso (mítico ficcional) y lo verdadero (realidad histórica).

Desde este punto de vista, los dos últimos relatos del papiro Westcar reconstruyen un origen divino, y al ser una narración que relata la creación de una nueva dinastía hace de ellos un mito de origen. Lo modélico, lo paradigmático en los relatos del papiro Westcar, es la imagen que de ellos se desprende, aquella que narra la conformación de una nueva dinastía, a partir del relato del nacimiento de tres niños que serán faraones en Egipto. Se construye de este modo un relato mítico, una historia fundante in illo tempore (Assmann 1997, p. 50) que está cargada de significados. Desde un punto de vista mítico-político legitima la existencia de la dinastía $\mathrm{V}$ y sus faraones como detentadores del poder monárquico. El mito confluye con la realidad histórica, pero el relato no se construye como una verdad objetiva, sino que el recuerdo se transmite culturalmente como un mito, por ende no hay en el relato una única verdad.

El mito relata y ritualiza eternamente la repetición de los orígenes, quedando instituido dentro del plano cosmogónico, el mito le otorga existencia a las ideas políticas, sociales y religiosas. En cambio, las creaciones literarias narran una historia mítica que permite incorporar la Historia al mundo pensado del eterno retorno. El

\footnotetext{
${ }^{130}$ La memoria cultural será analizada con relación a los dos últimos relatos del papiro Westcar en el capítulo V.
} 
mito al ser relatado se reactualiza, se lo revive una y otra vez cuando es narrado, cuando es recordado ${ }^{131}$. La relación que existe entre los mitos y las narraciones de ficción es que ambos relatan historias. En el caso de los dos últimos relatos del papiro Westcar el mito se incorpora a la narrativa de ficción, pudiéndose analizar cómo sus personajes y los hechos que ocurren se asemejan y coinciden con los mitos de la realeza o los mitos de origen del faraón (Salem 2009, p. 107).

Si bien estos relatos responden a un modelo de narración mítica en ellos se presentan ciertas particularidades que se circunscriben al contexto histórico tanto de lo que están narrando como del momento que fueron escritos. Siguiendo el modelo del mito, los dos últimos relatos del papiro Westcar no narran un origen cualquiera, sino que relatan literariamente el origen de la dinastía V. Por lo cual, el pasado de la dinastía $\mathrm{V}$ que se recuerda míticamente en los dos últimos relatos del papiro Westcar, se puede historizar.

El mito de origen del faraón es la esencia de la narración de los relatos del papiro Westcar. Existen elementos que en ellos aparecen y los enmarcan históricamente, sin que los conviertan en una narración histórica. Además, no es el acontecimiento histórico el que antecede y moldea al mito, sino que es el mito el que permite explicar los sucesos históricos (Cervelló Autuori 1996a, p. 21). El relato mítico literario permite darle sentido a un acontecimiento, en este caso la formación de la dinastía V, lo que permite deducir que este hecho fue sin duda trascendental de acuerdo a cómo los egipcios interpretaron su propia historia, y que se mantuvo en el recuerdo de la sociedad egipcia a través de su memoria cultural: un pasado mítico que es significativo porque solamente el pasado significativo es recordado (Assmann 1997, p. 49).

En la creación mítica literaria del origen de la dinastía $\mathrm{V}$ se evidencian elementos que son particulares y únicos; que reflejan lo pensado y recordado por la sociedad egipcia en relación a ella. Se recuerda a través de los relatos del papiro Westcar que los tres primeros faraones de la dinastía $\mathrm{V}$ fueron Userkaf, Sahura y Neferikara Kakai. Si bien históricamente no fueron hermanos, fueron representados

131 Podría pensarse que contar una historia que recuerda al mito en la ficción cumpliría la función que tiene el ritual en la liturgia, pues al ser relatado se trae una y otra vez al presente, se lo reactualiza y se lo repite. 
en el mito literario como trillizos. Son los diferentes contextos históricos que interceden e influyen en la interpretación que a través del mito se hace de ellos; especialmente el recuerdo se focaliza en el culto del dios Ra y la figura del faraón como su hijo. La solarización de la realeza subyace al sentido religioso que fue parte del culto de Estado durante Reino Antiguo y especialmente en la dinastía V.

\section{E1 faraón como hijo de Ra: $s 3 r^{r}$}

Como parte de la ideología y la política del Estado egipcio el faraón era reconocido por su inherente divinidad. En el Reino Antiguo fue con el dios solar Ra con quien estableció vínculos que hicieron a la esencia de la legitimación de la realeza. A partir de aquí se configura una idea que será central en la cosmogonía e ideología faraónica. Para un faraón la condición inherente para gobernar era ser hijo de un dios, ser hijo de Ra. Es decir, todos aquellos que no lo fueran quedaban excluidos de la posibilidad de acceder al trono y coronarse como reyes en Egipto (Salem 2009, p. 108). El faraón es el único hijo que el dios Ra tiene en la tierra, lo que le da al monarca un conocimiento del mundo divino que es vedado al resto de los hombres, pues su cuerpo mismo en esencia es divino (Quirke 2003, pp. 22 y ss.). Ya adjudicábamos al rey una posición intermedia entre los dioses y la humanidad, pero su legitimidad estaba otorgada por ser el último tras una larga de serie de reinados, el cual los dioses habían iniciado y la continuaban eternamente los faraones ${ }^{132}$.

Según Moreno García (2004, p. 163) la identificación del rey como hijo o amado de las divinidades era reflejo de la posición subalterna que tenía respecto a ellas, esa ubicación intermedia entre dios y la humanidad de la cual hacíamos referencia. Pero también era muestra de una relación de intimidad, dependencia y devoción entre divinidad y rey (Baines 1995, p. 11; Frankfort 1998b [1948], p. 66). Los dioses habían sido los primeros gobernantes de los hombres sobre la tierra y

${ }^{132}$ La continuidad con el pasado que la monarquía egipcia transmitió con la intención de ubicarse dentro de una tradición que la legitima como tal, se observa claramente en Canón de Turín. En el verso de este papiro escrito en hierático durante la dinastía XIX bajo el reinado de Ramsés II, se describe la sucesión sin interrupciones de los diferentes reinados de los faraones egipcios, iniciándose la lista con el gobierno de los dioses. La configuración de estas sucesiones son típicas en Listas Reales, al respecto Redford (1986) y Salem (2011). 
habitaban el mundo desde sus orígenes, a diferencia de ellos el faraón tenía un origen mundano, los dioses pertenecían a un mundo sólo habitado por la divinidad (Silverman 1991, p. 63). Si bien el rey fue una divinidad, por poseer la esencia divina, la percepción de su naturaleza se modificó y no fue estática a lo largo de su historia (Silverman 1991, p. 58; Salem 2010a, p. 276).

Una de las relaciones familiares que fue construida en las referencias biográficas de los faraones es la de ser el hijo de un dios. Esta designación que establece una relación de hijo de la divinidad, es equivalente a la idea de que el faraón es Horus en vida, en tanto que ambas acentúan el carácter divino que posee el rey, del cual hacíamos mención (Frankfort 1998b [1948], p. 66). Si bien en la mitología era Shu el único hijo del dios Ra (Frankfort 1998b [1948]; Lull 2006, p. 19 y ss.), la idea de que el faraón también lo fuera atestigua que el dios había confiado en él para que gobernase la tierra, es decir domine en el Estado egipcio. El rey podía ser simbolizado tanto como dios o como hijo del dios, siendo ésto último la esencia de la teología solar, aquella en la cual el faraón era engendrado del cuerpo del dios Ra y que a su muerte retornaba al cuerpo de su progenitor, se cumplía un ciclo que era divino -y también puede agregarse que era político- ya que "desde el momento de su concepción, durante toda la vida y hasta su triunfo final sobre la muerte, el rey era el hijo de Ra” (Wilson 1954, pp. 100-102).

La presencia del culto al dios Sol desde comienzos del Estado está siendo reconsiderada. La relectura del nombre del faraón Ra-neb de la dinastía II, como "señor de Ra", conlleva la aceptación de que el culto al dios Sol ya estaba presente en épocas tempranas del antiguo Egipto. Esta idea es sostenida con otras evidencias: el nombre del faraón Weneg está íntimamente ligado con el culto solar, según se desprende de Textos de las Pirámides ${ }^{133}$; nombres de funcionarios, escribas y miembros de la familia real se componen con el término $\mathrm{Ra}$; el título wr m3w que llevaron los sacerdotes de $\mathrm{Ra}$ en el templo de Heliópolis se detecta tempranamente para la dinastía II; y la emergencia paralela del culto de maat con el de Ra explicita la presencia del culto al Sol desde los primeros tiempos (Kahl 2007, pp. 2-3 y ss.). Esta

\footnotetext{
133 Al respecto véase la traducción de Textos de las Pirámides realizada por Allen (2005) con traducciones y comentarios. Un estudio crítico a la obra de Allen en Shmakov (2012).
} 
diseminada evidencia le permite a Kahl concluir que a partir de los reinados de Raneb y Weneg de la dinastía II se establece un cambio teológico que prioriza a $\mathrm{Ra}$ como deidad, como un nuevo paradigma dentro del Estado egipcio. Dicha modificación no fue el resultado de un proceso sin conflictos. La aceptación de la veneración de Ra en época temprana obliga a una relectura de fuentes conocidas, al mismo tiempo que posibilita pensar que la subordinación de los faraones de la dinastía II al poder divino de Ra le permitió una nueva legitimación.

Más allá de lo convincente que las fuentes puedan o no ser, en relación a la presencia del culto de Ra en la vida de la elite egipcia a partir de la dinastía II, no son evidencias que nos permitan reconstruir y reflexionar acerca del posicionamiento del rey como hijo del dios Ra. Únicamente son indicios de un paulatino ascenso del culto del dios Sol.

Este proceso se hará cada vez más evidente a finales de la dinastía III y principios de la dinastía IV, a través de la construcción de los complejos funerarios reales y los modos de escribir los nombres de los faraones. Por ejemplo, se incorpora la escritura del nombre del rey dentro de un cartucho. La forma ovalada del cartucho connota una figuración hacia lo solar, pues expresaría el movimiento que el sol realiza a diario como astro (Baines 1995, p. 9). Para algunos investigadores esta incorporación fue una innovación del monarca Huni, el último rey de la dinastía III, señal de la tendencia hacia la solarización de la realeza (Parra Ortiz 2009, p. 133)134. Mientras que para otros fue Snefru (Quirke 1990, pp. 20 y ss.) el primero en realizarla. Sin poder definir cuál fue el primero, es probable que para el reinado de Snefru la ideología solar estuviera ya fuertemente constituida en el Estado egipcio. La consagración de la religión solar se plasma en el complejo funerario de dicho monarca, quien construye la primer pirámide de caras lisas, facilitando el ascenso del difunto rey a los cielos de Ra (Parra Ortiz 2009, p. 135). La elevación -de ahí la marcada verticalidad de la pirámide- del rey al cielo significa su incorporación en el curso solar, y el reflejo del mapa del cielo en la tierra (Assmann 2005 [1996], p. 78),

${ }^{134}$ El mejor reflejo de esta tendencia lo otorga el propio complejo funerario de Huni, ahora cuadrado y con la forma que luego se estandarizará para el Reino Antiguo, esto es una pirámide subsidiaria, un templo alto, una calzada de acceso y un templo bajo, quedando de este modo planteadas las bases para el cambio ideológico y formal que transformaría a la monarquía durante la dinastía IV (Parra Ortiz 2009, p. 133). 
permitiéndole así su renacimiento. Al mismo tiempo la pirámide era venerada como símbolo en el templo de Heliópolis ${ }^{135}$.

Los faraones del Reino Antiguo edificaron las pirámides para el dios Sol que ellos mismos encarnaban, en lo que Assmann ha denominado como modelo encarnativo, al cual volveremos. Con las pirámides el rey se construye una tumba para él en tanto encarnación de Ra, y no para el dios Sol. De todos modos, obedece a la misma idea de configuración de un espacio sagrado, que permite al rey participar en la eternidad del cielo (Assmann 2005 [1996], p. 82).

A partir de la dinastía II y en adelante se observa el desarrollo del culto hacia el dios Sol con el incremento del uso de $r^{\complement}$ para formar el nombre del faraón. El primero de ellos es el segundo rey de la dinastía II (Dodson y Hilton 2005, p. 44) $n b-r^{\bullet} \odot \circlearrowright \equiv$, el faraón Nebra. En la dinastía III no hay evidencia que algún monarca haya incorporado la partícula $r^{\complement}$ en su nombre. En tanto que para la dinastía IV podemos asegurar que tres de ellos sí lo llevaron: el tercer faraón de la

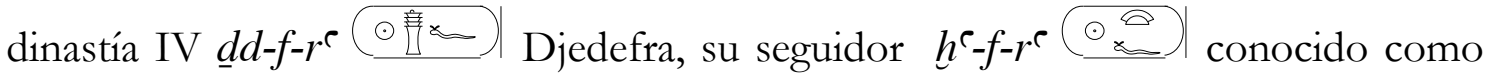

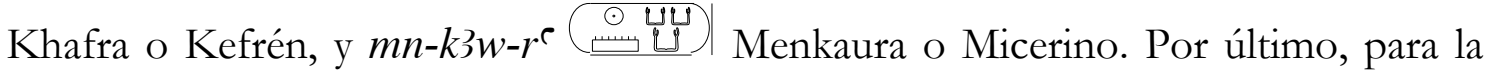
dinastía $\mathrm{V}$ tenemos el nombre de cuatro de sus faraónes: wśrt-s-k3-re

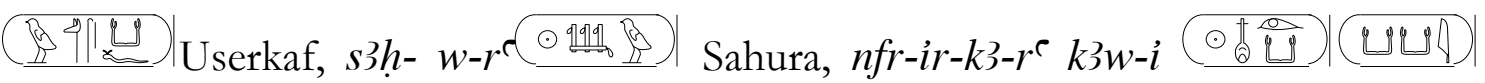

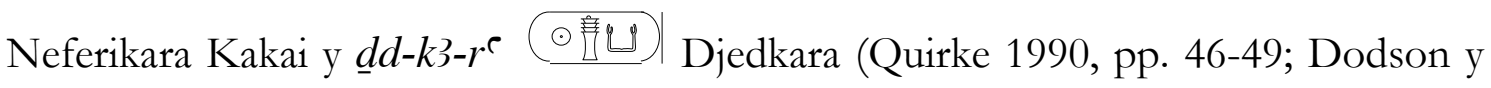
Hilton 2005, pp. 44-45)136.

Hay un incremento del uso del vocablo $r^{\complement}$ para la composición del nombre del faraón desde la dinastía II hacia la dinastía V. Su uso quedará totalmente constituido a partir de ella, es decir se canoniza. Luego la mayoría de los faraones utilizaron dentro de su nombre el término de $r^{\Upsilon 137}$.

\footnotetext{
135 Para comienzos de la dinastía IV otras huellas se destacan en el proceso de solarización. Con relación a la configuración espacial de los complejos funerarios del faraón Snefru véase Assmann (2005 [1996], pp. 71 y ss.) y Parra Ortiz (2009, pp. 135-136).

${ }^{136}$ Con relación a la composición morfológica de los nombres de los faraones en su protocolo, véase Aufrère (1982).

${ }^{137}$ Los faraones de la dinastía VI que llevaron $r^{\complement}$ dentro de su nombre fueron: Meryra o Pepi I, Merenra Nemtyemsaf, Neferkara o Pepi II (Quirke 1990, p. 49). Entre las dinastías VII y VIII: Netjerkara, Menkara, Neferkara II, Nikara, Neferkaura, Neferirkara II (Dodson y Hilton 2005, p. 70).
} 
La incorporación del culto del dios $\mathrm{Ra}$ como parte de la ideología de la monarquía se habría expresado con el título real $s_{3}^{3} r^{e}$, Hijo de Ra. Este título que simbolizaba la relación divina y familiar, fue el último en incorporarse y oficializarse de los cinco títulos del faraón. El término $s 3 r^{\ulcorner}$se antepuso al nombre del rey escrito dentro del cartucho, así se modificó el modo de escribir los nombres de los faraones y constituyó el nombre que se le otorgaba al monarca desde su nacimiento.

Los dos últimos relatos del papiro Westcar narran el nacimiento de los hijos de Ra como reyes en Egipto, quienes inauguran la dinastía V, es decir que el relato se contextualiza literariamente en esta época. Estos niños, en tanto hijos del dios Sol, es que podrán ejercer como reyes sobre las Dos Tierras. Los hijos de Reddjedet adquieren la posibilidad de gobernar por ser hijos del dios. En el relato literario se indica así una relación familiar que es divina. No se trataba de conformar una familia humana para que reinara en la tierra, sino que era la demostración de la intervención cósmica del dios Sol en la vida de aquellos que se encuentran en la tierra (Quirke 2003 , p. 23). De este modo, los dos últimos relatos del papiro Westcar construyen un mito de origen de la dinastía V como hija de Ra.

Esta relación se oficializó con el quinto título real que se antepuso al cartucho, lo que según el mayor número de interpretaciones se generaliza o canoniza a partir de la dinastía V (Fuscaldo 1966, p. 2). Fue el único nombre que el faraón adquirió anterior a su nacimiento (Kahl 2007, p. 8), de ahí que sea este el nombre de nacimiento del rey, como hijo del dios Ra. Es decir, que este nombre era parte del título honorífico del rey, que no fue abandonado una vez que se canonizó. La expresión en la titulatura real determinaba la pureza de la sangre divina del faraón, pues no había ningún elemento que se interpusiera entre el padre dios y el hijo rey, también fue simbolizada con la expresión "bijo de su cuerpo" (Colin Campbell 1912, pp. 3-4).

Tradicionalmente se ha estimado que el primer faraón en llevar el título de $s 3$ $r^{\complement}$ es Djedefra, quien accedió al trono tras haber triunfado en una disputa interna de la familia real, al casarse con Hetepheres II, media hermana de Keops (Kanawati 2003 , p. 2). O al menos fue el primer faraón en utilizar la frase $s 3 r^{c}$ dentro de su titulatura real (Quirke 1990, p. 25). 
En los fragmentos del trono de piedra encontrado en Abu Roash, adjudicado a Djedefra, tercer faraón de la dinastía IV, Müller (1964, p. 131) considera que es la primera vez que se escribe la expresión de $s 3 r^{e}$ en el protocolo real, y a partir de allí se generalizó dentro de la realeza (Dobrev 1993, p. 196) ${ }^{138}$. Como atinadamente menciona Fuscaldo (1966, p. 2) en las imágenes publicadas por Müller se observa arriba de la inscripción $n b$ h'w "señor de apariciones", las patas en posición de marcha características del pato rabudo ?ै (el signo jeroglífico G39 según la nomenclatura de Gardiner), el que se emplea para s3 "bijo". El disco solar que completaría la expresión $s 3 r^{\ulcorner}$, estaría grabado encima de éste, pero lamentablemente la lectura del signo solar $r^{e}$, el signo N5, no es segura. Sin embargo, la correcta lectura se garantiza comparándolas con dos inscripciones de Kefrén (Hays 2002, p. 21), sobre las cuales volveremos más adelante.

La visualización corrupta de los signos nos permite poner en duda la lectura completa de la expresión $s_{3}^{3} r^{\ulcorner}$. Su uso no es parte del título real de nacimiento del faraón Djedefra (Quirke 1990, p. 47). Está claro que no continúa en la escritura el cartucho con el nombre del rey, por lo que su determinación como Hijo de Ra puede ser interpretada como una mención de su condición divina, propia de la formación ideológica y cosmogónica de la realeza egipcia y no como título real. Lo que complejiza también la interpretación, es que en la oración anterior se menciona al rey en relación a los otros cuatro títulos: Horus, Dos Señoras, Horus de Oro y Rey del Alto y Bajo Egipto. Por ende, Hijo de Ra vendría a completar la titulatura, pero nuevamente al no estar dentro del cartucho, puede pensarse que el de $s^{3} r^{c}$ no es parte de su nombre como monarca.

138 Por dicha expresión se deduce que está dedicada al tercer faraón de la dinastía IV: hr hpr nbty hpr-m hrw nbw n-sw-bity ddd.f-re. "Horus que llega a existir las Dos Señoras, Horus de Oro, Rey del Alto y Bajo Egipto, Djedefra". Según Fuscaldo (1966, p. 2) se traduce como "Horus llega a existir, el que llega a existir como Dos Señoras, los Horus de oro, Rey del Alto y Bajo Egipto, Djedefra". 


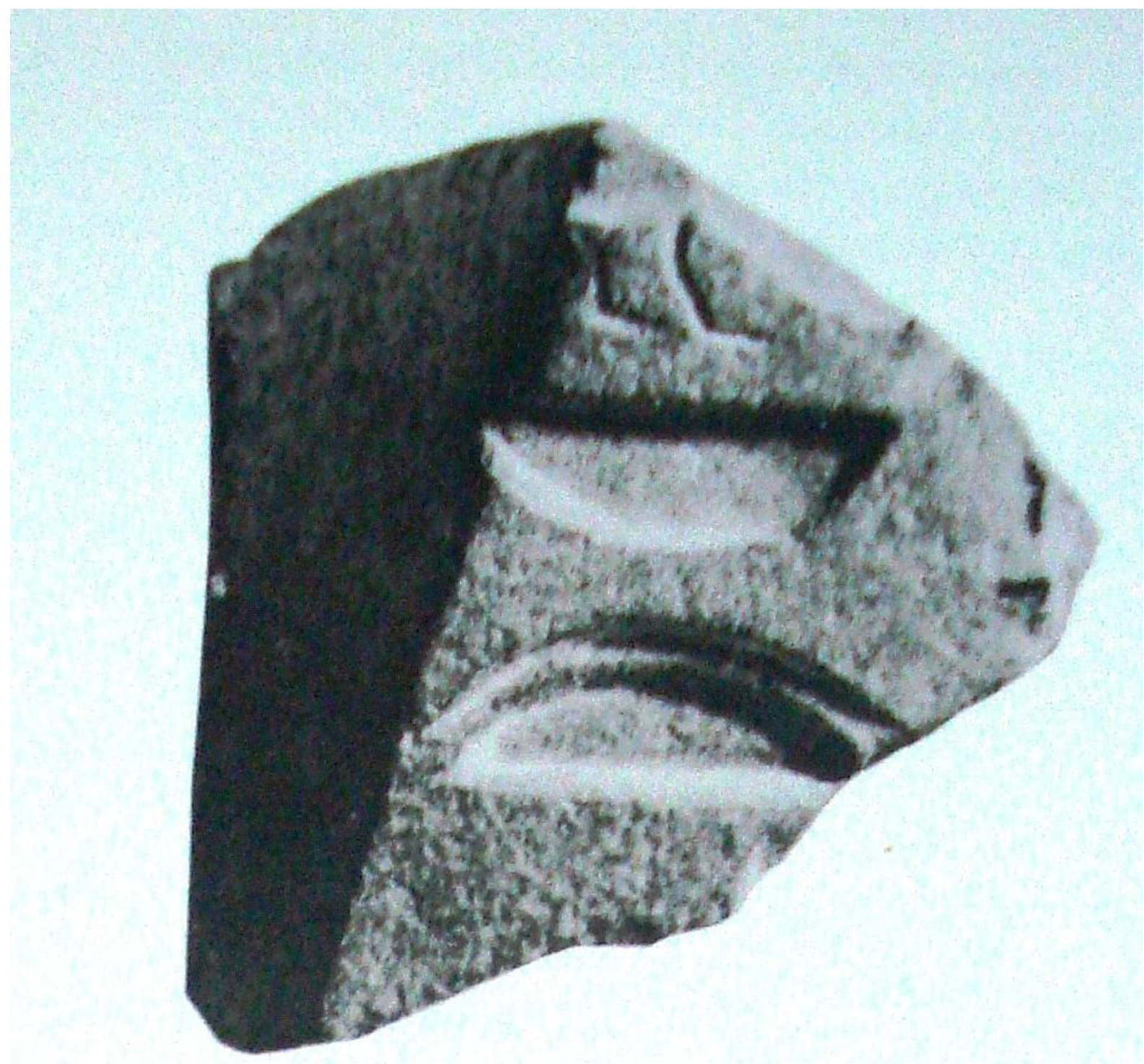

IMAGEN I. Parte de la inscripción publicada por Müller (1964, cuadro III) en la que se observan las patas del signo fon el que se escribe $s 3 r^{c}$ 
Además, se conoce que en Textos de las Pirámides el faraón es mencionado en algunos conjuros como hijo de Ra, pero esta asociación solamente se daba una vez que había muerto el rey (Fuscaldo 1966, p. 3). Por ejemplo, en el discurso 476139, la expresión hijo de Ra aparece asociada a la planta weneg, que a su vez se relaciona con el faraón de la dinastía II Weneg, y que está íntimamente vinculado con la lectura que Kahl (2007, pp. 3 y ss.) realiza del nombre del rey, como "Ra es mi señor". Señalábamos que esto da cuenta de la veneración al dios Sol en épocas tempranas, pero no están asociadas al empleo del término hijo de $\mathrm{Ra}$ como nombre de nacimiento del rey.

Al mismo tiempo, se conocen de la estatuaria del faraón Kefrén dos inscripciones publicadas y analizadas por Borchardt (1911) en las cuales se menciona la expresión hijo de $\mathrm{Ra}^{140}$. En ellas $s 3 r^{\top}$ no está en relación al nombre de nacimiento del rey. Lo mismo puede decirse para Micerino (Menkaura); en un sello cilíndrico dedicado a él puede leerse: $m n-k 3$. $w-r^{\complement} s 3 r^{\ulcorner}$mrii-ntr.w $r^{\ulcorner} n b$ "Micerino, bijo de Ra, amado por los dioses cada día" (Hays 2002, p. 21; Kaplony 1981, inscripción en cuadro $33)^{141}$.

En suma, con anterioridad a la dinastía $\mathrm{V}$ la expresión $s 3 r^{\complement}$ dentro de menciones reales no aparece escrita antes del nombre del faraón, sino que es una aposición al nombre del rey (Hays 2002, p. 21). Por ello, se insiste en que hijo de Ra todavía no está siendo utilizado por la realeza para destacar la posición del rey dentro de su titulatura honorífica ${ }^{142}$. De todos modos, la aparición de estas referencias en contacto directo con los faraones de la dinastía IV sugiere para Hays (2002, p. 22) que la noción transmitida por la expresión $s 3 r^{\ulcorner}$se había convertido en un elemento integral de la ideología real. Volveremos más adelante con esta idea, al

\footnotetext{
139 Este texto es conocido por cuatro copias, la de los faraones Pepi I, Merenra, Pepi II y la de la reina Neith.

${ }^{140}$ Hacemos referencia a las estatuas que Borchardt (1911) catalogó con los números 15 y 17. Al respecto también véase Fuscaldo (1966, pp. 2-3).

${ }^{141}$ Hays (comunicación personal) nos aclaró esta transliteración. Agradecemos a dicho investigador quien nos pemitió acceder a la publicación de Kaplony (1981, pp. 100-101 y cuadro 33).

142 Una postura contraria en Dobrev (1993, p. 179 y pp. 196 y ss.), quien asegura que el periodo decisivo a la evolución de la titulatura real se produce durante la dinastía IV, cuando se completan los cinco títulos reales, indicando que el título Hijo de Ra es la gran innovación dentro de la titulatura real de la dinastía IV. Sin embargo, ya examinamos lo problemático de esta evidencia.
} 
hacer referencia a otros elementos vinculados al dios $\mathrm{Ra}$, que están intrincados con la realeza egipcia.

Quien sí llevó el título honorífico de $s 3 r^{\complement}$ fue el segundo faraón de la dinastía V, Sahura. El mito de origen de la dinastía recordado en los dos últimos relatos del papiro Westcar se correlaciona con el título que Sahura proclamó para sí mismo. Como lo señala Hays (2002, p. 21) en una inscripción (Urk. I, 169, 8) del faraón Sahura en Siria puede leerse: $\odot$ 뻬에 esta inscripción, $s 3 r^{r}$ se vincula con el nombre del faraón escrito en un cartucho, por ende su relación como Hijo del dios Ra es parte de su título protocolar, pero aún se escribe posteriormente al nombre del rey.

El tercer faraón de la dinastía V, Neferikara Kakai fue el primero en llevar dos cartuchos con dos nombres diferentes. El primero de los nombres, Neferikara, fue aquel que el faraón utilizó en las paredes de los monumentos durante toda su vida, y mantiene una estrecha relación con el nombre de $\mathrm{Ra}$, de hecho contiene el término $r^{\ulcorner}$dentro de él. Mientras que Kakai es una innovación: fue utilizado una vez muerto el rey, es el nombre del faraón desde su nacimiento (Quirke 1990, pp. 26$27)^{144}$.

Como afirma Quirke (1990, p. 25) en el curso del Reino Antiguo la frase hijo de Ra que aparece mencionada como epíteto para el faraón Djedefra, evoluciona como título fijo para incorporarse como uno de los cinco títulos reales del rey, ya atestiguado para la dinastía $\mathrm{V}$.

La relación familiar, divina y exclusiva que mantuvieron los faraones de la dinastía $\mathrm{V}$ no es un simple argumento literario, sino que manifiesta la configuración del recuerdo que se plasma literariamente en los dos últimos relatos del papiro Westcar. Ellos reconstruyen una relación filial que se gestó durante la dinastía V. Este relato literario que narra el origen mítico de la dinastía $V$, se entrelaza a través

\footnotetext{
${ }^{143}$ Una posición contraria en Daressy (1916) para quien a partir de la dinastía VI $s 3 r^{\complement}$ precederá al nombre que se le reconoce al faraón al nacer.

${ }^{144} \mathrm{El}$ nombre en el primer cartucho podría haber sido un reemplazo pronunciado con el nombre de Horus durante la entronización del rey. Por este motivo, los egiptólogos denominan a este como nombre de coronación, y al segundo nombre en cartucho, como nombre de nacimiento (Quirke 1990, p. 26).
} 
de la memoria cultural egipcia con un proceso que fue histórico: el reconocimiento por parte de la ideología faraónica de que del rey era el Hijo del dios Ra.

El recuerdo de la relación familiar que tuvieron los faraones de la dinastía V, también puede ser considerado como un argumento a favor de que era una nueva línea real y diferenciada de la dinastía IV, más allá de que históricamente no hayan sido hermanos entre ellos. El reconocimiento de un nuevo linaje se contrapone a las ideas que han sugerido que los faraones que reinaron entre Shepseskaf -último faraón de la dinastía IV- y Teti -primer rey de la dinastía VI- no han formado un grupo separado. Si esto se aceptase no se podría colocar a dichos faraones conformando una dinastía aparte (Quirke 1990, p. 48).

El texto narrativo remite a la inauguración de una nueva época, la conformación de una nueva dinastía con un elemento más que significativo, su filiación divina. Esta transición debió haber tenido un fuerte arraigo dentro de la experiencia política y religiosa, en tanto es la que recuerdan los dos últimos relatos del papiro Westcar, (re)construyendo su mito de origen. La memoria egipcia destaca la relevancia del culto solar hacia la dinastía $V$, lo que quizá fue el motivo que determinó un nuevo linaje. No son claras las causas que determinaron este cambio dinástico, en principio porque políticamente no hay motivos evidentes de fractura dentro de la monarquía. Aunque no se reconocen actuando los mismos funcionarios entre una y otra dinastía (Parra Ortiz 2009, p. 146) ${ }^{145}$.

Assmann (2005 [1996], pp. 236-237) reconoce en los relatos del papiro Westcar una narración mítica, que explica la transición de dos modelos de configuración de la realeza. Uno constelativo, que equipara al faraón con un dios; el otro representativo, en el cual el faraón es hijo de un dios. Según Assmann los relatos del papiro Westcar son una historia modelada, con un trasfondo que es histórico. Se adaptan a lo que quiere transmitirse y recordarse: el origen divino de la dinastía $\mathrm{V}$, siendo los testimonios arqueológicos y epigráficos los que dan la razón al mito.

145 De todos modos se conoce un caso contrario, el de Ptahshepses, que en su longeva vida fue miembro de la administración de Menkaura, Shepseskaf, Userkaf, Sahura, Neferikara Kakai y Niuserra. 
Aquello que se recuerda a través de los dos últimos relatos del papiro Westcar es el nacimiento divino de tres figuras, Userkaf, Sahura y Neferikara Kakai. Ellos no fueron hermanos históricamente, pero el mito los pretende como tales. Pues es la narración del origen de la dinastía V. A diferencia los ciclos míticos de la reina Hatshepsut y los reyes Amenofis III y Ramsés II, nacen niños que son tratados individualmente, pero que en conjunto conforman una dinastía.

Que el recuerdo mítico-literario reconstruya el nacimiento divino de la dinastía V, pareciera nuevamente no ser una casualidad, sino que está en consonancia con la cosmogonía que surge durante este periodo, una expresión más de la manifestación de la religiosidad hacia $\mathrm{Ra}$, de la relación que los faraones de esta dinastía expresaron con el culto al dios solar. Sin embargo, según Hays (2002, p. 24) los relatos del papiro Westcar no hacen a los faraones de la dinastía V más solares que otros gobernantes egipcios. Ello porque Hays interpreta que el culto a Ra ya estaba establecido con anterioridad, y porque la representación literaria de los tres primeros faraones de la dinastía $\mathrm{V}$ como hijos del dios narra una situación que no es históricamente adecuada. Ya vimos que con las distinciones con respecto al uso del título de Hijo de Ra, se establecen otro tipo de vínculos con el dios.

Este modelo se refleja no sólo en el título real y el recuerdo que de ello plasmaron los egipcios en los dos últimos relatos del papiro Westcar, sino también en la configuración espacial y arquitectónica de los complejos funerarios de los faraones de la dinastía V y principios de la dinastía VI. En las pirámides de Huni y Pepi I se alcanza la perfección de un elemento que en las de Giza aún estaba en transición, esto es el templo adosado a la cara oriental de las pirámides, templo que adquiere su forma canónica con la dinastía V (Assmann 2005 [1996], p. 83).

Los faraones de la dinastía $\mathrm{V}$ encontraron una solución para expresar la nueva semántica de la realeza. Por un lado, los monarcas rompieron con la tradición de Giza, y se hicieron construir pirámides mucho más pequeñas. Además, se inició la edificación de un nuevo tipo de templo, el solar, que será una novedad para la época (Assmann 2005 [1996], p. 83). Si la dinastía IV buscó la perfección en la construcción de pirámides que equiparaban al rey con el dios Sol; la dinastía V 
incorporó en este proceso una forma arquitectónica cultual nueva, lugares de culto exclusivos para Ra (Salem 2009, p. 109).

La documentación escrita nos permite conocer que fueron los primeros seis faraones de la dinastía V quienes se hicieron construir un templo solar (Strudwick 2005, p. 28; Parra Ortiz 2009, p. 146). Solamente han quedado registros arqueológicos de dos de ellos, el más deteriorado es el templo solar de Userkaf en Abusir y un poco mejor conservado es el de Niuserra en Abu Gurob. Lo más probable es que el modelo que los faraones siguieron fue el del todavía no localizado templo solar de Heliópolis, en el cual se supone que en el centro se erigía una estructura que simbolizaba la colina primigenia o ben-ben.

Según Assmann (2005 [1996], p. 83) los templos solares estuvieron plenamente dedicados a la veneración del dios Ra. Por el contrario, Quirke (2003, pp. 158-159) argumenta que los nuevos edificios construidos por la dinastía V no son "templos solares" dedicados al dios, sino templos construidos para el culto del faraón. Los faraones de la dinastía $\mathrm{V}$ habían perdido un espacio geográfico que orientara sus tumbas mirando hacia la sagrada ciudad de Heliópolis. La solución a este problema fue según Quirke la construcción de los templos solares, "un medio de mantener la relación directa entre el lugar de enterramiento del rey, así como el hogar del dios sol en la tierra" (Quirke 2003, p. 158). La evidencia de que el lazo más fuerte de los templos solares era con el rey y no con el dios Ra, es el nombre que cada una de estas edificaciones llevó ${ }^{146}$. Este sentido que Quirke le otorga a los templos solares lo lleva a postular que no hubo dinastía más solar que la dinastía IV.

Hays (2002, p. 23) sostiene que estas nuevas edificaciones son la muestra de que el culto al dios Sol adquirió nuevas dimensiones, nuevas formaciones de sentido que únicamente pueden aceptarse si Ra es el padre del faraón, vínculos que según el autor están claramente establecidos ya en la dinastía IV. Por lo tanto, los templos solares no deben interpretarse como una ruptura, sino como una continuidad y profundización de las tradiciones solares dentro de la realeza.

\footnotetext{
${ }^{146}$ Los nombres de los templos solares fueron los siguientes: Userkaf lo llamó "Nekhenra:(lugar de nacimiento de Ra)"; Sahura "Sekhetra: (campo de Ra)"; Neferikara Kakai "Setybra: lugar del corazón de Ra"; Nyuserra "Shesepibra: (destinatario del corazón de Ra)" y Menkauhor "Akhetra: horizonte de Ra".
} 
Cabe destacar que los faraones de la dinastía $\mathrm{V}$ mantuvieron relaciones exclusivas con el dios Ra. De hecho, según Assmann (2005 [1996], p. 83), en estos santuarios solares es donde se expresa por primera vez el vínculo constelativo del rey, al ligar el culto funerario con el culto divino. Además, con el fin de la dinastía V, se concluirá la construcción de templos solares, pues no se conocen construcciones por fuera de esta dinastía. Según Moreno García (2004, p. 190) la multiplicidad de imágenes que se crearon alrededor del culto de las pirámides respondió a un largo proceso de búsqueda, en el cual algunas imágenes y monumentos permanecieron y otras se descartaron. Es dentro de esta búsqueda de expresión del culto solar que puede comprenderse la construcción de los templos solares por parte de la dinastía $\mathrm{V}$, y que luego fueran dejados de lado por las dinastías que le continuaron.

En suma, los dos últimos relatos del papiro Westcar recuerdan que fueron los tres primeros faraones de la dinastía $\mathrm{V}$ quienes nacieron de las relaciones de $\mathrm{Ra}$ con Reddjedet, y que desde su concepción fueron elegidos para gobernar Egipto. Es más, uno de ellos será el encargado de oficiar como sacerdote en el templo de Ra en Heliópolis. Por lo tanto, el primer elemento, y que es esencial en la historia del mito de origen del faraón, es que el rey es hijo de un dios. A diferencia de los ciclos míticos del Reino Nuevo, en los cuales solamente nace una niña o un niño, en los dos últimos relatos del papiro Westcar nacen trillizos. Es decir, tres niños hermanos de misma madre y mismo padre. El día de nacimiento de los trillizos será un elemento clave en la historia, éste coincide con la fecha en que $\mathrm{Ra}$ (re)nace anualmente. Los trillizos por su día de nacimiento también adquieren el mismo sentido cósmico, mítico y ritual que su padre Ra. A su vez, el rasgo divino de los tres futuros reyes es acentuado en el relato por la descripción de las formas de sus cuerpos al nacer, caracterización semejante de la que se hace de los dioses en relatos míticos como Destrucción de la Humanidad ${ }^{147}$.

${ }^{147}$ El mito de Destrucción de la Humanidad o el mito de La Vaca Celeste se encuentra en tres versiones completas en las tumbas de Seti I, Ramsés II y Ramsés III y ha sido muchas veces traducido, entre ellas se destacan: Maystre (1940, pp. 53-115); Brunner-Traut (2000 [1963], pp. 111-116); Galán (1998, pp. 55-56); Tyldesley (2011, pp. 180-182). 


\section{Padres divinos: Ra y Amón}

Los egipcios afirmaron y presentaron que el faraón era un hijo nacido de la relación entre una mujer terrenal con un dios, fuera o no de sangre real. Si bien en los relatos míticos la paternidad asumida por el dios Sol pareciera innegable, Goedicke en su artículo "Rudjet's delivery" ["El parto de Reddjedet"], cuestiona la paternidad de $\mathrm{Ra}$, ya que en el relato no se desprenden la cantidad de elementos necesarios que puedan asegurarlo. Goedicke (1985, p. 20) discute uno de los puntos cruciales del argumento del relato. Según el autor el hecho de que en el relato anexo del papiro Westcar el dios Ra envíe a los dioses para que ayuden a Reddjedet en el parto, no es motivo alguno para inferir su paternidad. En todo caso Ra sacaría provecho de esta situación, pero los beneficios no redundan en que él sea el padre, sino que el evento del nacimiento de los tres niños estaría de acuerdo con el "plan divino”. Según lo considera Goedicke (1985, p. 21; 1993, pp. 28 y ss.) el objetivo de este "plan divino" era posicionar a los niños recién nacidos en un futuro como reyes, los cuales impulsarán las construcciones de los templos y las donaciones de ofrendas para los dioses.

Sin embargo, Goedicke omite que la paternidad de $\mathrm{Ra}$ fue previamente anunciada por Djedi en el relato anterior, que corresponde al anuncio literario del nacimiento de los trillizos ${ }^{148}$. En el cuarto relato del papiro Westcar la paternidad argumental es afirmada por las palabras del mago: "Es la esposa de un sacerdote wab de $\mathrm{R} a$, señor de Sakhebu embarazada de tres hijos de Ra, señor de Sakhebu" ( relato, también reconocen al dios $\mathrm{Ra}$ como padre de los trillizos las diosas que asisten al parto de Reddjedet, cuándo Isis le pregunta a sus compañeras "¿Qué es esto que hemos venido para no hacer ninguna maravilla para aquellos niños según podamos informarle a su padre quién nos ha enviado?’ ( $p W .11 .10-12)$. A su vez, la comparación establecida con los ciclos míticos del Reino Nuevo esclarece este dilema, Ra al igual que Amón$\mathrm{Ra}$ reconocen ser los padres de los futuros reyes.

La función de $\mathrm{Ra}$ en los relatos del papiro Westcar es homóloga a la de Amón-Ra en el nacimiento divino de la reina Hatshepsut y los faraones Amenofis

148 Goedicke (1993, p. 25) asume que los relatos del papiro Westcar son una única pieza literaria, pero no cree que la información que se da en el cuarto relato pueda ser aceptada para reconocer la paternidad de Ra en el parto que se narra en el anexo. 
III y Ramsés II ${ }^{149}$. En éstos la descripción del momento previo y la concepción son narradas: el dios le pide permiso a los esposos de las reinas -es decir a los faraones Tutmosis I, Tutmosis IV y Seti I- para tener relaciones sexuales con sus esposas ${ }^{150}$. En la escena en que se representa la concepción, la figura masculina es el rey, pero el texto alude al dios, por ende hay un sincretismo entre el dios y el monarca. Goedicke (1985, p. 21) afirma que Reddjedet es una mujer casada y que sus hijos sólo podían ser fruto de su relación con Rauser. Sin embargo su condición no la inhibe como madre de los trillizos, sino que pareciera haber una concesión por parte del esposo. Al menos, esto no genera en el pensamiento egipcio alguna sanción moral, como sí lo pretende Goedicke.

Dejando de lado las discrepancias planteadas por Goedicke, es central la figura del personaje del dios Sol en los relatos del papiro Westcar. Esta posición que ocupa en la narración se correlaciona con la incipiente ideología hacia el culto solar y la posterior sustitución de la figura del dios solar por Amón, la cual será representada en los ciclos míticos del Reino Nuevo. Esta transición del dios Ra al dios Amón, se corresponde con un proceso teológico que según Colin Campbell (1912, pp. 5-8) es parte de la teología difundida por los sacerdotes de Amón que ajustaron en la figura de éste todas las atribuciones y funciones divinas que el dios Ra cumplía, entre ellas la de ser padre del rey. Por lo cual, para este investigador, su representación en los templos de los faraones del Reino Nuevo no era solamente parte de un programa legitimador de Hatshepsut y Amenofis III, sino una igualación del poder que este dios podía ejercer.

\footnotetext{
${ }_{149}$ En el capítulo II analizaremos las similitudes y diferencias de las acciones que realiza el dios progenitor en cada ciclo mítico. De todos modos, ya han quedado evidenciados los vínculos argumentales que correlacionan a los dioses Ra y Amón como padres en los mitos de nacimiento divino.

150 Destaca Wilson (1954, p. 101) que el hecho de que los faraones egipcios existían y que eran ellos los que procreaban a los niños que luego los sucederían como reyes, no era una situación que les provocara contradicción. Ello porque en el momento de engendrar, era el dios quien tomaba la forma del monarca y era su semen el que convertía al heredero al trono hijo de Ra. La sustitución del dios por los reyes es evidente en los ciclos míticos de la reina Hatshepsut y de los reyes Amenofis III y Ramsés II.
} 
En el Reino Antiguo, desde la ciudad de Heliópolis ${ }^{151}$, se había difundido el culto al dios solar. Iunu (Quirke 2003, p. 93) según el nombre que le dieron los egipcios, era el centro del sistema teológico -similar al papel de Tebas en la época Reino Nuevo- que inculcaba hacia y para el Estado, al mismo tiempo que transmitía a la sociedad egipcia la veneración del dios patrono de su ciudad, a la cual se le dedicaban todos los honores.

En el mito de origen del rey narrado en el papiro Westcar se destaca como espacio geográfico la ciudad de Heliópolis. En los relatos, Rauser es un sacerdote del templo de Heliópolis, aunque se menciona la categoría sacerdotal a la cual pertenecía. Asimismo acerca de los niños que están por nacer el dios Ra dice: " $\mathrm{R} a$ ha dicho de ellos que realizarán esta función excelente sobre todo el país entero y el mayor de ellos será Grande de los Videntes en Heliópolis" ( $p W .9 .10-12)$. El cargo sacerdotal $\frac{3}{5} 1$ wr m3w: "Grande de los Videntes" (Gardiner 2007, p. 561)152, era el título que llevaba el sumo sacerdote de Ra en el templo de Heliópolis, el cargo más alto al que un hombre del sacerdocio podía aspirar (Dodson y Hilton 2005, pp. 20-21; Quirke 2003, pp. $132-$ 135; Lefebvre 2003 [1982], p. 104). Es decir, los personajes de los relatos en el papiro ya sea por ser miembros del sacerdocio o "Grande de los Videntes", están vinculados con la veneración del culto a Ra en su ciudad principal, Heliópolis.

Todavía hoy, alrededor de este título sacerdotal, continúan las controversias, tanto sobre cuál es su correcta traducción, cuál es el significado más antiguo que puede interpretarse, principalmente si se tiene en cuenta que éste fue transformándose. Quirke (2003, pp. 132-135) examina los diferentes modos de escritura, interpretaciones y significados que el título fue adquiriendo. Para el III milenio la interpretación va de la mano de los significados más antiguos con los jeroglíficos $m 33$ "ver" y 3 "grande", que al estar la palabra sagrada y producirse la transposición honorífica de los signos puede interpretarse como "Aquel que ve al Grande", esto es que ve al dios o al rey.

${ }^{151}$ Lamentablemente la información que han arrojado las excavaciones en la ciudad de Heliópolis ha sido escasa y fragmentada. Al respecto véase Quirke (2003, pp. 93-142).

152 Según la traducción que se realice del título también puede encontrarse como "Mayor de los Videntes" (Dodson y Hilton 2005, p. 21) o "Principal de los Videntes" (Quirke 2003, p. 132). 
En tanto, para el Reino Antiguo $m 33 t$ "vidente" está escrito en singular 153 y se lo combina con el nombre de la ciudad de Heliópolis, y los títulos de este tipo como "Gran Sacerdote de Ptab en la ciudad de Menfis" o el de "Gran Sacerdote de Ra en la ciudad de Heliópolis" fueron utilizados por los más altos funcionarios de la corte real (Quirke 2003, pp. 133-134) ${ }^{154}$. En esta época eran los miembros vinculados a la familia real, especialmente los que llevan el título $s 3$ nsw "Hijo del Rey", los que ocuparon los cargos más trascendentes dentro de las estructuras del Estado, la mayoría de los cuales llegaron hasta ser visires (Baud 1999, pp. 170-188). A finales de la dinastía IV la responsabilidad de los ritos solares recayó en la figura del visir, según se evidencia claramente en la Piedra de Palermo (Quirke 2003, p. 133) ${ }^{155}$. Durante la dinastía IV el sistema burocrático egipcio estaba completamente instaurado (Lupo 2011) y a los cargos no se accedía ya por ser simplemente hombres considerados dentro de la esfera de confianza del rey, sino que empieza a ponerse de relevancia la idoneidad del conocimiento para la función a realizar, y prima la dedicación a tiempo completo.

Para finales de la dinastía VI en los cementerios los poseedores del título eran ahora funcionarios dentro del templo de Heliópolis, y parecen haber adquirido un poder económico y religioso propio, otorgado por donaciones del propio Estado según la Piedra de Palermo (Quirke 2003, p. 133). Estos sacerdotes eran enterrados durante finales del Reino Antiguo y el Primer Periodo Intermedio en las cercanías de la ciudad de Heliópolis, y no en el complejo real con pirámide como volvió a

\footnotetext{
153 Por lo general aparece como "Vidente de Horus y Seth". Pueden citarse varios ejemplos. En la tumba del visir Sekhemkara (G 8154 = LG 89) que gobernó a comienzo de la dinastía V, se menciona entre los títulos de su madre Hekenuhedjet: $m 33 t(h r)$ sth hm-ntr b3pf "Vidente de Horus y Seth, sacerdotisa de Bapef" (en www.gizapyramids.org). En la tumba G 8978 de la reina de la dinastía IV Khamerernebty I, se menciona a ésta o a su hija como madre de Khuenra (dueño de MQ 1) m33t wrt sth wrt hts "Vidented de Horus y Seth" (Reisener 1934, p. 11, fig. 10). En la misma tumba, se identifica a Washptah como m33t hqre sth wrt hts hmt nswt "Vidente de Horus y Seth, esposa del rey" (fotografía en www.gizapyramids.org, no publicada).

154 Por ejemplo, en la inscripción de la falsa puerta en la tumba de Kameni (G 4840) se refiere a Wenshet como wr m33w iwnw "Grande de los Videntes de Heliópolis" (Estela publicada en: Der Manuelian 2003, pp. 104-107; plts. 27-28)

155 La Piedra de Palermo es una de las fuentes más importantes para conocer los hechos ocurridos desde época predinástica hasta la dinastía V. Consta de tres registros; en el primero se lee el nombre y el año de gobierno del faraón en cuestión; en el segundo los acontecimientos ocurridos durante ese tiempo; y en el tercero registra la crecida del Nilo de cada año. Algunas de las publicaciones referidas a la Piedra de Palermo son: Daressy (1916); O’ Mara (1979); Clagett (1989); Serrano Delgado (1993, pp. 71-73).
} 
restituirse en el Reino Medio (Quirke 2003, p. 134). Por lo tanto, ateniéndonos a esta información, el "Grande de los Videntes" no era un cargo que asumió el faraón. En los relatos del papiro Westcar Userkaf será quien cumpla ese cargo: " $\mathrm{R} a$ ha dicho de ellos que (realizarán esta función excelente sobre todo el país entero y el mayor de ellos será Grande de los Videntes en Heliópolis" ( $p W .9 .10-12)$.

Quisiéramos destacar que el recuerdo reconstruye una realidad mítica, en la que los miembros de la familia que inició la dinastía $\mathrm{V}$ se hallaban intrínsecamente asociados al culto de Ra. El recuerdo sigue en parte el proceso histórico. En el Reino Antiguo el faraón es un miembro de la familia real, pero a partir de la dinastía $\mathrm{V}$ esta visión se modifica, y así se narra en el papiro Westcar. Ésto se explicará porque quienes ocuparon los cargos de Estado -en este caso el de sacerdote- son seleccionados entre los miembros del templo de Heliópolis. Desde esta perspectiva, según Drioton y Vandier (1964 [1938], p. 147), una de las posibles interpretaciones acerca del papiro Westcar, es su intento de destacar el cambio de la dinastía como obra de los sacerdotes de Heliópolis, cuya influencia habría aumentado probablemente durante la dinastía IV. De ahí que el recuerdo se centre en la ciudad de Heliópolis, que la familia involucrada en dar nacimiento a los futuros reyes provenga de ella, y se diga que el mayor de los niños ejercerá el cargo máximo en el sacerdocio en el templo de su padre Ra.

En suma, el Reino Antiguo era un tiempo de definición y redefinición de la ideología, las imágenes y el lenguaje religioso, una época en que se ha desarrollado el estilo y el repertorio del lenguaje egipcio de las formas (Assmann 2005 [1996], p. 87). A partir de aquí se comprende también la historia del recuerdo en Egipto. Las épocas que les siguen a las dinastías IV y V vuelven siempre a ellas para ver qué fue lo que pensaron, construyeron, cómo se organizaron y plasmaron simbólicamente sus ideas, recurren al pasado canonizándolo. En este sentido, la dinastía XII se hace eco del pasado y se legitima en él el título de $s 3 r^{\top}$, recordándose cuál es la relación política y familiar que ese título implica en sí mismo. El título creado por la dinastía $\mathrm{V}$ es retomado una y otra vez por los monarcas egipcios (Assmann 2005 [1996], p. 237). En los relatos del Westcar se recuerdan míticamente las vinculaciones familiares y religiosas que se crearon en el Reino Antiguo. 
Dodson y Hilton (2005, pp. 20-21) postulan que es recién con la dinastía XVIII que los miembros de la familia real comienzan a desempeñar cargos dentro de los grandes templos. Por su parte Quirke (2003, p. 134) asegura que no hay grandes sacerdotes en los centros de culto antes de este periodo (dinastía XVIII), y la máxima expresión es la unión del título sacerdotal, con el nombre de coronación del rey y el nombre del gran templo de Heliópolis y que no tiene paralelos en otras épocas. El autor afirma que "un papiro menciona al Principal de los Videntes de Khakaurehutaat, que significa 'Senusret III se encuentra en el Gran Templo' (butaat es el término que se refiere al santuario principal de Iunu). Un escarabeo conserva el nombre de otro Maakheruraemhutaat 'Amenemhat IV se encuentra en el Gran Templo’. La unión del alto título sacerdotal solar, el nombre de coronación del rey y el nombre del Gran Templo de la ciudad del sol es sorprendente y no tiene paralelos".

Es durante el Reino Medio que "videntes" es escrito en plural, por lo que puede leerse "El Principal de los Videntes". Esta interpretación ha conducido a una traducción: "Aquel que ve al Grande" resultado de la deformación de un título primitivo (Quirke 2003, p. 132; Lefebvre 2003 [1982], p. 104). Los que “ven” son los hombres responsables de la observación de los astros celestes, principalmente el sol (Quirke 2003, p. 132), y quizá ellos tuvieron alguna relación especial con su culto en la ciudad de Heliópolis.

De todos modos, más allá del recorrido que este título haya podido tener en la historia egipcia, si nos atenemos al relato mítico en el papiro Westcar, el dios Ra es el padre de los trillizos. La relación que los futuros reyes establecen con su padre es mítica, pues son hijos del dios como lo son los faraones en las teogamias del Reino Nuevo, y es simbólica porque nacen el mismo día que el dios Sol lo hace anualmente. Cabe destacar que en comparación con los ciclos míticos de la reina Hatshepsut y los reyes Amenofis III y Ramsés II, hay una modificación de la figura divina que cumple el rol de padre.

Las explicaciones que se han dado sobre el traspaso de la paternidad del dios Ra al dios Amón son diversas, y se relacionan con la formación y consagración del culto a cada dios. Desde una interpretación orientada por un determinismo 
geográfico, Wilson (1956, pp. 102-105) señala que la separación entre el Bajo y el Alto Egipto no solamente era una división ecológica y cultural que los egipcios manifestaron y configuraron simbólicamente como una dualidad, sino que también puso en pugna a ambas regiones por sus propias tradiciones, que se unían bajo la figura del rey-dios en una monarquía unificada. En este esquema cósmico y político la preponderancia del culto de Ra en la ciudad de Heliópolis estuvo delimitada por las condiciones de un espacio geográfico y las ideas eran creadas a través de la percepción de la realidad que los rodeaba (Wilson 1954, p. 63). Wilson observa los fenómenos naturales en el Alto Egipto, donde el Nilo fluye en dirección sur, punto geográfico que era la cara del país. No fue originariamente la orientación del sol la que determinó la teología. Dicha importancia fue otorgada luego de las primeras dinastías con la conformación de los vocablos que indicaban los puntos cardinales. En el Bajo Egipto el fenómeno natural más importante era la salida del sol por el Este, por lo que para el autor seguramente el culto al Sol fue más importante en el Norte y es posible que se extendiera a todo el territorio como teología de Estado, debido a una conquista del Sur por el Norte.

Este tipo de explicaciones fueron paulatinamente dejándose de lado y se desarrollaron las que analizaron los problemas políticos acaecidos entre las dinastías IV y V. Los cambios protagonizados por la dinastía V forman parte, según Serrano Delgado (2006, p. 263), de una línea concreta evolutiva del panorama religioso y político que se centraba en el culto a Ra (Salem 2010a, p. 278), la cual se reflejó en la monarquía a través de la adopción del título de $s 3 r^{\complement}$ en la titulatura real. Por otro lado, Kemp (2004, pp. 242-243) interpreta que el traspaso de la figura divina paterna de Ra a Amón radica en el problema que genera tener como deidad suprema al Sol. Sin embargo, en los textos funerarios Ra sigue siendo la figura preeminente ${ }^{156} \mathrm{y}$ en las teogamias el padre de los faraones es Amón-Ra. Según Drioton y Vandier (1964 [1938], pp. 146-147) la dinastía V es el resultado de la obra de los sacerdotes de Heliópolis que lograron que su acción perdurase en la historia de Egipto durante casi un siglo y medio, y parte de su éxito se debió por permitir la relación con otros dioses que ya estaban fuertemente arraigados en las creencias del pueblo egipcio. Si

\footnotetext{
${ }^{156}$ Con relación a la religión solar durante el Reino Nuevo, relacionado con Ra y Amón véase un estudio específico en Assmann (1995a).
} 
bien hemos detectado un proceso de solarización de la realeza, a partir de la dinastía IV, pero sobre todo con la dinastía $\mathrm{V}$, la teología estaba prestando mayor atención al poder del dios Sol como fuente suprema (Kemp 2004, p. 78).

El astro solar que tomaba figura humana al momento directo de su veneración perdía toda aura de misterio necesaria para todo tipo de ritual religioso, "los templos solares estaban a cielo abierto y los himnos se cantaban y las ofrendas se presentaban encima de una plataforma al aire libre. El Sol deparaba una buena imagen poética para el faraón, pero era un modelo bastante menos apropiado para su homólogo divino" (Kemp 2004, p. 242). Según el autor, este problema fue resuelto por los teólogos tebanos del Reino Nuevo al consagrar como dios supremo a Amón, una figura que permitía una representación de la divinidad con aspecto humano. En este sentido ya hemos mencionado que el ciclo mítico del nacimiento divino no aparece representado pictóricamente hasta el reinado de Hatshepsut. En todo caso volvemos a reflexionar acerca de los juegos textuales que la imagen y el texto posibilitan en la expresión del mito. Un texto únicamente escrito como lo son los relatos en el papiro Westcar facilita ciertas referencias a la figura paterna de Ra, como lo es el día de nacimiento de los trillizos que reúnen simbólicamente al padre con sus hijos. En el Reino Nuevo Amón-Ra es el padre quien preside la elección del futuro rey. En las teogamias $\mathrm{Ra}$ es representado en texto e imagen como un sincretismo de Amón: Amón-Ra. Mientras que en el papiro Westcar sólo es Ra el padre de los futuros de los reyes.

Para el Reino Nuevo (como también lo fue durante el Reino Medio) el centro difusor de la teología de Estado fue la ciudad de Tebas, donde la figura de Amón era el dios tutor de la ciudad. Una vez que ella se convirtió en el centro religioso de las Dos Tierras, su figura divina tomó un carácter más nacional. Por lo tanto, las figuras paternas divinas en los relatos míticos del nacimiento divino del rey están en consonancia con las creencias teológicas estatales, sin que ello modifique la esencia de lo que el mito quiere transmitir: que el rey es hijo del dios. La centralidad de la monarquía egipcia estaba en que el propio faraón era hijo de la divinidad, y en el caso del nacimiento divino del rey Amón se apropió del mito, siendo él quien engendraba al futuro rey de Egipto. 


\section{Ra, señor de Sakhebu}

"Es la mujer de un sacerdote de Ra, señor de Sakhebu (s3-hbbw) ...157" ( $p W .9$. 9). Así en el cuarto relato del papiro Westcar se indica que el padre de los trillizos es $\mathrm{Ra}$, asociándolo con la ciudad de Sakhebu. Se trata de una ciudad que para Lefebvre (2003 [1982], p. 104 nota 67) todavía no ha sido localizada, aunque cree que se encontraría en las cercanías de la ciudad de Heliópolis en el Bajo Egipto. Otros han afirmado que la ciudad estaría emplazada en Zât el Kôm, al norte de Abu Roash (Sauneron 1955, pp. 61-64 y Goedicke 1993, p. 33). La señalización de Ra como señor de Sakhebu, según Goedicke (1993, pp. 33-34), aleja al dios de su rol cósmico al anclarlo como una divinidad local. Para el autor, el nombre de la ciudad se asocia con el verbo $s \underline{h} b$ "tragar", lo que sugiere que es el lugar donde el dios Ra fue tragado. Esta vinculación geográfica se encontraría en el punto opuesto a la ciudad de Heliópolis en la cual el dios Ra entra al mundo. Para Goedicke el papiro Westcar destaca un punto que no es común en las narraciones egipcias, ésto es la etapa descendente del culto al dios Sol, y no su faceta ascendente relacionada con el momento de nacimiento.

Desde una interpretación mítica literaria, se explica que la faceta del dios $\mathrm{Ra}$ es también un aspecto creador y naciente del dios. Por un lado, porque el mensaje esencial que transmite el relato es el nacimiento de tres niños que serán reyes en Egipto gracias a que el dios $\mathrm{Ra}$ ha engendrado y reconocido su paternidad. Asimismo, hay un dato preciso en el relato que nos permite comprender nuevamente un trasfondo mítico en ellos: el lugar y fecha del nacimiento de los trillizos. Éste ocurrirá "el día 15 del primer mes de la estación prt” ( $(p W .9 .15)$ allí dónde "cuando los bancos de arena del canal de los Dos Peces quedan al descubierto" (pW. 9. 16). Si bien luego examinaremos más detalladamente este aspecto mítico, adelantamos que esta fecha se asocia con aquella en la cual el dios $\mathrm{Ra}$ (re)nace anualmente, es decir que se vincula con un dios Sol naciente y creador. Sus hijos, quedan así aparejados a esta función mítica de Ra, la de ser un dios cíclico que renace continuamente. Los "bancos de arena" es una metáfora conocida en la hora séptima del Libro del Amduat, en donde la serpiente Apofis sobre los bancos de arena quiere impedir el curso de la

\footnotetext{
${ }^{157}$ El subrayado es nuestro.
} 
barca de $\mathrm{Ra}^{158}$. Apofis dejaba al descubierto los bancos de arena impidiendo la navegación, pero en el papiro Westcar Djedi garantiza que ellos no se formen para dejar el descubierto la ciudad de Sakhebu, donde nacerán los trillizos. De todos modos, no queremos decir que el texto tenga alguna intencionalidad histórica, dichas referencias parecen estar más vinculadas al plano de lo mítico-literario.

Desde nuestra perspectiva, el dios $\mathrm{Ra}$ no pierde en ningún momento su carácter de dios cósmico, por el contrario las diferentes huellas míticas presentes en los dos últimos relatos del papiro Westcar dan cuenta de que es un dios promotor, dador de vida y creador.

\section{Madres humanas}

Frankfort (1998b [1948], pp. 68-69) considera que dentro de la cosmogonía egipcia la madre humana del faraón no tuvo ningún lugar dentro de la teología de la realeza. Pues, era el padre dios quien transmitía la esencia divina, y era gracias a él que el hijo nacido entre ambos podía declararse faraón. Las madres humanas son representadas y nombradas en los relatos del mito del origen divino del faraón, por ello podemos decir que los egipcios le dieron un espacio a la figura materna. La diferencia entre el relato del papiro Westcar y las teogamias del Reino Nuevo, es que en éstas últimas se destaca que la madre es reina. La relación entre la reina-madre y su consorte divino (Horus, Ra o Amón) muy pocas veces es subrayada en relación con la genealogía del rey (Frankfort 1998b [1948], p. 69) ${ }^{159}$.

Reddjedet es la protagonista en el relato anexo del papiro Westcar. La mujer es quien da a luz a los trillizos que ha concebido con el dios Ra. Mucho se ha especulado con relación a ella, y algunos han querido encontrar en figuras históricas relaciones directas con este personaje literario.

Altenmüller en "Die Stellung der Königsmutter Chentkaus beim Übergang von der 4. Zur 5. Dynastie" ["La posición de la reina Khentkaues I en la transición de la dinastía IV a la dinastía V'] hipotetiza que el personaje de Reddjedet no era

\footnotetext{
158 Analizaremos detalladamente este aspecto en el capítulo III.

${ }^{159}$ Kamutef fue el nombre que el faraón recibió como "Toro de su Madre". En este epíteto se destaca no sólo la característica divina del rey, sino la figura femenina en su procreación.
} 
más que el seudónimo de la reina Khentkaues I. Ella fue enterrada en Giza, en un complejo funerario ubicado entre las calzadas de Kefrén y Micerino. La tumba de esta reina (LG 100) es una gran mastaba, casi cuadrada, de considerables dimensiones, que no siguió las características convencionales de la época y tampoco se adosó a ninguna gran pirámide ${ }^{160}$. En su tumba se ha encontrado la inscripción de su nombre y título real (Parra Ortiz 2001, p. 65).

El título real de la reina Khentkaues I suscita controversias sobre su correcta traducción. Existen diferentes interpretaciones acerca de qué rol pudo haber tenido la mujer en la transición de la dinastía IV a la dinastía V. Se lee lo siguiente: z el título real, sin poder determinarse cuál es la correcta según las circunstancias históricas. La primera puede transliterarse como: nswt-bit mwt-nsw-bity y que ha sido traducida como “Rey Dual y Madre de un Rey Dual'. Mientras que la segunda posibilidad de transliteración es: $m w t$-nswy-bitwy y la suya es "Madre de Dos Reyes Duales" (Dodson y Hilton 2005, p. 62).

Por lo tanto, según la traducción que se acepte para el título de la reina, será el tipo de relación que se ha inferido que ella tuvo con los primeros faraones de la dinastía $\mathrm{V}$ y su posición dentro de la sucesión real y cambio dinástico, ya sea como madre o como esposa de uno o dos de ellos. En el caso de la primera traducción es posible que Khentkaues I haya ocupado el cargo de reina y que haya tenido un hijo quien también asumió el máximo cargo en la monarquía egipcia. Además, es probable que haya gobernado durante la minoría de edad de su(s) hijo(s), tal vez junto a Userkaf, porque también se sabe que la imagen de la reina ha sido alterada para mostrarla en actitud regia, llevando barba falsa. Esto indicaría que la primera traducción sería la correcta, y que por la ausencia de cartucho la función de "Rey Dual' sería en su rol de corregente (Dodson y Hilton 2005, pp. 62-65).

La segunda traducción permite pensar que Khentkaues I tuvo dos hijos que fueron reyes en Egipto. La primera interpretación es que haya sido madre de los dos primeros faraones y haya actuado como regente del primero. En este sentido Borchardt (1938, pp. 209-215) demuestra que los dos primeros faraones de la

160 Sobre esta tumba véase Porter y Moss (1974, pp. 288-289). 
dinastía V eran los hijos de Shepseskaf y Khentkaues I. Otra posibilidad es que la reina haya sido la madre del segundo y tercer rey de la dinastía $\mathrm{V}$ y corregente de Userkaf. En otra línea, Grdseloff (1943, pp. 25-70) opina que Userkaf fue hijo de la princesa Neferhetepes y de un príncipe que quizá haya cumplido la función de sacerdote de Heliópolis. El primer faraón de la dinastía V representaría a la rama líbica de la dinastía IV, y al no poder continuar con la posesión del trono, Sahura y Neferikara Kakai (sucesores de Userkaf) serían los hijos de Shepseskaf y Khentkaues I.

Si tomamos como válidas alguna de las dos interpretaciones, como lo han hecho determinados especialistas, la relación con el argumento de los dos últimos relatos del papiro Westcar se hace evidente. Reddjedet da a luz a tres niños hijos de Ra que regirán Egipto, siendo sus nombres los mismos de los tres hombres que gobernaron históricamente. ¿Es el personaje de Reddjedet un seudónimo de la reina Khentkaues I? Según Parra Ortiz (2001, p. 66) es probable que así haya sido; aunque son necesarias más evidencias para poder afirmarlo rotundamente. En todo caso no son más que suposiciones, por ejemplo que Userkaf y Sahura hayan sido hermanos, aunque influenciada por los relatos del papiro Westcar (Dodson y Hilton 2005, p. 66).

Para otros investigadores no están claros los motivos que impulsaron al cambio de dinastía -de la IV a la V-principalmente si se tiene en cuenta que según los egipcios ésta fue una transición sin mayores sobresaltos (Drioton y Vandier 1964 [1938], p. 173; Parra Ortiz 2001, p. 64). La memoria cultural conservó de esta época un cambio dinástico y le dio una nueva impronta como hijo del dios al faraón.

Los planteos de este tipo se traducen en interesantes discusiones sobre la posible plasmación de acontecimientos históricos en los textos literarios. Si se aceptan como válidas las sugerencias hechas para los relatos del papiro Westcar, al menos para el cuarto relato, éste sería una referencia histórica-literaria sobre los acontecimientos que rodearon la transición de la dinastía IV a la dinastía V. El personaje de Reddjedet asociado a la reina Khentkaues I seguramente ocupó un lugar destacado en la transición como la madre de los faraones que inauguraron la dinastía V. A los niños a los que se les pronostica su nacimiento en el cuarto relato, 
y nacen en el anexo al cuarto relato, se les otorga un nombre, el mismo con el cual se identifica a los tres primeros faraones de la dinastía $\mathrm{V}$. Todos estos elementos no hacen de los relatos del papiro Westcar un relato histórico, y seguimos estando de acuerdo con la premisa de Goedicke (1993, p. 34) que es una narración sin pretensión de verdad histórica, sino que trasmite un mensaje. Este mensaje refiere a que la dinastía $\mathrm{V}$ es una dinastía divina, es hija del dios $\mathrm{Ra}$ y la intencionalidad expresada en la memoria cultural egipcia es crear sobre ella un mito de origen, y no hacer de la narración un informe de acontecimientos pasados.

De todos modos, no está claro que pueda transferirse a la realidad histórica aquello que los relatos del papiro Westcar narran. Si nos atenemos a la narración mítica de este primer relato del origen divino del rey está claro que la figura de Reddjedet no tiene sangre real. El hecho que Reddjedet haya sido elegida por el dios Ra para ser la madre de sus hijos es lo que le otorga una posición de importancia, sin que su condición de una mujer no real sea motivo de exclusión. Reddjedet es la mujer de Rauser, un sacerdote de Ra en el templo de Heliópolis y quizá de allí pueda pensarse una relación cultual y política que quiera destacarse de la mujer para ser la madre de los trillizos.

La sangre no real de Reddjedet es una de las diferencias principales con las figuras maternas de las teogamias del Reino Nuevo, en estos mitos las madres son reinas. Recordemos que la madre de Hatshepsut es la reina Ahmose, la esposa de Tutmosis I, mientras que la madre de Amenofis III fue la reina Matemwia la esposa de Tutmosis IV, y por último Tuya la esposa de Seti I fue la madre del faraón Ramsés II. En el relato literario del papiro Westcar no hay ningún elemento que nos permita a entender que Reddjedet tuviera sangre real, lo que se dice de ella es que es la mujer de un sacerdote del templo de Ra en Heliópolis. Del único modo que puede adjudicarse a Reddjedet sangre real es si se acepta que el personaje literario corresponde a la figura histórica de la reina Khentkaues I, pero ya hemos realizado los reparos ante esta vinculación. Reddjedet no tiene sangre real, pero ella es importante en la historia, Keops no pregunta a Djedi ni por Ra ni por los hijos, sino que indaga “¿Pero quién es esta Reddjedet?”( 
Aunque las madres de los mitos de origen del rey no estén todas asociadas a la monarquía por medio de vínculos sanguíneos, no pierden entre ellas la misma esencia: la de ser madres de futuros reyes. Las mujeres en los relatos míticos del nacimiento divino del rey, son las partícipes necesarias para que el plan divino del dios pueda llevarse a cabo (Goedicke 1993, p. 34). Son ellas las que adquieren pleno protagonismo en el momento del parto, y su rol materno es concretado con éxito gracias a la ayuda de las diosas que las asisten en el momento del nacimiento de sus hijos. El rol que cada una cumplirá a lo largo del relato es idéntico, primero concibiendo y dando a luz a los niños, y luego estando a cargo de sus cuidados, y protección para que puedan cumplir el legado que los dioses han asumido para ellos. Estas funciones de madres y protectoras de sus hijos se asemejan a aquellas cumplidas en otros mitos por otras diosas, como es el caso de Isis en el relato mítico de Contienda entre Horus y Seth ${ }^{161}$. En en Contienda entre Horus y Seth, la diosa Isis desarrolla un rol de madre protectora de su hijo Horus, lo protege ante su enemigo Seth quien quiere despojarlo del trono que se ha ganado por ser legítimo heredero de su padre Osiris. En el relato del papiro Westcar, Reddjedet protege las diademas de sus trillizos, custodiando así su posibilidad de coronación como faraones en Egipto.

161 Contienda de Horus y Seth se encuentra en el papiro Chester Beatty I, custodiado por la Biblioteca Chester Beatty ubicada en la ciudad de Dublin. Una traducción completa en Gardiner (1931 y 1932c), también se destacan las traducciones de Brunner-Traut (2000 [1963], pp. 138-152); Wente (LAE, pp. 108-126); Lefebvre (2003 [1982], pp. 183-202); y Campagno (2004). 
Capítulo II

NACIMIENTO DIVINO DEL REY

Análisis comparativo 


\section{Representaciones del nacimiento divino del rey}

En el capítulo I hacíamos referencia a las representaciones, en texto e imagen, del relato del mito de origen del faraón en las paredes de los templos funerarios de la reina Hatshepsut y los monarcas Amenofis III y Ramsés II. El relato del nacimiento de la reina Hatshepsut y el de Amenofis III son los más completos que nos han llegado. Por este motivo, tradicionalmente se los toma como referencia al momento de construir un relato secuenciado del mito. Las otras referencias son secundarias, el deterioro de sus imágenes imposibilitan muchas veces ubicarlas dentro del relato mítico.

La identificación de un argumento encadenado nos permitió esclarecer que las teogamias del Reino Nuevo son un conjunto narrativo similar al que se narra en los dos últimos relatos del papiro Westcar. Éstos serían la primera representación escrita del relato de este mito. Lo que nos proponemos en este capítulo es reconstruir el relato del mito de origen del rey completo, y compararlo con los dos últimos relatos del papiro Westcar. Tenemos en cuenta cómo se van desarrollando las diferentes escenas y los personajes que actúan en cada uno, pudiéndose así examinar sus funciones y diferentes modos de representación.

El relato del nacimiento de la reina Hatshepsut es el único que se encuentra narrado en un templo funerario. En el caso del relato del nacimiento de Amenofis III está inscripto en una sala construida por el faraón en el templo de Luxor. Ramsés II representó su nacimiento en una capilla construida en honor a su madre, en un espacio subsidiario al Ramesseum. Y un cuarto relato se encuentra representado en el templo dedicado el dios Khonsu en Karnak.

En el templo funerario de la reina Hatshepsut las escenas ${ }^{162}$ se ubican en el registro inferior de las paredes sur, oeste y norte en la sección norte de la segunda terraza $^{163}$. La secuencia se desarrolla de sur a norte y se lee de izquierda a derecha y

162 Las escenas con traducción de los textos fueron publicadas por primera vez por Naville (1896 pp. 12-18; plts. XLVI-LV) y en Weindler (1915, plts. 3-12). Los textos jeroglíficos están publicados en URK IV, 216-234 y fueron traducidos al inglés por Breasted (1906, secc. 187-212) y al alemán por Brunner (1964), al español por Serrano Delgado (1993, pp. 141-145). Un comentario de las escenas y comparativo con otros ciclos míticos en Brunner (1964) y Gaballa (1976, pp. 53-60).

${ }^{163}$ Las representaciones y las inscripciones del nacimiento mítico fueron objeto de la política de destrucción llevada adelante por Tutmosis III y los adherentes a Tutankamon (Gaballa 1976, p. 54). 
contiene un total de quince escenas divididas cada una en registros (véase plano I) ${ }^{164}$.

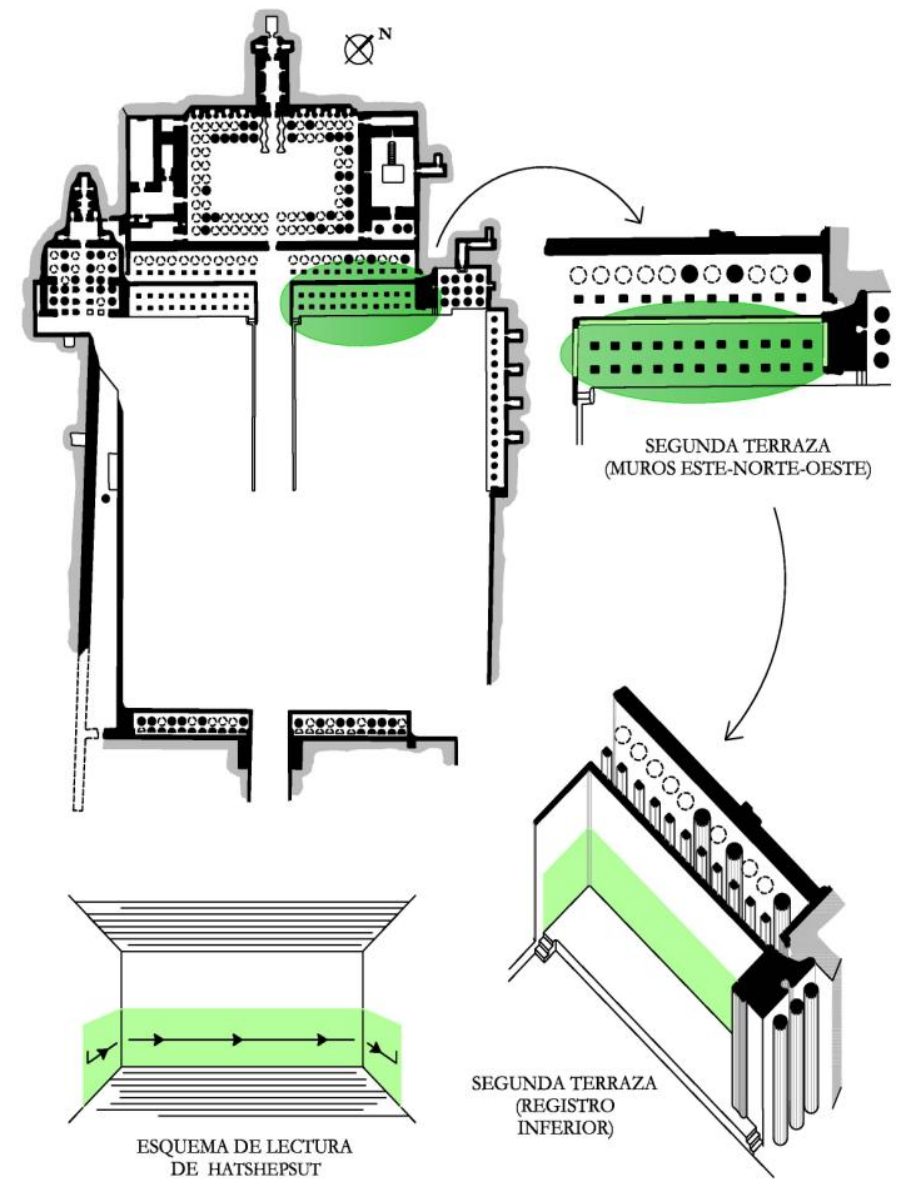

TEMPLO DE DEIR EL-BAHARI

ESCENAS DEL NACIMIENTO DIVINO DE HATSHEPSUT (ESQUEMA DE UBICACIÓN)

PLANO I. Ubicación de las escenas del nacimiento divino de la reina Hashepsut en Deir el-Bahari

Naville (1896, p. 13) no encuentra razón suficiente para afirmar que el faraón Tutmosis III tuviera la intención de destruir imágenes de los dioses, y no tiene dudas de que fue llevada adelante por Amenofis IV. Este faraón tuvo una política en contra del dios Amón y de los sacerdotes que abogaban por su clero. En este proceso las inscripciones que mencionaban a Tutmosis I fueron borradas. Ramsés II fue quien ordena su reconstrucción en honor de su padre Amón, pero solamente restauró las imágenes del nacimiento de la reina Hatshepsut y no los textos. En la actualidad se encuentran en muy mal estado y se dificulta mucho su lectura, impulsando a seguir las inscripciones de Amenofis III (Naville 1896, p. 13).

164 Comenta Goedicke (1992, p. 98) que es una sala pequeña la cual no posee ventanas, y la única forma de acceso a ella es a través del santuario principal del templo. Las escenas del nacimiento de Hatshepsut se encuentran en paralelo a las famosas representaciones de la expedición de la reina al Punt. 
El relato del nacimiento divino de Amenofis III se encuentra en el templo de Luxor en una sala sin techo con tres columnas en forma de flor de loto llamada "sala de nacimiento", ubicada en el lado este del templo hacia el extremo sur (véase plano II).

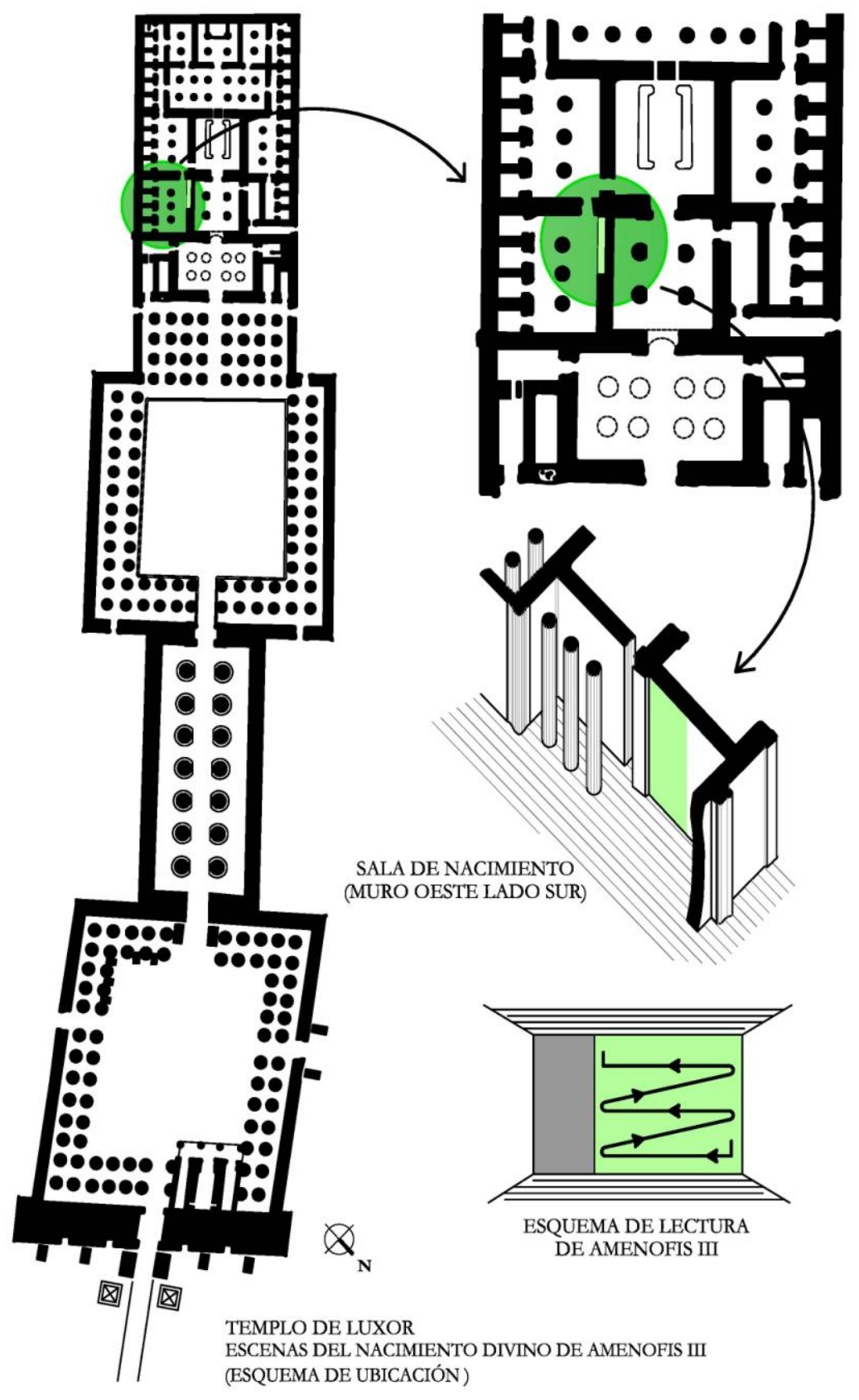

PLANO II. Ubicación de las escenas del nacimiento divino del faraón Amenofis III en el templo de Luxor 
Las escenas del nacimiento de Amenofis III se encuentran en la pared oeste ocupando tres registros ${ }^{165}$. Su lectura se inicia en el margen inferior derecho hacia la izquierda, llegando hasta el final de la pared. Continúa en el margen del medio con una lectura de izquierda a derecha y luego pasa a leerse la fila superior también en el mismo sentido.

Otra referencia del mito son dos bloques de piedra provenientes del Ramesseum, que representarían el nacimiento divino del tercer faraón de la dinastía XIX, Ramsés II (Kitchen 1982, p. 97) ${ }^{166}$. Ramsés II fue un gran devoto de su padre Seti I y de su madre Tuya, es por ello que envió a edificar en su templo funerario una capilla de dos habitaciones dedicada a su madre (véase plano III). Paralelamente sus paredes fueron decoradas con las escenas del mito del nacimiento divino (Kitchen 1982, p. 97), las cuales con posterioridad fueron reutilizadas en época ptolemaica como bloques para la construcción de un templo en Medinet Habu (Gaballa 1976, p. 54).

En estos dos bloques pueden observarse parcialmente cuatro escenas del nacimiento divino de Ramsés II, y también poseen en gran medida paralelos con las escenas y los textos de Deir el-Bahari y Luxor (RITANC, p. 441) ${ }^{167}$. La escena más clara que puede identificarse es el momento de la unión divina (Gaballa 1976, p. 54; RITANC, p. 441). Otras partes pueden ser confusas, y encajan en más de una escena del mito, por ejemplo se reconoce una figura de Hathor, pero esta diosa es representada varias veces a lo largo del ciclo mítico, desarrollando en él un rol principal.

\footnotetext{
165 En 1894 se publican por primera vez las escenas del nacimiento divino de Amenofis III en la edición del templo de Luxor realizada por Gayet, quien indica la sala con la letra $G$, las imágenes son publicadas íntegramente, plts. LXII-LXXII; LXVIII-LXVIII y figs. 192-205. Luego en Daressy (1898, pp. 68-71) quien completa la descripción de las escenas de la sala de nacimiento indicada con la letra P. Por su parte Colin Campbell (1912, pp. 18-48) realiza el primer comentario extenso de las escenas. Los textos en jeroglífico se encuentran en URK IV, 573. Brunner (1964, plts. 1-15) comenta escena por escena en comparación con los otros ciclos míticos del Reino Nuevo, traduciendo al alemán los textos. Gaballa (1976, pp. 53-60) analiza comparativamente las teogamias del Reino Nuevo.

166 Las escenas fueron analizadas por Gaballa (1976). Comentarios cruzados con otros ciclos míticos con traducciones de los textos en alemán en Brunner (1964). Los textos en jeroglífico en KRI II $665 \$ 254$ y traducidos en RITA II $446 \$ 254$.

${ }_{167}$ Recordemos que fue Ramsés II quien realizó la reconstrucción de las imágenes en el templo funerario de Hatshepsut.
} 


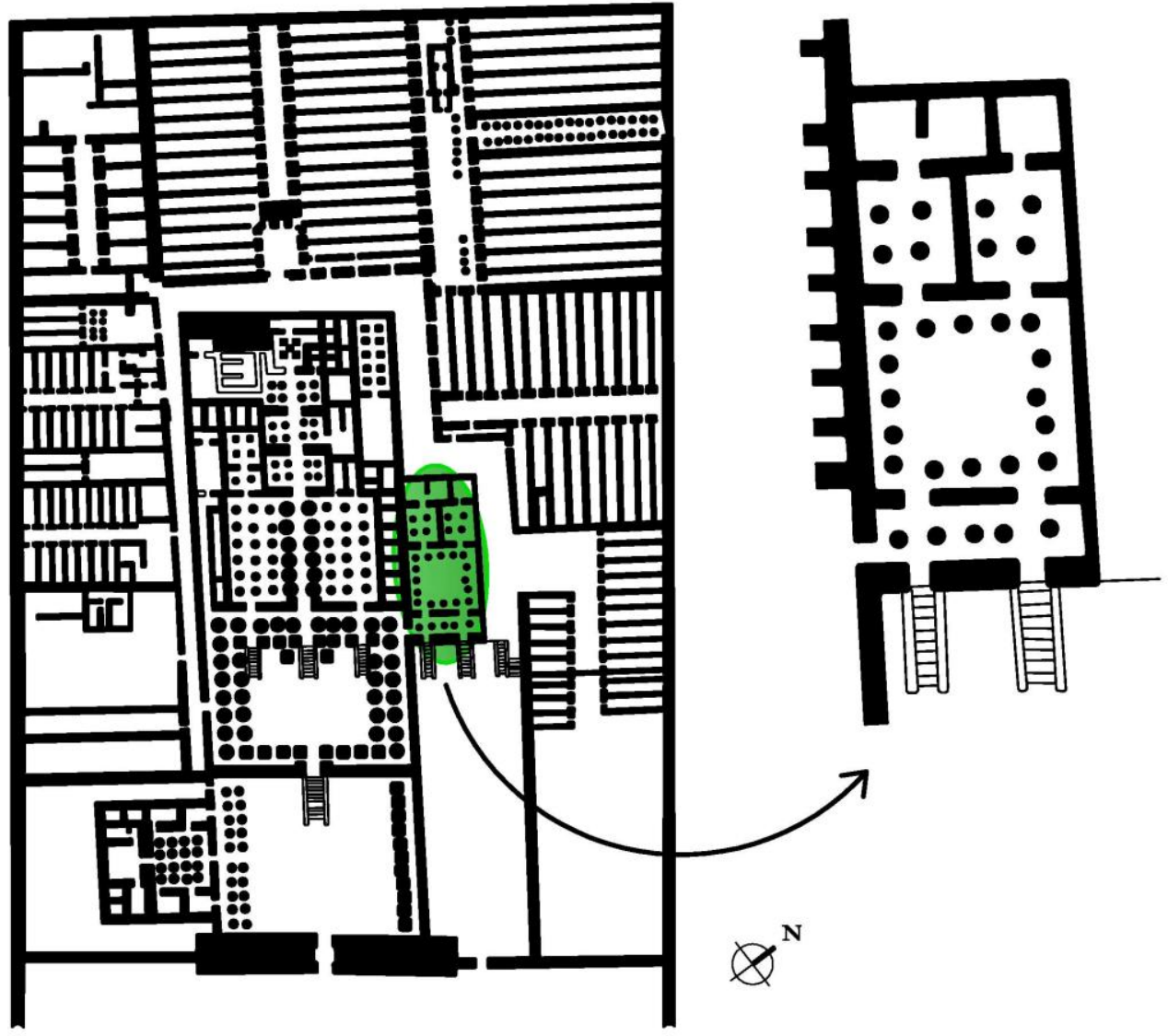

PLANO III. Ubicación de las escenas del nacimiento divino de Ramsés II en el Ramesseum 
Otra evidencia fragmentaria son unos bloques del recinto del templo de Khonsu en Karnak, los cuales fueron grabados en dos registros en la pared norte de la corte/audiencia pública (véase plano IV). El reciento dedicado a Khonsu fue construido con el re-uso de bloques que pertenecieron probablemente a una edificación durante las dinastías XXI-XXII o una época más tardía. Por lo que la identidad del faraón que protagoniza el nacimiento es desconocida (Gaballa 1976, p. 54). De estos bloques únicamente se conservaba la parte inferior de siete escenas, pero únicamente en cuatro pueden ser identificados los paralelos de las representadas en los templos de Deir el-Bahari y Luxor. La más clara semejanza se observa en la escena de la concepción del futuro rey.

Con lo que respecta a las restantes representaciones en el templo de Karnak, se han establecido conexiones con las escenas que se identifican en los ciclos míticos de época ptolemaica ${ }^{168}$. Por ejemplo, en el que caso de Denderah es seguro que algunas de sus escenas no han sido esculpidas en los templos de Deir el-Bahari y Luxor (Gaballa 1976, p. 54) ${ }^{169}$. Es decir, es una renovación de parte de la historia del

\footnotetext{
168 En época ptolemaica también existieron representaciones míticas del nacimiento del rey. Para ellas se destinó un espacio arquitectónico específico: "casas de nacimiento", "casas de reclusión" o mammisi, nombre que adquieren estos pequeños edificios ubicados en los grandes santuarios, tras la nominación dada por Champollion (Daumas 1958a). Todos los edificios de este tipo, datan de la dinastía XXX y de la época greco-romana en Egipto. Los mammisi más importantes que se han preservado son los de Philae, Kom Ombo, Edfu, Armant y Denderah. Los mammisi son construcciones rectangulares, en cuyas paredes exteriores se representan frutas y poseen un pórtico con columnas florares. Según Daumas estas construcciones eran espacios de reclusión en los cuales se relegaba a la mujer luego del parto, considerado un acto impuro. Estas casas eran construidas de forma tal que su parte interior estaba protegida contra el sol y el clima exterior. Dentro ellas se construía una habitación -cella- en cuyas paredes se representaba el nacimiento divino del hijo del dios, siempre siguiendo las tríadas divinas locales (Daumas 1958b, p. 44). Las escenas que allí se representan encuentran importantes paralelismos con las de los templos del Reino Nuevo de Deir el-Bahari y Luxor, pero algunas también rescatan las "innovaciones" que mencionábamos para el caso de las escenas de Karnak. Al respecto véase Daumas (1958a, 1958b, 1959).

${ }^{169}$ Por ejemplo, en uno de los mammisi en el templo de Armant se representaría el nacimiento divino de Caesarion, hijo del dios Amón-Ra y la reina Cleopatra, que fue destruido en la primera década del siglo XX (Colin Campbell 1912, p. 9). Si para Daumas (1958a, p. 44) son la expresión de la transmisión de la teogamia en época tardía, para Naville (1896, p. 12) la existencia de estos relatos es una demostración de cómo el mito del nacimiento divino tuvo una influencia en la formación de la mitología griega. Por ser de época tardía en relación a la posible datación de los relatos del papiro Westcar y el mito narrado durante las dinastías del Reino Nuevo, es que optamos por dejarlas de lado en al análisis. Considerar este tipo de construcciones nos obligaría a examinar el contexto específico para y en el cual fueron pensados, y que escapan de los intereses centrales de nuestra exégesis. Por este mismo motivo es que otras narraciones como el nacimiento de Alejandro Magno, o las influencias que pueden realizarse a partir de estudios como el de Isslieb quien compara el mito del nacimiento divino egipcio con la narrativa de la anunciación, nacimiento y el reconocimiento
} 
mito, pero que por su fragmentaria reconstrucción nos impide analizar el nuevo sentido que las escenas pudieron haber tenido.



TEMPLO KHONSU

PLANO VI. Ubicación de las escenas del nacimiento divino en el templo de Luxor de Khosu

divino de Jesús. Para un análisis del nacimiento divino egipcio y el Antiguo Testamento sugerimos la lectura de Keel (2006 [1997], pp. 240-251). 
Las representaciones textuales y en imágenes que han sido esculpidas en los templos del Reino Nuevo, nos permitirán recrear comparativamente los diferentes ítems del relato del nacimiento divino del rey. En particular los analizamos comparativamente con los dos últimos relatos del papiro Westcar. Lo que nos permitirá reafirmar que los relatos literarios son también una creación mítica, y desgranar las ideas que los analizan como relatos de ficción descontextualizados de un uso vinculado únicamente a la realeza y sus mecanismos de legitimación. Los textos literarios son una muestra más de la poliocularidad, al estar en ellos expresado el mito, la política y la religión.

Las diferencias entre estos relatos no sólo implican el contexto en que han sido inscriptas. Lo que más nos interesa analizar son las similitudes y disidencias entre cada uno de los relatos míticos. Entre el relato del nacimiento de la reina Hatshepsut y el de Amenofis III las coincidencias recién se introducen en la escena tres. Con el relato del papiro Westcar las relaciones son más fuertes a partir de la narración del nacimiento de los trillizos (relato anexo). Todo lo anterior al parto en las teogamias coincide con el anuncio a futuro, la profecía, de Djedi. La concepción en el papiro Westcar, si bien no es narrada, es asumida cómo tal cuando se pronostica que nacerán “... tres niños (que) está(n) en el vientre de Reddjedet ( $p W$. 9.7-8)". Se asume que no hay nacimiento sin concepción.

Este análisis nos permite comprender las modificaciones y particularidades que el relato tuvo en cada circunstancia. Asumimos que existen diferencias entre ellos, tanto entre las teogamias como con los relatos del papiro Westcar. Pero éstas no modifican la esencia de la narración mítica: el nacimiento de futuros reyes. En el relato literario las disidencias demuestran que el mito se construye ficcionalizando los hechos, justamente un modo de narrar que hace de los últimos relatos del papiro Westcar una narración mítica-literaria del origen divino de la dinastía $\mathrm{V}$. 


\begin{tabular}{|c|c|c|c|}
\hline Escena & $\begin{array}{l}\text { Hatshepsut: Templo de } \\
\text { Deir el-Bahari }\end{array}$ & $\begin{array}{l}\text { Amenofis III: Templo de } \\
\text { Luxor }\end{array}$ & $\begin{array}{l}\text { Userkaf, Sahura, } \\
\text { Neferikara Kakai: dos } \\
\text { últimos relatos del papiro } \\
\text { Westcar }\end{array}$ \\
\hline $\mathbf{I}$ & $\begin{array}{l}\text { Amón-Ra se encuentra con } \\
\text { el consejo de dioses }\end{array}$ & $\begin{array}{l}\text { Hathor se encuentra con la } \\
\text { reina madre Matemwia } \\
\text { ante Amón-Ra }\end{array}$ & \multirow{4}{*}{$\begin{array}{l}\text { Profecía de Djedi: Se anuncia } \\
\text { el nacimiento de tres niños } \\
\text { hijos del dios Ra y Reddjedet, } \\
\text { la mujer de un sacerdote } \\
\text { apodado Rauser. }\end{array}$} \\
\hline II & $\begin{array}{l}\text { Amón-Ra induce a la reina } \\
\text { Ahmose al encuentro } \\
\text { "narizcon nariz" }\end{array}$ & $\begin{array}{l}\text { Amón-Ra se encuentra con } \\
\text { el padre terrenal Tutmosis } \\
\text { IV }\end{array}$ & \\
\hline III & \multicolumn{2}{|c|}{ Amón-Ra se encuentra con Toth } & \\
\hline IV & \multicolumn{2}{|c|}{$\begin{array}{l}\text { Concepción divina del } \\
\text { futuro faraón }\end{array}$} & \\
\hline $\mathbf{V}$ & \multicolumn{2}{|c|}{$\begin{array}{l}\text { Amón-Ra se encuentra al cuerpo del futuro rey con } \\
\text { Khnum quien le da salud }\end{array}$} & $\begin{array}{l}\text { En cada nacimiento el dios } \\
\text { Khnum le da salud al cuerpo } \\
\text { de cada niño }\end{array}$ \\
\hline VI & \multicolumn{2}{|c|}{ Moldeado del faraón y su ka } & \multirow[b]{2}{*}{ No se relata } \\
\hline VII & \multicolumn{2}{|l|}{$\begin{array}{c}\text { El dios Toth se } \\
\text { encuentra con la reina }\end{array}$} & \\
\hline VIII & \multicolumn{2}{|c|}{$\begin{array}{l}\text { Los dioses conducen a la sala de nacimiento a la reina } \\
\text { madre }\end{array}$} & \\
\hline IX & \multicolumn{3}{|c|}{ Nacimiento divino } \\
\hline $\mathbf{X}$ & \multicolumn{2}{|c|}{ Presentación del niño a Amón-Ra } & \multirow{6}{*}{$\begin{array}{l}\text { Las diosas dejan como legado } \\
\text { tres coronas }\end{array}$} \\
\hline $\mathbf{X I}$ & \multicolumn{2}{|c|}{ del niño ante Amón-Ra } & \\
\hline XII & \multicolumn{2}{|c|}{$\begin{array}{l}\text { Amamantamiento y } \\
\text { crianza del recién nacido }\end{array}$} & \\
\hline XIII & \multicolumn{2}{|c|}{ El dios y su ka son llevados ante la divinidad } & \\
\hline XIV & $\begin{array}{c}\text { Horus y Amón-Ra } \\
\text { sosteniendo al fututo rey y } \\
\text { su ka }\end{array}$ & $\begin{array}{c}\text { Toth y Amón-Ra } \\
\text { sosteniendo al futuro rey y } \\
\text { su ka }\end{array}$ & \\
\hline $\mathbf{X V}$ & \multicolumn{2}{|c|}{$\begin{array}{c}\text { Anubis y Khnum junto a los dioses presentando ante } \\
\text { Safekhabui al niño }\end{array}$} & \\
\hline
\end{tabular}

CUADRO II. Comparación de la narración del nacimiento divino del rey entre el Reino Nuevo y los dos últimos relatos del papiro Westcar 


\section{Similitudes y diferencias entre los relatos del papiro Westcar y los ciclos míticos del Reino Nuevo}

Escenas I y II en el templo de Deir el-Bahari: Amón-Ra y el consejo de dioses. Amón induce a la reina a su encuentro

Estas dos primeras escenas del ciclo mítico del nacimiento divino del faraón únicamente las conocemos por aquellas que fueron grabadas en el templo de Deir el-Bahari. La primera escena ocupa todo el muro sur de la sala (Brunner 1964, p. 12). El sentido espacial y la dirección a partir de la cual se lee la primera escena no es claro, problema que ya había sido detectado por Naville (1896, p. 13) ${ }^{170}$. La segunda escena está casi destruida y apenas pueden diferenciarse las siluetas de los personajes ${ }^{171}$. Estas dificultades pueden sortearse lográndose una interpretación tentativa de la misma.

Notamos la ausencia de paralelismos entre las dos primeras escenas del relato del nacimiento de la reina Hatshepsut con los otros mitos de origen. Los dos últimos relatos del papiro Westcar omiten todos los acontecimientos ocurridos antes del parto de Reddejedet. En el relato literario no hay ninguna referencia sobre la decisión que llevó a Ra a elegir a esta mujer como madre de sus hijos, cómo se produjo el encuentro entre ellos y cuáles fueron los dioses que participaron en él. Estas discrepancias entre los relatos míticos quedarán atestiguadas a medida que se analicen las primeras escenas que lo describen.

La escena I se encuentra dividida en tres registros verticales. Siguiendo la lectura de derecha a izquierda en el primer recuadro el dios Amón-Ra "Rey de los dioses" está sentado en su trono mirando lo que se desarrolla hacia la izquierda. En el segundo recuadro, las figuras representadas se han borrado completamente sin poder identificarse los personajes que actuaban en ella, sólo pueden verse algunos signos jeroglíficos. El tercer recuadro, de mayores dimensiones en comparación a los otros dos, se subdivide en dos registros verticales. En él se encuentra escenificado el consejo de dioses conformado por un total de doce - seis en el

\footnotetext{
${ }^{170}$ La primera escena corresponde a la lámina XLVI publicada por Naville (1896, plt. XLVI).

${ }^{171}$ Las escenas dos, tres y cuatro corresponden a la imagen XLVII publicada por Naville (1896, plt. XLVII).
} 
registro superior, seis en el registro inferior ${ }^{172}$, quienes sostienen en su mano izquierda el cetro $w 3 s$ y en la derecha el signo ' $n h^{173}$. Montu preside el consejo"174. Tras él, el dios creador nacido de las aguas primigenias, patrono de la ciudad de Heliópolis: Atum, su figura en rojo es la única conservada, la de los otros dioses están reconstituidas (Naville 1896, p. 12) ${ }^{175}$. Le siguen el dios Shu ${ }^{176}$, junto a su hermana-esposa Tefnut ${ }^{177}$, y completan la fila inferior el dios Geb ${ }^{178}$ y la diosa Nut ${ }^{179}$. En la fila superior, a la derecha iniciando la hilera de dioses está el dios Horus con cabeza del halcón ${ }^{180}$; la diosa Neftis ${ }^{181}$; el dios Seth $^{182}$; y por último la diosa Hathor ${ }^{183}$.

${ }^{172}$ Naville (1896, p. 14) refiere a ellos como $\ominus \odot 777$ put netewru: "El ciclo de los dioses". De todas maneras, siguiendo a Gardiner (2007, p. 566) $\ominus \triangle 777$ puede transliterarse y traducirse como $p s \underline{d} t$ "conjunto de los nueve dioses, Enéada divina", que está representada: Atum, Shu, Tefnut, Geb, Nut, Osiris, Isis, Seth y Neftis, y Montu, Horus y Hathor que completan los doce dioses en la escena.

173 Se encontraría en el espacio estelar, ya que el signo $p t$ "cielo" recuadra toda la escena.

${ }^{174}$ Lo que puede leerse al lado de la figura del dios Montu es mntww wst, "Montu el Señor de Tebas" al igual lo hace Naville (1896, p. 13) como "Montu, Señor de Tebas". Este dios-halcón, asociado al culto solar era el patrono de la ciudad de Armant (Hermontis), situada al sur de Tebas y por ende fue el dios de toda la región tebana. Las primeras menciones de Montu proceden de la dinastía VI durante el reinado de Pepi I, y su mayor importancia es adquirida durante la dinastía XI, hasta que es desplazado por Amón. En el Reino Nuevo fue principalmente venerado como dios guerrero, cuyo aspecto adquiría el faraón durante la lucha (Hornung 1999a, pp. 70-71 y p. 256).

${ }^{175} \mathrm{Al}$ igual que Montu, para el caso de Atum se lee su nombre ' $t m$ y un signo del cetro $w 3 s$ con el cual no puede reconstruirse una lectura completa de la palabra que allí se escribió. El dios Atum "el indiferenciado" fue el dios creador según la teogonía heliopolitana, fue venerado como manifestación del atardecer, y siempre fue representado en forma humana (Hornung 1999a, p. 243).

${ }^{176} \mathrm{La}$ traducción corresponde a lo que claramente puede leerse junto a la figura del dios: $s 3 r^{\complement} s_{w}$ "Shu, Hijo de Ra". Este dios era el encargado continuamente de mantener separado el cielo de la tierra - los dioses Geb y Nut. Era el dios del espacio aéreo que queda entre ambos, de ahí que su nombre derive del verbo $\breve{w}$ "estar vació, al mismo tiempo que es luz que llenaba dicho espacio. Por lo general era representado en forma humana o con cabeza de león (Hornug 1999a, p. 76 y p. 258).

177 Claramente puede leerse: tfnt nbt pt "Tefnut Señora del Cielo". Tefnut y su consorte Shu formaron la primera pareja femenina-masculina creada por Atum (Hornung 1999a, p. 259).

178 Se lee: Gb tf it ntrw "Geb Padre de los Dioses". El dios de la tierra Geb generalmente era representado en forma humana, fue padre de los dioses, por ejemplo de Osiris.

179 Se lee: nwt mst ntrw "Nut Madre de los dioses". La diosa Nut era la madre de los dioses, y generalmente fue representada en forma de buitre, o en forma humana llevando la doble corona (no es el ejemplo que aquí citamos). En la ciudad de Tebas fue venerada como consorte del dios Amón, junto al dios-niño Khonsu formaban la familia divina tebana (Hornung 1999a, p. 256).

180 Se lee: $h r(w) s 33 s t$ ' 3 ntr nb nhh "Horus, Hijo de Isis, Grande del Dios, Señor de la Eternidad". Las funciones y representaciones del dios Horus son complejas, al respecto véase Hornung (1999a).

181 Se lee: nbt-hyt ityt ntrrw nbw "Neftis Soberana de todos los dioses". La diosa Neftis representada de modo antropomorfo y casi siempre acompañada de su hermana Isis (Hornung 1999a, p. 256) volverá su actuación en el mito del nacimiento tanto en las representaciones del Reino Nuevo como en el del papiro Westcar, ayudando a las mujeres en el momento del parto.

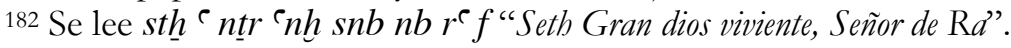

183 Se lee: ht- hr nbt int t3-wi "Hathor Señora de occidente y de las Dos Tierras". La diosa Hathor representada tanto de forma antropomorfa con corona de cuernos o en forma de vaca, es una de las 
El texto que está delante de Amón-Ra se ha borrado casi en su totalidad, sólo puede leerse parte del diálogo entre el dios Amón-Ra y el consejo de dioses: sm3 $n$ (i) n.s t3-wy m ḥtp íw rdi.n (i) n.s t3w nbw h3sswt nbt "Uniré para ella las Dos Tierras en paz: Daré para ella todas las tierras y todos los países extranjeros" (texto jeroglífico en Naville 1896, p. 14)184. "Ella" hace referencia a la niña por nacer y futura gobernante, Hatshepsut. Nada más puede leerse en la escena, por lo cual, si hubo alguna respuesta del consejo de dioses al dios Amón-Ra está destruida, y la desconocemos.

Naville (1896, p. 13) interpreta que Amón-Ra le cuenta al consejo de dioses que una nueva reina está por nacer, y que ella será grande y toda poderosa sobre las Dos Tierras. Según el autor, los dioses se reunieron para otorgarles a la reina Hatshepsut y a su hijo - de su propia carne- una madre terrenal. Es por ello que el dios Amón-Ra les pide que le den al futuro faraón ayuda y protección para que su reinado sea próspero. Por otro lado, la lectura que propone Gaballa (1976, p. 55) está sesgada por la destrucción de las inscripciones de la primera escena, al desconocer el autor el propósito que los dioses tenían. Brunner (1964, pp. 18-19) interpreta la escena como la proclamación del dios Amón-Ra a la Gran Enéada.

Lo que parece ser certero es la intención de Amón-Ra de darle a Egipto un nuevo gobernante, de ahí la reunión con los dioses y la posterior decisión de engendrarlo junto a la reina-madre Ahmose. Este propósito es el mismo que expresa el $n \underline{d} s^{185}$ Djedi en el cuarto relato del papiro Westcar, al anunciar que nacerán tres niños hijos del dios Ra y Reddjedet, y que ellos serán reyes en Egipto: “Es la esposa de un sacerdote wab de Ra, señor de Sakhebu embarazada de tres bijos de $\mathrm{R} a$, señor de Sakhebu. Ra ha dicho de ellos que realizarán esta función excelente sobre todo el país entero" (

En el relato del mito del nacimiento divino de Hatshepsut es el dios Amón$\mathrm{Ra}$ en persona quien toma la decisión. En el relato literario no se hace explícito si lo mismo lo realizó Ra, pero sí sabemos que ambos son los padres de los futuros reyes.

diosas madres por excelencia. Su figura volverá a aparecer en el ciclo mítico, cuidando y alimentando al niño recién nacido.

${ }_{184}$ Naville (1896, p. 14) traduce y translitera 584) 1 " h3st "países de las colinas, tierra extranjera".

185 En otros próximos capítulos volveremos a la figura del $n \underline{d} s$. 
Es a partir de esta perspectiva que pueden trazarse semejanzas en la decisión de brindarle a Egipto un nuevo rey. A su vez, en los relatos del papiro Westcar el nacimiento se construye literariamente como una profecía, el anuncio a futuro tiene como finalidad informarle a Keops quién le dará la clave para poder construirse una tumba perfecta, el autor de la narración literaria convierte la supuesta profecía en un relato mítico (Galán 1998, p. 31).

La profecía -anuncio a futuro- es un modo narrativo compartido con otros textos literarios, como lo es el caso de Profecía de Neferty, que desarrollaremos más adelante. La semejanza entre estos textos literarios es justamente un anuncio realizado por un $n \underline{d} s$, y en el anexo al cuarto relato en el papiro Westcar ese futuro literario se hace en parte realidad, es decir, nacen los tres niños. Ese nacimiento es el que delinea paralelismos con los nacimientos de Hatshepsut, Amenofis III y Ramsés II. Para el caso de la reina también existe una construcción a futuro, como en los relatos del papiro Westcar: Amón-Ra anticipa el nacimiento de un nuevo rey.

La escenificación en la cual se reúne el consejo de la Gran Enéada ante Amón-Ra, Brunner (1964, p. 19) la relaciona con la tradición literaria de las "Königsnovelle"186. Según el autor las palabras pronunciadas por Amón fueron escritas posteriormente a la representación de las imágenes, y ellas referirían al momento posterior a la concepción (escena IV). Las bendiciones del dios y el pedido de ayuda de Amón-Ra al consejo se repiten luego en el relato del ciclo mítico. Brunner (1964, pp. 19-20) afirma que son un tropo muy similar a lo que sucede en el relato del papiro Westcar. Suponemos que ello se relaciona con el inicio del anexo cuando el dios Ra: “...Entonces su majestad $\mathrm{R} a$, señor de Sakhebu, dijo a Isis, Neftis, Meshkeneh, Hequet y Khnum: 'Quisiera que ustedes vayan a asistir el parto de los tres niños que están en el vientre de Reddjedet..." ' $(p W .9 .22-24)$.

En la escena dos sobre el margen izquierdo del recuadro, el dios Amón-Ra está parado con su brazo derecho levantado sosteniendo con su mano un cayado, y con la izquierda agarra un signo ' $n h$. Frente a Amón-Ra, Toth sostiene con su mano derecha lo que pareciera ser un rollo de papiro. Según Naville (1896, p. 13) en esta

${ }^{186}$ Este concepto fue planteado por Hermann (1938). Al respecto véase: Loprieno (1996b, pp. $77-$ 295). 
segunda escena el dios Amón-Ra induce a la reina Ahmose para que se acerque a él, lo visite y así ella inhale el aliento de la vida, el encuentro "nariz con nariž, la concepción del futuro rey (escena IV).

Escenas I y II en el templo de Luxor: Hathor se encuentra con la reina madre Matemwia ante Amón-Ra. Amón-Ra se encuentra con Tutmosis IV

El motivo de la discrepancia entre las dos primeras escenas del ciclo mítico de Hatshepsut y Amenofis III es difícil de dilucidar y se han propuesto diferentes explicaciones $^{187}$. En la primera escena ${ }^{188}$ se observa de pie, a la derecha de la imagen, al dios Amón-Ra llevando una corona inusual, sosteniendo con una mano un cetro y con la otra el signo ' $n h$. Junto a él, un dios del cual no puede leerse su nombre, lleva sobre su cabeza una corona con cuernos y el disco solar. Esta representación de un ser divino hace suponer a los autores que allí estaba representada la diosa Hathor. Ambos están acompañando a la madre del niño que está por nacer, claramente puede leerse el nombre de Matemwia.

En la escena podemos leer unas pocas palabras del discurso del dios AmónRa: "Te doy la vida... en mi poder" (Colin Campbell 1912, p. 20). Lo que los dioses estarían haciendo es anunciarle a la reina Matemwia que pronto llegará su felicidad, porque ha sido la mujer elegida para concebir con el dios Amón-Ra al futuro rey de Egipto. Este encuentro es omitido en el papiro Westcar. Por el relato de la profecía de Djedi solamente conocemos que Reddjedet es la madre de los trillizos. Al igual

\footnotetext{
187 Gayet (1894) no tuvo en cuenta las dos primeras escenas en su publicación. Gayet aceptaría que allí se inicia el mito del nacimiento divino. Colin Campbell (1912, figs. A y B) publica dos fotografías para cada una de las escenas que describe, aceptándolas como parte del mito, pero lamentablemente la calidad de la fotografía y la propia destrucción de las imágenes, no facilitan la interpretación. Afortunadamente, ambas son elegidas entre la selección que realiza Brunner (1964, cuadro I y II) y en ellas puede apreciarse claramente la secuencia. Colin Campbell (1912, p. 19) sugiere que no hay razones que expliquen por qué el artista omite las dos primeras escenas en el templo de Luxor alterando lo que para el autor debiera haber sido el plan original, el de la copia exacta de las escenas del templo en Deir el-Bahari. Según Goedicke (1992, p. 103) no hay ninguna evidencia que indique que Amenofisis III estuviera familiarizado con las escenas del nacimiento divino en el templo de Deir el-Bahari, lo que explicaría las discordancias entre las escenas. Éstas para el autor fueron una política de sus escribas, más que una decisión del faraón de crear un programa de legitimación política para su reinado.

188 Un análisis de la escena en Colin Campebell (1912, pp. 20-21) quien titula la escena "Hathor Greets the Queen-Mother" ["Hathor saluda a la reina-madre"]. También en Brunner (1964, pp. 1221) y Gaballa (1976, p. 55).
} 
de lo que indicábamos para las dos primeras escenas en el ciclo mítico de Hatshepsut, ignoramos los motivos que impulsaron a Ra a elegirla, y cómo se dieron los encuentros previos a la concepción.

Los textos en la escena se refieren al encuentro íntimo "cara a cara y nariz con nariż” (Gaballa 1976, p. 55) entre Amón-Ra y Matemwia. Los textos, según la interpretación de Brunner (1964, pp. 26-27) no se corresponden a lo que en la escena se está representando, dando a entender que la no correspondencia entre la imagen y el texto fue producto de una mala copia del nacimiento divino de la reina Hatshepsut. El texto quizá correspondiese a la escena I del templo de Deir elBahari, pero, al no tener la escritura completa, es difícil aceptar estas conjeturas. Si bien Hathor está representada, el texto no la menciona y Amón-Ra utiliza supuestamente para referirse a ella el pronombre masculino: di.i n.k "yo di para ti" (Gaballa 1976, p. 55) ${ }^{189}$. En este relato la madre de Hatshepsut es representada por primera vez en la tercera escena, cuando es inducida por Amón-Ra para que se encuentre con él.

Estas discordancias son para Colin Campbell (1912, p. 21) un reflejo de cierta independencia que pudo haber tenido el artista del templo de Luxor, haciendo valer la supremacía del dios Amón-Ra sobre todos los dioses, lo que parece que fue el objetivo último de Amenofis III en relación a la construcción del templo de Luxor (Goedicke 1992, pp. 100 y ss.).

La segunda escena ${ }^{190}$ se centra en la figura de Amón-Ra representado a la derecha delante del rey Tutmosis IV, ubicado a la izquierda de la imagen. Hay acuerdo (Colin Campbell 1912, p. 22; Gaballa 1976, p. 56) sobre el sentido de esta escena como un gesto de cortesía que el dios tiene para comunicarle que él mismo

\footnotetext{
189 Recordemos que el pronombre sufijo. $k$ corresponde a la segunda persona singular masculino. ${ }^{190}$ La segunda escena es analizada por Colin Campbell (1912, pp. 21-22) quien la titula "Amon-Ra and Thothmes IV" [“Amón-Ra y Tutmosis IV”]. También en Brunner (1964, pp. 22-31) y Gaballa (1976, pp. 54-55).
} 
tomará la forma de su cuerpo para reunirse con la reina ${ }^{191}$. Los textos están corruptos siendo muy poco lo que puede leerse en ellos ${ }^{192}$.

El dios Amón-Ra (escena IV) se encarnará en la persona del rey para poder mantener relaciones con la reina. En el caso del relato del mito en el papiro Westcar no se hace mención explícita sobre quién sería el padre terrenal de los trillizos, pero se han generado ciertas controversias en torno a la figura del esposo de Reddjedet, Rauser. Si nos atenemos a las coincidencias con los mitos del Reino Nuevo, deberíamos aceptarlo como padre terrenal, en tanto que en los casos de Ahmose y Matemwia son sus esposos-faraones quiénes asumen la paternidad.

El esclarecimiento de esta cuestión la podemos vislumbrar con la actitud de Rauser al iniciarse el relato anexo, "Luego éstos se acercaron a la casa de Rauser y lo encontraron de pie con sus ropas dadas vuelta" ( $p W .10 .1-2)$. Lefebvre (2003 [1982], p. 105 nota 80) interpreta que la desprolijidad de sus ropas se explica por el estado de conmoción, nervios y ansiedad generadas porque su mujer ha entrado en trabajo de parto y pronto nacerán sus hijos. Por otro lado, son significativas las palabras de las diosas una vez que se retiran de la sala de parto "Las diosas salieron luego de ayudar a Reddjedet en el parto de los tres niños y ellas dijeron: ¡Ten alegría (en tu corazón) Rauser, te han nacido tres niños!" " ( $\not W .11 .3-6)^{193}$. Si bien en la predicción Djedi no es categórico sobre la paternidad biológica de Rauser -la cual le corresponde al dios Ra- ésta sería una paternidad terrenal al igual que Tutmosis I, Tutmosis IV y Seti I. Todos ellos cumplirán el rol de padres terrenales de los futuros reyes, siendo parte del ideal de sucesión al trono, de padre faraón a su hijo primogénito. Lo que no ocurre en el caso de los relatos del papiro Westcar, al no especificarse quien es la figura paterna.

\footnotetext{
${ }^{191}$ Un interrogante que puede plantearse con respecto a la interpretación de Gaballa sería hasta qué punto puede justificarse dentro de la cosmogonía egipcia hacer tan explícito el sincretismo que simbolizará el rey en la imagen siguiente, informando un dios a un rey que tomará su forma.

192 Colin Campbell (1912, p. 22) pone en evidencia una discordancia entre el texto escrito ante la figura del dios Amón-Ra y la lectura global que puede hacerse de la escena. Se hace mención del rey Tutmosis IV como un "bombre anciano", mientras que un análisis de su momia ha revelado que éste no tenía más de treinta años en el momento de su muerte. Además, este discurso se pronuncia en la escena del templo de Deir el-Bahari, en el diálogo entre Amón-Ra y Toth, con lo que se refuerza la idea de que el escriba copió el texto tal cual lo encontró en el templo de Hatshepsut sin respetar las imágenes en las dos primeras escenas. El artista del templo de Luxor decide representar al padre terrenal del futuro faraón Amenofis III, lo que no ocurre con Tutmosis I en el nacimiento divino de Hatshepsut.

${ }^{193}$ El subrayado es nuestro.
} 


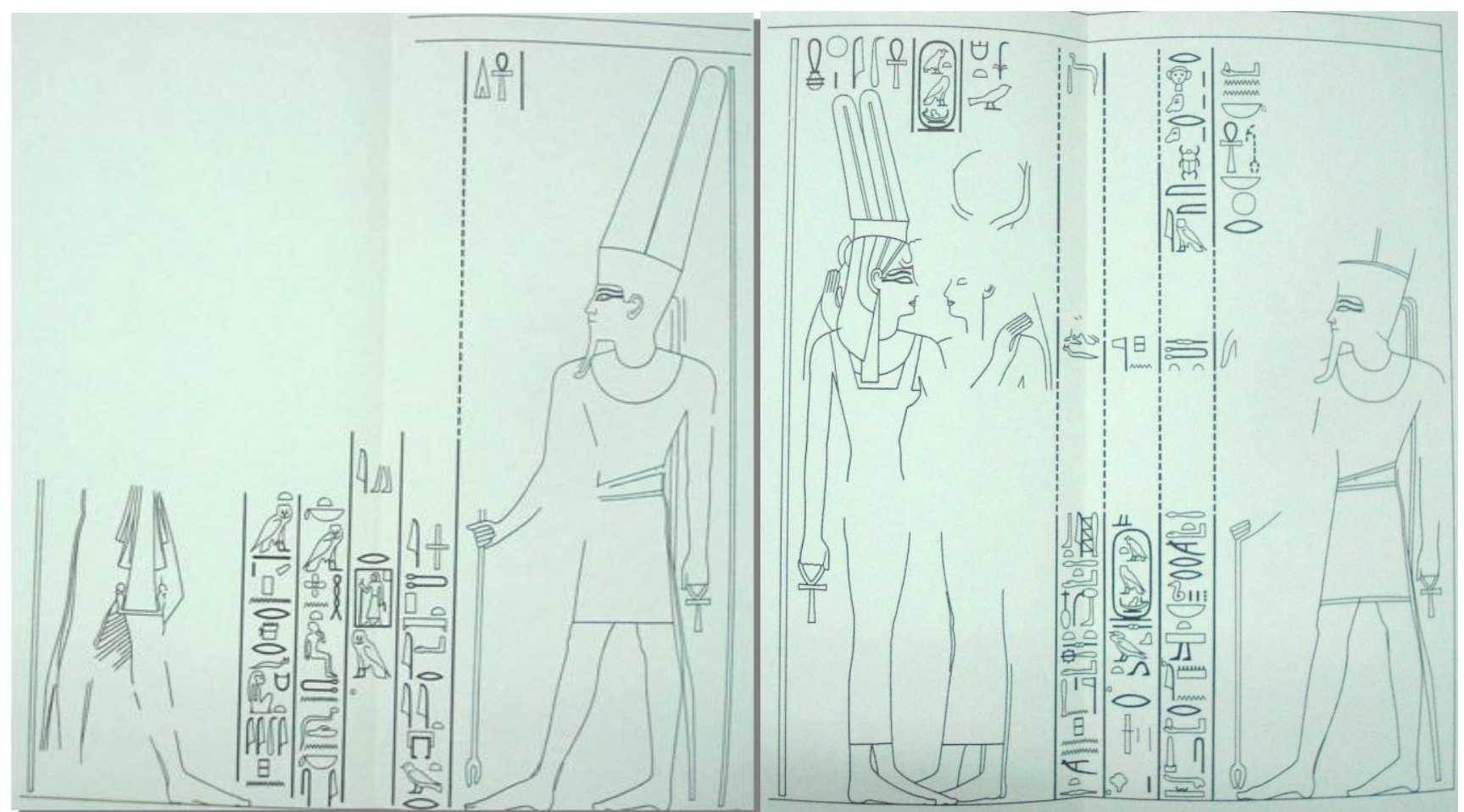

IMAGEN II Escenas I y II en el templo de Luxor (Brunner 1964, cuadros I y II) 
A partir de este momento comienzan los paralelismos entre las imágenes en el templo de Deir el-Bahari y el de Luxor. Al igual que las anteriores, esta escena se encuentra parcialmente destruida, pero lo fundamental en ella puede ser interpretado. Las diferencias que pueden apreciarse entre unas y otras son de detalle y no modifican lo sustancial del relato ${ }^{194}$.

Hasta el momento seguimos encontrando una narración que parece ser exclusiva de las escenas en los templos funerarios del Reino Nuevo. Una lectura detallada de los dos últimos relatos del papiro Westcar claramente da cuenta que el mito se inicia con una concepción ya consumada, omitiéndose los detalles previos y el encuentro sexual entre el dios $\mathrm{Ra}$ y Reddjedet. A su vez, se prescinden de las explicaciones sobre los motivos que el dios solar pudo haber tenido para decidir tener hijos y consagrarlos faraones, y la comunicación de su decisión a los dioses.

Sí pareciera haber diferencias entre las figuras paternas divinas. Por un lado, en los dos últimos relatos del papiro Westcar, el dios Ra es mencionado y él mismo participa como voz protagónica. Su mención no es tan reiterada como lo es AmónRa en las paredes de Deir el-Bahari y Luxor. Es llamativa la exposición de Amón-Ra en el mito del nacimiento divino, mucho más si se tiene en cuenta la tendencia de “ocultar" su imagen. La figura de Ra pareciera estar omnipresente a lo largo del relato del papiro Westcar, y no se describen los momentos centrales en que toma protagonismo. Por ejemplo, se omite la unión sexual con la madre de sus hijos, los futuros reyes en la cual el dios es absoluto protagonista.

En lo que continúa de la escena, en las teogamias del Reino Nuevo los protagonistas son el dios Amón-Ra y Toth. Amón-Ra (representado más alto que el dios Toth) está parado sosteniendo con una mano el cayado y con la otra toma de la mano a Toth, quien está caracterizado con cabeza de ibis. En el templo de Deir elBahari el dios Toth ya no lleva el rollo de papiro que sostenía en la escena anterior,

${ }^{194}$ La escena es analizada en Colin Campbell (1912, pp. 23-24) quien la titula "Amun-Ra and Thoth" [“Amón-Ra y Toth”]. Según el autor en el templo de Luxor se condensan las dos anteriores representaciones que se encuentran en el templo de Deir el-Bahari. También véase Brunner (1964, pp. 32-34) y Gaballa (1976, pp. 54-55). 
mientras que en el templo de Luxor sí lo hace. Es este dios quien conduce a Amón$\mathrm{Ra}$ hacia el palacio donde se concretará el encuentro con la reina en la habitación real. El dios Toth no tiene ningún tipo de participación en los relatos del papiro Westcar. Es complejo conjeturar el por qué de la ausencia de este dios en el relato narrativo, una de las opciones que podemos dar, y que se relaciona con la estructura narrativa, es que Toth está presente en la mayoría de las escenas que en el papiro Westcar se omiten. Es decir que es protagonista en los momentos previos al parto de Reddjedet.

\section{Escena IV en el templo Deir el-Bahari y Luxor: la concepción divina del futuro faraón}

La escena representa la visita del dios $\mathrm{Ra}$ a la reina, describiéndose el momento de la concepción del futuro rey tutelada por dos diosas ${ }^{195}$. La importancia de esta escena -que es una de las más logradas estilísticamente- se reconoce por el motivo que ella pretende describir. Según los egipcios en donde hubo nacimiento hubo concepción, y tanto el dios como el rey para nacer tienen que engendrarse en una diosa-madre y era el dios en quien recaía la capacidad divina de lograrlo (Frankfort 1998b [1948], pp. 190 y 191). La escena de la concepción adquiere relevancia en las representaciones del Reino Nuevo, pues nunca es omitida en ninguno de los ciclos míticos en los cuales se describe el nacimiento divino ${ }^{196}$. En cambio, sí lo es en el relato mítico del origen de la dinastía V en el papiro Westcar. En el papiro se omite la narración de la concepción, pero ésta sucedió en algún momento previo a la profecía de Djedi. El anuncio se realiza con una concepción ya consumada. Es decir, que sea descartado en la narración no implica que no haya existido el encuentro sexual entre el dios Ra y Reddjedet.

El motivo por el cual es omitido el momento de la concepción en el relato mítico en el papiro Westcar no resulta claro. Para comprender esta circunstancia,

195 Para el templo de Luxor Colin Campbell (1912, p. 24) la denomina "The Divine Nuptials" ["La boda divina"]. Comentarios sobre la escena IV en Naville (1896, p. 14; plt. XLVLII); Colin Campbel (1912, pp. 24-26); Brunner (1964, pp. 35-58; cuadro 4); Gaballa (1976, p. 55).

196 Esta misma escena no sólo se encuentra en Deir el-Bahari y Luxor -entre los cuales los paralelismos entre ambas representaciones son más que contundentes- sino también en las capillas de nacimiento de la época ptolemaica, como las de Denderah, Edfu, Philae y Esna (Naville 1896, p. 14). 
diremos que el mito del nacimiento se encuentra constantemente en un proceso de construcción. Sus escrituras en papiro o en pared implican diferentes modos de representación. Ellos permitieron o dieron la posibilidad de excluir o agregar ciertos pasajes al mito del nacimiento del rey. De hecho, las diferencias también se dan entre los relatos del Reino Nuevo.

Gaballa (1975, pp. 53-54) menciona la llamativa ausencia de toda representación pictórica del mito antes del Reino Nuevo, lo que puede ayudar a pensar en modificaciones que fueron produciéndose en el relato, siendo una de las versiones la que se encuentra en los templos funerarios de los faraones de la época imperial egipcia. A ello puede sumarse que la temática del momento de la unión sexual, sería más factible que fuera expuesta en forma pictórica más que narrativa, de ahí su ausencia en los relatos del papiro Westcar. El texto que acompaña la imagen podría decirse que cumple con lo esperado para un texto estilísticamente bien logrado.

Consideramos que el motivo que ha llevado a la omisión de la unión sexual entre el dios $\mathrm{Ra}$ y Reddjedet en el relato del papiro Westcar responde a que en éste el centro de la narración es la profecía. El juego entre aquello que ocurrirá -el nacimiento de los trillizos- y su cumplimiento en el relato anexo es la clave mítica literaria del texto. En este sentido, insistimos, que el anuncio de Djedi se realiza una vez que el encuentro sexual ya se ha cumplido. Djedi ya sabe que los niños están en el vientre de Reddjedet y que poco tiempo resta para su nacimiento.

En el caso de la concepción de la reina Hatshepsut la escena se destruyó completamente, y hoy en día lo que se observa es producto de continuas reconstrucciones tanto antiguas como modernas (Naville 1896, p. 11) ${ }^{197}$. En Deir el-

\footnotetext{
197 Naville (1896, p. 11) observa aquí una curiosidad: el nombre que se lee de la reina no es el de Ahmose (esposa del faraón Tutmosis I) sino el de Amosis I, que fue el de la reina AhmoseNefertari (con relación a la reina y sus títulos reales véase Dodson y Hilton 2005, pp. 124-126). Según Naville el nombre de la reina era reconocido bajo el reinado de Ramsés II y con frecuencia se lo representaba en las tumbas junto al difunto. Con su hijo el faraón Amenofis I fueron divinizados como patronos de la necrópolis tebana, donde ellos mismos habían sido enterrados (Dodson y Hilton 2005, pp. 126-127). No se ilumina con facilidad cuál es la razón por la cual encontramos el nombre de Ahmose-Nefertari y no el de la madre terrenal de Hatshepsut. Dudamos que fuera por falta de conocimiento del escriba que diseñó la escena. Lo más probable es que su mención en el encuentro crucial entre el dios Amón-Ra y la reina se deba a la estima divina que se le tenía a Ahmose-Nefertari. Tampoco nos queda claro si el nombre era el original de la escena o producto
} 
Bahari a la izquierda y en el templo de Luxor a la derecha, el dios Amón-Ra se halla sentado frente a la reina. Ahmose tiene el cabello decorado con un tocado de buitre, símbolo de la maternidad (Colin Campbell 1912, p. 24) y un uraeus sobre la frente. Matemwia lleva el mismo tocado y el uraeus en la frente, y además tiene puesta la corona de dos plumas, al igual que Amón-Ra. En la imagen del templo de Deir elBahari la cabeza del rey está borrada, pero es probable que haya llevado la cabeza de dos plumas para darle más identidad al sincretismo con el rey.

Los vestidos de las madres son similares, con el mismo tocado sobre el pecho. El dios y la reina no llevan sandalias en sus pies. Las piernas entre ellos están entrecruzadas por debajo de un estandarte que es sostenido en la parte de arriba por sus cabezas y la parte de abajo por dos diosas: Neith y Selket. Su presencia generalmente se ha vinculado con el nacimiento y la maternidad ${ }^{198}$. Las diosas se encuentran sentadas descalzas en un banco que en sus dos extremos forman un león ${ }^{199}$. En el templo de Deir el-Bahari el dios Amón-Ra con una mano le ofrece a la reina el signo ' $n h$, colocándolo ante su nariz y boca. Con la otra también brinda el signo ' $n h$ y el signo del poder a la reina a sus palmas extendidas. En cambio en la escena del templo de Luxor, la reina únicamente recibe el ` $n h$ entre su nariz y boca y sus manos vacías están entrelazadas. A pesar de estas disidencias, la posición de los actores es semejante otorgándose el mismo sentido a la representación.

Tanto el dios-rey como la reina quedan sostenidos en el aire, sus pies no tienen contacto con el mundo terrenal. Por lo tanto, la concepción se da en la esfera de los cielos y no en la de la tierra (West 1995, p. 350). Este es un espacio exclusivamente celestial, lo que acentúa todavía más el carácter divino del rey. Para el relato del papiro Westcar también puede suponerse una concepción en un espacio divino. Los trillizos obtendrán todas las características divinas según lo analizaremos

de una reconstrucción posterior, quizá en tiempos de Ramsés II cuando fue restaurada, que coincide con los momentos en que la reina fue divinizada. A su vez, cabe destacar que, como sucede con otros nombres que se escriben en los mitos, la realidad no debe necesariamente ajustarse a él, lo que no inhibe su análisis histórico.

198 Por ejemplo, según Colin Campbell (1912, p. 25) los actos que cumplen en diversos pasajes en el Libro de los Muertos. Al respecto véase Faulkner (2008) y Taylor (2010).

199 Entre ambas representaciones sólo varía qué figura sostiene cada diosa. En Deir el-Bahari la diosa Neith y la reina Ahmose (Ahmes-Nefertari) por Selket, mientras que en el templo de Luxor Selket sostiene al dios Amón-Ra, y Neith a la reina Matemwia. 
en el capítulo III. La relación de los futuros reyes con lo divino está otorgada por haber sido engendrados por un dios.

El texto en columnas verticales que acompaña toda la imagen de la concepción se escribe sobre los dos márgenes encuadrándola. En ellos se narra el momento de la unión sexual entre el dios y la reina, desde el momento en que Amón-Ra toma la forma del esposo de la reina, la encuentra durmiendo en el palacio, despierta y huele la fragancia divina. Continúan las palabras del dios Amón$\mathrm{Ra}$ quien anuncia el nombre del futuro hijo que engendró con la reina y que gobernará sobre las Dos Tierras.

Puede leerse: "Palabras dichas por este noble dios, Amón, Señor de los Tronos de las Dos Tierras. Él ha tomado la forma de la majestad de este su esposo, el rey del Alto y Bajo Egipto Aakheperkaré200. La encontró cuando ella estaba descansando en la belleza del palacio. Ella despertó ante la fragancia del dios, y sonrió frente a su majestad. Él se acercó inmediatamente, inflamado de pasión por ella; puso su deseo sobre ella e hizo que le viera en su forma de dios. Cuando llegó ante ella, que se regocijaba contemplando su belleza, su amor se encontró con su cuerpo, inundado como estaba por la fragancia del dios y todos sus aromas, provenientes del país del Punt' (Serrano Delgado 1993, p. 141).

Las palabras que siguen al texto citado son pronunciadas por Amón-Ra, en el templo de Deir el-Bahari: "En verdad que el nombre de esta hija que yo be colocado en tu vientre será Henemet-Amón Hatshepsut, (según) la expresión de las palabras salidas de tu boca. Ella desempeñará esta excelente realeza en esta tierra toda entera ${ }^{201}$. Mi energía será para ella; mi poder será para ella; mi fuerza será para ella; mi corona será para ella, de forma que ella gobernará las Dos Tierras y guiará a todos los vivientes... Las Dos Tierras se unirán a ella en todos sus nombres, sobre el Trono de Horus de los Vivientes. Yo la protegeré cada día, junto con el dios que está en su disco..." (Serrano Delgado 1993, p. 141).

A partir de este texto podemos trazar otros paralelismos con los relatos del papiro Westcar. La segunda oración nos recuerda a las palabras de Djedi refiriéndose a las dichos del dios solar, en el momento que le anuncia a Keops quiénes son estos tres niños que están por nacer del vientre de Reddjedet: " $\boldsymbol{R a} \boldsymbol{h a}$

\footnotetext{
${ }^{200}$ Es decir, Tutmosis I.

${ }^{201}$ El subrayado es nuestro.
} 


\section{dicho de ellos que realizarán esta función excelente sobre todo el país} entero"202 ( $\not W .9 .10-11)$. En ambos casos, por decisión de los dioses, serán sus hijos los próximos gobernantes del Alto y Bajo Egipto. Es decir, en todos los ciclos míticos se narra el motivo de la concepción: dar vida a futuros reyes de Egipto.

\section{Escena V: Amón-Ra se encuentra con Khnum}

Luego del encuentro entre el dios y la reina, Amón-Ra llama al dios Khnum. La V escena es casi idéntica en Deir el-Bahari y en Luxor ${ }^{203}$. Sobre el margen izquierdo está el dios Amón-Ra con la corona de plumas sobre su cabeza y el símbolo 'nh en una mano y en la otra el cetro. Son los mismos símbolos que sostiene el dios Khnum que está ante él en una proporción más pequeña. El motivo del encuentro es el encargo que el dios Amón-Ra le hace al dios Khnum²04.

En los relatos del papiro Westcar se omite el encuentro entre el dios Ra y Khnum. Pero el dios alfarero en el relato anexo cumplirá una función similar a la que desarrolla en las teogamias del Reino Nuevo. En ellas habla el dios Amón-Ra quien le pide a Khnum que moldee el cuerpo y el ka de su hija, la futura reina de las Dos Tierras, Hatshepsut. Si bien el diálogo entre los personajes está fragmentado pueden leerse en el templo funerario de la reina Hatshepsut las palabras del dios Khnum: "Yo he venido a ti para darte una forma (mejor) que (la de) todos los dioses. Te he dado toda tu vida y dominio, toda estabilidad, toda alegría junto a mí. Te he dado toda salud ${ }^{205}$, (asi como) todas las tierras. Te he dado todos los países extranjeros y toda (su) gente. Te he dado toda ofrenda, todo alimento..." (Serrano Delgado 1993, p. 142) ${ }^{206}$. Este texto, como ya lo ha explicitado Naville (1896, pp. 13-14), es la respuesta afirmativa al pedido del

\footnotetext{
202 El subrayado es nuestro.

${ }^{203}$ Esta escena Colin Campbell (1912, pp. 26-27) la llama "Amon-Ra and Khnum” [“Amón-Ra y Khnum"]. Es analizada por Naville (1896, p. 14 y plt. XLVIII); Brunner (1964, pp. 59-67, cuadro V) y Gaballa (1976, p. 55).

${ }^{204}$ En el texto que acompaña a la imagen puede apreciarse el pedido de moldear el cuerpo y el ka del futuro rey. Si bien la mayoría de los textos de la escena están destruidos, gracias a las dos versiones puede realizarse una reconstrucción.

${ }^{205}$ El subrayado es nuestro.

206 Texto jeroglífico en Naville (1896, p. 15).
} 


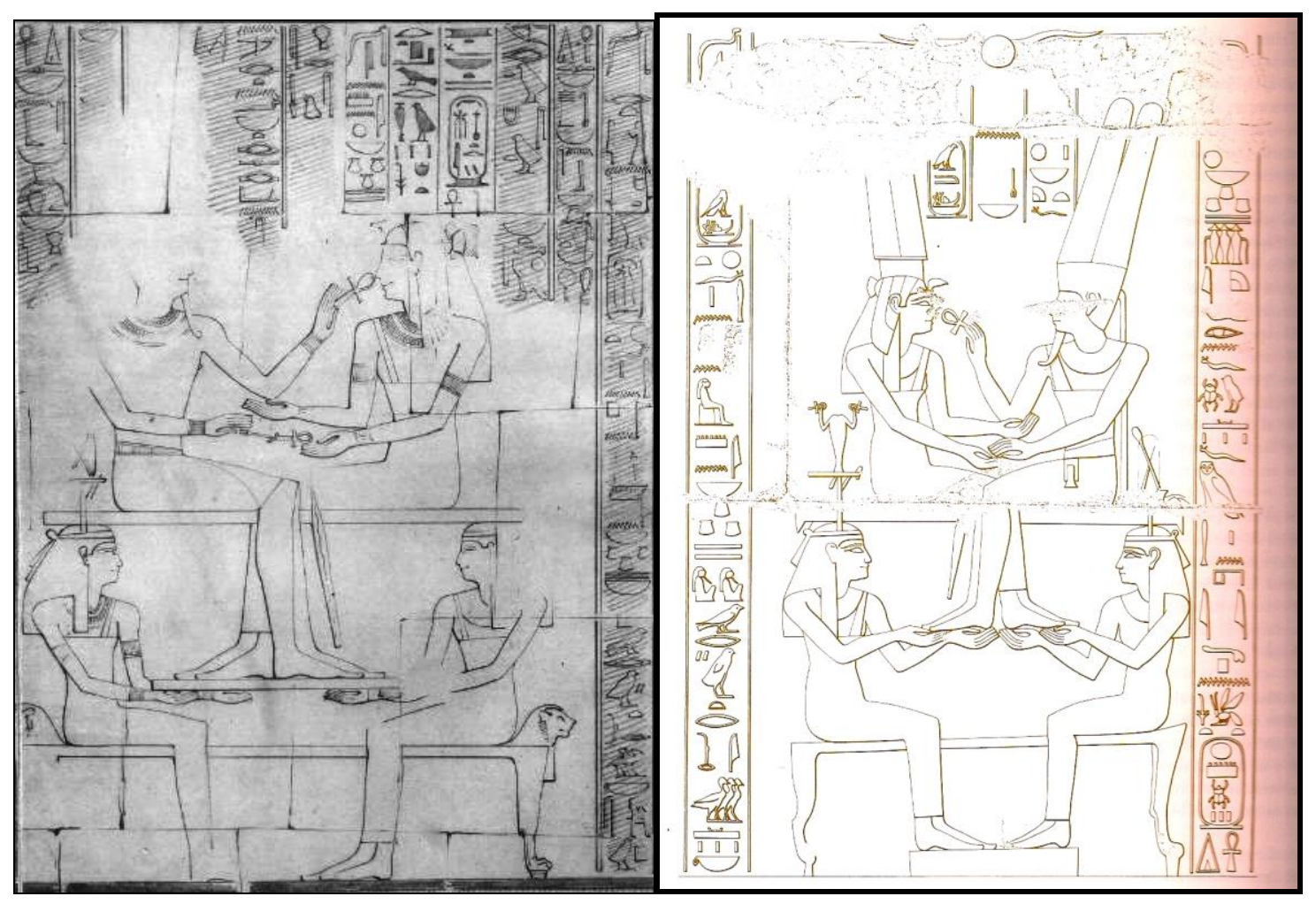

IMAGEN III. En el margen izquierdo se representa el nacimiento divino de la reina Hatshepsut (Naville 1896 plt. LI). En el margen derecho la escena de la concepción divina del faraón Amenofis III (Kemp 2004, p. 244) 
dios Amón-Ra de concretar el nacimiento del futuro faraón ${ }^{207}$. En el momento del nacimiento de los trillizos en el papiro Westcar el dios alfarero acompaña a las diosas durante el parto de Reddjedet y él es el encargado de hacer: “...saludables sus miembros..." 208 ( $\not W .10 .14)^{209}$. De este modo hay coincidencia en un aspecto con el cual se simboliza al dios Khnum, este dios es quien da salud y vida al cuerpo del futuro rey.

\section{Escena VI: moldeado del recién nacido y su ka}

En esta escena el pedido del dios se hace realidad. Tanto en el templo de Deir el-Bahari como en el de Luxor dos dioses participan de ella ${ }^{210}$. En el ciclo mítico de la reina Hatshepsut el dios Khnum se encuentra sentado sobre el margen izquierdo de la imagen, tiene sus manos abiertas extendidas, una sobre la cabeza del cuerpo del hijo del dios y la otra sobre la cabeza de su ka divino. En el de Amenofis III, el dios alfarero se ubica en el margen derecho de la escena, tiene sobre su cabeza de carnero el disco solar y los cuernos que lo rodean y extiende sus manos sobre el cuerpo del futuro rey y el de su ka. En ambos mitos el dios Khnum es el encargado de darle forma (tras el pedido de Amón-Ra) al futuro rey de las Dos Tierras ${ }^{211}$.

\footnotetext{
${ }^{207} \mathrm{El}$ autor también pone su atención en la mención de la procedencia de Khnum "el alfarero, señor de Her- Ur" (Serrano Delgado 1993, p. 142) Son disímiles las interpretaciones que se han dado con el transcurrir de las investigaciones acerca de la ubicación de la ciudad de Her-Ur $h r$-wr. Naville (1896, p. 14) afirmaba que se encontraba en el Nomo XVI en el Egipto medio, ciudad que tenía en su cementerio las famosas tumbas de Beni Hasan. Naville siguiendo a Newberry (no se menciona cuál es la publicación de este último) ha identificado la antigua ciudad de Her-Ur con la actual Hûr, que se encuentra a seis kilómetros al norte de Beni Hasan. Por su parte Colin Campbell (1912, p. 28) coincidió con esta última propuesta, y destacó que allí el dios Khnum posee un templo junto a su consorte Hequet.

${ }^{208} \mathrm{El}$ subrayado es nuestro.

${ }^{209} \mathrm{El}$ verbo que aquí se utiliza es: $s w \underline{d} 3$ “'bacer saludable”. Al respecto véase Faulkner (1991, p. 218).

${ }^{210}$ La escena VI Colin Campbell (1912, pp. 27-29) la denomina "The Moulding of the Child and his Ka" [“El moldeado del niño y su ka”]. La escena es analizada por Naville (1896, p. 14 y plt. XLVIII); Brunner (1964, pp. 68-74 y cuadro 6) y Gaballa (1976, p. 55).

${ }^{211}$ En la cosmogonía de Esna que se transmite por los textos conservados en el templo de Esna de la época del emperador romano Trajano, el dios Khnum es el dios que crea el mundo, que da forma a los hombres y a los dioses. Esta tradición de Khnum como dios demiurgo si bien se preserva en época tardía, seguramente se remonta a tiempos más tempranos (Lull 2006, pp. 35-36). El dios Khnum, adquiere su faceta de dios creador como se lo caracteriza en el mito de origen del faraón. La diferencia con éste último es que el dios alfarero crea ante una existencia ya concretada, en cambio en la cosmogonía de Esna, es Khnum el dios que dio la existencia desde el inicio.
} 
En el templo de Deir el-Bahari el dios es acompañado por Hequet quien está representada con cabeza de rana, sostiene en cada mano el signo ' $n h$. Una de sus manos se acerca a los cuerpos moldeados por el dios Khnum, y tiene su otra mano sobre su falda ${ }^{212}$.

En los relatos del papiro Westcar, si bien no hay una descripción sobre el moldeado del cuerpo y los kaw de los trillizos, Hequet (junto con otras diosas que luego también participaran en las narraciones del Reino Nuevo) acompaña a Reddejedet durante su parto y es quien ayuda a acelerar el nacimiento de cada niño.

Keel (2006 [1997], p. 240) sostiene que en Egipto una divinidad distinta es la responsable de cada fase de la generación. Amón es el encargado de la concepción; Khnum y Hathor/Hequet de la formación y vivificación del cuerpo; y del nacimiento se encargan divinidades especializadas en el parto ${ }^{213}$. Desde este punto de vista dar vida queda en manos de Khnum y Hathor/Hequet, esto mismo es lo que sucede en el relato del papiro Westcar y en las teogamias del Reino Nuevo.

Los animales anfibios (como las ranas) al igual que los mamíferos, aves y reptiles, fueron representados como divinidades, la mayoría de las veces con cabeza de animal y cuerpo humano. Hequet fue simbolizada completamente como rana, o con cabeza de rana, y sus funciones principales se asociaron a la protección en el parto (Hornung 1999a, pp. 108-109). La rana es símbolo de regeneración, nacimiento y fertilidad y en algunos casos también de resurrección (Colin Campbell 1912, p. 28; Wilkinson 1998, p. 109) ${ }^{214}$. En los relatos del papiro Westcar Hequet cumple este rol mítico-simbólico. Al comienzo del anexo al cuarto relato, Reddjedet está padeciendo un parto dificultoso: "Uno de aquellos días aconteció que Reddjedet estaba sufriendo y su parto era difícil" ( $p W .9 .21-22)$. La acción de "acelerar" realizada por la diosa Hequet puede implicar evitar el sufrimiento y garantizar un nacimiento exitoso.

\footnotetext{
${ }^{212} \mathrm{Al}$ igual que ocurre en la escena anterior Hequet es llamada "Señora de Her-ur". Hequet es protagonista de esta misma escena en el templo de Denderah (Gaballa 1976, p. 55).

${ }^{213}$ Como es el caso de la diosa Meshkeneh.

214 Ante estos rasgos simbólicos que se le adjudican a la rana en el antiguo Egipto el autor (Colin Campbell 1912, p. 28) recuerda que la diosa preside una de las escenas de la resurrección de Osiris.
} 
En el templo de Luxor la diosa que acompaña a Khnum claramente pareciera ser Hathor, aunque no pueda leerse su nombre (Colin Campbell 1912, p. 28; Gaballa 1976, p. 55). Sobre su cabeza lleva la corona con el disco entre los cuernos y al igual que para la diosa con cabeza de rana su acto se interpreta como dándole vida al futuro rey y a su ka. Por el contrario, Hathor no es mencionada como partícipe en el nacimiento de los trillizos en el mito en los relatos del papiro Westcar.

El moldeado del cuerpo del futuro faraón y su ka significa la concreción del plan que Amón-Ra ha ideado. El dios Khnum responde a su pedido de dar vida a un nuevo soberano. Es decir que se hace realidad aquello anunciado en las primeras escenas por Amón-Ra. Este sentido de cumplimiento de lo anticipado es lo que ocurre en el relato anexo en el papiro Westcar. La profecía de Djedi se concreta con los nacimientos de los trillizos (escena IX). Nacimiento que en las teogamias precede al moldeado del cuerpo del rey y su ka, acción en la cual participan los mismos dioses que están presentes en el parto de Reddjedet en el papiro Westcar.

\section{Escena VII: Toth y la reina}

En la séptima escena son dos los personajes que aparecen representados en los relieves: el dios Toth y la reina madre ${ }^{215}$.

En el templo de Deir el-Bahari, a la izquierda, el dios Toth, con cabeza de ibis, colocando uno de sus brazos al costado de su cuerpo, sostiene con su mano un signo ' $n h$. Toth extiende el otro brazo acercándolo hacia la reina Ahmose en gesto de abrazarla. Ella está dibujada en el margen derecho, con un vestido largo y portando sobre su cabeza la misma corona que en la escena de la concepción ${ }^{216}$. Naville (1896, pp. 14-15) interpreta que en esta escena el dios Toth le declara a la reina todos los títulos reales que se unirán a su nombre por ser la madre de un futuro rey divino.

\footnotetext{
215 La escena VII Colin Campbell (1912, p. 29- 30) la denomina "Thoth and Queen Mut-em-ua" [Toth y la reina Matemwia]. Es analizada en Naville (1896 pp. 15-16 y plt. XLVIII); Brunner (1964, pp. 75-83 y cuadro 7) y Gaballa (1976, p. 55).

${ }_{216}$ Recordemos que en la escena IV el nombre de la mujer no correspondía al de la madre terrenal de la reina Hatshepsut, pero aquí claramente aparece encartuchado el nombre de Ahmose.
} 
El templo de Luxor también se representa el encuentro entre el dios Toth y la reina Matemwia, el primero entre ambos en todo el ciclo. En una de las manos Toth lleva un rollo de papiro, y el otro brazo lo tiene extendido queriendo abrazar a la reina. Ella, con un vestido largo hasta los pies, porta sobre su cabeza la doble corona de plumas de Amón-Ra. Gaballa (1971, p. 55) afirma que este encuentro probablemente tiene la finalidad del anuncio del dios a la reina de los títulos dignos de una reina madre. Según Colin Campbell (1912, pp. 29-30) el mito del nacimiento divino, en realidad no pretendía justificar como hijo del dios al futuro gobernante sobre las Dos Tierras, sino legitimar la figura materna de este rey. Hemos ya especificado la radical importancia que el mito del nacimiento tiene para justificar el ejercicio del poder del faraón, ya que a través de esta historia se aduce su origen divino que le da el legítimo derecho de gobernar ${ }^{217}$.

Si este realmente fuera el sentido de la escena y el objetivo por el cual se representa al dios Toth no encontramos en este punto relación con el mito narrado en el papiro Westcar. Ello explicaría porque el dios no es mencionado en ningún momento del relato. Su participación en el nacimiento divino corresponde a todos los hechos entre el encuentro del dios Amón-Ra con el consejo de dioses, la concepción hasta el nacimiento. Justamente todos los que identificamos en el relato del papiro Westcar que corresponden a la profecía de Djedi.

En el relato mítico del papiro Westcar a la mujer que ejerce el rol de madre de los trillizos no se le detecta literariamente ningún rasgo de realeza, si bien se han realizado esfuerzos por vincular al personaje con reinas de la dinastía V V18. Reddjedet tampoco parece cambiar su rango social una vez convertida en madre de los futuros reyes.

\footnotetext{
217 El reconocimiento de las reinas madres terrenales es un aspecto lateral del mito, haciéndose necesario analizar específicamente los casos de Ahmose, Matemwia y Tuya. Por ejemplo, puede realizarse un examen que tenga en cuenta los contextos históricos y acción política de cada una de ellas.

${ }^{218}$ Hemos discutido este aspecto en el capítulo I.
} 


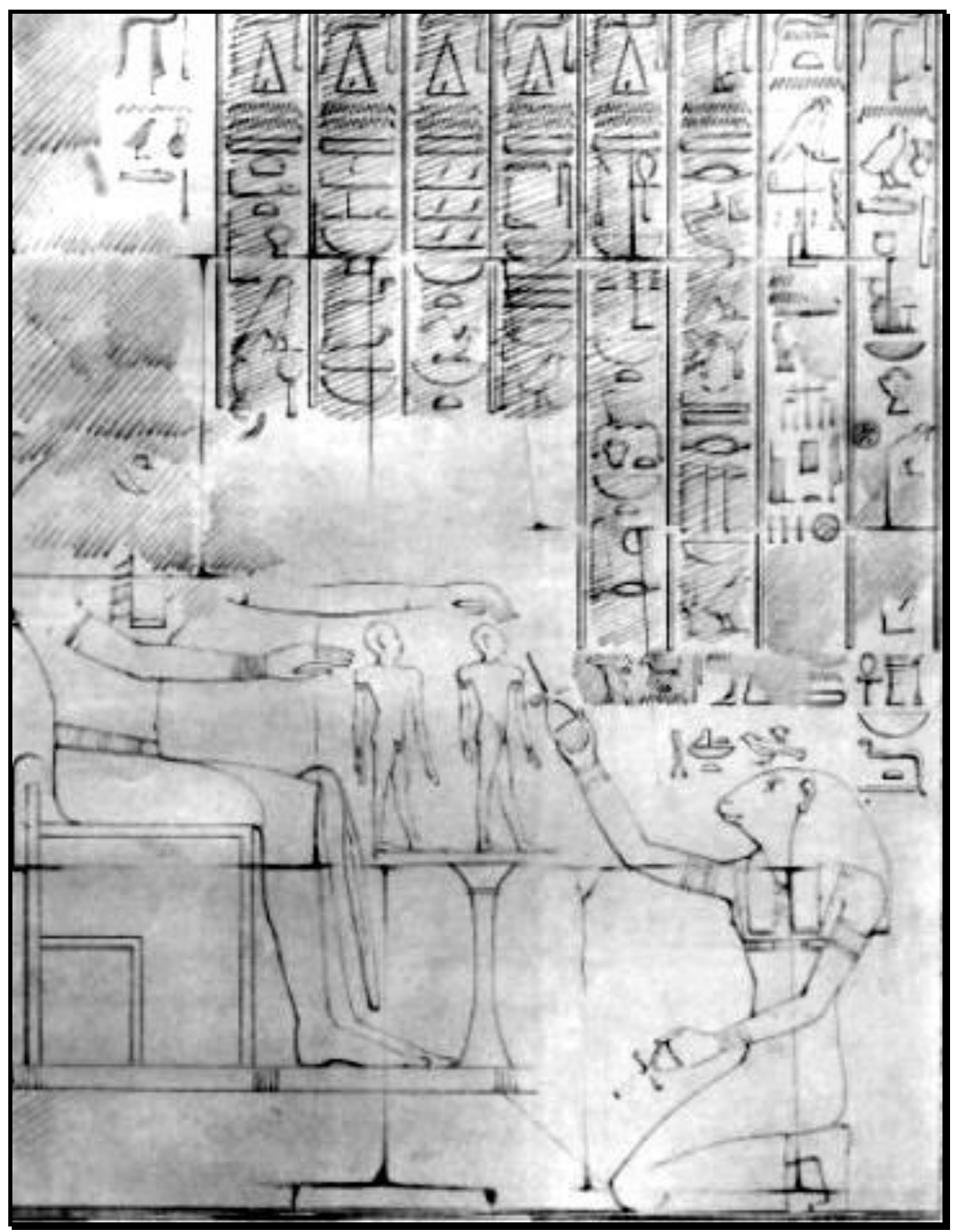

IMAGEN IV. Escena VI: el dios Khnum moldea el cuerpo y el ka de la futura reina Hatshepsut, mientras que la reina Hequet le da vida (Naville 1896 plt. XLVIII). 
Reddjedet no era reina, pero pertenecería al ser la mujer de un sacerdote a una clase privilegiada. Reddjedet tuvo una cercanía con el dios, al menos en el momento de la concepción que en la narración del papiro Westcar ya es un hecho consumado, pero en el relato no se le otorga una importancia especial a su posición social. En las teogamias del Reino Nuevo las madres reales son protagonistas que tienen voz, y pueden comunicarse y observar a los dioses. Tanto ellas como sus hijos tienen el privilegio de estar cerca de la divinidad.

\section{Escena VIII: los dioses conducen a la reina madre a la sala de nacimiento}

Esta escena se divide en tres registros verticales, pero lamentablemente el deterioro de la mayoría de las imágenes impide identificar los nombres de los personajes que participan, y se pierde gran parte del significado de toda la secuencia $^{219}$. La escena narraría el momento en que la reina madre embarazada es conducida por los dioses a la sala de nacimiento ${ }^{220}$.

En el primer registro en el templo de Deir el-Bahari la reina Ahmose (con el mismo tocado en la cabeza que en las escenas anteriores) es llevada de la mano por el dios Khnum, representado con cabeza de carnero, que se ubica a la izquierda de la escena. Con la otra mano sostiene un signo $` n h$, mientras que la diosa Hequet a su derecha con cabeza de rana, sostiene un cetro. Hequet vuelve a cumplir esta función de protectora en el parto, acompaña a la reina en todas las instancias de su embarazo, al igual que lo hacen con Reddjedet en los dos últimos relatos del papiro Westcar. En el templo de Luxor se sustituye a la diosa Hequet por Hathor. La reina Matemwia, con la corona de plumas de Amón-Ra, recibe vida de los dioses que se representan en tres registros en el margen derecho de la imagen. Esta parte del relato es omitida en el papiro Westcar. En él, el relato anexo se inicia cuando

\footnotetext{
219 A esta escena Colin Campbell (1912, pp. 30-31) la denomina "The Queen conducted by Hat-hor and Khnum to the Birth Room" ["La reina es conducida por Hathor y Khnum a la Sala de Nacimiento]. Es también analizada por Naville (1896, p. 16 y plts. XLIV y L); Brunner (1964, pp. 83-89 y cuadro 8) y Gaballa (1976, p. 56).

${ }^{220}$ El refinamiento de la expresión de la reina embarazada momentos previos al nacimiento del futuro rey fue destacado por los investigadores que han estudiado esta secuencia mítica (Naville 1896, p. 15; Gaballa 1976, p. 55).
} 
Reddjedet está por parir en su habitación: “...Éstas entraron ante Reddjedet y se encerraron en la babitación junto con ella..." ( $($ WW.10.6-7).

En la segunda parte de la escena en ambos relatos míticos, las imágenes de las divinidades están muy destruidas. Naville (1896, p. 14) contabiliza un total de doce dioses. Colin Campbell (1912, p. 30) cuenta nueve divinidades. Ninguno de los dos autores pudo determinar con claridad quiénes son los dioses que están participando aquí. Esta dificultad está presente, pues no se distingue ningún estereotipo de alguna divinidad y no pueden leerse nombres que hagan referencia a su identidad.

La tercera parte de la escena únicamente ha quedado atestiguada para el templo de Deir el-Bahari. En ella el dios Amón-Ra lleva la corona de dos plumas y sostiene en su mano el cetro de poder. Su función es conducir a la reina hacia la sala del nacimiento. El dios está mirando hacia la derecha, pero no sabemos a qué o a quiénes, pues está irremediablemente destruida toda la imagen. La participación de Amón-Ra en esta escena nos indica la preocupación que el dios tenía para que el nacimiento de sus hijos se produzca sin inconvenientes. Observamos una participación activa del padre divino al conducir a la parturienta hacia la sala del nacimiento dónde será asistida por los dioses (escena IX). Esta preocupación se relata de modo similar en el papiro Westcar. En él se narra: “...Uno de aquello días aconteció que Reddjedet estaba sufriendo y su parto era difícil. Entonces su majestad Ra, señor de Sakhebu, dijo a Isis, Neftis, Meshkeneh, Hequety Khnum: 'Quisiera que ustedes vayan a asistir el parto de los tres niños que están en el vientre de Reddjedet ${ }^{221}$..." " ( $p W .9 .21-24)$. En el papiro Westcar es el dios Ra en persona quien envía a los dioses a ocuparse de Reddjedet, la madre de sus trillizos.

${ }^{221}$ El subrayado es nuestro. 


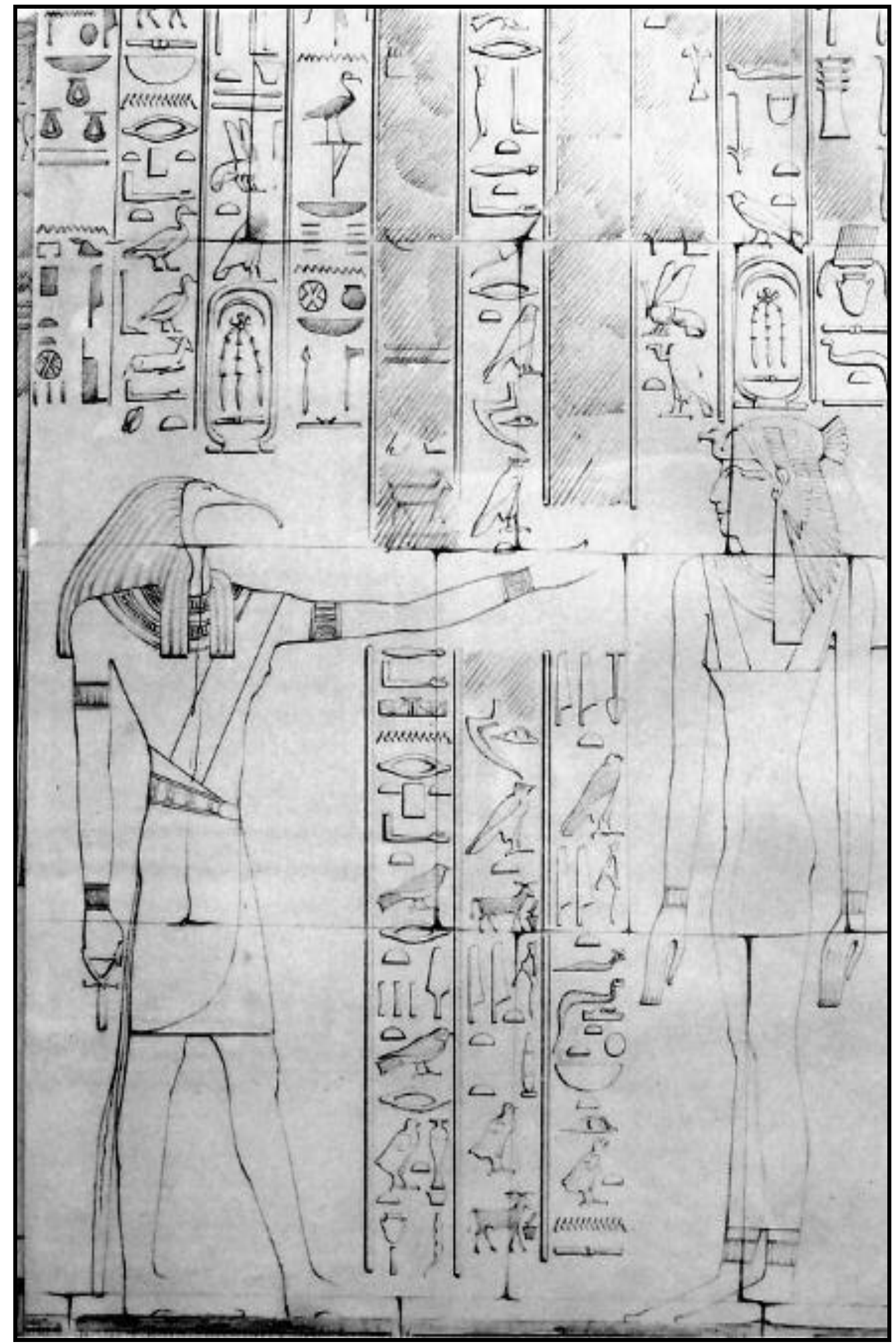

IMAGEN V. Escena VII: En el templo de Deir el-Bahari el dios Toth con cabeza de ibis frente a la reina madre Ahmose (Naville 1896, plt. XLVIII) 


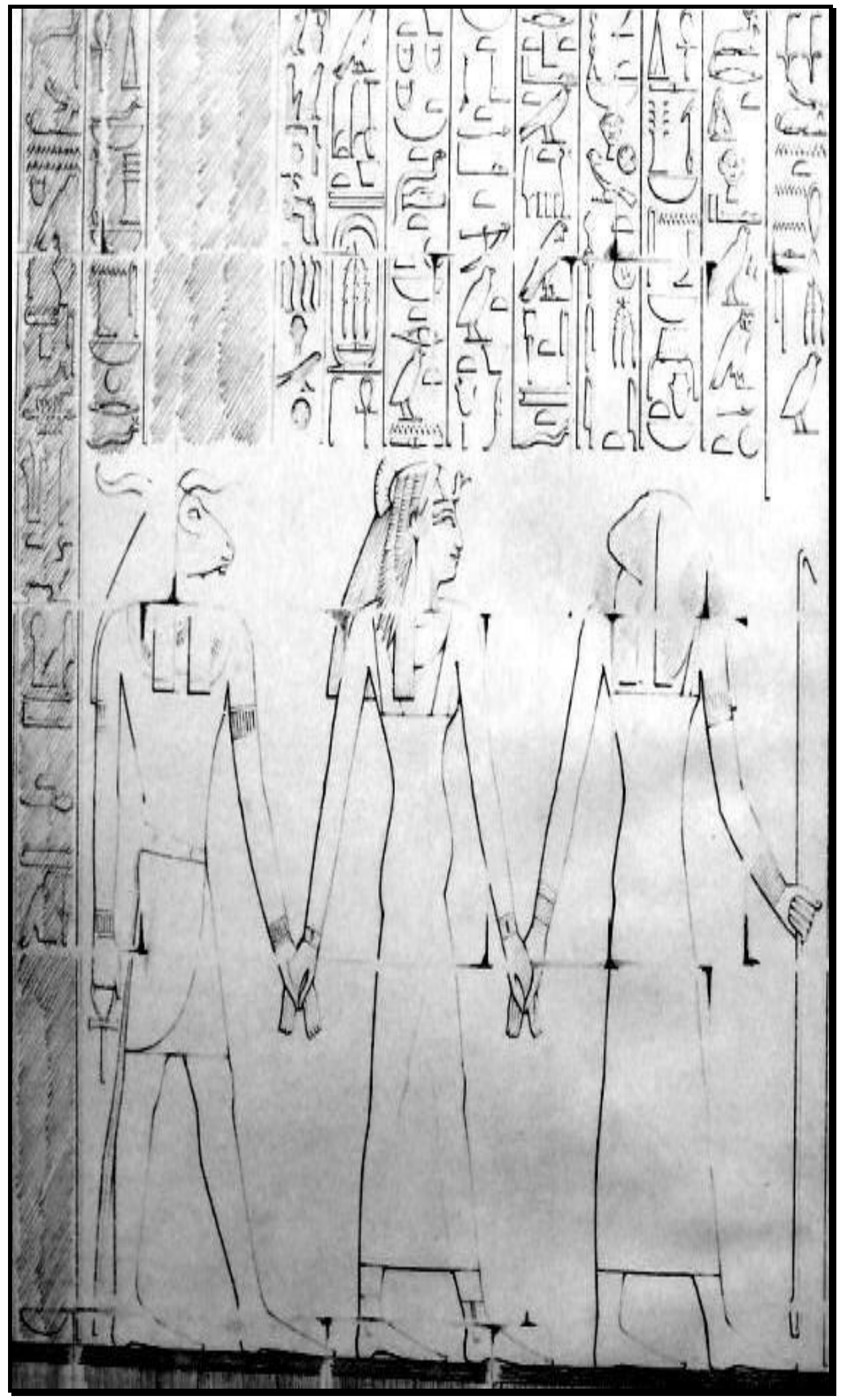

IMAGEN VI. Escena VIII: detalle en el templo de Deir el-Bahari de la reina Ahmose embarazada conducida por los dioses a la sala de nacimiento (Naville 1896, p. LII) 
Escena IX: nacimiento divino.

El nacimiento divino del faraón no se omite en ninguna de las narraciones del mito ${ }^{222}$. Tanto para las teogamias del Reino Nuevo como para el relato del papiro Westcar es el momento crucial de toda la narración mítica. La participación de los dioses en cada uno de los relatos del nacimiento divino del rey muestra entre ellos paralelismos contundentes.

En los ciclos míticos de Hatshepsut y Amenofis III el nacimiento es la escena más larga y compleja de ser interpretada y fue considerada la más importante por los antiguos egipcios (Gaballa 1976, p. 56) 223 . El gran número de dioses que participan en ella, y la multiplicidad de acciones es lo que caracteriza según Keel (2006 [1997], p. 245) el nacimiento como el verdadero clímax del ciclo $^{224}$. El momento del nacimiento divino es el argumento principal de la primera parte del anexo al cuarto relato del papiro Westcar, describiéndose el nacimiento de cada uno de los tres niños. Es el parto de Reddjedet un momento decisivo, y es el eje sobre el cual gira la conversación entre Keops y el mago en el relato anterior: la profecía de Djedi. Derchain (1986, p. 19) interpreta que la escena en el papiro Westcar está descripta en lenguaje de mito, en la cual los actos y las cosas se transforman en personas y se percibe una connotación mágica la cual el egipcio comprendió, pero que se escapa al lector moderno 225 . Analizaremos las coincidencias que se producen en el tipo de relato de los mitos del Reino Nuevo egipcio, y el papiro Westcar.

En los templos el conjunto de la escena se divide en tres registros horizontales. En Deir el-Bahari, en el margen derecho, ocupando dos registros, se

$222 \mathrm{El}$ nacimiento divino del faraón tampoco se omite en los relatos de época ptolemaica (Daumas 1958b; 1959 y Keel 2006 [1997], p. 247). Por ejemplo, en el templo de Armant se representa el nacimiento de un modo menos estético en comparación a las teogamias del Reino Nuevo (Keel 2006 [1997], p. 247 y fig. 337).

${ }^{223}$ La escena IX que Colin Campbell (1912, pp. 31- 35) analiza la denomina "The Birth" ["El nacimiento"]. También es examinada por Naville (1896, pp. 16-17 y plt. LI); Brunner (1964, pp. 90106 y cuadro 9) y Gaballa (1976, p. 56).

224 Según Keel (2006 [1997], pp. 245-247) el escaso naturalismo de las escena de la concepción y el nacimiento del rey probablemente no se deba a lo delicado de los procesos implicados, sino más bien al deseo de dar a ellos cierta "representación mistérica" y no la descripción del acontecimiento real. Lo que se contrapone con el naturalismo con el cual fue tratado el tema en época ptolemaica.

225 Derchain (1986, p. 17) considera que los textos literarios egipcios traen aparejado una dificultad: la de no poder conocer las intenciones con las cuáles fueron escritos, pues el lector moderno desconoce las referencias intertextuales que entre ellos se produce. 
representa a la diosa del nacimiento Meskheneh ${ }^{226}$. Ella está sentada con su corona típica sobre la cabeza, levantando una de sus manos dirigiendo todo el nacimiento ${ }^{227}$. La diosa es omitida en el templo de Luxor, mientras que es uno de los personajes divinos que asiste el parto de Reddjedet.

La figura de Meskheneh, otra forma de Hequet (Naville 1896, p. 17), es central para entender la escena. Es la partera de la joven reina y en el texto que está ante ella puede leerse: "Estoy detrás de ti, te protejo como Ra", similar a lo que ocurre en el papiro Westcar que también es partera de Reddjedet. En este relato “... Meshkeneh se le presentó ante ély dijo: 'Será un rey que ejercerá la realeza sobre este país entero'...” ( $p W .10 .13$ 14).

En Deir el-Bahari, en el registro superior, la reina Ahmose está sentada sosteniendo entre sus brazos al recién nacido. Frente a ella están arrodilladas cuatro diosas, la primera estira sus brazos en acción de querer sostener a la niña, mientras que las otras tres también estiran sus brazos. La última de ellas lleva sobre su cabeza el 'nh. Detrás de la reina, una diosa arrodillada que lleva en la cabeza un recipiente que simboliza el cordón umbilical, el recipiente tiene forma de cono truncado e invertido (Frankfort 1998b [1948], p. 98). Ella le ofrece a Ahmose dos signos ` $n h$ que sostiene en cada una de sus manos. Tras ella en fila y de pie, le siguen otras cuatro diosas, de las cuales la primera Neftis y la segunda Isis. Isis y Neftis también cumplen un rol fundamental en el parto de Reddjedet. Ellas dos hacen de parteras. En el relato del papiro Westcar se lee: “...Entonces Isis se colocó enfrente de ella y Neftis detrás de ella..." (

En el templo de Luxor, la reina madre Matemwia, sentada sobre un asiento en forma de $\llbracket 228$, estira sus dos brazos hacia los costados, los que son tomados por dos diosas colocadas a cada lado. Hacia la derecha de la imagen dos diosas sostienen

\footnotetext{
226 Frente de la diosa se dividen tres registros, que están delimitados por dos grandes asientos. Los extremos de los asientos forman una cabeza de león y las patas tienen la forma de garras (el mismo asiento que describíamos en la escena de la concepción). Estos asientos son casi idénticos en ambos templos. En Deir el-Bahari los tres registros están completos, excepto una figura en el extremo superior izquierdo del primero de ellos y una figura en el registro inferior. En el templo de Luxor están borradas parcialmente algunas de las figuras en el registro medio a la izquierda, y el enano Bes en la parte inferior derecha.

227 En el capítulo III analizaremos los símbolos míticos que aparecen alrededor de esta diosa.

228 Signo O 6 en la nomenclatura de Gardiner. Al respecto véase Gardiner (2007 [1927], p. 493).
} 
al recién nacido. El nombre de una de ellas está escrito dentro de un cartucho que termina con las manos $\mathcal{L}^{\ell}$ en forma de ka; detrás de él hay otra diosa con sus brazos estirados. A la izquierda detrás de la diosa que acompaña a la reina, se representan cuatro diosas paradas.

En el relato anexo al papiro Westcar es el dios Ra quien le pide a las diosas Isis, Neftis, Meshkeneh y Hequet y al dios Khnum que vayan a ayudar a Reddjedet, pues su parto se presenta con dificultades. El dios Ra les dice "QQuisiera que ustedes vayan a asistir el parto de los tres niños que están en el vientre de Reddjedet quienes cumplirán esta función excelente sobre este país entero. Ellos construirán vuestros templos, abastecerán vuestros altares, enriquecerán vuestras mesas de ofrendas y ellos harán grande vuestras ofrendas divinas" " (pW. 9. 23-28).

Similares palabras pronuncian los dioses ante la llegada de la reina Hatshepsut "Nosotros hemos venido para asegurar nuestra protección de vida, estabilidad y dominio tras ella y su ka, como Ra eternamente" (Serrano Delgado 1993, p. 142). En ambos relatos se transmite que la estabilidad del gobierno del monarca naciente se extenderá a la prosperidad de los dioses, la construcción de sus altares y la obtención de sus ofrendas, los augurios de los dioses hacia el futuro rey repercutirá positivamente si su gobierno es exitoso.

En el relato anexo en el papiro Westcar las diosas disfrazadas de bailarinas y el dios como su maletero llegan a la casa de Rauser y su mujer, y son ellas las que hacen de parteras. La secuencia se repite en el texto del mismo modo para los tres niños: "Entonces Isis se colocó enfrente de ella y Neftis detrás de ella, (mientras que) Hequet aceleraba el parto... Entonces ellas lo lavaron y cortaron su cordón umbilical y lo colocaron sobre un asiento de ladrillos. Entonces Meshkeneh se le presentó ante él y dijo: 'Será un rey que ejercerá la realeza sobre esta país entero', (mientras) que Khnum hizo saludables sus miembros" ( $\not W .10$. 7-15). Al igual que sucede con Ahmose y Matemwia las diosas rodean a la madre y la acompañan en el nacimiento del niño.

Respecto al segundo registro en el relato del nacimiento de Hatshepsut, debajo de la reina sentada, están representadas dos figuras ambiguas (más bien masculinas) arrodilladas con sus brazos extendidos en posición de alabanza en 
forma de ka. Sobre sus cabezas salen dos estandartes o cetros que se curvan hacia adentro; entre ellos un pilar djed y encima un signo ' $n h$, es sostenido por las figuras. A la izquierda, una figura masculina arrodillada ofrece dos signos ` $n h$; lo siguen en la misma posición cuatro dioses con cabeza de cocodrilo ${ }^{229}$. Hacia la derecha de las figuras centrales, siguen cuatro representaciones todas arrodilladas y con los signos ' hh en cada mano. La primera con cabeza de cocodrilo, es seguida por dos figuras masculinas, y la última tiene cabeza de carnero. Esta compleja escena se omite en el relato mítico en el papiro Westcar, ya que éste reconstruye lo esencial del relato.

Similar es lo que ocurre en el templo de Luxor, dos figuras centrales quienes sostienen un ' $n$ h. A diferencia de la escena en Deir el-Bahari, en el extremo izquierdo y derecho está representado el dios Khnum. Es decir, se describe su participación al igual que se lo hace en el mito de origen de la dinastía $\mathrm{V}$ en el papiro Westcar. Como ya analizábamos en la escena V, el dios Khnum es el encargado de dar vida y salud al cuerpo de cada recién nacido en los diferentes relatos del nacimiento divino del rey.

En el último registro, el inferior, en el templo funerario de Hatshepsut, en la misma línea vertical se ubican la reina sentada y las figuras masculinas arrodillas con sus brazos en posición de ka. Ellas se representan con un signo compuesto por un signo $s 3$ que significa protección (Wilkinson 1998, p. 199) rodeado a la derecha y a la izquierda por un cetro que se relaciona con el poder (en el templo de Luxor sólo uno a la izquierda). En conjunto es muy complejo interpretar el significado del signo, y muy pocos han dado su apreciación al respecto. Uno de ellos ha sido Colin Campbell (1912, p. 33), para quien el signo se identifica con el útero y el apéndice, de ahí que simbolizaría el nacimiento ${ }^{230}$.

A la derecha del signo compuesto le siguen cuatro figuras con un brazo alzado, la mano con el puño cerrando y el otro brazo apoyado sobre el pecho. Las primeras dos llevan cabeza de halcón y las otras cabezas de chacal. Ellas representan

\footnotetext{
${ }^{229}$ Las figuras de los cocodrilos obtuvieron una caracterización dual. Por un lado, son asociados al desorden cósmico y por consiguiente al dios Seth. Por el otro, como el dios Sol, emergían de las aguas y atacaban a aquellos que consideraban enemigos de la divinidad (Wilkinson 1998, p. 107).

${ }^{230}$ En la casa de nacimiento de Denderah se encuentra un grupo de signos formado por un $\mathrm{n} h \mathrm{~h}$, un pilar djed, un cetro w3s y un signo neb, similar al aquí comentado (Wilkinson 1998, p. 182).
} 
a Pe y Nekhem, simbolizando el norte y el sur (Gaballa 1976, p. 56). La diosa Hathor en Deir el-Bahari dice que ella viene del norte "Yo vengo de Pe y a Dep voy, he recorrido las marismas de los confines de los Caminos de Horus..." (Serrano Delgado 1993, p. 143).

En el margen inferior derecho se representa la figura del dios enano Bes. A su derecha y de costado con las manos hacia abajo, se encuentra la figura de la diosa Tauret ${ }^{231}$. La diosa es personificada con cabeza de hipopótamo, pies que son garras de león y cola de cocodrilo. Esta es una popular diosa protectora, mayormente representada por los egipcios en amuletos. Míticamente Tauris y Bes fueron los protectores del parto y el lecho de la parturienta (Hornung 1999a, p. 259).

\begin{tabular}{|c|c|c|c|}
\hline Personajes & papiro Westcar & $\begin{array}{c}\text { templo de Deir el- } \\
\text { Bahari }\end{array}$ & templo de Luxor \\
\hline Madre & $\begin{array}{l}\text { Reddjedet da a luz a } \\
\text { los trillizos }\end{array}$ & $\begin{array}{l}\text { Ahmose sostiene entre } \\
\text { sus brazos al niño } \\
\text { recién nacido }\end{array}$ & $\begin{array}{l}\text { Matemwia sentada es } \\
\text { tomada por sus brazos } \\
\text { por dos diosas que la } \\
\text { acompañan en el } \\
\text { nacimiento del niño }\end{array}$ \\
\hline Meskheneh & $\begin{array}{l}\text { es quien ante cada } \\
\text { recién nacido afirma } \\
\text { que es un futuro rey } \\
\text { que gobernará Egipto }\end{array}$ & $\begin{array}{l}\text { es quien dirige el } \\
\text { nacimiento mirando } \\
\text { toda la escena que } \\
\text { transcurre delante de } \\
\text { ella }\end{array}$ & \\
\hline Neftis & $\begin{array}{l}\text { se coloca por detrás de } \\
\text { Reddjedet y participa } \\
\text { como partera en el } \\
\text { nacimiento de los } \\
\text { trillizos }\end{array}$ & $\begin{array}{l}\text { se ubica detrás de la } \\
\text { reina acompañándola } \\
\text { en el momento del } \\
\text { nacimiento del niño }\end{array}$ & $\begin{array}{l}\text { se ubica detrás de la } \\
\text { reina acompañándola } \\
\text { en el momento del } \\
\text { nacimiento del niño }\end{array}$ \\
\hline Isis & $\begin{array}{l}\text { se coloca por delante } \\
\text { de Reddjedet y } \\
\text { participa como partera } \\
\text { en el nacimiento de los } \\
\text { trillizos }\end{array}$ & $\begin{array}{l}\text { se ubica detrás de } \\
\text { Neftis acompañando a } \\
\text { la reina en el momento } \\
\text { del nacimiento del niño }\end{array}$ & $\begin{array}{l}\text { se ubica detrás de } \\
\text { Neftis acompañando a } \\
\text { la reina en el momento } \\
\text { del nacimiento del } \\
\text { niño }\end{array}$ \\
\hline Hequet & $\begin{array}{l}\text { es quien acelera el } \\
\text { nacimiento de los } \\
\text { trillizos }\end{array}$ & & \\
\hline
\end{tabular}

CUADRO III. Comparación de la participación de los personajes entre los ciclos míticos en el momento del nacimiento del futuro faraón

231 También conocida como Tueris. 
Escena X: presentación del niño a su padre el dios Amón-Ra por Hathor

Esta escena narra la presentación del recién nacido a su padre-dios Amón$\mathrm{Ra}^{232}$. El papiro Westcar se interrumpe luego del nacimiento de los trillizos, por ello es muy difícil determinar si en algún momento estuvo narrada la presentación de los niños ante su padre y la descripción de su amamantamiento y crianza, lo que ocurre en las escenas X, XI y XII. Las similitudes sí se destacan entre los relatos del Reino Nuevo.

Uno de los paralelismos narrativos más interesantes que se dan en este momento del relato entre los mitos, es la descripción con características divinas que cada uno de los recién nacidos recibe ${ }^{233}$. En el manuscrito se lee: "un niño de un codo (de largo). Sus huesos eran fuertes y la cobertura de sus miembros era de oro y su tocado de verdadero lapislázuli23»' ( $($ WW. 10. 10-12). Al igual que el cuerpo de Hatshepsut, según las palabras pronunciadas por Hathor "... iHija (mía) de (mi) cuerpo, Maat-Ka-Ra, hija (mía) de oro fino!..235." (Serrano Delgado 1993, p. 143).

En los relieves del templo de Deir el-Bahari, en el margen derecho, la diosa Hathor, con el disco solar sobre su cabeza, se encuentra sentada sobre un trono y sostiene en sus manos al niño ante el dios Amón-Ra. En el margen izquierdo de la imagen, su padre, con la corona de plumas, lo acaricia con una mano y con la otra sostiene el signo ' $n h$.

En el ciclo de Luxor un gran agujero en la pared dificulta la lectura de la escena (Colin Campbell 1912, p. 35). La posibilidad de reconstrucción e interpretación se debe a los paralelismos con el ciclo del nacimiento de la reina Hatshepsut. Se puede ver en el margen derecho una cola -la misma que tiene AmónRa en Deir el-Bahari- y en el margen izquierdo un disco solar, el de la diosa Hathor. Ella sostiene al recién nacido entre sus manos y se lo está presentando a su padre Amón-Ra. Las palabras pronuncias por Hathor son las únicas que pueden leerse “...

\footnotetext{
${ }^{232}$ Es analizada por Colin Campbell (1912, pp. 35- 36) quien la denomina "First Presentation of the Child to Amon-Ra" ["Primera presentación del niño ante Amón-Ra"]. También examinada por Brunner (1964, pp. 107-113 y cuadro 10), Gaballa (1976, p. 56) y Naville (1896, p. 17 y plt. LII).

${ }^{233}$ Su relación mítico-simbólica será analizada en el capítulo III.

${ }^{234} \mathrm{El}$ subrayado es nuestro.

$235 \mathrm{El}$ subrayado es nuestro.
} 
llévale a él (una nodriza), y el amor para el..." (Colin Campbell 1912, p. 36). Palabras que parecen no tener contrapartida en el templo de Deir el-Bahari.

El texto que continúa en el templo de Luxor tiene una importancia especial, se lee: "Palabras de Amón, señor sobre el trono de las Dos Tierras. 'Viene, viene en paz, hijo de Ra, de sus (mis) entrañas, Ra-maat-neb, le da vida" (Colin Campbell 1912, p. 36). Es la primera vez durante el ciclo mítico que se asocia textualmente a Amón-Ra con el dios Ra como el padre del recién nacido, y es llamado como "hijo de sus cuerpo" (Colin Campbell 1912, p. 36). Esto nos recuerda a las palabras anunciadas por Djedi en los relatos del papiro Westcar el dios $\mathrm{Ra}$ reconoce también la paternidad hacia los futuros reyes: “...Es la esposa de un sacerdote wab de Ra, señor de Sakhebu embarazada de tres hijos de Ra, señor de Sakhebu...” (

Escena XI: segunda presentación del recién nacido ante Amón-Ra

En los relatos del Reino Nuevo se continúa con la presentación del recién nacido ante su padre divino, Amón-Ra ${ }^{236}$. Ahora el dios está sentado frente a la diosa Hathor y es él mismo quien sostiene entre sus brazos el cuerpo del niño. En el templo de Deir el-Bahari el dios padre, personificado con su corona de plumas, sostiene en sus manos la figura del ka del recién nacido. Al lado debería estar la imagen del niño abrazando al dios pero está muy borrosa, únicamente se ve una mano alzada. La diosa Hathor, con el disco solar entre los cuernos sobre su cabeza, levanta la palma de su mano en un gesto de acariciar al niño. Y en la otra mano sostiene un signo ${ }^{\top} n h$.

En esta escena pueden leerse las palabras pronunciadas por Ra-Haraktis: “... 'Yo te he concedido que tomes la posesión de las Dos Tierras como rey del Alto y Bajo Egipto, habiendo aparecido en gloria sobre el trono de Horus de forma que guies a los vivientes, según lo que ha ordenado tu Amón, que te ama"” (Serrano Delgado 1993, p. 144).

\footnotetext{
${ }^{236}$ La escena es examinada por Colin Campbell (1912, pp. 36-37) quien la denomina "Amon-Ra takes the Child in his Arms" [“Amón-Ra toma al niño entre sus brazos"]. También es analizada por Naville (1896, p. 17 y plt. LII); Brunner (1964, pp. 114-121 y cuadro 11) y Gaballa (1976, p. 56).
} 
En ambos templos reaparece en la acción la diosa Selket ${ }^{237}$. En Deir el-Bahari la diosa está parada en el extremo derecho de la escena. Ella lleva un signo ' $n h$ en la mano derecha, mientras la mano izquierda está borrada, por lo cual no puede saberse si llevaba algo. La diosa Selket es testigo de la presentación del niño ante Amón-Ra. Según Naville (1896, p. 17) Selket es una diosa que tiene como función supervisar el cuidado del recién nacido, idea que se comprende mucho mejor en la escena que continúa.

En el templo de Luxor, la diosa Hathor eleva su mano, contempla al recién nacido, lo acaricia y lo besa. El niño coloca su brazo alrededor del cuello del dios Amón-Ra quien pronuncia las palabras: "Ven en paz, hijo de mis entrañas, Ra-maat-nebbe hecho para ti millones de años, como Ra”. Colin Campbell (1912, p. 37) considera que toda la escena se elabora en relación a la idea de que el dios Amón-Ra está usurpando el lugar del dios Ra como padre del soberano. El planteo del autor puede desestimarse si se tiene en cuenta que la figura divina de Amón-Ra no es más que un sincretismo con $\mathrm{Ra}$, y no pareciera haber en ello una disputa entre dioses.

Aquí se introduce a la diosa Mut, consorte de Amón. La diosa Mut está representada con su figura típica de cabeza de buitre, una peluca y la doble corona de Egipto. Sostiene en su mano derecha una rama de palma de años, y en su mano izquierda lleva el signo de aniversarios $h b$-sd que cuelga de la rama (Colin Campbell 1912, p. 37) ${ }^{238}$. Del codo izquierdo de la diosa Mut cuelga un dispositivo que es el símbolo que significa "millones de aniversarios en la vida y fuera". Es decir, lo que la diosa desea para el futuro rey es una larga vida. Cerca de la rama de palma está restaurado el nombre de Ra de Amenofis III, con las palabras “... hijo, amado".

La diosa Mut no aparece en ningún momento en el ciclo mítico del nacimiento de la reina Hatshepsut. Ante esta diferencia Colin Campbell (1912, pp. 36-37) interpreta que el peso que el artista -o más precisamente de los sacerdotesera mucho mayor que en tiempos de la reina Hatshepsut, y ya para la época de

\footnotetext{
${ }^{237}$ Ella fue representada anteriormente en la escena de la concepción divina.

${ }^{238}$ Durante el Imperio Nuevo, y a medida que la figura de Amón se fortalecía junto al poder de los sacerdotes de Amón, la diosa Mut tomó un rol más predominante dentro del panteón egipcio. Así formó parte de la tríada más popular y extendida en Egipto para dicha época, la de Amón padre, Mut madre y Khonsu hijo. Esto le valió su reconocimiento como diosa "madre" (Hornung 1999a, pp. 202 y 256).
} 
creación de las escenas en Luxor el faraón Amenofis III ya había construido un templo en Karnak, y que Mut junto a Hathor ayudaban a enaltecer la grandeza de Amón-Ra.

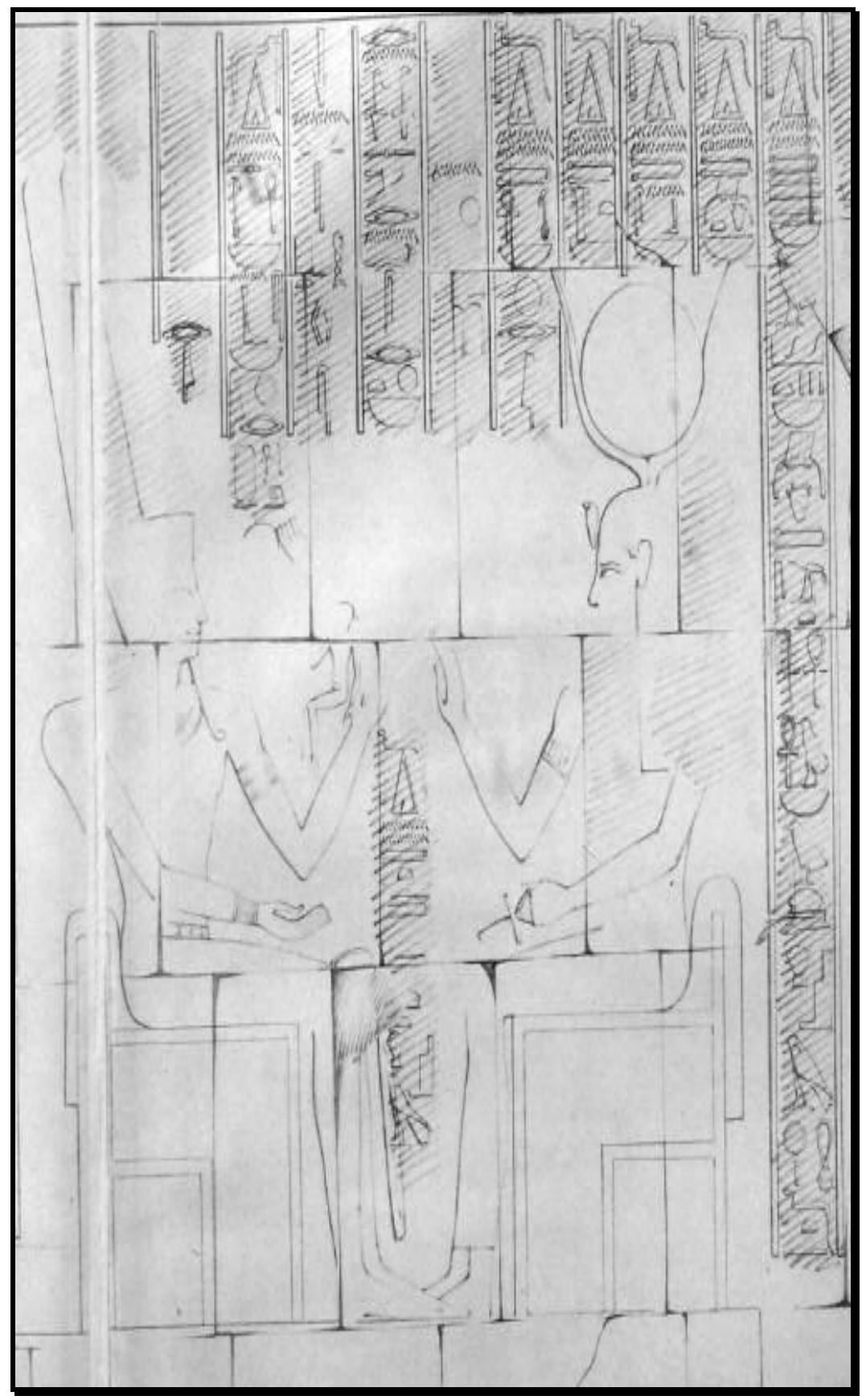

IMAGEN VII. Escena XI: el niño y su ka ante su padre Amón-Ra y la diosa Hathor (Naville 1896, plt. LII) 
Escena XII239: amamantamiento y crianza del futuro rey.

En esta escena también se encuentran significativos paralelismos entre los relatos míticos de Hatshepsut y Amenofis III $^{240}$. La narración se enfoca en el amamantamiento y el cuidado del recién nacido. Como mencionamos con anterioridad en los relatos del papiro Westcar no hay una descripción del desarrollo y crecimiento de los niños. Sí sabemos gracias a la predicción de Djedi, que ellos efectivamente crecerán y podrán hacerse cargo del Estado egipcio. Los dioses que participan en su parto dejan escondido en un saco de cebada un buen augurio para ellos: "Estos procedieron a marcharse al lugar de dónde habian venido, e Isis les dijo a los dioses: ¿Qué es esto que hemos venido para no bacer ninguna maravilla para aquellos niños según podamos informarle a su padre quién nos ha enviado?' Entonces ellos crearon tres coronas de señor, v.p.s. y las colocaron en la cebada" ( $\not W$. 11.9-13). Las coronas son la clave simbólica para lo que sigue en el relato: la coronación del rey. En las teogamias del Reino Nuevo es la segunda parte ritualizada del mito. En los relatos del papiro Westcar se deja abierta la posibilidad que ellos estuvieron narrados, o al menos que la coronación se concretará. Si hay coronación, hubo crecimiento y desarrollo de los trillizos.

En los templos de Deir el-Bahari y Luxor la imagen se divide en dos recuadros, sólo se cambia el sentido de lectura como hasta ahora venimos describiendo. En Deir el-Bahari el izquierdo, mucho más grande, se encuentra subdividido en tres registros, mientras que en Luxor es al revés. En el margen izquierdo superior en Deir el-Bahari, y derecho en Luxor, cuatro figuras están sentadas en un asiento largo con cabeza de león en sus dos extremos y patas de garras del mismo animal. La reina está en cuchillas mirando hacia el otro extremo de la escena. Sentada junto a la reina se encuentra una figura femenina que la atiende y acaricia su cabello. La reina lleva puesta la peluca denominada "modius" (Naville 1896, p. 17), que consiste en un cilindro para colocar el disco solar o los cuernos de vaca. Según Colin Campbell (1912, pp. 38-39) en el templo de Luxor quien

${ }^{239}$ En la exégesis que Colin Campbell (1912, pp. 36-38) realiza para el ciclo mítico del nacimiento divino de Amenofis III cuenta dos escenas con el número once. La primera escena once es la que aquí indicamos con el mismo número, y la que numeramos como XII, es la que el autor apunta como XI aclarando su posición, fila superior de la esquina izquierda.

${ }^{240}$ La escena XII es examinada por Colin Campbell (1912, pp. 38-40) quien la denomina "The Nursing of the Children" ["La crianza de los niños"]. Es también analizada por Naville (1896, pp. 17-18 y plt. LIII); Brunner (1964, pp. 122-134 y cuadro 12) y Gaballa (1976, p. 56). 
acompaña a la reina es una figura femenina de quien no se especifica su nombre. Gaballa (1976, p. 56) interpreta que la figura femenina es una diosa sin poder especificar cuál.

Enfrentadas a la reina y la figura femenina dos diosas Hathor, con cuerpo humano y cabeza de vaca con el disco solar entre los cuernos sobre sus cabezas, le dan el pecho al recién nacido y su ka.

En el registro inferior la diosa Hathor está personificada como vaca. La diosa en el templo de Luxor está amamantando los dos mismos cuerpos (Gaballa 1976, p. 56). En el templo de Deir el-Bahari si bien la imagen es borrosa no pareciera que el recién nacido esté representado.

En el otro recuadro de la representación, arrodillados en fila se representa una secuencia de dioses. Estos dioses le brindan cuidado y alimentación al hijo del dios. En el mito del nacimiento divino de Hatshepsut son cuatro dioses que intercaladamente unos llevan el signo del hmst y otros el del ka; estos últimos llevan una barba falsa. En el templo de Luxor son un grupo de nueve dioses, tres por cada registro, y sostienen sobre sus cabezas el hmst y el signo hbi, todos con barba falsa ${ }^{241}$. Por un lado, el hmst y el ka se conectarían con el sustento y las buenas cualidades, dignidad y funciones de los alimentos. Por el otro, el uso del $h b$ se referiría a la comida y los diversos productos que provee la naturaleza, particularmente la carne de vaca y de pescado (Gaballa 1976, p. 56). Esta interpretación no parece errónea si la comprendemos en el contexto de toda la representación. El hijo del dios está siendo alimentado por estas figuras divinas, y a medida que se desciende verticalmente por los registros se observa que el tamaño de niño se va acrecentando. Es decir, lo que la escena muestra es su desarrollo y cada representación es una etapa de su crecimiento. El niño sobre la falda de los dioses en el templo de Deir el-Bahari lleva sus manos al costado del cuerpo. En el ciclo mítico del nacimiento de Amenofis III, uno de los dedos de su mano se lo lleva hacia la boca, quizá la representación egipcia más clásica que se conoce de un niño.

\footnotetext{
${ }^{241}$ Señala Gaballa (1976, p. 56) que hasta el momento no se conoce con certeza el significado de estos símbolos, lo que significaron para los antiguos egipcios, pero quizá los signos se encuentren relacionados con Textos de las Pirámides.
} 
Esta escena es la descripción de la presentación del hijo del dios ante la Enéada de Karnak, la misma que el dios Amón-Ra había convocado al inicio del relato (Deir el-Bahari, escena I y II) ${ }^{242}$. Esta vez el dios llama a la Enéada con el objetivo que los dioses reconozcan al recién nacido como el futuro rey sobre las Dos Tierras. Gaballa (1976, p. 57) interpreta que las escenas son iguales en los dos templos, aunque nosotros observamos algunas diferencias que son interesantes.

En el templo de la reina Hatshepsut hay dos personajes, uno que está detrás con sus palmas hacia arriba, y el otro que sostiene al futuro faraón y su ka presentándoselo a tres divinidades. Las mismas están representadas verticalmente, y sus nombres se han perdido. Estas tres divinidades no están representadas en el templo de Luxor.

En el nacimiento de Amenofis III los dos personajes son el dios Hapi y una figura apodada Hekay. Hapi se encuentra a la izquierda, quien sostiene en su mano un puñado de signos $~(n h$, como señal de abundante vida y prosperidad para el futuro rey. A la derecha, Hekay está pintado de azul. Frente a estos dos se encuentra un dios con cabeza de halcón que puede identificarse con Horus, quien sostiene al niño y su ka. El dios Amón-Ra está frente a Horus (Colin Campbell 1912, p. 41). En Deir el-Bahari ese espacio lo ocupaban las tres divinidades.

\section{Escena XIV: Toth/Horus y Amón-Ra sosteniendo al fututo rey y su ka}

Lo que corresponde a la escena XIV es parte de lo que Colin Campbell (1912, pp. 44-45) considera parte de la escena XII²43. En Deir el-Bahari los dioses Horus y Amón-Ra son los personajes centrales de toda la escena. La representación de un dios con cabeza de halcón se lo identifica con Horus a pesar que no está escrito su nombre, quien sostiene al niño y su ka junto al dios Amón-Ra que está

\footnotetext{
${ }^{242}$ La escena es analizada por Colin Campbell (1912, pp. 41-44) denominándola "Third Presentation to Amon-Ra" [“Tercera presentación ante Amón-Ra]”. Es también examinada por Naville (1896, pp. 17-18 y plt. XLIII); Brunner (1964, pp. 135-145 y cuadro 13) y Gaballa (1976, p. 57).

${ }^{243}$ Esta escena es examina por Naville (1896, p.18 y plt. LIV); Brunner (1964, pp. 146-152 y cuadro 14) y Gaballa (1976, p. 57).
} 
frente a él. Contrariamente en el templo de Luxor es Toth quien acompaña al dios Amón-Ra.

\section{Escena XV: Anubis y Khnum junto a los dioses presentando ante Safekhabui al niño}

Esta última escena puede dividirse claramente en dos registros. El margen izquierdo es mencionado por Colin Campbell (1912, p. 44) como escena XIII, y por Naville (1896, p. 18) como la número XV244. Aquí se representan a dos dioses: Anubis y Khnum. En el templo de Deir el-Bahari Anubis acarrea un gran disco. En el templo de Luxor el dios solamente lleva un cetro ${ }^{245}$. Frente a él el dios Khnum, que en ambos templos se encuentra en la misma posición, sostiene un cetro.

La segunda parte de la escena, en el margen derecho, se subdivide en dos registros horizontales. En el templo funerario de Hatshepsut dos nodrizas sostienen al niño y su ka, mientras que un personaje masculino los alaba. Debajo en el registro paralelo dos figuras sostienen a un niño ya crecido y su ka, y están siendo recibidos por una figura femenina que lleva una cesta. Todos ellos están frente a la diosa Safekhabui y una figura masculina que está detrás de ella, ambos representados ocupando el espacio de los dos registros horizontales.

En el templo de Luxor la escena se divide del mismo modo y predomina la figura de la diosa Safekhabui. La sigue una figura masculina, quien sostiene una varilla similar de la que está representada en la escena XI y de la cual no puede leerse el nombre.

\footnotetext{
${ }^{244}$ Esta escena es analizada por Colin Campbell (1912, pp. 44-48) quien la denomina "Anubis and Khnum, with Goddesses, presenting the Child to Sefekh-abu" ["Anubis y Khnum, con las diosas, presentan al niño a Safekhabui']. Es también examinada por Naville (p. 18 y plt. LV); Brunner (1964, pp. 153-166 y cuadro 15) y Gaballa (1976, p. 57).

${ }^{245}$ En los templos ptolemaicos también Anubis rueda el disco, que según Naville (1896, p. 18) se asocia con la luna, según la mención que aparece en Denderah.
} 


\begin{tabular}{|c|c|c|}
\hline Escena & $\begin{array}{l}\text { Hatshepsut: Templo de Deir el- } \\
\text { Bahari }\end{array}$ & $\begin{array}{l}\text { Userkaf, Sahura, Neferikara Kakai: } \\
\text { dos últimos relatos del papiro } \\
\text { Westcar }\end{array}$ \\
\hline IV & $\begin{array}{l}\text { Palabras de Amón-Ra: “...Ella } \\
\text { desempeñará esta excelente realeza en } \\
\text { esta tierra toda entera...”(Serrano } \\
\text { Delgado 1993, p. 141) }\end{array}$ & $\begin{array}{l}\text { “...Ra ha dicho de ellos que realizarán } \\
\text { esta función excelente sobre todo el } \\
\text { país entero..." ( }(W .9 .10-11)\end{array}$ \\
\hline $\mathbf{V}$ & $\begin{array}{l}\text { Palabras de Khnum: “...Te he dado toda } \\
\text { salud...” (Serrano Delgado 1993, p. 142) }\end{array}$ & 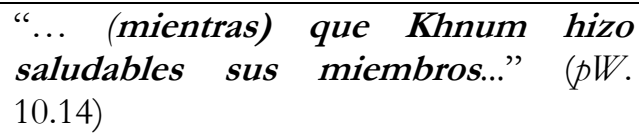 \\
\hline IX & $\begin{array}{l}\text { Palabras de Meshkeneh: “... Estoy detrás } \\
\text { de ti, te protejo como Ra...” (Naville } \\
\text { 1896, p. 17) } \\
\text { Palabras de los dioses: “...Nosotros } \\
\text { hemos venido para asegurar nuestra } \\
\text { protección de vida, estabilidad y } \\
\text { dominio tras ella y su ka, como Ra } \\
\text { eternamente...” (Serrano Delgado 1993, } \\
\text { p. 142) }\end{array}$ & 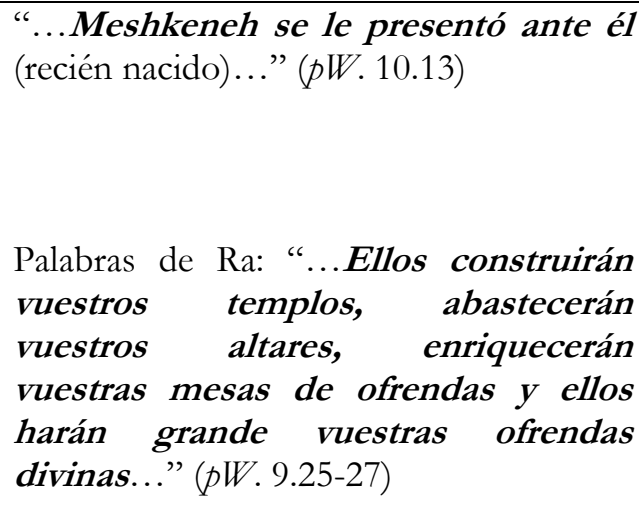 \\
\hline $\mathbf{X}$ & $\begin{array}{l}\text { Palabras de Hathor “...jHija (mía) de } \\
\text { (mi) cuerpo, Maat-Ka-Ra, hija (mía) } \\
\text { de oro fino!...” (Serrano Delgado 1993, p. } \\
\text { 143). }\end{array}$ & $\begin{array}{l}\text { “...un niño de un codo (de largo). Sus } \\
\text { huesos eran fuertes y la cobertura de } \\
\text { sus miembros era de oro y su tocado } \\
\text { de verdadero lapislázuli..." ( }(\mathrm{W} .10 . \\
10-12) \text {. }\end{array}$ \\
\hline XI & $\begin{array}{l}\text { Palabras de Amón-Ra: “...'Viene, viene } \\
\text { en paz, hijo de Ra, de sus (mis) } \\
\text { entrañas, Ra-maat-neb, le da vida" } \\
\text { (Colin Campbell 1912, p. 36). }\end{array}$ & $\begin{array}{l}\text { "...Es la esposa de un sacerdote wab } \\
\text { de Ra, señor de Sakhebu embarazada } \\
\text { de tres hijos de Ra, señor de } \\
\text { Sakhebu..." ( }(W .9 .9-10)\end{array}$ \\
\hline
\end{tabular}

CUADRO IV. Comparación de las narración entre el papiro Westcar y el mito del nacimiento de la reina Hatshepsut 


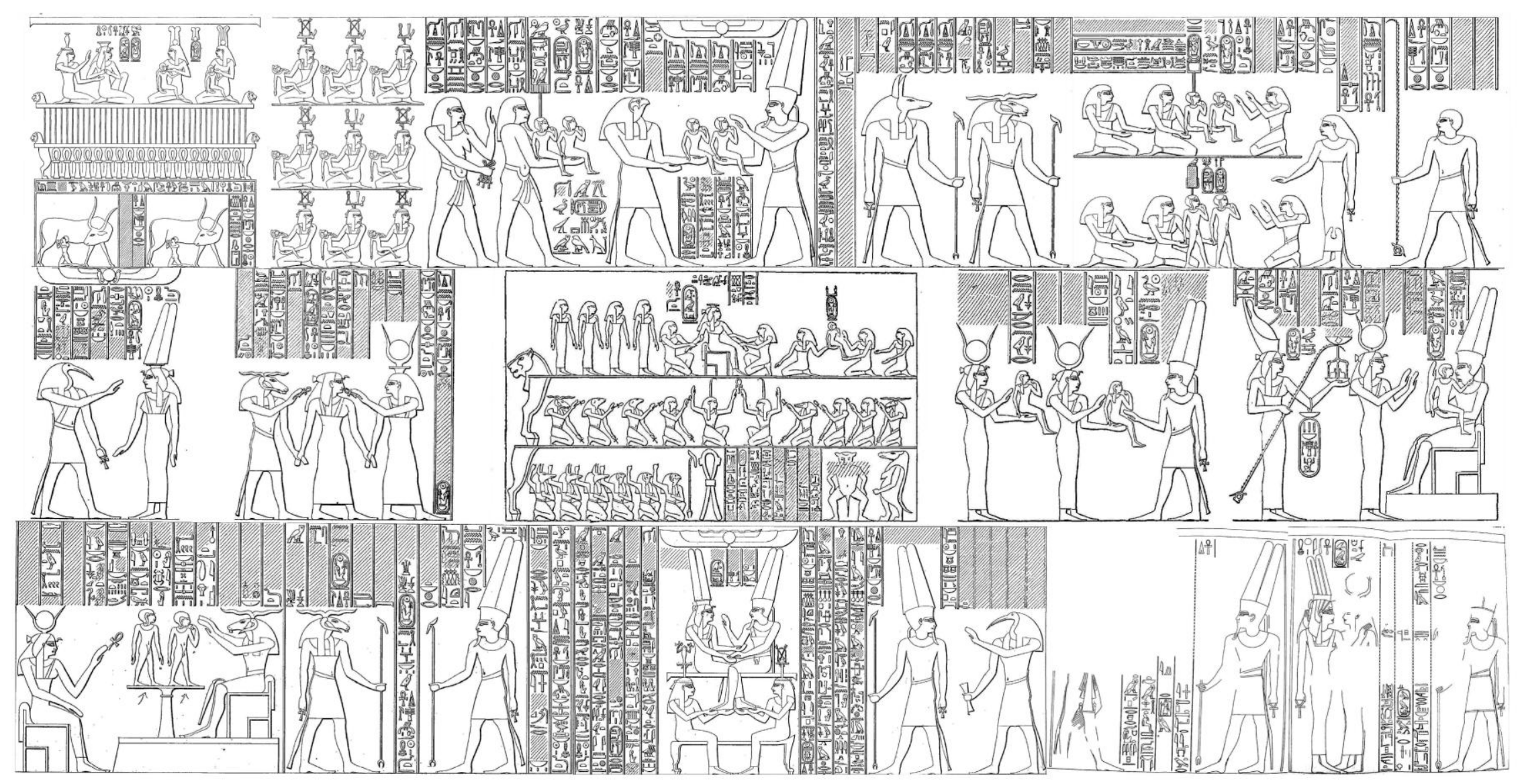

IMAGEN VIII. Reconstrucción completa de las escenas del nacimiento divino de Amenofis III. Las dos primeras escenas fueron tomadas de Brunner (1964, cuadros I y II), las restantes pertenecen a la publicación de Gayet (1894, figs. 192-205) 
Capítulo III

SÍMBOLOS MÍTICOS EN LOS DOS ÚLTIMOS RELATOS DEL PAPIRO WESTCAR 


\section{Simbología mítica}

En los capítulos anteriores hemos comprobado que los dos últimos relatos en el papiro Westcar son un mito de origen, el mito de origen de la dinastía $\mathrm{V}$ y lo hemos realizado a través del análisis de los paralelismos argumentales con las teogamias del Reino Nuevo.

Sin embargo, los rasgos míticos presentes en los dos últimos relatos del papiro Westcar no se limitan a la estructura argumental compartida con dichos ciclos míticos. En las narraciones literarias están presentes una multiplicidad de elementos que nos permiten también afirmar que se trata de un relato míticoliterario.

Baines (1996, pp. 361-362) señala que en los relatos narrativos se evidencian rasgos míticos en dos niveles de representación. Un primer nivel es el argumento, que se asocia con lo que hemos analizado en el capítulo anterior para los relatos del papiro Westcar. Con los ciclos míticos de origen del faraón del Reino Nuevo se distinguen analogías y diferencias argumentales, pero el núcleo básico (principalmente el relato del nacimiento) permanece entre ellos. Es decir, entre cada uno de los relatos del mito del nacimiento divino del rey los personajes que participan son casi los mismos, llevando a cabo roles similares, desarrollándose argumentos análogos. Por ejemplo, hemos analizado las similitudes que se establecen alrededor del dios Ra y Amón-Ra, o la diosa Meshkeneh. De este modo se recrea un modo similar de narrar el mito de origen del rey.

Un segundo nivel que distingue Baines (1996, pp. 362 y ss.) es el del signo o símbolo mítico presente en los relatos literarios. Con ello el autor refiere a la mención de pasajes narrativos, datos o figuras míticas que representan elementos que se relacionan a expresiones que son propias de espacios míticos-religiosos. Por ejemplo, Baines (1996, p. 363) destaca que en el relato mítico del Reino Nuevo sobre Horus y Seth, la presencia del dios Sobek es evocado en el relato como un estatus del mito. Ello porque su mención no constituye en sí misma un mito. Desde esta perspectiva de análisis, no propone el autor ningún ejemplo para los relatos del papiro Westcar. 
En el presente capítulo nos proponemos estudiar este nivel de la representación mítica en los dos últimos relatos del papiro Westcar. Estos rasgos no encajan necesariamente en la estructura argumental de los mitos de origen del faraón, pero ponen en evidencia el entrecruzamiento entre mito y literatura. Al mismo tiempo, enfatizan los rasgos que hacen de los recién nacidos seres divinos. Con ello no pretendemos contemplar toda la simbología mítica, pues excede el presente trabajo. A partir de los ejemplos que estudiamos queda establecida una metodología de trabajo que se puede hacerse extensible a otros textos literarios. Los ejemplos que aquí examinamos refieren a la fecha de nacimiento de los trillizos, la mención de la metáfora de los bancos de arena, las características físicas de los recién nacidos y la simbología alrededor de la diosa Meshkeneh.

Por lo tanto, en los relatos literarios las huellas de lo mítico son múltiples. Algunas veces se relacionan con estructuras narrativas de otros mitos, y otras priman los signos míticos. Pero en todos los casos se pone en juego la poliocularidad de la visión egipcia. Se destaca la multiplicidad de discursos que conforman el relato literario egipcio.

\section{Día de nacimiento de los trillizos}

En los dos últimos relatos del papiro Westcar se narra el plan divino de dar origen a una nueva dinastía, la dinastía V. Según los pronósticos de Djedi la nueva dinastía reinará cuando el nieto del rey Keops finalice su reinado (Goedicke 1993, pp. 24 y ss.). En el relato hay una gran preocupación por parte del faraón Keops en conocer quién es la madre de los futuros reyes de Egipto. Esta inquietud será la que desencadene la mención del día en que los trillizos nacerán. Esta ansiedad demostrada por el faraón Keops ha sido interpretada por Goedicke (1993, p. 30) como muestra de que la verdadera intención y ambición del rey era la de interrumpir lo que Ra ha designado: el nacimiento de los trillizos que marcarían el inicio de una nueva casa dinástica gobernando Egipto, en detrimento de la suya. De todos modos, no podemos inferir del texto tal presunción, pues no parece ser lo central del relato 
la personalidad de Keops y sus intenciones políticas, sino que el mensaje de los relatos del papiro Westcar es el nacimiento exitoso de una nueva dinastía ${ }^{246}$.

Como lo pronostica Djedi, "Ella dará a luz el día 15 del primer mes de la estación prt” ( $(W W .9 .15)$. Es interesante que un dato de estas características, tan preciso en un relato literario, no haya generado mayores discusiones e interpretaciones, e incluso se haya pasado por alto. Autores como Brunner-Traut (2000 [1963]); Lichtheim (1973); Simpson (LAE); Lefebvre (2003 [1982]); Parkinson (1998); Araújo (2000), López (2005) y Tyldesley (2011), quienes han traducido y analizado los relatos del papiro Westcar no realizan ningún comentario al respecto.

Por su parte, Goedicke (1993, p. 30) reconoce su incapacidad de poder vislumbrar el significado con relación al "día 15 del primer mes de la estación de prt". Principalmente porque los calendarios egipcios no fijan ningún evento de relevancia para esa fecha. Si consideramos los cálculos que los investigadores realizaron para determinar a que fecha correspondió el día 15 de la primera estación de prt, no existe ninguna relación con algún episodio. Además, sería muy discutible en qué año fijaríamos el nacimiento, durante algún momento de la dinastía XII cuando suponemos que se escribieron los relatos del papiro Westcar o en alguna fecha cercana al comienzo del reinado de Userkaf, entre otras posibilidades.

La datación del tiempo vinculada a la observación de la bóveda celeste, el conocimiento sobre el movimiento de los astros y la naturaleza era en el antiguo Egipto principalmente una función religiosa (Lull 2006, pp. 13 y ss.). Los sacerdotes fueron los encargados de estudiar los movimientos de las estrellas y las constelaciones. A partir de esta observación se fijaba el calendario que permitía mantener el orden de las cosas, orden que el faraón estaba obligado a garantizar ${ }^{247}$.

\footnotetext{
246 Se han realizado algunas interpretaciones acerca de la postura y caracterización de Keops a través de los relatos del papiro Westcar. En este sentido se ha interpretado que se transmite una imagen negativa del faraón, destacándose su aspecto más tiránico. La caracterización de Keops como un rey sin piedad es una idea que nos ha llegado desde Heródoto. Al respecto véase (Posener 1956, p. 16 y Salem 2008). Serrano Delgado (1992b) interpreta que relatos como los del papiro Westcar son un antecedente de la imagen que prima en textos del Primer Periodo Intermedio, aquella que coloca a los faraones como responsables del vaciamiento del país que genera una gran crisis.

247 Además, estos conocimientos eran utilizados para la construcción de los edificios sagrados y cultuales. Los egipcios orientaron astronómicamente sus monumentos (Belmonte Avilés 2000, p. 127).
} 
Entre los funcionarios egipcios el astrónomo egipcio era un sacerdote. Esto ha hecho suponer que esta tarea suprema era designada al máximo sacerdote del templo de Heliópolis, el Grande de los Videntes. Recordemos que este título aparece mencionado en el cuarto relato del papiro Westcar. Allí, el primero de los niños en nacer cumplirá este cargo en el templo de Ra, señor de Sakhebu, en el templo de Heliópolis: “... y el mayor de ellos será Grande de los Videntes en Heliópolis...” $(\phi W .9 .11-12)$. Es probable que en esta figura sacerdotal se escondiera un astrónomo (Lull 2006, pp. 53-54).

Los egipcios ordenaron el tiempo basándose en sus necesidades agrícolas, religiosas, sociales y administrativas, y de todo ello derivó en la formación de calendarios (Lull 2006, p. 65) 248 . Uno de ellos fue el calendario lunar basado en la observación de los movimientos uniformes que los astros tienen en la bóveda celeste, midiéndose de este modo el tiempo por unidades cíclicas. Los egipcios utilizaron la observación de la primera invisibilidad de la luna menguante antes del amanecer para organizar el calendario lunar, estructurado en 354 días y treinta meses (Lull 2006, pp. 83-91).

Los egipcios también contaron con un calendario civil. En él se dividió el año en tres estaciones de cuatro meses de treinta días cada uno, contabilizándose 360 días. A ello se le sumaban cinco días que formaban un "mes chico", los que se denominaron como días epagómenos. Para el calendario civil egipcio un año tenía un total de 365 días (Lull 2006, pp. 66-67).

Dividieron su calendario civil en tres estaciones, cada una de ellas recibió un nombre. La primera estación que marcaba el inicio del año egipcio fue 3ht, y correspondía a la primavera, momento del año en que la corriente del Nilo

\footnotetext{
248 Belmonte Avilés (2000, pp. 119-120) considera que fue la observación de dos fenómenos lo que llevó a la formación del calendario egipcio. Por un lado, si se miden las crecidas sucesivas del río Nilo en un lapso de 25 años, se obtendrá como resultado que el promedio entre dos crecidas es un total de 365 días, lo que equivale a la duración de un año. Pero, la crecida del Nilo no es una pauta última para la fijación de un calendario ya que esta no se repite igual año tras año, algunas crecidas tardan en repetirse 420 días, y otras sólo tardan 330 (también en Lull 2006, p. 74). Por lo cual, el segundo elemento que los egipcios tomaron en cuenta para la elaboración del calendario fue el orto helíaco de una estrella, que al provocarse un día preciso permite medir el paso del tiempo y de las estaciones. Los egipcios se guiaron por la ascensión helíaca de Sirio, que hace unos cinco mil años ocurría en fechas cercanas al solsticio de verano, por lo que era casi coincidente con la crecida del Nilo.
} 
desbordaba las orillas, inundando el territorio fértil entre agosto y septiembre, y luego retrocedía entre octubre y noviembre.

La segunda estación era prt. Era el momento propicio para la siembra, las condiciones estaban dadas para la germinación de la vegetación. Esto ocurría entre noviembre y enero, mientras que de febrero a marzo el moderado sol del invierno permitía la maduración de los cultivos.

La tercera estación, šmw, correspondía al verano. En marzo y abril cosechaban los cultivos, la tierra quedaba expuesta al fuerte sol y calor. Entre mayo y junio se agrietaba y se secaba, lo que facilitaba su aireación (Kemp 2004, p. 19; Lull 2006, p. 90).

Se conoce que los egipcios no calibraron su calendario en ningún momento, por lo que con el pasar de los años y los siglos se produjo un corrimiento entre el calendario civil y los fenómenos naturales que lo fijaron desde un inicio, como la inundación del Nilo ${ }^{249}$. Los investigadores tomaron como pauta para lograr acercarse a una datación absoluta el movimiento de las estrellas en la cúpula celeste. El orto helíaco de Sirio se constituyó en una pauta para determinar dataciones, gracias a que los egipcios conocían bien el movimiento de esta estrella, y dejaron constancia en diferentes documentos y monumentos, fechas de su primera visualización ${ }^{250}$.

\footnotetext{
${ }^{249} \mathrm{El}$ inconveniente era que al calendario egipcio le faltaba un cuarto de día a cada año, ya que cada año equivalía a 365, 25 días que es lo que tarda el sol en dar toda la vuelta al planeta Tierra. De este modo el año civil se iba retrasando, coincidiendo la inundación con el orto helíaco de Sirio una vez cada 1.460 años (Avdiev 1986, p. 30; Parra Ortiz 2003, p. 277). Al respeto Belmonte Avilés (2000, p. 122) descree que los egipcios no hubiesen notado esta distorsión, sino lo que primó en ellos fue su mentalidad conservadora y respetuosa de las tradiciones.

250 Por ejemplo, Belmonte Avilés (2000, pp. 121-122) considera hace aproximadamente 5.000 años el orto helíaco de Sirio ocurría en fechas cercanas a el primer día de la estación de prt coincidiendo con el solsticio de verano (junio en el hemisferio norte). Al mismo tiempo se inicia la inundación del río Nilo, y se da apertura al periodo de la siembra. A partir del orto helíaco de Sirio obtenemos otras fechas cercanas al día 15 del primer mes de la estación de prt. El templo de Abu Simbel parece estar orientado en dirección de la salida del sol, que coincidiría con la celebración de los 30 años de reinado del faraón Ramsés II, el primer día del primer mes de la estación de prt. En fechas próximas al año 1260 a.C. correspondería al 18 de octubre (Belmonte Avilés 2000, p. 128). Lull (2006, p. 161) no destaca ninguna singularidad para esta fecha según una tabla a de conversión entre el calendario civil egipcio con el calendario juliano y gregoriano (este último es el que está vigente en la actualidad).
} 
La fijación de una fecha exacta en algún año " $\mathrm{x}$ " vacía de contenido simbólico "el día 15 del primer mes de prt", momento en que nacen los trillizos en el relato literario. Pensamos que la interpretación acerca de esta fecha hay que buscarla en otro lado. Desde esta perspectiva, se desvirtúa el sentido mítico de "el día 15 del primer mes de prt" ( $p W$. 9.15). Se produce una contradicción en el mensaje simbólico que el relato transmite. Si esta fecha coincide con el momento que las aguas del río desbordan, lejos estaríamos de comprender la metáfora de los bancos de arena, fenómeno que se produce en el momento opuesto, cuando el Nilo no logra todo su caudal y deja al descubierto porciones de tierra.

"El día 15 de la primera estación de prt" ( $(W .9 .15)$ lo asociamos a la llegada del invierno en el hemisferio norte, que corresponde al fenómeno astronómico del solsticio de diciembre. En Egipto, el solsticio de invierno era el momento en el cual el sol alcanza su máxima declinación norte y sur, por lo que las noches se hacen más largas y los días más cortos. Simbólicamente esta fecha coincidía con una de las apariciones más importantes del dios $\mathrm{Ra}$, su nacimiento anual. Este acontecimiento debería producirse hacia el 21 de enero en el calendario lunar egipcio, lo que sería entre el 20 y el 23 de diciembre en nuestro calendario (Wells 1992) ${ }^{251}$.

El solsticio de invierno era un acontecimiento importante para los egipcios, y para todo el Cercano Oriente antiguo. Era considerado un tiempo de nacimiento y renovación anual. En el pensamiento mítico egipcio se pensaba que el dios $\mathrm{Ra}$ entraba diaria y anualmente por el 0este para renacer en el Más Allá, logrando atravesarlo. Así, el dios Ra renacía en la diosa Nut, es decir que renacía en el cielo. Esta relación divina entre el dios Ra (o Amón-Ra) fue expresada por ejemplo en el Texto de las Pirámides PT 479 (Allen 2005, p. 280): “Ob Ra, fecunda el cuerpo de Nut con la semilla de ese espiritu que ha de estar en ella"252.

En el cuerpo de la diosa celeste Nut se dibujaban todas las estrellas (Belmonte Avilés 2000, p. 110). Ella engendra al dios Sol al mismo tiempo que el

\footnotetext{
${ }^{251}$ En el calendario lunar el último mes de la estación de $\breve{m} w w$ es $m s w t r^{\ulcorner}$que significa "nacimiento de Ra”, lo que Lull (2006, pp. 90-91) ha como el momento en que termina el año y se da inicio a uno nuevo, que se transfirió luego al calendario civil egipcio.

${ }^{252} \mathrm{La}$ traducción es nuestra. Este texto corresponde a la antigua nomenclatura $\$ 990 \mathrm{a}$. Se encuentra en P 330, M 274 y N 29 según la clasificación de Allen (2005, p. 406). Una crítica a la traducción propuesto por Allen en Shmakov (2012, p. 26).
} 
dios la atraviesa, es decir, también la engendra a ella para desencadenar su propio nacimiento. Los sentidos míticos-simbólicos formados a partir de esta premisa son complejos, pero no contradictorios. Nut como diosa madre es la madre de Osiris el dios muerto. Mientras que a Hathor se la vincula con mayor frecuencia al faraón vivo, es decir a Horus. Como lo sugiere Frankfort (1998b [1948], p. 197) esta no es una premisa única e invariable, pues el dios $\mathrm{Ra}$, al igual que el faraón busca introducirse en la diosa. Ra a través de ella se une al circuito cósmico del renacer diario y anual, lo que implica lograr el camino hacia la inmortalidad.

Siguiendo estos sentidos míticos-simbólicos Wells (1992, pp. 305-321) sostiene que la diosa Nut se originó como una forma antropomórfica de la Vía Láctea. Según el autor, la posición particular en que se representó este grupo de estrellas en el cielo antes del amanecer en la mañana del solsticio de invierno, fue lo que dio origen al mito del nacimiento del Sol. En las tumbas tebanas se observa a Ra ingresar por la boca de Nut al atardecer y salir a la mañana siguiente por el canal de parto de la diosa. Esto está directamente relacionado con el amanecer diario y anual del dios Ra.

En las representaciones tebanas de la diosa Nut ella adquiere forma de arco y el dios se introduce en ella al anochecer, traspasando su cuerpo durante la noche y naciendo de ella al amanecer. Consideramos que los niños del papiro Westcar atraviesan el mismo ciclo que su padre Ra. Es el plan divino creado con el fin de formar una nueva dinastía (Goedicke 1993, pp. 25 y ss.). El nacimiento se simboliza en el mito. Los trillizos nacen el mismo día que su padre Ra lo hace anualmente, ellos representan una nueva dinastía y con ella traen lo nuevo a Egipto. No solamente serán faraones, ellos se homologan a su padre el dios Ra. Los trillizos al igual que el dios Sol logran sortear las dificultades que se les imponen en el camino, la esencia divina se los permite.

\section{Bancos de arena}

El momento del nacimiento de los trillizos coincide con el estiaje de las aguas del canal que conduce a la residencia donde Reddjedet dará a luz. El faraón Keops, luego de la respuesta de Djedi acerca de qué día nacerán los trillizos, acota: “Es 
cuando los bancos de arena del canal de los Dos Peces quedan al descubierto" ( $p W$. 9. 16$)^{253}$.

Con relación a la ubicación geográfica del canal de los Dos Peces poco puede decirse. No hay fuentes que atestigüen en qué lugar de Egipto se encontraba. Lefebvre sugiere (2003 [1982], p. 104) que atravesaba el nomo II del Bajo Egipto, posiblemente confundiéndose con el brazo Canópico del Nilo. Sin embargo, es mucho más lo que puede analizarse con relación a los símbolos que se expresan en la idea que los bancos de arena impedirán llegar a la residencia en la cual Reddjedet dará a luz a sus hijos.

Durante el Primer Periodo Intermedio los magnates provinciales utilizaron una diversidad de expresiones para dar cuenta de la situación política y económica que se estaba atravesando en Egipto, y que plasmaron en textos autobiográficos. A través de ellos se describe como los magnates locales cubrían las necesidades de la población, ante un Estado monárquico que no respondía por ellas. En la mayoría de estos textos prima la caracterización de un mundo sombrío, se vive una nueva situación política en la cual los nomarcas provinciales crean nuevos tópicos de expresividad que les permiten crear argumentos para la legitimación de su poder (Assmann 2005 [1996], p. 119). Por ejemplo, son recurrentes las ideas cómo “di pan al hambriento, vestido al desnudo", "di sepultura al que no tenía bijo", "construí un bote para el que no lo tenía", "rescaté al débil de la mano del que era más fuerte que ép", entre otras (Daneri de Rodrigo 1992, p. 49).

Es durante el Primer Periodo Intermedio que se gesta una tradición de inscripciones y biografías idealizadas que luego aparecerán reflejadas en textos literarios del Reino Medio como Admoniciones de Ipuwer y Profecía de Neferty (Morenz 2004, p. 201; Assmann 2005 [1996], p. 126). En estos textos literarios reaparece el mensaje del orden versus caos que caracterizó a las autobiografías.

En las autobiografías se crea una situación de aparente descontrol, en la que los únicos que tenían la posibilidad de lograr y garantizar la vuelta al orden eran los magnates locales. Ellos eran quiénes podían aprovisionar de alimentos a la sociedad y sanar las injusticias. En estos nuevos discursos construidos por los nomarcas regionales, se recurren a metáforas que aluden a la sequía como una situación

${ }^{253}$ El subrayado es nuestro. 
constante en Egipto, que impide un desarrollo óptimo de la agricultura, que pone en peligro la obtención de las materias primas necesarias para la vida.

Por ejemplo, los textos del Primer Periodo Intermedio aluden con frecuencia a las ideas de "aguas bajas" (mw nds) y de "bancos de arena" (tsw) que expresan el estiaje de las aguas y muestran las dificultades geo-climáticas que Egipto está padeciendo. Esta situación es parte fundamental de las disputas políticas que desembocaron en la descentralización del poder estatal durante el Primer Periodo Intermedio (Serrano Delgado 1992a) 254. Metáforas como la de los bancos de arena fueron, para Assmann (2005 [1996], p. 127), utilizadas durante dicho periodo, por ejemplo, la de la escasez ya era conocida.

Es en la tumba de Antifi, un nomarca del nomo de Hieracómpolis durante la dinastía IX, donde se encuentra una larga inscripción que se adecua claramente a estos parámetros. En la inscripción de Antifi puede leerse: "Mantuve a Mo'alla y a [Hor-mer] cuando el cielo estaba nublado y la tierra azotada por la tempestad; [todo el mundo moría] de hambre sobre este banco de arena de Apopis" (Assmann 2005 [1996], p. 126) 255 . En ella aparece la primera referencia de los bancos de arena que hasta el momento hemos podido rastrear. Está asociada con la figura del dios Apofis (Morenz 2004, p. 201), como luego aparecerá en otras referencias míticas, por ejemplo en Textos de los Sarcófagos ${ }^{256}$ y en Libro del Amduat257. Según Assmann (2005 [1996], p. 127) la asociación que se realiza con Apofis hace que las desgracias por las que atraviesa el nomo egipcio durante el Primer Periodo Intermedio adquieran una dimensión cósmica. Es con el dios Apofis y los bancos de arena que se está haciendo referencia al viaje del dios Sol en su barca durante la noche.

La figura de Apofis pareciera ser originaria de la cultura popular más o menos extendida durante el Reino Antiguo, pero se desconoce su mención en las imágenes o escritos durante el Reino Antiguo (Morenz 2004, p. 201). Es en Textos de los Sarcófagos que Apofis - descripto como una serpiente de agua- es mencionado frecuentemente como enemigo de la barca del dios Ra y los difuntos. Por ejemplo,

\footnotetext{
${ }^{254}$ Volveremos sobre este tema en el capítulo IV.

255 El subrayado es nuestro.

${ }^{256}$ Se sugiere ver la publicación de Textos de los Sarcófagos en Faulkner (1994).

${ }^{257}$ Se sugieren ver las publicaciones sobre Libro del Amduat en Piankoff (1954); Reeves y Wilkinson (1966); Porter y Moss (1991); Hornung (1999b; 2007).
} 
en el conjuro 414 de Textos de los Sarcófagos puede leerse que la barca sagrada del dios $\mathrm{Ra}$ que recorre las horas nocturnas, es atacada por la serpiente Apofis (Faulkner 1994, p. 65). Ésta será una de las características recurrentes en el rol mitológico con el cual se representó a la serpiente Apofis, la de obstaculizadora del tránsito de la barca de Ra durante la noche, con el objetivo de impedir que la barca llegara a destino, y se cumpla el ciclo (Morenz 2004, p. 203)

En el cuarto relato del papiro Westcar se menciona a los bancos de arena, aquellos mismos bancos sobre los cuales la serpiente se posa y traga las aguas dejando al descubierto las tierras, impidiendo la navegación. Esta imagen mítica fue representada por los egipcios durante el Reino Nuevo en el conjunto de textos e imágenes conocido como Libro del Amduat. En el segundo registro de la séptima hora, Apofis -en forma de serpiente- se posa sobre su banco de arena frente a la barca de $\mathrm{Ra}$ intentando imposibilitar su avance en el curso de las doce horas de la noche (Piankoff 1954, p. 281; Hornung 1999b, p. 38). El texto que acompaña la imagen de la serpiente describe a la figura de Apofis y su banco de arena como una "borrible de cara" de cuatrocientos codos de longitud (Piankoff 1954, p. 281; Hornung 2007, p. 230) 258 .

Por otro lado, en el tercer registro de la séptima hora representada en las paredes de la tumba de Tutmosis III, en el margen derecho cerrando la escena, se encuentra representado el cocodrilo Sokar reposando sobre un banco de arena, saliendo del montículo de arena una cabeza humana. Es "la cabeza de Osiris". El texto de esta escena suele referir al "ojo de Osiris", los miembros del cuerpo del dios Osiris fueron rescatados del agua y ahora son custodiados por el cocodrilo (Piankoff 1954, pp. 283-284; Hornung 2007, p. 291).

Hemos mencionado dos imágenes míticas que se relacionan con los bancos de arena. Una, la serpiente Apofis que bebe las aguas dejando al descubierto los bancos de arena que impiden la navegación. La otra, el cocodrilo Sokar reposa sobre los bancos de arena esperando tragarse al enemigo. Ambos dioses buscan impedir que el ciclo de Ra se cumpla exitosamente.

\footnotetext{
${ }^{258}$ Consideraciones generales sobre la séptima hora del Libro del Amduat se encuentran en Hornung (2007). La séptima hora ha sido representada en KV 9 de Ramsés IV, siendo la tumba publicada y analizada detalladamente por Piankoff (1954). También en KV 34 de Tutmosis III y KV 35 de Amenofis II publicadas por Bucher (1932).
} 
Esta interpretación se asocia al sentido mítico que los bancos de arena pudieron representar en el cuarto relato del papiro Westcar. Los bancos de arena que se forman en el canal de los Dos Peces también impedirán que cualquier barca pueda dirigirse a la residencia en la cual Reddjedet dará a luz a los futuros monarcas egipcios. Los bancos de arena en el relato del papiro Westcar adquieren el mismo sentido mítico y cósmico que se expresa en otros espacios como Textos de los Sarcófagos o Libro del Amduat.

En todos los casos mencionados se representa la misma idea mítica del renacer: la perturbación del orden que es seguida finalmente por el nuevo nacimiento, en el caso de los relatos del papiro Westcar, el nacimiento de los hijos de Ra, el nacimiento mítico de la dinastía V. Consideramos que la mención de los bancos de arena es un elemento más para pensar que el texto literario del papiro Westcar responde a un decir mítico.

Interpretamos que los bancos de arena en el cuarto relato del papiro Westcar podrían llegar a impedir que se concrete el plan divino de Ra. Ante algún inconveniente en el parto por agua no arribaría ningún barco a la residencia donde se encuentra Reddjedet. De todos modos, Djedi interviene en el relato para garantizar una óptima navegabilidad. El sabio hará que haya "allí cuatro codos de agua sobre los bancos de arena del canal de los Dos Peces" ( $\not W .9 .17-18)$. Según Goedicke (1993, p. 30) las palabras de Djedi deben ser interpretadas como un deseo o intención y no como una promesa que garantice aguas altas en el canal de los Dos Peces. Si bien sólo puede ser una promesa de Djedi, si tenemos en cuenta el relato anexo sabemos que literariamente el nacimiento de los trillizos se concreta.

En el anexo al cuarto relato del papiro Westcar Ra interviene en la situación. El dios envía a los dioses para que ellos asistan el parto de Reddjedet. Al igual que Ra logra sortear con éxito todos los impedimentos que se le presentan a diario para completar su ciclo, sus tres hijos también lograrán superar los obstáculos que se le imponen a su nacimiento. Quien los ayuda a lograrlo es Djedi con su magia, y su padre el dios Sol. 


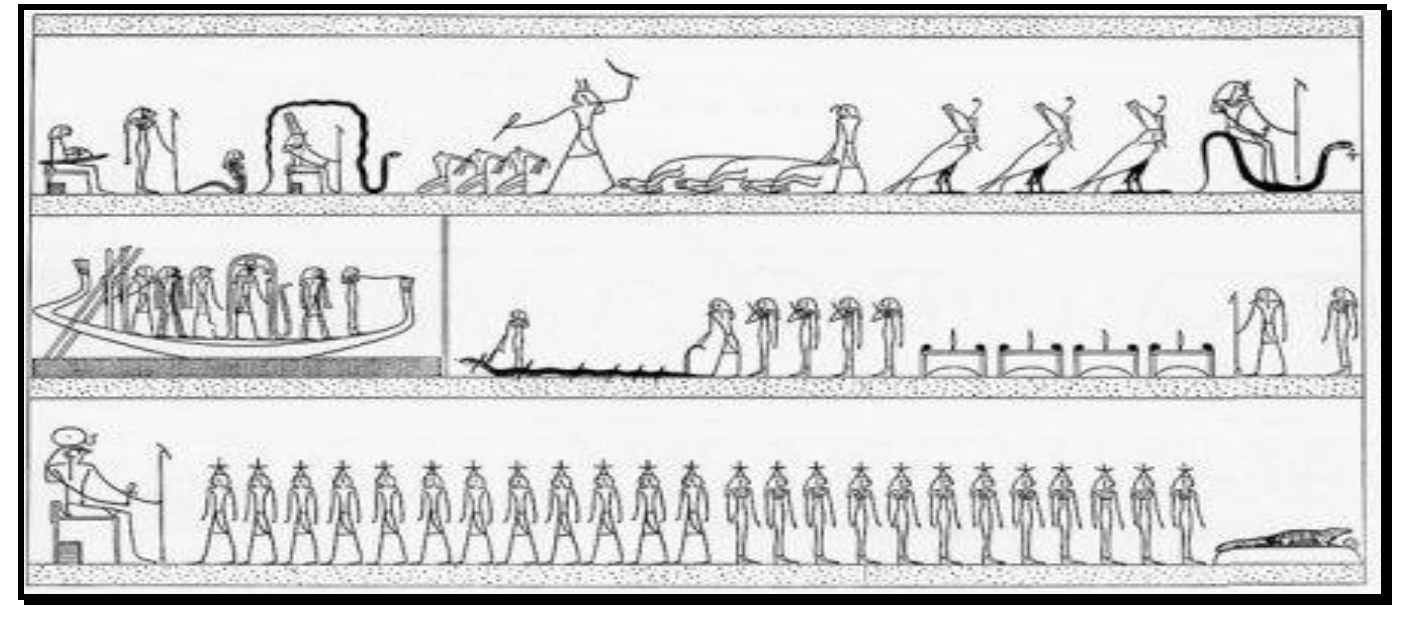

IMAGEN IX. Escena de la séptima hora del Amduat (Hornung 2007, pp. 214-215) 
Se crea una metáfora que se asocia con las ideas míticas de la esfera más solar del pensamiento egipcio, como dice Frankfort (1998b [1948], p. 190) “el sol nacía al amanecer, y las estrellas al anochecer. Aquí donde se introduce el concepto de procreación...". Aquella misma procreación que es el argumento central tanto de las teogamias del Reino Nuevo, como de los dos últimos relatos del papiro Westcar. Los recién nacidos en cada uno de estos relatos se acoplan a este sentido mítico de creación, por lo cual su legítimo derecho al trono no solamente lo indica ser hijos de un dios, sino que son parte de la procreación divina.

En otro sentido, Keops asegura que los bancos de arena del canal de los Dos peces impidieron que el mismo hubiera visto el templo de Ra. Interpretamos que el faraón hubiese notado que allí Reddjedet estaba embarazada de futuros reyes. Por lo cual, puede aducirse que los bancos de arena que en el momento del nacimiento se forman en las aguas del canal de los Dos Peces, quizá pretendían evitar que Keops se enterara antes de tiempo del futuro nacimiento, y pudiera de ese modo interrumpir el plan divino del dios Ra.

\section{Cocodrilo}

El cocodrilo es una figura que es representada en dos relatos del papiro Westcar. Las acciones que este animal realiza adquieren sentidos míticos. Su primera mención es en el segundo relato, devorando al amante de la esposa de Ubaoné. La figura del cocodrilo aparece nuevamente al final del anexo al cuarto relato. La servidora de Reddjedet descubre las diademas que los dioses habían dejado como presagio para los trillizos. Luego de una discusión, Reddjedet le pega a la mujer, que a modo de venganza, decide ir a contarle al faraón Keops sobre lo que ha descubierto. En el camino la servidora se encuentra con su medio hermano, quien al enterarse de lo que ella tenía en mente, nuevamente le pega. La servidora, al acercarse al lago a limpiarse, es devorada por un cocodrilo. A partir de aquí el manuscrito está corrupto, por lo cual desconocemos el final de la historia. Podemos suponer que el cocodrilo aparece para reprender a la servidora por amenazar con contar lo que ha descubierto. Es decir, que la mujer es castigada por intentar revelar el plan divino de $\mathrm{Ra}$ a Keops, quien puede llegar a evitar la coronación para 
continuar con su propia dinastía. El narrador con el relato de la profecía de Djedi nos ha informado que Keops ya estaba al tanto del nacimiento de los trillizos, pero literariamente Reddjedet y su servidora no tenían porque saberlo.

Según interpreta Goedicke (1993, p. 30) la mujer es repudiada dos veces. Primero por un pariente cercano, un hermano materno. Segundo, es devorada por un cocodrilo, lo que para Goedicke le da al texto un elemento moral, lo que se debe hacer y que no. Cuestionar a la autoridad, la de Reddjedet o la del hermano, es lo no permitido.

El cocodrilo aparece en los relatos como una metáfora de la muerte (Goedicke 1993, p. 30). En diversos textos se vincula tanto a la serpiente mayormente asociada con Apofis- y al cocodrilo como agentes del castigo, la destrucción y la definitiva desaparición del sujeto que ha cometido algún delito. Este era un castigo muy temido por los egipcios porque implicaba una muerte definitiva (Eyre 1976, p. 113).

En el anexo al cuarto relato en el papiro Westcar, se penaliza a la servidora por intentar develar un secreto (al menos ella lo creía de ese modo). Su rol en el texto no es otro que mostrar los obstáculos que se interponen al plan divino, de los hijos de Ra reinando en Egipto (Goedicke 1993, p. 30). El episodio se une a lo que analizábamos con anterioridad con relación a los bancos de arena: son referencias cercanas al mito que ponen en evidencia que las decisiones del dios son las que en última instancia se cumplen. Esto es lo que pone a los trillizos en una situación de privilegio, son los elegidos del dios Sol, son hijos de Ra por ello serán reyes en Egipto.

Eyre (1976, pp. 113 y ss.) plantea que muchas veces la muerte adquirió un sentido de llamado divino o de acción divina, es la acción del cocodrilo que se describe en los relatos del papiro Westcar la más importante demostración del uso de este reptil como agente de la persecución y la justicia. Además, según el autor, el arrebatamiento por un cocodrilo o por una serpiente no siempre era un castigo para los culpables, ni necesariamente fatal. Lo interesante en el segundo relato del papiro Westcar es que el cocodrilo no busca matar a su presa mediante una mordida fatal, sino por ahogamiento. Ahogar al hombre significa la prohibición del aliento de vida, 
que es sinónimo de falta de vida (Eyre 1976, pp. 106-107). La falta de respiración sigue a la destrucción. Según Eyre son más que relevantes los paralelismos entre la historia del papiro Westcar y los procesos del mundo de los muertos, en el momento del pesaje del corazón y la posibilidad que el cocodrilo devore al difunto. Las similitudes son demasiado llamativas para plantear una simple coincidencia entre ambas, por lo cual debe verse en ellas parábolas (Eyre 1976, p. 110).

\section{Cuerpos divinos}

La descripción del cuerpo de cada niño recién nacido en el anexo al cuarto relato del papiro Westcar como: “...un codo (de largo). Sus huesos eran fuertes y la cobertura de sus miembros era de oro y su tocado de verdadero lapislázuli’ $(p W .10 .11-12)^{259}$, nos acerca a una interpretación mítica, nos permite vincularlo con la caracterización que los egipcios hicieron respecto al cuerpo de los dioses. Contrariamente a lo sugerido por Goedicke (1985, p. 21), para quien esta descripción no tiene nada de maravilloso, sino que es parte del lenguaje poético que el relato posee. Consideramos que dicha representación del cuerpo de los recién nacidos se hace en relación a la idea misma que se tenía de un dios. Por lo tanto, se puede vincular con lo divino y lo mítico.

El oro y el lapislázuli fueron considerados en la antigüedad por los egipcios no solamente por el valor económico que estos materiales pudiesen haber tenido, sino también por su significado simbólico. Los ajuares de las tumbas, construidas para la eternidad, están realizados de oro y lapislázuli, lo que garantizaría la perdurabilidad de los mismos. Al mismo tiempo que todo ello le confería un sentido mágico.

La idea que los egipcios crearon alrededor de sus dioses les daba a ellos una característica divina esencial, el oro era considerado la "carne de los dioses" (Frankfort 1998 [1948], p. 70; Lefebvre 2003 [1982], p. 106). En algunos textos podemos leer referencias en este sentido. Por ejemplo, en el templo de Kanais de Seti I se lee: “EI oro es la carne de los dioses. No es cosa tuya. Recuerda cuales fueron las palabras de $\mathrm{Ra}$ cuando comenzó a hablar: 'Mi piel es oro puro”' (Gunn y Gardiner 1917, p. 248).

\footnotetext{
${ }^{259} \mathrm{El}$ subrayado es nuestro.
} 
En Cuento de El Náufrago se relata del siguiente modo el encuentro entre el marinero extraviado y una divinidad en forma de serpiente ${ }^{260}$ : “... descubri que era una Serpiente y que estaba aproximándose. Tenía treinta codos, su barba era de más de dos; su cuerpo estaba recubierto de oro, sus cejas de lapislázuli..." (Galán 1998, p. 36) 261 . Al igual que en el anexo al cuarto relato del papiro Westcar, se describe a la serpiente con cuerpo de oro y lapislázuli, y son justamente esas características las que sorprenden al náufrago, porque son ellas las que le dan la pauta, tanto al protagonista del relato como al espectador, que la serpiente es una figura divina.

En Textos de las Pirámides (1028-30), Pepi tiene que cruzar las aguas para lograr su resurrección. El faraón atraviesa el cuerpo de la diosa Nut, convirtiéndose el relato en un arquetipo del nacimiento de Ra. El rey difunto -como hijo de Rapretende asociarse con la familia celestial y por ello se hace llamar becerro de oro. Se lee: “Pepi viene a tí, Oh padre suyo! Pepi viene a ti, Oh Ra becerro de oro, nacido del cielo. El delicado de oro, formado por la vaca-Hesat' (Frankfort 1998b [1948], p. 192) ${ }^{262}$. Este relato se asemeja a la metáfora mítica del nacimiento de los niños en los dos últimos relatos del papiro Westcar. Los trillizos también logran del modo en que su padre Ra se adentra en las profundidades, al menos simbólicamente, y al nacer sus cuerpos firmes están revestidos de oro fino.

Horus también fue uno de los dioses asociados con el oro. En Libro de los Muertos (Faulkner 2008, pp. 73-74) hay un pasaje que versa acerca de cómo transformar el cuerpo de un difunto en un cuerpo divino, en un halcón de oro. Son abundantes las estatuillas de Horus realizadas en oro, o las representaciones de este dios con cuerpo de oro.

\footnotetext{
${ }^{260}$ El texto conocido como Cuento de El Náufrago se encuentra en el papiro San Petersburgo (papiro Golénischeff 1115). Está escrito en hierático en 123 columnas horizontales, exceptuando la línea 13. Actualmente está custodiando por el Museo de Moscú. El manuscrito es datado a mediados de la dinastía XII. Existen numerosas publicaciones acerca de este relato. Destacamos algunas de ellas: Golénischeff (1912; 1916); Erman (1927, pp. 29-35); Blackman (1932a, pp. 41-48); Lichtheim (1973, pp. 211- 215); Simpson (LAE, pp. 50-56); Goedicke (1974), Lefebvre (2003 [1982], pp. $57-$ 66); Kurth (1987, pp. 167-179); Baines (1990, pp. 55-72); Galán (1998, pp. 19-59); Parkinson (1998, pp. 89- 101); Araújo (2000, pp. 73-79); Quirke (2004, pp. 71-76); López (2005, pp. 77-86).

${ }^{261}$ El subrayado es nuestro.

${ }^{262} \mathrm{El}$ subrayado es nuestro.
} 


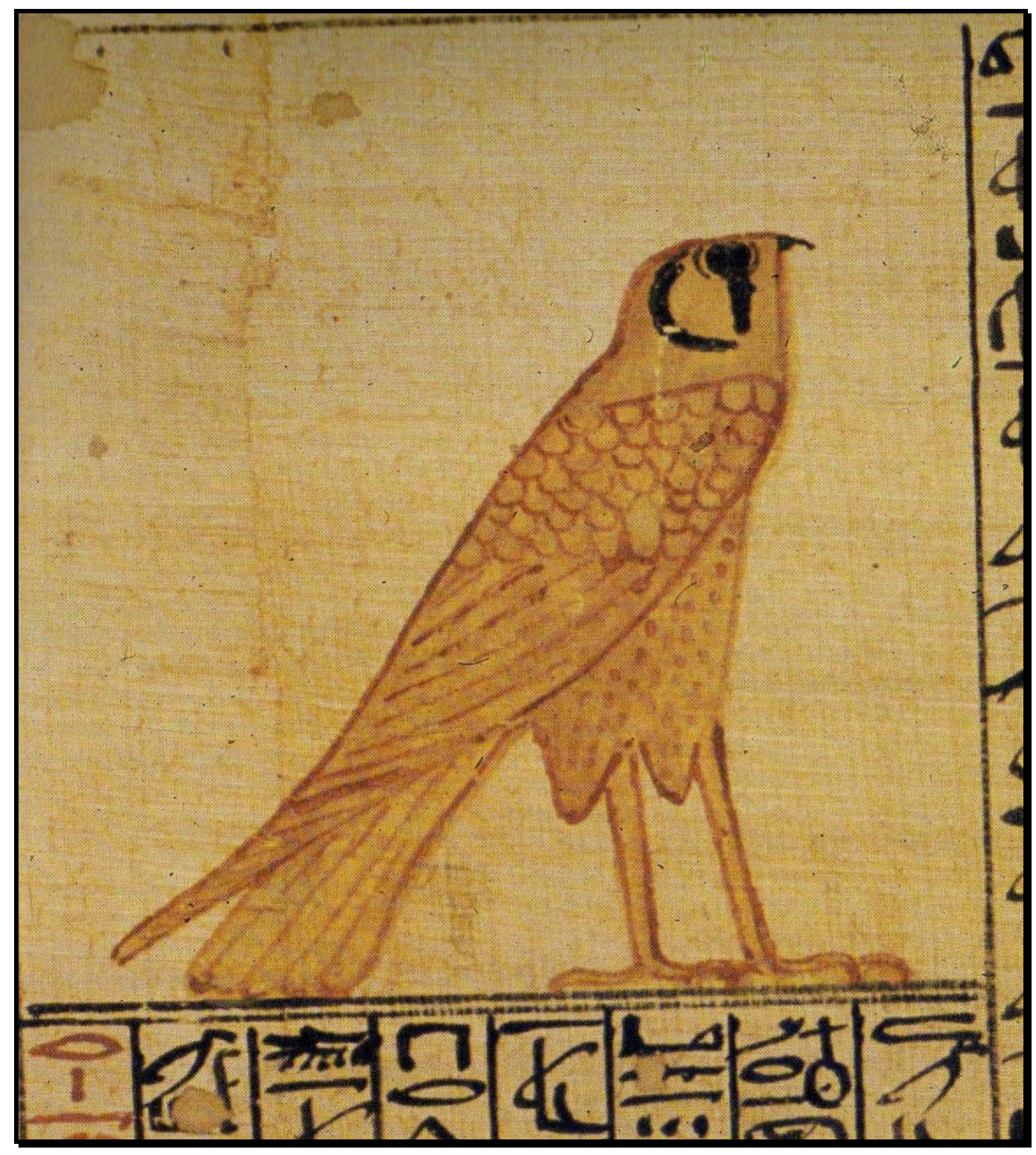

IMAGEN X. Representación del halcón de oro en el cual el difunto espera convertirse en el conjuro 77 del Libro de los Muertos (Faulkner 2008, p. 75) 
Otro ejemplo del oro como una cualidad divina de los dioses quedó descripto en el relato mítico Destrucción de la Humanidad. En él puede leerse: "Sucedió en el tiempo de Ra, el que se creó a sí mismo, cuando ya habia estado gobernado por los dioses y los bumanos juntos durante muchos años. Ra se había vuelto viejo en su realeza y ahora sus huesos estaban volviéndose de plata, su carne de oro y su pelo de verdadero lapislázuli..." (Tyldesley 2011, p. 180)263.

Estas descripciones del cuerpo de oro de los dioses se hicieron extensivas a los faraones, como parte de sus características divinas. Una de estas asociaciones se encuentra en el tercer título real que los faraones llevaron, nos referimos al "Horus de Oro". En el título, sobre el signo de oro, se escribe el nombre del monarca. De este modo, se le asigna al faraón la brillantez imperecedera propia del oro y también del sol (Frankfort 1998b [1948], p. 70), símbolo de eternidad para el faraón. Algo similar podemos pensar para el lapislázuli, que era una gema apreciada en la antigüedad. Con ella se fabricaban joyas y amuletos, y resistía el paso del tiempo sin perder su calidad. La asociación de la divinidad con estos materiales se pone en evidencia en los textos que analizamos a continuación.

La asociación de los faraones con cuerpo de oro está presente en una diversidad de relatos que atestiguan el sentido mítico de eternidad y su vinculación a lo divino que los antiguos egipcios le dieron. Un ejemplo que ya hemos hecho referencia en el capítulo anterior es el de las inscripciones del templo de Deir elBahari del nacimiento divino de la reina Hatshepsut. La diosa Hathor le dice a la recién nacida: “... iHija (mía) de (mi) cuerpo, Maat-Ka-Ra, hija (mía) de oro fino!...” (Serrano Delgado 1993, p. 143)264. Este texto es análogo al del relato anexo en el papiro Westcar. En ambos los cuerpos de los futuros faraones de Egipto son equiparados al cuerpo de que los dioses tienen, al ser caracterizados sus miembros como de oro. Desde esta perspectiva, nuevamente en el papiro Westcar hay un símbolo -el oro- que se asocia con lo mítico-religioso.

\footnotetext{
263 El subrayado es nuestro.

$264 \mathrm{El}$ subrayado es nuestro.
} 


\begin{tabular}{|c|c|}
\hline & Descripción de cuerpos divinos \\
\hline Anexo en el papiro Westcar & $\begin{array}{c}\text { "...un codo (de largo). Sus huesos eran fuertes y la cobertura de } \\
\text { sus miembros era de oro y su tocado de verdadero } \\
\text { lapislázuli" }(p W .10 .11-12)\end{array}$ \\
\hline $\begin{array}{l}\text { Nacimiento de la reina } \\
\text { Hatshepsut }\end{array}$ & $\begin{array}{l}\text { "... iHija (mía) de (mi) cuerpo, Maat-Ka-Ra, hija (mía) de oro } \\
\text { fino!..." (Serrano Delgado 1993, p. 143) }\end{array}$ \\
\hline Cuento de El Náufrago & $\begin{array}{c}\text { “... descubrí que era una Serpiente y que estaba aproximándose. Tenía } \\
\text { treinta codos, su barba era de más de dos; su cuerpo } \\
\text { estaba recubierto de oro, sus cejas de lapislázuli..." (Galán } \\
1998, \text { p. } 36)\end{array}$ \\
\hline Destrucción de la Humanidad & $\begin{array}{c}\text { "Sucedió en el tiempo de Ra, el que se creó a sí mismo, cuando ya habia } \\
\text { estado gobernado por los dioses y los humanos juntos durante muchos años. } \\
\text { Ra se había vuelto viejo en su realeza y ahora sus huesos } \\
\text { estaban volviendo de plata, su carne de oro y su pelo de } \\
\text { verdadero lapislázuli..." (Tyldesley 2011, p. 180) }\end{array}$ \\
\hline
\end{tabular}

CUADRO V. Narraciones acerca del aspecto divino de los dioses y los faraones 
El cabello azul con el cual nace cada uno de los niños hijos de Reddjedet, también envuelve un significado mítico. El cabello azul, dentro de las representaciones en el arte egipcio, es símbolo de divinidad, y su color es asociado al lapislázuli (Wegner 2009, p. 456). Además, el color azul se relaciona con la diosa Hathor, quien en las representaciones de nacimientos del Reino Medio, y también como hemos visto en la teogamias del Reino Nuevo, está presente en el momento del parto. Es decir, que los trillizos en su nacimiento adquieren rasgos que en sí mismos son divinos, son un simbolismo de lo sagrado del acto de su nacimiento.

\section{Danzas y cantos}

Cuando finaliza exitosamente el parto de los trillizos, las diosas Isis, Neftis, Hequet y Meshkeneh, que habían hecho de parteras, deciden dejar un legado a los recién nacidos. "Ellas volvieron entonces al lugar del que habian venido e Isis dijo a estas diosas: "Qué es esto que hemos venido para no hacer ninguna maravilla para aquellos niños según podamos informarle a su padre quién nos ha enviado?'. Entonces ellos crearon tres coronas de señor señor, v.p.s. y las colocaron en la cebada" ( $p W .11 .10-14)^{265}$.

Quien descubre las coronas es la servidora de Reddjedet. La parturienta la envía a buscar el saco de cebada que las enfermeras habían dejado en la casa. "Luego de esto, la servidora fue y abrió la puerta de esta habitación y escuchó en ella sonidos de cantos, bailes, gritos y todo aquello que se hace para el rey en esta habitación. Luego de esto se fue y le repitió todo lo que ella escuchó a Reddjedet. Entonces ella dio vueltas sobre esta habitación y ella no encontró el lugar dónde se producía. Entonces ella colocó su sien en el saco y encontró que éste se producía en su interior"' $(\not W .11 .26-12.4)^{266}$.

El relato literario destaca la cualidad divina y real de los trillizos. Allí donde se han preservado sus coronas, lo que se escucha son cantos y danzas que son propias de la festividad real.

\footnotetext{
265 El subrayado es nuestro.

$266 \mathrm{El}$ subrayado en nuestro.
} 


\section{Meshkeneh y los ladrillos de nacimiento}

La figura de la diosa Meshkeneh envuelve símbolos míticos. En el papiro Westcar la diosa junto a Isis, Nefetis y Hequet está presente en el momento del parto de los trillizos asistiendo a Reddjedet. Meshkeneh es la encargada de pronunciar ante el recién nacido: "Será un rey que ejercerá la realeza sobre este país entero" ( $p W .10 .13-14)$. En el mito de la reina Hatshepsut la diosa preside el nacimiento de la futura reina. En la escena Meshkeneh se encuentra sentada en su silla observando todo el desarrollo del nacimiento, permientiendo que este ocurra bajo su protección.

Mc Geough (2006, p. 315) sugiere que luego de cada nacimiento en el antiguo Egipto, el niño era acostado en un almohadón colocado sobre un ladrillo, y lo más probable que allí ocurriera algún tipo de ritual. De hecho, los nacimientos se realizaban en habitaciones especialmente destinadas para la labor de parto. Algo similar es lo que se narra en el anexo del cuarto relato del papiro Westcar. En una habitación Reddjedet es ayudada por las diosas para dar a luz y con cada niño se siguen el mismo procedimiento: "Entonces ellas lo lavaron y cortaron su cordón umbilical y lo colocaron sobre un asiento de ladrillos" ( $p W$. 10.11-12). El término utilizado en el manuscrito para ladrillo es $\underline{d} b t$. Roth y Roehrig (2002, p. 130) proponen novedosa intepretación para el término que aparece en el papiro Westcar. Los autores argumentan que el pasaje donde el nacimiento de los trillizos está haciendo alusión a los cuatro ladrillos meshkeneh sobre los cuales se colocaban las parturientas durante su labor de parto, uso que puede atestiguarse desde el Reino Antiguo hasta el periodo copto. La traducción que debe aceptarse para ifd $m \underline{d}$ dbt es "cuatro ladrillos". Wegner (2009, p. 473) sugiere que el uso de los cuatro ladrillos está en relación con los implementos mágicos específicos utilizados durante el Reino Medio durante los nacimientos.

Estos ladrillos estarían haciendo alusión a una de las formas con la cual se ha caracterizado a la diosa Meshkeneh. Ella es representada con cuerpo de ladrillo y una pequeña cabeza sobresaliendo de él. Un ejemplo de la diosa representada de este modo se encuentra en la escena de la confesión negativa en Libro de los Muertos que corresponde al papiro de Ani (Faulkner 2008, p. 14). 


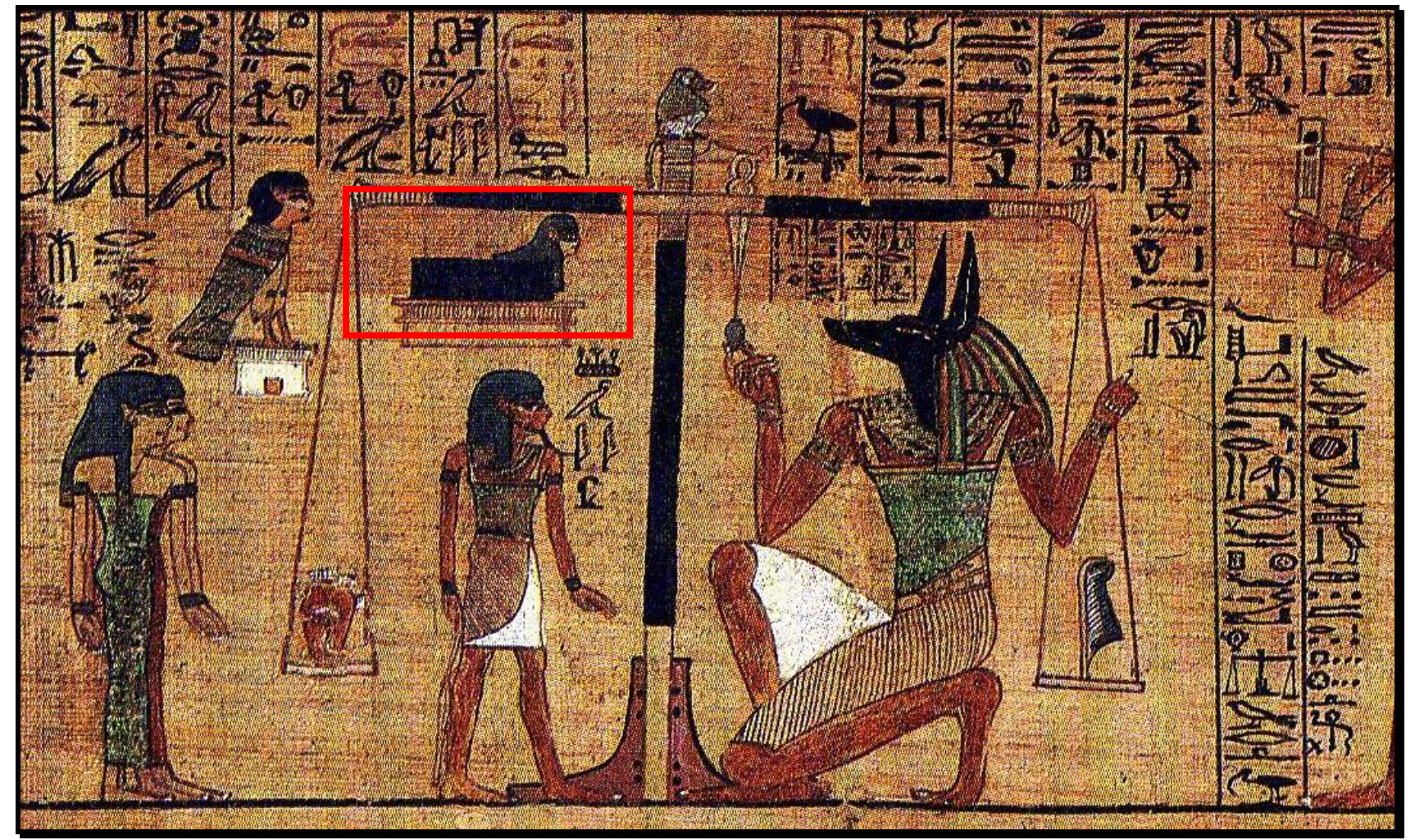

IMAGEN XI. Representación de la diosa Meshkeneh en la confesión negativa en el papiro de Ani (Faulkner 2008, p. 14) 
Uno de estos ladrillos fue descubierto en 2001 durante unas excavaciones al sur de Abidos. Este ladrillo está decorado con escenas que incluyen a la madre con su hijo recién nacido en brazos, dos figuras femeninas y animales, entre otros. Wegner (2009) es quien ha estudiado detalladamente los símbolos que están en él representados, y ha concluido que el ladrillo puede ser interpretado como un objeto ritual.

Nos interesa destacar el examen simbólico que realiza alrededor de las figuras maternas y las dos mujeres. Wegner (2009, pp. 455-471) concluye que estas representaciones se relacionan con la iconografía mágica propia de los nacimientos del Reino Medio. Por ejemplo, la iconografía de la rama del árbol se vincularía con el epíteto de Hathor como "Señora del sicomoro", que a su vez es una simbolización con el nacimiento y renacimiento de $\mathrm{Ra}$ en el horizonte (Wegner 2009, p. 451). La escena del ladrillo sintetiza un modelo mitológico explícito para comprender el evento del nacimiento humano, invocando directamente el nacimiento de $\mathrm{Ra}$, que a su vez es una asociación a la batalla que el dios Sol emprende contra la serpiente Apofis (Wegner 2009, p. 462).

Aquí encontramos un punto de contacto con la narración del nacimiento de los trillizos en el papiro Westcar. Decíamos, el nacimiento narrado en el papiro Westcar posee el mismo significado mítico que tiene el renacimiento de $\mathrm{Ra}$, simbolizado en la fecha de nacimiento de los trillizos y en la metáfora de los bancos de arena. Esta asociación mítica parece responder a la cosmovisión que los egipcios del Reino Medio tuvieron en relación al nacimiento humano, pues la simbología presente en unos y otros es similar. El uso de la iconografía que expresan las ideas religiosas del nacimiento solar en el horizonte oriental otorga una visión de un aspecto verdaderamente elemental de la práctica del nacimiento en el Reino Medio egipcio. El acto físico del nacimiento humano sobre los ladrillos fue concebido como una imitación del nacimiento del dios Sol (Wegner 2009, p. 463). En el papiro Westcar encontraríamos una expresión literaria de esta concepción mágica y mítica. Lo que nos permite replantear, nuevamente, el sentido mítico que este relato pudo haber tenido. 


\section{A modo de cierre}

A través de estos tres capítulos hemos visto los diferentes aspectos con los cuales los dos últimos relatos del papiro Westcar se relacionan con el discurso mítico. Esto nos ha permitido comprender a los relatos del papiro Westcar desde una perspectiva innovadora, aquella que pretende desestructurar las ideas que han vinculado a la narración literaria únicamente con la ficción.

Lejos de reivindicar una interpretación unilineal, se han establecido las similitudes argumentales y simbólicas entre los ciclos míticos de origen de la reina Hatshepsut y los reyes Amenofis III y Ramsés II, y los dos últimos relatos del papiro Westcar.

Por un lado, nos hemos referido a la estructura narrativa de cada mito, encontrando entre ellos idénticas representaciones que hacen de ellos un relato único.

En el capítulo II hemos analizado las escenas de los templos del Reino Nuevo e identificamos los cruces con el relato del papiro Westcar. Al mismo tiempo, indagamos sobre los diferentes discursos que se construyen en un relato más literario como el del papiro Westcar, y otros expresados en texto e imagen como los de las teogamias del Reino Nuevo.

Además, hemos identificado los diferentes roles y actitudes que los personajes adquieren en las narraciones, dando cuenta las similitudes de sentidos que hay entre ellos. Nos hemos referido a las figuras paternas de los dioses Ra y Amón-Ra, de los diferentes dioses partícipes como Isis, Hequet, Neftis, Meshkeneh, y las figuras femeninas que son madres.

Analizamos cómo los dos últimos relatos del papiro Westcar y las teogamias del Reino Nuevo recrean un arquetipo que es mítico. Este arquetipo se refiere a la narración del origen de un faraón que reinará en Egipto. Construimos una nueva idea sobre los textos del papiro: ahora puede decirse que son el primer ejemplo que nos ha llegado del mito de origen del rey, el origen divino de la dinastía V. Esta particularidad del argumento, nos ha impulsado a interpretar las diferentes vinculaciones entre el mito de origen de la dinastía $\mathrm{V}$ con los procesos que se produjeron entre las dinastías IV y V referente a la identificación del faraón como hijo del dios Ra. 
En el capítulo III, se han analizado diferentes aspectos simbólicos que asocian el relato del papiro Westar con el discurso mítico. Examinamos la mención del día del nacimiento de los trillizos -que coincidiría con el mismo día que Ra renace anualmente- y los bancos de arena que impedirían la navegación hacia la residencia donde Reddjedet dará a luz a sus hijos. Ambos son referencias y metáforas del nacimiento de $\mathrm{Ra}$ y las dificultades que el dios atraviesa en su ciclo diario y anual. Sus hijos, así como lo hace su padre en el mito, sortean en el texto literario los mismos inconvenientes, para nacer el mismo día. También nos referimos a la descripción de los cuerpos de los niños, caracterizados como una divinidad y a la mención de figuras mitológicas como los cocodrilos.

La presencia de discurso mítico en relatos como los del papiro Westcar no debe sorprendernos. La sociedad egipcia constituyó su pensamiento y su forma de comprender el mundo a través del mito. Nuestra tarea ha sido desestructurar el relato literario y reconstituir cuales son las bases míticas sobre las cuáles se creó. Lo que sigue -los capítulos IV y V- es otro aspecto fundamental del relato literario, su relación con la política. Los relatos del papiro Westcar se posicionan como una herramienta para la justificación del poder de los faraones de la dinastía XII, quienes recurren al mensaje que los textos literarios transmiten para crearse un origen legítimo. En los relatos del papiro Westcar este mensaje mítico construido se potencia con la formación de la memoria cultural en ellos. 
PARTE

II 


\section{Capítulo IV}

\section{LITERATURA Y POLÍTICA}

Invención, política y ficcionalización en el Reino Medio egipcio 


\section{Antecedentes de los textos literarios durante el Primer Periodo Intermedio}

El Primer Periodo Intermedio, que comprendió entre las dinastías IX a XI²67, fue un tiempo de cambios, crisis y revueltas políticas. Abrió nuevos espacios en los cuales se desarrollaron las riendas del poder. Las provincias habían atraído para sí mismas prerrogativas que hasta finales del Reino Antiguo habían sido exclusivas de la monarquía. El crecimiento de la administración y los polos de poder en las provincias conllevó fenómenos no deseados, aunque inevitables (Moreno García 2009 , p. 185). Las diferentes tendencias delegaron mayor poder y responsabilidades sobre los nomos egipcios. A su vez, dentro de ellos se desarrollaron intereses propios, tanto políticos como económicos. Se dieron procesos administrativos y económicos que a largo plazo pudieron coincidir con otros políticos, los cuales desembocaron en una disminución gradual de la autoridad regia y su traslado hacia poderes locales y palatinos. Por un lado, complicaban a la realeza en concentrar y transmitir centralmente sus órdenes. Por el otro, reforzaban la posición de sus agentes e interlocutores (Moreno García 2009, p. 186).

Durante esta época hubo una renovación de las formas de hacer política, que pusieron en conflicto las que se habían desarrollado hasta el momento. Esta novedad se reflejó en un declive de los grandes centros políticos tradicionales, a favor del auge de los centros regionales, y la aparición de un nuevo grupo, la aristocracia local (Serrano Delgado 2006, p. 270).

Uno de los grandes desafíos para los egiptólogos ha sido comprender los procesos que impulsaron la profunda disgregación territorial y política que se produjo durante el Primer Periodo Intermedio. Se difundieron una variedad de tesis y explicaciones. Para algunos las causas de esta crisis deben buscarse en el periodo que lo antecedió: el Reino Antiguo.

El Reino Antiguo fue una etapa de consolidación del poder de la monarquía egipcia, que afianzó formas del Estado unificado. Se crearon y consolidaron las bases ideológicas, por ende religiosas características de esta época. Por ejemplo, es

\footnotetext{
${ }^{267}$ De todos, modos algunos autores han incluido a las dinastías VII y VIII en el Primer Periodo Intermedio.
} 
en las pirámides dónde simbólicamente se hallan los cimientos que moldearon la sociedad egipcia del Reino Antiguo, y no al revés. Tras la construcción de la primera pirámide en Saqqara, se desató el proceso de trasformación de la sociedad egipcia y la formación de un Estado centralizado (Parra Ortiz 2009, p. 125). A través de los cambios acaecidos en la construcción de las pirámides, de las decisiones tomadas para sus formas y su organización, los modos de obtención y distribución de los recursos empleados para semejante tipo de construcciones, es que puede rastrearse según Parra Ortiz (2009, p. 125) el proceso de formación de los cimientos del Reino Antiguo.

Una de las tesis más conocidas -y no por ello menos criticada- es la crisis climática propuesta por Bell (1971) ${ }^{268}$. La autora sostiene que alrededor del 2200 a.C. (a finales de la dinastía VI) Egipto sufrió la primera Edad Oscura: en un ambiente social estable se produjo una anarquía (Bell 1971, p. 1). El motivo fue una crisis climática provocada por un descenso en el nivel de inundación de las aguas del río Nilo. Descenso que significó una merma en la producción y desarticulación del sistema de irrigación. La primera Época Oscura en Egipto, si bien fue un lapso corto de entre veinte y veinticinco años, provocó efectos traumáticos en la clase educada egipcia (Bell 1971, pp. 6-7).

Además de la escasez de granos a causa de una importante sequía (Serrano Delgado 1992a, p. 19) se ha especulado sobre una crisis socio-política provocada por un ascenso de la presión fiscal hacia los campesinos. La mayoría de ellos sufrió un deterioro general de sus condiciones de vida, y sólo unos pocos lograron sacar provecho de la situación (Moreno García 2004, pp. 276 y ss.). A partir del gobierno

\footnotetext{
268 Bell (1971, p. 1) consideró que durante la historia antigua se produjeron periodos oscuros, en los cuales la estabilidad de los Estados se interrumpía para dar paso a la descentralización política y la anarquía. La primera de estas épocas oscuras fue la acaecida en Egipto, al mismo tiempo que el imperio acadio se desintegraba. Tanto la ciudad de Biblos, como las que se encontraban en la costa siriopalestinense, fueron destruidas por el fuego y abandonadas. En Egipto las fuentes son muy categóricas en dar muestra de este proceso. La Piedra de Palermo hace explícito como el nivel de las aguas del Nilo van en disminución reinado tras reinado desde la dinastía I hasta la dinastía V. También las representaciones en tumbas de funcionarios de la dinastía VI reflejan un ambiente más árido (Serrano Delgado 2006, p. 272). Una de las críticas más consistentes que se ha realizado ante la teoría de la crisis climática viene de la mano de las nuevas evidencias paleoclimáticas, y la reinterpretación de los procesos y las fuentes, y puesta en valor de los elementos estructurales (Moreno García 2004, pp. 271 y ss.; 2009, pp. 181-190). Para un análisis más detallado del periodo: Aldred (1965), Strudwick (1985); Moreno García (2009, pp. 181-208).
} 
del faraón Snefru se inició una política institucional con el objetivo de recaudar una mayor cantidad de impuestos. Algunas medidas impulsaron la creación de centros de explotación agropecuaria (Parra Ortiz 2009, p. 134). Todos los recursos obtenidos de la recaudación fiscal sobre los campesinos, fueron destinados a la construcción de pirámides ${ }^{269}$.

El Primer Periodo Intermedio fue el producto de tendencias a largo plazo que llegaron a su madurez finalizado el Reino Antiguo (Moreno García 2009, p. 182). Los nomarcas de las provincias habían logrado mayor autonomía políticaeconómica y le disputaron el poder central al faraón, a la monarquía. El desvío del poder hacia individuos por fuera de la realeza, ocurrió a finales de la dinastía IV y principios de la dinastía V, incluso para Lupo (2011) hasta finales de la dinastía V. Se produjo un proceso de jerarquización y especialización de las personas que desplazó a los grupos vinculados al rey por lazos de sangre de los cargos más importantes en la administración del Estado. A partir de ahora se valorizaba la capacidad personal para alcanzar un lugar destacado (Baud 1999) 270.

Durante el Primer Periodo Intermedio no hubo un cuestionamiento a la monarquía como forma de gobierno. Es decir, no se produjo un intento de modificación de la monarquía como institución regente. Lo que estaba en controversia era quién estaba a cargo y hacía uso del poder. Esta puja de poder llevó a algunos magnates provinciales a representarse a sí mismos como reyes (Moreno García 2009, p. 190).

En el Primer Periodo Intermedio Egipto se separó en dos regiones, el norte y el sur. La primera, quedó en manos de los nomarcas quienes se adjudicaron las funciones que hasta hace un tiempo habían sido privativas del Estado, llegando a

\footnotetext{
${ }^{269}$ A lo largo del Reino Antiguo por todo el valle del Nilo el Estado recaudaba un porcentaje de lo que los campesinos cosechaban, las cosechan eran tasadas por funcionarios del Estado durante el "recuento de ganado". Los recursos obtenidos de la recaudación eran guardados en los almacenes del rey que estaban distribuidos por todo Egipto (Parra Ortiz 2009, pp. 140-141).

270 Moreno García (2009, p. 191) resaltó que en el ámbito doméstico se produjo el mismo fenómeno, un aumento de la cohesión del grupo familiar y en los valores centrados en el esfuerzo personal y no en las recompensas obtenidas del faraón. Es bien conocido que durante el Reino Antiguo la familia real, especialmente aquellos reconocidos como hijos del rey, tuvieron un papel central en el desarrollo de la administración y gobierno estatal (Strudwick 1985). El estado completamente institucionalizado se produjo a partir de su reacomodamiento desde las dinastías IV y V (Lupo 2011).
} 
alcanzar nuevas formas de organización política. En el sur, en cambio, siguió siendo más fiel a la monarquía. Gobernantes como los de la ciudad de Tebas iniciaron un proceso de reunificación que lograron definitivamente a inicios de la dinastía XII. Los conflictos ocurridos entre estas dos regiones no son la causa cabal para explicar el decaimiento de la capacidad de gobernar de la monarquía faraónica, y el desplazamiento de la capacidad organizativa hacia los magnates de las provincias.

El resquebrajamiento de los circuitos culturales palatinos, sumado al desvanecimiento de la fuerza centralizadora del Estado, posibilitó el avance cultural de las provincias. Se amplió el acceso al campo artístico y bienes culturales que anteriormente se encontraban restringidos a la realeza (Moreno García 2004, p. 272). Se produjo un desplazamiento, emulación y/o apoderamiento por parte de los magnates provinciales, que construyeron las tumbas privadas del Primer Periodo Intermedio, de los rollos escritos que habían sido guardados en los archivos reales (Assmann 2005 [1996], p. 115).

Se produjeron cambios en una multiplicidad de planos, indicio no tanto de una mayor prosperidad generalizada que se traducía en mayor riqueza, sino de diferentes modos de acceso al poder y la representación ideológica que se hacía de ello. Los trabajos arqueológicos constataron una significativa vitalidad en las ciudades durante el Primer Periodo Intermedio. Por ejemplo, la ciudad de Edfu se duplicó en superficie, y logró mayor acceso a bienes de lujo destinados a tumbas que no pertenecían a la elite (Moreno García 2009, p. 182).

Las tumbas son un reflejo de los procesos políticos y sociales acaecidos en el Primer Periodo Intermedio. Según estudios específicos, las tumbas eran construidas para albergar a un círculo de personas extenso (Assmann 2005 [1996], p. 116). La información arqueológica indica que se inclinó el manejo de las redes de poder hacia un nuevo actor social: los patrones (Assmann 2005 [1996], p. 116).

Muy lejos de significar una "época oscura” este Primer Periodo de Transición no representó un deterioro cultural, simbólico, político e ideológico de la sociedad egipcia $^{271}$. Como lo especifica Assmann (2005 [1996], pp. 118-119) no se generaron

\footnotetext{
271 Primer Periodo de Transición es un término que incorpora Assmann (1995b, 2005 [1996]), como
} alternativa para el cuestionado Primer Periodo Intermedio. 
rupturas con las tradiciones creadas en el Reino Antiguo. Por el contrario, se trató de una época de florecimiento e iluminada, con una nueva formación de sentido diferenciada.

El Primer Periodo Intermedio más que significar una decadencia en todas las esferas de la cultura, encarnó una continuación de las tradiciones y hasta un florecimiento de las mismas. En el interior de las inscripciones autobiográficas y en el marco del "discurso monumentalista" es que se consiguen apreciar las persistencias y modificaciones de un periodo a otro (Assmann 2005 [1996], p. 118). Se ha rotulado a dichos discursos con la categoría de "monumentales" como si se trataran de un género particular de textos. Se incluyen leyendas ilustradas de los templos, y las representaciones que se encuentran con motivos similares en edificios seculares, ya sea que sean texto o imagen (Parkinson 1991, p. 24) 272.

Las autobiografías son "los textos de tumba" más influyentes que se han conservado de la época. Estas narraciones apelaban, en un sentido amplio, a que los vivos recitasen para el difunto fórmulas funerarias que invocaban aquello que "el rey da", una fórmula que se repetía a lo largo de las tumbas (Parkinson 1991, p. 23). Durante el transcurso del Reino Antiguo, la literocracia egipcia había concebido con las autobiografías una herramienta única de autorepresentación (Assmann 2005 [1996], p. 118). A inicios de dicha época, se registraron los primeros ejemplos de este tipo de textos que finalmente se consolidaron con la dinastía VI (Lichtheim 1973 , p. 5).

Ante la nueva coyuntura política-ideológica iniciada a partir de la construcción de las pirámides, los funcionarios del Estado que vivían en las provincias, querían dejar en claro los contactos que poseían con el faraón y que gozaban de su confianza. Esto provocó una modificación en los textos

\footnotetext{
272 Parkinson (1991, p. 24) considera que la gran mayoría de los casos que denominamos como "monumental" es una categoría que se define por las superficies empleadas para la escritura del texto y no por el género propiamente dicho del texto. Según el autor, únicamente ciertos géneros y estilos fueron considerados adecuados para monumentos. Analizaremos en otro capítulo los recaudos que deben tenerse en cuenta al momento de hablar de "género". Lo que no lo suscribe al tipo de superficie que se emplee para la escritura del texto. Es decir, la superficie de escritura no define el tipo de texto, pues se esclarecerá (teniendo como eje el caso de los relatos del papiro Westcar) el modo que se entrecruzan los tipos de discursos, que no se ciñen a un único tipo de espacio en que fueron escritos o representados.
} 
autobiográficos. En la dinastía IV apenas existían, y sólo se detectan en las tumbas sencillas frases sobre la vida del difunto intercaladas entre otro tipo de textos. Con la dinastía $\mathrm{V}$ los textos autobiográficos pasan a ser mucho más amplios y narrativos (Parra Ortiz 2009, p. 158). Como señala Parra Ortiz, éste tipo de autobiografías estaban dispuestas para que el visitante de la tumba conociera acontecimientos concretos que tenían como protagonistas al faraón y al difunto, dejando claramente en evidencia las buenas relaciones, y los beneficios que el muerto tuvo del rey ${ }^{273}$.

Uno de los mayores exponentes de su género es Biografía de Uni ${ }^{274}$. Con Biografía de Uni los egipcios llegaron a la madurez orgánica de una narración con alta experiencia artística (Donadoni 1959, p. 50). Fue un texto valorado por su alta calidad estilística que los propios egipcios reprodujeron hasta época Saíta. Además es uno de los textos más extensos que se conocen de este tipo.

Uni fue un destacado personaje que vivió a lo largo del reinado de tres faraones Teti, Pepi I y Merenrá (Serrano Delgado 1993, pp. 171-172). En su autobiografía puede seguirse el recorrido que cumplió en el Estado, como si se tratase de una "carrera diplomática", en tanto que el ascenso político se lograba a través de las condiciones individuales y no por favores del rey.

El mayor corpus textual de obras autobiográficas fue producido por o para los magnates provinciales durante el Primer Periodo Intermedio. Los patrones configuraron nuevos sentidos a la expresión de las autobiografías en el Reino Antiguo. En las inscripciones dentro de sus tumbas, los protagonistas del Primer Periodo Intermedio expresaron su acción salvadora y de aprovisionamiento a la población en situaciones de escasez, en contraposición a las acciones del Estado faraónico (Assmann 2005 [1996], pp. 118-132). Una de las inscripciones más reconocidas, y sobre la cual volveremos en otro momento, es Autobiografía de Ankhtifi de $M o^{\prime}$ alla ${ }^{275}$. La inscripción perteneció al magnate provincial Ankhtifi, quien

\footnotetext{
273 Véanse los ejemplos que Parra Ortíz (2009, pp. 158 y ss.) analiza para tal afirmación.

${ }^{274} \mathrm{El}$ texto conocido como Biografía de Uni fue escrito en la tumba de este funcionario de la dinastía VI. Algunas publicaciones con traducción y comentario que se destacan son: Tresson (1919) y Lichtheim (1973, pp. 19-23).

275 Este texto Autobiografia de Ankbtifi de Mo'alla se encuentra en la tumba del Ankhtifi, que se encuentra en la ciudad de Hieracómpolis. La tumba fue descubierta en el año 1928 por Jacques Vandier. Vandier (1950) realiza una de las publicaciones más completas con traducción y
} 
vivió durante la dinastía IX y fue nomarca de la ciudad de Hieracómpolis, llegando a extender su poder hasta el nomo meridional de Edfu.

Es dentro de este corpus textual, que algunos investigadores detectaron antecedentes de las obras literarias egipcias clásicas del Reino Medio. Sin embargo, ya en 1927, Erman (1927, p. xxiv) había reflexionado en la introducción a Die Literatur der Aegypter [La literatura de los egipcios] acerca de que el Primer Periodo Intermedio fue la época en la cual se figuraron los textos precedentes a los literarios.

Existe una diferencia entre los textos autobiográficos e inscripciones del Primer Periodo Intermedio, y las obras literarias del Reino Medio. Los primeros, se encuentran escritos dentro del "discurso monumentalista", las paredes de las tumbas de faraones (como Textos de las Pirámides) o en las de los altos funcionarios de la monarquía. Durante el Primer Periodo Intermedio los magnates locales habían adquirido el suficiente poder y los recursos para erigirse tumbas decoradas con dimensiones considerables (como es el ejemplo que aquí tomamos de Ankhtifi). Mientras que el papiro escrito en hierático fue el soporte elegido para la escritura de los textos literarios. Se pasó de un espacio cerrado y menos ágil (por el empleo, la escritura jeroglífica), a uno más dinámico con otras posibilidades de visualización.

A raíz del carácter que este tipo de textos tomaron durante el Primer Periodo Intermedio, cada vez más extensos y con un desarrollo del arte de la prosa, es que algunos investigadores opinan que en ellos pueden encontrarse las primeras formas semejantes a los textos ficcionales.

Las enseñanzas y autobiografías pueden pensarse como un antecedente de los textos literarios egipcios. Tienen como protagonistas a los gobernantes locales y en ellos se detectan las primeras ideas sobre "hombres autosuficientes". Ideas que se continúan en las inscripciones del Reino Medio, en las cuales los logros personales no son el resultado de una ayuda real (Richards 2005, p. 24), como sí se pone de relieve en las autobiografías de los funcionarios del Reino Antiguo.

Assmann (2005 [1996], pp. 119 y ss.) identifica ciertos tópicos generadores de sentido que fueron recurrentes en los textos del Primer Periodo Intermedio, y luego

comentarios de la autobiografía. Otras publicaciones que se destacan son: Schenkel (1965, pp. $45-$ 57); Lichtheim (1973, pp. 85-86). 
reaparecieron en los textos literarios del Reino Medio. Se refiere a la escasez de productos básicos necesarios para la supervivencia y la garantía del aprovisionamiento de los recursos como fundamento legitimador (Assmann 2005 [1996], p. 127) 276 .

No queremos decir que los textos del Primer Periodo Intermedio sean textos literarios. Quizá funcionaron como una referencia o más acertadamente puede sugerirse que son parte de la experiencia en la palabra escrita en el antiguo Egipto. Se produjo un desarrollo en la escritura cada vez más notable, que nos habla de una tendencia al perfeccionamiento y desarrollo de las formas narrativas, y que se encausó en el advenimiento de textos literarios en el Reino Medio ${ }^{277}$. Unos y otros adquirieron formas que los distinguen, marcar estas distinciones nos parece sustancial pues, son estas características las que los hacen textos literarios.

Uno de los textos literarios relacionado con las autobiografías es Cuento de Sinubé, pues su introducción se corresponde directamente con ellas (Galán 1998, p. 76; Morenz 2003, p. 104). Según Galán, el texto muestra la evolución de las biografías póstumas, el paso de la enumeración de los cargos ocupados a la descripción detallada de los servicios cumplidos al monarca comparándolo con Biografía de Harjuf 278 . Vernus $(1995, \mathbb{S}$ 9) ve en Cuento de Simubé la existencia de una conciencia histórica individual, pudiéndose observar la exaltación de la singularidad de la experiencia personal, que permite formar una potencial cronología y ubica la historia del sujeto en una línea temporal. Sist (2008, p. 28) percibe con Vernus la utilidad de las autobiografías como fuentes para la comprensión de la percepción de la historia que los egipcios poseían desde lo individual.

Consideramos que lo más interesante que se desprende de todo este recorrido es preguntarse por qué se recurrió a la ficción como medio de expresión más allá de otros medios conocidos, ya aplicados por la estructura ideológica de la

\footnotetext{
${ }^{276}$ La metáfora típica es de la escasez será "bancos de arena", que ya analizamos detalladamente en otro capítulo, cuando indagamos sobre los símbolos míticos que están presentes en los dos últimos relatos del papiro Westcar.

${ }^{277}$ De todos modos una salvedad al respecto se hace necesaria. Se puede considerar un "progreso" en las formas de expresión de lo escrito únicamente porque conocemos el final de la historia, pues sabemos que luego aparecerán los textos literarios en el Reino Medio que vendrían a simbolizar una expresión sobresaliente con respecto a la palabra narrada.

${ }^{278}$ En URK I, pp. 123-127.
} 
monarquía. Se hará evidente que los textos literarios emplearán recursos que también son parte de la legitimación monárquica, estamos pensando específicamente en el mito que ya hemos analizado en capítulos anteriores.

\section{Reino Medio: política y literatura. El surgimiento de los textos literarios}

Lo ocurrido durante el Primer Periodo Intermedio conformó una coyuntura política novedosa. Una vez reunificado el Estado, a inicios de la dinastía XII, se produjeron nuevos desafíos, tendientes a la legitimación política-ideológica del faraón.

El acontecimiento más trascendente, y que los egiptólogos consideran como el hito que marca los comienzos del Reino Medio, es la victoria del faraón Mentuhetep II sobre el reino de Heracleópolis, lo que supuso el fin de la escisión política en Egipto (Diego Espinel 2009, p. 214). El conflicto entre el reino tebano y el heracleopolitano había puesto en marcha un sistema de alianzas entre diferentes localidades, principalmente de la región del Egipto medio, que apoyaban a uno u otro bando (Diego Espinel 2009, p. 215).

Ante esta situación de unificación comienza a producirse un discurso legitimador del nuevo contexto político. Los textos ponen en evidencia una temática que será recurrente a lo largo del Reino Medio, y que principalmente será el eje de la narración literaria: la manipulación del pasado con fines legitimadores.

Como ejemplo se pueden mencionar las inscripciones de la tumba del nomarca tebano Intef, hijo de Myt que se encuentra en la colina de Dra Abu elNaga. Las inscripciones de este importante personaje tebano son un llamativo ejemplo de la capacidad de iniciativas propias y la libertad de acción de los potentados locales frente a la corona, al menos hasta los primeros tiempos de Mentuhetep II (Diego Espinel 2009, p. 216). Como así también lo es la inscripción (posiblemente proveniente de Tebas) de un personaje anónimo conservada en la Estela Louvre C 252 en la que se aprecia para Diego Espinel (2009, pp. 216-217) "un gesto político con el que quería justificarse como el sucesor legítimo de los 
nomarcas anteriores y como un ejemplo a seguir en el futuro". Durante el Reino Medio se amplió el acceso a la escritura y a la expresión de la experiencia individual (Parkinson 1996, p. 155), generándose importantes cambios sociales.

Los motivos (temas) literarios son una parte de un flujo de influencias y relaciones político-ideológicas dadas al calor de los conflictos entre las provincias y la corona. Si bien pudo haberse producido una ampliación en el acceso de la escritura, su uso siguió siendo un privilegio para algunos pocos. Esto nos recuerda que los textos escritos solamente representan una parcialidad de la cultura (Parkinson 1991, p. 18), por lo cual únicamente podemos acercarnos a una parte de la sociedad. De todas maneras, no todos los temas literarios fueron inspirados de estos procesos, sino que pondremos en discusión acerca de la posibilidad de un origen por fuera de ellos, quizá existiendo estos relatos en forma oral con antelación a su escritura en el Reino Medio (Parkinson 1991, p. 17) 279.

Las fuentes literarias proporcionan un material invalorable para comprender parte de este proceso ${ }^{280}$. Estos textos parecieran ser una reflexión sobre el desorden político y social del Primer Periodo Intermedio. Al mismo tiempo que dan cuenta de las preocupaciones individuales, emergen categorías sociales que hablan de una desigualdad definida en relación a nuevos actores sociales y de la clase dominante en términos de estatus (Zingarelli 2011, pp. 1-2) 281.

La reconstrucción de la última etapa de la historia del Reino Medio ha sido reconsiderada, a partir del establecimiento de nuevos límites temporales que marcan su implosión y la configuración de un nuevo periodo histórico egipcio, el Segundo Periodo Intermedio ${ }^{282}$. La dimensión de la disolución de la centralidad egipcia característica del Reino Medio, y la posterior consolidación de tres nuevas identidades sociopolíticas (Avaris, Tebas y Kerma) todavía son difíciles de

\footnotetext{
279 De hecho esta es una posibilidad que se ha esgrimido para los relatos del papiro Westcar, lo cual analizaremos más adelante.

${ }^{280}$ Los textos literarios son el principal material que se ha preservado para comprender los procesos ocurridos durante el Reino Medio, ya que las diferentes estructuras edilicias, templos, tumbas o palacios (con las consiguientes representaciones murales, o cualquier tipo de escultura) están muy deterioradas y es mínima la información que puede obtenerse de ellas (Grajetzki 2006, pp. 1-2). 281 Agradecemos a la autora por el acceso a su trabajo antes de su publicación.

282 Ryholt (1997, pp. 5-6) propone incluir a la dinastía XIII en el Segundo Periodo Intermedio. La hipótesis del autor es que el Segundo Periodo Intermedio abarcaría desde c. 1800-1530 a.C.
} 
cuantificar (Flammini 2010, pp. 8-9)283. Principalmente, si se pretende dimensionar el proceso a través de lo que las fuentes parecen ser más bien categóricas: la emergencia de nuevos corpus de cerámica en las diferentes regiones de Egipto. Ello vendría a sugerir según Bourriau nuevas modalidades locales de producción, en detrimento de la articulación del Estado en esta esfera productiva (Flammini 2010, p. 9).

Los estudios actuales han comenzado a considerar fuertemente la existencia de lo que se podría llamar una clase social media ${ }^{284}$. En algún momento los historiadores interpretaron como una Edad Democrática (Wilson 1951, pp. 123-124; Hayes 1961, pp. 5-32) o la aparición de un tipo de "burguesía" (Loprieno 1988, p. 87). Estas ideas derivaron en una mala traducción del término de $n \underline{d} s$ como burgués. Algunas interpretaciones más actuales, como la de Richards (2005, pp. 14-17), argumentan a favor de la existencia de una clase media a comienzos del Reino Medio, principalmente basándose en evidencia funeraria. Según Parkinson (1996, p. 140) la denominación de personajes como $n \underline{d} s$ no está necesariamente vinculada al rol social real que cumplieron dentro de la sociedad egipcia, ni al modo en que la misma estaba conformada ${ }^{285}$.

Más allá de las diferentes interpretaciones es dentro de los textos literarios

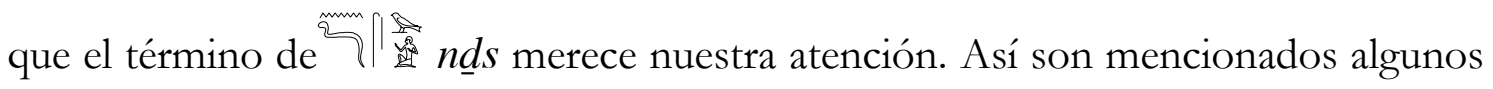
de los personajes en los relatos del papiro Westcar ${ }^{286}$, y otros personajes de relatos literarios, datados en el Reino Medio, como Profecía de Neferty, Admoniciones de Ipuwer, y Diálogo del Hombre con su $B a^{287}$. Zingarelli (2011, pp. 6-9) explica que el término ha

\footnotetext{
283 Agradecemos a la autora por el acceso a su trabajo antes de su publicación.

284 Zingarelli $(2011$, p. 2) hace referencia a diferentes términos con los cuales se menciona en los textos literarios a categorías sociales como $p^{\ulcorner} t$ interpretado como "elite" ("die Menschen" véase $W b$. 503); rmt traducido como "pueblo" y rhyt como "clases bajas" ("Volk" véase Wb. II. 447), entre otros. Los $p^{\complement} t$ estarían conformando una elite más fiel a la realeza egipcia, mientras que en la figura de los rhyt se asocia a un comportamiento moral cuestionable (Diego Espinel 2009, p. 504). Al igual que la mención de individuos como wrw/ 3 "grandes" o $n d s w$ "pequeños".

285 Para un estudio detallado de diferentes posturas sobre el tema véase Zingarelli (2011).

${ }^{286}$ En los relatos del papiro Westcar el término aparece en el segundo relato (líneas: 2,4-2,5; 2,10; $2,25 ; 3,2 ; 3,10 ; 3,11 ; 3,14: 3,16 ; 3,21 ; 3,22 ; 4,4)$ y en el cuarto relato (línea: 7,2). Las propuestas de traducción para el término han sido: "burgués" (Lefebvre 2003), "plebeyo" (López 2005; Sánchez Rodríguez 2003), “commoner" (Parkinson 1998), "fellow” (Quirke 2004), “townsman” (Simpson 1971). $287 \mathrm{Al}$ respecto véase Zingarelli (2011, pp. 6-11), mención de las fuentes literarias y no literarias donde se menciona la figura del $n \underline{d} s$.
} 
sido generalmente traducido como "pequeño hombre, huérfano, hombre común, burgués, hombre libre o ciudadano". De lo que se desprende que no hay uniformidad del rol del personaje literario, de la figura del $n \underline{d} s$ en los relatos. Para definirlo debería asumirse una definición de clase media que abarque desde la antigüedad hasta hoy, lo que pareciera una empresa metodológicamente poco factible, y la imposibilidad de detectar una conciencia de clase para esta "clase media" cuando en los textos dichos hombres no parecieran identificarse con esta clase (Zingarelli 2011, p. 12). Los $n \underline{d} s$ son parte del contexto político-social del Reino Medio. Lo interesante, como lo distingue la autora, es que su mención está presente en los textos de esta época, y desaparece en textos posteriores.

En la figura de los $n \underline{d} s$ puede identificarse el conjunto de individuos para quienes estaban destinados los textos literarios del Reino Medio egipcio. Quizá fueron parte de una clase egipcia, que junto a otros en sus inscripciones mostraban autonomía con respecto al favor real (Richards 2005, pp. 24-25). Esta nueva capa social era parte de la experiencia política del Primer Periodo Intermedio, y fueron parte de las tensiones políticas que concentraron poder individual hacia las provincias (Parkinson 1996, p. 137). Assmann (2005 [1996]) los identifica como los interlocutores para quienes los textos literarios egipcios fueron escritos.

Los textos literarios formaban un sentido normativo de ser egipcio. Educaban a la alta elite y formaban a los futuros funcionarios. Por otro lado, fueron ellos lo que adquirieron el poder suficiente para contrariar a la monarquía. Estos nuevos personajes serían los destinarios ideales de los relatos literarios, lo que Parkinson (1996, pp. 140-147 y p. 150) propone como una audiencia conformada por una elite o subelite de escribas. Las evidencias son escasas para que podamos determinar el circuito de trasmisión oral de los textos que nos permita reflexionar acerca de sus receptores. Sin embargo, la literatura surge como un espacio disidente de la elite cultural, como un medio de actuar y dirigir las críticas hacia el Estado mediante la ironía y la parodia (Parkinson 2002, p. 56).

Los procesos políticos posteriores a la victoria tebana son el marco histórico que nos permiten comprender la aparición de un tipo de escritura totalmente novedosa: la literatura. Lo que especialistas en el Reino Medio explicaron que la 
crisis política no sería subsanada mientras ejercían el poder los Mentuhetep. No hubo en ellos una firme intención de socavar el poder y autoridad a aquellos nomarcas que no generaban problemas a la monarquía, aunque no se sintieran sometidos a ella. En esta situación, más vinculada a problemas relacionados con la sucesión dinástica, es donde radicaría la explicación de la profunda crisis durante los reinados de Mentuhetep IV y de Sesostris I (Diego Espinel 2009, p. 224).

En Listas Reales no es mencionado el último rey de la dinastía XI lo que hace suponer que Mentuhetep IV pudo haber sido un usurpador (Grajetzki 2006, p. 25). En Canon de Turín'28 existe una "laguna" de siete años que va desde el reinado de Mentuhetep III al primer faraón de la dinastía XII (Diego Espinel 2009, p. 224) ${ }^{289}$. La única información concreta que se tiene de la existencia de este faraón está en las inscripciones de Wadi Hammamat ${ }^{290}$. En ellas se menciona el nombre del visir que organiza la expedición para obtener los materiales necesarios para la construcción de un sarcófago y unas estatuas para el rey Amenemhat. La coincidencia del nombre del visir del faraón Mentuhetep IV con el del primer rey de la dinastía XII, Amenemhat I, hace pensar a los investigadores que se trata de la misma persona.

Tras la sucesión de una serie de conflictos políticos, que no fueron resueltos hasta la definitiva asunción de Amenemhat I en el trono egipcio, se decidió colocar como corregente al trono a su hijo Sesostris I. Las interpretaciones sobre los hechos provienen de una lectura más bien factual de algunos textos literarios creados

288 Canon de Turín o Canon Real de Turín mide en la actualidad 1.7 metros de largo y se conserva en el Museo de Turín con el número de inventario 1874. En el verso del manuscrito se encuentra escrita la lista de reyes y se supone que existió algún tipo de introducción y el nombre del escriba. El número de páginas no puede determinarse por el carácter fragmentario del manuscrito, desconociéndose todo contexto de producción y para quién fue escrito (Redford 1986, pp. 2 y ss.). En el recto se encuentran registrados los envíos fiscales desde los oasis. Es interesante hacer notar que un texto con carácter oficial haya sido escrito sobre un papiro administrativo (Sist 2008, p. 26), pues como dice Redford (1986, p. 2) el papiro en la antigüedad debería haber tenido la misma medida que todos los documentos administrativos del Imperio Nuevo. La publicación de las imágenes en: Gardiner (1959). Un análisis de interés sobre el manuscrito en Málek (1982).

289 Canon de Turín no son buenas las lecturas que pueden realizarse por su mala conservación. No queda muy claro a qué correspondería el vacío de siete años mencionado por el escriba: que no pudo leer el nombre del rey que gobernó durante dichos años o fue un periodo sin rey (Grajetzki 2006, p. 25).

290 Las inscripciones halladas en el Wadi Hammamat y adjudicadas a Mentuhepet IV fueron publicadas por Couyat y Monet (1912). 
posteriormente a estos acontecimientos. En Enseñanzas de Amenenmbat $I^{291}$ el rey da cuenta de una conspiración en su contra: “... sin embargo, quien comía de mis provisiones formó opositores, a quien yo delegué mi autoridad promovió confabulaciones... Antes de que los cortesanos lo escucharan (de mi) te promuevo, antes de sentarme contigo y darte consejo, puesto que yo no lo habia planeado, no lo esperaba, no me habia percatado de la conspiración de los vasallos" (Galán 1998, pp. 66-67).

En esta misma línea de interpretación Cuento de Sinubé se inicia con un conflicto no del todo revelado al lector. Sinuhé, el protagonista, implícitamente da cuenta de una conspiración dentro de la corte real, que lo impulsa a huir. En otros textos literarios se han encontrado menciones a las posibles causas de la inestabilidad política antes de la asunción de Amenemhat I. Por ejemplo, en Profecía de Neferty se menciona la inmigración por el delta oriental de extranjeros que desestabilizaron la región. Extranjeros que en Admoniciones de Ipunver se dice que han llegado hasta Biblos. El intento de contener esta masa migratoria por parte del Estado se reflejó en la construcción de las "Murallas del gobernador", que son mencionadas en Cuento de Sinubé (Galán 1998, p. 69).

Una lectura de usurpaciones y traiciones no es la única propuesta para explicar estos acontecimientos. Según la interesante hipótesis de Diego Espinel (2009, p. 225) la proximidad de las inscripciones de Mentuhetep IV con una de Amenemhat I, expresaría la intención de este último de asemejarse al primero, y el hecho que haya sido escogido como su sucesor a falta de descendientes sanguíneos.

Un hito dentro de este proceso de crisis política fue el traslado de la capital egipcia. Tebas fue repentinamente abandonada trasladándose hacia un sitio probablemente cercano a la tumba de Amenemhat I en Lisht. La nueva ciudad capital Amenemhat-Itji-Tawy, que puede traducirse según Diego Espinel como (2009, p. 225) "Amenembat I es quien toma legalmente [o, también, según otro significado del verbo it ti, «por la fuerza»] las Dos Tierras". La nueva capital le dio identidad a la nueva

\footnotetext{
${ }^{291}$ La principal fuente de Enseñanzas de Amenembat I o Instrucciones de Amenembat I se encuentra en el papiro Millingen, actualmente perdido, y se data para la dinastía XII. Algunas traducciones pueden encontrarse en Erman (1927, pp. 72-75); Volten (1945, pp. 104-128); Posener (1956, pp. 61-86); López (1963, pp. 29-33); Helck (1969); Lichtheim (1973, pp. 135-138); Blumenthal (1984, pp. 85107; 1985, pp. 104-115); Goedicke (1988); Serrano Delgado (1993, pp. 97-99).
} 
dinastía según así lo entendieron los egipcios en Canon de Turín. En el se menciona a los faraones de la dinastía XII como los reyes de la "residencia de Itji-Tawy".

Los procesos que ocurrieron entre el Primer Periodo Intermedio y el Reino Medio, impulsaron a la monarquía egipcia a replantearse los modos de legitimación y a generar nuevas formas de expresión que justificaran la presencia de la dinastía encabezada por Amenemhat I. Este faraón fue el primero que pudo definitivamente encauzar la consolidación del Estado y enlazarse con las tradiciones del Reino Antiguo (Assmann 1995, pp. 146-147). Desde un principio, los faraones de la dinastía XII dejaron bien claros sus deseos de identificarse con el pasado. El pasado al que aspiraban acercarse era el de los reyes del Reino Antiguo, los cuales habían creado un Estado fuerte y centralizado, que les permitió construir las bases ideológicas que sostuvieron a la monarquía. En un sentido cósmico -pero también político e ideológico- el Reino Medio reproduce el nacimiento del Reino Antiguo pero con los signos cambiados (Assmann 2005 [1996], p. 146).

Gran parte de los cambios en los modos de legitimación encuentran explicación en los factores que emergieron con los procesos del Primer Periodo Intermedio, y que tienen su raíz en el Reino Antiguo. La monarquía del Reino Medio se hallaba ante un Estado radicalmente distinto, con relación al que habían enfrentado los faraones de las dinastías IV-VI. Los monarcas de la dinastía XII ya no gobernaban sobre una masa de funcionarios iletrados (lentamente profesionalizada), sino que debieron legitimar su posición ante un conjunto de individuos económica, militar y políticamente bien constituidos, con poder y muy instruidos (Moreno García 2004, pp. 282-283; Assmann 2005 [1996], p. 147).

Esta situación llevó a la búsqueda de nuevas formas de autolegitimación a favor de la dinastía XII. A su vez, le ofrecía a la monarquía el material humano para condensar dichas necesidades. Según Assmann (2005 [1996], pp. 147-148), la mejor herramienta que el Estado faraónico tenía a su disposición no eran los enfrentamientos militares ni la violencia indiscriminada, sino el poder de los discursos propagandísticos y aclaratorios. Ellos les proporcionaban un medio de legitimación, que Assmann (2005 [1996], p. 148) denomina "retórica de los motivos". La literatura será esta nueva arma de legitimación y de combate de la 
dinastía XII. Para ello tenía a su alcance un importante número de funcionarios letrados e instruidos ${ }^{292}$.

Durante el Primer Periodo Intermedio el poder se había balanceado hacia los nomarcas provinciales. Cuando el faraón egipcio Amenemhat I logró centralizar nuevamente el poder en la institución monárquica, la realeza debió justificarse ante la sociedad en general. Además debió legitimarse ante el grupo de magnates provinciales que le había disputado poder. La nueva dinastía tebana, al tratarse también ella de una usurpadora, hizo todo el esfuerzo para acreditar su posición. De ahí el desarrollo, durante la dinastía XII, del campo de la literatura para promover los valores de adhesión a la corona (Moreno García 2004, p. 283). Moreno García (2009, p. 182) considera a la literatura como producto del "rearme ideológico", utilizado por la monarquía del Reino Medio para legitimar su autoridad.

Entre los egiptólogos esta interpretación no fue considerada desde un inicio. Contrariamente, fueron numerosas las voces que proclamaron que los textos literarios no eran más que la expresión de acontecimientos históricos, sin un sentido político $^{293}$. Otros ven una influencia de la cultura oral y popular en los textos literarios. Pensamos que debería comenzar a valorarse la capacidad del Estado de tomarlas para sí como fuente de justificación política.

Desde que en el año 1956 Posener publicó Litterature et politique dans l'Egypte de la XIIe Dynastie [Literatura y politica en el Egipto de la dinastía XII] se modificó el modo en que los especialistas se acercaron a los textos literarios. Comenzaron a cuestionarse los textos literarios como espejo de una realidad histórica, un reflejo de los acontecimientos. Lentamente comenzó a interpretárselos como un universo de textos (Loprieno 1996a, p. 51). Las conclusiones de Posener establecieron su utilización política por los últimos faraones de la dinastía XI y los primeros de la XII, y la posterior proliferación de la literatura.

La tesis principal de Posener (1956), es que a través de los textos literarios se expresó la imagen que se deseaba para un rey -lo que reflejaba un incremento de las

\footnotetext{
292 Más adelante nos detendremos en los modos de educación y transmisión del saber especializado. ${ }^{293}$ Dedicaremos un apartado en este capítulo para comprender con mayor profundidad los fuertes lazos que unieron a la literatura con la política. Hasta aquí hemos expuesto el contexto histórico que explica gran parte de la situación.
} 
ideas morales respecto a sus obligaciones- y la decadencia de las clases sociales superiores durante el Primer Periodo Intermedio, entre otros temas relacionados a la realeza y la sociedad. Los textos literarios formaban parte del programa legitimador de la dinastía, lo que les daba a ellos una vinculación directa con lo político.

Las conclusiones obtenidas por Posener (1956) llevaron a ciertos investigadores a criticar el empleo del término de propaganda. Por un lado, Parkinson (1996, pp. 139-140) rechaza fuertemente su uso entendido como un mensaje desde el Estado para influenciar sobre un tema en particular. Considera que el empleo de este concepto despreciativo es parcialmente responsable ya que los textos estaban "embebidos" en la ideología egipcia. En definitiva, para el autor el uso del término propaganda para los escritos egipcios significaba hacer un análisis reductible del espacio que ocuparon en la sociedad egipcia antigua y que es particularmente problemático para los textos literarios egipcios, más que nada por la posible audiencia (Parkinson 1996, p. 139) ${ }^{294}$.

La critica queda sin sentido según Simpson (1996, p. 438). El autor resalta que Posener nunca utilizó el concepto de propaganda, sino que ha sido una comprensión posterior de la crítica, y que el autor se refería a la política y al mensaje que los textos querían transmitir para justificar y fortalecer el poder del faraón.

Consideramos que el concepto debe ser utilizado con cuidado, especialmente por las connotaciones peyorativas de carácter social y político que recibió desde mediados del siglo XX (Simpson 1982a, p. 266). Por lo cual debe ajustarse la definición del término en el contexto -uso- del antiguo Egipto. Simpson (1982a, p. 266), si bien declara cierta incomodidad en su uso, define propaganda como: "un mensaje, comunicación o afirmación dirigida por su autor en beneficio de un individuo o de un grupo (un dios, un rey, un funcionario, una clase) o de una

294 De todos modos es interesante traer a la discusión las críticas de la escuela británica de egiptología (Simpson 1996, p. 438), ella pone en cuestionamiento el uso de la literatura con un fin político, como publicidad del buen gobierno, de su legitimidad. Al respecto véase Wilson (1957, p. 277) y Parkinson (2002, p. 15). 
ideología (culto, realeza, ambición personal, un grupo con un interés especial) a una audiencia específica o general" 295.

El texto propagandístico lleva un mensaje implícito o explícito que busca persuadir a la audiencia que lo recibe. La posibilidad de una narración política de este tipo no ha sido considerada para los relatos del papiro Westcar. Los especialistas no han visualizado la relación propaganda-relatos del papiro Westcar, como sí lo han establecido para relatos contemporáneos al manuscrito, como Profecía de Neferty, Admoniciones de Ipuwer, y Lamentaciones de Khakheperresenebu.

Estimamos que los investigadores han descartado analizar a los relatos del papiro Westcar en clave de propaganda porque tienen un argumento que a primera vista carece de contenido político, dejándose llevar por la primacía de lo mágico y lo anecdótico. Dentro de la monarquía unificadora de las Dos Tierras a fines de la dinastía XI y principios de la dinastía XII, existió un grupo de receptores de los textos literarios, que a la vez podrían ser los mismos que los producían. Desde este punto de vista, podemos comprender los mensajes que los relatos transmiten.

El Reino Medio significó un periodo de esplendor de la alta cultura. Los egipcios mismos fueron los que experimentaron, creyeron y representaron a esta época como una edad de oro en la tradición escrita -literaria- egipcia (Parkinson 1991, p. 8; Assmann 2005 [1996], p. 147). El periodo del Reino Medio fue considerado por ellos como un "renacimiento" que se expresaba a través de la cultura (Assmann 1997, p. 8)296. Los textos literarios de las dinastías XII y XIII fueron la representación de un periodo clásico (Baines 1995, p. 22) ${ }^{297}$. Esta alta estima estimuló su continua reproducción, llegando a considerarse a la lengua del

\footnotetext{
295 Simpson en su artículo sigue analizando la función de la propaganda, principalmente para el Reino Nuevo donde luego del periodo amarniano realmente empieza a dominar el elemento propagandístico en la estatuaria.

296 En este sentido Assmann (1997, p. 8) nos recuerda que el lema principal del programa de gobierno de Amenemhat I fue whm mswt "renovación de nacimiento". La historia de Egipto muchas veces se la encasilló dentro de un programa sin renovación, como si sus tres mil años de historia hubiesen permanecido inmutables (Tiradritti 2008, p. 17). Observamos que si bien se codificó la representación y el recuerdo del pasado, este recuerdo implicó también cambios y renovación, lo que no se modificó fue el pasado como modelo de legitimación y autoridad.

297 Parkinson (1998, p. 138) llegó a comparar el proceso acaecido en Egipto con el renacimiento inglés, como un proceso de cambio en la experiencia individual, observándose por ejemplo un incremento en el acceso a los textos funerarios. En este contexto de cambios del individuo y la sociedad es que comprendió el surgimiento de la literatura (Parkinson 1998, pp. 138-139 y ss.).
} 
Reino Medio como lengua sacra hasta finales de la historia faraónica; fue la principal fuente de inspiración para el arte de la Época Baja (Assmann 2005 [1996], p. 147).

El arte de escribir, por ende el arte de la administración, la política, el derecho, la economía, los conocimientos técnicos y los literarios, entre otros saberes, requerían de una técnica especializada de enseñanza-aprendizaje. En estos ámbitos, además de prepararse a los futuros escribas en el arte de la escritura, se estableció la puerta de entrada a las reglas de la clase, la literocracia. Dicha clase intelectual no estuvo dada por el nacimiento, sino por la educación y poseía sus propias normas de reclutamiento, socialización y reproducción estructural (Assmann 1999, p. 8). Fue dentro de ella donde floreció la literatura egipcia (Parkinson 1996, 133). Tanto la audiencia como los autores de los textos literarios fueron probablemente de la elite o subelite literaria (Parkinson 1996, p. 140).

La escuela es el término, por cierto anacrónico (Assmann 1999, p. 8), por el cual nos referimos a la institución que tenía a su cargo la formación del escriba ${ }^{298}$. Las escuelas seguían métodos muy precisos de educación. Las clases sólo existieron para los primeros cuatro años de educación elemental (Assmann 1999, p. 8). En ellas no solamente se enseñaba a leer y escribir, sino que también los textos eran memorizados y recitados, haciendo de la educación egipcia una educación oral299.

Esta escuela que institucionalizaba el aprendizaje de la escritura puede ser identificada con las pr-`nh, las "casas de vida" 300 . Eran los centros de formación más importantes que conocemos del antiguo Egipto. Las $p r-{ }^{\complement} n h$ eran mantenidas por principales templos que se encontraban distribuidos por el territorio egipcio. Dentro de este espacio los textos eran copiados y reproducidos por los aprendices de escriba (Araújo 2000, p. 34) ${ }^{301}$. Además conocemos espacios denominados como

\footnotetext{
${ }^{298}$ Los propios egipcios ponderaron al escriba como uno de los funcionarios más importantes del Estado y quienes llegaron a esta posición de poder lo hacían evidente. Por ejemplo Moreno García (2004, p. 115) destaca que a los altos funcionarios del Reino Antiguo les gustaba representarse como escriba, una famosa escultura es la del escriba sentado actualmente en el Museo del Louvre. Una idea que se transmite en los textos, el ejemplo más claro y en este sentido es la Sátira de los Oficios.

${ }^{299}$ Más adelante volveremos sobre este aspecto.

$300 \mathrm{Al}$ respecto véase Gardiner (1938).

$301 \mathrm{Si}$ bien los textos eran de diversa índole, incluyendo temas de religión, astronomía, medicina, matemática, etc. algunas $p r-{ }^{\top} n h$ figuraban como centros especializados. Por ejemplo, Bubástis, Abidos y Saís eran reconocidas instituciones especializadas en medicina para el periodo tardío.
} 
"casa de textos" o "casas de rollos de papiros", que funcionaban como bibliotecas, tomando un término anacrónico. Eran espacios que, paralelamente a las $p r-{ }^{\complement} n h$, se destinaban para archivar los textos manuscritos, tanto los de carácter privado como los que pertenecían a los templos (Araújo 2000, pp. 34-35) ${ }^{302}$.

La escuela formó al escriba dentro de la ideología faraónica. En otras palabras, la escuela era, al mismo tiempo, un espacio de formación, creación y transmisión de los valores culturales básicos, e instrumento de poder. Tanto los textos escritos, como los trasmitidos en forma oral, que eran aprendidos de memoria como parte del método de instrucción, formaban la función de identidad que Assmann (1999, p. 8) estima para los textos culturales, al mismo tiempo que eran el fundamento para el aprendizaje $\mathrm{e}^{303}$.

La escuela en el Reino Medio egipcio adquirió un carácter preponderante, en ella la cultura estaba en constante elaboración. Los miembros de la elite podían expresar sus ideas y dar cuenta de su saber acerca de sus propias tradiciones y creencias, tanto culturales, políticas como ideológicas. En el Reino Medio el saber se puso por escrito (Assmann 2005 [1996], p. 155). Aquel conocimiento que se transmitía en forma oral ahora se pasaba por escrito, se codificaba, al mismo tiempo que se daba forma y se instruía acerca de cómo "ser" egipcio.

Por el método de enseñanza de la lengua, nos ha llegado una numerosa cantidad de textos escritos de todo tipo. Son aquellos a los que Erman (1890) tempranamente se refirió como "textos escolares", y en donde las marcas del aprendiz y del maestro están a la vista en la grafía ${ }^{304}$. Los relatos fueron valorizados como obras literarias dignas de ser útiles para la práctica de la lecto-escritura y caligrafía. De hecho, forman parte de las secciones más importantes de la literatura egipcia (Lefebvre 2003 [1982], p. 16). Para el caso de los relatos del papiro Westcar

\footnotetext{
302 Estas bibliotecas son mencionadas en algunos textos, por ejemplo en la Estela de Abidos, en la cual el faraón Neferhotep envía a buscar los rollos de papiros para la construcción de una estatua en la "biblioteca del templo de Osiris".

303 Con respecto al concepto de identidad personal e identidad colectiva véase Assmann (1997, pp. 99-128).

304 Existían también textos producidos por escribas catalogados de "textos especialistas", su contenido era un saber especializado. Por ejemplo, los papiros matemáticos o los papiros médicos
} 
es interesante remarcar que no se evidencian marcas de intervenciones del maestro señalando errores del escriba aprendiz $z^{305}$.

A través de los textos los escribas dejaron constancia sobre lo que pensaban de su profesión. Por ejemplo, en Sátira de los Oficios, puede leerse: "Mira, no bay una profesión que esté libre de director, excepto el escriba. Él es el jefe. Si conoces la escritura, te irá mejor que en las profesiones que te he presentado. Míralos en su miseria [...] Un (sólo) día en la escuela te será beneficioso. Es (algo) para la eternidad; su trabajo es (como) piedra" (Serrano Delgado 1993, p. 223) ${ }^{306}$. En este texto apreciamos cómo los escribas valoraban su profesión, en detrimento de las demás. Para ellos ser escriba significaba el rango más alto al cual se podía aspirar. La palabra escrita bien empleada era aquello que lograba la tan ansiada eternidad. Serrano Delgado (1993, p. 225) interpreta que este relato se inscribe dentro de la tradición propagandística característica del Reino Medio. Según el autor estas palabras estaban a favor de la reforma administrativa producida a partir de la dinastía XII, que necesitaba el fortalecimiento de una clase funcionarial (los escribas) que sostuviera las gestiones políticas del nuevo gobierno.

La trascendencia de la figura del escriba y de la palabra escrita fue reconocida en otros textos. Por ejemplo, se evocan los nombres de aquellos escribas que lograron una trascendencia por estar dotados del empleo de la buena palabra. En Canto del Arpista su autor dice "He oído los dichos de Imuthés y de Hardedef con cuyas palabras habla boy día todo el mundo". Y en el verso del papiro Chester Beatty IV se lee: ¿Hay alguno aqui como Hordedef? ¿Hay otro como Imbotep? Ninguno de nuestros parientes es como Neferty, o Khety, el primero de ellos, déjame recordarte el nombre de Pathemdjehuty, el de Khakheperrasenebu, ¿Hay otro como Ptabhotep? ¿O como Kaires? (Coletta 2008). Según Coletta (2008) a Hordedef y a Ptahhotep se le atribuyen enseñanzas. Neferty sería el autor de la profecía que lleva su nombre. Khakheperresenebu sería el responsable de

\footnotetext{
305 Quizá porque la copia sea de algún escriba especializado. En realidad no sabemos quién fue su autor y con qué fin escribió los relatos en el rollo de papiro. Sin embargo, ya en la traducción de los relatos damos cuenta de algunos "errores" del escriba.

306 Este texto se conserva en copias de las dinastías XVIII y XIX, los más completos son el papiro Sallier II y el papiro Anastasi VIII. Ambos se encuentran custodiados por el British Museum. La escritura original del texto puede retrotaerse al Reino Medio. Una reproducción del texto con traducción en Brunner (1944). Otras traducciones que pueden consultarse: Lichtheim (1973, pp. 184-192); Simpson (LAE, pp. 329-336), Parkinson (1991, pp. 72-76); Serrano Delgado (1993, pp. 221-225).
} 
Lamentaciones de Khakheperresenebu. Khety sería el escritor de Enseñanza de Amenemhat y Sátira de los Oficios. Por último, Kaires habría escrito Enseñanza de Kagemi307.

La escuela era un ámbito donde se encontraban los miembros de la literocracia y hacían alarde de su monopolio en el conocimiento de la escritura. Allí se producían las discusiones sobre los temas que luego eran puestos por escrito, o al menos se generaba un circuito en el cual los textos eran escritos y leídos. Fue un ambiente propicio para el impulso de las "bellas letras" (Daumas 1972, p. 390). Pensamos que los textos literarios que se produjeron durante el Reino Medio egipcio fueron inseparables del proyecto de reorganización que el Estado emprendió a principios de la dinastía XII.

Esta contextualización permite comprender muchos de los temas que son tan recurrentes en los textos literarios clásicos. El Reino Medio les dio sentido, al mismo tiempo que eran parte del proceso y resultado de los acontecimientos históricos que habían atravesado la política y el control del poder. Estos textos estaban destinados a consolidar a los miembros de la dinastía XII a la cabeza de la monarquía. La literatura mantuvo estrecha relación con la política, tuvo un vínculo con un Estado que se estaba reorganizándose e intentaba (re)construir las bases sobre las cuales asentar su poder.

Assmann (2005 [1996], p. 158) señala tres puntos necesarios para la reorganización monárquica. En primer lugar, la restauración de las normas que conducían la ordenación de la sociedad, de la ética y el altruismo. En segundo lugar, estas normas debían ser universalizadas por medio de la formación de sujetos. Por último, la difusión de la norma como parte de una nueva "cultura" en una amplia elite cultural. El Reino Medio logró llevar adelante este proyecto de reorganización estatal, sosteniendo una política cultural que se adecuaba a ello. Las nuevas normas sociales fueron fijadas por escrito.

En conclusión, para nosotros, la literatura fue un medio por el cual se expresaron las nuevas ideas, normas y recuerdos que debían establecerse para la

307 Enseñanza de Kamegi y Enseñanza de Ptahhotep son dos textos que se encuentran en el papiro Prisse. Este papiro fue descubierto en la ciudad de Tebas por Émile Prisse d'Avennes. Actualmente se conserva en la Biblioteca Nacional de Francia. Su versión facsimilar fue publicada por Prisse en 1847. Otras publicaciones: Virey (1887); Erman (1927, pp. 54-67); Žába (1956). 
consolidación de una nueva dinastía. Pensamos que el proceso de reacomodamiento político permitió una nueva formación cultural. Se abrió un espacio para que los escribas participaran en esta nueva lógica estatal, y pudieran expresar a través de nuevos escritos o recopilaciones de tradiciones orales, las ventajas e infortunios de un Estado que estaba afianzándose.

\section{Verdad histórica o ficcionalización en los textos literarios del Reino Medio}

El contexto histórico en que se encuadró la aparición de los textos literarios, nos permite comprender los debates historiográficos que indagaban sobre sí eran relatos de hechos históricos, la ficcionalización de acontecimientos pasados o una absoluta invención. La distinción entre ficción y verdad es problemática. No son homogéneos los parámetros establecidos para la distinción en tiempo y espacio. Los límites que juzgan una obra literaria se modifican. No se establecieron los mismos límites en el pasado que en la actualidad (Chartier 1999, p. 125). Estos elementos deben ser considerados para "restablecer una lectura histórica de las obras literarias que no destruya su condición de literaria” (Chartier 1999, p. 125).

Mencionábamos la posibilidad de que los textos del Primer Periodo Intermedio, sean antecedente de los literarios del Reino Medio. Con relación al carácter y temática que tomaron los textos del Primer Periodo Intermedio, Bell (1971, p. 7) fue una de las primeras en proponer que estos textos pueden denominarse como una "literatura pesimista", que no es otra cosa que el reflejo del colapso del Reino Antiguo. De todos modos, la noción de literatura pesimista no hizo mella entre los investigadores y tomó un rumbo diferente.

Hay una diferencia sustancial entre los textos del Primer Periodo Intermedio y los del Reino Medio. Las enseñanzas y las autobiografías se circunscriben a un ámbito cultual, el de la tumba. Los literarios se desprenden de la escritura mural y pasan a papiro. Los textos literarios expresan, circunstanciados por el contexto que enmarcó su emergencia, una multiplicidad de ideas con una característica distinta a los demás tipos de textos escritos: la ficcionalidad. 
La (auto)biografía pretende una exigencia de verdad en la narración de acontecimientos de la vida de una persona, pero en última instancia no deja de ser un juego retórico propio de este "género literario" (Saer 1991, p. 1). En ellas el narrador se confunde $-\mathrm{O}$ se hace uno- con el protagonista acoplándose a una narración que tiene intención de verdad, sin que necesariamente trasmitan una realidad histórica y concreta. Si las autobiografías poseen este sesgo de transmitir una verdad, "la ficción no solicita ser creída en tanto que verdad, sino en tanto que ficción. Ese deseo no es un capricho de artista, sino la condición primera de su existencia, porque sólo siendo aceptada en tanto que tal, se comprenderá que la ficción no es la exposición novelada de tal o cual ideología, sino un tratamiento específico del mundo, inseparable de lo que trata” (Saer 1991, p. 2).

Los textos del Reino Medio que son literarios comparten la ficción como herramienta de expresión ${ }^{308}$. Recorrimos ya las dimensiones políticas del Reino Medio que fue el recuadro político-ideológico que atravesó y estimuló la emergencia de la literatura. Al contrario de lo que Saer pensó para el arte del artificio, la ficción y lo político-ideológico serán parte de una identidad y realidad, que si bien es novelada, no dejará de representar por medio de la ficción acontecimientos y realidades subjetivas tendientes a legitimar políticamente la nueva dinastía.

Desde una perspectiva más historicista Coulon (1997, pp. 109-110 y pp. 123127) propone un análisis de la veracidad histórica de las autobiografías a través de los metadiscursos presentes en ellas. Es decir, en los textos se representan los acontecimientos históricos. Las discusiones acerca en una narración histórica de estas autobiografías, son planteadas del mismo modo que se hace para los textos literarios. Para las autobiografías específicamente puede argüirse que el rechazo a la ficcionalización de los acontecimientos no es un argumento a favor de la verdad (Saer 1991, p. 1).

Posiblemente personajes como Ankhtifi existieron. Sus palabras tienen parte de verdad histórica, y estaban impulsadas por el contexto sociopolítico en el cual se circunscriben sus textos biográficos. $\mathrm{Y}$ en parte son retóricas, impulsadas por un

\footnotetext{
308 En el capítulo VI se desarrollará cómo los egiptólogos proponen esta definición para los textos literarios egipcios, llegando a plantear la existencia de una diversidad de géneros literarios.
} 
sentido legitimador y político. En este tipo de textos, los magnates provinciales expusieron los motivos fidedignos de su posición como "líderes", afianzando a lo largo del Primer Periodo Intermedio el "género literario" de las enseñanzas y autobiografías, creando una tradición. Como expresa Donadoni (1959, p. 54) no son tanto como un género literario cerrado en sí mismo y con un sentido formal, sino un depósito de razones.

En los dos últimos relatos del papiro Westcar, la sucesión política luego de la finalización de la dinastía IV parece ser el problema principal del argumento. El mago Djedi pronostica al faraón Keops el próximo nacimiento de tres niños, hijos del dios Ra y Reddjedet, que gobernarán Egipto sucesivamente del reinado del nieto del Keops. Un cambio de dinastías es lo que subyace en los dos relatos. Esta sucesión de los hechos no puede ser impedida, pues es clara la intención del dios Ra de darle a Egipto nuevos gobernantes, sus hijos.

Goedicke (1993, p. 35) afirma que falta información para considerar cuáles pudieron haber sido los objetivos políticos del papiro Westcar. Para el autor, si bien es clara la narración de una sucesión política, de un cambio dinástico, en el texto no se menciona ninguna posición política del personaje de Reddjedet, por ende no puede asociárselo con la figura histórica de Sobeknefru y el final de la dinastía XII. El hecho que para el personaje de la madre de los trillizos hijos de Ra no se explicite ninguna posición de rango, nos parece uno de los rasgos más destacables a ser analizados.

Sobeknefru fue hija de Amenemhat III y la primera reina en llevar todos los títulos reales propios del rey y se hizo representar con todos los artilugios de la realeza faraónica (Bryan 1997, p. 30). Se desconocen las causas que motivaron el cambio dinástico luego de su muerte (Bryan 1997, p. 30) ${ }^{309}$. Quizá por la contemporaneidad entre el reinado de Sobeknefru y la escritura de los relatos del papiro Westcar, fue que Goedicke resaltó una posible relación que finalmente descartó, entre el personaje de Reddjedet y la reina Sobeknefru.

\footnotetext{
309 Hasta el momento no se ha encontrado el lugar donde ha sido enterrada, y no hay ningún monumento dedicado a su nombre. Hija del faraón Amenemhat III y esposa real de Amenemhat IV, algunos investigadores han discutido sobre la posible corregencia de Sobeknefru junto a Amenemhat III o Amenemhat IV (Bryan 1997, pp. 29-30).
} 
De todos modos, consideramos que reducir toda la interpretación a una relación espejo realidad histórica-acontecimientos políticos limita el campo analíticoconceptual sobre los textos literarios. Los limita porque deja de lado las ideas que hacen hincapié en el contexto que fueron elaborados los textos literarios, con una intencionalidad política que va más allá del acontecimiento, que trata al texto como un recurso legitimador dentro un programa político pensado y no como mera crónica. Se amplía el análisis al realizar cruces con otros discursos como el mito. Chartier (1999, p. 125) visualizaba como problema, la pérdida de la condición de obra literaria, cuando los historiadores la analizan como si se tratase de un documento histórico.

Goedicke (1993, p. 25) también reflexiona sobre la ficcionalización que caracteriza a los relatos del papiro. Entiende que la mención de los personajes no es histórica, sino un recurso literario utilizado por el escriba para hablar de alguien en la apariencia de una figura histórica. Goedicke piensa en un público conocedor, familiarizado, con el marco histórico y sus personajes, que se nombran y que han muerto un siglo antes que el presente narrativo de los relatos. Un nombre como el de Keops podría ser más fácilmente conocido, pero no puede inferirse el mismo saber para Nebka entre el público en general (Goedicke 1993, p. 24).

Estamos de acuerdo con esta postura. Consideramos que los relatos del papiro Westcar son, valga la redundancia, relatos, y como tales lo que se narra en ellos es una ficción. Que se tomen nombres, lugares, hechos que son parte de la experiencia histórica, no implica necesariamente que se cuenten como verdad histórica, o sean un reflejo de ella. Al contrario, son parte del recurso que el autor utiliza para su narración, para contar una historia: la ficcionalización de hechos y personajes. Su mención es parte de un medio para un fin, la trasmisión de ideas, la apreciación sobre un hecho y/o personaje.

Este planteo fue realizado teóricamente por Eyre (1996, p. 415) para quien la "historia" de los héroes en los relatos literarios no fue una historia real, sino que fue creada por los procesos de la imaginación. Todos los personajes que aparecen en los relatos del papiro Westcar son por lo tanto personajes literarios, no históricos pero quizá si reales. Que hayan existido estas personas históricamente no implica que sus 
acciones sean hechos de la Historia, sino como reflexionó Eyre (1996, p. 415), fueron creados con un propósito literario, por un autor individual para su audiencia contemporánea. La estructura narrativa se caracterizó por la incredulidad del público, lo que fue un indicador fundamental de la ficción y por lo tanto de la propia literatura (Eyre 1996, pp. 415-416).

\section{Reino Medio: literatura y recuerdo}

La literocracia a partir de la dinastía XII, por primera vez, formó una alianza entre recuerdo y literatura (Assmann 2005 [1996], p. 106). Mediante el texto literario se expresó el recuerdo sostenido del Primer Periodo Intermedio como una época en las cual se desenvolvieron situaciones catastróficas. Este recuerdo de un pasado trastocado le permitió a la monarquía ubicarse en una posición restauradora y garante de la paz, del orden. "La retrospección al Primer Periodo Intermedio no acontece con ánimo nostálgico, sino legitimador” (Assmann 2005 [1996], p. 107).

La memoria fue un tópico compartido entre los textos literarios del Reino Medio. Consideramos que Profecía de Neferty o Admoniciones de Ipumer fueron un recuerdo codificado del Primer Periodo Intermedio (Assmann 2005 [1996], p. 137). Y que los dos últimos relatos del papiro Westcar lo fueron del Reino Antiguo. Todos estos textos comparten la misma idea de que todo recuerdo significa la reconstrucción del pasado, y hay una intencionalidad en cuáles son los elementos que se recuerdan y cuáles los que se olvidan ${ }^{310}$.

Esta visión difundida y aceptada sobre los textos literarios del Reino Medio, no encaja para los relatos del papiro Westcar. La hipótesis sobre la que indagamos es que la dinastía $\mathrm{V}$ es legítima en cuanto ella es hija del dios, de Ra. El recuerdo del Reino Antiguo adquiere una importancia sustancial, ya que son las dinastías IV y V hacia las cuáles el recuerdo se dirige.

Como bien lo comprende Assmann (2005 [1996], p. 137) "no existe el pasado «en sí», sino sólo el pasado recordado. Y el pasado es recordado cuando se necesita ser recordado". Por lo tanto, la literatura interpretada como recuerdo exime

310 Analizaremos detalladamente esta perspectiva en el capítulo V. 
la posibilidad que los textos ficcionales sean un reflejo de la realidad, sino que la realidad es alcanzada y mediada por la memoria. Nos ocuparemos en un próximo capítulo en analizar cuáles son los alcances del recuerdo, como se conforma y cómo los relatos del papiro Westcar construyen un recuerdo del origen divino de la dinastía $\mathrm{V}$.

El recuerdo del pasado si bien es una temática compartida intertextualmente entre los relatos literarios del Reino Medio, si se analiza en detalle observamos que no hay una construcción del pasado unánime entre los textos. Es decir que la percepción del trascurrir del tiempo no es la misma, si en Profecía de Neferty el faraón Snefru estaba aburrido en su palacio, y pide a sus colaboradores que lleven hacia su palacio a un hombre sabio que con bellas palabras, buena elocuencia, pueda entretenerlo ${ }^{311}$. Neferty fue el hombre elegido, y le preguntó al rey: “iendrá que ser con respecto a lo que ha pasado, o bien con respecto a lo que debe llegar, soberano, v.p.s., mi señor? Y su majestad v.p.s. dijo 'Ciertamente que con respecto a lo que debe acontecer, si hoy mismo (algo) ha sucedido, pásalo por alto"” (Lefebvre 2003 [1983], p. 115).

De modo contrario en el cuarto relato del papiro Westcar, el príncipe Hordedef no le contará a su padre Keops una historia del pasado como lo han hecho sus hermanos, pues para el hijo del rey en ellas no se distingue lo que ha sido verdad de lo que ha sido mentira, privilegiando saber lo que ocurrirá en el futuro. Por ello decide darle a conocer a su padre la existencia de un hombre sabio que vive en su tiempo, quien predicará el futuro. Después de esto el hijo del rey Hordedef (6.23) se puso de pie para hablar y dijo: "[...] en el conocimiento de aquellos que pasaron no se sabe [distinguir] la verdad de la mentira. Hay bajo tu majestad en tu propio tiempo y es desconocido $[\ldots] ”(p W .6 .22-24)$.

Hordedef está demostrando un gran escepticismo, incredulidad que para Eyre (1996, p. 416) fue uno de los motivos de los textos literarios. Es por eso que el hijo del rey descarta las historias contadas por sus hermanos, los magos que las protagonizan han muerto y no son por ende verificables. Razón por la cual presenta Djedi un mago contemporáneo. Eyre (1996, p. 416) interpreta que los egipcios

\footnotetext{
311 Se volverá nuevamente en otros capítulos sobre la idea del aburrimiento en los textos literarios y míticos.
} 
comprendieron como Historia "un tópico literario, un uso selectivo y con un propósito de la narrativa, que jugó en su instancia superior a la ficción pura y simple"312.

En dichos textos, si bien coinciden en recordar al Primer Periodo Intermedio, la mediación del sentimiento y la experiencia (seguramente de quien escribe el texto) pone en evidencia cuán distinta puede ser la percepción del pasado. En última instancia esto nos afirma que en el antiguo Egipto la sociedad principalmente la elite cultural y política- no estaba interesada en conocer y transcribir el pasado en si mismo, por el contrario el pasado fue una construcción, una elaboración que fue expresada en los textos literarios egipcios.

Pero en todos los casos -y no únicamente para los textos literarios- el pasado era una fuente de autoridad (Eyre 1996, p. 415). El término que nos pues ayudar a dilucidar esta problemática es el de memoria futura ${ }^{313}$. Esta es una definición que fue pensada para los dos últimos relatos del papiro Westcar, de todos modos se hace extensible para otros textos contemporáneos en los que subyace la misma temática. La memoria futura refiere a que el presente, pasado y futuro literario -argumento de los relatos- es en verdad el pasado histórico para el autor. Por lo cual hay un conocimiento de los hechos históricos y una influencia directa del contexto en el cual el autor se encuentra implantado, lo cual propicia a la selección e interpretación de los acontecimientos, que son presentados narrativamente principalmente como un futuro.

En definitiva para los textos literarios la referencia del pasado fue utilizado como un marco literario, más como ficción que como el registro de hechos contemporáneos, y el relato ficcional -o acontecimental- fue esencialmente literarioideológico y no la presentación neutral de hechos reales (Eyre 1996, p. 417).

\footnotetext{
312 La traducción es propia.

313 Nos referiremos a esta problemática específicamente en el próximo capítulo.
} 


\section{Capítulo V}

\section{MEMORIA Y LITERATURA EN EL REINO MEDIO EGIPCIO}

Memoria futura y recuerdo en los dos últimos relatos del papiro Westcar 


\section{Memoria colectiva, marcos sociales y usos de la memoria}

El hombre por naturaleza es un ser social, vive e interactúa en comunidad. Cada grupo social crea ciertos parámetros que lo identifican como tal y excluye a quienes no los comparten. Esto significa que cada identidad colectiva corresponde a un tipo de formación que es social, pero principalmente es cultural (Assmann 1997, pp. 107-108). Dentro de la construcción de estos parámetros de identidad social y cultural la memoria es un factor clave.

La memoria individual por sí misma no existe, no sólo porque para obtener un recuerdo no basta con reconstruir pieza a pieza el hecho que quiere ser rememorado, acudiendo a la experiencia del individuo que actuó en él, sino porque necesitamos del grupo para recrear, dar sentido y comprender nuestro recuerdo (Halbwachs 2004b [1950], pp. 34 y ss.). De este modo, nace una memoria colectiva, que es un concepto difuso pero práctico que hace referencia a ciertas formas de conciencia del pasado que son aparentemente compartidas por un conjunto de individuos (Candau 2002, p. 61).

La memoria colectiva fue por primera vez definida por el sociólogo francés Maurice Halbwachs (2004a [1925]; 2004b [1950]), quien afirmó que el recuerdo es una actividad colectiva. La memoria colectiva es la encargada de transmitir la identidad colectiva (Assmann 2008, p. 23). El recuerdo del pasado es necesario para afirmar la identidad del individuo y del grupo (Todorov 2002 [2000], p. 199). Son dichas referencias al pasado las que impulsan y mantienen la cohesión de los grupos y de las instituciones que componen la sociedad (Pollak 2006, p. 25).

La memoria, como acto de permanencia del pasado en el presente, es siempre social, porque es en comunidad que el hombre recuerda. "Los recuerdos son evocados desde afuera y son los grupos de los cuales el individuo forma parte aquellos que dan los medios para reconstruir el recuerdo, siempre y cuando (al menos temporalmente) el individuo adquiera la forma de pensar del grupo" (Halbwachs 2004a [1925], p. 9). Por sí solo el individuo pierde su capacidad de rememorar, siendo los marcos sociales de la memoria aquellos que permiten y delimitan el cuándo, cómo y qué recordar. 
Fuera de los marcos sociales de la memoria no hay recuerdo, fuera de los marcos sociales no hay posibilidad que los hombres que viven en sociedad puedan fijar y recuperar sus recuerdos (Halbwachs 2004a [1925], p. 101). Según Halbwachs, los individuos articulan su memoria por distintos mecanismos que los delimitan en el recuerdo: la pertenencia a una familia, a una religión o a una clase social determinada (Halbwachs 2004a [1925]; Huici Urmeneta 2007, p. 33). A lo que debe agregarse el límite más sustancial: el lenguaje, en tanto que la reconstrucción de un recuerdo pasa por las circunstancias del acontecimiento pasado, las mayores dificultades y restricciones las halla en las convenciones verbales (Halbwachs 2004a [1925], p. 104). "Las simples palabras que la sociedad nos propone tienen un poder evocador y proporcionan el sentido de esta evocación como cualquier ideación" (Candau 2002, p. 65). La palabra es la que le otorga al hombre la posibilidad de estar en contacto con su comunidad, comunicarse con los demás y de ahí su posibilidad de recordar. Es por ello, que las convenciones verbales son el marco más elemental y estable de la memoria colectiva (Halbwachs 2004a [1925], pp. 84-104).

Si bien puede considerarse que la rememoración hace referencia a un proceso de conciencia, de conciencia individual, es el juego de lenguaje el que lleva a cabo la exteriorización del recuerdo. La mediación lingüística que hay entre recuerdo y relato del recuerdo no puede únicamente circunscribirse en un proceso que se desencadena y produce a partir de una conciencia originariamente privada (Ricœur 1999, p. 20). El diálogo entre memorias individuales, el entretejido entre tradiciones y memorias individuales, son las que constituyen la memoria colectiva (Jelin 2002, p. 22). Es la sociedad la que genera percepciones que provocan los diferentes recuerdos hay algunos que pueden ser tenidos en cuenta y construidos por el colectivo social (Candau 2002, p. 62), y otros son descartados.

Entonces, la expresión del recuerdo que el individuo realiza mediante el lenguaje es colectiva en dos sentidos. Uno, porque el lenguaje en sí mismo es colectivo, y el otro porque el recuerdo nace desde el interior a partir de lo que otros provocan. Además, porque las nociones de tiempo y espacio son construcciones colectivas (Jelin 2002, p. 23). Por un lado, se afirma que los recuerdos son cambiantes y se modifican porque los individuos que forman una comunidad no 
piensan ni recuerdan las mismas cosas en el mismo tiempo (Candau 2002, p. 62). Por el otro, se agrega que las nociones de pasado y presente son cultural e históricamente construidas (Jelin 2002, p. 23), por ende se modifican los marcos sociales desde los cuales se encuadra el recuerdo.

El lenguaje es en la memoria un medio para un fin. La narración de las experiencias que los sujetos y las sociedades atraviesan los ubica a éstos en el pasado (Sarlo 2005, p. 29). En tanto que los sujetos ponen en palabras lo vivido, reconstruyen los acontecimientos en las normas propias de un texto. Según Sarlo (2005, p. 29 y pp. 45-46) no hay experiencia pasada sin narración, sin embargo los sujetos no recuerdan toda la experiencia en sí, sino que hay una reconstitución parcial, mediada por los marcos sociales. Es decir, no son restituidos en su plenitud. En este proceso, la memoria selecciona lo que quiere ser rescatado del pasado, qué desea recuperar de la experiencia, pues no todo queda registrado en la memoria (Todorov 2000, p. 16; Pollak 2006, p. 37).

Son principalmente las narraciones testimoniales y las de ficción (entre ellas la novela), las que componen los modos del lenguaje que el recuerdo emplea para su enunciación ${ }^{314}$. El texto se instituye apelando a una comunicación previa, es decir que en él siempre está en juego el pasado (Assmann 2008, p. 15). Las situaciones traumáticas que una sociedad -y sus sujetos individualmente- experimentan dejan profundas huellas.

En la sociedad antiguo egipcia el Primer Periodo Intermedio se constituye en una experiencia de este tipo. Durante el Reino Medio se alcanzó un nuevo lenguaje el literario- que permitió recordar aquellos acontecimientos. El marco narrativo para el recuerdo fue la ficción, se ficcionalizaron los acontecimientos, lo que no significa que no hayan ocurrido. Pues la memoria recuerda sobre lo que ha sido, lo reinterpreta, lo reconstruye sobre una base que es real, aunque luego se exprese como imaginación (Ricœur 1999, p. 30).

Entre algunos textos del Reino Medio se comparte una misma forma de construir el pasado, como son los ejemplos de Admoniciones de Ipuwer, Profecía de

\footnotetext{
314 Este tema ha sido profundamente estudiado para las experiencias concentracionarias del siglo XX. Como síntesis al respecto véase Pollak (2006).
} 
Neferty, o Lamentaciones de Khakheperresenebu. En ellos se crea el mito de una Edad Oscura (Morenz 2003, p. 108), describiéndose el pasado del Primer Periodo Intermedio como un tiempo de desorden social y desestabilización política.

En este tipo de textos literarios el recuerdo se codifica (Assmann 2005 [1996], p. 137). Esto significa que el pasado es construido como símbolo que le da sentido a las acciones del presente, en este caso pensamos como presente la dinastía XII. Los primeros faraones que lograron la reunificación del Estado egipcio luego del Primer Periodo Intermedio, sintieron la necesidad no tanto de explicar su pasado, como de darle legitimidad a su presente. De ahí que en los textos literarios se crea un sentimiento de pérdida, en que el pasado aparece como evocación de lo perdido (Assmann 2005 [1996], p. 139). Lo perdido es el orden, del Reino Antiguo, y el Primer Periodo Intermedio se simboliza como una etapa caótica y susceptible al descontrol social y político.

El foco de estos textos está en los marcos sociales que dan forma al recuerdo en el presente. En un texto post eventum (Posener 1956, p. 28; Lefebvre 2003 [1982], p. 112; Cervelló Autuori 1996, p. 192 y Assmann 1997, p. 53) como Profecía de Neferty, hay una declaración hacia el futuro que ya es pasado. Nacerá y pondrá orden Ameny, un hombre del sur, que no sería otro que el propio Amenemhat I, el primer faraón de la dinastía XII. De este modo, Profecía de Neferty se transforma en una herramienta de legitimación, "el Estado del Reino Medio se legitima evitando una catástrofe” (Assmann 2005 [1996], p. 133). Esta catástrofe sería la crisis del Primer Periodo Intermedio que, al sostenerse en la memoria, permite en el presente afirmar que es aquello que la dinastía puede evitar.

En Profecía de Neferty y en Admoniciones de Ipuwer se crea este mito profético de un mito-histórico de la Edad Oscura (Morenz 2003, p. 108). En Profecía de Neferty puede leerse: "Te muestro al propietario en la indigencia, en tanto que el extranjero está satisfecho. Aquél que ni tenía para llenar por si mismo (sus graneros), se encuentra (ahora) despojado de sus recursos" (Lefebvre 2003 [1982], p. 118). Mientras que en Admoniciones de Ipuwer se encuentran referencias de este tipo: "Mira, esto es lo que le ha ocurrido a la gente: el que no podia construirse una casa para si mismo ahora es poseedor de murallas... Mira, 
el poseedor de riquezas pasa la noche sediento y el que mendiga sus desperdicios es abora poseedor de cuencos desbordantes de cerveza" (Serrano Delgado 1993, p. 83).

La literatura construye una nueva semántica política como herramienta del Estado. Su función es la legitimación de su poder. Los acontecimientos políticos ocurridos durante del Primer Período Intermedio indicaban que era una situación que no podía volver a ocurrir. Así, esta etapa se constituía como una lección que no debía olvidarse, el pasado era una carga que debía afrontarse y no repetirse. Los textos como Profecía de Neferty y Admoniciones de Ipuwer muestran la cara aleccionadora del pasado, recordando qué factores podían alterar el orden social. En el caso de los relatos del papiro Westcar, se recuerda un pasado lejano que no formaba parte de la memoria reciente de la sociedad, y el recuerdo del origen de la dinastía $V$ es una lección de lo correcto, de lo que sí debía ser.

Los dos últimos relatos del papiro Westcar son una narración mítica del recuerdo. Lo que se simboliza y rescata del pasado no es el caos del Primer Periodo Intermedio, sino su situación previa. El recuerdo literario que están narrando no posee la intencionalidad de mantener en la memoria un pasado trastocado. El relato del papiro Westcar pretende construir una legitimidad para el presente a través del recuerdo de una época dinásticamente estable, justificándose por medio de otros argumentos retóricos narrados en él. Desde este punto de vista, los relatos del papiro Westcar son únicos y encontramos en ellos una representación literaria del Reino Antiguo.

En la memoria inscripta en el papiro Westcar quedó la huella de procesos políticos, religiosos y sociales -cambios y decisiones- ocurridos durante el Reino Antiguo y que terminan de afianzarse en el Reino Nuevo. Por un lado, nos referimos al paso de la teocracia identitaria a la teocracia representativa del rey (Assmann 2005 [1996], pp. 235-237). En este traspaso político y religioso, el dios Ra se constituye como padre de los faraones en Egipto. Los relatos del papiro Westcar recuerdan que dichas modificaciones se hacen profundas y definitivas -provocando un cambio dinástico- en la dinastía V. A su vez, hay una simbolización de cómo es la nueva dinastía divina. Se recuerda a los tres primeros faraones de la dinastía V como 
hermanos, y desde su origen está creada la sucesión de gobiernos, el orden es lo que los caracteriza.

La codificación de un pasado ordenado en los dos últimos relatos del papiro Westcar, se contrapone al recuerdo del Primer Periodo Intermedio. Todos estos textos muestran los diferentes modos de concebir el pasado que los egipcios construyeron para sí: orden- caos- orden. Por un lado está el Reino Antiguo con la transición a la dinastía $\mathrm{V}$, una dinastía divina y ordenada. Por otro Neferty e Ipuwer que expresan el caos. En éstos su presente nuevamente es el orden, un orden que se construye en base a la legitimación del ciclo mítico que está siendo cumplido, de ahí la necesidad de codificar el pasado.

Hemos dejado para el final Lamentaciones de Khakheperresenebu, ya que si bien expresa el recuerdo codificado del pasado como Ipuwer y Neferty, también hay un profundo cuestionamiento a la repetición, planteándose la necesidad de un "nuevo lenguaje". Khakheperresenebu enuncia una gran angustia: las palabras conocidas con anterioridad y ya pronunciadas no le son útiles para expresarse, para demostrar sus emociones. Los sentimientos que Khakheperresenebu padece son causados por el estado de penuria y confusión que atraviesa Egipto (Coletta 2008) durante el Primer Periodo Intermedio. En el texto puede leerse: “ $¡$ Ah! Si yo dispusiera de discursos desconocidos, versos extraordinarios, en un lenguaje nuevo (todavia) no manifestado, libre de repetición, no expresado por la tradición, (de) lo que ha sido dicho por los ancestros. Purgaría mi cuerpo de lo que está en él, al dejar salir todas mis palabras, porque, por cierto, lo que (ya) ha sido dicho (sólo) puede ser repetido. Lo que ha sido dicho, dicho está, no son para jactarse las palabras de los ancestros descubiertas por los que vinieron después" (Coletta 2008).

Lo que estas palabras manifiestan es totalmente atípico en la literatura egipcia. Lo que Khakheperresenebu está pidiendo es renovación y no repetición. Esta idea de novedad y transformación que pretende el sabio se resume en sus propias palabras: “...lo que (ya) ha sido dicho (sólo) puede ser repetido...” (Coletta 2008). Lo que entra en el universo cosmogónico de la repetición es todo lo que ya ha sido creado. A pesar de que el escriba se da cuenta de la necesidad de un nuevo lenguaje, a pesar de sus críticas, él mismo no puede alejarse de las fórmulas conocidas, sus palabras terminan siendo similares a las de otras lamentaciones (Coletta 2008). Según Vernus 
(1995) el pensamiento fundamental que nos transmite Lamentaciones de Khakheperresenebu es la refutación de la idea tradicional de que el presente se dedica a la repetición del pasado, lo que el autor llama ideología faraónica, siendo la idea central del texto que "el presente es irreductible al pasado" (Vernus 1995, \$6-7). Según Kadish (1973, p. 88) la verdadera tragedia de Khakheperresenebu es darse cuenta de la necesidad de nuevas palabras y no poder lograrlo.

\section{Memoria cultural}

Un condicionante de la memoria colectiva son los límites temporales, esto es la incapacidad de recordar más allá de una o dos generaciones. Esto significa que no se puede (res)guardar, acceder, construir e interpretar mediante la memoria pasada temporalmente más de dos generaciones. Sin embargo en los dos últimos relatos del papiro Westcar, el recuerdo va mucho más allá de este límite generacional, remitiéndose a un pasado lejano. Entre el momento de escritura de los relatos del papiro y el tiempo del argumento literario hay aproximadamente 600 años de diferencia. En este caso, la memoria puede ser juzgada más como imaginación que como recuerdo.

El paso del tiempo desvirtúa todo sentido de pertenencia directa del recuerdo con el pasado. El presente pierde todo marco referencial con el pasado lejano. Al momento de estudiar la memoria, Assmann (1997; 2008) reparó en esta problemática e introdujo el concepto de memoria culturaß ${ }^{315}$. A través de la memoria cultural se puede acceder al pasado más remoto, pues con este tipo de memoria "la cultura se hace consciente de la profundidad del tiempo y desarrolla de inmediato

\footnotetext{
315 En realidad la "invención" del concepto memoria cultural también debe ser adjudicado a Aleida Assmann, el propio Jan Assmann (2008, p. 140) reconoce que el concepto de texto cultural adeuda gran parte de la obra de Aleida Assmann. El interés por la memoria como dispositivo mental y cultural del matrimonio Assmann se desarrolla a partir de las discusiones que se dieron en Alemania tras el Holocausto. Aleida Assmann desde una perspectiva más psicoanalítica es la primera que empieza a indagar sobre los aspectos culturales de una sociedad en la formación de memorias compartidas, por ejemplo en una publicación del año 1998, sobre la cuál Jan recurre en más de una oportunidad, "Estabilizadores del recuerdo. Afecto, símbolo, trauma", la autora analiza los estabilizadores del recuerdo, tanto internos como externos a la memoria, siendo los aspectos culturales trascendentales.
} 
una idea de simultaneidad cultural que permite identificarse con las formas de expresión de un pasado milenario...” (Assmann 2008, p. 48).

La memoria cultural traspasa el tiempo generacional porque su recuerdo se posiciona tanto en el consciente como en el inconsciente de la sociedad ${ }^{316}$. Según interpreta Assmann el inconsciente no se devela en la tradición, pues si a ella se la comprende en su sentido convencional no tiene en cuenta la renovación, no es innovadora, es lo que se canoniza e impide el cambio en la continuidad cultural (Assmann 2008, p. 45 y p. 60). Por ejemplo, en Lamentaciones de Khakheperresenebu el sabio reclamaba renovación, pero según Assmann (p. 1997, p. 69) alcanzar algún tipo de innovación significaría olvido, pues se han perdido en la sociedad todas las condiciones de almacenamiento del conocimiento, de producción y guardado de memoria, como así también su acceso.

El olvido se supera con la memoria cultural que al acceder al inconsciente, logra recuperar lo que una sociedad crea como ideario de lo que debe ser y no ser, que se simboliza pero que no se codifica (Assmann 2008, pp. 58-59). La imagen de lo sagrado es uno de los elementos más visibles que dan cohesión al cuerpo social. La memoria cultural que "expande y reproduce una conciencia de unidad, particularidad y co-pertenencia entre los miembros de un grupo" (Assmann 2008, p. 59) se vale también de aspectos inconscientes de la transmisión y la transferencia intergeneracional, que la sociedad archiva. Este archivo es en primera instancia, una noción que señala el pasado, "debería poner en tela de juicio la venida del porvenir" (Derrida 1995, p. 41), es decir el futuro que se está construyendo.

En la memoria cultural, que recuerda un pasado figurado simbólicamente, la historia de facto viene transformada en una historia recordada. El mito es el modo en que se recuerda este pasado (Assmann 1997, p. 26). Assmann (1997, p. 27) define por mito como "una historia fundante, una historia que es recordada para aclarar el presente a la luz de los orígenes". A través del mito la historia relatada y recordada se transforma en una historia real; se alcanza la actualización del recuerdo, lo que implica también la actualización de la identidad colectiva mediante el ritual.

\footnotetext{
316 Este aspecto, Assmann lo reconoce como deudor de la teoría freudiana.
} 
El concepto de memoria cultural nos permite abordar los dos últimos relatos del papiro Westcar, como una fuente de análisis de la política que se está construyendo en el Reino Medio. Asimismo nos habilita a analizarlos como textos literarios que responden a un marco histórico contextual presente y desde el tiempo que retoman y delinean la cultura egipcia. La memoria no es arbitraria en la selección del pasado, tampoco lo es dentro de los parámetros culturales. Pues "la tradición no es enteramente una repetición mecánica de las formas antiguas..." (Kemp 2004, p. 133); es decir, existe modificación, invención y selección en el recuerdo. Por lo tanto, hay que comprender a los textos literarios dentro del movimiento mismo que la cultura trae aparejada, y en ese devenir entender la memoria misma.

En este sentido, en los relatos del papiro Westcar las imágenes, símbolos y representaciones que se construyen traen consigo una vuelta al pasado para "rescatar" los vínculos existentes entre la realeza y el culto heliopolitano, al dios Ra. Al mismo tiempo, no se apartan de la cosmovisión con la cual la sociedad se piensa a sí misma, esto es el discurso mítico. Los dos últimos relatos del papiro Westcar recuerdan los hechos del pasado expresándose de modo análogo a los mitos de origen del rey. De este modo, se recuerda y se reactualiza la legitimación de la dinastía por ser hija del dios.

Es por ello que la vuelta al pasado responde a una dinámica cultural, en la cual el recuerdo se reacondiciona hacia el presente político. Al ser también cultural la memoria es parte del discurso mítico de la sociedad. Por ejemplo, observamos en la figura del rey como representante del dios que si bien el epíteto $s 3 r^{\complement}$ puede interpretarse como la culminación de un proceso de identificación de la realeza con el culto a $\mathrm{Ra}$, la relación que se recuerda tras de sí trae aparejado un proceso que es dinámico. Es al mismo tiempo, una identificación que se reactualiza en las dinastías XII y XIII cuando se crea una representación mítico-literaria del origen de la dinastía $\mathrm{V}$.

El pasado que se recuerda es trasmitido en la memoria futura de los relatos del papiro Westcar en sentido de y como un mito. El origen es el que marca el conocimiento del pasado, y su comprensión es la que configura todo el sentido de 
ser del presente y del futuro, en última instancia el contexto histórico y marco social que impulsa a recordar.

\section{Memoria futura}

El recuerdo parte desde el presente. Ricœur (1999, pp. 25-30) retomando a Platón afirma que la memoria es "la presencia de una cosa ausente", es decir que la relación se da entre el pasado -lo ausente- y el presente momento en el que se está recordando. El presente es el que impone los marcos sociales y contextuales. Pero a esto hay que añadirle un tiempo más, pues "podríamos decir que recordar consiste en configurar en el presente un acontecimiento pasado en el marco de una estrategia para el futuro, sea inmediato o a largo plazo" (Candau 2002, p. 31).

La memoria misma lleva implícito el futuro del tiempo presente, pasado que se está recordando (Candau 2002, p. 33). Es decir, el tiempo que la memoria percibe en el recuerdo no es únicamente el momento pasado al que alude concretamente, sino todas las sensaciones a futuro que marcaron ese tiempo presente-pasado, futuro que es también pasado cuando se recuerda. Por esta razón, dice Candau (2002, p. 33) "no podemos recordar un hecho pasado sin que el futuro de ese pasado se integre a su recuerdo...el tiempo del recuerdo no es el pasado, 'sino el futuro-ya-pasado-del-pasado" ".

En los relatos del papiro Westcar, la memoria incorpora este tiempo: el futuro ya pasado del pasado. En el manuscrito la memoria es un proceso que se imprime literariamente, puede decirse que "lo literario" es el medio empleado para su expresión. En un plano narrativo el pasado, el presente y el futuro son elementos partícipes en el relato, pudiéndose construir un continuum del tiempo en la narración.

El presente literario es la dinastía IV. Los tres primeros son relatos del pasado. En la corte del rey Keops, los hijos del rey cuentan a su padre historias protagonizados por reyes anteriores a Keops. Desde ese presente literario, los hijos recuerdan acciones de magos y faraones. El cuarto relato continúa en la corte de Keops, donde el mago Djedi incorpora un nuevo tiempo a la narración: el futuro. La predicción de Djedi relata "aquello que sucederá", o sea el nacimiento de tres niños 
hijos del dios Ra y Reddjedet. Ese futuro construido literariamente es el presente de la acción en el anexo al cuarto relato, que concretamente narra el nacimiento de los trillizos. Por lo tanto, el futuro vaticinado por Djedi se hace realidad literariamente.

Para el autor de los relatos del papiro Westcar estos tiempos construidos literariamente poseen una característica particular, todos ellos son pasados históricos. Sabemos que los acontecimientos narrados por el autor de los relatos del papiro Westcar son parte de su pasado porque en cada mención que realiza del faraón Keops emplea el epíteto "justificado". Este siempre es utilizado cuando se menciona a un personaje real o no real que ya ha muerto. Ya sea que el autor se posicione en algún momento del Reino Nuevo, o más cercanamente al periodo hicso, las dinastías III, IV y V son sus pasados históricos.

Es decir, el narrador está posicionado en un tiempo posterior al de los hechos relatados y el relato es sobre el pasado, por ello hablamos de memoria. A su vez, es una memoria cultural, pues en la narración literaria el recuerdo supera los límites generacionales de la memoria colectiva, y el propio relato se funde con el mito para confluir con la tradición de que el faraón es hijo del dios. Este proceso de memoria narrativamente expresada es lo que llamamos memoria futura. Con este concepto podemos expresar que el recuerdo del pasado en la narración literaria es una anticipación a futuro, que ya es pasado para los creadores de la obra literaria.

Es posible visualizar una línea temporal que es literaria, que se entrecruza con la línea temporal histórica. Lo que en el relato literario se narra como futuro y desenlace de la obra -el nacimiento de los trillizos- es un origen mítico para el presente histórico del autor. Sugerimos entonces, que si ese presente es la dinastía XII, hay en ella un intento por sostener en el recuerdo ese pasado idealizado. Durante el Reino Medio el poder tendió a reconstituir modelos del pasado. Si el Primer Periodo Intermedio se convirtió en una Edad Oscura (Morenz 2003, p. 108), el Reino Antiguo -en especial la dinastía V- fue un modelo a imitar. 


\begin{tabular}{|c|c|c|c|c|}
\hline & $\begin{array}{l}\text { Tiempo } \\
\text { narrativo } \\
\text { pasado }\end{array}$ & $\begin{array}{l}\text { Tiempo } \\
\text { narrativo } \\
\text { presente }\end{array}$ & $\begin{array}{l}\text { Tiempo } \\
\text { presente del } \\
\text { autor }\end{array}$ & $\begin{array}{l}\text { Tiempo } \\
\text { narrativo } \\
\text { futuro }\end{array}$ \\
\hline Primer relato & $\begin{array}{l}\text { dinastía III, } \\
\text { Socere? }\end{array}$ & dinastía IV & & \\
\hline Segundo relato & $\begin{array}{l}\text { dinastía III, } \\
\text { Nebka }\end{array}$ & dinastía IV & & \\
\hline Tercer relato & $\begin{array}{l}\text { dinastía IV, } \\
\text { Snefru }\end{array}$ & dinastía IV & & \\
\hline Cuarto relato & & dinastía IV & $\begin{array}{l}\text { dinastías XII y } \\
\text { XIII }\end{array}$ & $\begin{array}{l}\text { dinastía V- } \\
\text { Nacimiento de } \\
\text { los trillizos: } \\
\text { memoria futura }\end{array}$ \\
\hline Relato anexo & dinastía IV & $\begin{array}{l}\text { dinastía V- } \\
\text { Nacimiento de los } \\
\text { trillizos }\end{array}$ & & \\
\hline
\end{tabular}

CUADRO VI. Entrecruzamiento del tiempo narrativo con el tiempo presente del autor en los relatos del papiro Westcar 
A través de los relatos del papiro Westcar, deducimos que esta dinastía constituía en la memoria cultural egipcia un ideal de gobierno ordenado. También la sucesión dinástica que se narra sin ningún sobresalto político, es la expresión de un orden deseado, alcanzado gracias a que ha intervenido el dios. La continuidad fue un punto destacado dentro del pensar y sentir el paso del tiempo en la sociedad antiguo egipcia, se creaba un modelo de lo que debía hacerse mediante la repetición. Como fuente de autoridad y autenticidad, el interés por el pasado quedó demostrado en la administración, en la actitud piadosa del rey y en la explicación intelectual que se daba al momento en que el tiempo y el cosmos se encontraron (Kemp 2004, pp. 28 y ss.).

Sin embargo, la dinastía $\mathrm{V}$ no fue únicamente una imagen respetada $\mathrm{y}$ emulada por su constitución divina, sino también en otros aspectos. En este sentido, Assmann (2005 [1996], p. 83) nos recuerda que cuando los reyes del Reino Medio construyeron pirámides, no tuvieron como modelo las de Guiza de la dinastía IV, sino que imitaron las más pequeñas como la de Unas (dinastía V) o la de Pepi II (dinastía VI). Si bien eran más reducidas en tamaño, habían alcanzado la perfección al tener el templo adosado a su cara este, templo que adquiere su forma canónica durante la dinastía V. Además, como ya hemos visto, la construcción de obeliscos en los templos solares por parte de los faraones de la dinastía V, estaba en consonancia con la idea que el papiro Westcar también recuerda: "que el rey no se encarnaba en el dios, sino seguía un modelo constelativo al ligar el culto funerario con el culto divino" (Assmann 2005 [1996], p. 83).

Baines (1996, p. 368) argumenta que Cuento de El Náufrago es el relato literario del Reino Medio en el cual se puede encontrar el uso más extensivo del mito, formándose una estructura del "relato dentro del relato"317. Según el autor se construye una visión del futuro transformada en una narrativa acerca del pasado. A pesar de que el pasado es narrado como un pasado cercano en el tiempo, de hecho hay un distanciamiento espacio-temporal de la estructura y del contenido del relato, que habilita a que en él se elabore un sentido del pasado y futuro absolutos.

\footnotetext{
317 La misma que proponemos para los relatos del papiro Westcar, según veremos en próximos capítulos.
} 
Conjuntamente, se produce una alianza con el mito que converge en un tiempo mítico, lo que a su vez le da un carácter ficcional al texto al modificarse un contenido potencialmente histórico en uno mítico-literario.

Algo similar podemos analizar para los relatos del papiro Westcar. Con la memoria futura designamos el distanciamiento espacio-temporal que se produce entre el autor y lo narrado. Por cuanto los hechos narrados y mitificados en los dos últimos relatos del papiro Westcar son un pasado histórico para el autor. La diferencia principal entre este relato y Cuento de El Náufrago es que en el papiro Westcar, hay referencias históricas específicas dentro de la ficción. Se acude al recurso de apelar al pasado, con la utilización de nombres de personajes históricos (no ficcionales) como protagonistas.

Desde esta perspectiva Posener (1956, p. 28) piensa a Profecía de Neferty, como un texto post eventum (Lefebvre 2002 [1982], p. 112; Cervelló Autuori 1996a, p. 192), lo cual puede hacerse extensible para relatos como Admoniciones de Ipuwer o Lamentaciones de Khakheperresenebu. Según Posener, en un texto post eventum se construye una narración literaria que se centra en acontecimientos pasados como marco temporal de la ficción. La memoria tiene como característica que el pasado histórico es narrado como acontecimiento a futuro, como profecía.

En Profecía de Neferty se pronostica la llegada de un rey salvador Ameny, probablemente Amenemhat I, personaje que habría sido contemporáneo o pasado para el autor de la obra. Mientras, en los dos últimos relatos del papiro Westcar, Djedi anuncia la consagración de una nueva dinastía con el nacimiento de trillizos, que serán los tres primeros faraones de la dinastía V. Nuevamente el autor se ubica en un tiempo cercano o contemporáneo a los hechos que se relatan, que sin embargo, son narrados literariamente como "aquello que sucederá". Hemos dicho que en el anexo al cuarto relato del papiro Westcar ese futuro ficcional se concreta en un presente ficcional. En cambio, en Profecía de Neferty, la concreción del futuro literario solamente se rescataría en lo histórico. Ello porque el cumplimiento de la profecía de Neferty, únicamente puede comprobarse si aceptamos que Ameny es un nombre con el cual identificar al faraón Amenemhat I. 


\section{La narración literaria y la selección de los hechos del pasado}

Con la memoria futura observamos como en un texto se construye literariamente el recuerdo del pasado. Halbwachs afirma que el recuerdo procede a la reconstrucción del pasado. Es decir que no existe el pasado en sí, sino el pasado recordado (Assmann 2005 [1996], p. 137). Al no tener el pasado histórico sentido en sí mismo, el sentido y el valor que se imprime sobre él proceden de los sujetos humanos que lo están recordando; de ahí derivan las diferentes interpretaciones sobre los hechos (Todorov 2002 [2000], p. 211).

El futuro asigna otro límite al recuerdo. Solamente se recuerda aquello que es válido en términos de utilidad hacia el futuro que quiere construirse. Desde esta perspectiva, el pasado es (re)construido y (re)interpretado; la memoria selecciona los hechos del pasado (Todorov 2000, p. 16). Los sentidos del pasado son creados por los interrogantes y necesidades del presente, están marcados por las diferentes interpretaciones que se han producido sobre los acontecimientos, integrándose las expectativas a futuro en dicha (re)elaboración.

En palabras de Todorov "algunos rasgos del suceso serán conservados, otros inmediatamente o progresivamente marginados, y luego olvidados". Quienes tienen en sus manos qué elementos serán recordados son los miembros de la sociedad que tienen el poder. En este mismo sentido Florescano (1997 [1980], pp. 93-94) resalta que la reconstrucción del pasado por la clase dominante ha sido siempre un instrumento de dominación indispensable. En el Egipto del Reino Medio hallamos una clase, en la que se encuentran los escribas, que puede recurrir al recuerdo del pasado, tiene la facultad de elegir qué se recuerda y cómo se recuerda. En este sentido Petrucci (2002, p. 123) apela a lo que Le Goff definía como memoria: "uno de los lugares de la ideología y, a través de la representación del pasado que ella presenta, contribuye a justificar el presente y proyectar el futuro en una perspectiva social”.

Los condicionamientos de la memoria imponen qué recordar sobre el pasado. El contexto histórico en el cual se encuentra posicionado el grupo que recuerda impone un límite, pues se ponen en juego ideas y valores que priman en ese momento, y no los que estaban en el pasado. Desde esta perspectiva, se deja de 
lado la idea de una memoria individual, para pensarla colectiva y cultural. Tal como lo afirmábamos, es la memoria colectiva de un grupo político la que tiene el poder sobre el recuerdo. Los marcos entre los cuales la memoria encuentra sus límites son sociales. En este caso el colectivo social lo representa la clase dominante, siendo que sus preocupaciones sobre el presente son las que impulsan a reflexionar y a recordar ciertas cosas en detrimento de otras, y los intereses sobre qué recordar se van alterando en tanto el grupo se modifica (Halbwachs 2004a, [1925] p. 167).

Podemos pensar esto en relación a los textos literarios egipcios. Si bien ellos refieren al pasado, no representan la memoria del conjunto de la sociedad, sino la de un grupo de hombres que tenían el conocimiento exclusivo de la escritura. Este es un claro condicionamiento del recuerdo, por un lado porque no accede el conjunto de la sociedad a decir qué y cómo debe recordarse, y por otro, porque la selección de los acontecimientos implica un uso para este grupo político. A partir de las disputas de qué recordar, es que la memoria colectiva ha sido objeto de poder. Apoderarse de ella y del olvido ha sido uno de los principales objetivos de las clases dominantes, en cuanto que pueden manipular la selección del recuerdo. Por ende, según Le Goff (1991 [1971], p. 134) la memoria colectiva revela los mecanismos de manipulación.

Bowman y Woolf (2000, pp. 17-23) analizan la relación entre la palabra escrita y el poder. Para los autores se producen dos tipos de vinculaciones, una es el poder ejercido sobre los textos, la otra el poder ejercido mediante el uso de los textos.

La primera refiere principalmente a las restricciones de circulación, lectura y acceso a la palabra escrita, que es manipulada por un grupo de personas para legitimar su conducta. Además, se determina cuál debe ser la lectura "autorizada" o "correcta" de un texto. Dentro de este marco, se ponen en juego las interpretaciones de lo escrito, "las relaciones del pasado son también objeto de esta clase de manipulación, tanto como lo son las profecías sobre el futuro" (Bowman y Woolf 2000, p. 19). En relación a los dos últimos relatos del papiro Westcar, se refiere a la mención de personajes históricos en los textos literarios, y hasta qué punto estos eran conocidos por la audiencia que los recibía. Ya hemos dicho que el uso de personajes históricos era un recurso más de apelación al pasado por parte del 
escritor, y que su uso establece una visión de cómo era ese pasado, y cómo debía ser recordado.

El segundo vínculo entre la palabra escrita y el poder es aquel que se ejerce mediante los textos. Ello alude a la legitimación de las acciones del presente mediante la interpretación o la reinterpretación de un pasado, que algunas veces puede ser desconocido (Bowman y Woolf 2000, p. 20). En esta perspectiva los textos literarios egipcios como Profecía de Neferty, Admoniciones de Ipuwer o los relatos del papiro Westcar, configuran diferentes interpretaciones sobre el pasado. Si bien la línea de reelaboración del pasado parece ser unívoca - tendiente a legitimar el presente de la dinastía XII- está claro que esta justificación del poder se basa sobre dos pasados: el del Reino Antiguo como modelo ordenado a continuar y emular, y el Primer Periodo Intermedio como el pasado caótico superado.

Es por ello que en la selección de los hechos del pasado se (re)construye un simbolismo del mismo. Retomamos aquí lo que analizábamos en los primeros capítulos. Esto es que los dos últimos relatos del papiro Westcar no pretenden la reconstrucción histórica de los acontecimientos, sino que son el recuerdo literario del pasado. En este recuerdo se elige el modo en que el pasado quiere ser reconstituido en el presente: el mito literario es el recurso para expresar que la dinastía $\mathrm{V}$ tuvo un origen divino, que sus tres primeros faraones fueron hermanos, hijos de Reddjedet -la esposa de un sacerdote- y el dios Ra.

\section{E1 recuerdo del origen. Acuerdos y discrepancias entre Listas Reales y los relatos del papiro Westcar}

Las percepciones sobre el transcurrir del tiempo son una construcción cultural (Assmann 2005 [1996], pp. 21 y ss.). Cada sociedad ha elaborado un modo de pensar, transmitir, observar y producir el paso del tiempo. Y ello está íntimamente ligado al recuerdo del pasado, y a los diferentes modelos interpretativos sobre él. De esta forma, el tiempo cultural supera la dicotomía entre tiempo cíclico y 
tiempo lineal si se acepta la propuesta de Eliade (2006 [1949])318; o la oposición entre sociedades frías y sociedades calientes si lo ponemos en los términos expuestos por LéviStrauss $(1981 ; 1984)^{319}$.

Los egipcios expresaron su percepción sobre el paso del tiempo mediante dos concepciones, que si bien se excluyen mutuamente son constituyentes de una misma realidad (Galán 2004, p. 39). Como analiza Galán en su artículo "El paso del tiempo y el recuerdo del pasado en el antiguo Egipto”, una es la concepción cíclica del tiempo, expresada principalmente en textos de carácter funerario y religioso. La otra es la concepción lineal, formulada en lo que Galán denomina un contexto laico o civil. Lo concluyente para el autor es que los egipcios miraban constantemente hacia el pasado, "eran conscientes de que para entender su realidad debían conocer el pasado, pues el estado de las cosas en el momento presente era consecuencia de una situación anterior" (Galán 2004, p. 43).

La existencia de un tiempo cíclico fue expuesta por Vernus (1995) en términos de ideología faraónica. Según el autor, ésta se caracterizaba por la repetición de un modelo de referencia, el origen, dándose en la sociedad egipcia un esfuerzo constante por interpretar el curso del tiempo, no como una sucesión de eventos siempre diferentes unos de otros, sino, como la repetición ininterrumpida de lo que se ha puesto en marcha durante la Primera Vez, edad de la creación y en la de los dioses en la tierra (Vernus 1995, \& 7 ) 320.

\footnotetext{
318 Recordemos que los análisis de Eliade (1992 [1963]; 2006 [1949]) han concluido que el transcurrir del tiempo percibido por los hombres en las sociedades antiguas -como la egipcia- no era más que la repetición del acto primordial y mítico realizado por los dioses, trasformado en arquetipo que se repite una y otra vez. Este tiempo cíclico se opone al tiempo lineal, la percepción moderna del transcurrir del tiempo en la cual se construye una línea del tiempo en que los acontecimientos se anteceden y suceden los unos a los otros.

319 Según el autor ninguna de estas dos formas se encuentra en estado puro. En las sociedades frías su medio externo está cercano al cero de la temperatura histórica (Lévi- Strauss 1981, p. 32). Ellas pretenden congelar los efectos que los acontecimientos históricos pudieran tener en su equilibrio y continuidad (Lévi- Strauss 1984, p. 339), por lo que su meta es resistir a la modificación de su estructura (Lévi- Strauss 1981, p. 32). Sólo lo alcanzan parcialmente, son las instituciones de la sociedad las que ejercen una función reguladora para prevenir la formación de un acontecimiento (Lévi- Strauss 1984, p. 341). Por otro lado, las sociedades calientes han interiorizado su historia, y la constituyen como el motor de su desarrollo, caracterizado por la necesidad incontenible de cambio y modificación (Assmann 2005 [1996], p. 25).

320 Lo que aquí analiza Vernus nos recuerda lo que Lévi- Strauss planteaba con relación a la resistencia que las sociedades frías ponen a la irrupción del acontecimiento en la estructura. Según
} 
La construcción del tiempo cíclico o del tiempo lineal fue expresada en diferentes textos; entre los que veremos se destacan los literarios y Listas Reales. Si bien lo común en todos ellos es -como decía Galán- la referencia al pasado, veremos que la dicotomía fue sentida y expresada por los egipcios, trasluciéndose en los textos las diferentes concepciones sobre el transcurrir del tiempo, y de recordar el pasado.

El origen mítico, aquel creado y vivido por los dioses, es siempre una referencia a un pasado lejano. Este tiempo de la Primera Vez es aquel que permitía el acontecer actual (Eliade 2006 [1949], pp. 31 y ss.). Por ejemplo, las Listas Reales como la Piedra de Palermo, Cánon de Turín o Lista Real de Abidos están creadas con una misma idea: la linealidad de reinados. Dioses y faraones formaban una misma línea de tiempo, en la cual el monarca actual era el heredero del gobierno creado por los dioses. De este modo, no se destacaba una trascendencia individual del rey, sino que éste se posicionaba como un arquetipo: cada faraón es rey al igual que el anterior, que, al mismo tiempo -y como todos los monarcas- es equivalente al reinado del dios. Es así como la linealidad se lee como circularidad del discurrir del tiempo (Salem 2011), dejándose sin contenido al devenir histórico (Lévi- Strauss 1984, pp. 340 y ss.).

Para los egipcios el pasado que se refleja en Listas Reales "era un modelo del orden, la sucesión continua y casi totalmente pacífica de los reinados de los faraones anteriores, cada uno de los cuales cedía el trono a su sucesor sin que hubiera interrupciones en la línea dinástica" (Kemp 2004, pp. 29-30). En el mismo sentido Sist (2008, p. 27) afirma que el mensaje de continuidad fue la imagen más importante sobre el pasado que construyó el Reino Nuevo. Sin embargo, en los dos últimos relatos del papiro Westcar, que para muchos autores han sido escritos durante el Reino Medio, sabemos que se narra literariamente el nacimiento de tres niños hijos de Ra que conforman una línea dinástica, similar a Listas Reales. En el texto puede leerse que Djedi le dice al rey Keops: "Piensa tu bijo, luego su bijo, luego uno de ellos" ( $(2 W .9 .15)$. Con estas palabras Djedi anuncia cuál es el orden lineal de

Vernus (1995 \8) la visión egipcia del mundo es ahistórica. Los eventos no son percibidos como una sucesión de hechos. 
monarcas que gobernaron y gobernarán sobre las Dos Tierras, esto es: Keops, el hijo de Keops, el nieto de Keops, Userkaf, Sahura y Neferikara Kakai.

Como ya hemos explicitado, en los dos últimos relatos del papiro Westcar se relata el origen de la dinastía $\mathrm{V}$, mientras que Listas Reales rememoran el origen de la monarquía desde sus inicios, recrean las ideas de las teologías, en las cuales primero reinaron los dioses. Sin embargo, ambos son una narración mítica, pues los relatos del papiro Westcar se homologan con el mito de origen del rey. En última instancia todos los relatos están en consonancia con el recuerdo de un pasado que se convierte en modelo. Por un lado, modelo de legitimación de la realeza a través del énfasis en su naturaleza divina, ya sea porque es heredera del gobierno de los dioses o por ser hija del dios. Por otro, porque el modelo es el que justifica el presente, el orden plasmado en una sucesión ordenada.

Sobre esto último también hay una coincidencia de interpretación y recuerdo del pasado, esto es, la visión sin interregnos políticos, adecuándose al sentir continúo de un tiempo sin interrupciones, que viene dado de los orígenes mismos. La disposición de linealidad de dinastías en la Piedra de Palermo transmite un ideal de orden, modelo de continuidad pacífica sin perturbaciones que los egipcios poseían con relación al pasado y que querían transmitir (Kemp 2004, p. 28) ${ }^{321}$. Asimismo en Lista Real de Abidos y en Lista Real de Abidos de Ramsés II ${ }^{322}$, el recuerdo omite algunos gobernantes, aquellos que corresponderían a los periodos de debilidad y divisiones internas en Egipto (Kemp 2004, p. 30).

Es decir, opera la selección del recuerdo, qué es válido y qué no es posible rememorar en función del presente. La omisión de algunos gobernantes reafirma el ideal y modelo del pasado que tenían los egipcios, más allá de las irrupciones que de hecho se dieron en la centralización del gobierno monárquico (Salem 2011). En el caso de los dos últimos relatos del papiro Westcar sucede algo similar. La línea histórica que se recuerda literariamente no es fiel a los acontecimientos históricos.

\footnotetext{
${ }^{321}$ La Piedra de Palermo al ser la primera evidencia que se ha encontrado que expresa la idea de continuidad con el pasado, algunos historiadores la han considerado como un prototipo y un modelo de registro de las futuras Listas Reales.

322 Una reproducción del texto jeroglífico en KRI II, pp. 539-540. Una traducción en inglés en RITA II, pp. 348-349.
} 
Pues, si sólo tres faraones siguieron al reinado de Keops se omiten al menos dos reinados. Además, cuenta que a los tres primeros de la dinastía $\mathrm{V}$ los une una relación de hermandad, lo que no se corresponde con la realidad histórica.

\section{Representaciones del pasado en los relatos literarios del Reino Medio}

Una de las características de los textos literarios del Reino Medio es que en ellos abundan las referencias al pasado, ya sea de un pasado alejado o cercano (Morenz 2003, p. 103). Encontramos referencias a pasados lejanos, en Profecía de Neferty, Admoniciones de Ipuner, Lamentación de Khakheperresenebu, entre otros. Recordemos que en estos textos se construye un recuerdo codificado del pasado y se supone el Primer Periodo Intermedio como una época caótica que logró ser superada gracias a las acciones del presente. Mientras, los relatos del papiro Westcar construyen un pasado mítico, el origen de la dinastía $\mathrm{V}$.

Con relación a las referencias a un pasado reciente en Cuento de Sinubé puede leerse al iniciarse el relato, en el momento que el protagonista hace alusión al rey a quien sirve: "Yo soy un asistente, quien sigue a su señor, y sirviente de la dependencia real de la noble, rica en favores, esposa del rey Sesostris, Jenumsetm hija del rey Amenembat en Kaneferu, la venerada Nefertu” (Galán 1998, p. 82).

Es por ello que Morenz (2003, p. 104) interpreta que esta introducción en Cuento de Sinubé se relaciona directamente con las autorepresentaciones o autobiografías, lo que ya había sido detectado por Galán (1998, p. 76). Ya hemos analizado las autobiografías como posibles antecedentes de los textos literarios del Reino Medio. Por ejemplo, en Biografía de Uni pueden leerse las referencias y representaciones a un pasado cercano: "Jamás se habia hecho nada similar para ningún servidor..." o, refiriéndose a la relación que el protagonista tuvo con el rey, "Yo actué en todos los aspectos de acuerdo con aquello por lo que su majestad alabo" (Serrano Delgado 1993, pp. 168-171).

Este tipo de menciones son frecuentes en las autobiografías de los funcionarios que, si bien conforman una temporalidad que es lineal, esta linealidad nada tiene que ver con la de Listas Reales, pues en ellas al menos hay una muestra de 
relación directa con el origen mítico que trasciende y forma la realidad. Mientras en el caso de Sinuhé o las autobiografías, son una referencia al pasado individual (Salem 2011), lo que para Vernus (1995 \$9) se traduce en una consciencia individual.

Uno de los aspectos destacados con relación a las representaciones del pasado son las diferentes valoraciones que se expresan en los textos literarios. En las referencias que citaremos se observa que los egipcios no estaban interesados por conocer lo ocurrido, argumentando que en el pasado era difícil poder distinguir lo que verdaderamente ocurrió y lo que no.

En Profecía de Neferty el rey Snefru se encuentra en su palacio aburrido, y le solicita a sus servidores que le traigan a un hombre que pueda entretenerlo con bellas palabras. Como sabemos el hombre escogido para tal cometido es el sabio Neferty, quien le pregunta al faraón: "¿Tendrá que ser con respecto a lo que ha pasado, o bien con respecto a lo que debe llegar, soberano, V.P.S., mi señor? Y su majestad V.P.S. dijo 'Ciertamente que con respecto a lo que debe acontecer, si hoy mismo (algo) ha sucedido, pásalo por alto" (Lefebvre 2003 [1982], pp. 114-115). En este sentido, otro ejemplo son las palabras de Hordedef con relación al relato de sus hermanos: "[...] en el conocimiento de aquellos que pasaron no se sabe [distinguir] la verdad de la mentira. Hay bajo tu majestad en tu propio tiempo y es desconocido [...]”. ( $p W .6 .6$. 23-24)

Estas menciones son complejas considerando que algunos los textos egipcios tienen como parte de su esencia ser narraciones míticas, siendo que éstas hacen referencia al pasado. Podemos sugerir que lo mítico, al ser una realidad vivida como una experiencia cotidiana, no adquiere interés pues lo que se vive, se lo hace arquetípicamente, se repite. Lo que sí despierta mayor curiosidad es lo nuevo porque no se conoce, no se ha vivido. Es por ello que los textos literarios se construyen retóricamente como anuncios a futuro, a pesar que sabemos que el presente, el pasado y el futuro literario son para los autores pasados históricos.

Es aquí que el concepto de memoria futura adquiere una importancia transcendental. En ella, el pasado de los textos literarios aparece descripto en forma de predicción, presagio o profecía realizada por hombres sabios. El "hecho histórico" es incorporado al relato como anuncio de algo que ocurrirá. Pareciera no encajar en las estructuras míticas y pareciera no estar relacionado con relatos de 
hechos pasados que trascienden en la realidad. Según Cervelló Autuori (1996a, pp. 17-21) son los acontecimientos vividos como transcendentales los que se incorporan a las estructuras míticas.

\section{A modo de cierre}

En este apartado hemos analizado cómo se formaron, en relación a los acontecimientos políticos, los textos autobiográficos que han sido considerados por algunos investigadores como el antecedente directo de los textos literarios. De todos modos, hemos destacado la singularidad de la obra literaria en la ficcionalización del acontecimiento narrado. Así, los sucesos del Reino Antiguo o del Primer Periodo Intermedio se configuran más como inspiración, que como narración de una realidad.

La ficción se instauró en el Reino Medio como una novedosa herramienta de expresión que le fue útil a la monarquía para autolegitimarse. Así, para algunos investigadores los textos de la literatura "clásica" pueden leerse en clave de propaganda. Un concepto a nuestro entender poco operativo, tanto por lo obsoleto como por lo restrictivo del mismo en el análisis de los textos literarios.

Los textos literarios del Reino Medio formaron parte de un programa político de la monarquía, pero ello no se traduce en un mecanismo sistemático de elaboración literaria para legitimarla en el poder. Los procesos políticos que transcurrieron entre finales del Reino Antiguo y comienzos del Reino Medio son mucho más complejos, como para determinar un mero uso propagandístico.

La alianza producida entre recuerdo y literatura nos resulta más productiva para comprender los sentidos de los textos literarios. En ellos el recuerdo se codificó, es decir, el presente de la dinastía XII mantuvo el pasado vivo. Los modos en que la memoria limitó el recuerdo del pasado, a través del rescate de algunos acontecimientos y el descarte de otros, es que visualizamos la intención que pudo subyacer en ellos.

Con lo que respecta a los relatos del papiro Westcar, se articula con los mitos de origen del faraón, homologándose con ellos. En el cuarto relato se anuncia el 
nacimiento de tres niños que serán los tres primeros faraones de la dinastía $V$. Literariamente el recuerdo del origen de la dinastía $V$ es una construcción narrada a futuro, futuro que se hará realidad en el relato anexo. En él se representa una situación que es presuntamente histórica, que se describe como un presente literario.

Las narraciones como Admoniciones de Ipuwer, Profecía de Neferty, y Lamentaciones de Khakheperresenebu recuerdan una situación de caos político. Por su lado, el papiro Westcar remite su recuerdo al Reino Antiguo, a la transición entre la dinastía IV a la V. El sentido de este recuerdo surgido desde el contexto de la dinastía XII lo hemos explicado a través de continuar ese modelo dinástico, que hacía de los faraones legítimos herederos del poder, gracias a que eran hijos del dios.

Esta legitimación política de la dinastía XII toma forma de ficción. En el papiro Westcar, el cuarto relato y su anexo forman un mito de origen de la dinastía V. El recuerdo literario toma forma de mito para explicar su origen. Este entrecruzamiento de tiempos, el ficcional y el histórico, sólo es posible en un relato literario. Contrariamente, en Listas Reales que refieren a los orígenes de la realeza, hay una descripción lineal de reinado tras reinado. El tiempo cósmico de los orígenes se repite como una sucesión de hechos. No es un recuerdo descripto como algo que sucederá, sino que es lo sucedido la concreción de ese tiempo cósmico de los orígenes.

Solamente en un texto literario se puede narrar el origen desde el futuro. Ello es parte de su característica de ficcionalidad. Dicho futuro narrativo, al ser un pasado histórico del autor, es lo que nos impulsa a hablar en términos de recuerdo. La memoria futura, una formación narrativa exclusiva de los dos últimos relatos del papiro Westcar, se construye en términos míticos. Ello porque el recuerdo a futuro es el origen. Es decir, la memoria literaria del origen mítico de la dinastía V. 
PARTE

III 
Capítulo VI

\section{LITERATURA EN EL ANTIGUO EGIPTO}

Teoría y aspectos críticos 


\section{1. ¿Qué es la literatura egipcia? Controversias sobre el concepto de literatura egipcia}

En un estado de la cuestión sobre la literatura antiguo egipcia es ineludible la mención de Emmanuel de Rougé, quien inaugura en el año 1852 esta rama de la egiptología con la publicación del relato Dos Hermanos ${ }^{323}$. De Rougé instala dentro del estudio del campo egiptológico un nuevo grupo de textos: los literarios. Para él las obras literarias debían ser consideradas dentro los estudios concernientes a la sociedad egipcia antigua al mismo nivel que otro tipo de fuente informativa.

De Rougé era miembro de un grupo de investigadores que iniciaron las traducciones de los textos literarios egipcios, entre los que se destacaron Charles Wycliffe Goodwin y François-Joseph Chabas $^{324}$. A partir de las publicaciones de 1852 se abre el debate sobre la naturaleza de los relatos populares egipcios, así reconocidos por los especialistas de la época ${ }^{325}$. De Rougé y sus compañeros inician una primera etapa de recuperación y recopilación de textos ficcionales. Sus investigaciones y el interés por la temática dentro de la egiptología alentaron la realización de la reconocida antología de relatos literarios egipcios de Gastón Maspero publicada por primera vez en 1882.

La obra del egiptólogo francés logra su edición definitiva en 1911, cuando fueron incorporados y traducidos los relatos del papiro Westcar. La publicación era

\footnotetext{
323 Hacemos referencia al artículo de de Rougé (1852) publicado por la Reveu archéologique. Dos Hermanos, que nos ha llegado en buen estado de conservación en el papiro d' Orbinay (BM 10183), actualmente resguardado por el British Museum. El texto se encuentra escrito en neogipcio y su escritura data para finales de la dinastía XIX, momento en que se cree que vivió Ennena, el escriba de la obra (Lefebvre 2003 [1982], p. 152). Una edición completa del cuento ha sido publicada por Gardiner (1932a, pp. 9-29) y traducciones con comentarios en Maspero (2002 [1911], pp. 1-16); Erman (1927, pp.150-161); y Lefebvre (2003 [1982], pp. 149-165). Un análisis detallado y con enfoques disímeles sobre los cuentos en Blumenthal (1972); Hollis (2008); Wettengel (1992; 2003).

324 Sin embargo, estos dos autores en ningún momento intentaron clasificar teóricamente la literatura egipcia. Ellos se encontraban más bien preocupados en la formación de la palabra y el sonido, en la determinación y el significado del texto, problemáticas que se ajustaban más a las preocupaciones de su propio tiempo. Es decir, que se enfocaron en dejar hablar a las obras literarias por sí mismas, más que hablar sobre las obras literarias (Schenkel 1996, p. 22). Para un análisis pormenorizado de las publicaciones y trabajos de de Rougé, Goodwin y Chabas véase Schenkel (1996, pp. 22-27). En este artículo Schenkel expone un estado de la cuestión de los trabajos dedicados a analizar la literatura egipcia, teniendo en cuenta desde las primeras publicaciones, hasta las discusiones sobre el concepto de textos literarios, pasando por la cultura hasta los géneros literarios.

325 Por ejemplo Wilhelm Mannhardt quien los designa como los "cuentos populares más antiguos" en el mundo (El- Shamy 2002, p. ix).
} 
una recopilación de los "cuentos populares" egipcios, sin un orden específico, y no realiza ningún análisis sobre las dificultades de las traducciones. Si bien Maspero realiza una extensa introducción, no tiene por objetivo definir teóricamente el concepto de textos ficcionales/literarios. La traducción en inglés más moderna de El-Shamy (2002, pp. xi-xii) nos recuerda que Maspero tenía una preocupación desde la mirada de un egiptólogo y especialista de las letras y no de un folklorista o antropólogo. Por ejemplo, en ningún momento menciona el concepto "folklore". Existe en Maspero un interés por vincular los relatos egipcios con cuentos populares de otras culturas, el lugar de origen de los relatos, y cómo se desarrollaron en diferente tipo de relatos ${ }^{326}$. Este tipo de análisis no es tenido en cuenta para los relatos del papiro Westcar. La obra de Maspero significó un reconocimiento del papiro egipcio cada vez más amplio entre los especialistas.

Hasta el momento solamente habían sido editadas las obras de Erman, investigador alemán que inició y encabezó el grupo de intelectuales de lo que se conoce como la "escuela de Berlín”. Los estudios gramaticales serán continuados por uno de los discípulos más sobresalientes de Erman: Sir Alan Gardiner (Schenkel 1996, p. 26) ${ }^{327}$. Erman contribuye al estudio de la lengua egipcia clásica, e hizo un gran esfuerzo por sistematizar su estudio con la publicación de gramáticas egipcias. Un ejemplo es la gramática egipcia de 1889 sobre los relatos del papiro Westcar, la primera publicación que se realizó sobre los relatos y que por mucho tiempo no fue superada 328 .

En el año 1923 Erman publica una de las obras fundamentales sobre literatura egipcia: Die Literatur der Ägypter [La literatura de los egipcios] que fue traducida al inglés cuatro años más tarde: The literature of the Ancient Egyptians: poems, narratives, and manuals of instruction, from the third and second millennia B.C. [La literatura del antiguo Egipto: poemas, narrativas y manuales de instrucciones, del tercer y segundo milenio a.C.]. En 1927 también sale a la luz el primer estudio sistemático de la literatura egipcia

\footnotetext{
326 Para un análisis del libro de Maspero y la obra del autor véase el-Shamy (2002, pp. VII-CLIV).

327 Schenkel (1996, p. 26) considera el trabajo de este grupo una segunda etapa dentro de la investigación de la literatura egipcia.

328 También hacemos referencia a Erman (1890). La misma preocupación la tuvo Gardiner (2007 [1927]), quien creó una de las gramáticas sobre lengua egipcia clásica más utilizada para su aprendizaje hasta la actualidad.
} 
(Coletta 2011, p. 13), publicado por el alemán Max Pieper bajo el título Die ägyptische Literatur [La literatura egipcia], texto que nunca fue traducido al inglés. En este trabajo, Pieper realiza una extensa introducción donde deja sentadas sus ideas sobre lo que constituye la literatura egipcia, y propone nuevas traducciones para los textos literarios egipcios, entre ellos los del papiro Westcar.

Erman establece un orden sistemático para analizar los textos según la época. El primer grupo corresponde a la época oscura que separa el Reino Antiguo del Reino Medio, los escritos adquirieron el término de "literatura clásica". Se mantuvo un lenguaje literario, elevado, para los textos de ficción, aislado de la palabra cotidiana o de los cuentos populares, como los del papiro Westcar (Erman 1927, pp. xxv-xxvi). Un segundo grupo se ubica en el Reino Nuevo tardío. Aquí se desarrolló en oposición a la vieja tradición literaria. Las formas propias de la poesía significaron el decaimiento del lenguaje elevado, transformándose en líneas cortas que Erman (1927, pp. xxx- xxxix) analiza detalladamente.

La idea según la cual en los textos literarios del Reino Nuevo se introdujo un lenguaje vernáculo, que se nutrió de las historias populares de los egipcios, permaneció en los análisis sobre la literatura egipcia, y fue de vital influencia en los estudios sobre el papiro Westcar. Por ejemplo, Assmann (1999, p. 12) habla más de setenta años después, de una "literatura del entretenimiento" para el periodo ramésida. Antes de ello, el autor visualiza que algunos textos, como los del papiro Westcar, tienen dentro de su argumento entretener al rey ${ }^{329}$, pero no hace de ellos relatos sujetos a una representación para el entretenimiento. Esta idea no se encuentra únicamente vinculada al tipo de lenguaje, sino también al uso de alegorías o metáforas. También había influenciado en los estudios de Lefebvre (2003 [1982]) quien, incluso, ha llegado a desvalorizar relatos como los del papiro Westcar por considerarlos de un lenguaje vulgar y destinados a lo más bajo del pueblo egipcio, y a ensalzar los textos propios de la realeza, creados en un lenguaje refinado ${ }^{330}$. Las relaciones políticas con la monarquía egipcia pueden ponerse en evidencia y no necesariamente se desprenden del "tipo de lenguaje" del texto. Esto se encuentra

\footnotetext{
329 Volveremos más adelante sobre ello.

${ }^{330}$ En el capítulo VIII trataremos esta discusión con más detalle.
} 
sujeto a una valorización actual y no parece contemplar los parámetros egipcios. Para la sociedad egipcia el texto literario se desarrollaba en la escuela. Tanto su contenido, como su estructura mítica que permanece y forma parte de ellos, y el contexto que subyace a su creación, es lo que los constituye no únicamente en relatos literarios, sino también un lenguaje compartido con lo mítico-político.

En la década del setenta Assmann estaba muy lejos de valorizar a los textos literarios mediante categorías como las que citábamos. En el año 1974 publicó en la edición de Spuler las series de Handbuch der Orientalistik, bajo las influencias del estructuralismo $^{331}$. Eran investigadores como Roman Jakobson, Iuri Lotman y Juri Nikolajewitsch Tynjanow, quienes guíaban sus interpretaciones (Assmann 1999, pp. 1-3). Assmann creía que conceptos como el de la autoreflexibidad (postulado por Jakobson) eran de utilidad dentro del campo egiptológico ${ }^{332}$. Para el autor el problema siempre giró en torno a pensar algún tipo función para la literatura, en este caso la egipcia. Assmann (1999, pp. 1-3) opinaba que el problema se enmarcaba dentro de una cuestión mayor: la definición del género y la cuestión de los factores morfogenéticos. En sus conclusiones había una clara influencia estructuralista. Según él, en la literatura egipcia no existía géneros como se los conoce en la teoría literaria moderna, ya que no existían géneros universales como así tampoco puede hablarse de una tradición textual sin género. Se proyectaban las conclusiones de Todorov (2003 [1972], pp. 10-13) quien no negaba la existencia de géneros literarios, sino que advertía el riesgo de utilizar categorías fijas sin tener en cuenta las particularidades de cada sociedad que produce el texto.

Assmann (1999, pp. 3-4), consideraba que la función determina la forma y el significado del texto. Ello no parece cumplirse para los textos literarios, cuyo significado no está sujeto a un contexto funcional específico, no hay ningún contexto que forme el significado. Según Assmann lo que caracterizaba a la literatura egipcia era su independencia del contexto, el significado estaba

331 Tanto el propio Assmann (1999, pp. 1-4) como Moers (1999, pp. 43-45) reconocen la importancia de esta publicación, en la cual quedó en evidencia el paso del estructuralismo de la década de 1970 al posestructuralismo -década del 1990 hasta el presente. Esto muestra que algunos egiptólogos quedaron por fuera de los debates de la crítica literaria.

${ }^{332} \mathrm{La}$ idea de autorreflexividad o literaturidad es lo que para Jakobson le da identidad a la obra literaria, es decir que se define en tanto que es lo que hace de una obra una obra (Todorov 2008, p. 37). 
completamente dentro del texto. La tendencia que muestran los textos literarios es la de completar la ausencia del contexto mediante un marco -elaborado o no- que es una narrativa del contexto, con el propósito de hacer que el texto esté libre de cualquier inserción contextual específica. Era esa independencia del contexto la característica distintiva de la literatura en el antiguo Egipto. De estas opiniones se retractará más de veinte años después, cuando difunda sus ideas sobre los textos culturales y la influencia de la cultura y la tradición en su formación.

No fue Assmann el único que recibió la influencia del estructuralismo. Esta corriente repercutió directamente en los estudios de las formas gramaticales de los textos egipcios. El puntapié inicial hacia el estudio de la métrica de textos egipcios había comenzado treinta años antes, con el reconocimiento previo del carácter acentual de la métrica copta (Rosenvasser 1976, p. 8) ${ }^{333}$. En la década del sesenta, las discusiones giraron en torno a la posibilidad de la construcción de textos en forma de versos. Quien encabezó los estudios dentro de la lengua egipcia clásica y neogipcio, fue Gerhard Fecht (1963; 1964; 1965; 1967; 1972). Fecht considera que la acentuación es una de las características de la métrica egipcia (Rosenvasser 1976, pp. 12-13). Rosenvasser, uno de los más importantes exponentes dentro de la tradición egiptológica hispana, se suma a este debate con un artículo del año 1976 titulado "Introducción a la literatura egipcia. Las formas literarias". Allí asegura que el desconocimiento de la vocalización de la lengua egipcia constituye una de las mayores limitaciones sobre la comprensión de la literatura del antiguo Egipto (Rosenvasser 1976, pp. 7-8)334. La mayoría de sus ideas que son tomadas como conclusiones finales quedan únicamente en el plano de lo hipotético.

\footnotetext{
333 La conclusión principal a la cuál habían llegado investigadores como Erman (1897) y SäveSöderbergh (1949) se basaba en que del mínimo de palabras acentuadas o de grupos acentuados, provenía la construcción métrica del verso (Rosenvasser 1976, p. 8). En la misma época uno de los primeros trabajos extensos para lengua egipcia clásica fue Vikentiev (1935).

334 Ante esta deficiencia Rosenvasser (1976, pp. 8-16) propone una métrica egipcia, bajo la presuposición de un paralelo entre el carácter acentual de la métrica copta con el de la métrica egipcia, es decir que el número de palabras acentuadas brinda la construcción métrica del verso. En su artículo el autor expone una crítica a la teoría de la métrica de Fetch, aduciendo que su pretensión de revelar "un orden métrico arquitectónico en toda composición para determinar su sentido y la función de sus elementos integrantes, lo ha conducido, a construcciones artificiosas en contra del sentido natural del texto o del que provee el paralelismo de los miembros o es dado por una construcción estrófica indiscutible" (Rosenvasser 1976, p. 15).
} 
También tuvieron influencia en investigadores como Foster (1980); Mathieu (1988; 1990; 1994; 1997) y Günter Burkard (1993) ${ }^{335}$. Ellos constituyen la primer fase del formalismo egiptológico que, como sintetiza Moers (1999, p. viii), “estuvieron orientados hacia modelos retóricos clásicos, mediante los cuales diferentes investigadores intentaron definir la literatura egipcia mediante los términos de 'sustanticial criteria'".

En la ya mencionada publicación, Rosenvasser da a conocer su interpretación acerca de la conceptualización de los textos literarios del antiguo Egipto. Según el autor, a lo largo de su historia los egipcios han elaborado formas literarias reconocibles tanto por su estilo como por su contenido ${ }^{336}$. Considera dos categorías -prosa y verso- como principales y una tercera, no sin menor importancia, y relacionada a las anteriores: el discurso simétricamente estructurado o el estilo discursivo o sentencioso. Además, según Rosenvasser, existía una libre relación entre los géneros en un mismo tiempo (Rosenvasser 1976, pp. 17 y ss.).

En rasgos generales, este tipo de trabajos estaban más ligados al análisis de la lengua, y en particular no tuvieron mayor repercusión sobre los estudios relativos al papiro Westcar. Sí lo tuvieron para otros textos como Cuento de El Náufrago o Admoniciones de Ipuwer, este último analizado por el mismo Fecht. Así, los estudios de la literatura egipcia adquirieron su propia etapa formalista. Se aplicaba la lingüística al análisis de los textos, sin ser el argumento un punto de interés en ellos (Eagleton 1998, pp. 12-15) para los investigadores.

Assmann (1999, pp. 2-3) en su artículo "Cultural and Literary Texts" [“Textos culturales y literarios"] desestima el estructuralismo, al considerarlo solamente fructífero en términos del lenguaje específico. No son adecuados para el autor los términos de la poética para definir un texto como literario o no literario ${ }^{337}$. Consideramos que algunas categorías son todavía útiles para comprender los relatos

\footnotetext{
$335 \mathrm{Al}$ respecto de estas publicaciones véase Moers (1999, p. vii).

336 En otro capítulo se retomará la discusión sobre la posibilidad de utilizar la categoría de género para los textos literarios egipcios. Analizaremos más detalladamente los diferentes medios estilísticos que Rosenvasser (1976, pp. 19-47) estipula para la literatura egipcia.

337 Más adelante nos detendremos en los postulados actuales de Assmann, para quien la función de los textos es el límite que determina su carácter.
} 
literarios egipcios, como los del papiro Westcar ${ }^{338}$. En nuestra investigación sí realizamos un recorrido estructuralista, pero se aleja de los estudios métricos y gramaticales, y se acerca a conclusiones más generales sobre la formación estructural de los relatos. Son los estudios proppianos sobre la estructura del relato, aquellos que nos posibilitarán comprender una unidad entre los relatos del papiro Westcar, que no sólo nos indican un sentido de unidad entre todos ellos, sino también que no hubo improvisación, sino mentes creativas en su creación 339 .

El interés por los textos literarios puede constatarse si tenemos en cuenta las publicaciones sobre la temática que se han editado desde finales del siglo XIX y principios del siglo XX. El acercamiento e interpretación de estos textos ha estado distanciada de los estudios de la sociología literaria y de la crítica literaria (Zingarelli 2010, p. 210) ${ }^{340}$, distancia que está siendo saldada en las últimas décadas. Se ha iniciado una discusión que pretende definir qué se concibe por texto literario o literatura, y a partir de aquí la egiptología comenzó a hacerse eco de las teorías literarias tan desarrolladas durante el siglo XX.

Un punto de inflexión en los estudios sobre la literatura egipcia es el texto de Posener del año 1956 Litterature et politique dans l'Egypte de la XIIe Dynastie [Literaturay politica en el Egipto de la dinastía XII]. Dicha publicación abre un nuevo panorama sobre la conceptualización de la literatura en el antiguo Egipto. Posener determina, en su extenso trabajo, que detrás de la mayoría de los textos literarios del Reino Medio subyacía una intención política. Su artículo marca una impronta trascendental en la historiografía, dando paso a investigaciones sobre los vínculos entre literatura y política $^{341}$. Pierden la exclusividad, dentro de este campo, los trabajos relacionados

\footnotetext{
338 Hay quienes como Lepper (2007, p. 1130), que ha estudiado en particular los relatos del papiro Westcar, piensan que se deben tomar muchos recaudos al momento de realizar estudios que sigan fielmente y sin discusión al estructuralismo más clásico. La autora se abre a nuevas perspectivas de análisis con métodos estadísticos y comparativos para el estudio del lenguaje.

$339 \mathrm{Al}$ respecto véase el capítulo VIII.

${ }^{340} \mathrm{Lo}$ que también queda en evidencia si se observan los textos y obras publicadas, centradas en las discusiones filológicas- gramaticales y en la traducción de textos. Al respecto véase Gumbrecht (1996, pp. 3-18) y Schenkel (1996, pp. 21-38)

341 La repercusión del trabajo de Posener no fue inmediata entre sus contemporáneos, y en la actualidad sus estudios tienen más reconocimiento.
} 
con la gramática, la métrica y filología que se habían dado hasta entonces (Moers 1999, pp. vii-viii), abriéndose la posibilidad a otro tipo de interpretaciones ${ }^{342}$.

En 1959 Donadoni intenta una obra diferente, hoy bastante olvidada, su Storia della Letteratura Egiziana Antica [Historia de la Literatura egipcia antigua]. El autor analiza a los textos egipcios desde "los orígenes" hasta la edad tardía. Su trabajo intenta visualizar una evolución en ellos, más que comprender los momentos históricos y particulares en los cuáles fueron creados y pensados. Lo más complejo del análisis de Donadoni es que toma, como conjunto, una diversidad de textos que no necesariamente han sido considerados como literarios. Abarca desde Textos de las Pirámides, pasando por las autobiografías, los textos del Reino Medio “clásicos”, y la poesía amorosa. Se dificulta para el lector comprender qué es lo propiamente literario.

Al igual que Posener, Donadoni (1959, pp. 109-132) reserva un apartado a la "Letteratura política" ["Literatura política"] del Reino Medio, en el que analiza textos como Campesino Elocuente ${ }^{343}$, Profecía de Neferty, los relatos del papiro Westcar, Enseñanza para Merikara ${ }^{344}$, entre otros. Por ejemplo, sostiene el autor que lo trascendental de Profecía de Neferty es la llegada de un nuevo rey. Para Donadoni (1959, pp. 109-111) Profecía de Neferty no es necesariamente la narración de una realidad, pero sí pretende ser una historia real. Esto la hace responsable de su veracidad: la noticia de un futuro obvio. Algo similar observa brevemente para los relatos del papiro Westcar. En el cuarto relato también hay un anuncio que literariamente se hará realidad en el anexo. Donadoni no profundiza en el sentido

\footnotetext{
342 Por ejemplo, en los trabajo de Fechts que aplican la teoría de la métrica.

343 El texto conocido como Campesino Elocuente o Cuento del Campesino Elocuente, se conserva en cuatro manuscritos escritos sobre papiro. El papiro Berlín 3023, con 326 líneas y el papiro Berlín 3025, con 145 líneas, ambos pertenecientes a la colección Athanasi son datados para la dinastía XII. Misma datación que se acepta para el papiro Butler 527 (British Museum 10247), que contiene unas 40 líneas. Por último, el papiro Berlín 10499, con 138 líneas, es datado hacia la dinastía XIII. Destacamos traducciones con transliteraciones y comentarios: Gardiner y Vogelsang (1908); Vogelsang (1964 [1913]) y Gardiner (1923). Traducciones con comentarios: Maspero (2002 [1913], pp. 35-54); Faulkner (LAE pp. 31-49); Lichtheim (1973, pp. 169- 192); Lefebvre (2003 [1982], pp. 68-89); Parkinson (1998, pp. 54-88) y Araújo (2000, pp. 225-243).

${ }^{344}$ Este texto conocido tanto como Enseñanza para Merikara o Instrucciones para Merikara se conserva en tres papiros del Reino Nuevo, que podrían datarse a finales de la dinastía XI o a comienzos de la dinastía XII. El texto, traducciones y transliteraciones pueden encontrarse en: Gardiner (1914, pp. 20-36); Volten (1945); Faulkner (LAE, pp. 180-192); Helck (1977); Parkinson (1991, pp. 52-54 está incompleto), Serrano Delgado (1993, pp. 90-95).
} 
político de estas narraciones, que aquello que la narración profetiza como un futuro posibilitó la legitimación política de la monarquía en la dinastía XII.

A partir de este momento los estudios sobre los textos literarios del antiguo Egipto estuvieron marcados por una fuerte dicotomía: "hecho" o ficción". Algunos investigadores descartan toda posibilidad de considerar a los textos literarios como fuentes históricas, piensan que en ellos únicamente se narran acontecimientos ficcionales. La literatura es entendida como obra de "imaginación, no sin libre de crítica" (Eagleton 1998, p. 11), mientras que lo real se deja para la crónica. Otros investigadores proponen que son relatos que reflejan acontecimientos históricos

Por ejemplo, Barta (1969) sugiere que los textos de tipo literario eran narraciones históricas más o menos fieles de los hechos acontecidos durante el Primer Período Intermedio.

Posener (1963) por su parte, se acerca a la postura para la cual los textos literarios eran reflejo de los hechos históricos. Según él la literatura es un aporte fundamental para el conocimiento de la historia del antiguo Egipto. Denomina a este tipo de narraciones contes historiques, viendo en los relatos fuentes indirectas que informan de hechos que otras fuentes omiten, resaltando la influencia del presente en la evocación del pasado al cual acuden los textos literarios ${ }^{345}$.

En la actualidad se reconoce los textos literarios como fuente histórica. Este es uno de los primeros pasos para posicionar a la fuente literaria dentro de los análisis históricos, más allá de las consideraciones sobre su ficcionalización.

Muy pocos trabajos han estudiado al papiro Westcar desde este punto de vista. Goedicke $(1985 ; 1993)$ reconoce a estos relatos como una creación del arte literario. Supone que subyacen en ellos elementos históricos, pero que no necesariamente mencionan hechos históricos. Por su parte, Altenmüller (1970)

\footnotetext{
345 En esta línea se ha desarrollado una vigorosa discusión sobre el texto literario Admoniciones de Ipunver. Uno de los primeros comentarios lo realizó Gardiner (1909, pp. 17-18) quien consideró que el relato de Ipuwer era un reflejo de la situación histórica que debió desarrollarse durante el Primer Periodo Intermedio. Otra perspectiva la propuso Van Seters (1964, pp. 13-23) que relaciona el relato literario con el periodo hicso y el Segundo Periodo Intermedio. Una interpretación novedosa fue la propuesta por Castañeda Reyes (2003) para quien Admoniciones de Ipunver estarían describiendo un proceso de revolución político-social producida en Egipto durante el Primer Periodo Intermedio.
} 
identifica el personaje de Reddjedet como seudónimo de una reina de la dinastía $\mathrm{V}$ y Jenni (1998) argumenta que reflejan la situación política de la transición entre Amenemhat I y Sesotris I. También Hays (2002) los analiza para comprender la solarización de la realeza en el Reino Antiguo y las particularidades en el pasaje de la dinastía IV a la dinastía V. En los capítulos anteriores hemos esgrimido nuestra posición con respecto a cada una de estas interpretaciones.

A partir de la década del setenta se publicaron un gran número de obras de antologías de textos literarios egipcios. El problema que todas ellas comparten es que ninguna intenta conceptualizar profundamente el término de literatura egipcia, la que podría haberse dado como una consecuencia lógica de las discusiones que se estaban desarrollando paralelamente, como las de Posener y Assmann. Las antologías se repiten unas con otras y se organizan internamente de modo similar. En cada una hay una introducción general -más o menos extensa- sobre la literatura, y luego se dividen haciendo coincidir cada apartado con un relato. Por lo general, a la traducción del texto se antepone un resumen del argumento, una síntesis de las publicaciones existentes sobre el relato y se clasifican a los textos dentro de diferentes categorías. Estimamos que la mayor preocupación es la de reunir traducciones de los textos, que hacer sobre ellos un debate teórico.

En el año 1973 Pritchard edita The Ancient Near East: An Anthology of Texts and Pictures [El Cercano Oriente Antiguo: una antología de textos e imágenes] con la intención de hacer asequible al público en general los textos del antiguo oriente, los que cree fundamentales para comprender su historia. No solamente tiene en cuenta textos de tipo literario, sino también religiosos, míticos y político-administrativos.

El libro está dividido por tema y por región geográfica. Wilson es el encargado de las narraciones, mitos, textos históricos, rituales, himnos, sabidurías sobre el antiguo Egipto. Justamente este tipo de categorías fueron recurrentes en la organización de las antologías. Se observa una diversidad de criterios por los cuáles se incluyen textos dentro de estas recopilaciones, no siendo claro qué es lo que define lo propiamente literario. Se excluyen relatos como los del papiro Westcar, en los cuales hay una marcada ficcionalidad que a nuestro entender los constituye en 
literatura, y se tienen en cuenta otros textos como himnos religiosos o textos de tumbas, que no se incluirían para nosotros dentro del universo de lo literario.

Otra antología es la de Lichtheim, una las más extensas, la cual se divide en tres volúmenes. En el primero, sobre textos del Reino Antiguo y Reino Medio, se encuentra la traducción de los relatos del papiro Westcar. El segundo volumen, del año 1976, se ocupa de los textos del Reino Nuevo. El tercero es publicado en 1980 y reúne todos los textos correspondientes al último milenio de la historia del antiguo Egipto. En la introducción del primer volumen, Lichtheim (1973, pp. 9-10) sostiene que los textos literarios del Reino Medio son textos políticamente tendenciosos que no poseen base histórica alguna, y que son obras de pura inspiración literaria. Para la autora textos como Profecía de Neferty y Admoniciones de Ipuwer reducen toda su temática a la fórmula "orden versus caos", y enfocan el mal como un fenómeno social, encontrando en un faraón fuerte el garante de la armonía (Lichtheim 1973, pp. 9-10).

Los textos que traduce Lichtheim en el primer volumen son de diversa índole y temática. Divide su antología en dos partes, la primera corresponde al Reino Antiguo y se compone de cinco apartados: inscripciones monumentales provenientes de tumbas privadas, decretos reales, Textos de las Pirámides; tratados teológicos y literatura didáctica ${ }^{346}$. Dentro de este último capítulo incluye instrucciones, que son un antecedente de lo que para el Reino Medio se considera cuentos en prosa. Esta definición es la que incluye a los relatos del papiro Westcar, traducidos en la segunda parte del libro que contiene los textos del Reino Medio. Esta misma categoría contiene Cuento de El Náufrago y Cuento de Sinhué.

En esta misma línea, se encuentra la antología publicada por Simpson ( $L A E$, pp. 2-3), quien destaca el desconocimiento que se ha tenido durante mucho tiempo de los textos literarios egipcios, exceptuando a los especialistas en la materia. Según Simpson el desciframiento de los jeroglíficos durante las primeras décadas del siglo XIX permitió conocer una gran cantidad de textos de naturaleza diversa: religiosos, administrativos, económicos, políticos y literarios. Con respecto a los literarios

\footnotetext{
346 En literatura didáctica Lichtheim traduce Instrucciones de Hordedef, Instrucciones para Kagemni y Instrucciones de Ptabhotep.
} 
encuentra significativos paralelos con los del Cercano Oriente, como los Mesopotámicos y el Antiguo Testamento. Simpson ( $L A E$, p. 3) afirma que estas composiciones son tanto narrativas y cuentos, como instrucciones y poesía, pero no elabora ningún tipo de definición al respecto. Selecciona los textos para su antología el mérito literario o las pretensiones literarias (Simpson 1973, p. 4), pero en ningún momento hace explícitas las características que hacen de los mismos textos literarios. Así, el autor selecciona diversos escritos ordenados cronológicamente y divididos en precarias categorías: cuentos y narrativas de la literatura del Reino Medio e historias del Egipto tardío: instrucciones, lamentaciones, diálogos, poesías, himnos y canciones. A los relatos del papiro Westcar los enmarca dentro de la categoría/género narrativo de cuento, junto con Campesino Elocuente, Cuento de El Náufrago y Cuento de Sinubé.

En el reconocido libro Romans et Contes Égyptiens de l'Époque Pharaonique [Novelas y cuentos egipcios de la época faraónica], Lefebvre (2003 [1982], p. 15) se propone constituir una obra superadora de la antología de su par francés Maspero. Lefebvre considera que esta antología ha quedado obsoleta, ya que luego de 1911 se descubrieron textos que es necesario tener en cuenta y porque para muchos de los pasajes pueden plantearse mejores traducciones. Según Lefebvre, las obras egipcias fueron utilizadas como práctica de escribir en el oficio del escriba, y no todas son auténticamente cuentos. El autor establece paralelos con el estilo de la famosa creación árabe Mil y Una Noches, relatos de acontecimientos ficcionales. Justamente los relatos del papiro Westcar se compararían con esta obra ${ }^{347}$.

Dentro de la categoría de cuentos establecida por Lefebvre, los del papiro Westcar pertenecen a una subcategoría donde la magia adquiere un lugar destacado: los cuentos maravillosos. Según el autor, caracterizan por ser relatos de proezas de magos, nacimientos extraordinarios, donde hay animales que hablan, etc. Para el investigador lo que es inherente a todos los relatos egipcios es lo maravilloso que está presente -en mayor o menor medida- en todo tipo de relato. Por otro lado, existen obras en las que lo ficcional se destaca en detrimento de lo maravilloso:

\footnotetext{
347 Las derivaciones que esta interpretación ha producido las discutiremos detalladamente en el próximo capítulo.
} 
narraciones más o menos fieles a sucesos reales, históricos, relatos con trasfondo histórico o novelas (Lefebvre 2003 [1982], pp. 16-18).

Estas interpretaciones sobre la literatura egipcia parecieran estar imbuidas de un clima de época y carecen de valor crítico analítico tendiente a la elaboración de un concepto de literatura para el antiguo Egipto. La discusión oscila entre las dos posturas mencionadas, considerar la literatura como narración de evento histórico o desde una perspectiva meramente lingüística y/o artística (Loprieno 1996a, p. 40). La valoración de un texto como literario o no literario se otorga por la calidad estilística del relato, diferenciando lo que es parte de un lenguaje armado y producido del lenguaje cotidiano. Según Eagleton (1998, p. 16) esta distinción vacía el concepto de literatura, ya que no hay nada propio de una obra literaria que la caracterice como tal. No hay nada, ni siquiera en el lenguaje, que permita diferenciar el texto literario de algún otro tipo de texto (Eagleton 1998, p. 17) 348.

A partir de 1990, la historiografía se aparta de la publicación de antologías y comienzan a darse debates fructíferos y más sistemáticos. En 1995, en la ciudad de los Ángeles, se lleva adelante el simposio “Ancient Egyptian Literature: History and Forms", y cuatro años más tarde los trabajos allí desarrollados son publicados por Moers en Definitely: Egyptian literature [Definitivamente: literatura egipcia]. Mientras, en 1996 Loprieno, quien se ha destacado por su interés en la temática, edita uno de los libros más importantes: Ancient Egyptian literature. History and Forms [La literatura del antiguo Egipto: Historia y Formas].

El libro editado por Loprieno contó con la participación de más de diez egiptólogos, como Parkinson, Baines, Blumenthal y Gnirs. Está dividido en seis partes que buscan abarcar todas las aristas sobre la problemática de la literatura egipcia, más una introducción a cargo Gumbrecht (1996, pp. 3-18) "Does Egyptology need a 'theory of literature’?” [“¿Necesita la egiptología una 'teoría de la literatura’?’]. En ella, el autor reconoce lo complejo de la temática, no sólo porque

\footnotetext{
348 Esta misma idea la retomaremos más adelante, para aportar una crítica a los planteos como los de Lefebvre acerca de "lo maravilloso" como característica inherente a los textos literarios egipcios rasgo que delimita una visión sobre el género del relato en cuestión. Analizaremos más adelante que son el contexto y las valoraciones culturales las que hacen de una obra una obra literaria, y que estos valores son transitorios (Eagleton 1998, pp. 19-28).
} 
es difícil en sí misma, sino también porque tanto la cultura del antiguo Egipto como la literatura son dos instituciones o discursos con sus propias tradiciones, que convergen en un diálogo tan recíproco, como problemático. De hecho, en el recorrido que hemos realizado hasta la década de 1990 la egiptología tuvo con la teoría de la literatura una relación compleja y ha estado, de algún modo, retrasada. En cambio, con estas nuevas publicaciones se reabrirá el debate sobre la literatura egipcia, ahora bajo la influencia del postestructuralismo. Para Assmann (1999, p. 1) este contexto postestructuralista es, justamente, lo que habilita, ahora sí, a comprender cómo leer un texto literario egipcio. Estas nuevas ideas volcadas al campo de la egiptología, estimularon la conceptualización de la literatura como una construcción cultural, es decir que la literatura, como cualquier otro producto del lenguaje, es un medio de comunicación construido (Moers 1999, p. 45).

En la primera parte de History and Forms titulada "The Search for Egyptian Literature" ["En búsqueda de la literatura egipcia"], Loprieno escribe uno de los artículos que más repercusiones ha logrado. En "Defining Egyptian literature: Ancient texts and modern theories" ["Definiendo la literatura egipcia: textos antiguos y teorías modernas”] (1996a, pp. 42-43) Loprieno define los elementos que indican la especificidad de la literatura, tomando para ello los elementos hermenéuticos que comúnmente son empleados por la teoría literaria moderna (Araújo 2000, p. 39). Loprieno define cuáles son las características que un texto egipcio debe poseer intrínsecamente para poder ser clasificado como literario y proporciona tres categorías- recepción, ficcionalización e intertextualidad- como base para un estudio del discurso literario egipcio.

Por recepción entiende que existen tres actores que interactúan, por un lado la obra y quien escribe la obra y por otro el lector-receptor (Loprieno 1996a, p. 54). La recepción es una categoría hermenéutica primaria para las culturas que procesan su pasado (Baines 2007) ${ }^{349}$. Esta categoría supone que hay alguien que recibe la obra, pero debemos subrayar que el problema de la circulación del texto, lo que Assmann (1999, pp. 5-6) denomina comunicación, es uno de los aspectos centrales en los

349 Este mismo artículo fue publicado en Baines, J. 1989. "Ancient Egyptian concepts and uses of the past: $3^{\text {rd }}$ to $2^{\text {nd }}$ millennium BC evidence". En Layton, R. (Ed.). Who needs the past? Indigenous values and archeaology. Routledge, Londres. 
textos escritos en el antiguo Egipto. A lo cual debe agregarse la dificultad de establecer, para la mayoría de los textos literarios, los espacios de recepción, problemática que abordaremos más adelante.

La ficcionalidad consiste en que lo que describe el texto no coincide necesariamente con la realidad histórica, lo que no implica que el texto no haga referencia a realidades históricas ${ }^{350}$. En todo caso, el texto se encuentra influenciado por un contexto histórico determinado que es importante para comprender las obras literarias (Galán 1998, p. 12). Por ejemplo, los textos del Reino Medio son producto de un contexto peculiar, en los cuales la dinastía XII pretende sostener en el recuerdo el caos del Primer Periodo Intermedio para legitimarse en el poder (Assmann 2008, pp. 136-137). Así, se comienzan a revalorizar las ideas expuestas treinta años antes por Posener, al darle un marco político a las creaciones literarias.

Con relación al término de ficcionalidad, Araújo (2000, p. 39) bien hace notar que el mismo no se restringe a la idea de "invención” o "imaginación”, sino que alude al "efecto de alejamiento planteado por el lenguaje que escapa de lo cotidiano, o que se identifica con el empleo de figuras retóricas". Para nosotros no alcanza diferenciar sólo los medios por los cuales los textos literarios se hacen presentes por ejemplo el empleo del papiro como soporte- o sus potenciales receptores, todos elementos que le dan justamente sus características literarias, sino que dentro de ellas debemos destacar los modos de expresión, la recurrencia a ciertas temáticas, el uso de figuras retóricas de carácter metalingüístico, la idea de mímesis, la presencia de narradores (Araújo 2000, p. 39) o el uso de metáforas, incluso la yuxtaposición con otros medios de expresión -como el mítico/pictórico- que son elementos que permiten avanzar sobre otro tipo de textos, como el caso del relato del origen divino del rey en el papiro Westcar.

350 De este modo Loprieno retoma la discusión dicotómica entre realidad histórica o ficcionalización de los hechos. El autor está más de acuerdo con la postura de Goedicke (1993) que mencionábamos específicamente para los relatos del papiro Westcar, y se opone a aquellos egiptólogos como Barta (1969) para quien las obras literarias egipcias aluden en gran medida a acontecimientos históricos. 
El concepto de intertextualidad ${ }^{351}$, es quizá el más importante e influyente de los tres términos propuestos por Loprieno para analizar los textos del antiguo Egipto. La intertextualidad se refiere a que su texto forma parte de un "universo de textos" con los cuales se relaciona e interactúa, lo que significa que el texto nunca es verdaderamente una creación del autor (Loprieno 1996a, p. 51). Es decir, los textos no solamente se asocian a un contexto, hay, además, un diálogo entre ellos, lo que posibilita asociar más ampliamente los acontecimientos históricos e interpretarlos, al mismo tiempo que se nos abre la posibilidad de relacionar el texto ficcional con otros discursos textuales, como el mito.

Queremos destacar dos cuestiones acerca del concepto de intertextualidad propuesto por Loprieno que aportan a nuestra investigación. En primer lugar, un texto no es de un único autor, porque sobre él influye el contexto y la tradición cultural en la cual escribe. En segundo lugar, dentro del "universo de textos" la literatura puede interactuar con otros discursos que no necesariamente sean literarios, es decir que puede descubrirse una relación textual con otro tipo de textos, como el mítico. Esto último lo propuso Baines en su trabajo "Myth and Literature" ["Mito y Literatura"] (1996, pp. 361-366), donde analiza, por primera vez de manera explícita y teóricamente, la relación existente entre mito y literatura. El autor reconoce que en los textos literarios puede identificarse el estatus del mito. Si bien ya nos hemos referido a esta problemática, queremos sintetizar que según Baines (1996, pp. 361 y ss.) el estatus de lo mítico puede darse en dos niveles diferenciados, no excluyentes. Por un lado el símbolo del mito, la mención de una deidad, de un lugar, es decir lo que no constituye un mito en sí mismo pero sí hace referencia a él. Y, por otro lado, un segundo plano que incorpora la historia mítica

\footnotetext{
351 El concepto de intertextualidad tiene una tradición de discusión teórica dentro de la teoría literaria moderna, y entre los especialistas existen diferentes posturas. En 1969 Kristeva propuso la noción de intertextualidad, que repercutió ampliamente en la crítica literaria. Kristeva (2001 [1969], p. 190) retomó a Bajtin quien introdujo dentro de la teoría literaria la idea de que "todo texto se construye como un mosaico de citas, todo texto es absorción y transformación de otro texto", y precisó que en un texto el lenguaje se lee doble, es decir, intertextualmente. Por su parte, Genette (1989 [1962], pp. 10-11), considera a la intertextualidad como una de las cinco relaciones transtextuales definiéndola como la "manera más restrictiva, como una relación de copresencia entre dos o más textos, es decir, eidéticamente y frecuentemente, como la presencia efectiva de un texto en otro", siendo el ejemplo más explícito y literal el uso de la cita, mientras que formas menos explícitas y menos canónicas son el plagio, y la alusión, e interrelaciones textuales como bipertexto. Al respecto véase Genette (1989 [1962]).
} 
como parte del argumento del relato literario. Baines realiza un recorrido por algunos textos literarios del Reino Medio y del Reino Nuevo dando muestra de las relaciones, de cómo el mito se inserta en los discursos literarios.

Las conclusiones de Baines nos permiten expresar una de nuestras principales propuestas del presente estudio. Nos posibilita entrecruzar dos tipos de discursos, el mítico y el literario, tal como analizamos en profundidad en los primeros capítulos cuando examinamos los dos últimos relatos del papiro Westcar, y el mito de origen del faraón del Reino Nuevo representado en los templos funerarios de Hatshepsut, Amenofis III y Ramsés II. A su vez, hemos analizado cómo los dos últimos relatos del papiro Westcar construyen literariamente, a través del recuerdo, el mito de origen de la dinastía $\mathrm{V}$.

En la citada edición de Loprieno, Assmann publica su controversial artículo "Kulturelle und literarische Texte" [“Textos culturales y literarios"] (pp. 59-82) 352, del cual ya hemos hecho algunas referencias. En este trabajo, Assmann (1999, pp. 115) expone sus ideas acerca de los textos culturales. Según el autor, las principales funciones de los textos culturales son las de actuar con un sentido vinculante normativo 353 -codificando las normas del comportamiento social- la de configurar un programa cultural formativo que transmite y reproduce de una generación a otra una auto-imagen, identidad cultural, como los mitos (Assmann 1996, pp. 140-141; Assmann 1999, p. 7). En palabras de Assmann (1996, p. 141): “los textos culturales pretenden una vinculación de toda la sociedad, determinan su identidad y su coherencia, estructuran el horizonte de sentido sobre el cual la sociedad se comprende a sí misma, y la conciencia de unidad, pertenencia e idiosincrasia, a través de cuya transmisión el grupo se reproduce a lo largo de las generaciones y vuelve a reconocerse a sí mismo”.

\footnotetext{
352 Este artículo fue publicado en la edición de Moers (1999, pp. 1-15) con el título "Cultural and literary texts" [“Textos culturales y literarios"]. Debido a la accesibilidad del idioma inglés tomamos esta edición.

353 Goody (1990 [1986], p. 49) admite que todas las sociedades humanas poseen sistemas normativos que se encuentran mucho más extendidos en las sociedades estatales que en las tribales, que al fijarse su formulación se convierte más inclusiva y elaborada.
} 
La función de identidad de los textos culturales se explica, en gran medida, porque eran útiles para iniciar a los hombres en el conocimiento de la escritura, se enseñaban y eran trasmitidos de generación a generación (Assmann 1999, p. 8). No nos referimos a cualquier tipo de cultura, sino la cultura del escriba que representó la cultura en general. Sabemos que la práctica religiosa y mítica (Shafer 1991, p. 3) y la literaria, eran una parcialidad de la experiencia egipcia (Parkinson 1991, p. 18), de su cultura. Los escribas representaban a una minoría letrada, miembros de la elite administrativa y la clase dominante. Los acontecimientos de finales de la dinastía XII e inicios de la dinastía XIII, produjeron un marco funcional que consagró políticamente una clase, aquella que creó los más importantes textos literarios del Reino Medio.

En este sentido, Moreno García (2004, p. 273) interpreta los textos literarios del Reino Medio como creaciones culturales, complementarias a las enseñanzas y que planteaban un nuevo marco ideológico para los usurpadores tebanos creadores de la dinastía XII. Los entiende por función del contexto histórico que les dio origen y otorgó sentido, lo que hemos analizado como ficcionalidad (Loprieno 1996a, p. 43).

El final del Primer Periodo Intermedio había sido una experiencia decisiva en la mente de la elite egipcia. Los textos literarios parecen reflejar los sentimientos y las ideas de los procesos que llevaron a la pérdida de poder de la monarquía. En este contexto, para Assmann (1999, p. 9) las obras literarias fueron "textos culturales con una función específica en el marco de la cultura textual o de escribas, y formaron la memoria cultural de la nueva elite gobernante".

Al hacer hincapié en las influencias contemporáneas a la producción del texto, Assmann se aleja de las ideas que descontextualizan al texto de su contexto y le dan todo su significado y su contenido interno. Dentro de este contexto formativo de los textos culturales, la memoria, en tanto archivo cultural de la sociedad y la tradición, es un elemento esencial que conforma, moldea y crea a los textos. La memoria cultural es uno de los conceptos claves que ha acompañado nuestra exégesis. Recordemos que la memoria cultural se expresa literariamente en textos como los del papiro Westcar, en los cuales se narra el origen de la dinastía V, y en 
donde se recuerda, de un modo específico e intencional, cómo fue ese origen. Ese recuerdo debemos comprenderlo en el contexto primario desde el que se está rememorando. Se recordaba el origen divino, a los faraones como hijos del dios Ra. Este mito pudo haber tenido las repercusiones políticas durante el Reino Medio.

Otro artículo de la edición de Loprieno que nos ayuda a pensar sobre el concepto de literatura, es el de Eyre "Is Egyptian historical literature 'historical' or ‘literary’” [“¿Es la literatura histórica egipcia ‘histórica’ o ‘literaria’?] ( 1996, pp. 415433). El autor considera el pasado como una importante fuente de autoridad, atribución que fue reflejada en los textos escritos. Particularmente observó que la literatura egipcia estaba situada en una especie de "cuento de hadas", esto es que en los textos, la historia se superponía con la mitología. Según Eyre la narrativa literaria estaba delimitada por un realismo mágico, donde la audiencia era al mismo tiempo construida y entretenida por la yuxtaposición de lo familiar con lo exótico, de lo mágico con lo heroico, y podían identificarse con los sentimientos humanos y la conducta de los personajes en un ambiente exótico. Los relatos del papiro Westcar tienen algo de esta atmósfera mágica, porque ellos nos trasladan a un mundo de fantasías donde las proezas se hacen realidad. Pero esa fantasía también tiene una cuota de realidad, un contexto político y social en el cual se están redactando las historias, y una intencionalidad de dar a conocer el origen de la dinastía V. Lo familiar que piensa Eyre podría ser, justamente, ese mundo de la realeza más o menos conocido que pretende legitimarse, por lo menos ante un grupo letrado.

Por su parte, Quirke (1996, pp. 263-276) hace un aporte al debate sobre la conceptualización de la literatura egipcia en su artículo "Narrative literature" [“Literatura narrativa"], en el cual define la narración como el relato -de ficción o no ficción- de un suceso y sus acontecimientos. Quirke afirma que la narración es una estratégica selección de textos como cualquier otra, como cualquier comunicación humana, ni neutral ni inocente. Sostiene el autor que la idea de una selección sobre el contenido del texto es fundamental para pensar los textos literarios del antiguo Egipto, principalmente porque dan cuenta de una intencionalidad. En especial para aquellos textos catalogados como meramente literarios/ficcionales, en los que subyace una pretensión política, textos como los dos últimos relatos del papiro 
Westcar, en los que evidencia una aguda e intencionada selección de los hechos del pasado a través de su recuerdo expresado literariamente.

Parkinson es uno de los investigadores que también ha publicado una gran variedad de libros y artículos sobre la literatura egipcia. En 1997 en Voices from Ancient Egypt. An Anthology of Middle Kingdom Writings [Voces del antiguo Egipto. Una antología de escritos del Reino Medio] realiza un recorrido sobre los tipos y significados de la escritura del Reino Medio, un periodo en el cual es evidente la proliferación de textos escritos. Para el autor, muchos de estos relatos que comenzaron a circular en forma escrita, ya eran conocidos en forma oral. La idea de una circulación anterior de los relatos la sugerimos en el caso del papiro Westcar, pues destacamos una estructura tripartita que puede ser vista como un momento de transición de una cultura oral a una escrita donde aún es necesario mantener ciertas reglas mnemotécnicas. Aquí Parkinson (1991, p. 25) destaca que el grupo de textos que corresponden a la definición de alta literatura es un limitado número de copias provenientes del Reino Medio.

En este libro Parkinson propone nuevas traducciones para una gran variedad de textos. Y se atiene sólo a los literarios en The Tale of Sinube and Other Ancient Egyptian Poems [El cuento de Sinubé y otros poemas del antiguo Egipto]. A modo de antología, divide el libro en secciones. En la primera, que corresponde a "tales" ["relatos"/“cuentos"], propone una traducción y una interpretación de los relatos del papiro Westcar. Sin embargo, en este libro no expone consideraciones generales sobre el concepto de literatura, como sí realiza luego en Poetry and culture in Middle Kingdom Egypt: a dark side to perfection [Poesía y cultura en el Reino Medio egipcio: un lado oscuro de la perfección] donde limita el concepto de textos literarios a "un cuerpo coherente" que mantiene rasgos claramente definidos en términos de ficcionalidad, género, contexto social y discurso. Parkinson (2002, p. 3) entiende la literatura en términos de "una institución definida y creada por su cultura". Considera que son los reflejos de ciertos procesos socio-históricos los que determinan el desarrollo cultural de una sociedad. Para el autor en las obras literarias se aprecian procesos históricos, sin que ello implique que pierdan sus cualidades ficcionales. En este trabajo, Parkinson aborda todas las aristas que definen lo literario, desde la función 
del autor, pasando por la división en género, hasta la circulación y difusión del texto. En una publicación más reciente, Readings Ancient Egyptian Poetry. Among Other Histories [Lecturas de la poesía antiguo egipcia. Entre otras historias], se ocupa de la poesía y hace un recorrido por los paisajes egipcios actuales buscando interpretar los pasajes poéticos, en los cuales los antiguos egipcios se inspiraron.

A inicios del siglo XXI, comienzan a publicarse antologías de textos egipcios, mucho más renovadas que las anteriores, al pretender ser más profundas en los estudios introductorios acerca de qué es la literatura egipcia. Quien logra una de las mejores antologías realizadas, y no por eso mayormente conocida, es la del investigador brasileño Araújo, Escrito para a eternidade [Escritos para la eternidad] publicada en 2000. Aquí Araújo hace desde un repaso de los métodos de fabricación del papiro como soporte principal de los textos, hasta una explicación de la función del escriba dentro de la sociedad egipcia antigua. Araújo muestra un profundo interés en revisar cuáles fueron los diferentes conceptos que propulsaron una definición de la literatura egipcia, reconociendo las teorías que subyacen a cada una de ellas. Como así también discute acerca de las diferentes formas literarias que pueden encontrarse.

En esta misma línea de antologías, en 2004 Quirke publica Egyptian literature 1800 BC, Questions and Readings [Literatura egipcia 1800 a.C, interrogantes $e$ interpretaciones], en la cual ofrece un análisis detenido sobre las cuestiones referentes a la clasificación, producción y conceptualización de textos literarios. La publicación de Quirke se diferencia de las otras por ser la única que propone una transliteración de cada uno de los textos, al mismo tiempo que los traduce. El autor, sólo tiene en cuenta textos literarios producidos durante el Reino Medio egipcio, ya que desestima que anteriormente se hayan preservado relatos literarios. Quirke (2004, pp. 9-10) está convencido de que el grueso de las obras que han llegado hasta nuestros días fueron producidas en una tercera etapa del Reino Medio, en la fase más tardía entre los cambios producidos por Sesostris I y Amenemhat III, alrededor del 1850 al 1800 a.C. hasta el final de esta etapa hacia 1700 a.C.

Quirke (2004, pp. 11-21) realiza una compleja y amplia clasificación de los textos y la datación de los períodos de los que sobrevivieron cada tipo de texto. El 
interés del autor radica en llegar a una definición de literatura egipcia que sea el resultado de la observación de datos empíricos, y no únicamente de una teorización, para dar cuenta si dichos textos pueden responder a las expectativas modernas de la noción de literatura.

La obra póstuma de Jesús López publicada en 2005, Cuentos y fábulas del Antiguo Egipto, reproduce la lógica de las antologías de las décadas de 1970 y 1980, se destaca que hay una modernización en la traducción de algunos textos, y varios son publicados por primera vez en español como idioma original. La muerte del autor ha dejado inconclusas las conclusiones. En el prefacio, López observaba que para los textos literarios egipcios no está del todo clara su diferenciación en géneros literarios, por lo que proponía abarcar la traducción de la mayor cantidad de textos posibles $^{354}$. Entre ellos López tuvo en cuenta al papiro Westcar, Profecía de Neferty, y Dos Hermanos que se encuentran más comúnmente en antologías, y otros más novedosos como la Disputa de los árboles del huerto 355 o Khonsuembeb y el espiritu ${ }^{356}$.

Una de las publicaciones más recientes es la de Tyldesley, Mitos y Leyendas del Antiguo Egipto, en la cual la autora analiza y traduce mitos y leyendas, entendiendo por mito "una historia tradicional ambientada en el pasado, con un elemento sobrenatural, que se utiliza para explicar o justificar lo que de otro modo es inexplicable", mientras que define por leyenda "una historia tradicional, no verificable, ambientada en el pasado, relativa a gentes o lugares reales, o que se pensaban que lo eran" (Tyldesley 2011, p. 8). Si bien las definiciones son generales y en ellas pueden incluirse una diversidad de textos del antiguo Egipto, lo más problemático a nuestro entender es que para Tyldesley este tipo de relatos carecen de estructura narrativa. Esta idea se contrapone con lo que nosotros hemos

\footnotetext{
${ }^{354} \mathrm{El}$ autor se había la propuesto traducción de veintitrés textos pero sólo finalizó dieciocho.

355 Este texto se encuentra en el recto del papiro Turín 1966 datado para la dinastía XX. Algunas de las publicaciones que se destacan, de los manuscritos con reproducción facsimilar Maspero (1883 y 1886); Pleyte y Rossi (1869-1876) y una la más completa López (1992). Algunas traducciones fueron realizadas por Foster (1974, pp. 81-95); Mathieu (1996, pp. 81-93) y López (2005, pp. 141-156).

356 No se ha preservado ninguna copia de este texto en papiro, todas las que conocemos están escritas en hierático entre las dinástias XIX y XX sobre ostraca, ellas son: O. Turín CGT 57314, 57315, 57317 y 57318; O. Viena 3722; O. Florencia 2616 y 2617; O. Louvre 667-700: O. IFAO 1251 (I-II) y 1252 (I-II) y O. Gardiner 306. Si bien hay otras, la más importante publicación de los manuscritos corresponde a Gardiner (1932b, pp. xiii-xv y 89-94). Y algunas traducciones totales o parciales fueron realizadas por Maspero (2000 [1911], pp. 229-232); Wente (LAE, pp. 137-141); Lefebvre (2003 [1982], pp. 175-181) y López (2005, pp. 182-192).
} 
analizado con respecto al mito de origen del rey. Tanto en los templos funerarios del Reino Nuevo como en los relatos del papiro Westcar ha quedado en evidencia que sí hay una estructura, pues hay una historia que es compartida y que se guía con las mismas estructuras, ya sea que la narración sea en papiro o en imágenes y texto. Además, para el caso del papiro Westcar, los conceptos proppianos nos permitirán dar cuenta de una estructura narrativa compartida entre los primeros cuatro relatos escritos en el manuscrito.

El problema de lo literario, dentro del campo egiptológico, es una preocupación de las últimas décadas. Si bien se conocen y se han traducido obras literarias desde sus inicios, su definición ha sido compleja. Por un lado, están los trabajos que han sesgado el análisis únicamente a los temas vinculados con la gramática, la paleografía y las cuestiones relativas al carácter en verso o en prosa que los textos pudieran tener. Por otro lado, las antologías han dejado como legado categorías laxas acerca de qué es lo literario, al incluir todo tipo de textos. Por último, son recientes los estudios que pretenden discutir y definir lo propiamente literario. El problema de éstos últimos es que han tenido una escasa repercusión en los trabajos específicos sobre las obras literarias, al menos con lo que concierne al papiro Westcar ${ }^{357}$.

Nuestro análisis, sin dejar de ser crítico, es deudor de muchas de estas discusiones. En capítulos anteriores hemos destacado la ficcionalización como el rasgo central del texto literario. Si bien muchos textos egipcios son narrativos, no en todos ellos se incluye la ficción, la que permite expresar y transmitir ciertas ideas que otros textos no. La ficción no hace de ellos pura invención, y no los vacía de contenido. Tampoco significa que la realidad histórica no sea parte de ellos. Los textos narrativos ficcionales son parte de la realidad al mismo tiempo que toman elementos de la realidad.

La ficción en los dos últimos relatos del papiro Westcar permite al escriba diferenciarse de otros relatos "modélicos" que recuerdan el pasado. El tiempo narrativo varía del modo que el pasado se figura, por ejemplo, en Listas Reales. Esta innovación sólo es permitida dentro del campo de la ficción, pues permite imaginar

\footnotetext{
357 Esta idea luego quedará demostrada cuando refiramos en el próximo capítulo a los estudios específicos que se han realizado sobre el papiro Westcar.
} 
un suceso, anunciar un acontecimiento en un tiempo narrativo que ya es pasado histórico para el autor.

Posener (1956), fue uno de los investigadores que ha dejado una impronta fundamental: los textos literarios son también textos políticos. Es decir, que el escenario político que movía a la sociedad formaba el ambiente en el cual los textos eran producidos. Los relatos literarios no eran ajenos a la realidad política. En el caso del papiro Westcar, hay una definición de lo político en la temática misma del relato. La consagración de una nueva dinastía como hija del dios Ra, legitima políticamente el modo de concebir la monarquía faraónica: el rey es rey porque es hijo de un dios. Al mismo tiempo educa acerca del modo de concebir la realeza, lo que Assmann (1996; 1999) destaca como el sentido normativo de los textos culturales.

Al adjudicarle un sentido político a los textos literarios percibimos uno de los aspectos fundamentales de las obras literarias egipcias: la multiplicidad de discursos que se entrecruzan en ellas. Loprieno (1996a, p. 51) comprendió que estos textos son parte de un "universo de textos". El diálogo con otros relatos permite, a nuestro entender, integrar dentro de la narrativa ficcional otros discursos. Baines (1996, pp. 361-362 y ss.) destaca que el mito también forma parte de obras literarias. Así, el papiro Westcar ficcionaliza un mito, el mito de origen del faraón. Se integran a la ficción otros modos de narrar, transformándose la obra literaria en una literatura mítica y política. Sostenemos que confluye en la literatura una multiplicidad de discursos narrativos, multiplicidad que es propia del modo de aprehender y comprender la realidad (multiplicidad de aproximaciones) de la sociedad del Egipto faraónico.

En los próximos dos capítulos discutiremos los rasgos de la ficción en los relatos del papiro Westcar. Algunos investigadores han destacado un solo rasgo de los relatos, lo mágico y lo maravilloso, adjudicándoseles la pertenencia a un único género literario, el de cuento (de hadas). A través del análisis de la estructura narrativa determinaremos los rasgos característicos de la ficción narrada en el papiro Westcar, lo que nos permitirá terminar de argumentar que en ellos convergen diferentes discursos conformando una única composición literaria. 


\section{Capítulo VII}

\section{ACERCA DEL PAPIRO WESTCAR}

Historia, características formales, estudios específicos, datación y argumento 


\section{Historia del papiro Westcar}

El papiro Westcar es uno de los manuscritos más conocidos entre los egiptólogos. Fue descubierto a finales del siglo XIX y ha sido la atracción de una gran cantidad de investigadores, principalmente debido a su contenido mágicoliterario. En la actualidad el papiro se conserva en el Neues Museum de la ciudad alemana de Berlín, adonde llegó entre las pertenencias heredadas por la institución luego del fallecimiento del egiptólogo Karl Richard Lepsius, quien dirigió el departamento de antigüedades egipcias del Museo a partir del año 1865.

El papiro adquirió su nombre por el apellido de la familia inglesa Westcar, la primera propietaria del manuscrito. Henry Westcar se dedicaba a la comercialización de piezas antiguas. Su hija fue la heredera, no solamente de una inmensa fortuna monetaria, sino también de objetos de gran valor material y cultural, entre ellos, el papiro.

La compra-venta de antigüedades era habitual a finales del siglo XIX. Las grandes colecciones que en la actualidad pueden visitarse en los principales museos europeos, obtuvieron sus piezas gracias a la compra o la donación por parte de sus países de origen, o a raíz de que arqueólogos e investigadores pagados por museos o Estados "descubrían" y enviaban sus hallazgos a las salas museológicas para su exhibición.

Henry Westcar era un importante criador de ganado que entre 1823-1824 realizó una expedición a Egipto y Nubia en busca de antigüedades que fueran factibles de ser vendidas 358 . Henry Westcar en su diario de expediciones dejó constancia, pero sin mayores especificaciones, que encontró el manuscrito entre momias y sarcófagos en una tumba del Valle de Gurna (Herzog 1969, p. 204 y Lepper 2008, pp. 15-16). Debemos tomar con recaudo la información proporcionada por el señor Westcar. Que éste lo haya descubierto en el Valle de Gurna no significa necesariamente que haya sido éste el contexto primario del papiro. En todo caso, debemos realizar el estudio de los relatos del papiro Westcar

\footnotetext{
358 Un trabajo referente a la vida y al diario de viaje de Henry Westcar por Egipto y Nubia fue publicado por Herzog (1969). Allí pueden leerse transcripciones de partes del diario de Henry Westcar en las cuales detalla su recorrido por las tumbas y templos.
} 
con la premisa de que se desconoce el lugar de almacenaje y quiénes eran propietarios del rollo de papiro en la antigüedad.

Luego de su descubrimiento, el manuscrito quedó en manos de la familia Westcar y, hasta que fue ingresado a la colección de papiros del museo de Berlín, estuvo guardado en la biblioteca Bodleiana de Oxford en exposiciones intermitentes (Erman 1890, p. 1). El propio Erman hizo averiguaciones sobre su historia y detalló que no han quedado registros sobre el tiempo en que el manuscrito estuvo en la biblioteca, pues la institución no conserva registros de los papiros que estuvieron allí guardados.

Al morir Henry Westcar, el papiro fue heredado por su hija, quien con un gran interés por las antigüedades, resguardó la colección de su padre. Entre 19381939, la señora Westcar conoció al egiptólogo alemán Lepsius, quien estaba de paso por Inglaterra. Y, convencida de las buenas cualidades intelectuales del prominente egiptólogo y que era la persona más idónea para estudiar el contenido del papiro, decide obsequiárselo.

Lepsius fue, por lo tanto, el primer egiptólogo de renombre que tuvo entre sus manos el papiro, aunque no realizó estudios específicos sobre él. Que no lo haya hecho podría estar relacionado con que, en los años que el egiptólogo tuvo a su alcance el manuscrito, la ciencia egiptológica estaba en un proceso de consolidación como disciplina. Además que los estudios sobre lengua egipcia antigua eran incipientes y su lectura era posible. No olvidemos que el texto está escrito en hierático y quizá este tipo de grafía imponía dificultades extras a su traducción y análisis.

Más allá de estas dificultades, fue Lepsius el primero en reconocer que en el papiro se mencionan nombres de reyes de las primeras dinastías de la historia del antiguo Egipto, y en comprender claramente el valor de este texto (Erman 1890, pp. 1-2). Seguramente esto lo motivó a publicar el papiro, y le encargó a Max Weidenbach, un reconocido artista dedicado a la pintura interesado en la egiptología, la confección de una copia facsimilar del manuscrito, que hoy se encuentra guardada en los archivos del museo de Berlín (Lepper 2007, p. 1125). 
Lamentablemente Lepsius no llegó a concretar la edición ${ }^{359}$. Murió en 1886 y el papiro se encontraba entre sus pertenencias que fueron heredadas por el museo de Berlín. Allí se lo catalogó con el número de inventario 3033. Como parte de la colección del Museo el manuscrito se dio a conocer a la comunidad egiptológica de la época y fue el investigador alemán Erman quien efectuó los primeros estudios comprometidos y publicaciones sobre el papiro. Erman dejó registradas cuáles eran sus condiciones mientras lo estudió, sus medidas y cuáles eran las partes que no podían ya restituirse. Además la primera transliteración y traducción completa, como así también todas las apreciaciones primarias sobre el texto, se las debemos a este investigador.

Erman, con un conocimiento de la lengua egipcia clásica, y con una aguda visión de futuro, sacó fotografías al original con las tecnologías más avanzadas de la época. Al mismo tiempo lo tradujo y transliteró, con la finalidad de lograr una mayor perdurabilidad del texto más allá del deterioro mismo de la pieza egipcia (Erman 1890, p. 3).

Que hoy en día tengamos el privilegio de poder estudiar manuscritos de más de 5.000 años de antigüedad, más allá del azar que hizo que se preservaran unos textos y se perdieran para siempre otros, tiene que ver con las propiedades físicas del papiro, el material utilizado para construir los rollos utilizados como hojas (Quirke 2004, pp. 12-13). Es así como en óptimas condiciones, por ejemplo resguardado del calor, es mínima su destrucción por el paso del tiempo que se produce por el material.

Aún en la actualidad el papiro Westcar es una extraordinaria pieza de museo. Por su alta calidad de conservación y su estética agradable, ha sido siempre elegido para la exhibición del público en general. El papiro se expone en el Neues Museum en la "Sala Papyrusellung"360, que reúne una gran cantidad y diversidad de papiros egipcios de todos los periodos y clases. En la sección que exhibe manuscritos de

359 Según Erman (1890, p. 2) lo que imposibilitó a Lepsius concretar la publicación del papiro Westcar fue que poseía otras prioridades relacionadas con su dirección de las expediciones en Egipto, como así también su arrogancia que no le hubiese permitido nunca editar un texto incompleto, y la incapacidad del propio Lepsius de interpretarlo.

${ }^{360}$ En el año 2009 se crea el Neues Museum de Berlín, un edificio dedicado exclusivamente para la exhibición piezas de la antigüedad egipcia, mesopotámica y clásica. 
contenido literario, pueden observarse las nueve hojas que conforman el recto del papiro Westcar.

\section{Características y conservación del papiro Westcar}

El papiro es un manuscrito escrito en hierático, exponente de la más alta calidad de la escritura egipcia. En su estado actual contiene cinco relatos egipcios únicos; de los que hasta el momento, no se han encontrado otras versiones ${ }^{361}$. Es imposible determinar fehacientemente cómo estuvo pensado su diseño original (Goedicke 1993, p. 24), pues al estar incompleto no se puede contemplar la totalidad de la obra.

El papiro es de un color amarillo oscuro con bordes cortados bien definidos. Las medidas proporcionadas por Erman (1890, pp. 3-4) fueron de 169 centímetros de longitud y 33 centímetros de ancho. Estas fueron las mismas medidas dadas por Lefebvre (2003 [1982], p. 93) a inicios de la década de 1980, pero no estamos seguros que haya vuelto a medir el manuscrito. Según Erman (1890, pp. 3-4), las medidas de las hojas varían entre 21 y 13 centímetros. Si se suman los datos proporcionados por Lepper (2008, p. 19) la cuenta total de todas las páginas da como resultado una longitud de 155 centímetros, es decir que muestra una reducción de 14 centímetros con respecto a los datos proporcionados por Erman en 1890362. Hay que tener en cuenta que la primera hoja es la más deteriorada de todas y sus actuales 13 centímetros pueden haber sido más originalmente, teniendo en cuenta las medidas de las restantes hojas del papiro ${ }^{363}$.

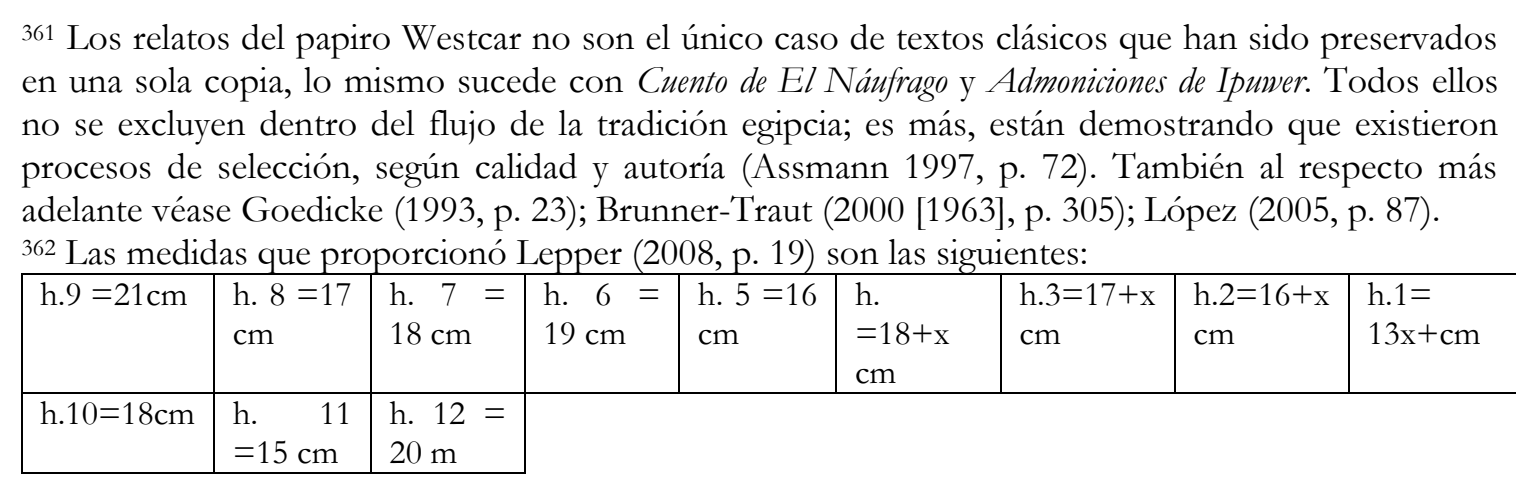

No sabemos si Lepper midió o no el espacio que queda en blanco entre los márgenes de cada hoja. 363 Lamentablemente estas medidas no pudimos corroborarlas al encontrarse el papiro Westcar en exposición para el público en general, por ende al estar resguardo en una vitrina impide esta tarea. 
El color negro predomina en la grafía, las líneas de color rojo marcan la separación entre los relatos en cada hoja y algunas están en la mitad de los relatos ${ }^{364}$. El papiro donde están escritos los relatos es un palimpsesto (Erman 1890, p. 3), es decir que el manuscrito ha sido reutilizado y aún son visibles algunas huellas de una escritura anterior. En el antiguo Egipto, los escribas reservaban el uso de rollos de papiros nuevos para los documentos más prestigiosos, por ejemplo para registros de gobierno, mientras que la reutilización del papiro era frecuente en otro tipo de documentos escritos (Parkinson 1991, p. 14).

El papiro posee cinco páginas pegadas las unas a las otras, separadas por márgenes dejados en blanco, que también recuadran la escritura. Las páginas uno a cuatro del recto poseen dos hojas cada una, mientras que la página cinco sólo tiene una hoja. La página uno corresponde a las hojas uno y dos; la página dos corresponde a las hojas tres y cuatro; la página tres corresponde a las hojas cinco y seis; mientras que las hojas siete y ocho pertenecen a la página cuatro. La página cinco es la hoja nueve. El verso del papiro tiene tres hojas, que serían las páginas cuatro y cinco del recto: la hoja número diez (hoja nueve del recto), la hoja once (ocho del recto) y la hoja doce (siete del recto).

Por consiguiente, puede resumirse que las primeras nueve páginas se encuentran sobre el recto (las únicas que están en exhibición) y las tres últimas sobre el verso del papiro, esto es al dorso de las páginas nueve, ocho y siete. Por lo que en total son doce hojas seguidas unas a las otras sin numerar. En cada una de las hojas se modifica la cantidad de líneas. El esquema del número de líneas en cada hoja es el siguiente:

364 Parkinson (1991, p. 16) destaca que el uso de la línea roja en los distintos textos tenía la intención de resaltar frases y marcar distinciones, agregar respuestas en una carta, y realizar inserciones o correcciones en el texto. El uso más frecuente del rojo fue para indicar el inicio o el final de una sección del texto, marcas en rojo que pueden coincidir con las líneas del verso. 
Hoja 1 = 12 líneas se visualizan. Blackman (1988) y Lepper (2008, p. 19).

Hoja $2=25$ líneas: ninguna línea en rojo.

Hoja $3=25$ líneas: no se observan líneas en rojo.

Hoja 4= 25 líneas: la 17 y la 18 en rojo.

Hoja 5= 25 líneas: la 13 y la 14 en rojo.

Hoja $6=26$ líneas: las 22 y 23 en rojo.

Hoja 7 = 26 líneas: la línea 13 en rojo. Blackman (1998) no marca línea en rojo.

Hoja $8=26$ líneas: las 5- 6 y 22 en rojo.

Hoja $9=27$ líneas: las 21 y 22 en rojo.

Hoja 10= 26 líneas (Lepper 2008, p. 19). 26 líneas: no se ven líneas en rojo (Blackman 1988).

Hoja 11= 26 líneas (Lepper 2008, p. 19). 26 líneas: no se ven líneas en rojo (Blackman 1988).

Hoja 12= 26 líneas (Lepper 2008, p. 19). 26 líneas: 8 y 9 líneas en rojo (Blackman 1988).

CUADRO VII. Número de líneas en cada hoja del papiro Westcar 
El primero de los relatos carece de inicio, pues el manuscrito está destruido, y únicamente puede leerse lo que sería el final. La última parte del papiro también se encuentra corrupta y la historia se interrumpe bruscamente sin poder leerse su final. Estas condiciones de ausencia del principio y el final del papiro hacen que se desconozca si alguna vez el manuscrito contuvo más relatos, o algún otro tipo de escrito. Las condiciones de conservación son buenas para las partes existentes, solamente algunos fragmentos del papiro están destruidos o la tinta borrada. Dichas deficiencias no producen dificultades en la lectura e interpretación del texto.

En resumen, del papiro Westcar se conservan cinco relatos, tres completos y dos incompletos. Algunos historiadores han supuesto que, si cada relato corresponde a una narración contada por uno de los hijos del rey Keops, nueve deberían ser los relatos que el papiro contuvo originariamente, ya que nueve son la cantidad de hijos que tuvo el faraón (Brunner-Traut 2000 [1963], p. 304); es decir que se habrían perdido los cinco primeros relatos. Por su lado, López (2005, p. 87) deja abierta la posibilidad de que en la parte desaparecida del papiro se encontraban uno o varios relatos. Goedicke (1993, p. 23) sugiere que hubiera podido tener más textos ya que en el manuscrito falta el colofón - que otros textos si tienen- y porque la última hoja preservada es de idéntico tamaño que las anteriores ${ }^{365}$. De todos modos, suponer si el manuscrito tuvo más relatos queda en el plano de la especulación.

\section{Discusiones sobre la datación del papiro Westcar}

Erman fue el primer investigador que propuso una fecha de escritura para los relatos del papiro Westcar. En Die Märchen des Papyrus Westcar [Los cuentos (de hadas) del papiro Westcar] determina que los relatos formarían parte del grupo de textos escritos durante el Reino Medio y comienzos del Reino Nuevo. Para Erman (1890, p. 5) el formato de los manuscritos -altura de las hojas, altura de la página, ancho de la página y cantidad de líneas- es lo que constituye uno de los criterios sustanciales a

365 En algunos textos literarios suele encontrarse alguna firma o un colofón que indica quién es el propietario del rollo de papiro o quién ha sido el escriba del texto. Por ejemplo en el papiro d' Orbinay el relato posee un epílogo que advierte que "Aquel que hable mal de este libro, Toth será adversario para ép' (Lefebvre 2003 [1983], p. 165). 
tener en cuenta para su datación. El autor complementa su conclusión con los estudios paleográficos de la escritura (Erman 1890, p. 6).

Erman se guía por las conclusiones obtenidas por Borchardt quien afirmó que existen diferencias entre el formato de los textos del Reino Medio y los del Reino Nuevo. Es posible entonces comparar una y otra época. Para Erman la datación más exacta del papiro Westcar se logra a través de su comparación con el papiro Ebers, elaborado en tiempos del faraón Amenemhat I, es decir en los primeros tiempos de la dinastía XII, o durante la época hicsa y principios del Reino Nuevo egipcio. Erman ya había manifestado interés por estudiar y comprender la gramática de la lengua egipcia antigua a partir de este extenso manuscrito, que describe procesos médicos, había sido ya reconocida por Erman (1889, p. 5). Para el autor, la envergadura del papiro Ebers estaba concedida por la buena calidad estilística; no es un texto producto del acto del aprendizaje de la escritura, lo que denomina "textos escolares", sino que fue realizado por escribas especializados, con conocimientos específicos de la escritura.

Con respecto a las particularidades del formato de los papiros Erman (1890, p. 5) afirma que: los textos del Reino Medio y los primeros tiempos del Reino Nuevo tienen hojas entre 38 y 42 centímetros de ancho. Mientras que los que corresponden al Reino Nuevo poseen hojas entre 16 y 20 centímetros de ancho. Por lo tanto, las copias del papiro Ebers y el papiro Westcar se incluyen en el primero de los grupos. Además comparten la característica de que dos páginas se reparten en el espacio de una hoja, de forma tal que los pegamentos no están escritos (Erman 1890 , p. 5) 366 .

Por otro lado, según Erman (1890, p. 5), entre los escritos no comerciales, y no religiosos de los distintos periodos también se encuentran diferencias en la altura y ancho de las hojas. Los relatos del papiro Westcar fueron incluidos por el investigador en el grupo de una datación media ${ }^{367}$, ya que la altura de las hojas del

\footnotetext{
366 Por lo que intuimos en las fotos los pegamentos sí pueden estar escritos, algunos signos terminan sobresaliéndose del margen, como se observa en la imagen XII.

${ }^{367}$ Los grupos que Erman (1890 p. 6) identifica son tres. El primero, el más antiguo de todos, lo conforman los textos que poseen una altura de las hojas entre los 15 y 17 centímetros, con páginas más anchas que altas y entre 12 y 14 líneas. Un segundo grupo constituido por textos de datación media con una altura de las hojas de 30 centímetros, con páginas más altas que anchas y una
} 
manuscrito las midió de 33,5 centímetros, con páginas más altas que anchas y un total de 24 a 26 líneas.

Concluye Erman (1890 p. 6) que los relatos del papiro Westcar pertenecerían al mismo periodo de tiempo que el papiro Ebers, lo cual les daría una datación de su producción original mucho más cercana al Reino Medio que a la dinastía XIX, a pesar de que la copia que se conserva sea posterior al periodo hicso. Los mismos resultados obtuvo Erman con el análisis paleográfico de la escritura que realizó a lo largo de la traducción de los relatos del papiro Westcar.

Las traducciones y estudios que se publicaron posteriormente sobre los relatos aceptaron como válidas las conclusiones obtenidas por Erman. Las propuestas de datación eran más bien menciones de contextualización de los relatos, sin ningún aporte significativo a su exégesis.

Quien realizó una de las traducciones fue Petrie $(1895)^{368}$. Veremos más adelante que Petrie tenía en mente otras preocupaciones para su libro, y que justamente- no propuso datación para los textos literarios egipcios.

También Maspero (2002 [1911], p. 20) aceptó las conclusiones obtenidas por Erman con relación a la datación de los relatos del manuscrito. Concuerda con Erman que el papiro Westcar se asemeja al papiro Ebers, y que su producción puede ser fechada durante los últimos tiempos de la dominación hicsa en las Dos Tierras. Siguiendo al egiptólogo alemán, Maspero (2002 [1911], p. 20) subraya que es posible que la redacción original del manuscrito haya sido una ejecución mucho más antigua; las particularidades del estilo demuestran que su confección original puede retrotraerse a la dinastía XII. En este sentido la historia de Keops y los magos sería contemporánea a historias como Sinubé y Campesino Elocuente, ejemplares de cuentos populares egipcios (Maspero 2002 [1911], p. 20).

cantidad de 20 a 26 líneas. El tercero y más tardío de los grupos lo consideró para textos con una altura de las hojas aproximadamente de 20 centímetros, más anchas que altas, de 9 a 15 líneas.

368 En el año 2002 el libro de Petrie es reeditado en español con el título Cuentos Egipcios en la colección Érase una vez. Biblioteca de Cuentos Maravillosos, a cargo del editor español José J. de Olañeta. 


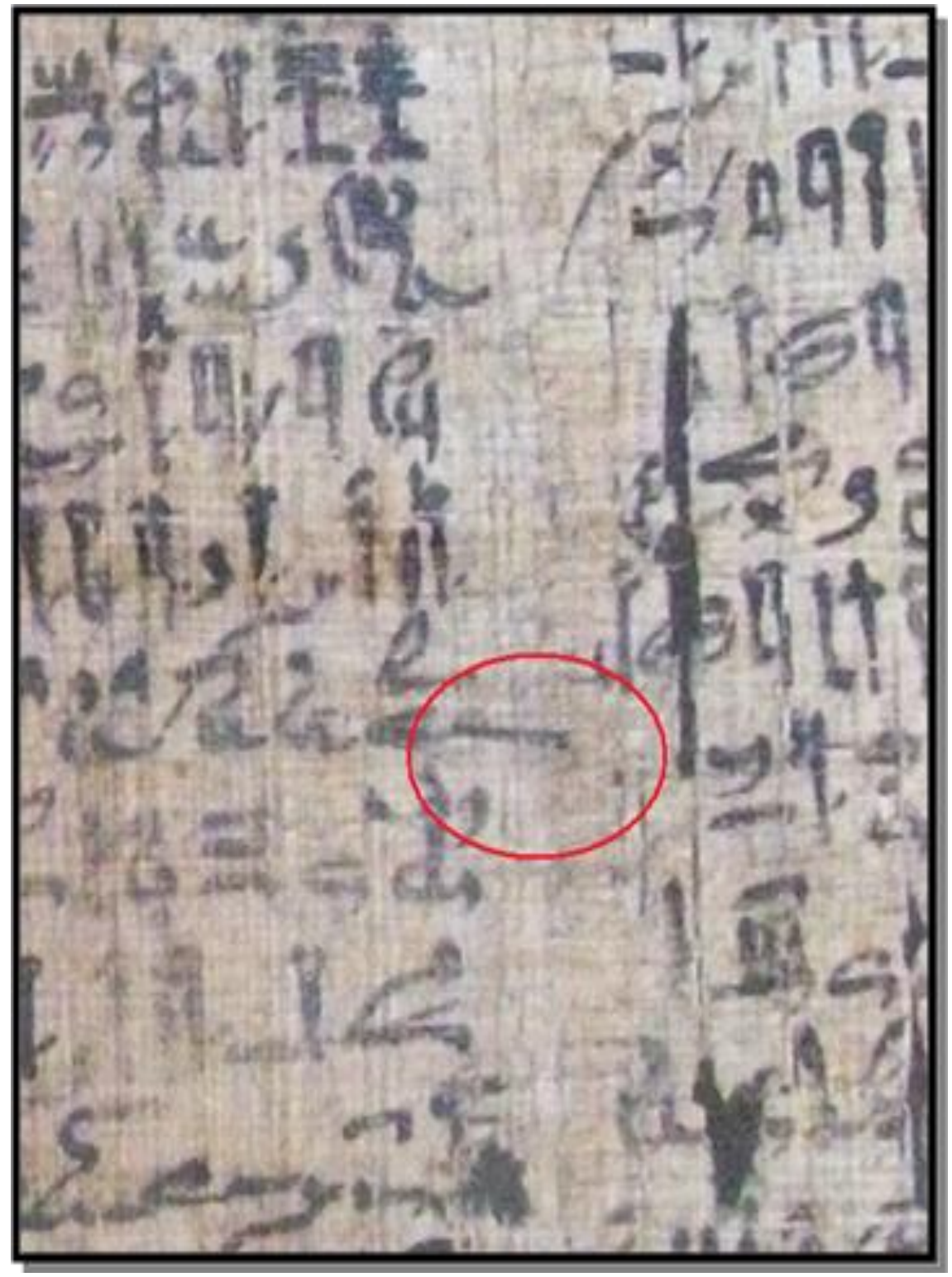

IMAGEN XII. Margen en blanco que une la página ocho con la nueve (de izquierda a derecha) en donde se observa una marca de la grafía del escriba que sobresale del margen (fotografía propia) 
Por su parte, Brunner-Traut (2000 [1963], pp. 303-304) indica que el manuscrito fue escrito durante el siglo XVII a.C., a comienzos de la época hicsa, y que algunas partes del texto compilado podrían ser más recientes en el tiempo. De todos modos, los relatos se basarían en un texto anterior de la dinastía XII, y que para la autora podrían representar los apuntes de relatos populares más antiguos. Para Brunner-Traut (2000 [1963], p. 304) se transcriben en forma de relato acontecimientos relativos a los cambios entre la dinastía IV y la dinastía V.

Entretanto, Lichtheim (1973, p. 215) destaca que, si bien las palabras están escritas en lengua egipcia clásica del Reino Medio, el papiro data de la época hicsa durante el Segundo Periodo Intermedio. Al igual que Simpson (1973, p. 15), para quien el papiro Westcar fue escrito en el periodo hicso antes de la dinastía XVIII, pero la composición original puede ubicarse para la dinastía XII. En tanto, el investigador francés Lefebvre (2003 [1982], p. 91) señala que el papiro Westcar es una copia realizada en época hicsa, lo más probable a finales del Segundo Periodo Intermedio, cuyo original sería de tiempos anteriores, quizá de la dinastía XII, o incluso antes.

Por otro lado, Goedicke (1993, pp. 35-36) afirma que los relatos del papiro Westcar pueden ser producto de los primeros tiempos del Reino Nuevo egipcio, pues no hay ninguna razón que justifique que hubieran sido compuestos a finales del Reino Medio. En todo caso, según el autor, debe aceptarse lo propuesto por Erman que por la paleografía, formato y disposición los relatos pueden datarse para el periodo hicso (Goedicke 1993, p. 23). Los estudios más recientes avalarían esta idea $^{369}$. Siendo cierta la posibilidad que los relatos sean copia de un manuscrito más antiguo, se abre el interrogante de si el texto existente es producto de una revisión posterior o es fiel al original (Goedicke 1993, p. 24).

Parkinson (1998, p. 105) afirma que el papiro puede ser datado aproximadamente para el 1600 a.C., al igual que lo hace López (2005, p. 87) quien agrega que la escritura permite datar la copia a finales de la ocupación hicsa, es decir, lo que equivale a la dinastía XVII tebana. De todos modos, López asume también la

\footnotetext{
369 Algunas publicaciones actuales analizan, discuten y proponen una nueva datación de los textos literarios clásicos.
} 
posibilidad de que la fecha de composición del original sea anterior, que hacia el Reino Medio se haya hecho en una primera redacción. Si bien la lengua es la del egipcio clásico, en muchos pasajes se encuentran construcciones neoegipcias, como es frecuente en varios textos de la dinastía XII.

Jenni (1998, pp. 113 y ss.) realiza un gran esfuerzo por situarlos en un contexto histórico que dé sentido a los relatos del manuscrito, argumentando que fue propaganda de Sesostris I, el segundo faraón de la dinastía XII, y por ende debían haber sido escritos contemporáneamente. De todos modos, Jenni no parece ser muy convincente en este sentido, pues no detectamos ningún elemento -literario o no literario- que nos permita aducir un contexto de producción bajo el reinado de Sesostris I. Sí puede hablarse, como hemos visto, de un programa legitimador más general de la dinastía XII, con una referencia desde el recuerdo del origen divino de la dinastía $\mathrm{V}$, sin que ello signifique un análisis bajo el término de propaganda.

Quirke (1996, p. 271; 2004, p.77) sostiene que la escritura de los relatos del papiro Westcar puede ser fechada para el Segundo Periodo Intermedio, cuando los hicsos ocuparon el poder del Estado egipcio, entre 1800-1550 a.C. Observa, además, que el lenguaje del manuscrito es característico de la fase más tardía del Reino Medio, por lo que podría ser datado para esta época o para el Segundo Periodo Intermedio cuando fue copiado el texto en el papiro (Quirke 1996, p. 271).

Parkinson (2002, pp. 295-296) efectúa una breve pero interesante síntesis de las posturas que se han esgrimido con respecto a la datación del papiro Westcar, dando cuenta que se trata todavía de una discusión abierta. Para Parkinson (2002, p. 296) que los relatos del papiro Westcar hayan sido escritos en la lengua característica del Reino Medio tardío, lo inclina a estimar una fecha tardía de composición, idea que confirma mediante la comparación con otros relatos literarios fechados aproximadamente para finales de la dinastía XII que hacen uso del mismo tipo de lenguaje.

Lepper (2007) pone en revisión todos los postulados que se han formulado para fechar los relatos del papiro, y sugiere que no todos los ellos fueron escritos durante el mismo periodo. Su principal hipótesis es que existen diferencias en el origen y la fecha de cada relato que componen el manuscrito. La autora intenta 
comprobar estas disimilitudes mediante un análisis sobre el tipo de palabras que el escriba -o los escribas- emplean y los diferentes giros estilísticos que hay en cada relato (Lepper 2007, p. 1125).

En los últimos años, en el marco de congresos y jornadas, se ha vuelto a cuestionar la datación de la escritura de los textos literarios egipcios considerados "clásicos", es decir, el conjunto de escritos literarios creados por la elite cultural durante Reino Medio. Por ejemplo, en junio de 2010 se realizó en Gotinga el Seminario "Dating Egyptian Literary texts" ["Datando/fechando textos literarios egipcios"], dónde algunos investigadores propusieron nuevas dataciones para muchos de los relatos "clásicos". Si bien no se han realizado propuestas específicamente para los del papiro Westcar, comienza a modificarse el panorama que contextualiza contemporáneamente algunos textos con otros ${ }^{370}$. Los resultados son aún preliminares y la mayoría de estos trabajos están próximos a ser publicados $^{371}$. Algunos revisan la datación de la elaboración original de los textos literarios, la trasladan más cercana o contemporánea al Reino Nuevo. Su forma "clásica" -propia del Reino Medio- en realidad no sería más que arcaísmos intencionales del escriba.

Si se aceptara que los textos que considerábamos producidos en el Reino Medio son, en realidad, de un periodo posterior como el Reino Nuevo, habría que tener en cuenta algunos aspectos. En primer lugar, se modifican las intenciones que subyacen en ellos y los diálogos que entablan con otros relatos, es decir, se alteran hipótesis y conclusiones. Si bien esta nueva datación no ha sido propuesta específicamente para Westcar, la idea que conecta a este relato con una "literatura del recuerdo" propia del Reino Medio se vería interrumpida y se revalorizarían otros puntos de análisis, como por qué el Reino Nuevo crea este tipo de relatos. A su vez, que las discusiones sobre el momento de su escritura, tras un periodo de circulación

\footnotetext{
370 Puede visitarse el sitio web http: www.datingegyptiantexts.com, donde se encuentra un resumen y listado de las comunicaciones.

371 Principalmente se debate sobre Profecia de Neferty, Enseñanzas de Amenenhat y Lamentaciones de Khakheperrasenebu. Estas nuevas ideas se sustentan en renovados trabajos gramaticales y filológicos de los textos, que recogen los avances del conocimiento de la lengua egipcia producida en las últimas décadas, diferenciándose de las herramientas que los egiptólogos de principios del siglo XX tuvieron al momento de la datación de la mayoría de los textos literarios.
} 
oral, se retrasaría y descontextualizarían otros relatos que sí se conocen copias para las dinastías XII y XIII.

De todos modos, la datación de los relatos del papiro Westcar -y los textos literarios "clásicos" en general- es una discusión que está abierta. Erman según su estudio de la contrastación gramatical de los relatos del papiro Westcar y el papiro Ebers, dedujo que el papiro Westcar fue escrito durante la época en que los hicsos invadieron Egipto, o sea el Segundo Periodo Intermedio pero que, por su estructura gramatical, puede establecerse una escritura originaria en algún momento del Reino Medio, más cercana a la dinastía XII. Es decir, resumiendo, que el manuscrito que hoy se conserva en el Neues Museum de Berlín sería la copia de un texto muy anterior, de relatos ya conocidos para la dinastía XII, en el Reino Medio (Maspero 2002 [1911], p. 18; Lichtheim 1973, p. 215; Simpson 1973, p. 15; Brunner-Traut 2000 [1963], p. 303; Lefebvre 2003 [1892], p. 91; Quirke 2004, p. 77; López 2005, p. 87; Günter Burkard 2007, p. 186). Para algunos autores sería incluso antes (Lefebvre 2003 [1892], p. 91; Brunner-Traut 2000[1963], p. 303), si bien no especifican cuándo.

Los investigadores que han trabajado con los relatos del papiro Westcar, ya sea en artículos más específicos o realizando antologías de relatos del antiguo Egipto, han validado la propuesta de Erman sin mayores discusiones, reproduciéndola sin aportar ningún nuevo análisis que pueda refutar o reafirmar dichas conclusiones. Quien propone una idea diferente es López (2005, p. 87). Para él los relatos corresponden a la lengua egipcia clásica, aunque aparecen fórmulas neo-Egipcias, al igual que en textos contemporáneos del Reino Medio. Es decir, que, como escuetamente lo había sugerido Erman los relatos del papiro Westcar pueden tener una escritura originaria hacia inicios del Reino Nuevo, durante los primeros reinados de la dinastía XVIII. 
ESQUEMA LADO RECTO PAPIRO WESTCAR - PAPIRO BERLIN 3033

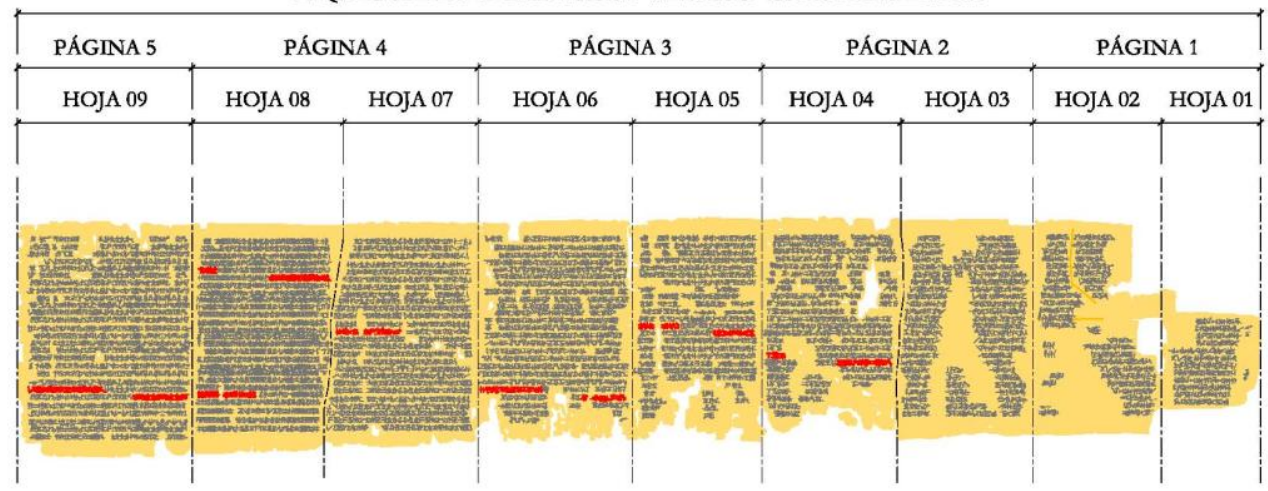

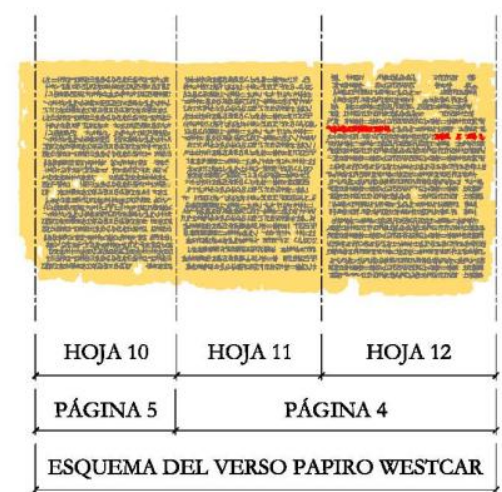

CUADRO VIII. Esquema del papiro Westcar 


\section{Títulos y categorización de los relatos del papiro Westcar}

Una de las características de las narraciones literarias del antiguo Egipto es que no poseían títulos que los identificaran, es por ello que los investigadores, por convención, los han ido nombrando. Es así que algunos textos han adquirido el nombre de su descubridor o de la primera persona que los estudió, como es el caso del papiro Westcar o el papiro d' Orbinay. Un segundo modo, es denominarlos por el lugar donde es custodiado como sucede con Profecía de Neferty que su único manuscrito en papiro se conoce como el papiro 1116 del Museo del Hermitage, y con Admoniciones de Ipunver, que se encuentra en el recto del papiro Leiden 344, o Westcar que corresponde al papiro Berlín 3033. Por último, puede llevar el nombre del lugar dónde fue originariamente encontrado, como el papiro Ramesseum A del texto Cuento de Sinubé, también conocido como papiro Berlín 10499.

Por otro lado, los relatos se conocen con títulos que los investigadores le han dado, como si se tratasen de relatos modernos. Estos títulos son los que comúnmente se utilizan, aunque no hay unanimidad en ellos ${ }^{372}$. Con respecto al papiro Westcar, cada investigador ha propuesto un nombre para el conjunto y para cada relato en particular.

El primero en ponerle un título fue Erman, en Die Sprache des Papyrus Westcar. Eine Vorarbeit zur Grammatik der Älteren Aegyptischen Sprache [El lenguaje del papiro Westcar. Un trabajo preliminar sobre la gramática de la lengua egipcia clásica], es decir, lo nombró por quien fue su descubridor. En una segunda publicación, propuso lo que luego se trasmitió como el "título de la obra" al denominarlo Die Märchen des Papyrus Westcar [Los cuentos (de hadas) del papiro Westcar]. El uso del término märchen fue una primera aproximación a la idea de lo mágico y maravilloso, a la que luego se recurrió más de una vez.

Petrie (1895, pp. 9 y ss.) claramente rescató la idea de märchen, tituló "Tales of the Magicians" ["Cuentos de magos"], proponiendo los nombres de los hijos del rey para cada relato. Al primero le omite título; el segundo se llama "Khafra's Tale" [“Cuento de Khefrén"], el tercero, "Baufra`s Tale" [“Cuento de Baufré"], y el

\footnotetext{
372 Por ejemplo, Profecia de Neferty también se la conoce como Cuento Profético.
} 
cuarto, "Hordedef's Tale" [“Cuento de Hordedef”] incluyendo el anexo. Años después, Maspero (2002 [1911], p. 17) refirió a ellos de modo similar como "The King Khufui and the magicians" [“El rey Keops y los magos”], pero indicó con un margen en blanco la separación entre los relatos. El nombre escogido por Maspero será luego tenido en cuenta por diferentes autores.

Las antologías publicadas a partir de la década de 1970 se encargaron de catalogar los relatos del papiro Westcar, y cada autor propuso diferentes títulos. Para Lichtheim (1973, pp. 215 y ss.) los relatos del papiro Westcar son cuentos en prosa, de ahí que su traducción se encuentre en el apéndice cinco del apartado dos: "Prose Tales" [“Cuentos en prosa”]. Los tituló “Three Tales of Wonder" [“Tres cuentos maravillosos”], destacando el carácter mágico de los mismos. Sin motivo aparente, descarta a los dos primeros relatos preservados en el papiro, y al tercero lo llama "The Boating Party" ["La diversión/el paseo en Bote"], haciendo alusión al argumento cuando el rey se divierte en el río tras el consejo del mago. Al cuarto lo titula "The Magician Djedi" [El mago Djedi], por el nombre de uno de los protagonistas, mientras que el anexo lleva el nombre de "The Birth of the Royal Children" [“El nacimiento de los niños reales”].

Por su parte, Simpson (1973, pp. 15 y ss.) utiliza "King Cheops and the Magicians" ["El rey Keops y los magos"], propone subtítulos para cada relato que conforma con el número de relato y detalla las maravillas del argumento. Al primero lo llama "First Tale: End of the Marvel in the Time of King Djoser" ["Primer cuento: final de la maravilla realizada en el tiempo del rey Socer']; al segundo "Second Tale: The Marvel which happened in the time of King Nebka" ["Segundo cuento: una maravilla ocurrida en el tiempo del rey Nebka”], al tercero: "Third Tale: The Marvel Which Happened in the Reing of King Snefru" ["Tercer cuento: una maravilla ocurrida en el reinado del rey Snefru”], al cuarto "The Fourth Tale: A Marvel in the Time of King Khufu Himself" ["Cuarto cuento: una maravilla en los tiempos del rey Keops mismo"], y al relato anexo lo titula: "The Birth of the Kings" [“El nacimiento de los reyes”]. Simpson así destaca el carácter narrativo de los relatos del papiro Westcar, de hecho su traducción pertenece a la primera parte del libro "Narratives and Tales of the Middle Egyptian Literature" ["Narrativas y 
cuentos de la literatura egipcia media”], y enfatiza sobre un aspecto del argumento de los relatos: que en cada uno de ellos se narra una proeza mágica.

Muy similar es lo que propone Lefebvre (2003, [1982], pp. 91 y ss.) quien titula "Cuentos del papiro Westcar". El primero de los relatos se llama "Primer cuento: Un prodigio bajo el reinado de Djeser"; el segundo, "Segundo cuento: Un prodigio bajo el reinado de Nebka, o el cuento del marido engañado"; el tercero, "Tercer cuento: un prodigio en el reinado de Snofru. El cuento de las remeras"; el cuarto, "Cuarto cuento: un prodigio bajo el reinado de Keops. El mago Djedi"; y por último, "Anexo al cuarto cuento: el nacimiento de los reyes de la dinastía V".

En una antología más moderna, Parkinson (1998, pp. 102 y ss.) denomina a los relatos como "The Tale of King Cheops' Court" ["El cuento en la corte del rey Keops]". Parkinson no realiza divisiones con subtítulos, sino que se adecua en su traducción a los números de líneas del papiro. Algo similar es lo que realiza Quirke (2004, pp. 77 y ss.), quien los denomina "Tales of Wonder at the Court of King Khufu" ["Los cuentos de maravillas en la corte del rey Keops]". Tampoco propone subtítulos, sino que divide la traducción y transliteración en párrafos siguiendo las líneas del papiro, y remarca con letra en "negrita" las partes del relato que coinciden con las líneas rojas del papiro.

La propuesta de López (2005, pp. 87 y ss.), "Los cuentos del papiro Westcar", contiene una separación en subtítulos muy similar a la propuesta por Simpson y Lefebvre. Al primero lo llama: "Final del primer cuento. Un prodigio en tiempos del rey Djeser"; al segundo, "Segundo cuento. Un prodigio en tiempos del rey Nebka: el mago Ubaoné y su mujer”; al tercero, “Tercer cuento. Un prodigio en tiempos del rey Snefru: el mago Djadjaemankh y el paseo del rey por el lago”; y al cuarto, "Cuarto cuento: Un prodigio en tiempos del rey Keops: el mago Dedi"; y, por último, "Relato añadido al cuarto cuento: El nacimiento de los reyes de la $\mathrm{V}$ dinastía”.

De este modo, se observa la existencia de un denominador común al momento de titular los relatos del papiro Westcar, siendo lo mágico/maravilloso el el elemento que se destaca de su argumento. 


\section{Trabajos específicos sobre el papiro Westcar: traducciones, transliteraciones y estudios}

Los estudios sistemáticos sobre los relatos del papiro Westcar se iniciaron con los trabajos del egiptólogo alemán Erman, quien en 1886 publica un breve artículo, "Ein neuer Papyrus des Berliner Museums", encargado por el Museo de Berlín para dar a conocer su nueva adquisición ${ }^{373}$. Tres años después, Erman edita la primera publicación en forma de gramática de la lengua egipcia: Die Sprache des Papyrus Westcar. Eine Vorarbeit zur Grammatik der Älteren Aegyptischen Sprache [El lenguaje del papiro Westcar. Un trabajo preliminar sobre la gramática de la lengua egipcia clásica]. En ella no solo realiza un análisis gramatical detallado de los cinco relatos, sino que sienta las bases de la gramática del antiguo Egipto. Fue ésta una de las primeras publicaciones de este tipo y en ella Erman pone en consideración diversos problemas que los textos presentaban. $\mathrm{Al}$ mismo tiempo era una especie de manual de aprendizaje de la lengua egipcia antigua del Reino Medio. Las características de esta publicación la convirtieron en una consulta obligada para los interesados en el papiro Westcar, y para aquellos que buscan especializarse en lengua egipcia antigua.

En 1890, Erman publica un segundo libro acerca del papiro Westcar, Die Märchen des Papyrus Westcar [Los cuentos (de hadas) del papiro Westcar], que se convierte en el primer trabajo específico sobre los relatos del manuscrito, y su primera transcripción completa. Erman tiene en cuenta tanto los problemas relacionados con la gramática y filología como así también los vinculados con su datación. Sin duda, ésta es una de las obras más importantes escritas sobre los relatos del papiro Westcar, que abrió las puertas a posteriores estudios ${ }^{374}$.

\footnotetext{
373 Conocemos esta publicación según la cita que hace de ella Maspero (2002 [1911], p. 17) y que vuelven a mencionar Lefebvre (2003 [1982], p. 91) y López (2005, p. 89). Hasta el momento no la hemos podido encontrar. La Biblioteca del Neues Museum no ha conservado una copia del mismo (Lepper 2010, comunicación personal).

${ }^{374}$ Los trabajos que continuaron fueron muchas veces el reflejo y copia de los planteos de Erman, sin haber en ellos una crítica a sus ideas. Este abordaje similar queda en evidencia si se comparan las obras dedicadas a la publicación de los textos literarios egipcios. Por ejemplo pensamos en los trabajos realizados por Maspero, Lefebvre, Lichtheim, Simpson, López. Véase más adelante comentario sobre estas obras.
} 


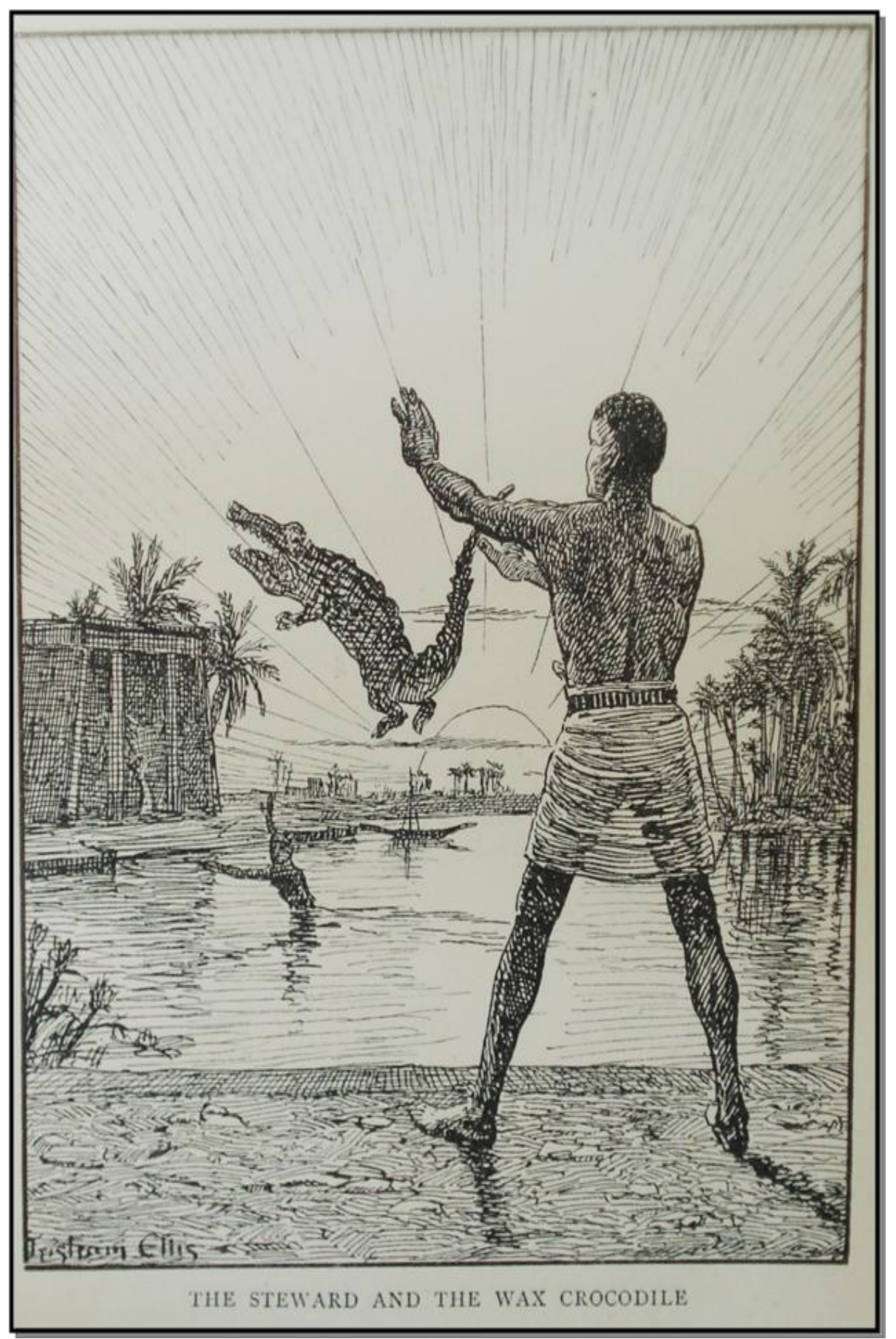

IMAGEN XIII. Representación en el libro de Petrie (1895) del segundo relato del papiro Westcar, el momento en el cual el mago toma en sus manos al cocodrilo para castigar al amante 
Entre finales del siglo XIX y principios del siglo XX se editaron obras que recopilaban relatos del antiguo Egipto, publicadas en diversos idiomas, la mayoría de ellas con poco rigor académico, siguiendo los paradigmas propios de la egiptología de esas décadas. El reconocido arqueólogo inglés Petrie, uno de los pioneros de la actividad arqueológica sistemática en Egipto, publica en 1895 una recopilación de relatos del antiguo Egipto, según sus propias palabras, para cubrir la ausencia de una obra de textos egipcios en inglés (Petrie 1895, p. 2). En Egyptian Tales [Cuentos/relatos egipcios], Petrie destaca una fuerte connotación fantástica en los relatos. Su intención es que el lector se transporte al mundo del antiguo Egipto por medio de la imaginación, para lo que adapta la traducción a fórmulas conocidas de la ficción como "Érase una vez..." e incorpora láminas que ilustran pasajes de los relatos, como las imágenes número XIII y XIV, a cargo del famoso dibujante británico Tristram Ellis. La intención de Petrie (1895, pp. 2-4) con los dibujos es dar más fidelidad a la imagen que se construía del mundo egipcio antiguo.

La siguiente publicación que pone en consideración a los relatos del papiro Westcar es la tercera y definitiva edición de la obra en francés del egiptólogo Maspero, Les Contes populaires de l'Égypte ancienne [Los cuentos populares del antiguo Egipto]. Allí Maspero (2002 [1911], pp. 17 y ss.) propone una nueva traducción de los relatos, realiza un repaso de las publicaciones anteriores y resume brevemente el argumento de cada uno.

Maspero (2002 [1911], pp. 17-18) tiene una mirada muy aguda con relación a los relatos del papiro Westcar y hace mención a algunas problemáticas que reaparecerán en posteriores discusiones. Por un lado, se pregunta sobre la veracidad histórica de la narración del origen de la dinastía V. Canon de Turín da cuenta de un quiebre en la cronología egipcia con el faraón Userkaf, mientras que otras fuentes manifiestan que el cambio de dinastía se efectuó sin inconvenientes. Sí cree en la narración de que Userkaf era hijo de Ra, que no poseía sangre real y no tenía ningún derecho al acceso a la realeza. Desde esta perspectiva, se acerca a las teogamias tebanas, las de Hatshepsut y Amenofis III, quienes sin tener sangre real accedieron al cargo de monarcas, trasmitiendo una historia similar: que eran hijos del dios. 
Por lo tanto, Maspero no sólo reconoce los paralelismos con las narraciones míticas de Hatshepsut y Amenofis III, sino que también intuye su contenido político en el hecho de que los reyes no fueran parte de la familia real, condición casi inalterable para acceder al cargo de faraón. Por ello existió la creación de un relato que en el caso de los dos últimos del papiro Westcar es mítico-literario- en el cual el monarca hace legítima su condición de rey a través de su reconocimiento como hijo del dios.

Los trabajos sobre el papiro Westcar estuvieron en sintonía con las preocupaciones de su época alrededor de la literatura egipcia antigua. Es así que en un primer conjunto de trabajos, publicados hasta la década de 1940, las discusiones giraron en torno a las nociones de filología y propuestas de nuevas traducciones para algunas líneas específicas. Incluimos aquí las publicaciones de Peihl (1897); Blackman (1925; 1927; 1930; 1936); Spiegelberg (1929); y Smither (1939) quienes discutieron algunos pasajes de los relatos, proponiendo nuevas interpretaciones y traducciones. Por ejemplo, el trabajo de Gardiner (1925) puso en consideración la naturaleza del término ipwt, tema que también fue examinado por Green (1930) y Berggren (2006) ${ }^{375}$, y posteriormente la década de 1970 por Barns (1972) y Mordechain Gilula (1978).

En 1959, Kurt Sethe, en Ägyptische Lesestücke zum gebrauch im akademischen unterricht [Relatos egipcios de lectura para su uso en la enseñanz̧a académica], editó la segunda versión en texto jeroglífico de los relatos del papiro Westcar. Una tercera versión completa fue publicada en 1988 por Blackman: The Story of King Keops and the Magicians. Transcribed from Papyrus Westcar (Berlin Papyrus 3033) [La historia del rey Keops y los magos. Transcrito del papiro Westcar (papiro Berlín 3033)]. Estas obras y las clásicas

\footnotetext{
375 En su trabajo, Gardiner concluye que el término ipwt debe ser entendido, y por ende traducido, como "cámara secreta" e interpreta que Keops desea conocer los detalles de esta cámara secreta porque busca construirse una semejante para sí mismo. El término ha sido siempre un punto de discusión en las diferentes traducciones de los relatos y el más completo análisis al respecto fue realizado por Berggren (2006) en un complejo y extenso estudio de la morfología y etimología de ipwt para el papiro Westcar.
} 
de Erman son las más importantes transcripciones publicadas sobre el papiro Westcar, constituyéndose en referencias obligadas para quienes lo estudien ${ }^{376}$.

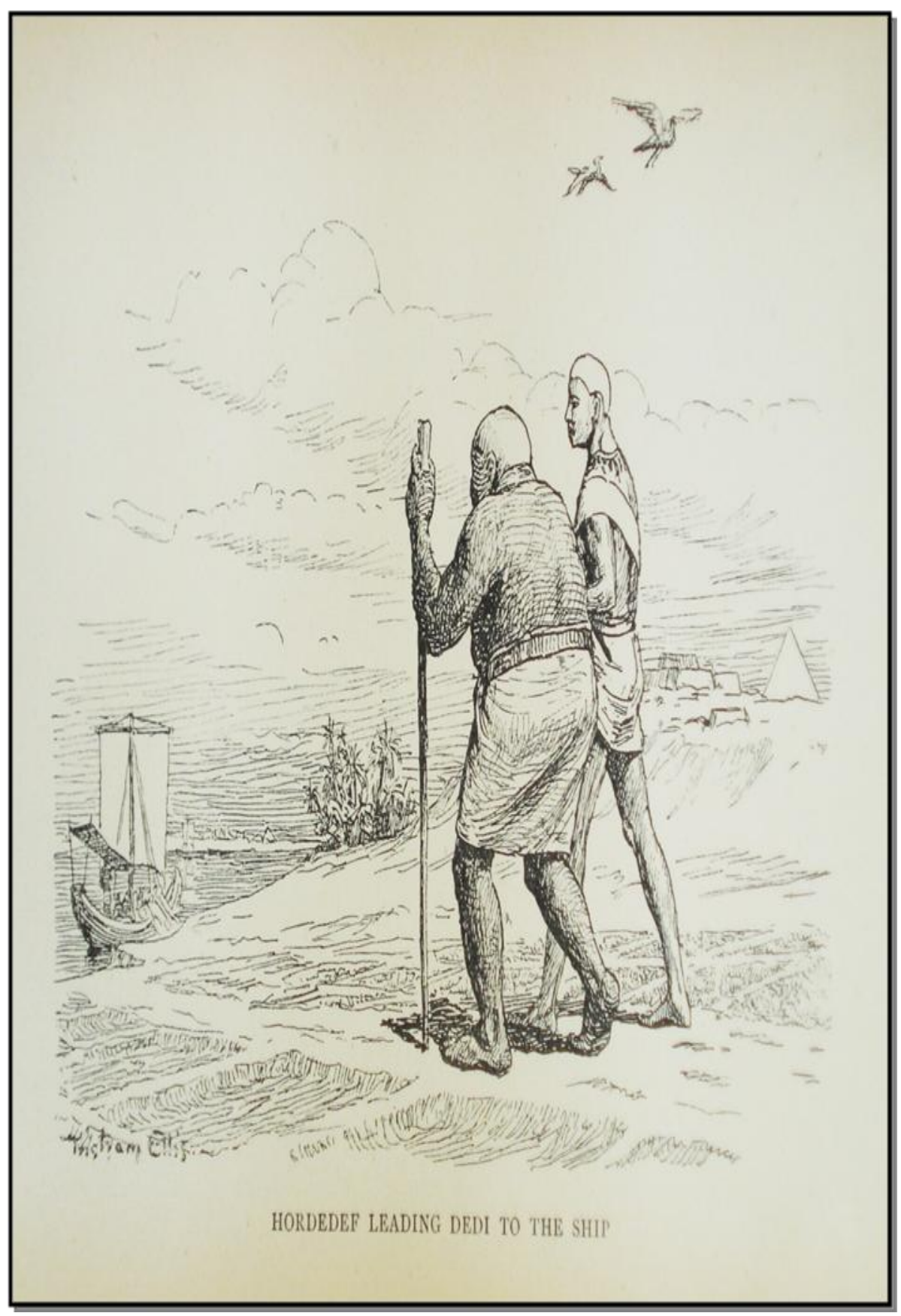

IMAGEN XIV. Representación en el libro de Petrie (1895) del cuarto relato cuando el hijo del rey Keops, Herdedef, busca al mago Djedi para llevarlo a la corte real

\footnotetext{
${ }^{376}$ La traducción que se propone en la presente tesis se realizó a partir del texto jeroglífico de
} Blackman (1998). 
Como ya hemos observado a partir 1970 se publicaron un gran número de antologías que incorporaron los relatos del papiro Westcar. En la mayoría de ellas se emplea la datación considerada por Erman, a la vez que tienen una misma forma de organizar la estructura de presentación de los relatos del papiro, y de los restantes textos literarios egipcios. Con respecto a su organización estas obras poseen una breve introducción que está acompañada con un resumen del argumento, una mención de las obras y trabajos que se han publicado con anterioridad sobre los relatos, ya sea su traducción o transliteración, y finalmente la traducción propuesta por el autor, a veces acompañada con notas a pie de página para aclarar ciertos pasajes dudosos o conflictivos en la traducción.

En inglés, podemos destacar la obra de Lichtheim (1973, pp. 215-222) ${ }^{377}$; Simpson (1973, pp. 15-30); Parkinson (1998, pp. 102-127); Quirke (2004, pp. 77-89) esta última que se distingue por tener una transliteración y traducción de los relatos. En alemán, podemos mencionar las de Brunner-Traut (2000 [1963], pp. 52-65 y pp. 302-305) 378; Günter Burkard (2007, pp. 185-195). En francés, existe la de Lefebvre (2003 [1982], pp. 91-108)379. En italiano, se destaca la de Bresciani (1969, pp. 178188). Traducciones originales en español fueron realizadas por Serrano Delgado (1993, pp. 67-70) ${ }^{380}$ y López (2005, pp. 87-104), además de la de Sánchez Rodríguez (2003), quien publicó los textos en jeroglífico y propuso una traducción teniendo en cuenta las construcciones gramaticales al estilo de una gramática de la lengua egipcia.

Entre tanto se editaban estas obras generales, los relatos del papiro Westcar eran olvidados en los trabajos específicos, fueron muy pocos los publicados en revistas especializadas. Se destaca el artículo de Derchain (1986, pp. 15-21), "Deux notules a propos du Papyrus Westcar" [“Dos anotaciones a propósito del papiro Westcar"] donde el autor realiza dos aclaraciones.

La primera: para Derchain debe matizarse la sugerencia que se ha realizado (Sethe 1959, p. 27; Brunner-Traut 2000 [1963], p. 305) con relación a la omisión del

\footnotetext{
377 Sólo traduce los últimos tres relatos.

378 Esta es la referencia de la traducción en español de Brunner-Traut realizada por Pablo Villadangos.

${ }^{379}$ Esta es la referencia de la traducción en español de la obra de Lefebvre realizada por Serrano Delgado.

380 Sólo traduce el relato anexo.
} 
pasaje en el cual Djedi actúa sobre un toro. Según Derchain (1986, p. 16) lejos de pertenecer a otra historia- como algunos han supuesto- el pasaje tiene la función de autenticar el poder del mago, donde la rápidez de la acción realizada da cuenta de sus conocimientos.

La segunda: Derchain (1986, p. 17) destaca que la interpretación de los textos literarios egipcios trae aparejada dos problemas. Uno, intrínseco, la dificultad de la interpretación de los registros de la lengua egipcia; el significado de las metáforas y la originalidad de las situaciones descriptas; y el empleo de los mitos como referencia de la vida profana, nos permite acercarnos al verdadero significado. La otra, extrínseca, que refiere a la imposibilidad de interpretación por parte de los lectores modernos de conocer las intenciones con las cuales los textos fueron escritos. Pues, el lector moderno no conoce sus referencias intertextuales.

Más allá de estas dos dificultades, Derchain (1986, pp. 18-19) destaca que es evidente el carácter maravilloso del último relato del papiro Westcar. Lo maravilloso no sería la transformación de diosas en personajes humanos. Sino que lo más sorprendente es que Rauser acepta, sin reparos, la ayuda de bailarinas en el parto de su mujer, como si fuera una situación corriente que bailarinas tengan conocimientos sobre obstetricia en el antiguo Egipto, lo que para Derchain es bastante improbable. A nuestro entender, Derchain pierde de vista lo que hemos destacado como un rasgo fundamental del relato: su ficcionalidad. Que las diosas se transformen en bailarinas, que Rauser les permita entrar a su casa a ayudar a Reddjedet, es propio de un marco ficcionalizado del relato mítico, y no hay que buscar en ello algún tipo de racionalidad.

Por último, Derchain (1986, p. 20) destaca que toda la escena del nacimiento de los trillizos está descripta en lenguaje de mito, destacándose los rasgos mágicos de los actos que realizan las diosas/bailarinas. Lo puramente mágico, para el autor es una interpretación más egipcia que moderna. Pues, habría que preguntarse por qué el autor del papiro Westcar ha escrito este relato. Según Derchain no sería demostrar el origen divino de los reyes, sino que se narra detalladamente cómo se producen los nacimientos en Egipto. Y la intención última no puede ser develada, ya que desconocemos las circuntancias en las que fue compuesto. Lo único que puede 
saberse es cómo fue hecha: la historia de Reddjedet está construida sobre el esquema de la mujer adúltera del segundo relato, pero a la inversa.

Goedicke publica dos artículos sobre los relatos de papiro Westcar, a los cuáles ya hemos remitido. En el primero de ellos "Rudjet's delivery" ["El parto de Reddjedet] de 1985, Goedicke sugiere revisar la idea que ha tratado al relato anexo simplemente como la narración de un parto. Destaca la sugerencia iniciada tímidamente por Erman (1890, p. 11) y luego retomada por Posener (1940, pp. 90 y ss.) de que en el relato se tiene la intención de demostrar la naturaleza divina del rey, como hijo del dios. Verlo como prototipo de la narración de la reina Hatshepsut en la cual se declara hija del dios Amón-Ra, es para Goedicke (1989, pp. 19-20) erróneo por dos motivos. En primer lugar porque que sea el dios Ra quien envía la ayuda de las diosas al parto de Reddjedet no justifica su paternidad. En segundo lugar, tampoco lo es el legado maravilloso que los dioses otorgan a los trillizos -las diademas. Ya hemos analizado oportunamente la idea de Goedicke. Sólo reiteraremos que la paternidad de $\mathrm{Ra}$ está atestiguada en el cuarto relato que antecede al anexo, y que nuestra postura se acerca a aquella que ve en los relatos del papiro Westcar una narración mítica, la del origen de nuevos reyes.

En 1993, Goedicke publica lo que es para nosotros el primer trabajo crítico acerca del papiro Westcar. En "Thougts about the papyrus Westcar" ["Reflexiones acerca del papiro Westcar'], el autor propone como tesis principal que la narración se basa en el relato de un plan divino, la llegada de nuevos reyes para gobernar Egipto, lo que se cumple efectivamente en el relato anexo. Aquí está lo que es para Goedicke el tema central de la composición literaria: la transición de la dinastía IV a la dinastía $\mathrm{V}$ y, aunque el escenario de la corte real es un recurso literario, no constituye una narración histórica. El autor considera que si el texto hubiese circulado en una esfera especializada, con conocimiento sobre los acontecimientos pasados, no hubiera sido necesario ningún tipo de referencia histórica. Pero que, por el tipo de lenguaje, lo más probable es que el texto estuviese destinado a una esfera no especializada.

Eyre (1992, pp. 280-281) en un artículo muy sintético, llama la atención sobre el juego de palabras, doublé entendre, que se visualiza en los relatos de papiro Westcar, 
un dispositivo que es recurrentemente utilizado en los textos egipcios. El autor propone para el segundo relato del marido engañado, un juego de palabras con el verbo sfh "liberar", que la audiencia fácilmente puede detectar porque está habituada a este tipo de lenguaje. Esto mismo se repite en el cuarto relato con Djedi, quien tiene la habilidad de caminar detrás de un león utilizando una cuerda, término que tiene como raíz el signo $f h$; nuevamente la audiencia encontraría un juego de palabras fácil de detectar para ellos.

Eyre (1992, p. 281) encuentra paralelismos entre el simbolismo del cocodrilo como una figura ambivalente, tanto destructora como creadora-regeneradora de vida, que el mago Ubaoné tiene la capacidad de controlar, al dominar mágicamente al animal. Djedi tiene igual relación con la vida y la muerte, ya que puede restituir la vida a un animal recién muerto. Eyre se pregunta si este significado mítico-simbólico estaba al alcance del público general de los relatos del papiro Westcar.

Meltzer (1994, pp. 69-175) reconoce que sus ideas son producto de las discusiones que mantuvo siendo estudiante con el profesor Goedicke. En su artículo "The Art of the Storyteller in papyrus Westcar: an Egyptian Mark Twain?" ["El arte de narrar: ¿un Mark Twain egipcio?’] destaca cómo en los relatos del papiro Westcar el autor logra una expresión marcada por un ritmo humorístico y un lenguaje florido, especialmente en el cuarto relato en el diálogo que Djedi mantiene con el rey Keops y con su hijo Hordedef. Este tipo de escritura, semejante a la representación teatral, envuelve a la audiencia en una atmósfera única que se acerca a la calidad de un escrito de Mark Twain. Para Meltzer, sin duda, el creador de estos relatos era un escritor que conocía perfectamente el arte de la escritura.

Jenni (1998, pp. 113-141) propone, como ya había sugerido Goedicke (1993, p. 24), que los relatos del papiro Westcar no se asemejan a una serie heterogénea de relatos, sino que forman una composición literaria integrada. La autora destaca el juego entre tiempo pasado y presente, en dónde las hazañas maravillosas se convierten en un espectáculo sin igual. Pero, para Jenni los relatos del papiro Westcar persiguen también un fin propagandístico, que forma parte de la propaganda política del faraón Sesostris I. Esto es que la recreación literaria de un mito conocido sobre la transición de la dinastía IV a la dinastía $\mathrm{V}$, pretende 
acercarse al periodo de cambio entre Amenemhat I y Sesostris I, dándole legitimidad a este último ${ }^{381}$. Jenni destaca que la idea literaria central es lo que puede denominarse la "doctrina del hijo". En ella se proyecta la intención del hijo de construir su historia biográfica, que le otorga acceso al trono egipcio, en analogía a la herencia de los trillizos en el papiro Westcar. Además, interpreta que el castigo del cocodrilo a los adúlteros en el segundo relato del papiro Westcar es símbolo de la venganza que Sesostris I quería perpetrar hacia sus enemigos.

Hays (2002) en "Historicity of Papyrus Westcar" ["La historicidad del papiro Westcar'], está preocupado en determinar a partir de qué momento histórico adquiere importancia la figura de "hijo de Ra" dentro de la ideología de Estado. Para Hays las diferentes fuentes sostienen que el culto al dios Ra ya estaba presente en la dinastía IV. En este sentido, los relatos del papiro Westcar sólo representarían un aumento de la preeminencia del culto de $\mathrm{Ra}$ en la dinastía $\mathrm{V}$. Lo que narran literariamente no es históricamente adecuado, pues la solarización de la realeza es previa a los tres primeros faraones de la dinastía $\mathrm{V}$ que se declaran, en el papiro, hijos del dios Ra.

Entre los trabajos más recientes vale la pena señalar el realizado por Lepper (2007, pp. 1125-1136; 2008). En Untersuchungen zu pWestcar. Eine philologische und literaturnissenschaftliche (Neu-) Analyse [Estudios sobre el papiro Westcar. Algunos estudios filológicos y literarios (Nuevos) análisis], presentó la hipótesis de que los relatos del papiro Westcar no hayan sido escritos por una misma persona. Alcanzó esta conclusión a través de un extenso trabajo en el cual examinó los dispositivos estilísticos, la gramática y el vocabulario de cada texto individualmente, basándose en la idea primaria de que cada autor maneja en su escritura un léxico que le es propio. La autora reactualiza los trabajos que analizan detalladamente la escritura del papiro, incorporando conceptos de la lingüística moderna.

\footnotetext{
381 Para Jenni en este mismo sentido podría leerse Enseñanza para Merikara, en la cual se narra el traspaso del poder de padre a hijo.
} 


\section{Argumento de los relatos del papiro Westcar}

$\mathrm{El}$ argumento y la estructura del papiro Westcar se dividen en dos partes. Por un lado, un grupo integrado por los cuatro primeros. Veremos similitudes -y también diferencias- que hacen de ellos un conjunto narrativo en argumento y estructura. Una segunda parte la compone el quinto relato, que no mantiene una línea argumental con los otros cuatro, como así tampoco se asemeja en su composición estructural. Lo analizaremos detalladamente en el próximo apartado.

En los cuatro primeros relatos del papiro Westcar el presente narrativo de la acción transcurre durante algún momento de la dinastía IV, bajo el reinado del faraón Keops. Con un público reunido en la corte faraónica, uno a uno de sus hijos se para ante su padre-rey para hablar. Entretener al rey es el disparador argumental desde el cual se desarrolla la acción. Sus hijos proponen distraerlo con buena elocuencia y una historia divertida. Cada historia contada por un hijo del rey constituye un relato del papiro, y en todos ellos el nudo de la acción se resuelve a través de un acto mágico.

La escena de una corte real que reúne a altos miembros de la elite cultural y política no es distinta a otras imágenes descriptas en otros textos literarios, el ejemplo más cercano es Profecía de Neferty. Aquí aparece una particularidad interesante: el faraón en persona toma en sus manos el rollo de papiro y la pluma para dejar asentadas las palabras que Neferty tiene para decir. No parece ser usual la idea de que el propio faraón sea el encargado de tomar nota. El hecho más bien recuerda a algunas imágenes de los templos funerarios, donde el dios Toth sostiene en sus manos el rollo de papiro, como parte de una de sus funciones más destacadas, la de ser escriba ${ }^{382}$.

Más allá de estas observaciones, la relación entre Profecía de Neferty y los cuatro primeros relatos del papiro Westcar es clara en un punto: una corte real que está

\footnotetext{
382 Podemos poner como ejemplo una escena que analizamos en otro capítulo. En las primeras imágenes del mito del nacimiento divino de la reina Hatshepsut, Toth es representado reiteradamente llevando un rollo de papiro. El dios era el encargado de registrar toda la situación cuando el rey convoca a la Enéada para comunicar la decisión de la necesidad de un nuevo rey en Egipto.
} 
siendo espectadora de palabras pronunciadas por un personaje dotado de buena retórica.

El lector puede imaginar cómo trascurre toda la escena. Los personajes se ubican alrededor de una figura central, el faraón. El orador principal se coloca delante de él, sobre su vientre. Puede imaginarse una corte opulenta en la cual hay miembros de la elite política, funcionarios del rey, mujeres del harén, etc. que son espectadores ${ }^{383}$.

Los tres primeros hijos le cuentan a Keops historias ocurridas en el pasado, protagonizadas por faraones que reinaron en tiempos anteriores y por magos que resuelven un conflicto por medio de imponentes capacidades en el uso de la magia. Mientras, en el cuarto relato, se introducirá una diferencia, pues se narrará ya no una historia pasada sino que un mago de la corte real demostrará sus saberes mágicos al rey.

Con respecto al primero de los relatos solamente podemos leer su final. El texto conservado se inicia con la tercera persona del singular que introduce las palabras de Keops. El rey recompensa con mil panes, cien jarras de cerveza, un buey y dos medidas de incienso (sntrr) al rey Socer ${ }^{384}$. A partir de la mención de Socer es que se deduce que la historia pudo haber estado ambientada durante su reinado, y que quizá lo tuvo como protagonista ${ }^{385}$. También ofrece un cántaro de cerveza y

\footnotetext{
${ }^{383}$ Una imagen semejante se describe en Campesino Elocuente. Un campesino de la región del wadi del Natrum, quien posee una gran capacidad de oratoria, debe concurrir una y otra vez a la residencia del intendente de la provincia Rensi. El gobernador es el encargado de garantizarle al campesino justicia por un robo que sufrió en su tierra, pero el funcionario no muestra intención de solucionar su problema, sino que en las buenas palabras del campesino encuentra un buen entretenimiento. El don que posee el campesino es justamente lo que le impide lograr justicia con mayor rapidez.

384 El rey Socer reconocido ampliamente por los especialistas como el primer faraón de la dinastía III, aún así existen dudas al respecto. Algunos autores han supuesto que Nebka podría haber sido su antecesor. En el Reino Antiguo, el rey llevó el nombre de Netjerkhet. El más conocido, Socer, corresponde a su nombre de $n s w$-bity y no se encuentra en las inscripciones de este periodo; solamente comenzó a usarse para referirse a su persona en el Reino Nuevo (Parra Ortiz 2009, p. 125). Su obra más reconocida fue la construcción de la primera pirámide escalonada que inició la historia de la forma piramidal. Para Assmann (2005 [1996], p. 72) fue la historia del Reino Antiguo, lo que sintetizó el concepto de "ideología de la piedra", en la que la construcción de la pirámide escalonada fue el mayor símbolo del cambio cultural de la época (Assmann 2005 [1996], p. 74).

385 En el papiro no puede leerse el nombre del personaje, aunque algunos historiadores han supuesto que podría tratarse de Imhotep (Serrano Delgado 2003, p. 9). Imhotep fue un hombre altamente reconocido y divinizado por los egipcios de la antigüedad, especialmente por su labor como funcionario del faraón Socer, tanto como constructor de la pirámide escalonada y como sus conocimientos sobre magia y medicina.
} 
una porción de carne a quien se supone que es el personaje mago/jefe-lector del relato $^{386}$. Pero, lamentablemente, no puede reconstruirse cuál era la trama de la historia, cuál era su mago protagonista y cuál su hazaña.

El segundo relato se inicia con las palabras del narrador en tercera persona del singular: "Entonces el hijo del rey Kefrén se levantó para hablar y dijo...”. ( $p W$. 1.18). Continúan las palabras del príncipe que describen sucesos durante el reinado del faraón Nebka ${ }^{387}$. Es la historia del jefe-lector Ubaoné ${ }^{388}$ quien era engañado por su mujer con un $n \underline{d} s^{389}$. Descubierta la mentira Ubaoné crea un cocodrilo de cera, objeto sobre el cual recita una fórmula mágica: "Cuando venga a bañarse en mi estanque $[\ldots]$ el $n \underline{d} s[\ldots] "(p W .2 .24-25)$.

Luego de enunciadas las palabras mágicas, Ubaoné le pide a un servidor que deje el cocodrilo de cera en el estanque donde siempre se encontraban su mujer y el amante. Una tarde en que estaban allí, el $n \underline{d} s$ se acerca a las aguas y es tragado por el cocodrilo de cera, que en ese momento se convierte en uno de verdad. Durante siete días el $n \underline{d} s$ permanece bajo el agua, hasta que llegan al sitio el jefe-lector Ubaoné con el faraón Nebka, a quien quería mostrarle el prodigio que había realizado ${ }^{390}$. Junto al estanque, Ubaoné llama al cocodrilo que al salir del agua lleva al $n \underline{d} s$ consigo. Toma al animal con la mano, que vuelve a transformarse en uno de cera.

\footnotetext{
386 En el antiguo Egipto, los jefes-lectores eran hombres de renombre vinculados al templo, sacerdotes que por su sabiduría realizaban ciertas funciones piadosas relacionadas a la entrega diaria de ofrendas a los dioses o a los rituales privados durante el funeral, como la lectura de los pasajes de libros sagrados que le permitían al difunto su entrada en el Más Allá (Sauneron 1998, pp. 60-63; Dodson y Hilton 2005, pp. 20-21). Las tareas que cumplían en los templos los unía a diario con las divinidades, conociendo lo que ellas designaban para los hombres. En el caso de Djedi toda la caracterización de su personaje responde a la de un hombre sabio.

${ }^{387}$ Nebka podría haber sido el primer faraón de la dinastía III, padre o hermano del más conocido Socer. Su nombre de coronación fue "Señor del Ka". Según Parra Ortiz (2009, p. 143), el faraón Nebka o Baka, no puede leerse. Según las inscripciones que se han preservado correctamente, sería el sucesor de Kefrén.

388 No se han encontrado referencias sobre la existencia de un personaje histórico llamado Ubaoné. Al igual que en el cuarto relato en el papiro Westcar personajes de la historia no llevan nombre, quizá para que el público receptor de la obra pueda sentirse identificado con los personajes. Las mujeres sin nombre son un recurso que se repite en otros textos, por ejemplo en Dos Hermanos la mujer que intenta seducir a Bata no tiene nombre y son literariamente acentuadas sus características femeninas.

${ }^{389}$ Ya hemos discutido sobre el término $n \underline{d} s$ en el capítulo IV.

${ }^{390}$ El número de siete días en que el amante de la mujer de Ubaoné permanece bajo el agua, no pareciera tener ningún significado especial. Lefebvre (2003 [1982], pp. 95-96) asumió en todo caso que es la cantidad de días que el rey Nebka retiene al mago en su residencia.
} 
El mago le cuenta a Nebka qué había sucedido entre el $n \underline{d} s$ y su mujer, y el faraón es el que decide sobre su destino final: ordena al cocodrilo que desaparezca con el $n \underline{d} s^{391}$, y envía a quemar a la mujer de Ubaoné392. Ésta no será la única vez que la figura del cocodrilo aparece como un animal utilizado para la condena. Con la condena del faraón finaliza el relato, en palabras de Khefrén.

El final del segundo relato es narrado por una voz sin nombre en tercera persona del singular. La voz introduce las palabras del rey Keops, quien se encarga de recompensar a su par el rey Nebka, con la misma cantidad de productos y alimentos que otorgó anteriormente al faraón Socer. Keops recompensa también al jefe-lector Ubaoné, tal como lo hizo con el mago del relato anterior, pues quedó demostrado el alcance de sus poderes.

El tercero de los relatos se inicia con una nueva aparición, en tercera persona singular, que introduce las palabras de Baufré ${ }^{393}$. Este hijo real relatará un prodigio ocurrido durante los años del rey Snefru394.

Aburrido el rey en su palacio llama al jefe-lector Djadjaemankh, quien le aconseja que salga de paseo por el lago ${ }^{395}$. Snefru pide que le preparen una embarcación con las mujeres más bellas del palacio; ellas serán las que remen desnudas, con sus cabellos trenzados cubiertos con redecillas. Al verlas remar el faraón se alegra, pero en medio del paseo las mujeres detienen la marcha. A la

\footnotetext{
391 Es interesante resaltar que en el relato es el faraón quien tiene la última palabra sobre lo que ocurrirá con los amantes. El faraón puede decir sobre la vida y la muerte (Eyre 1975, p. 107). Es el mago Ubaoné quien muestra la capacidad de mantener un control sobre lo incontrolable; el poder sobre la muerte y la resurrección (Eyre 1992, p. 281).

392 La mujer recibe el mismo castigo que su amante, la muerte; es quemada y sus cenizas son arrojadas al río. Una interpretación sobre el adulterio de la mujer de Ubaoné en Derchain (1986, pp. 20-21).

393 Baufré es uno de los hijos de Keops a quien se lo asocia con la figura de Bicheris en la lista de Manetón (Raice 1999, p. 33). Es mencionado en un grafito del Wadi Hammamat, inscripción de la cual se ha deducido un corto reinado como rey egipcio antes de Micerino (Lloyd 1993, p. 77). Lo más probable es que sea Baufré quien está enterrado en la mastaba 7320 en Giza (Edwards 1970, p. 172).

394 Snefru es reconocido por los especialistas como el primer faraón de la dinastía IV. Su nombre aparece en las listas más importantes, Lista Real de Abidos, Lista Real de Saqqara y Canon de Turín. Poco se sabe de la familia real de esta época (Dodson y Hilton 2005, p. 51). Se supone por el papiro Prisse, también llamada Inscripción de Kagemni (un alto funcionario que vivió entre finales de la dinastía $\mathrm{V}$ y principios de la dinastía VI) que su padre fue Huni, el último faraón de la dinastía III. 395 Volveremos a la idea del aburrimiento más adelante.
} 
capitana de las mujeres se le había caído un colgante al agua, Snefru le ofrece reemplazarlo por otro pero la mujer no acepta.

Entonces, el faraón pide que Djadjaemankh se haga presente en el lugar, contándole lo sucedido con el colgante de la remera. El jefe-lector pronuncia mágicas palabras y las aguas del lago se dividen en dos lo que permite encontrar el colgante de la muchacha. Éste devuelto, el jefe-lector logra volver las aguas a su estado natural. Con este prodigio finaliza el relato de Baufré ${ }^{396}$, nuevamente se introduce la palabra del faraón Keops a través de la intervención de un narrador en tercera persona del singular. El rey, tras constatar las capacidades del mago y su antecesor, envía a sus servidores que lo recompensen del mismo modo que lo hizo con los personajes de los dos relatos anteriores.

En el cuarto relato en el papiro Westcar, aparece una diferencia argumental con los otros relatos. El príncipe Hordedef no le contará a su padre historias del pasado, vividas por otros faraones y magos que ya han muerto. El príncipe le propone a su padre Keops que un mago de verdad se haga presente en la corte, para que él pueda presenciar con sus propios ojos las grandes proezas que se realizan en su tiempo. Hordedef se aleja de las historias que sus hermanos han contado porque no pueden diferenciar lo que es verdad y lo que es mentira, pues son historias del pasado que no pueden ser contadas en su presente.

Es así que el príncipe da a conocer a su padre Keops la existencia de un $n \underline{d} s$ de 110 años, llamado Djedi, que vive en la ciudad Djed-Snefru y que es capaz de realizar los más extraordinarios actos de magia ${ }^{397}$, además de ser conocedor del número de las cámaras secretas (iptw) del santuario (wnt) de Toth ${ }^{398}$.

\footnotetext{
396 Sobre algunas interpretaciones acerca de un ritual alrededor de la figura de Hathor, Derchain (1969, pp. 21-22); Hays (2002, p. 28) y Goedicke (1993, p. 23).

397 La edad de Djedi ha llevado a diversos comentarios entre los especialistas. Lefebvre (1944, pp. 106-119) dedicó un artículo a este tema. En él subrayó que 110 años era un número sagrado para los egipcios en la antigüedad, el cual indicaba la duración ideal de la existencia humana (Lefebvre 1944, pp. 106-107), si bien no encontró ninguna explicación "lógica" que indique el por qué de este número. Encontró que no únicamente Djedi fue uno de los hombres reconocidos en haberlo logrado, sino también el autor de Máximas de Ptabhotep (papiro Prisse) que lo alcanzó gracias a la generosidad del rey. Otro caso célebre fue el de Amenofis hijo de Hapu, quien vivió durante la dinastía XVIII y fue escriba real y arquitecto favorito del faraón Amenofis III, quien fue el que le otorgó el privilegio de alcanzar los 110 años. Quizá fue su edad el motivo por el cual los ptolemaicos le rindieron culto a su persona (Lefebvre 1944, p. 109). De todos modos parece
} 
El hijo real emprende una travesía en busca del mago Djedi. Lo encuentra, y Dedefhor le pide que lo acompañe hasta la corte pues su padre, el faraón, lo espera. Una vez en la corte real Djedi se explaya en sus capacidades mágicas, entre ellas cortar la cabeza de animales y volverlas a unir, sin que pierdan la vida. Una de sus mayores virtudes es la predicción del futuro, y es así que realiza el anuncio del nacimiento de tres niños hijos del dios Ra que serán reyes en Egipto ${ }^{399}$.

Finalizada esta demostración Keops interroga a Djedi sobre el número de las cámaras secretas del santuario de Toth. Pero Djedi confiesa no saberlo, solamente conoce dónde se encuentra. El rey le ordena que se lo diga, sin embargo, Djedi argumenta que no será él quien se lo alcance, sino el mayor de los tres niños que están en el vientre de Reddjedet, la mujer de un sacerdote de Ra en el templo de Heliópolis. Djedi pronostica que los tres niños hijos del dios Ra serán faraones en Egipto, el mayor de ellos, Grande de los Videntes en Heliópolis. A Keops le preocupan esas predicciones, pero el mago le aclara que gobernarán cuando recién finalice el reinado de su nieto.

El nacimiento de los trillizos será el día quince del primer mes de prt, justamente la época en que los bancos de arena del canal de los Dos Peces

cumplirse en un reconocimiento, con posibilidad de enterramiento en la necrópolis tebana, para personajes de alto rango, a través de decretos reales dictados por los faraones (Lefebvre 1944, pp. 110-115). Este número tuvo gran influencia ya que en el Antiguo Testamento (Génesis 37:50 Josué 24:39) se menciona que la edad de José es la de 110 años, revelando para el autor la profunda influencia egipcia en la redacción del Génesis. Por otra parte Assmann (2005 [1996], pp. 204-210) analizó la relación de este número con el juicio de los muertos. Éste se practicaba en el Reino Medio, el muerto se defendía de las acusaciones formuladas contra actos "impuros" que pudo haber cometido en el ámbito religioso exclusivamente, y contradice la idea de Kees que durante diez años el hombre vive lejos de la imperfección.

398 El significado y la traducción de este término no es claro. Al respecto véase Gardiner (1925) y Berggren (2006). Este pasaje del relato es una demostración de las ansias del faraón Keops de construir una tumba perfecta para él. En la estela del faraón Neferhotep de la dinastía XIII en la ciudad de Abidos, se expresa que es él quien quiere contar con los papiros de los tiempos de los orígenes de Atum para construir una estatua de Osiris. Esta misma ambición aparece en los cuentos de Setne-Jamauat ambientado en el reinado de Ramsés II, pero que es de época grecoromana. Puede leerse "aquel libro que el mismo Toth ha escrito con su mano, cuando ha descendido detrás de los dioses... y que habia encontrado en una serie de cajas sumergidas en medio del agua de Coptos" (Diego Espinel 2006, p. 210).

${ }^{399}$ El escriba omite una de las habilidades mencionadas por Dedefhor, la de "bacer marchar un león tras él con la correa arrastrando por el suelo". Esta supresión ha llevado suponer a Lefebvre (2003 [1982], p. 103) que el escriba olvidó copiar el pasaje. De hecho, en el texto menciona una correa que permanecía tendida en el suelo, pero no fue previamente utilizada en las demostraciones de Djedi. $\mathrm{Al}$ respecto véase Derchain (1986, pp. 16-17). 
imposibilitan la navegación por el estiaje de las aguas ${ }^{400}$. El rey preocupado por la situación hace prometer Djedi que con su magia garantizará la navegabilidad de las aguas del canal. El relato finaliza cuando Keops le retribuye al mago con grandes raciones de alimentos y le permite habitar la casa de Dedefhor junto al príncipe.

El quinto relato se inicia con el pedido del dios $\mathrm{Ra}$ a los dioses que se dirijan a la casa de Reddjedet a socorrerla en el parto de los trillizos. Así, desde un comienzo, es evidente la diferencia argumental de este relato anexo con los otros conservados en el papiro. No se relata ninguna historia de un mago, ni contada por ningún hijo del rey, sino que narra los acontecimientos vaticinados por el mago Djedi en el cuarto relato. Lo que en el relato anterior era un futuro anunciado, es aquí el presente. Es decir, que el tiempo narrativo de la acción literaria se modifica, ahora aquello que había sido anunciado como un futuro es presente: el nacimiento de los trillizos.

El dios Ra envía a las diosas Isis, Neftis, Meskhenet, Heket y el dios Khnum a la casa de Reddjedet, para ayudarla en el parto. Los dioses, que no querían ser reconocidos, se disfrazan: ellas de bailarinas y Khnum de maletero que las acompaña en su travesía. Son recibidos por el esposo de Reddjedet, Rauser, quien les permite entrar a la sala del parto. Las diosas la ayudan, cada una cumpliendo una función específica. Mientras Isis se coloca delante de la mujer para recibir a los niños, Neftis se coloca detrás, y Heket le realiza masajes en el vientre. Khnum, por su parte, le da salud a los cuerpos, y Meskhenet pronuncia ante cada niño: "Será un rey que ejercerá la realeza sobre este país entero" ( $p W .10 .13-14)$. Una vez finalizado el parto de los trillizos las diosas reciben como paga, por parte de Rauser, un saco de cebada. Pero, ellas no se retiran sin antes dejar un prodigio para los recién nacidos: fabrican para cada niño una diadema de soberano que esconden en el saco de cebada que les dio Rauser, a quien le piden dejarlo en una habitación sellada hasta que puedan regresar nuevamente a la casa.

Pasados los días de purificación postparto de Reddjedet se genera un conflicto entre ella y la servidora, de quien no sé da nombre alguno. Un día, en la

\footnotetext{
${ }^{400}$ En el capítuo III hemos analizado el significado mítico literario de la fecha de nacimiento de los trillizos.
} 
casa se necesitaba cebada, pero sólo quedaba aquel saco que las bailarinas habían dejado. Reddjedet le ordena a su servidora que vaya a buscarlo de todos modos, pues Rauser se encargaría luego de reemplazarlo. Cuando la servidora entra a la habitación donde se guardaba la cebada escucha que del saco provenía todo tipo de cantos, música y aclamaciones. Lo revisa y encuentra las diademas que los dioses habían dejado como legado a los futuros reyes. La servidora le muestra a Reddjedet lo que ha encontrado, quien se asegura proteger las diademas en un cofre sellado para que nadie pueda acercarse a ellas.

Unos días después Reddjedet se enoja con la servidora y ordena una golpiza para ella. La mujer, enfurecida, amenaza a Reddjedet con contarle al rey Keops que ella ha tenido tres hijos con el dios Ra. Decidida a encontrarse con el rey, la servidora se encuentra con su hermano mayor y le cuenta lo que está sucediendo. Pero este, furioso por verse involucrado le da una golpiza. La servidora se acerca al lago a buscar agua y es devorada por un cocodrilo.

El relato finaliza bruscamente cuando el hombre le cuenta a Reddjedet afligida porque no encontraba a su criada- que la servidora fue devorada por un cocodrilo luego de recibir una golpiza de su parte tras expresarle su intención de denunciar a Reddjedet ante el faraón Keops ${ }^{401}$.

${ }^{401}$ Lamentablemente, el manuscrito está destruido y no podemos reconstruir el final de la historia, pero vemos que nuevamente en el papiro aparece la condena de la muerte. La mujer es devorada completamente por el cocodrilo, así sucede con el amante en el segundo cuento. Eyre (1976, p. 108) sugiere que el cocodrilo es uno de los tantos significados mitológicos que se encuentran en este tipo de relatos literarios. 


\begin{tabular}{|c|c|c|c|c|}
\hline Relato & $\begin{array}{l}\text { Reinado en el } \\
\text { cual se realiza la } \\
\text { acción mágica }\end{array}$ & $\begin{array}{l}\text { Hijo real que } \\
\text { relata la historia }\end{array}$ & $\begin{array}{l}\text { Quién realiza la } \\
\text { acción mágica }\end{array}$ & Acción mágica \\
\hline Primer relato & Socer & ¿? & ¿? & ¿? \\
\hline Segundo relato & Nebka & Khefrén & Ubaoné & $\begin{array}{l}\text { Fabrica un cocodrilo } \\
\text { de cera y lo convierte } \\
\text { en uno real }\end{array}$ \\
\hline Tercer relato & Snefru & Baufré & Djadjaemankh & $\begin{array}{l}\text { Separa las aguas del } \\
\text { Nilo y vuelve a } \\
\text { ponerlas en su lugar }\end{array}$ \\
\hline Cuarto relato & Keops & $\begin{array}{l}\text { Introducido por } \\
\text { Hordedef }\end{array}$ & Djedi & $\begin{array}{l}\text { Corta la cabeza de un } \\
\text { animal y vuelve a } \\
\text { unirla al cuerpo sin } \\
\text { que éste pierda la vida } \\
\begin{array}{l}\text { Pronostica } \\
\text { nacimiento de los } \\
\text { trillizos }\end{array}\end{array}$ \\
\hline Relato anexo & Keops & & $\begin{array}{l}\text { Ra y Reddjedet son } \\
\text { los padres de los } \\
\text { trillizos } \\
\text { Los dioses asisten el } \\
\text { parto }\end{array}$ & $\begin{array}{l}\text { Nacimiento de los } \\
\text { trillizos } \\
\text { Los dioses fabrican } \\
\text { diademas para los } \\
\text { futuros faraones }\end{array}$ \\
\hline
\end{tabular}

CUADRO IX. Síntesis argumental de los relatos del papiro Westcar 
Capítulo VIII

\section{RELATOS DEL PAPIRO WESTCAR \\ Unidad de sentidos: estructura, género y estilo}




\section{1. ¿Género literario?}

El concepto de género literario es producto de una construcción histórica y no se han dado definiciones unánimes a lo largo de los siglos en los que el tema ha sido tratado ${ }^{402}$. Con el término se intentó clasificar a los textos literarios según parámetros compartidos, formando familias de géneros y subgéneros, diferenciándose en cada uno de ellos distintas formas y medios de expresión de lo literario. La problemática ha sido abordada desde la Grecia clásica. Aristóteles fue uno de los primeros pensadores en plantear la existencia de géneros literarios, y brindó los parámetros que se discutieron durante siglos. Pero -como decíamos- no se han generado acuerdos en cuáles deberían ser las constantes esenciales de un texto para que pertenezca a tal o cual género literario ${ }^{403}$.

La discusión alrededor de los géneros literarios excede completamente nuestro trabajo, por lo que nos limitaremos a hacer referencia a ciertas posturas que nos permitan problematizar lo referente a los textos literarios egipcios. Por ejemplo, las teorías que subrayan las dificultades de categorizar una obra literaria en un género.

En este sentido, Chartier (1999, p. 125) se refiere a los modos de lectura. Estos no son los mismos en tiempo y espacio, lo que lleva a pensar que los sistemas de clasificación no son iguales entre comunidades distintas, y mucho menos lo son los límites que distinguen la ficción de la realidad.

\footnotetext{
402 En el clásico manual sobre teoría literaria de Wellek y Warren (1974, pp. 271-285) los autores realizan un repaso por las diferentes posturas y tratamientos del concepto de género literario, desde las primeras formulaciones de Aristóteles y Horacio, hasta los investigadores contemporáneos (para un análisis al respecto véase Schaeffer (2006 [1989], pp. 5-44).

403 Aristóteles en La Poética propuso una de las primeras clasificaciones para los géneros literarios: épica, lírica y dramática. Desde esta primera formulación se han producido cambios, por ejemplo en la actualidad el género de la épica ha extendido su significado y es denominado como narrativa incluyendo entre otros subgéneros a la épica. La novela y el cuento son considerados también como subgéneros narrativos. Dentro del género dramático se incluirían como subgéneros la comedia y la tragedia. Por último, para la lírica, se reconocen los subgéneros de odas, himnos y elegías, entre otros.
} 
Problematización sobre el uso de los géneros literarios en los textos literarios egipcios del Reino Medio. Un estado de la cuestión

En el caso de los textos literarios egipcios podemos diferenciar dos tipos de problemas yuxtapuestos. En primer lugar, si es posible -o no- catalogar mediante géneros a los textos literarios egipcios ${ }^{404}$. En segunda instancia, si las categorías ya existentes son útiles para tal fin, o si se hace necesario crear nuevos términos.

Estas problemáticas no se circunscriben a la literatura egipcia, sino que surgen frente a una diversidad de textos literarios de la cultura universal y generan diversas posturas dentro de la teoría literaria, donde la clasificación de los textos, la utilidad de las categorías, y la generación de nuevas es algo que se sigue debatiendo.

En primer término, podemos observar una ausencia significativa de los textos literarios egipcios dentro de los trabajos que analizan el género en la literatura universal. Intuimos que hay un profundo desconocimiento sobre los textos literarios egipcios, lo que ha llevado a desestimarlos dentro del corpus de la literatura universal ${ }^{405}$, por lo tanto a alejarlos de la indagación de los parámetros de los géneros literarios. De todos modos, veremos que la discusión sobre los géneros en los textos literarios egipcios, y en particular en los del Reino Medio, es sumamente compleja.

Pero, ¿son válidas las categorías genéricas para los textos literarios egipcios? Kees, en su artículo de 1970 (Assmann 1999, pp. 2-3), niega que los géneros literarios, como se conocen en la teoría literaria moderna, puedan ser empleados para la literatura del antiguo Egipto, sin que ello genere dificultades en el análisis, o algún tipo de ruptura o discontinuidad con los textos literarios. Como señala Assmann (1999, p. 3), Kees estaba pensando en las categorías tradicionales de género, como el drama, la épica y la lírica, y no se permitía pensar una posibilidad de reformulación de los conceptos para ser aplicados a textos del antiguo Egipto.

La de Kees es una de las posturas más radicales al respecto, y algunos investigadores que estuvieron de acuerdo con ella en su momento posteriormente

404 En sí misma es compleja y discutida la conceptualización de literatura y qué textos pertenecen a ella.

$405 \mathrm{Al}$ mismo tiempo, hay que tener en cuenta que su traducción es de finales del siglo XIX, cuando la discusión con respecto a los géneros de los textos literarios la antecede en siglos. 
han ido matizando su posición y actualmente consienten estudiar los géneros para los textos literarios egipcios. Es el caso de Parkinson, quien aborda extensivamente la problemática en su artículo "Types of literature in the Middle Kingdom" ["Tipos de literatura en el Reino Medio”], y luego más sintéticamente en el apartado "Genre" ["Género"] de su libro Poetry and Culture [Poesía y Cultura]. El egiptólogo sostiene que los géneros modernos no pueden ser aplicados a la literatura egipcia. Pero admitida esta imposibilidad Parkinson (1996, p. 297) sugiere el interés y la importancia de trabajar con géneros en la literatura egipcia, en especial a realizar estudios por tipos literarios. Con este concepto, estaría haciendo referencia a los estilos en que los textos fueron escritos, es decir, el medio de expresión utilizado más allá de la clasificación bajo un género literario.

En este sentido, Lichtheim (1973, pp. 10-11) alega que la literatura egipcia empleó tres estilos: la prosa, la poesía y un estilo intermedio entre ambos ${ }^{406}$. Los mejores exponentes del estilo de la prosa en el Reino Medio son: Cuento de El Náufrago, los relatos del papiro Westcar, y Cuento de Sinubé; observándose que entre el primero y el último hay un refinamiento de la prosa, de más simple a más compleja.

Assmann (1999, p. 3-4) haciendo referencia a su artículo de 1970, intenta demostrar que no pueden establecerse géneros universales, pero que tampoco existe una tradición textual egipcia sin géneros literarios (Assmann 1999, p. 3). Es decir que, más allá de la definición de género literario, es posible su uso para los textos literarios egipcios, en tanto lo es para la literatura universal. Esta idea se vincula con las desarrolladas por el estructuralista Todorov (2003 [1972], p. 11), para quien no puede negarse la existencia de los géneros literarios universales, ya que sería desconocer que cada obra, cada texto, mantiene relaciones con otras obras, con otros textos 407 . En otras palabras "los géneros son precisamente esos eslabones

\footnotetext{
406 La poesía egipcia se caracterizó por utilizar dispositivos al estilo oracional, caracterizado por la repetición regular de intervalos, creando estrofas, lo que la distancia de la prosa (Lichtheim 1973, pp. 11-12).

${ }^{407}$ Este tipo de relaciones son sobresalientes y viene a afirmar una vez más la estrechez teórica que Assmann tuvo, en sus comienzos, con el estructuralismo, siendo que fue el primero en definir la literatura egipcia en términos exclusivamente estructuralistas (Moers 1999, p. viii).
} 
mediante los cuales la obra se relaciona con el universo de la literatura" (Todorov 2003 [1972], p. 11) ${ }^{408}$.

Assmann (1999, p. 3) propone que la definición de género debe identificarse con una función específica o con lo que se denomina "Sitz im Leben" 409 . El género, al ser independiente del contexto en que se produce el texto cumple una función determinada dentro del mismo ${ }^{410}$. Es decir, el género no está otorgado por el significado al encontrarse éste disociado en el texto (Assmann 1999, pp. 3-4)

La reformulación de los paradigmas lleva a Assmann a plantear una de las tesis más sobresalientes sobre los escritos literarios egipcios, la que refiere al texto como texto cultural. Al detectar una función específica del texto -normativa y de identidad- se deja de lado al género. Ahora, la diferencia tiene que ver con que si el texto es narrativo o no narrativo y, en todo caso, su forma se determina a partir de la función que cumplen como texto cultural. Esto no impide a Assmann utilizar categorías que son propias de la teoría del género. Por ejemplo, cada vez que hace mención del papiro Westcar ser refiere a "Cuentos de...".

De todos modos, debemos aclarar que la referencia del contenido textual del papiro Westcar como "cuento" no es condición de que el autor esté pensando en la teoría de los géneros y exista una concientización absoluta del uso de dicho concepto. Consideramos que los egiptólogos en general se han regido por categorías heredadas, principalmente las establecidas a fines del siglo XIX. En el caso del papiro Westcar, las propuestas de Erman fueron las que delimitaron los puntos a seguir. El investigador alemán, al momento de buscar un título que englobe y con el cual puedan identificarse a los relatos del papiro Westcar, los denomina märchen ${ }^{411}$. El concepto alemán de märchen es lo más próximo a lo que en castellano llamaríamos

\footnotetext{
408 Según Todorov (2002 [2000], pp. 7-22) el concepto de género debe ser matizado y cualificado, para lo cual propuso la diferenciación entre géneros históricos -que son el resultado de una observación de los hechos literarios- y géneros teóricos -que se infieren de la teoría literaria-. A la vez dentro de estos últimos, se diferencian los géneros elementales, caracterizados por la existencia o ausencia de un solo rasgo estructural, y los géneros complejos, definidos por la existencia o ausencia de un conjunto de rasgos.

${ }^{409}$ Es complejo el significado de este término, si nos atenemos a su traducción "situación en la vida", da cuenta de la importancia del contexto -situacional- en el cual se produce el texto. Es decir, que el contexto influye sobre el texto.

${ }^{410}$ Pues, para Assmann (1999, p. 3), no hay un contexto que permita formar su significado.

411 Término que aparece en el título de la primera publicación de los cuentos del papiro Westcar: Die Märchen des Papyrus Westcar [Los cuentos (de badas) del papiro Westcar].
} 
“cuento de hadas". El término reconoce que el contenido del papiro Westcar es literario y que éste puede clasificarse como cuento.

Lichtheim (1973, p. 9) considera que en el Reino Medio se produjo un amplio número de trabajos literarios, en una vasta variedad de géneros y con un completo dominio de las formas, lo que lo convirtió en la Edad Clásica de la literatura egipcia. Alguno de los géneros que Lichtheim (1973, pp. 3-9) considera en su análisis son las autobiografías y las instrucciones de sabiduría. Rastrea el desarrollo de las formas y temáticas que predominaron de cada uno desde el Reino Antiguo hasta el Reino Medio.

Lichtheim y otros investigadores, asumirían que los procesos intelectuales, y por ende culturales son los mismos en todas las culturas, y por lo tanto crean idénticos textos literarios. Lichtheim (1973, p. 11) reconoce géneros para los textos literarios egipcios a partir de la existencia de géneros "universales" y no se detiene a pensar cuáles serían los géneros propios de la cultura del antiguo Egipto. En cambio, consideramos que en cada sociedad existen diferencias en el proceso intelectual y cultural (Goody 1990 [1986], p. 47), que derivan en diferentes modos de crear textos literarios, por ende no hay géneros únicos.

Por su parte, Parkinson (1996, pp. 297-299) propone desprenderse de la teoría clásica (que Kees sí tuvo en cuenta) y toma como eje de análisis las teorías modernas; en las cuales los géneros se circunscriben culturalmente, es decir, son un producto cultural, que se crea y se desarrolla dentro de la cultura que está escribiendo los textos literarios. Interpretamos que el género se circunscribe cultural e históricamente. Por eso, para estudiar, en este caso, la escritura del antiguo Egipto, debemos investigar si se desarrollan géneros en ese momento histórico y cultural.

Parkinson (1996, pp. 298-299) analiza cuáles han sido los géneros y subgéneros de los textos literarios egipcios. Pero, aclara, el concepto de género es una categoría flexible y propensa al cambio, ya que al ser los géneros obra de la tradición, cada nueva creación implica una reevaluación de la categoría. La definición de género, la literatura misma, es problemática dentro de cualquier cultura escrita, y particularmente dificultosa cuando se encuentra por fuera de la tradición escrita popular (Parkinson 1991, p. 21). Por lo tanto, si bien hasta el momento no se 
posee entre los egiptólogos una terminología específica para los textos egipcios, no significa que el concepto de género no exista (Parkinson 1996, p. 297) o que no se pueda realizar el esfuerzo de analizar un texto en el marco de un género literario.

En este sentido, si se aceptara, teniendo en cuenta las limitaciones ya mencionadas, el uso del concepto de género literario para los textos escritos por la sociedad del antiguo Egipto, la narrativa sería la categoría más acertada para los relatos del papiro Westcar. Entendemos por narrativa una expresión literaria en la cual se relatan acontecimientos de una realidad ficcionada, narrados por lo general en primera o tercera persona del singular. El autor inventa una realidad mediante la creación de personajes, y la delimitación de un tiempo y un espacio para la acción.

Para Quirke (1996, p. 268), en el antiguo Egipto, la narrativa aparece en manuscritos de finales del Reino Medio. Se trata de composiciones fechadas en ese periodo, pero que han sobrevivido únicamente en copias realizadas en el Reino Nuevo. Para el autor, son textos del género narrativo; en el que se incluye el subgénero del cuento. De hecho, algunos especialistas han explicitado esta categoría y han incluido a los relatos del papiro Westcar como uno de los más claros exponentes.

Quirke (1996, pp. 268-272) argumenta que en la literatura narrativa del Reino Medio egipcio pueden diferenciarse dos tipos de textos literarios. Por un lado, los textos en los cuales la narrativa aparece en una breve sección del texto ${ }^{412}$; y, por otro, aquellos en los que la narrativa ocupa toda la composición. En este segundo grupo incorpora a relatos del papiro Westcar, junto con Tale of the Sporting King y Tale of Fishing and Fowling (Quirke 1996, pp. 270-272).

Parkinson (2002, p. 295) esgrime la idea que el papiro Westcar se iniciaba probablemente con un prólogo narrativo, similar a lo que ocurre en Profecía de Neferty, por lo tanto, si hubiese que pensar un subgénero para el manuscrito la parodia sería el más adecuado. Años antes Parkinson (1996, p. 310) ya había considerado que en los escritos literarios egipcios los géneros no se presentaban en

412 Dentro de este tipo de textos, el autor incluye Discurso de Sasobek y Profecía de Neferty, que se inician con un pequeño pasaje narrativo que presenta la situación y los principales personajes del relato. También comprende Campesino Elocuente o Enseñanzas de Amenembat I de desarrollo narrativo más extendido (Quirke 1996, pp. 268-269). 
estado puro, pero que hay un género que predomina. Si se tomase como válida la premisa de Parkinson, los relatos del papiro Westcar se aproximarían a una parodia, en sintonía con Profecía de Neferty, pero habría también algo de elogios reales, como en Campesino Elocuente y de la novela real ${ }^{413}$, como en Cuento de Neferkare y Sasenet ${ }^{114}$.

A continuación, acotaremos el análisis al Reino Medio, periodo de la escritura primaria de los relatos del papiro Westcar. Parkinson (1996, pp. 297- 298) concibió que la literatura de este período se engloba en un género predominado por un canon, es decir, poseen "un patrón formal codificado por la tradición cultural" (Parkinson 1996, p. 297). Si bien, para el autor, no puede determinarse la cantidad de textos que pertenecieron originariamente a él, las evidencias -aunque fragmentarias- son suficientes para establecer un modo común entre ellos, un género.

El tema de la tradición es un problema mucho más amplio. Algunos investigadores, han pensado que la tradición -en tanto repetición de la forma- ha caracterizado el arte egipcio ${ }^{415}$. De todos modos, la tradición puede implicar también algún tipo de modificación. En este sentido, Kemp (2004, pp. 133 y ss.) considera que los textos son parte de la cultura que está en movimiento, lo que implica que no hay una fijación canónica inmóvil acerca de qué y cómo escribir, sino una (re)adaptación constante según el contexto.

Quizá Erman no tuvo la intención de polemizar, pero reconocía que el contenido del papiro Westcar eran textos de carácter literario, pertenecientes al género de la narrativa y formaban parte de la subcategoría de relatos, particularmente cuentos de hadas. Desde allí, lo que prevaleció y no se discutió fue

\footnotetext{
413 Sobre características generales de la novela real véase Loprieno (1996b, pp. 277- 295). En este artículo, el autor reconoce que uno de los principales problemas radica en el criterio que se adopta para definir dicho género, pues se producen diferentes cuerpos textuales. No es suficiente con considerar una trama que tenga como eje la figura real, ya que ésta era por sí misma central en la sociedad egipcia. Frente a una trama textual diversa observa. por ejemplo, las representaciones literarias sobre el primer rey proveniente de cuentos e instrucciones del Reino Medio, como es el caso de Profecía de Neferty, el papiro Westcar y Cuento de Neferkare y Sasenet. Algunos investigadores han estimado, a partir de las actitudes del personaje de Keops en el papiro Westcar, una personalidad despiadada con su pueblo.

${ }^{414}$ Este texto se encuentra en copias del Reino Nuevo y periodos posteriores. Se destaca el papiro Chassinat I que se encuentra en el Museo del Louvre y la tablilla 13539 resguardada por el Oriental Institute de la Universidad de Chicago.

${ }^{415} \mathrm{Al}$ respecto véase Cardoso (2000, pp. 3-15).
} 
el hecho de catalogar el papiro Westcar dentro del género de la narrativa. Las mayores disidencias las hallamos en el campo del subgénero, pues surgió un abanico de posibilidades. Si bien se destacaron cuento o cuentos maravillosos, los investigadores han problematizado muy poco la utilización de dichas categorías. Más allá de esto, quedaba aceptado implícitamente que el contenido del papiro Westcar era literario. Ya hemos visto en el capítulo anterior las diferentes posiciones que se han desarrollado al respecto y hemos explicado nuestra postura.

López (2005, p. 15) afirma que "tal como nosotros los comprendemos, los géneros literarios no están a menudo suficientemente diferenciados cuando se trata de textos egipcios. Se puede dudar frecuentemente de si este o aquel texto es un ‘cuento', una 'fábula' o un 'mito"'. La duda que López plantea es significativa, en tanto que son los propios modos de pensamiento de la sociedad egipcia antigua que impiden la separación entre uno y otro tipo de categoría, pues los textos son una expresión más del discurso múltiple de la sociedad, que no permite una categorización taxativa al respecto ${ }^{416}$.

\section{Estructura tripartita en los relatos del papiro Westcar}

En Romans et contes égyptiennes de l'époque pharaonique [Novelas y cuentos egipcios de la época faraónica] Lefebvre (2003 [1982], p. 91) consideró a los relatos del papiro Westcar como “... ligados artificialmente los unos a los otros, formando un conjunto similar a un 'cajón de sastre', a la manera de la Novela de los siete sabios o las Mil y Una Noches". Esta idea ya estaba presente en Erman (1889, p. 6) quien recalcó la sencillez del lenguaje utilizado en los relatos del papiro Westcar y su fácil comprensión, características que los asemejan a los cuentos populares árabes de $\mathrm{Mil}$ y Una Noches. La misma apreciación la realizó López (2005, p. 87), al acotar que "no

\footnotetext{
416 En relación a ello Simpson ( $L A E$, pp. 2-5) considera que el pensamiento egipcio más que clasificatorio era multiplánico, por lo que también contradice la posibilidad de categorización de los textos literarios en un único género.
} 
se trata de un cuento, sino de una serie de cuentos enlazados artificialmente con mucha naturalidad..."417.

Las valoraciones de estos investigadores, la mención de una unión artificial, conlleva también un presupuesto de sentido de falsedad entre los relatos. Es decir, no existe una línea transversal que los ligue, más allá de un argumento "maravilloso" compartido. La pretendida unidad estaría proporcionada por el argumento mágico de los relatos, lo que al mismo tiempo lleva a categorizarlos dentro del grupo “cuentos fantásticos". Lo que Lefebvre (2003 [1982], p. 91) y López (2005, p. 87) han dado a entender es que cada relato del papiro Westcar ha sido dispuesto sin un parámetro a seguir, sin un fin, en tanto y en cuanto no hay entre ellos una vinculación estructural que los relacione.

En cambio, opinamos que un análisis formal de cada uno de los relatos del papiro Westcar nos permite encontrar ciertos puntos de contacto que les dan a ellos un sentido de unidad funcional. Esto es que cada relato comparte con los otros una misma organización interna del cómo contar, lo que aquí consideraremos como estructura narrativa. Nos referimos a un mismo estilo narrativo y a un mismo sentido argumental, que nos lleva a pensar la construcción no como una antología sino cómo una única pieza literaria (Goedicke 1993, p. 25). En este sentido, Suhr (1999, pp. 97-98) afirma que el relato del príncipe Hordedef introduce las acciones del mago Djedi, que son la parte central del argumento del cuarto relato, a través de la metalepsis; y son justamente estos movimientos argumentales, más allá de la trama, lo que une al cuarto relato del papiro con los otros tres.

La valorización del relato en tanto corpus de expresión y transmisión de ideas ha sido una temática recurrente en las discusiones analíticas de la crítica literaria. Por un lado, se ha planteado la posibilidad de pensar al relato como una sucesión de acontecimientos, es decir, como una obra de arte creada de la mano de un autor genio, el narrador, que tiene la virtud de crear relatos -mensaje- partiendo de una estructura, de un código (Barthes 1982, p. 10).

\footnotetext{
417 Araújo (2000, p. 65) nos recuerda que Posener a comienzos de la década de 1970 comentaba que en los textos antiguos era familiar crear narrativas en donde se disponían historias separadas, similar a los cuentos árabes de Mily Una noches.
} 
Por otro lado, existen teorías que toman al relato en relación a otros relatos, por lo tanto pone en exégesis toda la universalidad de relatos, viendo que entre ellos existe un punto común: la estructura. Los fundadores del formalismo ruso se propusieron, a través del trabajo empírico, realizar una teoría elaborada de la literatura (Todorov 2008, pp. 1-24) 418 para asentar las bases de dicha estructura.

Los formalistas rusos y los continuadores de esta escuela han desarrollado una teoría del relato. Propp, Barthes, Todorov y Greimas, han contribuido, desde una diversidad de ideas, a pensar las diferentes unidades y relaciones que conforman el relato, buscando los aspectos propios de la literatura, sus rasgos inherentes que la definen, aquello que Jakobson llama literaturidad (literaturnost), es decir lo que hace de la literatura una obra literaria (Eichenbaum 2008, p. 37).

Barthes (1982, pp. 11 y 12) postula que el relato es un discurso (conjunto de frases) organizado, con sus propias reglas, lo que es ir más allá de pensar a la frase como la última unidad elemental del relato. Barthes (1985, pp. 15 y ss) propuso que pueden diferenciarse tres niveles en una obra narrativa: en primer lugar, las funciones que permiten distinguir unidades narrativas mínimas, dado que el carácter funcional de ciertos segmentos es lo que permite correlacionar un segmento con otro dentro del relato otorgando una unidad narrativa. En segundo lugar, la participación de los personajes enlazan las acciones que dan unidad al relato. Por último, la narración, que profundiza la relación entre quien da y quien recibe el relato. Analizaremos este punto con mayor profundidad, cuando abordemos la problemática del autor y el receptor de las obras literarias escritas. Lo que se desprende del análisis de Barthes es que puede encontrarse en cada relato una "coherencia" interna que lo delimita como tal, permite distinguir una organización propia.

Desde ya la reflexión con y acerca de los relatos del papiro Westcar no se convierte en una aplicación directa de los conceptos, sino que el ejercicio analítico

\footnotetext{
418 El corpus teórico de los formalistas rusos es muy denso e imposible de abarcar en su totalidad en este trabajo. Todorov (2008) ha publicado una compilación de los textos más importantes de la escuela, incluyendo en el capítulo I el texto de Boris Eichenbaum (2008, pp. 31-76) "La teoría del 'método formal"' que realiza un recorrido por las principales teorías de los formalistas. Otra compilación de textos se encuentra en Cuesta Abad y Jiménez Heggernan (2005). Sobre una interpretación general de los formalistas rusos veáse Bennett (1979).
} 
requiere, como sugiere Lepper (2007, p. 1127), a veces una redefinición y otras la creación de nuevas nociones teórico-metodológicas.

En este sentido, podemos distinguir en el papiro Westcar ciertas formas y estructuras que se repiten en los relatos maravillosos, sin enredarse en distinguir clasificaciones y temas para los cuentos (Propp 2007 [1985]). El concepto de ley de permutabilidad nos proporciona una herramienta analítica sustancial, que establece que "los cuentos tienen una particularidad: sus partes constitutivas pueden trasladarse sin ningún cambio a otro cuento" (Propp 2007 [1985], p. 15) ${ }^{419}$. Lo que debe reconocerse dentro de un cuento es su unidad elemental e indivisible, que no necesariamente es parte de la estética (Propp 2007 [1985], p. 23). Qué hacen los personajes en los cuentos es lo que posibilita aislar la función "definida desde el punto de vista de su significado en el desarrollo de la intriga” (Propp 2007 [1985], p. 32). Es esta propuesta teórica la que nos permite reconocer en los relatos del papiro Westcar, esas estructuras mínimas que están denotando las acciones -funciones- de los personajes, y que pueden trasladarse sin dificultad.

Entonces, ¿cuáles serían estas unidades elementales en los relatos del papiro Westcar? Si analizamos cada uno de los primero cuatro relatos que hoy se conservan en el manuscrito podemos distinguir unidades narrativas (Barthes 1982, pp. 9-17), que se caracterizan por las idénticas funciones que los personajes realizan en ellas.

Por lo tanto, distinguimos tres unidades narrativas:

1. Presentación: la acción está regida por el personaje que presenta la historia. La narración que se desencadena por un problema.

2. Acto mágico: la acción está regida por un acto mágico que es la resolución del problema.

3. Retribución: la acción es la gratificación por el acto mágico.

\footnotetext{
${ }^{419} \mathrm{El}$ análisis de Propp (2007 [1985], pp. 9-21) pone en evidencia que son estas estructuras que permutan las que hacen imposible la tematización de los cuentos, ya sean maravillosos o fábulas. Para Propp (2007 [1985], pp. 18-26) es necesario un estudio previo y científico para poder determinar los temas válidos, que en sí mismos no están aislados, sino que se vinculan siempre los unos a los otros. Para el autor, la dilucidación de las leyes de la estructura de los cuentos es lo que permitirá definirlos.
} 
De este modo, quedan identificadas las constantes que están presentes en los cuatro primeros relatos del papiro Westcar, es decir, sus funciones básicas e indivisibles. Lo que cambia son los nombres de los personajes, sus atributos, el espacio dónde se desarrolla la acción. Las unidades narrativas no son independientes, se necesitan mutuamente para dar sentido a las otras y al conjunto, el relato ${ }^{420}$. Es decir, siguiendo la propuesta proppiana, lo que permanece en las estructuras son las funciones que se ejercen en cada una de ellas y son los personajes lo que nos permite identificarlas, aislarlas del conjunto narrativo. A su vez, las funciones entendidas bajos los términos de Barthes, unen las unidades elementales conformando el todo del relato.

Partiendo de este modo de entender los relatos, podemos agregar que lo que identificamos como presentación sitúa a los personajes en tiempo y espacio, mientras que el nudo del relato se desarrolla en la segunda unidad. A su vez, la acción mágica puede subdividirse en dos unidades más pequeñas:

1. a) un problema que se resuelve con la 2.b) realización de un acto mágico, que siempre resuelve positivamente el conflicto.

Por último, la historia se cierra con la gratificación del rey hacia el mago que ejecuta el acto (Salem 2008).

A continuación, ejemplificamos cada una de estas unidades siguiendo el argumento de los relatos, en el siguiente cuadro:

\begin{tabular}{|c|c|c|c|}
\hline Relato & Presentación & Acto mágico & Retribución \\
\hline $\begin{array}{l}\text { Primer } \\
\text { relato }\end{array}$ & & & $\begin{array}{l}\text { "[Entonces la Majestad] del rey del } \\
\text { Alto y Bajo Egipto Keops, justificado } \\
\text { [dijo: Que sean dados mil panes,] } \\
\text { cien jarras de cerveza, un buey [y dos } \\
\text { medidas de incienso al] rey del Alto y } \\
\text { Bajo Egipto Socer, justificado, Y que }\end{array}$ \\
\hline
\end{tabular}

${ }^{420}$ Recordemos que Goedicke (1993, p. 24) es uno de los primeros en plantear la idea de una composición única para los relatos del papiro Westcar. Luego Jenni (1998, pp. 113 y ss.) los considera como una unidad literaria y con coherencia interna, los analiza como propaganda política de Sesostris I. 


\begin{tabular}{|c|c|c|c|}
\hline & & & $\begin{array}{l}\text { sean dados una torta, una jarra [de } \\
\text { cerveza], una porción de carne }[y \text { una } \\
\text { medida de incienso para el sacerdote- } \\
\text { lector en jefe }[\ldots] "(p W .1 .12-17)\end{array}$ \\
\hline $\begin{array}{l}\text { Segun } \\
\text { do } \\
\text { relato }\end{array}$ & $\begin{array}{l}\text { "Entonces el hijo del rey Kefrén se } \\
\text { levantó para hablar y dijo: 'Haré } \\
\text { que tu majestad escuche un prodigio } \\
\text { que ocurrió en el tiempo de tu } \\
\text { antepasado Nebka, justificado". } \\
(\text { WW.1.18-19). }\end{array}$ & $\begin{array}{l}\text { "Entonces Ubaoné dijo: 'Tráeme mi } \\
\text { estuche de ébano y oro'. El hizo }[\ldots] \\
\text { que un cocodrilo }[\ldots] \text { de siete }[\ldots] \text { y } \\
\text { recitó [una fórmula mágica]: 'Cuando } \\
\text { venga a bañarse en mi estanque }[\ldots] \text { el } \\
\text { nds }[\ldots] .(p W .2 .21-25) \text {. }\end{array}$ & $\begin{array}{l}\text { "Entonces la Majestad del rey del } \\
\text { Alto y Bajo Egipto Keops, justificado } \\
\text { dijo: 'Que sean dados mil panes, cien } \\
\text { jarras de cerveza, un buey y dos } \\
\text { medidas de incienso al rey del Alto y } \\
\text { Bajo Egipto Nebka, justificado, Y } \\
\text { que sean dados una torta, una jarra } \\
\text { [de cerveza], una porción de carne [y } \\
\text { una medida de incienso para el } \\
\text { sacerdote-lector en jefe Ubaoné. Todo } \\
\text { fue becho como lo ordenó su } \\
\text { majestad". (pW. 4.11-17). }\end{array}$ \\
\hline $\begin{array}{l}\text { Tercer } \\
\text { relato }\end{array}$ & $\begin{array}{l}\text { "Entonces Baufré se levantó para } \\
\text { hablar y dijo: 'Haré que tu } \\
\text { majestad escuche un prodigio que } \\
\text { ocurrió en el tiempo de tu padre } \\
\text { Snefru, justificado". (pW. 4.17- } \\
\text { 19). }\end{array}$ & $\begin{array}{l}\text { "Entonces el sacerdote-lector en jefe } \\
\text { Djadamankh recitó sus palabras } \\
\text { mágicas. Entonces puso una mitad del } \\
\text { lago sobre la otra y encontró el colgante } \\
\text { con forma de pez depositado sobre una } \\
\text { piedra. Lo buscó y se lo entregó a su } \\
\text { dueña. Mientras el agua tenía doce } \\
\text { codos en el medio, totalizando } \\
\text { veinticuatro codos después que fue } \\
\text { doblado. Entonces recitó sus palabras } \\
\text { mágicas y regresó las aguas del lago a } \\
\text { su posición (original). (pW. 6.7-12). }\end{array}$ & $\begin{array}{l}\text { Entonces la Majestad del rey del } \\
\text { Alto y Bajo Egipto Keops, justificado } \\
\text { dijo: 'Que sean dados mil panes, cien } \\
\text { jarras de cerveza, un buey y dos } \\
\text { medidas de incienso al rey del Alto y } \\
\text { Bajo Egipto Snefru, justificado, Y } \\
\text { que sean dados una torta, una jarra } \\
\text { [de cerveza], una porción de carne [y } \\
\text { una medida de incienso para el } \\
\text { sacerdote-lector en jefe } \\
\text { Djadjaemankh. Todo fue hecho como } \\
\text { lo ordenó su majestad'. (pW. 6.17- } \\
\text { 22). }\end{array}$ \\
\hline $\begin{array}{l}\text { Cuarto } \\
\text { relato }\end{array}$ & $\begin{array}{l}\text { "Después de esto el hijo del rey } \\
\text { Hordedef se puso de pie para } \\
\text { bablar y dijo: [...] en el } \\
\text { conocimiento de aquellos que } \\
\text { pasaron no se sabe [distinguir] la } \\
\text { verdad de la mentira. Hay bajo tu } \\
\text { majestad en tu propio tiempo y es } \\
\text { desconocido [...]. (pW. 6.22-25). }\end{array}$ & $\begin{array}{l}\text { "Entonces Djedi recitó sus palabras } \\
\text { mágicas y el ganso se levantó sobre sus } \\
\text { patas del mismo modo que su cabeza, y } \\
\text { a continuación se acercaron la una con } \\
\text { la otra, y el ganso se levantó } \\
\text { cacareando. Entonces el hizo que se le } \\
\text { trajera un ganso khetaa y lo mismo se } \\
\text { bizo para él. Entonces su majestad } \\
\text { bizo que se le trajera un toro cuya } \\
\text { cabeza fue derribada en el suelo. } \\
\text { Entonces Djedi recitó sus palabras }\end{array}$ & $\begin{array}{l}\text { "Su majestad se dirigió hacia su } \\
\text { palacio y entonces su majestad dijo: } \\
\text { Que se envie a Djedi a la casa del } \\
\text { bijo del rey Hordedefy que viva junto } \\
\text { a él. Que le sean dados mil panes, } \\
\text { cien jarras de cerveza, un buey y cien } \\
\text { paquetes de puerros. Todo fue hecho } \\
\text { como lo ordenó su majestad". ( } p W \text {. } \\
\text { 9.18-21). }\end{array}$ \\
\hline
\end{tabular}




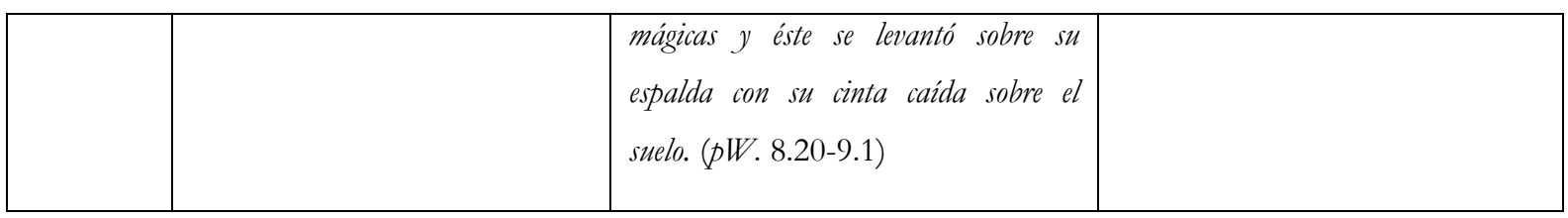

\section{CUADRO X. Unidades natrativas en los relatos del papiro Westcar}

Al verificar esta organización de la estructura interna en los cuatro primeros relatos, queda desestimada la idea de Lefebvre -reproducida por otros autores- que los relatos del papiro Westcar han sido escritos en el mismo manuscrito sin sentido alguno de pertenencia los unos de los otros. Por el contrario, la morfología de los relatos pone en evidencia que existía entre ellos una relación, una correlación de funciones.

Las tres unidades narrativas mínimas que hemos identificado para los cuatro primeros relatos del papiro Westcar no se pueden distinguir en el último de los relatos. Por lo tanto, existe una ruptura que debe ser analizada.

No se ha dado una discusión historiográfica sobre si el último relato es el quinto o si se trata de un anexo al cuarto. Pero, a partir de los títulos y las formas en que los egiptólogos han organizado las traducciones, y de las interpretaciones de los investigadores ${ }^{421}$, queda implícito que está añadido al cuarto relato.

Entonces, si el último relato del papiro Westcar no se relaciona desde un carácter funcional, ¿cuál es la relación que mantiene con ellos? Nosotros postulamos que la relación es de tipo argumental con el cuarto relato. Éste centra parte de su argumento en la profecía anunciada por Djedi al faraón Keops sobre el nacimiento de tres niños hijos del dios Ra y Reddjedet, la esposa de un sacerdote de Ra en el templo de Heliópolis. El anexo se inicia con la narración del parto de Reddjedet en su casa y es la plasmación argumental de la predicción de Djedi. Como ya hemos

\footnotetext{
${ }^{421} \mathrm{Ya}$ nos hemos referido a los diferentes títulos que se han propuesto para este relato. Podemos sintetizar que Lefebvre (2003 [1982], p.92 y p. 105) lo describe como "capítulo suplementario", anexo al cuarto. Del mismo modo lo piensan Lichtheim (1973, p. 220); y Simpson (LAE, pp. 15 y 26) y López (2005, p. 96) al llamarlo "El nacimiento de los niños reales".
} 
dicho, lo que en el cuarto relato es futuro narrativo, en el anexo es presente de la acción.

Por lo tanto, podemos concluir que las cuatro primeras historias pertenecen a un mismo grupo de relatos, donde las acciones de los personajes son las que definen una unidad narrativa y funcional. Es decir que no fueron dispuestos en un mismo manuscrito como una recopilación de historias que nada tenían que ver unas con otras. Parece que el/los escritor/es, o, si se prefiere, el relator, respeta una forma establecida de narrar. Conocidas las unidades, bastaba con "llenarlas" de contenido argumental y estilístico, esto es, elegir a los personajes, el tiempo y el espacio de la acción, el problema, etc.

Pero también el argumento nos sirve como un elemento para pensar la relación que se establece entre los relatos. Si realizamos un análisis del contenido, observamos ciertos parámetros comunes que otorgan más fuerza a nuestra hipótesis de unidad de los relatos del papiro Westcar.

Los primeros cuatro relatos son historias que los príncipes, hijos del faraón Keops, le cuentan a su padre. Se sitúan en un mismo marco espacial para dar inicio a la acción: la corte del rey. Cada historia es narrada por un príncipe con la finalidad de entretener a su padre ${ }^{422}$.

"Entretener al rey" es el leit motiv de cada relato, utilizado también en otras obras de la literatura egipcia. El aburrimiento no tiene que ser considerado un rasgo negativo en la personalidad de Keops y característica de su reinado. Por el contrario, es una idea recurrente en los discursos del antiguo Egipto. Por ejemplo, en el tercer relato del papiro Westcar el rey Snefru está aburrido. Lo mismo aparece en Profecía de Neferty: el rey, aburrido en su corte, pide a sus hijos entretenerse y ellos van en búsqueda de Neferty para que propicie bellas palabras: "Busquéis a uno que sea agudo de espiritu, o entre vuestros hermanos a uno que sea eminente, o entre vuestros amigos a uno que haya realizado una hazaña, (en fin, un hombre) que sea capaz de decirme hermosas palabras y frases escogidas, que mi Majestad se divertirá escuchando" (Lefebvre 2003 [1982], p. 114). Las buenas palabras, como instrumento de entretenimiento, se presentan como

${ }^{422}$ Quizá esta idea de encadenamiento de relatos como entretenimiento a un superior es lo que llevó a pensar a Lefebvre sus paralelismos con los relatos árabes de Mily Una Noches. 
argumento central en Campesino Elocuente: un campesino cuya única arma de defensa es su palabra.

La idea del aburrimiento se encuentra también presente en los mitos de la creación. Según la cosmogonía Heliopolitana, el aburrimiento y la soledad eran las condiciones en las que el dios Atum se encontraba antes de crear la primera pareja sexuada que conlleva a una sucesión divina de creación de otras parejas de dioses y con ellas del universo en general ${ }^{423}$.

La descripción narrativa del aburrimiento del faraón podría estar lejos de ser la motivación "real" de los relatos. Es decir, no imaginemos en un plano real e histórico a los hijos de Keops sentados a su alrededor contando historias para divertirlo. Se trata de ficción, estos relatos son la expresión estética de una situación no necesariamente real.

Además, el "estar aburrido" no significa un estado de inacción. Es, por el contrario, una figura que, por lo general, desencadena hechos. En el tercer relato del papiro Westcar el faraón Snefru, aburrido en su palacio, envía a sus servidores a llamar al jefe-lector Djadjaemankh quien le aconseja cómo "divertirse". Por su parte, Keops, inquieto por conocer a Djedi lo manda a llamar. Es decir, que en los relatos del papiro Westcar y en otras narraciones el aburrimiento impulsa a la acción (Salem 2008).

Entonces, además de compartir una estructura tripartita, los cuatro primeros relatos del papiro Westcar, son considerados como unidad por aquello que ellos narran. Las cinco son "historias maravillosas", la magia está presente en cada uno. Los cuatro primeros relatos narran historias mágicas, todas protagonizadas por hombres sabios (magos o jefes-lectores) que deslumbran por sus hazañas y que atrapan al espectador con sus acciones sorprendentes, como abrir las aguas del río en dos y volverlas a unir, manipular la vida y la muerte, o predecir el futuro. Mientras que, en el relato anexo, se narra una historia también mágica y maravillosa, pero de un carácter diferente. En la narración del nacimiento divino de los trillizos

${ }^{423}$ Esta idea fue desarrollada en el seminario dictado por la Dra. Zingarelli Andrea en el primer cuatrimestre del año 2007. 
son los dioses los que realizan la acción mágica: la elaboración de las coronas como augurio a los futuros reyes.

Es muy importante para nosotros destacar que, además, el cuarto relato, y especialmente su anexo, tienen una fuerte impronta mítico-política. Si bien son narraciones mágicas, en los relatos prevalece una estructura argumental que los vincula con los mitos de origen del rey, esto es que la legitimación política del niño que será faraón surge de haber nacido hijo del dios.

En síntesis, la magia es un elemento que está presente en los cinco relatos del papiro Westcar. Existe una unidad que es argumental, una secuencia de narraciones maravillosas coherentes que hacen del papiro Westcar una única composición literaria.

En la obra literaria se muestran las virtudes que son adjudicadas a los sacerdotes-lectores, desde Ubaoné, quien transforma un cocodrilo de cera en uno de verdad, hasta Djedi que puede volver la cabeza recién cortada de una oca a su lugar. ¿Por qué contar historias mágicas? ${ }^{224}$ Se narran conocimientos vedados al común de los hombres. Una acción que al ser maravillosa sorprende por sí misma. La palabra es el arma que garantiza la realización del acto mágico. Las palabras enunciadas por los magos nunca son reveladas al lector, su secreto potencia la idea de que unos pocos tienen la capacidad y el poder para conocerlas y pronunciarlas.

A pesar que hemos indentificado una unidad argumental, existen también significativas diferencias entre los relatos. Los tres primeros recuerdan maravillosas historias ocurridas en el pasado, pero el cuarto relato no es un acto de evocación del hijo del rey Hordedef, sino el surgimiento de un nuevo elemento en la trama. El príncipe pone en duda la veracidad de las historias relatadas por sus hermanos: "no se sabe [distinguir] la verdad de la mentira" ( $\not W$. 6.23-24), e informa a su padre sobre la existencia de un hombre sabio que vivía en la ciudad de Djed-Snefru, llamado Djedi.

\footnotetext{
${ }^{424}$ Hubert y Mauss en su tradicional artículo "Esquisse d'une théorie générale de la magie" ["Ensayo de una teoría general de la magia"], han estudiado la magia como fenómeno sociológico. Para ellos el motivo por el cual las sociedades trasmiten y le dan identidad a las figuras de magos es para aplacar sus propios miedos. La misma sociedad les confiere poder y los coloca es un lugar de privilegio.
} 
El rey Keops envía a buscar al mago y éste es llevado hasta la corte, donde Djedi realiza sus actos mágicos, que caracterizan al cuarto relato como tal. A diferencia de los otros, el presente narrativo de la acción se traslada a la dinastía IV en la corte de Keops. Es decir, que se continúa con el mismo fin narrativo: relatar historias relacionadas con Keops y actos maravillosos, aunque en el cuarto relato, Djedi actúa en un tiempo narrativo presente. El cambio de argumento no altera la estructura interna del cuarto relato; presentación, acción mágica y retribución del faraón.

En el anexo al cuarto relato también hay un cambio de argumento (recordemos que también de estructura). La corte del rey Keops no es más el escenario de los hechos, el faraón ha dejado de ser el protagonista, y ninguno de sus hijos es el narrador, esto es lo que sucede en el nacimiento de los trillizos que el mago había anunciado. La acción cambia de espacio, a una casa, y Reddjedet y su esposo-sacerdote, ahora son los protagonistas. Los dioses acuden a ellos enviados por Ra para ayudar en el dificultoso parto de la madre de los futuros faraones.

Recordemos que, a pesar de todas las diferencias funcionales y de argumento, hay rasgos del anexo que lo vinculan con los restantes relatos del papiro. El primero es de carácter general; que en el relato anexo también se narran acontecimientos maravillosos y ocurren actos mágicos. El nacimiento de los niños es en sí mismo extraordinario, pues son hijos del dios Ra y una mujer no divina, esposa de un sacerdote del templo de Heliópolis. El segundo rasgo es el acto mágico que los dioses realizan para los recién nacidos, la elaboración de tres coronas que usarán en el ejercicio de su poder como reyes, según lo predestinado por Djedi.

En el anexo al cuarto relato, la profecía del mago Djedi se hace realidad: lo anunciado se hace existente, las palabras sabias dejan de ser un prodigio, se materializan. Los hechos legitiman la predicción del sabio, el futuro (narrativo) se hace presente. 


\section{Contenido mágico de los relatos del papiro Westcar}

Uno de los modos en se han clasificado los relatos, ha sido a través de la categoría "cuentos fantásticos". Como hemos mencionado, es a partir del título que Erman escogió para ellos que se destaca un contenido ficcional y mágico ${ }^{425}$.

Las primeras interpretaciones sobre el carácter de los relatos del papiro Westcar relacionaban su contenido argumental -actos mágicos sorprendentes realizados por magos sabios- con un género literario, los cuentos maravillosos. Y así fueron catalogados los relatos del papiro Westcar.

Esta idea fue considerada y reproducida por Maspero (2002 [1911], pp. $17-$ 19) quien describió el argumento de los relatos haciendo hincapié en los aspectos maravillosos que se narran en ellos. En la misma línea de interpretación está la introducción de Lefebvre a su obra Romans et Contes Égyptiens de l'Époque Pharaonique [Novelas y cuentos egipcios de la época faraónica], en la que clasificó los cuentos egipcios traducidos en su antología ${ }^{426}$. Los relatos del papiro Westcar, junto con Cuento de El Náufrago, Príncipe predestinado, la segunda parte de Dos Hermanos, El Espectro y El pastor que vio una Diosa, fueron catalogados como: “...relatos en que predomina lo

\footnotetext{
425 En la gramática que edita Erman (1889), los relatos del papiro Westcar no se encuentran en la categoría de märchen. En la introducción realiza un recorrido por el tipo de textos que se han escrito en el antiguo Egipto, destacando el lenguaje especializado que aparece en los cuentos, a diferencia de textos contemporáneos que podrían ser considerados como literarios. Como aclara Goody (1990 [1986], p. 50) 'los llamados componentes 'mágicos' destacan en la literatura egipcia, incluyen conjuros, calendarios de los días favorables, la interpretación de los sueños, consultas a los oráculos, y amuletos que contienen textos escritos para protegerse".

426 En total Lefebvre (2003 [1982], pp. 17 y ss.) describe seis categorías. La primera, cuentosescenario, término que son una parte secundaria de la obra literaria de la que forman parte, como las súplicas del Campesino Elocuente y el exordio en Profecía de Neferty. En segundo lugar los cuentos denominados mitológicos por el rol mítico de los protagonistas. Ellos serían Leyenda del dios del mar y Aventuras de Horus y Seth. Una tercera categoría es la que engloba Querella de Apopi y de Sekenenre, La toma de Joppe, Princesa de Bakbtan, relatos que narrarían anécdotas más que hechos históricos. En tanto que Verdad y Mentira es clasificado como cuento filosófico. En último término Dos Hermanos (exceptuando los rasgos maravillosos) es considerado como relato psicológico. Una de las críticas que Propp (2007, pp. 12-13) realiza a sus contemporáneos es que la clasificación que proponen se basa en una clasificación a priori, hasta se divisa la intuición antes que la elucidación. Esta crítica se puede aplicar a las categorías de Lefebvre, que no parecen ser producto de una deducción del propio corpus literario, y si lo fuera es poco factible que conociéramos la totalidad de la literatura egipcia para proponer una clasificación de este tipo.
} 
maravilloso, o donde la magia desempeña un papel preponderante: hazañas de magos, hechiceros que dominan los elementos, nacimientos extraordinarios, curaciones milagrosas, signos premonitorios, y anuncios misteriosos, animales dotados de palabras, los prodigios se suceden para el mayor disfrute de los oyentes" (Lefebvre 2003 [1982], pp. 17-18)427.

Ya hemos dicho que Lefebvre se acerca a una estructura inconexa de los relatos del papiro Westcar, similar a los cuentos árabes de Mil y Unas Noches. Estas ideas repercutieron en otros investigadores que las aceptaron sin mayor análisis y discusión ${ }^{428}$. Por ejemplo Lichtheim (1973, p. 215-216); Simpson (1973, p. 15); Parkinson (1998, pp. 103-104); Brunner-Traut (2000 [1963], p. 52); Quirke (2004, p. 77), mencionan en sus antologías que los relatos del papiro Westcar son de un carácter mágico y maravilloso.

Uno de los trabajos que se propone analizar el papiro Westcar dentro de un género literario es el de la investigadora alemana Lepper (2007, p. 1132; 2008). La autora considera que pueden catalogarse dentro del género de la prosa, siendo justamente los relatos del manuscrito los exponentes más antiguos de este tipo en la literatura del antiguo Egipto. Recordemos que para Lepper el estilo es lo que en última instancia delimita la marca personal del escriba, por medio de la gramática y el vocabulario se evidencian distintos tipos de grafías en los relatos.

Las interpretaciones que han intentado definir los textos literarios egipcios a partir de un género literario específico generan dificultades interpretativas. En primer lugar, porque no hay un consenso sobre cómo definir un género literario para relatos de la antigüedad. En segundo lugar, no hay acuerdo sobre qué tipo de género representaría cada relato. Lo que deriva en un tercer punto, la restricción de pensar los relatos representando un género, y perder de vista la multiplicidad de discursos que en ellos se entrecruzan, como hemos analizado para el papiro Westcar.

\footnotetext{
${ }^{427} \mathrm{El}$ subrayado es nuestro.

${ }^{428}$ No hay entre estos autores una teorización con respecto a las características de los relatos del papiro Westcar, lo que se observa en ellos es el uso de términos como "maravilloso", "fantástico", "asombroso", "extraordinario", ya sea en la descripción del argumento de los relatos o en la incorporación del adjetivo en el título propuesto para los cuentos del papiro Westcar.
} 
Desestimamos los intentos de categorizar los relatos egipcios en los géneros literarios de la teoría literaria moderna, principalmente porque éstos han "encasillado" a los textos, perdiéndose una de las características esenciales del pensamiento egipcio: la multiplicidad de aproximaciones.

La multiplicidad implica que dentro de un texto puede aparecer más de un género literario, y que su funcionalidad no es necesariamente sólo literaria. Por ejemplo, reducir un género literario a la función de entretenimiento, pierde de vista las intenciones políticas y las referencias míticas que pueden subyacer en los textos. De hecho, podemos pensar que los textos literarios tienen dos aspectos fundamentales en el mundo de la palabra escrita y ficcionalizada, por un lado proveen entretenimiento y por el otro constituyen una aventura intelectual (Morenz 2003, p. 102), esta última permite concebir su relación con lo político.

Lo más significativo es que el mundo conceptual egipcio se diferencia sustancialmente de los esquemas mentales de la actualidad, esté o no expresado literariamente. Como hemos ya indicado, si bien la sociedad egipcia antigua produjo textos literarios, la catalogación de un texto como literario o no literario es un debate que permanece hoy en día entre los investigadores. Si bien los propios egipcios reconocieron a algunos textos como parte de una "literatura clásica", en ningún momento teorizaron sobre sus formas, tipo de contenido, etc.

Se hace necesario, entonces, releer los textos literarios partiendo de una multiplicidad de aproximaciones y, desde una perspectiva analítica, establecer las relaciones que los vinculan -entre otras- con las expresiones políticas. Es decir, ligar al texto con el contexto político en que fue pensado, analizando las relaciones con el origen y el pasado, que responden a una necesidad política concreta, y las influencias más directas del mito como estructura del pensamiento base en la sociedad del antiguo Egipto ${ }^{429}$.

${ }^{429}$ Recordemos la postura de Posener en Litterature et politique dans l'Egypte de la XIIe Dynastie [Literatura y política en el Egipto de la dinastía XII], quien fue uno de los primeros investigadores en dar a conocer los vínculos existentes entre la elite intelectual egipcia, miembro sustancial de la monarquía egipcia, y los textos que ella produce. En este artículo Posener planteaba que los cambios políticos sociales ocurridos en Egipto luego del Primer Periodo Intermedio se ven reflejados en la literatura del Reino Medio (Posener 1956, p. 9), analizando cuáles son las referencias políticas presentes en los textos literarios como Profecía de Neferty, Diálogo de un Hombre con su Ba, 
El texto literario por sí sólo, como escrito "que narra una historia” pierde su valor. Lo que proponemos es el entrecruzamiento de los textos literarios y no literarios que están en permanente diálogo con los relatos del papiro Westcar, y poder ver, a través de ellos, no solamente intencionalidades políticas, sino también la esfera del pensamiento que trasciende al texto, al mismo tiempo que lo funda como relato.

No queremos decir con ello que no puedan comprenderse a los relatos egipcios en géneros literarios. Desestimar que la literatura egipcia posee géneros literarios es no reconocer la existencia de las relaciones que los textos literarios mantienen con el universo más amplio de la literatura, pues, en palabras de Todorov (2003 [1972], p. 11) "los géneros son precisamente esos eslabones mediante los cuales la obra se relaciona con el universo de la literatura". En este sentido, Loprieno (1998, pp. 50 y ss.) fue uno de los primeros egiptólogos en plantear la intertextualidad como rasgo intrínseco de los textos literarios, y en sostener que deben ser leídos y estudiados dentro de un universo de textos.

Lo maravilloso de los relatos del papiro Westcar trajo aparejado otras discusiones que han ocupado tendidamente a los especialistas, y que han repercutido en el estudio del papiro Westcar. Si bien estas controversias pueden analizarse separadamente se encuentran íntimamente relacionadas entre sí. En primer lugar, refieren al rasgo de ficcionalidad de los relatos, que implica asimismo, en segundo término, discutir la validez de los textos literarios como fuentes históricas en tanto reflejo de de la realidad, de lo cual ya nos hemos ocupado en el capítulo IV más extendidamente.

La ficcionalidad supone que los relatos solamente pueden ser analizados como textos en los que nada se relaciona con el mundo real, no ficcionales. La propia aceptación de géneros literarios reforzaba la idea que era un mundo ficticio lo

General Sisené, Canto del Arpista y los cuentos del papiro Westcar, entre otros. Asimismo, Assmann (2005 [1996], p. 136) afirma que los textos literarios del Reino Medio son el recuerdo codificado de los acontecimientos del Primer Periodo Intermedio, siendo ellos escritos políticamente tendenciosos y sin base histórica. Si los textos literarios son el reflejo o no de una realidad histórica es un extenso debate que hemos abordado específicamente en otro capítulo, pero que está presente como problemática a lo largo de todo el trabajo. 
que trasmitían estos cuentos, idea que consideramos fue la que impulsó a Erman a categorizar a los relatos del papiro Westcar como märchen.

\section{Cultura popular, tradición oral, representación y autoría}

La relación entre oralidad y escritura ha sido analizada en profundidad para las sociedades antiguas, y existe una extendida tradición historiográfica para las sociedades clásicas. Sin embargo, gran parte de la discusión se ha reducido a la "teoría oral" aplicada a los poemas homéricos y otros textos griegos, y no ha integrado a los textos egipcios. Por su parte, la egiptología tampoco ha desarrollado específicamente esta problemática, más allá de algunos pocos trabajos dedicados al tema ${ }^{430}$. Uno de los motivos de este vacío interpretativo es la todavía no saldada discusión alrededor de los problemas métricos de los textos literarios egipcios: si deben ser leídos en prosa o poesía (Coletta 2009, pp. 1-2). De hecho, esta discusión sigue en pie para los relatos del papiro Westcar. En los últimos años Lepper (2007, p. 1132) ha insistido en una escritura en prosa para los mismos ${ }^{431}$.

La oralidad con relación a la difusión, trasmisión y producción de la cultura egipcia son de gran interés para los egiptólogos, porque la egipcia básicamente fue una sociedad de cultura oral, a pesar de que lo que sabemos de ella es a través de los textos escritos. Para Parkinson (2002, p. 56), durante el Reino Medio la cultura trasmitida oralmente fue más que significativa, canciones, cuentos y sabidurías folclóricas, aunque haya quedado una evidencia muy escasa. Es más, para Silverman (1991, p. 63), muchas de las fuentes literarias escritas que se crearon para dar cuenta de la posición justificada del rey, fueron previamente originadas en leyendas o tradiciones populares ${ }^{432}$.

La escritura era monopolio del Estado, lo que se evidencia con los porcentajes acerca de la población alfabetizada. Estos varían, según el historiador, desde un uno por ciento (Baines 1983, p. 585; Baines y Eyre 1983, pp. 65-72), hasta

\footnotetext{
${ }^{430} \mathrm{Al}$ respecto véase Parkinson (2002 pp. 55-63).

${ }^{431}$ La autora (Lepper 2007, p. 1132) considera que también Unamón estaría escrito en prosa.

432 Para Assmann (1999, p. 6) el circuito más frecuente de la circulación era la vía oral, entretanto que la escritura era utilizada en los campos culturales donde la comunicación requería el uso de almacenamiento artificial.
} 
un diez por ciento del total de la población (Te Velde 1986, pp. 253-265), pasando por una postura intermedia que oscilaría entre el tres al cinco por ciento de la población (Araújo 2000, p. 41). El número de una población letrada nos informa que las experiencias, costumbres y el conocimiento se transmitían en forma oral. La expresión oral era, incluso el método empleado en la escuela especializada (Assmann 1999, p. 8). De todos modos, como ha indicado Chartier (1999, pp. 120-121), en el mundo antiguo hay muchas razones por las cuales fueron dictados los textos. Una dificultad técnica y material la imponía el propio rollo de papiro que, al obligar a la persona a sostenerlo con las dos manos, obstaculizaba la tarea de quien quisiera copiarlo. La forma de saldar el impedimento fue el dictado ${ }^{433}$. La otra razón se infiere del poder y autoridad que adquiría quien dictaba; se colocaba al escriba en una condición inferior, al delegársele únicamente la acción mecánica de escribir ${ }^{434}$.

De todos modos, la palabra oral en una cultura extinta como la egipcia, se ha perdido casi definitivamente, lo cual es una gran desventaja. El historiador se encuentra en desventaja y debe utilizar fuentes doblemente indirectas. El historiador llega, parafraseando a Chartier (1999, p. 114), a las oralidades mudas, escritas por individuos vinculados a la esfera dominante, pero también hay que tener en cuenta que la oralidad es propia de la cultura popular (Ginzburg 1981 [1976], pp. 11-12). Sin embargo, algunas reminiscencias de la palabra oral se plasmaron en la escrita, principalmente en la cualidad de la repetición. Ella no es un problema para los autores de las obras literarias ya que forma parte de su formación estructural; sin repetición el proceso de tradición se derrumba. La innovación -al estilo de Lamentaciones de Khakheperresenebu- es lo que se convierte en un problema, pues la innovación significaría olvido (Assmann 1997, p. 69) 435.

En síntesis, sólo podemos aproximarnos a la cultura oral egipcia antigua por medio del discurso escrito (Parkinson 2002, p, 55), lo que no deja de ser una parcialidad subjetiva del desarrollo cultural oral, textos escritos que se transforman

433 Si bien pudo existir este tipo de impedimento técnico como aduce Chartier (1999, pp. 120-121) hay que considerar que la oralidad forma parte de la cultura de dicha sociedad.

${ }^{434}$ Sin embargo, en Profecía de Neferty es el propio rey quien toma el rollo y la pluma y toma nota de las palabras de Neferty.

${ }^{435}$ En la tradición oral la repetición y memorización era la cualidad del cantante, su capacidad era más valorada cuanto más podía recordar, es decir que a mayor conocimiento más alto era el rango que ocupaba (Assmann 1997, p. 69). 
en filtros intermedios y deformantes. Más allá de estas limitaciones, no implica que las fuentes sean inutilizables (Ginzburg 1981 [1976], pp. 11-14). Para (re)conocer parte del lenguaje hablado, nos queda como posibilidad metodológica rastrearlo en fuentes escritas. Nos encontramos con una gran diversidad de textos, de los cuales analizamos los literarios datados hacia el Reino Medio, particularmente los contenidos en el papiro Westcar.

La afirmación que la cultura egipcia era esencialmente oral, no implica decir que haya sido una cultura inferior. Por ejemplo, señalamos que los intelectuales -en tanto individuos ligados a la exploración creativa- eran una parte activa de las sociedades sin escritura (Goody 1990 [1986], pp. 29-30). Además a lo largo de la historia egipcia se puede observar un gran desarrollo cultural, del arte y de las ciencias, que demuestran que el conocimiento fluía, al menos entre las capas sociales que podían producirlo y transmitirlo.

Los propios egipcios valoraron a las diferentes esferas de la comunicación, y le dieron una significación muy especial a la palabra. Por ejemplo, en una de las tradiciones cosmogónicas acerca de la creación del mundo, el dios Ptah crea el universo a través de la palabra. En Piedra de Shabaka $a^{436}$, sobre la cual ha quedado plasmada importantísima información acerca de la teología menfita, puede leerse: "Estos tomaron forma en el corazón (de Ptab) y tomaron forma en la lengua (de Ptab), en la forma de Atum, pues Ptah es más grande, que da (vida) a todos los dioses y a todos sus kas, por medio de su corazón y de su lengua....

De este modo, sucedió que el corazón y la lengua cobraron supremacía sobre todo miembro (del cuerpo) según la enseñanza que él (Ptah, como corazón) está en todo cuerpo y ella (Ptah, como lengua) en toda boca de todos los dioses, todos los hombres, todo el ganado..." (Lull 2006, p. 31).

En el texto se aprecia el significado trascendente de la palabra hablada para la sociedad antiguo egipcia. La acción de hablar, la expresaban a través del verbo

436 Piedra de Shabaka (BM 498) fue escrita durante la dinastía XXV (Lull 2006 p. 31), allí un comentario sobre la cosmogonía menfita), si bien sus raíces pueden hallarse en escritos del Reino Antiguo (Sethe 1928, pp. 2-5). De todos modos, los estudios filológicos y paleográficos también han sugerido que teniendo en cuenta la presencia de una gran números de formas lingüísticas propias del neogipcio, su datación original no puede ir más allá de la época ramésida (Junge 1973, pp. 195-204). 
$\| \vec{A}$ 通 $m d w$, que lleva el determinativo del hombre sentado con la mano en la boca, lo que simboliza que las palabras salen de la boca, es decir son habladas, pronunciadas. En definitiva, más allá de las apreciaciones que los egipcios tuvieron de su oralidad, se hace evidente que el Egipto faraónico permaneció en gran medida como una cultura oral, y fue la escritura un fenómeno limitado tanto en lo social como en lo cognitivo (Parkinson 1991, p. 19).

Algunos investigadores han interpretado que los textos mítico-literarios, datados en el Reino Medio, pudieron haberse originado en un ámbito oral, para luego pasarse por escrito. Al menos para algunos de ellos parece estar claro que antes que los relatos se pusieran por escrito, constituían historias que se contaban y se cantaban. Esto podría atestiguarse en las canciones escritas en varias tumbas del Reino Antiguo, o con Textos de las Pirámides, que serían producto de una práctica oral previa a la escritura (Morenz 2003, p. 102). Desde esta perspectiva, Daumas (1972, p. 390) sostiene que la ausencia de una firma en los cuentos tiene que ver con que procedían de datos folklóricos más antiguos ${ }^{437}$ y nadie sabía a quién pertenecía la narración.

Podemos afirmar que para los textos literarios del periodo la transición entre la poesía oral y la escrita no fue un cambio drástico (Parkinson 2002, p. 55), pues según indica Todorov (1971, p. 161) los géneros están en constante transformación, siempre en movimiento de uno más antiguo a uno más nuevo, ya sea por inversión, por desplazamiento o por combinación.

Si la literatura del Reino Medio consta de prototipos de la poesía oral más antigua es un tema que aún puede debatirse (Morenz 1996, p. 38; Parkinson 2002, p. 55), pues el problema es muy complejo. Para Parkinson (2002, pp. 56-57) la relación entre la oralidad y la escritura es una dicotomía que va desde la "transcripción" o la "transposición" del lenguaje hablado al discurso escrito, siendo muy difícil poder determinar el modo exacto en que se produjo dicha transmisión

Esta posibilidad también le cabe a los relatos del papiro Westcar, y ha sido ya vislumbrada por Baines (1996, pp. 365-367), quien al compararlos con el relato

437 Volveremos a esta cuestión más adelante. 
del Mito de Horus y Seth encontró fórmulas narrativas convencionales comparables. Para Baines (1996, pp. 360-365) las formas narrativas podrían proceder tanto de una tradición de relatos orales o de textos escritos, y lo más plausible es que la conformación de las narraciones se haya producido paralelamente. Más aún, el investigador opina que los relatos del papiro Westcar pueden ser evidencia de que las narraciones literarias expresan relatos míticos, o si se prefiere, que partes del relato puedan constituir un mito.

Dadas las formas propias de escritura del papiro Westcar, no descartamos la posibilidad de concebir un origen oral para los relatos. De hecho, es generalizada la idea que la llamada literatura fantástica tendría elementos de una transmisión oral (Araújo 2000, p. 41). Como lo han definido especialistas del lenguaje, la repetición de pasajes, palabras, así como también la recitación rítmica, han sido consideradas huellas de oralidad en los textos escritos. Ong (2006 [1982], pp. 62 y ss.) afirma que eran herramientas de la memoria y del lenguaje que los recitadores de culturas orales utilizaban al pronunciar y narrar sus historias. Otro indicio de oralidad podemos detectarlo en la ordenación tripartita de los relatos, que como hemos analizado, es la fórmula escrita que se repite en el texto escrito. Si hubiese existido algún intérprete o trasmisor de los relatos del papiro Westcar, bastaba con que recordase las tres partes fundamentales y cómo se secuenciaban en la narración.

De todos modos, asumir esta posición como definitiva trae consigo algunas dificultades, sin contar que las fuentes son muy débiles para reafirmar dicha postura. Quienes han estudiado el pasaje de la palabra hablada a la palabra escrita, han indicado que los rasgos de repetición solamente aparecen en una etapa inicial (Ong 2006 [1982], pp. 28 y ss.), cuando aún no habían depurado la lengua escrita y sus formas de expresión.

Si relacionamos lo mencionado con los relatos del papiro Westcar podemos asumir que el texto fue escrito originariamente al inicio del Reino Medio cuando comienzan a producirse en Egipto los primeros textos literarios. Los pasajes repetitivos estarían indicando una fase inicial de desarrollo de la escritura literaria en el antiguo Egipto, y nos permite datar a los relatos en las proximidades de las dinastías XII y XIII. 
La reiteración de párrafos es uno de los rasgos característicos del papiro Westcar. Por ejemplo, en el anexo al cuarto relato, se repite, con cada nacimiento, el juego de palabras con el nombre del niño ${ }^{438}$ : "Entonces Isis se colocó enfrente de ella y Neftis detrás de ella, (mientras que) Hequet aceleraba el parto. Entonces Isis dijo: "No seas xxx en su útero, éste es tu nombre $x \times x$. Este niño se escurrió sobre sus manos como un niño de un codo (de largo). Sus huesos eran fuertes y la cobertura de sus miembros era de oro y su tocado de verdadero lapislázuli. Entonces ellas lo lavaron y cortaron su cordón umbilical y lo colocaron sobre un asiento de ladrillos. Entonces Meshkeneh se le presentó ante él y dijo: 'Será un rey que ejercerá la realeza sobre esta país entero', (mientras) que Kbnum bizo saludables sus miembros".

La repetición como recurso aparece también en otros relatos del Reino Medio egipcio. En ellos el patrón de expresión se caracteriza por ser aditivo y no subordinado, con un uso de fórmulas prominente y de agregación (Parkinson 2002, p. 56). Por ejemplo, en Cuento de El Náufrago. López (2005, p. 78) explica que el narrador es un hábil escriba influenciado por el estilo "oral", al recurrir a una gran cantidad de fórmulas, como si se encontrara ante un auditorio. Estas fórmulas fueron estudiadas por Vikentiev (1935), quien analiza el esquema de la métrica en Cuento de El Náufrago concluyendo que es claramente una pieza poética, con un periodo rítmico comprendido de dos a cuatro líneas; las líneas contienen de dos a cuatro tensiones y las divisiones métricas corresponden a la sucesión de ideas (Vikentiev 1935, p. 1). La fórmula $2 \int \mathrm{mm}$ dd in "dicho por" es reiterada una y otra vez para introducir los párrafos, prueba de que es una obra popular que se transmitía oralmente, donde la forma poética permitía al narrador menos esfuerzo memorístico (López 2005, p. 78) y facilitaba la recitación.

La repetición en una sociedad como la egipcia impide el olvido de las tradiciones culturales que a través de ella se transmiten. En el momento que un cantante pierde las condiciones de almacenamiento de su saber repetido oralmente, se ritualiza su performance y pasa al mundo de lo escrito; la literatura fue su primera forma de comunicación (Assmann 1997, pp. 68-69). El rito es parte inherente de la

\footnotetext{
${ }^{438}$ Lo único que se modifica es el orden de las acciones que realizan los dioses, no así las oraciones que son idénticas. En el nacimiento de Userkaf y Sahura primero los niños son colocados sobre el banco de ladrillos y luego la diosa Meshkeneh pronuncia sus palabras mientras Khnum le da saludo al cuerpo del recién nacido. En el nacimiento de Neferikara Kakai primero ocurren las acciones de éstos últimos, y luego el niño es colocado en el asiento de ladrillos.
} 
memoria cultural, otro medio de trasmisión y preservación de la cultura. En los relatos del papiro Westcar se inscribe míticamente aquello que se concibe como realidad: el modo legítimo por el cuál un faraón se proclama como tal.

Como hemos dicho, la repetición ha sido una práctica utilizada por los egipcios en los textos literarios y para los relatos del papiro Westcar queda esclarecida su estructura tripartita y repetitiva, y la repetición de estrofas en el nacimiento de los trillizos. Sin embargo, no podemos asumir con exactitud a qué se debe este tipo de organización del relato. Pues también puede proponerse que el uso de estas fórmulas repetitivas era un recurso memorístico de los relatores, y, que cuando pasaron a ser escritos, continuaron determinando la organización de los relatos. O puede sugerirse que dicha estructura permitiría una lectura mucho más ligera.

Podemos agregar que, justamente, la oralidad llevó a la formación de hombres especializados en la recitación, de hecho los hijos de Keops entretienen a su padre con la elocuencia. Costumbre que como comenta Tyldesley (2011, pp. 1415), sobrevivió más allá del mundo de los faraones, al punto tal que cuando Amelia B. Edwards trabajaba en el templo de Medinet Habu a finales del siglo XIX, un narrador árabe recitó por horas los cuentos de Mil y Unas noches y otras historias. Ésto le permite afirmar a Tyldesley que en el antiguo Egipto la mayoría de la gente hombres y mujeres- nunca accedían a un rollo de papiro, sino que aprendían las historias de memoria, de tanto escucharlas y repetirlas ${ }^{439}$. Por su parte, Galán (1998, p. 34) destaca que "los autores de los textos recurren a la repetición de situaciones y pasajes cortos, con el posible objetivo de ayudar al lector a seguir la trama argumental"; y por qué no para facilitar una representación teatral o lectura en "voz alta", pues el argumento sugiere un contexto de teatralización.

Frente a la idea de un origen oral de los relatos del papiro Westcar, se ha planteado, además, la posibilidad que la trasmisión oral se produzca dentro del ámbito de una cultura popular, diferenciada de una cultura de elite y letrada, centralizada y dirigida por y para los miembros de la monarquía egipcia, o cercanos a

${ }^{439}$ Esta misma anécdota se repite cincuenta años más tarde cuando la antropóloga Winifred S. Blackman expresa el gusto que los egipcios tenían por contar historias, los narradores semiprofesionales se encontraban por todo Egipto y conocían las historias más bellas. 
ella. Un contexto no cortesano es una opción que ha sido puesta en consideración por algunos autores, si bien en esta idea no hay justificaciones, pues no van más allá de una lectura más bien literal de los relatos.

Brunner-Traut (2000 [1963], pp. 303-304) propone que los relatos del papiro Westcar están basados en un texto anterior a la dinastía XII (alrededor del año 2000 a.C.), y que podrían ser los apuntes de relatos populares más antiguos, los cuales se transcribieron en forma de cuento tiempo más tarde.

Lefebvre (2003 [1982], pp. 92-93) plantea que los relatos del papiro Westcar se vinculan con obras como Principe predestinado, Mito de Horus y Seth o Dos Hermanos, obras de las dinastías XIX y XX, por el estilo simple, sin rebuscamientos y descuidado, que reiteran numerosos giros lingüísticos y expresiones. Además, poseen un vocabulario poco variado, hasta podría decirse pobre, y contienen palabras que no se ven en otros textos literarios, lo que lleva a deducir que pertenecen al lenguaje utilizado por el pueblo.

Por otro lado, para López (2005, p. 87) predomina la lengua del egipcio clásico, con algunas construcciones gramaticales neoegipcias propias de textos literarios del Reino Medio y, al final del relato anexo, se observan ejemplos de lengua vulgar y popular.

A la afirmación que los relatos del papiro Westcar poseen una clara huella del lenguaje popular de la sociedad egipcia, se agregó la idea que las formas repetitivas de la palabra son expresión de vulgaridad, propias de lo más bajo de la sociedad egipcia antigua ${ }^{440}$. Se asoció lo popular con una condición de enunciación de la palabra burda, rústica y vulgar. Lo que, justamente para Lepper (2007, p. 1125), generó que sean poco estudiados por los especialistas.

Quizá estas deducciones sean producto de una mala interpretación de lo que Erman (1889, p. 6) quiso decir al calificarlos de lenguaje sencillo. Porque Erman afirmaba que los relatos del papiro Westcar eran de la más alta calidad estilística y quien los hubiese escrito debería al menos tener un conocimiento especializado en la escritura y la gramática de la lengua egipcia.

${ }^{440}$ Ejemplos del uso de un lenguaje vulgar en textos del Reino Medio en Sethe (1927, pp. 44-45). 
El diálogo, al final del anexo al cuarto relato, que entablan la servidora de Reddjedet y su hermano, ha sido calificado como lenguaje vulgar y popular. Lefebvre (2003 [1982], p. 107 nota 96) explica que la oración: "Qué es que tú hagas (ir.t.st) esto, esto $(n 3 n 3) ? " 441$ ( $(2 W .12 .11)$ es parte de la lengua vulgar pero que, lo más probable, es que allí el texto se encuentre corrupto, quizá por algún error del escriba. Se hace necesario, entonces, corregir el texto ir.t que indica segunda persona por ir.s en tercera persona femenino "ella hace". Por su parte, López (2005, p. 104, nota 91) aduce que el diálogo está escrito en un estilo incorrecto, con el cual el autor imita la lengua vulgar, siendo difícil proponer un análisis gramatical para estas frases. Sugiere que puede leerse in irt st $n 3$ r.i, sin ser claro si la partícula in indica un énfasis, introduce una interrogación, o es un agente del infinitivo irt.

Lefebvre (2003 [1982], p. 101, nota 53) y López (2005, p. 104, nota 91) tildan al diálogo entre los hermanos de incorrecto, aducen que, por el contrario, la conversación entre Djedi y el hijo del rey Hordedef corresponde a un estilo mucho más "correcto" o "adecuado". Se trata de una conversación más reglada y protocolar, mucho más propia de miembros de la corte y mejor conocida por nosotros por poseer un carácter más estereotipado. Las "licencias estilísticas", solamente fueron empleadas en los textos literarios. El lenguaje coloquial no fue utilizado en los monumentos, que únicamente aceptaron una escritura formal (Parkinson 1991, p. 19).

De todos modos, reconocer que en un determinado pasaje en un texto literario pertenece o es reflejo del lenguaje popular es problemático, principalmente porque no tenemos las fuentes que nos indiquen cuál es el lenguaje popular egipcio $^{442}$. Y aunque las tuviéramos, es difícil de aceptar el uso de calificativos despectivos para dirigirse a dichos fragmentos, no siendo válida la asociación de lo popular con vulgar y una baja calidad estilística del texto.

En este sentido, Chartier (1999, pp. 33-34) advierte sobre los peligros que conlleva la distinción entre cultura dominante, y cultura popular, como categorías opuestas del desarrollo cultural. Además, realiza una crítica a quienes sostienen que

${ }^{441}$ Para este pasaje proponemos la siguiente interpretación: in irt.st $n 3$ r.i "Esto se hace contra mi?" ${ }^{442}$ Quien ha proporcionado ejemplos de lengua "vulgar" en los textos del Reino Medio egipcio fue Sethe (1927, pp. 44-45). 
las ideas generadas en la esfera dominante son difundidas de arriba hacia abajo, logrando ser impuestas a los sectores populares de manera unívoca. Ginzburg (1981 [1976], pp. 9-13) se explaya sobre la posibilidad de una relación recíproca entre ambas esferas de la cultura. Al respecto, Zingarelli (2010, p. 16) considera que los textos del antiguo Egipto se escriben en el espacio de la elite, pero "recogen huellas, marcas y signos de la cultura oral, inaccesible para el historiador'.

Las relaciones entre las tradiciones orales de la población egipcia y la estetización por parte de la elite cultural, no fueron, sin embargo, problematizadas por los historiadodes (Zingarelli 2010, p. 16). No pusieron en evidencia la capacidad narrativa estilística de la elite letrada, porque la puesta por escrito de una tradición oral no significa simplemente una transcripción o transposición del relato (Parkinson 2002, p. 57), además, implica una estilización de la oralidad, que la palabra escrita fije la subjetividad de su autor.

Las especulaciones sobre la lengua popular egipcia como vulgar, traían aparejada la idea de que los relatos estaban destinados a la capa social más pobre de la sociedad egipcia antigua, "porque es sobre todo a las clases humildes, a los fellabin de la época, a quienes se dirigían estos cuentos, a gentes fáciles de entretener y poco exigentes en cuanto al gusto, que así eran distraídas de su vida monótona y ruda" (Lefebvre 2003 [1982], p. 93). Lefebvre cree en un público humilde y acostumbrado al empleo y la expresión artística simple. Observa que las intervenciones de la tercera persona en singular que dicen: “(Asi se) saluda a este (hombre) venerable” $[p W .7 .20$ 21]; "Es así cómo se saluda al hijo del rey" [pW. 7. 26-8.1] irrumpe en el relato para informarle al público cómo debe uno hablar y dirigirse correctamente, pues no está acostumbrado a fórmulas de cortesía.

Goedicke (1993, p. 26), por el contrario, asume que el público al cual estaban destinados los relatos del papiro Westcar seguramente era especializado, al menos familiarizado con los nombres históricos de algunos personajes que en ellos aparecen mencionados. Keops seguramente era un nombre conocido por la mayoría de la sociedad egipcia, pero ¿qué sucede con Nebka? Sólo espectadores imbuidos en la historia faraónica podían reconocerlo como rey egipcio. 
La discusión acerca de quiénes eran los destinatarios de los textos literarios del Reino Medio egipcio aún no está saldada. Así, todavía es necesario problematizar a qué sector social pertenecían aquellos que escribían dichos textos literarios y cómo circulaban. Este debate se enmarca entre los dos ejes esenciales de la producción textual, quién crea y quién recepciona la obra.

La autoría de los textos literarios egipcios es muy compleja, pues partimos del desconocimiento de los sujetos-autores que firman los textos literarios. De hecho, no hay ninguna palabra en lengua egipcia que pueda definirse como "autor”, Lo que ha llevado a inferir que la mayoría eran obras anónimas, por lo menos los "clásicos" que integran el corpus preservado para el Reino Medio (Parkinson 1991, p. 25).

La idea de obras anónimas podemos aceptarla si pensamos en un "autor desconocido", que no es lo mismo que afirmar que no hayan tenido autor (Derchain 1996, pp. 86 y ss.). En este sentido, queremos resaltar que los textos sapienciales sí indican el nombre de un personaje, como un autor moderno (Daumas 1972, p. 390; Lichtheim 1973, p. 6). Los sapienciales son los únicos textos que indican el autor; de un sabio famoso que transmite el conocimiento. Según Daumas (1972, p. 390) los cuentos eran del pueblo, por eso no podía identificarse autor alguno. Parkinson (1991, p. 25) agrega que las enseñanzas son esencialmente una cualidad individual y son, en última instancia, "discurso perfecto" 443.

Para la gran mayoría de los textos literarios no se reconoce un autor, sí un nombre equivalente. En los casos que poseen la firma de un escriba no se trata necesariamente del autor, podría pertenecer a un estudiante que copiaba el texto (Daumas 1972, pp. 313-357). Además, puede suceder, como en el papiro Westcar, que la destrucción del manuscrito en su comienzo y final nos impida saber si algún escriba reconoció su autoría.

443 Parkinson (1991, pp. 25-26) identifica dos tipos de literatura sapiencial. Un primer grupo conformado por el género de las "enseñanzas", en las cuales los protagonistas son personajes de la elite, incluyendo al rey, que dejan por escrito para sus hijos, la naturaleza de la vida ideal. Un segundo grupo incluye textos mucho más reflexivos, que se acercan a un contexto ficcionalizado, más complejo para el análisis. Recordemos que para Lichtheim (1973, p. 97) las enseñanzas datadas entre las dinastías XII y XIII son la continuación del género de las instrucciones sapienciales creadas durante el Reino Antiguo, que incluían entre sus fórmulas proverbios populares, mientras que las del Reino Medio se vuelven composiciones con un lenguaje diferente, con mayor tono ético, de altura moral, lo que para Serrano Delgado (1993, pp. 95- 96) fue el resultado de la evolución ideológica del Primer Periodo Intermedio. 
Solamente en unos pocos relatos del Reino Medio y algunos del Reino Nuevo se han preservado nombres de escribas reconocidos por los propios egipcios. Para el Reino Medio, estamos pensando Ptahhotep y Khakheperresenebu cuyos textos, para algunos investigadores, entrarían en la clasificación de Instrucción o Lamento, y no de texto literario. En tanto, que para el Reino Nuevo podemos referirnos a un conocido texto que recoge literariamente de la memoria cultural los nombres de grandes escritos del antiguo Egipto: "He oído los dichos de Imuthés o de Hardedef con cuyas palabras habla boy en dia todo el mundo..." (Daumas 1972, pp. 390392).

De todos modos, la ausencia de un nombre de autor no debe ser un escollo para el análisis. La figura de autor es construida, como lo es la del narrador o un personaje de la ficción. Es decir, el nombre del autor no se homologa a un sujeto de carne y hueso. En este sentido, Foucault (1969) propone la función autor en la que al sujeto a quien se le atribuyen las palabras escritas no es el único responsable del texto que produce. La función está ligada a mecanismos específicos y complejos que no aluden indefectiblemente a un sujeto (Foucault 1969, p. 66). En palabras de Suhr (1999, p. 92) no hay autor de los textos literarios egipcios, éste se encuentra por fuera de la obra.

Según Eco (1996, p. 19) el autor empírico de un texto narrativo se distingue del autor modelo. Poco aporta conocer las razones psíquicas y las pasiones individuales que los románticos reconocían como un "genio individual” del sujeto que creó la obra.

Nosotros consideramos que el texto literario egipcio no se reconoce por ser una obra de creación individual, sino de un conjunto. Y, además, debemos sumarle las características propias del proceso creativo de una cultura oral como la antigua egipcia.

Las culturas orales y escritas, identifican diferentes roles del individuo en el proceso creativo y en la problemática del intelectual. En las sociedades con rasgos primordialmente orales los hallazgos son anónimamente incorporados dentro de la tradición cultural del conjunto de la comunidad. Lo que no se traduce en una pérdida del proceso creativo (Goody 1990 [1986], p. 37). En conclusión, según 
Goody (1990 [1986], p. 37), "la firma individual está siempre borrada en el proceso de transición generativa".

El problema del intelectual se presenta en todo tipo de sociedades. En la egipcia se distingue la figura del autor/escriba, quien formó parte de una esfera cultural políticamente privilegiada. Pero quizá no pueda hablarse de la existencia de un "campo cultural", al estilo de Bourdieu, si pensamos que las obras se encuentran afectadas por el contexto de relaciones sociales en el cual la obra fue creada, y que el autor se encuentra situado histórica y socialmente en una sociedad (Foucault 1969, p. 13 y p. 43). En última instancia, como ha planteado Dosse (2006, pp. 19-20), todas las sociedades han tenido sus escribas, sus letrados o artistas que impulsaban la transmisión o enriquecían la herencia cultural, hombres que ponían a disposición de las clases dominantes (de una elite cultural que incluye al rey y sus funcionarios) el conocimiento de los textos y el arte. De hecho esto sucedió en Egipto, y lo vemos en el argumento de los textos literarios y en las restricciones para la contemplación del arte cultual.

Resulta muy complejo identificar sobre quiénes recaía la acción primaria de pensar o tomar de la cultura oral un relato y ponerlo por escrito. Consideramos que respondían a un ambiente de elite monárquica. No significa que hayan pertenecido a un grupo a favor de la ideología de gobierno, porque si bien la mayoría de los textos tienen como finalidad la legitimación de la realeza egipcia, no podemos pasar por alto que en algunos también se presentan cuestionamientos a la figura del rey o de altos funcionarios ${ }^{444}$.

Por último, quisiéramos agregar que el antiguo Egipto no se puede abordar desde una historia intelectual, que es la disciplina que según Dosse (2006, p. 14) "tiene como ambición el hacer que se expresen al mismo tiempo las obras, sus autores, y el contexto que las ha visto nacer, de una manera que rechaza la alternativa empobrecedora entre una lectura interna de las obras y una aproximación externa que priorice únicamente las redes de sociabilidad. La historia intelectual pretende dar cuenta de las obras, de los recorridos, de los itinerarios, más allá de las

\footnotetext{
${ }_{444}$ Algunos investigadores se han hecho eco de la pésima caracterización que se hace del faraón Keops en los relatos del papiro Westcar.
} 
fronteras disciplinarias". Pues, algunos de los aspectos que integran el recorrido de una historia intelectual quedan absolutamente diluidos o irrecuperables por el historiador del antiguo Egipto. Por ejemplo, uno de estos aspectos es la circulación del texto, si bien podemos discutir sobre el contexto de producción, el movimiento del texto no está a nuestro alcance, y sólo podemos realizar especulaciones. De todos modos, se hace necesario realizar el esfuerzo de tratar de reconstruir el circuito de producción, difusión y contextualización de las ideas expresadas en los relatos literarios, en última instancia porque es un tema de la cultura en general ${ }^{445}$.

Ya hemos analizado cuán complejo es describir y delimitar internamente los miembros del conjunto de la elite cultural que escribe los textos literarios. Ahora indagaremos sobre un tema que nos parece fundamental, la recepción del texto, y desarrollaremos una de nuestras hipótesis en relación a los relatos del papiro Westcar su representación/performance.

Al iniciar su artículo "La estética de la recepción de las obras literarias" Vodička (1989, p. 55) se encuentra con la apertura de un nuevo campo de estudio sobre los textos literarios, aquel que indaga acerca de cómo la obra es percibida, interpretada y valorada por los lectores. Pero ¿había lectores en el antiguo Egipto? o ¿una audiencia que escuchaba la lectura de un hombre especializado?

Observamos que los textos literarios del Reino Medio construyen audiencias ficcionales (Parkinson 2002, p. 57), como es el caso de los relatos del papiro Westcar y Profecía de Neferty. En ellos se ficcionaliza una corte real espectadora de las historias relatadas por los hijos del rey, o la observación de la acciones de los $n \underline{d} s$ como Djedi y Neferty. Hay una gran intención performativa (Parkinson 2002, p. 75), y no sólo desde lo argumental, pues estos textos fueron creados para ser escuchados, y no tanto para ser leídos, no fueron compuestos en voz alta, es decir que es una literatura auditiva más que de creación oral (Parkinson 2002, p. 52).

\footnotetext{
445 Esto nos permite hacer un comentario que habíamos dejado de lado, y refiere al contexto en que eran guardados los textos literarios, como los del papiro Westcar. Si bien se supone que fue encontrado en una tumba del Valle de Gurna, es imposible rastrear este contexto, por lo cual se ha perdido irremediablemente una parte sustancial, la que refiere a su sentido de circulación escrita. Parte de lo que proponemos en este apartado es poder distinguir algunos vestigios de lo oral en el texto escrito, y si cabe alguna posibilidad que su origen sea no meramente el ámbito intelectual de lo escrito, sino de una instancia primaria de creación oral de los relatos del papiro Westcar. Lo que nos lleva a reflexionar sobre un ámbito de circulación y quizá de representación.
} 
Daumas (1972, pp. 393-394) con una gran habilidad imaginativa, la describió como una literatura "mas espontánea"446, un público palatino de las diferentes cortes provinciales, el cual gozaba de que le cantasen las emociones que ellos sentían. Haciendo una alusión al papiro Westcar, supone que era aquella misma corte la que también disfrutaba de escuchar las historias destinadas a distraer al faraón. Para el autor, estos relatos "eran narrados por cuentistas en la corte, o quizá también en ciertos círculos de auditores más humildes, en las encrucijadas de la capital o de las poblaciones de cierta importancia” (Daumas 1972, p. 394).

Daumas plantea aquí una idea que luego se desarrolló entre los investigadores, la de una posible representación teatral de los relatos, lo que no deja de ser una cuestión controvertida. Tomado de la tradición clásica, el concepto performance sugiere una teatralización de los textos escritos, de ahí algunas formas de su escritura: la rima, la repetición o la escenificación ${ }^{447}$.

La performance es un aspecto trascendental de la literatura del Reino Medio egipcio. En ella se incluyen escritos dramáticos y canciones, y se desarrolló en forma de mitos y diálogos, pero no se hace presente el drama como lo conoce la tradición occidental (Parkinson 1991, p. 27). De todos modos, según Parkinson (1991, p. 27) la performance no es únicamente un punto de la literatura, sino también de otros tipos de textos como los himnos y los elogios, que quizá fueron "cantados" o "recitados". Algunos pasajes en tumbas privadas llevan a sugerir dicha posibilidad"48.

En el Egipto, hasta el momento, no se han encontrado estructuras arquitectónicas que permitieran algún tipo de teatralización, como por ejemplo sí ha distinguido la cultura de la Grecia clásica. Tampoco se hallaron representaciones pictóricas en templos y tumbas de reyes o nobles, que así lo sugieran ${ }^{449}$. Es decir, que una posible teatralización se desprende únicamente de los textos literarios.

\footnotetext{
446 Daumas (1972, p. 393) plantea que los textos firmados por reconocidos escribas que se hacían eco de un auditorio selecto, refinado, pretencioso y pedante, a diferencia de aquellos más espontáneos.

${ }^{447}$ Un trabajo que trata esta problemática en Gillam (2009).

${ }^{448}$ Un ejemplo es una tumba de la dinastía X del nomarca Khety II de Asyut, su autobiografía no se ajusta a los estándares conocidos y está escrita en tercera persona "El fue" (Parkinson 1991, p. 27).

449 Estamos pensando en formas teatrales, pues estarán quienes dirán que por ejemplo la procesión que acompaña al muerto bien representadas en las tumbas del Valle de los Nobles.
} 


\section{A modo de cierre}

La estructura narrativa tripartita -presentación, acto mágico, retribución-es exclusiva para los cuatro relatos del papiro Westcar. Esta estructura permite definir tres cuestiones fundamentales. En primer lugar, que existe una unidad, es decir son una única composición literaria. En segundo lugar, los rasgos de repetición sugieren que los relatos pudieron formar parte de una cultura oral, quizá circularon con anterioridad al momento en que fueron escritos durante el Reino Medio. En tercer lugar, puede referirse una posible representación teatral de los relatos.

Las tres unidades narrativas dan cuenta de un modo de estructurar lo literario. Lo ficcional toma forma y se acomoda a ciertas temáticas, para luego llenarse de contenido durante el relato. La ficción sigue siendo el rasgo predominante. Dentro de ella algunos investigadores han querido destacar que lo maravilloso es el elemento clave, pero no es el único. En el capítulo $V$ analizábamos que uno de los rasgos que se destaca en el papiro Westcar es el modo en que se acerca al pasado. El relato del recuerdo es un rasgo presente en otras obras literarias del Reino Medio egipcio, en las cuales lo maravilloso necesariamente no predomina en ellas.

El problema ha sido estipular una única categoría a las obras literarias. Definir en ellas un género literario que diera cuenta de sus rasgos básicos y así poder diferenciarla de otros géneros y otras obras no literarias. Los relatos del papiro Westcar han sido mayormente caratulados como märchen (cuento de hadas) o cuentos. La dificultad no radica en el intento de categorizarlo, de hecho somos consientes que hay rasgos propios de lo literario. Hemos insistido en destacar que la narrativa ficcional los convierte en una obra literaria. Pero no se restringen a un único modo de narrar y presentan formas narrativas que no necesariamente son literarias. De ahí la dificultad de definirlos por un único género literario. En los relatos del papiro Westcar se presenta el mito como parte de su narrativa, simbología y argumento, haciendo de ella una narración mítica-literaria. 


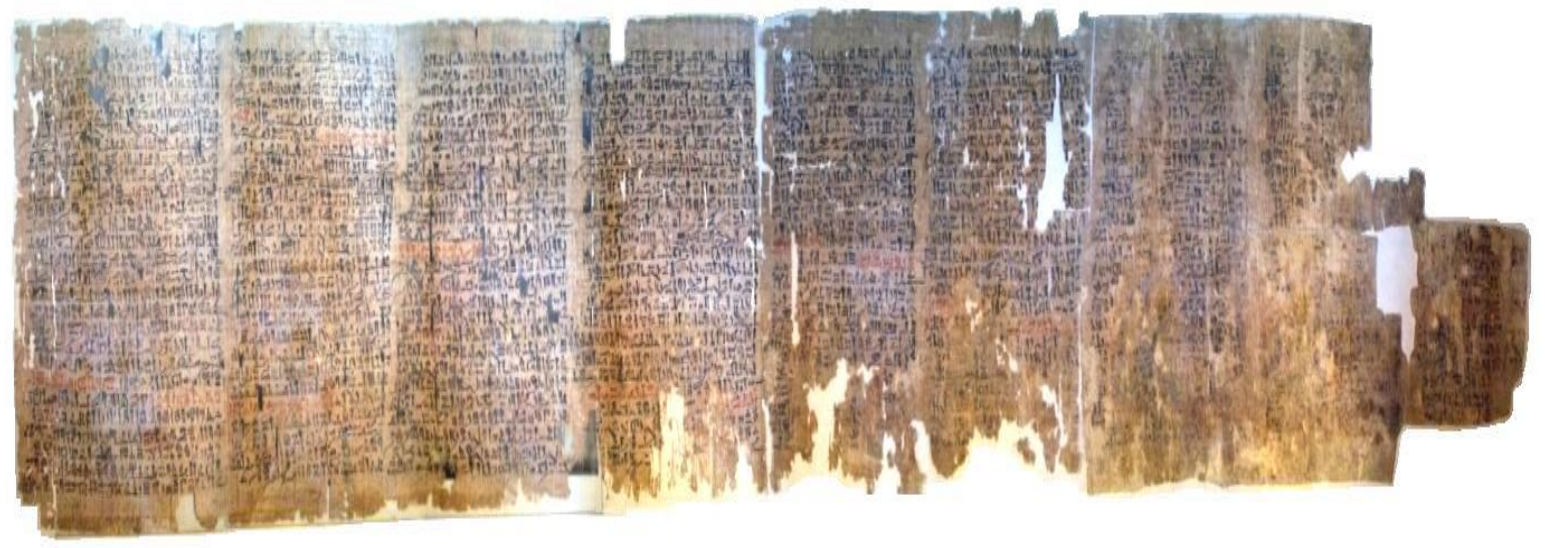

IMAGEN XV. Recto del papiro Westcar (la fotografia es nuestra) 
Reflexiones finales 
Nos propusimos poder establecer las especificidades que en los dos últimos relatos del papiro Westcar acreditan una forma de pensar, conceptuar y crear el mundo según los egipcios. No la totalidad de la sociedad egipcia, pero al menos sí aquella que tuvo el acceso, el privilegio y la exclusividad del uso de la expresión escrita. Esta vez, la búsqueda de lo social, lo cultural y lo mítico no se inició a partir de la indagación de textos escritos en templos o pirámides, un campo más explorado dentro de la tradición egiptológica. Elegimos una fuente literaria porque, desde un principio, confiamos en que textos literarios, como los del papiro Westcar, podían decirnos mucho al respecto. Que fuera literaria no suponía que no fuera política y cultural. Asumimos que en ella se integraban diferentes modos de expresión de lo político, lo cultural, lo religioso, lo literario y lo mítico.

Comprendimos que los textos literarios asumen una funcionalidad en el Egipto del Reino Medio. Uso que se encuentra intrínsecamente vinculado con los procesos políticos, sociales e ideológicos que formaron parte del periodo. Los relatos del papiro Westcar se hallan insertos dentro de este marco histórico que los elabora e interpreta. Un contexto que nos permite comprender las intenciones de la palabra escritura, asociada al poder y al discurso mítico.

Los dos últimos relatos del papiro Westcar- al igual que lo hacen la mayoría de los relatos literarios contemporáneos a él- son parte de una estrategia de Estado. Una creación de un grupo de hombres, cercanos a la corte del rey o integrantes de la corte del rey, que encontraron una novedosa forma de expresarse. El relato de ficción aparece así en la escena de la cultura egipcia. Los textos literarios construyeron un modo de acercarse al pasado que es exclusivo en ellos. Los acontecimientos de épocas anteriores eran narrados como "algo que ocurrirâ", aquello que le puede suceder a la sociedad si no se cumplen las normas del orden, de lo natural. Cada obra literaria concebía lo que era correcto y lo que no lo era, y algunas de ellas daban soluciones a los conflictos ficcionalizados.

En este marco de la palabra ficcionalizada, los investigadores detectaron que lo que se narraba era paralelo, reflejo o "crónica" de los acontecimientos políticos anteriores al Reino Medio, el Primer Periodo Intermedio. Los análisis trazaban paralelismos entre el texto literario y el acontecimiento, como si el texto creara una verdad, una verdad histórica de lo sucedido. Ésto les permitía a los historiadores 
encontrar la clave de los procesos políticos y sociales. Contrariamente pensamos que la literatura dio apertura a una forma de reflexionar sobre los acontecimientos, y no ser una narración del acontecimiento. En la narración del pasado se puso en escena, y como el marco de referencia para expresarse era el pasado, lo conocido, la historia de lo vivido, era natural que se recurriera a situaciones, nombres, lugares que formaban parte del mundo egipcio. Pero, no necesariamente, se traducía como una verdad de lo acontecido en la obra literaria.

El texto literario fue una herramienta de reflexión. Pensamos que los dos últimos relatos del papiro Westcar, junto a otras obras literarias, fueron una forma de pensar el pasado, y no fueron un espejo de una realidad acontecida. Los dos últimos relatos del papiro Westcar interpretaron el pasado. La narración literaria se trasforma, de este modo, en un recuerdo sobre el pasado. Como todo recuerdo, se halla enmarcado en el presente. El hoy estimula y restringe el recuerdo. Se circunscribe el recuerdo en el mismo transcurso de reflexión sobre el pasado. En el proceso de la memoria el pasado no existe por sí mismo, sino que se crea una imagen sobre él. Se simboliza, se modifica, se selecciona lo que quiere ser recordado.

Los dos últimos relatos del papiro Westcar son el recuerdo literario de la transición de la dinastía IV a la dinastía V. Hemos insistido que no son la narración de los acontecimientos que giraron alrededor del traspaso de una hacia otra dinastía. Sin embargo, como todo recuerdo, está inspirado en una realidad. Sobre el pasado se reflexiona y se elige lo que el recuerdo quiere transformar como realidad. En los dos últimos relatos del papiro Westcar lo pensado y lo recordado literariamente adquiere una dimensión mítica.

El recuerdo de un origen en la cosmogonía egipcia refiere siempre a un discurso mítico. El origen es el mito de lo creado. Lo creado es la realidad que se reactualiza en la narración. Concluimos que los dos últimos relatos del papiro Westcar son la narración literaria del recuerdo del mito de origen de la dinastía V. En este recuerdo literario del pasado el mito es el marco de referencia. El mito es el medio por el cual se adquiere la realidad. El recuerdo elige algunos aspectos de lo pasado que luego se narran míticamente. En esa narración mítica es cuando, para los egipcios, el pasado se hace realidad. Que no es lo mismo que sean reflejo de una realidad histórica, sino que son una realidad construida, un pasado 
míticamente creado. No es ésta una realidad única e inmodificable, sino que es una realidad que se transforma y adquiere particularidades según el marco social y político que está influenciando sobre él.

El recuerdo del mito de origen de la dinastía V nos permite explicar qué fue lo que los egipcios pensaron acerca de ese pasado. Así, sabemos que se quiso mitificar que los tres primeros faraones de la dinastía V, Userkaf, Sahura y Neferikara Kakai fueron trillizos. Los hermanos tuvieron como padre al dios Ra y como madre a la mujer de un sacerdote llamada Reddjedet. Se recuerda que ellos nacieron el día 15 del primer mes de la estación de prt y que el parto fue exitoso gracias a la participación de las diosas Isis, Neftis, Hequet y Meshkeneh, y el dios Khnum.

A través de la identificación de las similitudes narrativas con el relato del origen del rey de la reina Hatshepsut, Amenofis III y Ramsés II, es que establecimos que lo que se narra en el papiro Westcar es el relato de un mito. Se ha destacado en el análisis no únicamente las similitudes entre los mitos, aquellas que refieren a la consagración de un nuevo monarca por ser hijo de un dios. Sino, también, las diferencias dadas entre ellos. Ellas dan cuenta que el mito es una construcción compleja, que no siempre se propone la repetición de la formas, por el contrario se adapta a las necesidades e inquietudes que llevan a la formación de ese mito.

Las principales disidencias entre las teogamias del Reino Nuevo y el mito en el papiro Westcar se encuentra en el contexto en que se narra el mito y la forma en que éste se construye literariamente. En primer lugar, solamente en el caso de la reina Hatshepsut puede afirmarse que se trata de un mito narrado en un templo funerario de un faraón. Mientras que en el caso de Amenofis III, el relato se encuentra en el templo de Luxor, en una capilla dedicada al faraón. Y en el tercer caso, Ramsés II, si bien fue representado en su templo funerario, lo hizo en una capilla subsidiaria destinada a destacar a la figura materna y no su origen divino. En cambio, el mito narrado en el papiro Westcar, nos ha planteado la dificultad de establecer los espacios de circulación, acceso y visibilidad del relato. En segundo lugar, se han establecido diferencias entre las narraciones, siendo la principal que el mito en el papiro Westcar es una narración a futuro. La predicción de Djedi se inicia con una concepción ya consumada, por ende ésta no es narrada. La narración a 
futuro es, justamente, lo que otorga un rasgo de ficcionalización al texto. Esta característica es esencial en los textos literarios, en ellos el mundo narrado es ficcionalizado, y de ahí su diferencia con el mito. Pero la diferencia se encuentra en el modo de narrar y no en lo que quiere ser transmitido, el mensaje. Decimos, que los dos últimos relatos del papiro Westcar son el relato literario del mito de origen del rey, que al igual que los mitos del Reino Nuevo, el mensaje es legitimar en el gobierno a un monarca por ser hijo de un dios.

También, el relato mítico encuentra otras aristas que hacen del texto literario un texto sagrado. Una diversidad de símbolos míticos giran en torno a la narración del nacimiento de los trillizos. El relato literario se relaciona con los modos de percibir míticamente la realidad. De este modo, el relato asemeja a los recién nacidos con las figuras divinas. Ellos al igual que los dioses tienen cuerpos de oro y ojos de lapislázuli. La diosa Meshkeneh, quien proclama a los trillizos futuros reyes, trae consigo aparejada la simbología mágica otorgada a los nacimientos durante el Reino Medio y el Reino Nuevo.

Este recuerdo mítico del origen de la dinastía $\mathrm{V}$, es parte de un modo de interpretar el pasado que se diferencia con el recuerdo expresado en otros textos. En Profecia de Neferty, Admoniciones de Ipuwer o Lamentaciones de Khakheperresenebu el pasado literario recuerda una situación de crisis política que debe ser superada. La salida política al caos se encuentra en el presente, en la dinastía XII que se instituye como la garante del orden sobre las Dos Tierras. El pasado codificado posee un fin político, que no toma el mismo sentido en el papiro Westcar. En él, se transmite un pasado modelo: el de la transición política hacia una monarquía hija de Ra.

El modelo constelativo monárquico fue el resultado de diferentes procesos políticos que se detectan a partir del Reino Antiguo, pero que parecen consagrarse definitivamente con la dinastía $\mathrm{V}$ y la institución definitiva del quinto título real, el de $s 3 r^{r}$. De todos modos, en lo que hemos insistido en nuestro trabajo, es que más allá de las discusiones historiográficas que giran en torno a la solarización de la realeza, hay que prestar atención a la memoria cultural egipcia. Ella nos trasmite que la dinastía solar, hija del dios $\mathrm{Ra}$, fue la dinastía V. Aquí los egipcios visualizaron un quiebre dentro de la transición monárquica. Y este recuerdo se estableció siguiendo los modos propios de la construcción mítica del origen. Es por ello que podemos 
afirmar que la memoria cultural transmitida en el papiro Westcar recuerda el origen de la dinastía V como una dinastía "hija de Ra". Este recuerdo, consideramos, que se formalizó en el Reino Medio, como un mecanismo de establecer lazos políticos que proponen continuar aquello que se instauró en el pasado.

Es por ello que hemos comparado el papiro Westcar con Listas Reales, en las cuales se plantea una continuidad de hechos que se legitiman por ser la repetición del acontecimiento mítico. Pero, a diferencia de ellas, en el papiro Westcar, el pasado se instaura como un anuncio a futuro. La memoria futura es un modo exclusivo del recuerdo en el papiro Westcar. La profecía anunciada por Djedi, es el pasado mítico narrado.

Los textos literarios en el papiro Westcar conforman una unidad narrativa. Esta unidad narrativa fue desestimada por los investigadores, que no concibieron ningún sentido de unidad entre los relatos. Sin embargo, a través del establecimiento de estructuras mínimas - presentación, acto mágico y retribución- hemos logrado establecer un mismo modo de narrar en ellos. Demostramos que el vínculo del anexo con el cuarto relato representa la materialización de la profecía de Djedi.

Además, hemos discutido sobre categorías que se le han adjudicado al papiro Westcar, y que han sido reproducidas por los investigadores, sin una profunda discusión. Hacemos referencia al concepto de género literario. El mayor inconveniente que hemos establecido para el uso de este término, es que la asunción de un género literario para el papiro Westcar, destierra lo que hemos analizado aquí: que los textos son el entrecruzamiento de una diversidad de discursos- mítico, político y literario. Esta diversidad, a nuestro entender, responde a la multiplicidad de pensamiento que constituyó a la sociedad faraónica. Por ello, establecer un género literario para estos relatos, pareciera responder más a necesidades de la crítica literaria moderna, y limita el análisis.

Similar es lo que pudimos indagar acerca del establecimiento de autores a las obras. Lo que nos ha llevado a diferenciar entre el "autor" como creador único, consagrado y genio de la obra literario, frente a los sujetos que son miembros de una sociedad y están afectados a su época, y ponen por escrito o inventan relatos. La discusión se complejiza si tomamos en cuentas las unidades narrativas, pues ellas, también dan cuenta de que en el papiro Westcar subyace la influencia de una cultura 
oral. Pues, la repetición de estructuras es propia de una etapa en que la narración oral está siendo puesta por escrito. 
Apéndice de fuentes 


\section{Profecía de Neferty}

Comentario y argumento

El texto conocido como Profecía de Neferty o Cuento profético es un relato literario en el cual los protagonistas son el primer faraón de la dinastía IV Snefru y el mago (nd $\underline{d})$ Neferty, reconocido en la antigüedad por sus dotes en el habla, es quien le pronostica al rey los acontecimientos que padecerá Egipto próximamente. Semejante a lo que ocurre con los relatos del papiro Westcar, es el marco de la corte real lo que otorga el argumento al relato para que Snefru reclame la presencia de mago. En esta primera parte del texto, en la cual se contextualiza la escena y es el faraón en persona quien toma la pluma para escribir las palabras del sabio, se ha considerado la parte más narrativa del relato; mientras que lo que constituye propiamente la profecía las oraciones se acortan y adquieren forma de verso, asemejándose a un diálogo con estrofas que se repiten (Parkinson 1998, p. 131).

El relato es principalmente la descripción de una situación caótica, en la cual el orden natural garantizado por maat ha sido invertido, trastocado por un mundo gobernado por isfet, el caos. Para algunos historiadores esta narración es la descripción literal de los acontecimientos ocurridos durante el Primer Periodo Intermedio, donde se da constancia de un proceso histórico, es decir el relato es un reflejo de los acontecimientos (Barta 1974), en el cual el orden natural creado durante el Reino Antiguo sufrió una profunda crisis y transformación, y la unión de los Dos Tierras se consolidó nuevamente a partir de las luchas políticas encabezadas por la ciudad sureña de Tebas y Heracleópolis en el Bajo Egipto. De ahí, la descripción que realiza el relato sobre la llegada de un "nuevo rey salvador" proveniente del sur quién será el que logre llevar adelante el proceso definitivo de la unificación estatal, este personaje literario de nombre Ameny sería un seudónimo de la figura histórica Amenemhat I.

De este modo Profecía de Neferty reconstruiría literariamente el proceso político mediante el cual la dinastía XII tebana concluyó el proceso de reunificación de Estado egipcio y que dio comienzo a una nueva etapa en la historia egipcia, la que los historiadores identifican con el Reino Medio. De todos modos, son recurrentes las advertencias a través de las cuales se hacen referencias a las 
dificultades que presenta realizar una lectura literal de relato, que deja de lado las interpretaciones simbólicas y políticas que contextualmente dan origen al relato. Esta idea es transferible a los relatos literarios en general, sobre los cuales se han producido las discusiones que versan sobre realidad novelada o reflejo de la realidad.

En una interpretación mítico-política Assmann (1995b; 2005 [1996], pp. 133139) pone en consideración que Profecía de Neferty se ajusta a los sentimientos egipcios con relación al Primer Periodo Intermedio. Parkinson (1998, p. 131) destaca lo reflexivo del discurso de Neferty, relacionándose con las enseñanzas, de hecho considera las lamentaciones como uno de los géneros más sobresalientes de a literatura del Reino Medio egipcio. Desde esta apreciación adquiere importancia lo que destaca Assmann (2005 [1996], pp. 137-139) acerca de interpretar la Profecía en clave de un "recuerdo codificado", la necesidad de perpetuar en la memoria egipcia el recuerdo del Primer Periodo Intermedio como una época de "un mundo al revés", en tanto que Amenemhat I en la figura del Ameny literario será el hombre nacido en el sur que logrará centralizar en su personas las fuerzas que controlen el caos, es decir garantizar el curso legítimo de maat. La reelaboración del pasado se realiza en términos de dualidad: orden versus caos, anarquía versus autoridad, extranjeros versus egipcios (Parkinson 1998, p. 132). De esto modo, la construcción literaria de una época de Egipto sin monarca no sólo ayudaría a comprender que significaría para la sociedad egipcia el anuncio de la llegada de un nuevo del rey, sino que coloca al fundador de la dinastía XII, con Amenemhat I como figura central, en tanto salvadora y única garante del orden. En otras palabras, tras la desintegración del orden, será el rey quien logre regenerar el país del caos (Parkinson 1998, p. 133), como la (re)creación del mundo por los dioses en el origen del Universo según lo comprende la cosmogonía egipcia. En Profecía de Neferty la restauración de maat no significa la inversión de un orden existente, sino el retorno al orden (Assmann 1997, p. 54).

Un sentido político para el relato había sido ya destacado por Simpson (LAE, p. 7) al considerarlo dentro de una literatura de propaganda o pesimista, y junto a las Instrucciones reales y los Himnos en honor al faraón Sesostris III, son composiciones que describen los comienzos de la dinastía XII. 
De un modo similar, como ocurre con el cuarto relato del papiro Westcar, el presente literario se ubica en un pasado remoto para el autor de la obra, y la codificación del recuerdo de un pasado trastocado se produce en forma de anuncio, lo que ocurrirá en un futuro. Si bien literariamente será el rey que vendrá -Ameny o Amenemhat I- el que pondrá orden sobre el mundo invertido, cuando lo más probable que el texto haya sido escrito contemporáneamente o luego del reinado del primer faraón de la dinastía XII.

El relato se ha preservado en diversas copias fragmentadas en dos tablillas de madera de la dinastía XVIII, una conservada por el Museo del Cairo con el número de inventario 24224; y la tablilla del Museo Británico 5647. Mientras que el papiro San Petersburgo 1116B es el manuscrito que contiene la versión más extendida que se conoce del relato, datada su confección durante la dinastía XVIII, para el reinado de Tutmosis IV, de todos modos el relato original sería de una época anterior, aproximadamente hacia el año 2000 a.C. El texto escrito en hierático con un total de 71 líneas de texto, de las cuales 65 son horizontales y 6 son verticales, con una medida aproximada de alto de 156 centímetros (Lefebvre 2003 [1982], p. 112). El papiro actualmente está custodiado por el Museo del Hermitage de San Petersburgo en la ciudad de Moscú, Rusia. Por último en tres ostraca de época ramésida; el ostracón de Liverpool 13624; ostracón Petrie 38 y el ostracón del Instituto Francés de Arqueología Oriental, en la ciudad egipcia de El Cairo, procedente de Deir-el Medina (Lefebvre 1982, pp. 112-113).

\section{Publicaciones}

Araújo, E. 2000. Escrito para a Eternidade. Impresa Oficial do Estado, Brasilia. pp. 194-200.

Erman, A. 1927. The literature of the Ancient Egyptians: poems, narratives, and manuals of instruction, from the third and second millennia B.C. Methuen, Londres, pp. 151-157.

Gardiner, A.H. 1914. "New Literary Works from Ancient Egypt". JEA 1, pp. 100106. 
Goedicke, H. 1977. The Protocol of Neferyt (The Prophecy of Neferti). Johns Hopkins University Press, Baltimore.

Golénischeff, W. 1916. Les papirus hiératiques n 1115, 1116 A y B de l'Ermitage impérial à Saint Pétersbourg. San Petesburgo.

Helck, W. 1970. Die Prophezeiung des Nfr.tj. Otto Harrassowitz, Wiesbaden, pp. 3447.

Parkinson, R.B. 1998. The Tale of Sinuhe and Other Ancient Egyptian Poems, 1940-1640 BC. Oxford University Press, Oxford, pp. 131-143.

Quirke, S. 2004. Egyptian literature 1800 BC, questions and readings. Golden House Publications, Londres, pp. 135-139.

Lichtheim, M. 1973. Ancient Egyptian Literature. A Book of Readings. The Old and Middle Kingdoms. Vol 1. University of California Press, California, pp. 139-145.

López, J. 2005. Cuentos y Fábulas del Antiguo Egipto. Editorial Trotta, Barcelona, pp. 24-39.

\section{Admoniciones de Ipuwer}

Comentario y argumento

El texto conocido como Admoniciones de Ipuwer, Lamentaciones de Ipuwer o Diálogo de Ipuwer y el Señor de Todo, son las palabras mediante las cuales el sabio Ipuwer describe un Egipto donde el caos está omnipresente. Al igual que Profecía de Neferty, este relato se lo cataloga comúnmente dentro de los textos literarios de las lamentaciones o pesimista, en los cuales según Simpson ( $L A E$, p. 8) al igual que Profecia de Neferty se describe un mundo en desorden.

A partir del análisis del contenido del texto se han dado algunas discusiones que pretenden encontrar en él la descripción de los procesos políticos que afectaron a Egipto durante el Primer Periodo Intermedio, lo que también vendría a afirmar una datación de producción contemporánea a dicha época (Gardiner 1909, pp. 1-2). Una postura contraria, es la que data la producción del texto para el Segundo Periodo Intermedio egipcio, por ende los acontecimientos que relata se ajustan a los 
sucesos ocurridos a partir de la invasión de los hicsos (Van Seters 1964). Mientras que para Lichtheim (1973, pp. 149-150) Admoniciones de Ipuwer es parte de las obras de la literatura clásica del Reino Medio egipcio, pero no es más que una composición sin trasfondo histórico, producto de la imaginación.

Por otro lado Assmann (1995; 2005 [1996], pp. 133-139) ha interpretado el relato dentro de aquellos textos que recuerdan al Primer Periodo Intermedio como una etapa crítica egipcia, un recuerdo que debe ser sostenido y estabilizado como una época desdichada en tanto que posiciona a la dinastía XII como la única garante de que no vuelvan a repetirse dichos procesos. En el caso de Admoniciones de Ipuwer es en la retórica literaria del pasado: el recuerdo alecciona las acciones del presente.

El sentido de un mundo dado vuelta ha sido comprendido como una búsqueda personal de reorientar los valores perdidos socialmente, como ocurre también en Diálogo del Hombre con su Ba y Lamentaciones de Khakheperresenebu, donde se expresa una profunda angustia por la pérdida del orden. Mientras que también se ha sugerido que Admoniciones de Ipuwer es una culpabilización hacia el dios o el faraón por los procesos que la sociedad egipcia está atravesando; de hecho para Parkinson (1998, p. 169) el final del relato que es la parte más narrativa de texto -si bien está perdido- da cuenta de una disputa en la cual el Señor responde por los motivos de una imperfecta creación del mundo, una disputa que traza semejanzas con Diálogo del Hombre con su Ba. Por otro lado se ha interpretado que el relato es la demostración de una "revolución social" que se produjo en Egipto durante el Primer Periodo Intermedio (Castañeda Reyes 2003, pp. 51-146 y 199-224).

El texto Admoniciones de Ipuwer se conserva en una copia única escrita en hierático en el recto del Papiro Leiden 344, actualmente custodiado por el Rijksmuseum van Oudheden (Museo Nacional de Antigüedades) en la ciudad holandesa de Leiden, y uno de los fragmentos del manuscrito se expone dentro de las colecciones del museo para el público en general. Preservado en diecisiete piezas sus medidas actuales son de 378 centímetros de longitud y 18 centímetros de altura. El texto está mayormente escrito en verso y posee 236 líneas, algunas de ellas no pueden reconstruirse completamente. 


\section{Publicaciones}

Donadoni, S. 1959. Storia della Letteratura Egiziana Antica. Nuova Accademia Editrice. Milán, pp. 70-79.

Enmarch, R. 2005. The Dialogue of Ipuwer and the Lord of All. Griffith Institute Publications. Alden Press. Oxford.

Erman, A. 1927. The literature of the Ancient Egyptians: poems, narratives, and manuals of instruction, from the third and second millennia B.C. Methuen, Londres, pp. 92-108.

Faulkner, R. 1964 "Notes on the Admonitions of an Egyptian sage". JEA 50, pp. 24-36.

Faulkner, R. 1973. “The Admonitions of an Ancient Egyptian Sage”. En Simpson, W. (ed.), LAE, Londres, New Haven y Londres, pp. 210-229.

Gardiner, A. 1909. The Admonitions of an Ancient Egyptian Sage, from a Hieratic Papyrus in Leiden (Pap. Leiden 344 Recto). J. C. Hinrichs, Leipzig.

Helck, W. 1995. Die “Admonitions” Pap. Leiden I 344 recto. Kleine Ägyptische Texte, Harassowitz, Wiesbaden.

Lichtheim, M. 1973. Ancient Egyptian Literature. A Book of Readings. The Old and Middle Kingdoms. Vol 1. University of California Press, California, pp. 149-163.

Parkinson, R. B. 1998. The Tale of Sinube and Other Ancient Egyptian Poems, 1940-1640 BC.). Oxford University Press, Oxford, pp. 166-199.

Quirke, S. 2004. Egyptian literature 1800 BC, questions and readings. Golden House Publications, Egyptology 2, Londres, pp. 140-150.

Serrano Delgado, J. M. 1993. Textos para la Historia Antigua de Egipto. Ediciones Cátedra, Madrid, pp. 80-84.

\section{Lamentaciones de Khakheperresenebu}

Comentarios y argumento

El texto conocido como Lamentaciones de Khakheperresenebu o Colección de palabras de Khakheperresenebu no ha estado en el foco de atención de los egiptólogos, 
de hecho no es común encontrar su traducción en las antologías. En parte, este desinterés puede relacionarse por lo complejo del discurso de Khakheperresenebu, una de las obras más originales de la literatura egipcia y que presenta una gran dificultad de lectura y traducción, tanto por los errores cometidos por el escriba, como por una constante utilización de metáforas que complejiza su comprensión (Chappaz 1979, p. 4). Por otro lado, porque la obra pone en tela de juicio tópicos que eran aceptados por el conjunto de la sociedad (Vernus 1995, \ 1).

Lamentaciones de Khakheperresenebu tiene la particularidad de inciarse con un exordio ${ }^{450}$. Khakheperresenebu, al igual que a Neferty, lo conocemos a través de su mención en el Papiro Chester Beatty IV ${ }^{451}$; y por su mención entre los personajes en Lista de Sabios que se ha encontrado en Saqqara452. Este sabio egipcio que posiblemente vivió a mediados de la dinastía XII ${ }^{453}$, está atravesado por una profunda angustia, pues en las palabras comunes, ya dichas en otros tiempos y por otros hombres como él, no encuentra que expresen los conflictos que se están viviendo en Egipto, del mismo modo que se exponen en Admoniciones de Ipuwer y Profecía de Neferty. En este sentido para Chappaz (1979, p. 10) Lamentaciones de Khakheperresenebu no aporta ningún tipo de originalidad, lo que para Coletta (2009, p. 6) es muestra de los procesos de autorreferencialidad e intertextualidad propios de estos textos.

De todos modos, si bien el tema que resalta la antagónica relación entre orden-caos, Khakheperresenebu se coloca como un hombre reflexivo ante la situación, es el primer "escritor atormentado" de la historia de la literatura (Assmann 1997, p. 70), la originalidad de sus reflexiones son la matriz del problema:

\footnotetext{
${ }^{450}$ En el exordio puede leerse lo siguiente: "La recolección de palabras, la reunión de versos, la búsqueda de discursos con corazón inquisitivo, hecha por el sacerdote uab de Heliópolis, el hijo de Seni Khakheperreseneb, llamado Ankhu. El dice:...” (Coletta 2009, p. 7).

${ }^{451}$ Gardiner (1935, plts. 19).

452 Yoyotte (1952, pp. 67-72).

${ }^{453}$ Las discusiones sobre la datación giran alrededor de que el nombre de Khakheperresenebu es parte del nombre de coronación del faraón Sesostris II, según se atestigua en Lista Real de Abidos y en Listas Real de Saqqara: $h^{\complement}$ hpr $r^{\complement}$ Khakheperra, con la añadidura de la expresión de deseos de senebu de buena salud, lo que se comprendería como "Que el rey Khakheperra tenga salud". Además de la designación del apodo Ankhu "el que vive" (Vernus 1995, \2; Coletta 2008). Esta relación ha impulsado a algunos investigadores a estimar que Khakheperresenbu nació durante el reinado de Sesostris II, por lo que el texto es contemporáneo a este rey y a Sesostris III (Urrela Quesada 2008, p. 208).
} 
no encuentra en las palabras ya pronunciadas formulaciones que se adecuen a los problemas por los cuales la sociedad egipcia está atravesando, la tradición no le otorga a Khakheperresenebu una solución para pensar el presente, como también lo refiere Coletta (2009, p. 6). Su originalidad reside en la licencia que se permite Khakheperresenebu en reflexionar sobre los modos en que tradicionalmente se produjeron los textos. Un dilema que para Kadish (1973, p. 88) no se resuelve, la verdadera angustia de Khakheperresenebu es haber captado el centro del problema, pero no puede resolverlo con la formulación de nuevos modelos de expresión.

La tensión en el texto discurre entre la imposibilidad de que la tradición le otorgue a Khakheperresenebu una explicación del presente, siendo que de todos modos es su deber encontrar en el pasado las respuestas para el presente. Pues, para Vernus (1995, \ 5 y 6) la tradición egipcia mantiene reglas de inmutabiliad, pero una tradición que Khakheperresenebu rechaza por no esclarecer los acontecimientos que está viviendo. Lo mismo que sugiere acerca de Enseñanza de Ptahotep; Vernus (1995 \$ 6) retomando a Posener, considera que el objetivo mismo de las enseñanzas es el de rescatar y transmitir la tradición. Es por ello que se expresa una nueva forma de percibir el mundo, que está fundada "en la idea de que el presente es irreductible al pasado" (Vernus 1995, $\int 7$ ).

Lamentaciones de Khakheperresenebu se preserva en dos versiones. La primera, en la tablilla EA 5645, de origen desconocido, que se conserva en el British Museum. La segunda, es un ostracón del cual sólo se preservan las fotografías tomadas por Gardiner, y que en la actualidad se guardan en el Griffith Institute de Oxford.

\section{Publicaciones:}

Erman, A. 1927. The literature of the Ancient Egyptians: poems, narratives, and manuals of instruction, from the third and second millennia B.C. Methuen, Londres. pp. 108-110. Lichtheim, M. 1973. Ancient Egyptian Literature: A Book of Readings. Vol. I: The Old and Middle Kingdom. University of California Press. Berkeley. pp. 145-149. 
Parkinson, R. B. 1998. The Tale of Sinube and Other Ancient Egyptian Poems, 1940-1640 BC.). Oxford University Press, Oxford, pp. 166-199.

Quirke, S. 2004. Egyptian Literature 1800BC. Questions and readings. Golden House Publications, Londres, pp. 173-175

Simpson, W. K. 1973. "The Lamentations of Khakheperre-sonbe”. En W. K. Simpson (Ed.). LAE, New Haven and London. Yale University Press, Londres. pp. $230-233$. 
Cronología 

Paleolítico Inferior
c. $700 / 500000-250000$ B.P.
Paleolítico Medio
c. $25000-70000$ B.P.
Grupo de Transición
c. $70000-50000$ B.P.
Paleolítico Superior
c. $50000-24000$ B.P.
Paleolítico Tardío
c. $24000-10000$ B.P.
Epipaleolítico
c. 10000-7000 B.P.

\section{PERIODO NEOLÍTCO SAHARIANO \\ c. $8800-4700$ a.C.}

$\begin{array}{ll}\text { Neolítico Temprano } & \text { c. } 8800-6800 \text { a.C. } \\ \text { Neolítico Medio } & \text { c. } 6600-5100 \text { a.C. } \\ \text { Neolítico Tardío } & \text { c. } 5100-4700 \text { a.C. }\end{array}$

\section{PERIODO PREDINÁSTICO c. 5300-3000 a.C.}

Bajo Egipto 456

Neolítico

c. $5300-4000$ a.C.

(o c. 6400-5200 B.P.)

Complejo cultural de Maadi

c. 4000-3200 a.C.

Alto Egipto

Periodo Badariense ${ }^{457}$

c. $4400-4000$ a.C.

Periodo Amraciense (Nagada I)

c. 4000-3500 a.C.

Periodo Gerzense (Nagada II)

c. $3500-3200$ a.C.

Después de c. 3200 a.C. la misma secuencia cronológica se aplica a todo Egipto

Nagada III/ "Dinastía 0" c. 3200-3000 a.C.

\footnotetext{
${ }^{454}$ La cronología fue tomada de Shaw, I. 2007 (2000). Historia del Antiguo Egipto Oxford. La esfera de los libros, Madrid. pp. 623-628.

455 Las fechas del Período Paleolítico se basan principalmente en fechas de Carbono 14 sin calibrar y, por lo tanto, se ofrecen como años de radiocarbono B.P. ("antes de nuestra era" en inglés) y no como fechas a.C.; para todo el Neolítico las fechas se citan tanto como B.P. como a.C. Todas las demás fechas son a.C. o d.C.

${ }^{456}$ El término "Bajo Egipto" se refiere al delta, Fayum y una zona que se extiende hasta cien kilómetros al sur de El Cairo.

${ }^{457}$ El Badariense pudo haber sido una cultura restringida a la región de Badari, cercana a Asyut en el Egipto Medio, más que una fase cronológica para todo el sur de Egipto.
} 


\section{Dinastia I}

c. $3000-2890$

Aha

Djer

Djet

Den

Reina Merneith

Anedjib

Semerkhet

Qaa

\section{Dinastía II}

c. 2890-2686 a.C.

Hetepsekhemwy

Raneb

Nynetjer

Weneg

Sened

Peribsen

Khasekhemuy

\section{REINO ANTIGUO}

\section{6-2125 a.C.}

Dinastía III

2686-2613

Nebka

2686-2667

Socer (Netjerikhet)

2667-2648

Sekhemkhet

2648-2640

Khaba

2640-2637

Sanakht?

Huni

2637-2613

Dinastía IV

Esnefru

2613-2589

Khufu (Keops)

2589-2566

Djedefra (Radjedef)

2566-2558

Khafra (Kefren)

2558-2532

Menkaura (Micerino)

2532-2503

Shepseskaf

2503-2498

Dinastía V

2494-2345

Userkaf

2494-2487

Sahura

2487-2475

Neferirkara

2475-2455

Shepseskara

2455-2448

Raneferef

2448-2445

Nyuserra

2445-2421 
Mankauhor

2421-2414

Djedkara

Unas

2414-2375

2375-2345

Dinastía VI

2345-2181

Teti

2345-2323

Userkara [un usurpador]

2323-2321

Pepi I (Meryra)

2321-2287

Merenra

2287-2278

Pepi II (Neferkara)

2278-2184

Nitiqret

2184-2181

Dinastias VII y VIII

$2181-2160$

Numerosos reyes llamados Neferkara, probablemente imitando a Pepi II

\section{PRIMER PERIODO}

INTERMEDIO

Dinastias IX-X

2160-2025

(Heracleopolitana)

Khety (Meryibra)

Khety (Naekaura)

Khety (Wahkara)

Merykara

Dinastía XI (sólo en Tebas)

2125-2055

[Mentuhotep I (Tepy-a: “el Antepasado I”)]

Intef (Sehertawy)

2160-2055 a.C.

Intef II (Wahankh)

2125-2112

Intef III (Nakhtnebtepnefer)

2112-2063

2063-2055

\section{REINO MEDIO}

2055-1650 a.C.

Dinastía XI (en todo Egipto)

2055-1985

Mentuhotep II (Nebhepetra)

2055-2004

Mentuhotep III (Sankhkara)

2004-1992

Mentuhotep IV (Nebtawyra)

1992-1985

Dinastía XII

1985-1773

Amenemhat I (Sehetepibra)

1985-1956

Senusret I (Kheperkara)

1956- 1911

Amenemhat II (Nubkaura)

1911-1877

Senusret II (Khakheperra)

$1877-1870$

Senusret III (Khakaura)

1870-1831

Amenemhat III (Nimaatra)

1831-1786 
Amenemhat IV (Maakherura)

Reina Sobekneferu (Sobekkara)

Dinastía XIII

Wegaf (Khutawyra)

Sobekhotep (Sekhemra-khutawy)

Iyhkernefert Neferhotep (Sankhtawy-sekemra)

Ameny-intef-amenemhat (Sankhibra)

Hor (Awibra)

Khendjer (Userkara)

Sobekhotep III (Sekhemra-sewadjtawy)

Neferhotep I (Khasekhemra)

Sahathor

Sobekhotep IV (Khaneferra)

Sobekhotep V

Ay (Merneferra)

Dinastía XIV

1773-1650

Soberanos menores, probablemente

Contemporáneos de la dinastía XIII o la

Dinastía XIV.
1786-1777

1777-1773

1773- después de 1650

\section{SEGUNDO PERIODO \\ 1650-1550 a.C. \\ INTERMEDIO}

Dinastia XV (Hicsos)

1650-1550

Salitis/Sekerher

Khyan (Seuserenra)

c. 1600

Apepi (Aauserra)

c. 1555

Khamudi

Dinastía XVI

Primeros soberanos tebanos,

Contemporáneos de la dinastía XV

Dinastía XVII

c. $1580-1550$

Rahotep

Sobekemsaf I

Intef VI (Sekhemra)

Intef VII (Nubkheperra)

Sobekemsaf II

Siamun (?)

Taa (Senakhtenra/Seqenenra)

c. 1560

Kamose (Wadjkheperra)

1555-1550 


\begin{tabular}{lc|}
\hline REINO NUEVO & $\mathbf{1 5 5 0 - 1 0 6 9}$ a.C. \\
\hline & \\
Dinastia XVIII & $1550-1295$ \\
Ahmose (Nebpehtyra) & $1550-1525$ \\
Amenhotep I (Djeserkara) & $1525-1504$ \\
Tutmosis I (Aakheperkara) & $1504-1492$ \\
Tutmosis II (Aakheperenra) & $1492-1479$ \\
Tutmosis III (Menkheperra) & $1479-1425$ \\
Reina Hatshepsut (Maatkara) & $1473-1458$ \\
Amenhotep II (Aakheperura) & $1427-1400$ \\
Tutmosis IV (Menkheperura) & $1400-1390$ \\
Amenhotep III (Nebmaatra) & $1390-1352$ \\
Amenhotep IV/Akhenaton (Neferkheperurawaenra) $1352-1336$ \\
Neferneferuaton (Esmenkhkara) & $1338-1336$ \\
Tutankamon (Nebkheperura) & $1336-1327$ \\
Ay (Kheperkheperura) & $1327-1323$ \\
Horemheb (Djeserkheperura) & $1323-1259$
\end{tabular}

\section{PERIODO RAMÉSIDA}

1295-1069 a.C.

Dinastía XIX

1295-1186

Ramsés I (Menpehtyra)

1295-1294

Seti I (Menmaatra)

1294-1279

Ramsés II (Usermaatra Setepenra)

1279-1213

Menrenptah (Baenra(

1213-1203

Amenmessu (Menmira)

1203-1200?

Seti II (Userkjeperura Setepenera)

1200-1194

Saptah (Akehnrasetepenra)

1194-1188

Reina Tausret (Sitrameritamun)

1188-1186

Dinastia XX

1186-1069

Sethnakht (Userkhaura Meryamun)

1186-1184

Ramsés III (Usermaatra Meryamun)

1184-1153

Ramsés IV (Heqamaatra Setepenamun)

1153-1147

Ramsés V (Usermaatra Sekheperenra)

1147-1143

Ramsés VI (Nebmaatra Meryamun)

1143-1136

Ramsés VII (Usermaatra Setepenra) Meryamun) 1136-1129

Ramsés VIII (Usermaatra Akhenamun) 1129-1126

Ramsés IX (Neferkara Setepenra)

1126-1108

Ramsés X (Khepermaatra Setepenra)

1108-1099

Ramsés XI (Menmaatra Setepenra)

1099-1069

\section{TERCER PERIODO INTERMEDIO 1069-664 a.C.}

Dinastía XXI

Esmendes (Hedjkheperra Setepenra)

Amenemnisu (Neferkara)
1069-945

1069-1043

1043-1039 
Psusennes I [Pasebakhaenniut]

(Akeheperra Setepenamun)

1039-991

Amenemope (Usernaatra Setepenamun)

993-984

Osorkon el Viejo (Akheperra setepenra)

984-978

Siamun (Netjerkheperra Setepenamun)

978-959

Psesennes II [Pasebkhaenniut]

(Titkheperura Setepenra)

959-945

Dinastía XXII

945-715

Sheshonq I (Hedjkheperra)

945-924

Osorkon (Sekhemkheperra)

924-889

Sheshonq II (Heqakheperra)

c. 890

Takelot I

889-874

Osorkon II (Usernaatra)

$874-850$

Takelot II (Hedkheperra)

$850-825$

Sheshonq III (Usermaatra)

$825-773$

Pimay (Usermaatra)

$773-767$

Sheshonq V (Aakheperra)

$767-730$

Osorkon IV (Aakheperra)

730-715

Dinastia XXIII

818-715

Reyes en varios centros, contemporánea

con el final de la dinastía XXII, la dinastía XXIV

y la dinastía XXV, incluye a:

Pedubasttis I (Usermaatra)

Iuput I

Sheshonq IV

Osorkon III (Usermaatra)

Takelot III (Usermaatra)

Rudamon (Usermaatra)

Peftjauwybast

Iuput II (Usermaatra)

Dinastia XXIV

727-715

Bakenrenef (Bocoris)

Dinastia XXV

747-656

Piy (Menkheperra)

$747-716$

Shabaqo (Neferkara)

716-702

Shabitqo (Djedkaura)

702-690

Taharqo (Khunefertemra)

690-664

Tanutamani (Bakara)

664-656

BAJA ÉPOCA

664-332 a.C.

Dinastia XXVI

664-525

[Nekau I

672-664] 
Psamético I (Wahibra)

664-610

Nekau II (Wehemibra)

610-595

Psamético II (Neferibra)

595-589

Apries (Haaibra)

$589-570$

Ahmose II [Amasis] (Khnembra)

$570-526$

Psamético III (Ankhkaera)

526-525

Dinastía XXVII (Primer Periodo Persa)

$525-404$

Cambises

525-522

Darío I

$522-486$

Jerjes I

486-465

Artajerjes I

$465-424$

Darío II

424-405

Artajerjes II

405-359

Dinastía XXVIII

404-399

Amirtayo

404-399

Dinastia XXIX

399-380

Neferites I [Nefaarud]

399-393

Hakor [Akoris] (Khnemmaatra)

393-380

Neferites II

c. 380

Dinastia XXX

380-343

Nectanebo I (Kheperkara)

$380-362$

Teo (Irma atenra)

$362-360$

Nectanebo II (Senedjemibra setepenanhur) 360-343

Segundo Periodo Persa

$343-332$

Aratjerjes III Ocus

343-338

Arses

338-336

Darío III Codoman

336-332

\section{PERIODO PTOLEMAICO}

332-30 a.C.

Dinastía macedónica

332-305

Alejandro Magno

332-323

Filipo Arrideo

323-317

Alejandro IV458

317-310

Dinastía ptolemaica

Ptolomeo I Sóter I

$305-285$

Ptolomeo II Filadelfo

$285-246$

Ptolomeo III Evérgetes

246-221

458 Alejandro IV fue sólo un gobernante nominal, 310-305. 
Ptolomeo IV Filópator

221-205

Ptolomeo V Epífanes

205-180

Ptolomeo VI Filométor

180-145

Ptolomeo VII Neo Filópator

145

Ptolomeo VIII Evérgetes II

170-116

Ptolomeo IX Sóter II

116-107

Ptolomeo X Alejandro I

107-88

Ptolomeo IX Sóter II (restaurado)

$88-80$

Ptlomeo XI Alejandro II

80

Ptolomeo XII Neo Dióniso (Auletes) 80-51

Cleopatra VII Filópator

$51-30$

Ptolomeo XIII

$51-47$

Ptolomeo XIV

$47-44$

Ptolomeo XV Cesarión

44-30 
Bibliografía 
Aldred, C. 1965. Egypt to the end of the Old Kingdom. Thames and Hudson, Londres.

Altenmüller, H. 1970. "Die Stellung der Königsmutter Chentkaus beim Übergang on der 4. Zur 5. Dynastie". Chronique d'Égypte 45, pp. 223-235.

Allen, J.P. 2005. The Ancient Egyptian Pyramid Texts. Society of Biblical Literature, Atlanta.

Allen, J.P. 2010. Middle Egyptian. An Introduction to the Language and Culture of Hieroglyphs. Cambridge University Press, Cambridge.

Amícola, J. y de Diego, J.L. (Dirs.). 2008. La teoría literaria hoy. Conceptos, enfoques, debates. Ediciones al Margen, La Plata.

Araújo, E. 2000. Escrito para a Eternidade. Impresa Oficial do Estado, Brasilia.

Aristóteles. La Poética. Gredos, Madrid.

Assmann, A. 1998. "Stabilisatoren der Erinnerung - Affekt, Symbol, Trauma”. En Rüsen, J. y Straub, J. (Ed.). Die dunkle Spur der Vergangenheit. Psychoanalytische Zugänge zum Geschichtsbewusstsein. Erinnerung, Frankfurt, pp. 131-153.

Assmann, J. 1977. “Die Verborgenheit des Mythos in Ägypten”. GM 25, pp. 7-43.

Assmann, J. 1995a. Egyptian Solar Religion in the New Kingdom. Re, Amun and the crisis of polytheism. Kegan Paul, Londres y Nueva York.

Assmann, J. 1995b. Egipto a la luz de una teoría pluralista de la cultura. Akal, Madrid.

Asmman, J. 1996. "Kulturelle und literarische Texte". En Loprieno, A (Ed.). Ancient Egyptian literature. History and Forms. E.J. Brill, Leiden, pp. 59-82.

Assmann, J. 1997. La memoria cultural. Scrittura, ricordo e identità politica nelle grandi civilità antiche. Biblioteca Einaudi, Torino.

Assmann, J. 1999. "Cultural and Literary Texts". En Moers, G. (Ed.). Definitely: Egyptian literature. Lingua Aegyptia, Gotinga, pp. 1-15.

Assmann, J y Blumenthal, E. (Eds.). 1999. Literatur und Politik im pharaonischen und ptolemäischen Ägypten. IFAO, El Cairo.

Assmann, J. 2005 [1996]. Egipto: Historia de un sentido. Abada Editores, Madrid.

Assmann, J. 2003. Moisés el egipcio. Oberón, Madrid. 
Assmann, J. 2008. Religión y memoria cultural. Diez estudios. Lilmod- Libros de la Araucaria, Buenos Aires.

Aufrère, S. 1982. "Contribution à l'étude de la morphologie du protocole "classique". BIFAO 82, pp. 19-73.

Avdiev, V.I. 1986. Historia social y económica del antiguo oriente: el Egipto faraónico. Akal, Madrid.

Baines, J. 1990. "Interpreting the Story of the Shipwrecked Sailor". JEA 76, pp. 5276.

Baines, J. 1994. "Contexts fate: literature and practical religion”. En Eyre, C. y otros. The Unbroken Reed. Studies in the Culture and Heritage of Ancient Egypt in Honour of A.F. Shore. Egypt Exploration Society, Londres.

Baines, J. 1995. “Kingship, definition of culture and legitimation”. En O' Connor, D. y Silverman, D.P. (Eds.). Ancient Egyptian Kingship. E.J. Brill, Leiden, pp. 3-47.

Baines, J. 1996. "Myth and literature". En Loprieno, A (Ed.). Ancient Egyptian literature. History and Forms. E.J. Brill, Leiden, pp. 361-377.

Baines, J. 1997. "Kingship before literature: the World of the king in the Old Kingdom”. En Gundlach, R. y Raedler, Chr. (Eds.). Selbstversta"ndnis und Realität, Beiträge zur ägyptischen Königsideologie. ÄAT 36/1, Wiesbaden, pp. 125-174.

Baines, J. y otros. 2003. "Research on Egyptian literature: Background, Definitions, Prospects". En Hawass, Z. (Ed.). Egyptology at the Dawn of the XXIth century. The American University in Cairo Press, El Cairo, pp. 1-47. Vol. 3.

Baines, J. 2007. Visual and Written Culture in Ancient Egypt. Oxford University Press, Oxford.

Baines, J. y Eyre, Ch. 1983. "Four Notes on Literacy“. GM 61, pp. 65-96.

Barns, J. W. B. 1972. "Some Readings and Interpretations in Sundry Egyptian Texts".JEA 58, pp. 159-166.

Barta, W. 1969. Das Gespräch eines Mannes mit seinem Ba (Papyrus Berlin 3024). MÄS 18, Munich.

Barta, W. 1974-1975. "Die Erste Zwischenzeit im Spiegel der pessimistischen Literatur". Jb. Oriente Lux 24, pp. 50-61.

Barta, W. 1975. Untersuchungen zur Göettlichkeit des regierenden Köenigs. Ritus und Sakralkënigtum nach Zeugnissen der Frühzeit und des Alten Reiches. MÄS 32, Munich 
Barthes, R. 1982. Análisis estructural del relato. Ediciones Buenos Aires, Barcelona.

Barret-Ducrocq, F. 2006. ¿Por qué recordar? Granica, Buenos Aires.

Baud, M. 1999. Famille royale et pouvoir sous l'Ancien Empire égyptien. IFAO, El Cairo.

Bell, B. 1971. "The Dark Ages in Ancient History. I. The First Dark Age in Egypt". American Journal of Archeology 75, pp. 1-26.

Bell, B. 1975. "Climate and the History of Egypt: The Middle Kingdom". American Journal of Archeology 79, pp. 223-269.

Belmonte Avilés, J.A. 2000. “Astronomía y arquitectura: el papel de los astros en la cultura y el arte del Egipto antiguo”. En Molinero, M. A. y Sola, D. (Coords.). Arte y sociedad del Egipto antiguo. Ediciones Encuentro, Madrid, pp. 109-136.

Bennett, T. 1979. Formalism and Masrxism. Routledge, Nueva York.

Berggren, J. 2006. The ipwt in Papyrus Westcar. Master's Thesis - Advisor: Lana Troy Uppsala University, Uppsala.

Bernstein, R. 2002. Freud y el legado de Moisés. Siglo XXI, México D.F.

Blackman, A.M. 1925. "Philological Notes". JEA 11, pp. 210-215.

Blackman, A.M. 1927. "Some philological and other notes”. JEA 13, pp. 187-192.

Blackman, A.M. 1930. "Notes on certain passages in various Middle Egyptian Texts". JEA 16, pp. 65-68.

Blackman, A.M. 1932. Middle Egyptian Stories. BIAE 2, Bruselas.

Blackman, A.M. 1932b. “The Story of Sinuhe”. En BIAE 2, Bruselas, pp. 1-44.

Blackman, A.M. 1936. "The story of Sinuhe and other Egyptian texts". JEA 22, pp. 34-44.

Blackman, A.M 1988. The Story of King Keops and the Magicians. Transcribed from Papyrus Westcar (Berlin Papyrus 3033). J.V. Books, Londres.

Blumenthal, E. 1972. "Die Erzählung des Papyrus d'Orbiney als Literaturwerk". Zथ̈S 99, pp. 1-17.

Blumenthal, E. 1984. “Die Lehre des Königs Amenemhet”. Z ̈̈S 111, pp. 85-107.

Blumenthal, E. 1985. “Die Lehre des Königs Amenemhet”. ZÄS 112, pp. 104-115. 
Borchardt, L. 1897. Festschrift für Georg Ebers. Engelmann, Leipzig.

Borchardt, L. 1911. Catalogue général des antiquités égyptiennes du Musée du Caire: Statuen und Statuetten von Königen und Privatleuten. Vol. I. Reichsdruckerei, Berlín.

Borchardt, L. 1938. “Die Stammuter der 5ten Dynastie”. ASAE 38, pp. 209-215.

Bourdieu, P. 2003. Campo de poder, campo intelectual. Quadratta, Buenos Aires.

Bowman, A.K. y Woolf, G. 2000. Cultura escrita y poder en el mundo antiguo. Gedisa, Barcelona.

Breasted, J. H. 1906. Ancient records of Egypt: historical documents from the earliest times to the Persian conquest. Vol. I. Russell and Russell, Nueva York.

Bresciani, E. 1969. Letteratura e poesia dell'antico Egitto. Giulio Einaudi, Turín.

Brunner, H. 1944. Die Lehre des Cheti, Sohnes des Duauf. J.J. Augustin, Glückstadt.

Brunner, H. 1964. Die Geburt des Gottkönigs. Studien zur überlieferung eines altägyptischen mythos. Otto Harrassowitz, Wiesbaden.

Brunner-Traut, E. 2000 (1963). Cuentos del Antiguo Egipto. EDAF, Madrid.

Bryan, B. 1997. Mistress of the House, Mistress of Heaven: Women in Ancient Egypt. Hudson Hills Press, Manchester.

Bryan, C. 1930. The Papyrus Ebers. Geoffrey Bles, Londres.

Bucher, J.P. 1932. Les textes des tombes de Thotmosis III et Aménophis II. Imprimeire de l'Institut Français d'Archéologie, El Cairo.

Budge, E.A.W. 1914. The Literature of the Ancient Egyptians. J.M Dent and Sons Limited, Londres.

Budge, E.A.W. 1931. Egyptian Tales and Romances. Pagan, Christian and Muslim. Thornton Bulterworth Limited, Londres.

Caminos, R. 1953 Literary fragments in the hieratic script. Griffith Institute, Oxford.

Campagno, M. 2004. Una lectura de La Contienda entre Horus y Seth. Ediciones del Signo, Buenos Aires.

Campagno, M. 2006. "De los modos de organización social en el Antiguo Egipto: lógica de parentesco, lógica de Estado”. En Campagno, M. (Ed.). Estudios sobre parentesco y Estado en el Antiguo Egipto. Ediciones del Signo, Buenos Aires. 
Campbell, J. 2006. El héroe de las mil caras. Psicoanálisis del mito. Fondo de Cultura Económica, Buenos Aires.

Candau, J. 2002. Antropología de la memoria. Nueva Visión, Buenos Aires.

Cardoso, C.F.C. 2000. O culto diario aos deuses nos templos egipcios do Reino Novo. Uma análise a partir da iconografia das capelas da "mansão de milhões de anos" de Séty I em Abydos.

Cervelló Autori, J. 1996a. Egipto y Africa. Origen de la Civilización y la Monarquía faraónica en su contexto africano. Editorial Ausa, Barcelona.

Cervelló Autori, J. 1996b. "Dinastía 0”. Revista de arqueología 183, pp. 6-15.

Cervelló Autori, J. 2009. "La aparición del Estado y la Época Tinita". En Parra Ortiz, J.M. (Coord.). El antiguo Egipto. Sociedad, Economía y Política. Marcial Pons, Madrid, pp. 67-124.

Castañeda Reyes, J.C. 2003. Sociedad antigua y respuesta popular. Movimientos sociales en Egipto antiguo. Universidad Autónoma Metropolitana, México.

Chappaz, J-L. 1979. "Un manifeste littéraire du Moyen Empire: Les lamentations de Kha-kheper-reseneb”. BSEG 2, pp. 3-12.

Chartier, R. 1999. Cultura escrita, literatura e historia. Conversaciones con Roger Chartier. Fondo de Cultura Económica, México D.F.

Chartier, R. 2005. El presente del pasado. Escritura de la historia, historia de lo escrito. Universidad Iberoamericana, México D.F.

Chartier, R. 2007. La historia o la lectura del tiempo. Gedisa, Barcelona.

Clagett, M. 1989. Ancient Egyptian Science. A Source Book: Knowledge and Order. American Philosophical Society, Filadelfia. Vol. 1-2.

Clayton, P. 1994. Chronicle of the Pharaohs. The Reign-by-Reing Record of the Rulers and Dynasties of Ancient Egypt. Thames and Hudson, Londres.

Coletta, F. 2008 “El lamento de Khakherrasenebu”. En Zingarelli, A. P. (Ed.). El Antiguo Egipto: Pensamiento y sociedad en los textos literarios. En prensa.

Coletta, F. 2009. "Oralidad y escritura en la literatura del antiguo Egipto". Presentado en XII Jornadas Interescuelas/Departamentales de Historia, Bariloche.

Coletta, F. 2011. "Debates en torno a la literatura del antiguo Egipto". Publicado en actas III Jornadas Nacionales de Historia Antigua- II Jornadas Internacionales de Historia Antigua, Córdoba. 
Colin Campbell, C. 1912. The Miraculous Birth of King Amon-Hotep III. And Other Egyptian Studies. Oliver and Boyd, Edimburgo.

Coulon, L. 1997. "Véracité et rhétorique dans les autobiographies égyptiennes de la Primière Période Intermédiare”. BIFAO 97, pp. 109-138.

Couyat, J. y Monet, P. 1912. Les Inscriptions hieroglyphiques et hieratiques du Ouadi Hammamat. IF $A O$, El Cairo.

Cuesta Abad, J.M y Jiménez Heffernan, J. (Eds.). 2005. Teorías literarias del siglo XX. Akal, Madrid.

Daneri de Rodrigo, A. 1992. Las Dinastías VII-VIII y el periodo beracleopolitano en Egipto. Problemas de reconstrucción histórica de una época de crisis. Programa de Estudios de Egiptología, Buenos Aires.

Daressy, M.G. 1898. Notice explicative des ruines du Temple de Louxor. Imprimerie Nationale, El Cairo.

Daressy, M. G. 1916. "La Pierre de Palerme et la chronologie de l'Ancien Empire". $B I F A O$ 12, pp. 161-214.

Daumas, F. 1958a. Les mammisis des temples égyptiens. Société d'Edition Les Belles Lettres, París.

Daumas, F. 1958b. "Les mammisis d'Égypte et de Nubie". Bulletin de la Société Française d'Égyptologie, pp. 43-49.

Daumas, F. 1959. Les mammisis de Dendera. IFAO, El Cairo.

Daumas, F. 1972. La civilización del Egipto faraónico. Editorial Juventud, Barcelona.

Davies, B. D. 1992. Egyptian Historical Records of the Later Eighteenth dynasty. Aris \& Phillips, Warminster. Vol. IV.

Davies, G.N. 1943. The Tomb of Rekh-mi-Re at Thebes. Arno Press, Nueva York.

Derchain, P. 1969. "Snéferou, et les rameuses". RdÉ 21, pp. 19-25.

Derchain, P. 1986. "Deux notules à propos du Papyrus Westcar". GM 89, pp. 15-21.

Derchain, P. 1996. “Auteur et société”. En Loprieno, A. 1996. Ancient Egyptian literature. History and Forms. E.J. Brill, Leiden, pp. 83-94.

Derrida, J. 1995. Mal de Archivo. Una impresión freudiana. Trotta, Madrid. 
Der Manuelian, P. 2003. Slab Stelae of the Giza Necropolis. The Peabody Museum of Natural History of Yale University. The University of Pennsylvania Museum of Archeology and Anthropology. Nueva Haven y Filadelfia.

Dévaud, E. 1916. Les maximes de Ptahhotep d' après le Papyrus Prisse, les papyrus 10371, 10435 et 10509 du British Museum et la Tablette Carnavon. University of Fribourg, Friburgo.

Diego Espinel, A. 2006. Etnicidad y territorio en el Egipto del Reino Antiguo. Universidad Autónoma de Barcelona, Barcelona.

Diego Espinel, A. 2009. "El Reino Medio". En Parra Ortiz, J. M. (Coord.). El Antiguo Egipto. Sociedad, Economía, Política. Marcial Pons, Madrid, pp. 209-271.

Dodson, A y Hilton D. 2005. Las familias reales del Antiguo Egipto. Oberon, Madrid.

Donadoni, S. 1959. Storia della Letteratura Egiziana Antica. Nouva Accademia, Milán.

Dosse, F. 2006. La marcha de las ideas. Historia de los intelectuales, historia intelectual. Publicaciones de la Universidad de Valencia, Valencia.

Drioton, È. y Vandier, J. 1964 (1938). Historia de Egipto. EUDEBA, Buenos Aires.

Dobrev, V. 1993. "Considérations sur les titulatures des rois de la IVe dynastie égyptienne [avec 16 planches]”. BIF AO 93, pp. 179-204.

Eagleton, T. 1998. Una introducción a la teoría literaria. Fondo de Cultura Económica, México D.F.

Ebbel, B. 1937. The Papyrus Ebers. The greatest Egyptian medical document. Levin y Munskgaard, Copenague.

Eco, U. 1996. Seis paseos por los bosques narrativos. Lumen, Barcelona.

Edwards, I.E.S. 1970. The Cambridge Ancient History. Early History of the Middle East. Cambridge University Press, Cambridge.

Eichenbaum, B. 2008. "La teoría del 'método formal". En Todorov, T. (Comp.). Teoría de la literatura de los formalistas rusos. Siglo XXI, Buenos Aires.

Eliade, M. 1954 (1949). Tratado de historia de las religiones. Instituto de Estudios Políticos, Madrid.

Eliade, M. 1992 (1963). Mito y realidad. Labor, Barcelona.

Eliade, M. 1998 (1956). Lo sagrado y lo profano. Paidós, Barcelona. 
Eliade, M. 2005 (1959). Mitos, sueños y misterios. Kairós, Barcelona.

Eliade, M. 2006 (1949). El mito del eterno retorno. Arquetipos y repetición. Emecé, Buenos Aires.

El- Shamy, H. 2002. "Introduction”. En Maspero, G.M. Popular Stories of Ancient Egypt. Oxford University Press, Oxford.

Enmarch, R. 2005. The Dialogue of Ipuwer and the Lord of All. Griffith Institute Publications, Oxford.

Erman, A. 1886. "Ein neuer Papyrus des Berliner Museums". National- Zeitung, Berlín.

Erman, A. 1889. Die Sprache des Papyrus Westcar. Eine Vorarbeit zur Grammatik der Äteren Aegyptischen Sprache. Dieterich'sche Verlagsbuchandlung, Gotinga.

Erman, A. 1890. Die Märchen des Papyrus Westcar. W. Spemann, Berlín.

Erman, A. 1897. Bruchstücke koptischer Volksliteratur. Akademie der Wissenschaften, Berlín.

Erman, A.1927. The literature of the Ancient Egyptians: poems, narratives, and manuals of instruction, from the third and second millennia B.C. Methuen, Londres.

Eyre, C. J. 1976. "Fate, Crocodiles and Judgement of the Dead: Some Mythological Allusions in Egyptian Literature". SAK 4, pp. 103-114.

Eyre, C. J. 1992. "Yet Again the Wax Crocodile: P. Westcar 3, 12". JEA 78, pp. 280281.

Eyre, C. 1996. "Is Egyptian historical literature 'historical' or 'literary'?". En Loprieno, A. (Ed.). Ancient Egyptian literature. History and Forms. E.J. Brill, Leiden, pp. 415-433.

Faulkner, R. O. 1964 "Notes on the Admonitions of an Egyptian sage". JEA 50, pp. 24-36.

Faulkner, R.O. 1991. A Concise Dictionary of Middle Egyptian. Griffith Institute, Oxford.

Faulkner, R. O. 1994. The Ancient Egyptian Coffin Texts. Aris \& Phillips, Warminster.

Faulkner, R. O. 2008. The Ancient Egyptian Book of the Dead. The British Museum Press, Londres 
Fecht, G. 1963. "Die Wiedergewinnung der altägyptischen Verkunst”. MDAIK 19, pp. 54-96.

Fecht, G. 1964. "Die Form der altägyptischen Literatur: Metrische und stilistische Analyse”. ZÄS 91, pp. 11-63.

Fecht, G. 1965. "Literarische Zeugnisse zur 'Persönlichen Frömmigkeit' in Ägypten”. ZÄS 92, pp. 10-32.

Fecht, G. 1967. “Zur Frühform der Amarna-Theologie”. ZÄS 94, pp. 25-50.

Fecht, G. 1972. Der Vorwurf an Gott in den 'Mahnworten des Ipu-wer', zur geistigen krise der ersten zwischenzeit und ibrer bewältigung. C. Winter-Universitätsverlag, Heidelberg.

Fischer-Elfert, H-W. 2003. "Representations of the Past in New Kingdom Literature". En Tait, J. (Ed.). Never Had the Like Occurred'. Egypt's view of its past. University College London, Londres, pp. 119-137.

Foster, J.L. 1974. Love Songs of the New Kingdom. Scribner, Nueva York.

Foster, J.L. 1977. Thought couplets and clause sequences in a literary text: the Maxims of Ptabbotep. Society for the Study of Egyptian Antiquities, Toronto.

Foster, J.L. 1980. "Sinuhé: The Ancient Egyptian genre of narrative verse". JNES 39, pp. 89-117.

Foucault, M. 1969. “Qu'est-ce qu'un auteur?” Bulletin de la Société française de philosophie 3, pp. 73-104.

Foucault, M. 2004. La arqueología del saber. Siglo XXI, Buenos Aires.

Flammini, R. 2010. "Configuraciones sociopolíticas en una conyuntura de descentralidad estatal: el Segundo Periodo Intermedio en el Antiguo Egipto (c. 1800-1530 a.C.). En Dell’Elicine, E.; Francisco, H.; Miceli, P. y Morin, A. (Eds.). Pertenencia, Limites y Condiciones del Concepto de Estado. Actas de las II Jornadas Pensar el Estado en las Sociedades Precapitalistas, Buenos Aires, Instituto de Ciencias de la Universidad Nacional de General Sarmiento. En prensa.

Florescano, E. 1997 (1980). "De la memoria del poder a la historia como explicación”. En Pereyra, C. y otros. Historia ¿Para qué? Siglo XXI, México D.F.

Frankfort, H. 1998a. La religión del antiguo Egipto. Una interpretación. Laertes, Barcelona.

Frankfort, H. 1998b (1948). Reyes y dioses. Estudio de la religión del Oriente Próximo en la antigüedad en tanto que integración de la sociedad y la naturaleza. Alianza, Madrid. 
Frazer, J. G. 1996 (1922). La rama dorada. Fondo de Cultura Económica, México D.F.

Fuscaldo, P. 1966. "La expresión $s 3$ r' en el protocolo de coronación de la dinastía IV'. RIHAO, Buenos Aires.

Gaballa, G.A. 1976. Narrative in Egyptian Art. Philipp von Zabern, Mainz.

Galán, J.M. 1998. Cuatro Viajes en la Literatura del Antiguo Egipto. Centro Superior de Investigaciones Científicas, Madrid.

Galán, J.M. 2002. El Imperio egipcio. Inscripciones, ca. 1550-1300 a.C. Trotta, Barcelona.

Galán, J.M. 2004. "El paso del tiempo y el recuerdo del pasado en el antiguo Egipto". Separata Revista de Dialectología y tradiciones populares de la antropología del tiempo y de la Historia.

Galán, J.M. 2009. "El Reino Nuevo I: la construcción del imperio”. En Parra Ortiz, J.M. (Coord.). El antiguo Egipto. Sociedad, Economía y Política. Marcial Pons, Madrid, pp. 301-388.

Gardiner, A. 1909. The Admonitions of an Ancient Egyptian Sage, from a Hieratic Papyrus in Leiden (Pap. Leiden 344 Recto). J. C. Hinrichs, Leipzig.

Gardiner, A.H. 1914. "New Literary Works from Ancient Egypt”. JEA 1, pp. 100106.

Gardiner, A.H. 1923. “The Eloquent Peasant”. JEA 9, pp. 5-25.

Gardiner, A. H. 1925. “The Secret Chambers of the Sanctuary of Thoth”. JEA 11, pp. 1-5.

Gardiner, A. 1931. The Library of A. Chester Beatty, Description of a Hieratic Papyrus with a Mythological Story, Love-songs and other Miscellaneous Texts. The Chester Beatty Papyri No.1. Emery Walker, Londres.

Gardiner, A. H. 1932a. The Tale of The Two Brothers. BIAE, Bruselas.

Gardiner, A.H. 1932b. Late-Egyptian Miscellanies. BIAE 7, Bruselas.

Gardiner, A.H. 1932c. Late-Egyptian Stories. BIAE 1, Bruselas.

Gardiner, A.H. 1935. Chester Beatty gift and Hieratic Papyri in the British Museum. British Museum, Londres.

Gardiner, A.H. 1938. “The House of Life”. JEA 24, pp. 157-179. 
Gardiner, A. H. 1959. The Royal Canon of Turin. Griffith Institute, Oxford.

Gardiner, A.H. 2007 (1927). Egyptian Grammar. Being an Introduction to the study of Hieroglyphs. Griffith Institute, Oxford.

Gardiner, A.H. y Vogelsang, F. 1908. Die Klagen des Bauern. J.C. Hinris'schen Buchahandlung, Leipzig. 2 Vols.

Gayet, A. 1894. Le temple de Louxor, Constructions d'Aménophis III. Cour d'Aménophis, salle bypostyle, salle des Offertoires, salle du Lever et sanctuaire de Maut. E. Leroux, París.

Genette, G. 1989 (1962). Palimpestos. La literatura en segundo grado. Taurus, Madrid.

Genette, G. 2001 (1989). Umbrales. Fondo de Cultura Económica, México D.F.

Giedion, S. 1986. El presente eterno: los comienzos de la arquitectura. Alianza, Madrid.

Gillam, R. 2009. Performance and Drama in Ancient Egypt. Duckworth, Londres.

Gilula, M. 1978. "Pyr. 604c-d and Westcar 7/17-19”. JEA 64, pp. 45-51.

Gil Paneque, C. 2005. "La institución de la Esposa del dios al servicio de la monarquía de principios de la dinastía XVIII". En Actas del Segundo Congreso Ibérico de Egiptología. 12-14 de Marzo de 2001. Bellaterra, Barcelona.

Ginzburg, C. 1981 (1976). El queso y los gusanos. El cosmos, según un molinero del siglo XVI. Muchnik Editores, Barcelona.

Girard, R. 2006. Los orígenes de la cultura. Conversaciones con Pierpaolo Antonello y Jaão Cezar de Castro Rocha. Trotta, Madrid.

Goedicke, H. 1974. Die Geschichte des Schiffbruchigen. Harrassowitz, Wiesbaden.

Goedicke, H. 1977. The Protocol of Neferyt (The Prophecy of Neferti). Johns Hopkins University Press, Baltimore.

Goedicke H. 1985. "Rudjedet's Delivery”. VA1, pp. 19-26.

Goedicke H. 1986. “Gentlemen's Salutations”. VA2, pp. 161-70.

Goedicke, H. 1988. Studies in "The Instructions of King Amenemhet I for his son". Van Siclen Books, San Antonio.

Goedicke, H. 1992. Problems concerning Amenophis III. Halgo, Baltimore.

Goedicke, H. 1993. “Thoughts about Papyrus Westcar”. ZÄS 120, pp 23-36. 
Goody, J. 1990 (1986). La lógica de la escritura y la organización de la sociedad. Alianza, Madrid.

Goody, J. 1996. Cultura escrita en sociedades tradicionales. Gedisa, Barcelona.

Golénischeff, W. 1916. Le Conte du Naufregé. IFAO, El Cairo.

Golénischeff, W. 1916. Les papyrus hiératiques n 1115, 1116 A y B de l'Ermitage impérial à Saint Pétersbourg. Manufacture des Papiers de l’État, San Petesburgo.

Grajetzki, W. 2006. The Middle Kingdom of Ancient Egypt. Duckworth, Londres.

Grdseloff, B. 1943. "Deux inscriptions juridiques de l' Ancien Empire". ASAE 1943, pp. 25-70.

Green, F.W. 1930. "The Secret Chambers of the Sanctuary of Thot". JEA 16, pp. 33-34.

Greimas, A.J. y Courtès, J. 1979. Dictionnaire raisonné de la théorie du langage. Hachette, París.

Greimas, A.J. 1983. La semiótica del texto. Ejercicios prácticos: análisis de un cuento de Maupassant. Paidós, Barcelona.

Griffith, F. L.1898a. The Petrie Papyri. Hieratic Papyri from Kahun and Gurob. Text. Quatrich, Londres.

Griffith, F. L. 1898b. The Petrie Papyri. Hieratic Papyri from Kabun and Gurob. Plates. Quatrich, Londres.

Gumbrecht, H. 1996. "Does Egyptologie need a 'theory of literature'?". En Loprieno, A. (Ed.). 1996. Ancient Egyptian literature. History and Forms. E.J. Brill, Leiden, pp. 3-18.

Gundlach, R. 1997. "Die Legitimationen des ägytischen Königs- Versuch einer Systematisiernung”. ÄUAT 36, pp. 11- 20.

Gunn, B. y Gardiner, A. 1917. "New Renderings of Egyptian Texts". JEA 4, pp. 241-251.

Günter Burkard, H.J.T. 1993. Uberlegungen zur Form der ägyptischen Literatur die Geschichte des Schiffbrüchigen als literarisches Kunstwerk. Harrassowitz, Wiesbaden.

Günter Burkard, H.J.T. 2007. Einführung in die altägyptische literaturgeschichte. Altes und Mittleres Reich. Lit, Berlín. Vol. 1.

Halbwachs, M. 2004a (1925). Los marcos sociales de la memoria. Anthropos, Madrid. 
Halbwachs, M. 2004b (1950). La memoria colectiva. Prensas Universitarias de Zaragoza, Zaragoza.

Hayes, W. C. 1953. "Notes on the Government of Egypt in the Late Middle Kingdom". JNES 12, pp. 31-39.

Hayes, W. C. 1961. "The Middle Kingdom in Egypt". Edwards, I.E.S., Gadd, C.J. y Hammonds, N.G.L. (Eds.). Cambridge Ancient History I. Early History of The Middle East (464-531). Cambridge University Press, Cambridge.

Hays, H. M. 2002. “The Historicity of Papyrus Westcar”. ZÄS 129, pp. 20-30.

Helck, W. 1969. Der Text der “Lehre Amenembets I für seinen Sobn”. Harrassowitz, Wiesbaden.

Helck, W. 1970. Die Prophezeiung des Nfr.tj. Harrassowitz, Wiesbaden, pp. 34-47.

Helck, W. 1977. Die Lehre für König Merikaré. Harrassowitz, Wiesbaden.

Helck, W. 1995. Die “Admonitions” Pap. Leiden I 344 recto. Kleine Ägyptische Texte, Harassowitz. Wiesbaden.

Hermann, A. 1938. Die ägyptische Königsnovelle. J.J. Augustin, Hamburgo.

Herzog, V.R. 1969. "Über Henry Westcars Tagebuch einer Reise durch Ägypten und Nubien (1823-24)". MDAIK 24, pp. 201-211.

Hollis, S. 2008. The Ancient Egyptian "Tale Of Two Brothers": a mythological, religious, literary and historic-political study. Bannerstone Press, Indiana.

Hornung, E. 1973. “Die 'Kammern' des Thot-Heiligtumes”. Z ̈̈S 100, pp. 33-35.

Hornung, E. 1999a. El Uno y los Múltiples. Concepciones egipcias de la divinidad. Trotta, Madrid.

Hornung, E. 1999b. The Ancient Egyptian Books of the Afterlife. Cornell University Press, Ithaca y Londres.

Hornung, E. 2001. The Secret Lore of Egypt: Its impact on the West. Cornell University Press, Ithaca y Londres.

Hornung, E. 2007. The Egyptian Amduat. The Book of the Hidden Chamber. Living Human Heritage Publications, Zurich.

Hubert, H. y Mauss, M. 1971 [1903]. "Esquisse d'une théorie générale de la magie". En Hubert, H. y Mauss, M. Sociologie et Anthropologie. PUF, París. 
Huici Urmeneta, V. 2007. Espacio, tiempo y sociedad. Variaciones sobre Durkheim, Halbwachs, Gurvitch, Foucault y Bourdieu. Akal, Madrid.

Jakobson, R. y otros. 2008. Teoría de la literatura de los formalistas rusos. Siglo XXI, Buenos Aires.

Jelin, E. 2002. Los trabajos de la memoria. Siglo XXI, Madrid.

Jenni, H. 1998. “Der Papyrus Westcar”. SAK 25, pp. 113-141.

Junge, F. 1973. "Zur Fehldatierung der Sog. Denkmals memphitischer Theologie oder Der Beitrag der ägyptischen Theologie zur Geistesgeschichte der Spätzeit”. $M D A I K 29$, pp. 195-204.

Kadish, A.G. 1973. "The Complaints of Kha-Kheper-Rē'-Senebu”. JEA 59, pp. 7790 .

Kahl, J. 2007. "Ra is my Lord" Searching for the Rise of the Sun Gods at the Dawn of Egyptian History. Harrassowitz, Wiesbaden.

Kanawati, N. 2003. Conspiracies in the Egyptian Palace. Unis to Pepy I. Routledge, Londres y Nueva York.

Kaplony, P. 1981. Die Rollsiegel des Alten Reiches II. Katalog der Rollsiegel. A Textes/B Tafeln. Fondation égyptologique Reine Élisabeth, Bruselas.

Kayser, W. 1985. Interpretación y análisis de la obra literaria. Gredos, Madrid.

Keel, O. 2006 (1997). La iconografía del Antiguo Oriente y el Antiguo Testamento. Trotta, Madrid.

Kemp, B. 2004. El Antiguo Egipto. Anatomia de una civilización. Crítica, Barcelona.

Kitchen, K. A. 1982. Pharaoh triumphant. The Life and Times of Ramesses II. The American University in Cairo Press, El Cairo.

Kitchen, K. A. 1991. "The Chronology of Ancient Egypt”. World Archeology 23, pp. 201-208.

Kitchen, K.A. 2001. Ramesside inscriptions. Translated and annotated. Notes and comments. Blackwell, Oxford.

Knigge, C. 1997. "Die Bekleidung der Ruderinnen in der Geschichte des Papyrus Westcar”. GM 161, pp. 103-105.

Koening, Y. 1994. Magie et magiciens Dans l'égypte ancienne. Pygmalion, París. 
Koselleck, R. 2001. Los estratos del tiempo: estudios sobre la historia. Paidós, Barcelona.

Kramer, N. S. 1965. Mitologías del Mundo Antiguo. Enciclopedia Esencial, Barcelona.

Kristeva, J. 2001 (1969). Semiótica 1. Espirar, Madrid.

Kurth, D. 1987. "Zur Interpretation der Geschichte des Schiffbrüchigen”. SAK 4, pp. 167-179.

Lantéri-Laura, G. y otros. 1972. Introducción al estructuralismo. Nueva Visión, Buenos Aires.

Lefebvre, G. 1944. 'L' âge de 110 ans et la viellesse chez les Égyptiens”. Comptesrendus des séances de l'année 88, pp. 106-119.

Lefebvre, G. 2003 (1982). Mitos y cuentos egipcios de la época faraónica. Akal, Madrid. [Traducción por Serrano Delgado, J.M].

Le Goff, J. 1991 (1971). El orden de la memoria. El tiempo como imaginario. Paidós, Barcelona.

Lepper, V.M. 2007. "New readings of an Old Text: Papyrus Westcar". Proceedings of the Ninth International Congress of Egyptologists. Grenoble 6-12 Septiembre 2004. OLA 150, pp. 1125-1136.

Lepper, V.M. 2008. Untersuchungen zu pWestcar. Eine philologische und literaturwissenschaftliche (Neu-) Analyse. Harrassowitz, Wiesbaden.

Lesko, L.H. 1986. “Three Late Egyptian Stories Reconsidered”. En Lesko, L.H. (Ed.), Egyptological Studies in Honor of Richard A. Parker. Brown University Press, Hanover y Londres, pp. 98-104.

Lévi-Strauss, C. 1981. "El campo de la antropología”. En Antropología estructural. Mito, sociedad, humanidades. Siglo XXI, México D.F., pp. 9-36.

Lévi-Strauss, C. 1984. El pensamiento salvaje. Fondo de Cultura Económica, México D.F.

Lévi-Strauss, C. 2002. Mito y significado. Alianza, Madrid.

Lichtheim, M. 1973. Ancient Egyptian Literature. A Book of Readings. The Old and Middle Kingdoms. Vol 1. University of California Press, Berkeley.

Lloyd, A.B. 1993. Herodotus: Commentary 99-182. Brill, Leiden.

López, J. 1963. “Le papyrus Millingen”. RE 15, pp. 29-33. 
López, J. 1992. “Le Verger d'amour”. RdÉ 43, pp. 133-143.

López, J. 2005. Cuentos y Fábulas del Antiguo Egipto. Editorial Trotta, Barcelona.

Loprieno, A. (Ed.). 1996. Ancient Egyptian literature. History and Forms. E.J. Brill, Leiden.

Loprieno, A. 1996a. "Ancient texts and modern theories". En Loprieno, A. (Ed.). Ancient Egyptian literature. History and Forms. E.J. Brill, Leiden, pp. 39-58.

Loprieno, A. 1996b. "The 'King's Novel"'. En Loprieno, A. (Ed.). Ancient Egyptian literature. History and Forms. E.J. Brill, Leiden, pp. 277-295.

Loprieno, A. 2001. La pensée et l'écriture. Pour une analyse sémiotique de la culture égyptienne. Cybele, París.

Loprieno, A. 2009. "Lengua, política y religión en el Antiguo Egipto". En Campagno, M.; Gallego, J. y García Mc Gaw, C.G. (Comps.). Política y religión en el mediterráneo antiguo. Egipto, Grecia, Roma. Miño y Dávila, Buenos Aires.

Lorton, D. 1979. "Review: Towards a Constitutional Approach to Ancient Egyptian Kingship". JAOS 99, pp. 460-465.

Lull, J. 2006. La astronomía en el antiguo Egipto. Universitat de València, Valencia.

Lupo, S. 2011. "El papel de los hijos reales en la consolidación del estado durante el Reino Antiguo: una alternativa de análisis”. Cuadernos del Sur-Historia 39, pp. 109122.

Lustig, J. 1999. "Kingship, Gender and Age in Middle Kingdom Tomb Scenes and Texts". En Lustig, J. (Ed.). Anthropology and Egyptology. A Developing Dialogue. Sheffield Academic Press, Sheffield.

Málek, J.1982. “The original Version of the Royal Canon of Turin”. JEA 69, pp. 93106.

Manetón. 1993. Historia de Egipto. Alianza Editorial, Madrid.

Mariette, A. 1864. "La table de Saqqarah". Revue archéologique 10, pp. 169-186.

Maspero, G.M. 1883. "Les chants d'amour du papyrus de Turin et du papyrus Harris n 500”. Journal Asiatique, pp. 5-47.

Maspero, G.M. 1886. Études égyptiennes. Imprimerie Nationale, París. Vol. I. 
Maspero, G. M. 2002 (1911). Popular Stories of Ancient Egypt. Editado y traducción por Hasan El- Shamy. Oxford University Press, Oxford.

Mathieu, B. 1988. “Études de métrique Égyptienne I”. RdÉ 39, pp. 63-82.

Mathieu, B. 1990. “Études de métrique Égyptienne II”. RdÉ 41, pp. 127-141.

Mathieu, B. 1994. “Études de métrique Égyptienne III”. RdÉ 45, pp. 139-154.

Mathieu, B. 1996. La poésie amoureuse de l'Égypte ancienne. IFAO, El Cairo.

Mathieu, B. 1997. “Études de métrique Égyptienne IV”. RdÉ 48, pp. 109-163.

Maystre, Ch. 1940. "Livre de la Vache du Ciel dans les tombeaux de la Vallée des Rois”. BIFAO 40, pp. 53-115.

Mc Geough, K. 2006. "Births Bricks. Potter's Wheels and Exodus 1,116”. Biblical Studies on the Web 87, pp. 305-318.

Meeks, D. y Favard-Meeks, C. 1994. La vida cotidiana de los dioses egipcios. Temas de Hoy, Madrid.

Meltzer, E. S. 1994. "The Art of the Storyteller in Papyrus Westcar: An Egyptian Mark Twain?”. En Bryan, B. y Lorton, D. (Eds.). Essays in Egyptology in Honor of Hans Goedicke. Van Siclen Books, San Antonio, pp. 169-75.

Meyer, E. 1909. Geschichte des altertums. C. Cotta'sche Buchhandlung Nachfolger, Stuttgart.

Molinero, M. A. y Sola, D. (Coords.). 2000. Arte y sociedad del Egipto antiguo. Ediciones Encuentro, Madrid.

Moers, G. (Ed.). 1999. Definitely: Egyptian literature. Lingua Aegyptia, Gotinga.

Moers, G. 1999. "Introduction. Definitely? Current trends in Egyptological literary studies. En Moers, G. (Ed.). 1999. Definitely: Egyptian literature. Lingua Aegyptia, Gotinga, pp. vii-ix

Moers, G. 1999. "Travel as narrative in Egyptian literature”. En Moers, G. (Ed.). Definitely: Egyptian literature. Lingua Aegyptia, Gotinga, pp. 43-61.

Montesperelli, P. 2004. Sociología de la memoria. Nueva Visión, Buenos Aires.

Moreno García, J.C. 2004. Egipto en el Imperio Antiguo (2650-2150 a.C.). Bellaterra, Barcelona. 
Moreno García, J.C. 2009. "El Primer Período Intermedio". En Parra Ortiz, J.M. (Coord.). El antiguo Egipto. Sociedad, Economía y Politica. Marcial Pons, Madrid, pp. 181-208.

Morenz, L.D. 2003. "Literature as a construction of the past in the Middle Kingdom". En Tait, J. (Ed.). Never Had the Like Occurred'. Egypt's view of its past. University College London, Londres, pp. 101-117.

Morenz, L.D. 2004. "Apophis: on the origin, name and nature of ancient Egyptian anti-god". JNES 63, pp. 201-205.

Morkot, R. 2003. "Archaism and Innovation in Art from the New Kingdom to the Twenty-sixth dynasty". En Tait, J. (Ed.). Never Had the Like Occurred'. Egypt's view of its past. University College London, Londres, pp. 79-99.

Mudrovcic, M.I. 2005. Historia, narración y memoria. Los debates actuales en filosofía de la bistoria. Akal, Madrid.

Müller, H. W. 1964. "Der Gute Gott Radjedef, Sohn des Rê”. ZÄS 91, pp. 129-133.

Murnane, W.J. 1977. Ancient Egyptian Coregencies. The Oriental Institute, Chicago.

Naville, E. 1896. The Temple of Deir el Bahari. Egypt Exploration Fund, Londres. Vol. II.

O’ Connor, D. y Silverman, D.P. (Eds.). 1995. Ancient Egyptian Kingship. E.J. Brill, Leiden.

O’ Connor, D y Cline, E.H. (Eds.). 2001. Amenhotep III: Perspectives on His Reign. University of Michigan Press, Ann Arbor.

O' Mara, P. F. 1979. The Palermo stone and the archaic kings of Egypt. Paulette, California.

Ong, W.J. 1996 (1982). Oralidad y escritura. Tecnologías de la palabra. Fondo de Cultura Económica, Buenos Aires.

Parra Ortíz, J.M. 2001. Las pirámides: Historia, mito y realidad. Editorial Complutense, Madrid.

Parra Ortíz, J.M. 2003. Gentes del Valle del Nilo: la sociedad egipcia durante el Egipto faraónico. Editorial Complutense, Madrid.

Parra Ortíz, J.M. 2009. "El Reino Antiguo”. En Parra Ortiz, J.M. (Coord.). El antiguo Egipto. Sociedad, Economía y Política. Marcial Pons, Madrid, pp. 125-180.

Parkinson, R. B. 1991. Voices from Ancient Egypt: An Anthology of Middle Kingdom Writings. University of Oklahoma Press, Oklahoma. 
Parkinson, R.B. 1996. "Individual and Society in Middle Kingdom Literature". En Loprieno, A (Ed.) Ancient Egyptian literature. History and Forms. E.J. Brill, Leiden, pp. 137-155.

Parkinson, R. B. 1998. The Tale of Sinube and Other Ancient Egyptian Poems, 1940-1640 BC. Oxford University Press, Oxford.

Parkinson, R. B. 1999. "The dream and the knot: contextualizing Middle Kingdom literature. En Moers, G. (Ed.). Definitely: Egyptian literature. Lingua Aegyptia, Gotinga.

Parkinson, R.B. 2002. Poetry and culture in Middle Kingdom Egypt: a dark side to perfection. Continuum, Londres.

Parkinson, R.B. 2009. Readings Ancient Egyptian Poetry. Among Other Histories. WileyBlackwell, Sussex Occidental.

Petrucci, A. 2002. La ciencia de la escritura. Primera lección de paleografía. Fondo de Cultura Económica, Buenos Aires.

Piankoff, A. 1954. The Tomb of the Ramesses VI. Pantheon Books, Nueva York.

Pieper, M. 1927. Die Ägyptische literatur. Akademische Verlagsgellschaft Athenaion, Wildpark y Postdam.

Peihl, K. 1897. “Quelques passages du Papyrus Westcar”. SPHINX 1, pp.71-80.

Petrie, W. M. Fl. 1895. Egyptian Tales. Metheun \& Co, Londres.

Pleyte, R. y Rossi, F. 1869-1876. Papyrus de Turin. E.J. Brill, Leiden. Vol. 1-2.

Pollak, M. 2006. Memoria, olvido, silencio. La producción social de identidades frente a situaciones límite. Ediciones al Margen, La Plata.

Porter, B. y Moss, R. 1974. Topographical bibliography of ancient Egyptian Hieroglyphic, text, Reliefs, and Paintings. Memphis. Griffith Institute, Oxford. Vol. 3.

Porter, B. y Moss, R. 1991. Topographical bibliography of ancient Egyptian Hieroglyphic, text, Reliefs, and Paintings. Griffith Institute, Oxford. Vol. 4.

Porter, B. y Moss, R. 2004. The Theban Necropolis. Griffith Institute, Oxford.

Posener, G. 1940. De la divinité du pharaon. Imprimerie Nationale, París.

Posener, G. 1956. Litterature et politique dans l'Egypte de la XIIe Dynastie. Honoré Champion, París. 
Posener, G. 1963. 'L'apport des textes litteraires a la connaissance de l'histoire égyptienne“. En Donadoni, S. (Ed.). Fonti indirette della Storia Egižiana. Centro di studi semitici, Roma.

Prisse, É. 1847. Facsimile d'un papyrus égyptien en caracteres hiératiques trouvé à Thèbes donné á la Bibliothèque royale de Paris. Lithographique de Lemercier, París.

Pritchard, J.B. (Ed.). 1950. Ancient Near Eastern Texts relating to the Old Testament. Princeton University Press, Princeton.

Pritchard, J.B. (Ed.) 1973. The Ancient Near East: An Anthology of Texts and Pictures. Princeton University Press, Princeton.

Propp, V. 1991. "Las transformaciones de los cuentos fantásticos”. En Jakobson, R. y otros. Teoría de la literatura de los formalistas rusos. Siglo XXI, Buenos Aires.

Propp, V. 2007 (1928). Morfología del cuento. Akal, Madrid.

Quirke, S. 1990. Who were the Pharaohs? A history of their names with a list of cartouches. British Museum Press, Londres.

Quirke, S. 1996. "Narrative literature". En Loprieno, A (Ed.) Ancient Egyptian literature. History and Forms. E.J. Brill, Leiden, pp. 263-276.

Quirke, S. 2003. Ra, el dios del Sol. Oberon, Madrid.

Quirke, S. 2004. Egyptian literature 1800 BC, Questions and Readings. Golden House Publications, Londres.

Raice, M. 1999. Who's who in ancient Egypt? Routledge, Londres.

Redford, D.B. 1967. History and Chronology of the Eighteenth Dynasty of Egypt. Seven Studies. University of Toronto Press, Toronto.

Redford, D.B. 1986. Pharaonic King-Lists, Annals and Day-Books. A contribution to the Study of the Egyptian Sense of History. Benben Publications, Mississauga.

Redman, Ch. 1990. Los orígenes de la civilización. Desde los primeros agricultores hasta la sociedad urbana en el Próximo Oriente. Crítica, Barcelona.

Reeves, N. y Wilkinson, R. H. 1966. The Complete Valley of the Kings. Thames \& Hudson, Londres.

Reisner, G.A. 1934. "The Servants of the Ka”. BMFA 189, pp. 2-12.

Renaud, O. 1991. Le Dialogue du Désespéré avec Âme Une interprétation littéraire. Cahiers de la Société d'Egyptologie, Ginebra. 
Richards, J. 2005. Society and Death in Ancient Egypt: Mortuary Landscapes of the Middle Kingdom. Cambridge University Press, Cambridge.

Ricœur, P. 1999. La lectura del tiempo pasado: memoria y olvido. Arrecife, Madrid.

Ricœur, P. 2006. Del texto a la acción. Fondo de Cultura Económica, Buenos Aires.

Ricœur, P. 2008. La memoria, la historia, el olvido. Fondo de Cultura Económica, Buenos Aires.

Ritner, R.K. 1992. "Egyptian Magic: questions of legitimacy, religious orthodoxy and social deviance". En Lloyd, A.B. (Ed.). Studies in Pharaonic Religion and Society in Honour of J.Gwyn Griffiths. British Library Cataloguing in Publication Data, Londres.

Robins, G. 1996. Las mujeres en el antiguo Egipto. Akal, Madrid

Roccati, A. 1982. La litterature historique sous l' ancien empire égyptien. Les Éditions du Cerf, París.

Roccati, A. 1990. "El escriba". En Donadoni, S, (Ed.). El hombre egipcio. Alianza, Madrid. pp. 81-106.

Rodríguez, P. 1997. Mitos y ritos de la Navidad. Origen y significación de las celebraciones navideñas. Ediciones Grupo Z, Madrid.

Rosenvasser, A. 1938. Las ideas morales en el antiguo Egipto. Universidad Nacional del Litoral, Santa Fe.

Rosenvasser, A. 1976. "Introducción a la Literatura Egipcia. Las formas literarias". RIHAO 3, pp. 6-46.

Rosenvasser, A. 1981. "Reproches a Ra por la Injusticia de los Hombres". Cuadernos del Sur 14, pp. 221-230.

Rosell, P.M. 2010. "El rey como buen pastor. La reconstrucción de la imagen del faraón en el Reino Medio”. Cabier Caribéens d’Egyptologie, 13/14, pp. 161-174.

Roth, A.M y Roehrig, C. 2002. "Magical Bricks and the Bricks of Birth". JE $A$ 88, pp. 121-139.

Ryholt, K.S.B. 1997. The political situation in Egypt during the Second Intermediate Periodod c. 1800-1530. B.C. Museum Tusculanum Press, Copenague.

Saer, J.J. 1991. “El concepto de ficción”. Punto de Vista 40, pp. 1-3. 
Salem, L. 2007. "El nacimiento divino de la V dinastía: su construcción desde un recuerdo". XI Jornadas Interescuelas/ Departamentos de Historia, Tucumán.

Salem, L. 2008. "Papiro Westcar: Unidad de sentidos, Recuerdo y legitimación del poder". En Zingarelli, P. (Ed.) El Antiguo Egipto: Pensamiento y sociedad en los textos literarios. En prensa.

Salem, L. 2009. "Mito y literatura egipcia. Acerca de un mito de origen en los dos últimos cuentos del Papiro Westcar". Publicado en Actas XII Jornadas Interescuelas/Departamentos de Historia, Bariloche.

Salem, L. 2010a. "La realeza egipcia: Dios padre- hijo rey. Algunas consideraciones míticas literarias sobre el faraón como Hijo de Ra”. Trabajos y Comunicaciones 36, pp. 271-292.

Salem, L. 2010.b "Nacimiento mítico de tres futuros reyes: aspectos simbólicos y consideraciones literarias sobre los dos últimos cuentos del papiro Westcar". En De Araújo, L.M. y Das Candeias Sales, J. (Ed.). Novos Trabalhos de Egiptologia Ibérica. Instituto Oriental e Centro de História da Faculdade de Letras da Universida de Lisboa, Lisboa, pp. 1031-1046. Vol. II.

Salem, L. 2011. "Concepciones sobre el tiempo pasado y futuro en el antiguo Egipto”. Sin publicar.

Sarlo, B. 2005. Tiempo pasado. Cultura de la memoria y giro subjetivo. Una discusión. Siglo XXI, Buenos Aires.

Säve-Söderbergh, T. 1949. Studies in the Coptic Manichaean Psalm-Book: Prosody and Mandaean parallels. Almquist y Wiksells, Uppsala.

Sánchez Rodriguez, A. 2003. El papiro Westcar. Asociación Andaluza de Egiptología, Sevilla.

Sanmartín, J. y Serrano, J.M. 2006. Historia antigua del Próximo Oriente. Mesopotamia y Egipto. Akal, Madrid.

Sauneron, S. 1955. "Sakhebou”. BIFAO 55, pp. 61-64.

Sauneron, S. 1998. The Priests of Ancient Egypyt. Cornell University Press, Ithaca y Londres.

Schaeffer, J-M. 2006 (1989). ¿Qué es un género literario? Akal, Madrid.

Schenkel, W. 1965. Memphis, Herakleopolis, Theben. Die epigraphischen Zeugnisse der 7.-11. Dynastie Ägyptens. Harrassowitz, Wiesbaden. 
Schenkel, W. 1996. “Ägyptische Literatur und ägyptologische Forschung: eine wissenschaftsgeschichtliche Einleitung". En Loprieno, A (Ed.) Ancient Egyptian literature. History and Forms. E.J. Brill, Leiden, pp. 21-38.

Serrano Delgado, J.M. 1992a. "Una época crítica en la Historia de Egipto. El Primer Período Intermedio I”. Revista de Arqueología 40, pp. 12-23.

Serrano Delgado, J.M. 1992b. "Una época crítica en la Historia de Egipto. El Primer Período Intermedio II”. Revista de Arqueología 40, pp. 9-18.

Serrano Delgado, J.M 1993. Textos para la Historia antigua de Egipto. Cátedra, Madrid.

Serrano Delgado, J.M. 2006. “Libro II. El Egipto faraónico”. En Sanmartín, J. y Serrano, J.M. 2006. Historia antigua del Próximo Oriente. Mesopotamia y Egipto. Akal, Madrid, pp. 179-340.

Sethe, K. 1927. Erläuterungen zu den Aegyptischen Lesestücken: texte des Mitteleren Reiches. J.C. Hinrichs, Leipzig.

Sethe, K. 1928. "Das 'Denkmal memphitischer Theologie' der Schabakostein des britischen Museum". En Sethe, K. (Ed.). Untersuchungen zur Geschichte und Altertumskunde Aegyptens. J.C. Hinrichs, Leipzig.

Sethe, K. 1959. Ägyptische Lesestücke zum gebrauch im akademischen unterricht. Texte des Mitteleren Reiches. George Olms, Zurich.

Shafer, B.E. 1991. "Introduction”. En Shafer, B.E. (Ed.). Religion in Ancient Egypt. Gods, Myths, and Personal Practice. Cornell University Press, Ithaca y Londres, pp. 3-6.

Shmakov, T.T. 2012. Critical analysis of J.P. Allen "The Ancient Egyptian Piramid Texts". Preliminary results. A.K. Eyma, Osmk-Tricht.

Silverman, D.P. 1991. "Divinity and Deities in Ancient Egyptp". En Shafer, B.E. (Ed.). Religion in Ancient Egypt. Gods, Myths, and Personal Practice. Cornell University Press, Ithaca y Londres, pp. 7-87.

Simpson, W.K. 1973. The Literature of Ancient Egypt. An Anthology of Stories, Instructions, and Poetry.Yale University Press, New Haven y Londres. Vol. 1.

Simpson, W. K. 1982a. "Egyptian Sculpture and Two-Dimensional Representation as Propaganda". JEA 68. pp. 266-271.

Simpson W. K. 1982b. “Pap. Westcar”. LÄ4, pp. 744-746.

Sist, L. 2008. "The importance of History in Ancient Egypt". En Tiradritti, F. (Ed.). Egyptian renaissance. Archaism and the Sence of History in Ancient Egyptian. Museum of Fine Arts, Budapest. 
Smither, P.C. 1939. "The Transcription of the w3hy-Hall in P.Westcar". JE $A$ 25, p. 104.

Strudwick, N.C. 1985. The Administration of Egypt in Old Kingdom: the highest titles and their holders. KPI, Londres.

Strudwick, N.C. 2005. Texts from the Pyramid Age. Society of Biblical Literature, Atlanta.

Suhr, C. 1999. "Zum fiktiven Erzähler in der ägyptischen Literatur". En Moers, G. (Ed.). Definitely: Egyptian literature. Lingua Aegyptia, Gotinga, pp. 91-129

Tait, J. (Ed.) 2003. Never Had the Like Occurred'. Egypt's view of its past. University College London, Londres.

Tait, J. 2003. "Introduction- '... Since the time of the gods'. En Tait, J. (Ed.). Never Had the Like Occurred'. Egypt's view of its past. University College London, Londres, pp. $1-13$.

Taylor, J.H. (Ed.). 2010. Journey Through the Afterlife. Ancient Egyptian Book of the Dead. British Museum Press, Londres.

Te Velde, H. 1986. "Scribes and Literacy in ancient Egypt". En Vanstiphout, H. L.J. (Ed.). Scripta Signa Vocis: Studies about Scripts, Scriptures, Scribes and Languages in the Near East, presented to J.H. Hospers. Egbert Forten, Groningen.

Tiradritti, F. 2008. "Renaissence. Archaism. The sense of History". En Tiradritti, F. (Ed.). Pharaonic Renaissance. Archaism and the Sense of History in Ancient Egypt. Museum of Fine Arts, Budapest.

Todorov, T. 1971. “The Origin of Genres”. New Literary History 8, pp. 159-170.

Todorov, T. 2000. Los abusos de la memoria. Paidós, Buenos Aires.

Todorov, T. 2002 (2000). Memoria del mal, tentación del bien. Indagación sobre el siglo XX. Península, Barcelona.

Todorov, T. 2003 (1972). Introducción a la literatura fantástica. Ediciones Coyoacán, México D.F.

Todorov, T. (Comp.). 2008. Teoría de la literatura de los formalistas rusos. Siglo XXI, Buenos Aires.

Tresson, P. 1919. L'Inscription d'Ouni. IFAO, El Cairo.

Trigger, B. G. y otros. 1985. Historia del Egipto Antiguo. Crítica, Barcelona. 
Troy, L. 1986. Patterns of queenship in ancient Egyptian myth and history. Acta Universitatis Upsaliensis, Uppsala.

Troy, L. 2009. "Religion and Cult during the Time of Thutmose III". En Cline, E. y O'Connor, D. (Eds.). Thutmose III. A New Biography. Michigan University Press, Michigan. pp. 123-182.

Tyldesley, J. 2011. Mitos y Leyendas del Antiguo Egipto, Crítica, Barcelona.

Urruela Quesada, J.J. 2008. Egipto faraónico. Política, economía y sociedad. Ediciones Universidad de Salamanca, Salamanca.

Vandier, J. 1950. Mo'alla: La tombe d'Ankbtifi et la tombe de Sébekhotep. Imprimerie de l'Institut Français d'Archeologie Orientale, El Cairo.

Vandier, J. 1955. Manuel d'archéologie égyptienne. Les grandes époques. L'architecture religieuse et civile. Picard, París. Vol. 2.

Vaccarini, C. 2008. "Literatura". En Amícola, J. y De Diego, J.L. (Dircs.). La teoría literaria hoy. Conceptos, enfoques, debates. Ediciones al Margen, La Plata.

Van Seters, J. 1964. "A date for the 'Admonitions' in the Second Intermediate Period". JEA 50. pp. 13-23.

Vernus, P. 1995. Essai sur la conscience de l' Histoire dans l' Egypte pharaonique. Librairie Honoré Champion, París.

Vikentiev, V. 1935. "The metrical Scheme of the 'Shipwrecked Sailor'. BIFAO 24, pp. 1-40.

Virey, P. 1887. Études sur le papyrus Prisse. Le Livre de Kagimna et les Leçons de Ptah Hotep. Bibliotheque de l'Ecole des Hautes-Etudes, París.

Vodička, F. 1989. "La estética de la recepción de las obras literarias". En Warning, R. (Ed.). Estética de la recepción. Visor, Madrid.

Vogelsang, F. 1964 (1913). Kommenter zu den Klagen des Bauern. G. Olms Verlagsbuchhandlung, Hildesheim.

Volten, A. 1945. Zwei Altägyptischen politische Schriften: die Lebre für König Merikarê (Pap. Carlsberg IV) un die Lehre des Königs Amennemhet. Munksgaard, Copenague.

von Beckerath, J. 1997. Chronologie des pharaonischen Ägyptens. Philipp von Zabern, Mainz. 
Wegner, J. 2009. "A decorated Birth-Brick from south Abydos: New Evidence on child birth and Birth Magic in the Middle Kingdom". En Silverman, D.P., Simpson, W.K., Wegner, J. (Eds.). Archaism and Innovation: Towards Defining the Cultural Expression of Egypt's Middle Kingdom, Yale University and University of Pennsylvania, Nueva Haven y Filadelfia.

Weill, R. 1947. "Le livre du « désespéré », le sens, l'intention et la composition littéraire de l'ouvrage". BIF $A O 45$, pp. 89-154.

Weill, R. 1948. "Notes sur l'histoire primitive des grandes religions égyptiennes". $B I F A O 47$, pp. 59-150.

Weindler, G. Geburts- und Wochenbetts-Darstellungen auf Altägyptischen Tempelreliefs. C.H. Beck, Munich.

Weinrich, H. 1999. Leteo. Arte y crítica del olvido. Siruela, Madrid.

Wellek, R. y Warren, A. 1974. Teoría literaria. Gredos, Madrid.

Wells, R.A. 1992. "The Mythology of Nut and the Birth of Ra". SAK 19, pp. 305321.

Werbrouck, M. 1949. Le temple d' Hatshepsout a Deir el Bahari. Fondation égyptologique Reine Élisabeth, Bruselas.

West, J.A. 1995. The traveler's key to ancient Egypt. A guide to the sacred placer of ancient Egypt. Quest books, Illinois.

Wettengel, W. 1992. "Zur Rubrengliederung der Erzählung von den zwei Brüdern". GM 126, pp. 97-106.

Wettengel, W. 2003. Die Erzählung von den beiden Brüdern : der Papyrus d'Orbiney und die Köningsdeologie der Ramessiden. Orbis Biblicus et Orientalis. Friburgo-Gotinga.

White, H. 2003. El texto histórico como artefacto literario y otros escritos. Paidós, Barcelona.

Wildung, D. 2003. "Looking back into the Future: the Middle Kingdom as a Brindge to the Past". En Tait, J. (Ed.). Never Had the Like Occurred'. Egypt's view of its past. University College London, Londres, pp. 61-78.

Williams, R. 1980. Marxismo y literatura. Ediciones Península, Barcelona.

Wilkinson, R.H. 1998. Cómo leer el arte egipcio. Guía de jeroglíficos del antiguo Egipto. Crítica, Barcelona.

Wilson, J. 1951. The Burden of Egypt. Chicago University Press, Chicago. 
Wilson, J. 1954. "Egipto”. En Frankfort, H; Frankfort, H.A; Wilson, J.A.; Jacobsen, T. El pensamiento prefilosófico I. Egipto y Mesopotamia. Fondo de Cultura Económica, México D.F., pp. 45-163.

Wilson, J. 1957. "Book Review: Litterature et politique dans l'Egypte de la XIIe Dynastie". JNES 16, pp. 275-277.

Wilson, P. 2003. Hieroglyphs: A very Short Introduction. Oxford University Press, Oxford.

Yates, F.A. 2005. El arte de la memoria. Siruela, Madrid.

Yerushalmi, Y. 2006 [1988]. "Reflexiones sobre el olvido". En Yerushalmi, Y. y otros. Usos del olvido. Nueva Visión, Buenos Aires. pp. 13-26.

Yerushalmi, Y. y otros. 2006 [1988]. Usos del olvido. Nueva Visión, Buenos Aires.

Yoyotte, J. 1952. "A propos d'un monument copié par G. Daressy (contribution à l'historie littéraire)". BSFE 11, pp. 67-72.

Žába, Z. 1956. Les Maximes de Ptahhotep. Academia Tchécoslovaque des Sciences, Praga.

Zingarelli, A.P. 2010. “Introducción”. Trabajos y Comunicaciones 36, pp. 207-230.

Zingarelli, A.P. 2011. "Literatura y sociedad en el Egipto faraónico”. Trabajo presentado en XIII Jornadas Interescuelas/Departamentales de Historia, San Fernando del Valle de Catamarca. Sin publicar. 